Ricardo Lacerda Baitelo

\title{
Modelo de Cômputo e Valoração de Potenciais Completos de Recursos Energéticos para o Planejamento Integrado de Recursos
}

Tese para a obtenção de título de Doutor em Engenharia Elétrica da Escola Politécnica da

Universidade de São Paulo 
Ricardo Lacerda Baitelo

\section{Modelo de Cômputo e Valoração de Potenciais Completos de Recursos Energéticos para o Planejamento Integrado de Recursos}

Tese para a obtenção de título de Doutor em Engenharia Elétrica da Escola Politécnica da

Universidade de São Paulo

Área de Concentração:

Sistemas de Potência

Orientador:

Prof. Dr. Luiz Cláudio Ribeiro Galvão

Co-orientador:

Prof. Dr. Miguel Edgar Morales Udaeta 
Este exemplar foi revisado e alterado em relação à versão original, sob responsabilidade única do autor e com a anuência de seu orientador.

São Paulo, 21 de janeiro de 2011.

Assinatura do autor

Assinatura do orientador

FICHA CATALOGRÁFICA

Baitelo, Ricardo Lacerda

Modelo de cômputo e valoração completa de potencias de recursos energéticos para o planejamento integrado de recursos / R.L. Baitelo. -- ed.rev. -- São Paulo, 2011.

$400 \mathrm{p}$.

Tese (Doutorado) - Escola Politécnica da Universidade de São Paulo. Departamento de Engenharia de Energia e Automação Elétricas.

1. Recursos energéticos (Planejamento) I. Universidade de São Paulo. Escola Politécnica. Departamento de Engenharia de Energia e Automação Elétricas II. t. 
A Paulo Prata Lacerda e Humberto Baitello 


\section{Agradecimentos}

Ao Prof. Dr. Luiz Cláudio Ribeiro Galvão, pelo grande apoio à realização deste trabalho e, antes disso, a participação pivotal ao desenvolvimento das pesquisas do PIR na USP.

Ao Prof. Dr. Miguel Edgar Morales Udaeta pela orientação dos trabalhos neste amplo e universalmente complexo tema, pelas tergiversações metodológicas, pelas elucubrações ao longo deste ciclo de quase uma década e pelas discussões holísticas, cujo charme sempre foi a baixa probabilidade de resvalarem em consenso.

Aos colegas Mário Biague e Rodrigo Carneiro pela inestimável assistência teórica e prática e pela infinita generosidade nos inúmeros momentos de dificuldade - ou mesmo de bonança -em que a materialização do cômputo e valoração de potenciais completos teimava em se concretizar.

Aos demais integrantes do PIR, representados por Pascoal Rigolin, Jonathas Bernal, Paulo Kanayama, André Gimenes, Flávio Azevedo e outros tantos que fizeram parte do grupo e contribuíram com valiosas idéias, questionamentos pertinentes e constante disposição em enriquecer discussões técnicas e científicas e elevar a qualidade do trabalho realizado.

Aos colegas do Greenpeace, pela vivência e experiências ímpares, pelos constantes questionamentos sociopolíticos - e também pela frutífera (des)confiança nas bases exatas e cartesianas -, que alimentaram esta pesquisa de forma decisiva.

Aos amigos e família - representada principalmente pelos meus pais Rita e Norval - pelo apoio e pela compreensão quanto à duração desta longa tarefa sabática - e dominical -, que demandou alta prioridade e disponibilidade nestes últimos anos.

E principalmente à Clarissa Passos, companheira de vida, inspiradora de teorias científicas e prosaicas e fomentadora de epifanias cotidianas, que suavizaram o grau de atrito desta jornada. 


\section{Índice}

Lista de Figuras

Lista de Siglas e Abreviaturas

Resumo

Abstract

1. Introdução .................................................................................................................................................................. 1

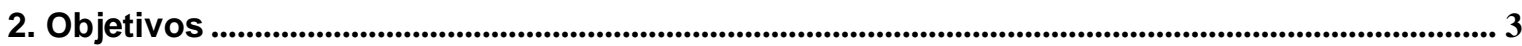

3. Justificativa e Contextualização ………………………..................................................................................... 5

3.1. Energia, Transformações e Consequências..............................................................................5

3.2. Mudanças Climáticas................................................................................................................................... 6

3.3. Panorama Energético no Mundo e no Brasil....................................................................................... 7

3.4. Perspectivas Energéticas e Crescimento de Baixo Carbono ..................................................... 9

4. Planejamento Integrado de Recursos ...................................................................................................... 14

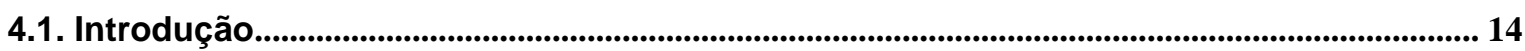

4.2. Origem do PIR ...................................................................................................................................................... 14

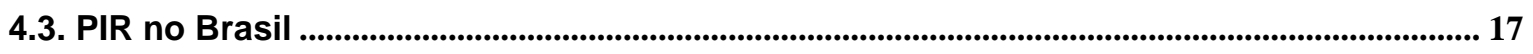

4.4. Metodologia do PIR ......................................................................................................................................... 18

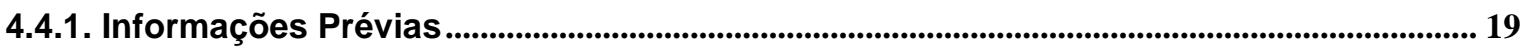

4.4.2. Caracterização de Recursos Energéticos............................................................................... 2

4.4.3. Cômputo e Valoração dos Potenciais Completos (CVPC) ........................................................ 20

4.4.4. Ranqueamento de Recursos Energéticos .................................................................................. 20

4.4.5. Previsão da Demanda Energética ........................................................................................................ 21

4.4.6. Mapeamento Energoambiental ........................................................................................................... 21

4.4.7. Plano Preferencial Integrado de Recursos Energéticos ........................................................... 21

4.4.8. Plano de Ação .............................................................................................................................................. 22

5. Cômputo e Valoração dos Potenciais Completos de Recursos Energéticos ........................... 24

5.1. Conceito e Justificativa............................................................................................................................. 24

5.2. Estado da Arte de Procedimentos Correntes de Valoração.......................................................... 26

5.3. Metodologia para Cômputo e Valoração de Potenciais Completos do Lado da Oferta.. 28 


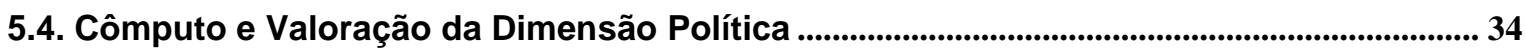

5.4.1. Conceituação da Dimensão Política para o PIR .................................................................. 34

5.4.2. Procedimento da Valoração de Atributos Políticos ....................................................................... 36

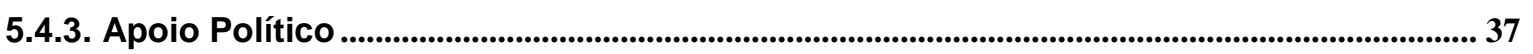

5.4.3.1. Instrumentos Políticos de Incentivo .................................................................................................. 37

5.4.3.2. Tarifas Feed-in ........................................................................................................................................... 38

5.4.3.3. Sistema de Cotas e Certificados Verdes............................................................................. 39

5.4.3.4. Sistema de Licitação e Leilão ........................................................................................................... 40

5.4.3.5. Subsídios e Medidas Fiscais........................................................................................... 41

5.4.3.6. Algoritmo de Cômputo e Valoração .................................................................................................. 43

5.4.4. Procedimentos de Aspectos Legais............................................................................................................. 45

5.4.4.1. Algoritmo de Cômputo e Valoração .................................................................................................... 48

5.4.5. Envolvidos e Interessados (En-In) ..................................................................................50

5.4.5.1. Algoritmo de cômputo e valoração ....................................................................................... 58

5.4.6. Posse de Fonte Energética e Integração Transfronteiriça ....................................................... 61

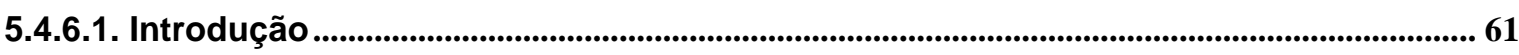

5.4.6.2. Disponibilidade e Propriedade de Fontes Energéticas............................................................ 62

5.4.6.3. Questões Políticas Pertinentes à Posse de Fontes Energéticas........................................ 63

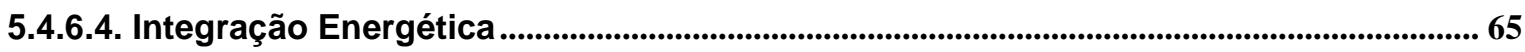

5.4.6.5. Algoritmo de Cômputo e Valoração ..................................................................................................... 67

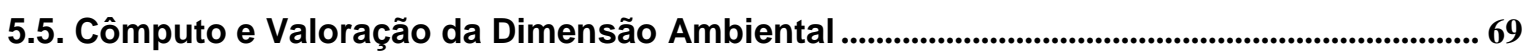

5.5.1. Definição da Dimensão Ambiental para o PIR .............................................................................. 69

5.5.2. Procedimento da Valoração de Atributos Ambientais ........................................................... 71

5.5.3. Poluição Atmosférica ........................................................................................................................ 74

5.5.3.1. Algoritmo de Cômputo e Valoração .............................................................................................. 76

5.5.4. Produção de Gases de Efeito Estufa no Setor Energético........................................................ 79

5.5.4.1. Algoritmo de Cômputo e Valoração ………................................................................................... 80

5.5.5. Ocupação do Solo .......................................................................................................................................... 84

5.5.5.1. Algoritmo de Cômputo e Valoração ...................................................................................................... 88

5.5.6. Poluição e Degradação do Solo ............................................................................................................ 90 


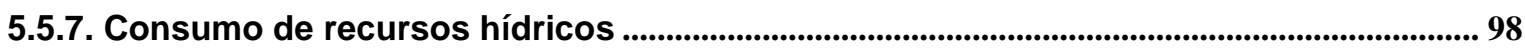

5.5.7.1. Algoritmo de Cômputo e Valoração ...........................................................................102

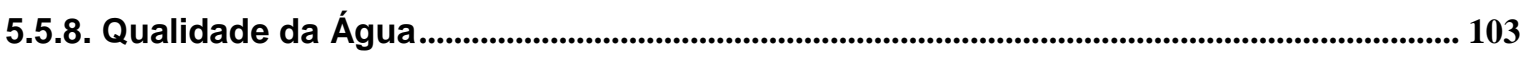

5.5.8.1. Algoritmo de Cômputo e Valoração ......................................................................................... 107

5.6. Cômputo e Valoração da Dimensão Social..................................................................110

5.6.1. Definição da Dimensão Social para o PIR .......................................................................110

5.6.2. Cômputo e Valoração da Dimensão Social para o PIR........................................................... 112

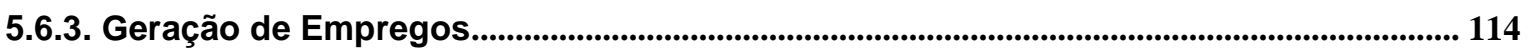

5.6.3.1. Subatributo: Quantidade de Empregos.......................................................................................... 114

5.6.3.2. Algoritmo de Cômputo e Valoração .........................................................................116

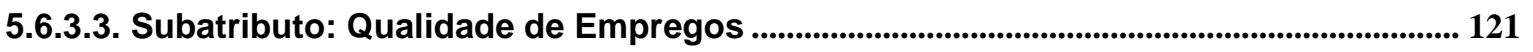

5.6.3.4. Algoritmo de Cômputo e Valoração ...................................................................................... 125

5.6.4. Atributo: Impactos de Desequilíbrio Ambiental no Meio Social .......................................... 127

5.6.4.1. Algoritmo de Cômputo e Valoração ........................................................................................ 129

5.6.5. Atributo: Impacto Humano decorrente da Ocupação Espacial de Empreendimentos133

5.6.5.1. Algoritmo de Cômputo e Valoração ............................................................................................. 137

5.6.6. Influência no Desenvolvimento Local .............................................................................. 139

5.6.6.1. Algoritmo de Cômputo e Valoração .............................................................................. 144

5.6.7. Alteração de percepção de conforto .............................................................................................. 147

5.6.7.1. Algoritmo de Cômputo e Valoração .............................................................................................. 151

5.7. Cômputo e Valoração da Dimensão Técnico- Econômica.................................................. 154

5.7.1. Definição da Dimensão Técnico- Econômica ....................................................................... 154

5.7.2. Procedimentos de cômputo e valoração de atributos técnico-econômicos .................. 156

5.7.3. Custo de geração de energia .................................................................................................................... 166

5.7.3.1. Algoritmo de Cômputo e Valoração ............................................................................... 168

5.7.4. Domínio Tecnológico ...................................................................................................................................... 170

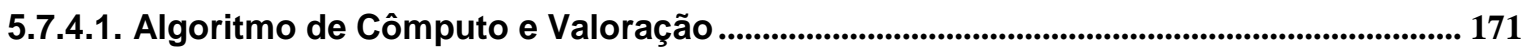

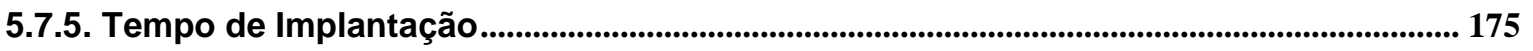

5.7.5.1. Algoritmo de Cômputo e Valoração .........................................................................177 
5.7.6.1. Algoritmo de Cômputo e Valoração ............................................................................................ 185

5.7.7. Distância de Geração de Recurso Energético a Centro de Consumo............................. 188

5.7.7.1. Algoritmo de Cômputo e Valoração .......................................................................................... 192

5.7.8. Cômputo e Valoração de Potenciais Energéticos ............................................................... 197

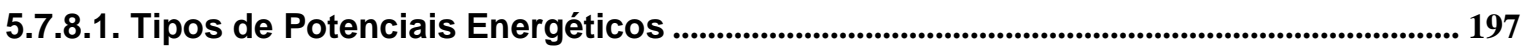

5.7.8.2. Potencial Teórico de Recursos Energéticos.................................................................... 198

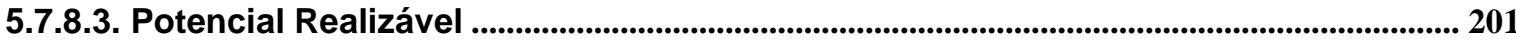

5.7.8.4. Potencial de Mercado.................................................................................................................. 204

5.7.8.5. Algoritmo de Cômputo e Valoração ......................................................................................... 207

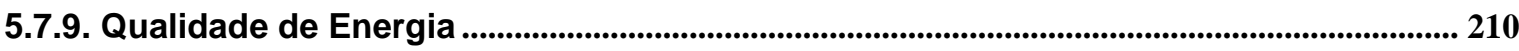

5.7.9.1. Alteração de Qualidade de Energia em Sistemas de Geração de Pequeno Porte (RELO) .................................................................................................................................................................... 212

5.7.9.2. Alteração de Qualidade de Energia por RELDs ................................................................. 215

5.7.9.3. Algoritmo de Cômputo e Valoração ................................................................................................ 216

5.8. Metodologia para Cômputo e Valoração de Potenciais Completos do Lado da Demanda 219

5.9. Cômputo e Valoração da Dimensão Ambiental ................................................................... 223

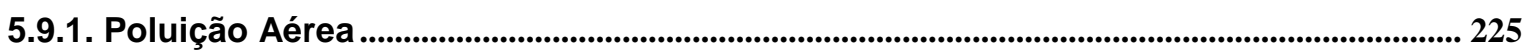

5.9.1.1. Algoritmo de Cômputo e Valoração ..................................................................................226

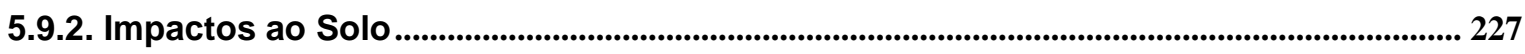

5.9.2.1. Algoritmo de Cômputo e Valoração ..................................................................................... 228

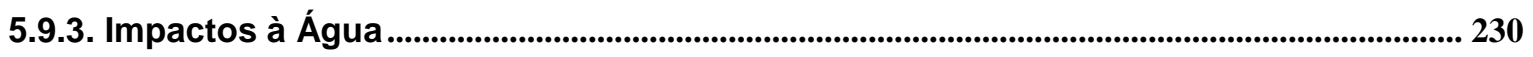

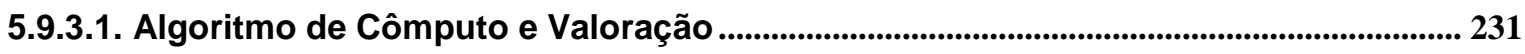

5.10. Cômputo e Valoração da Dimensão Social ....................................................................... 234

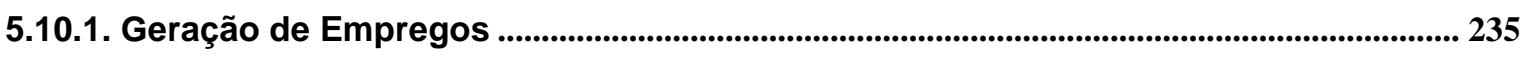

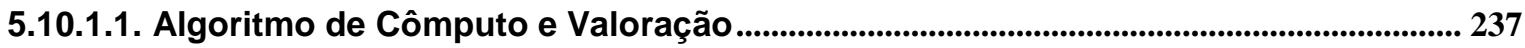

5.10.2. Influência no Desenvolvimento Local.................................................................................. 238

5.10.2.1. Algoritmo de Cômputo e Valoração.......................................................................................... 240

5.10.3. Impactos de Desequilíbrio Ambiental no Meio Social ................................................. 241

5.10.3.1. Algoritmo de Cômputo e Valoração ...................................................................................... 242 
5.10.4. Impacto Humano pela Ocupação Espacial de Empreendimentos

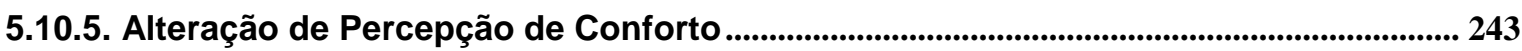

5.10.5.1. Algoritmo de Cômputo e Valoração............................................................................................ 245

5.11. Cômputo e Valoração da Dimensão Política ........................................................................... 247

5.11.1. Instrumentos Políticos de Incentivo ................................................................................................. 249

5.11.1.1. Algoritmo de Cômputo e Valoração............................................................................................. 251

5.11.2. Envolvidos e Interessados (En-In) ........................................................................... 252

5.11.2.1. Algoritmo de Cômputo e Valoração............................................................................................ 254

5.11.3. Posse de Recursos e Integração Energética Transfronteiriça............................................ 255

5.11.3.1. Algoritmo de Cômputo e Valoração.............................................................................................. 256

5.12. Cômputo e Valoração da Dimensão Técnico- Econômica......................................................... 258

5.12.1. Custos de RELDs .................................................................................................................................... 259

5.12.1.1. Custo de Energia Economizada................................................................................................... 259

5.12.1.2. Custo Evitado de Demanda (CED) .............................................................................. 260

5.12.1.3. Algoritmo de Cômputo e Valoração.............................................................................................. 261

5.12.2. Valoração de Domínio Tecnológico .......................................................................................... 263

5.12.2.1. Algoritmo de Cômputo e Valoração.............................................................................................. 263

5.12.3. Tempo de Implantação....................................................................................................................... 264

5.12.3.1. Algoritmo de Cômputo e Valoração............................................................................................ 265

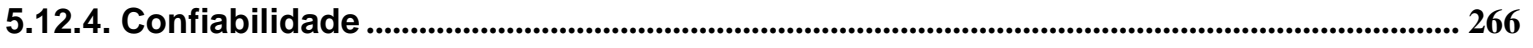

5.12.4.1. Algoritmo de Cômputo e Valoração................................................................................. 268

5.12.5. Valoração de Potenciais Energéticos .......................................................................................... 270

5.12.5.1. Potencial Teórico de Recursos Energéticos ......................................................................... 270

5.12.5.2. Potencial Realizável ........................................................................................................................ 271

5.12.5.3. Potencial de Mercado ........................................................................................................ 272

5.12.5.4. Algoritmo de Cômputo e Valoração................................................................................. 272

6. Estudo de Caso ............................................................................................................................................. 275

6.1. Cômputo e Valoração de Potenciais Completos de Pequenas Centrais Hidrelétricas 276

6.1.1. Dimensão Técnico Econômica ................................................................................................................ 276

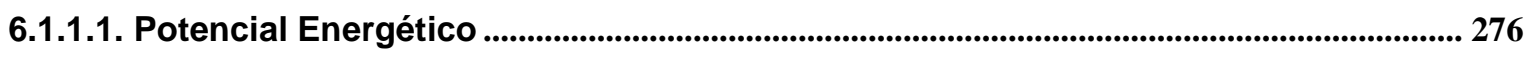


6.1.1.2. Tempo de Implantação ..................................................................................................................... 279

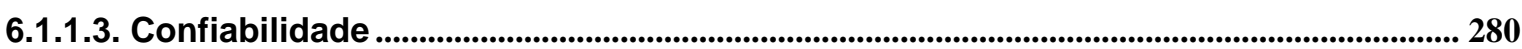

6.1.1.4. Distância de recurso energético a centro de consumo ......................................................... 281

6.1.1.5. Cômputo e Valoração de Domínio Tecnológico .................................................................. 282

6.1.1.6. Custo unitário de Geração de Energia .......................................................................................... 282

6.1.1.7. Qualidade de Energia.............................................................................................................................. 283

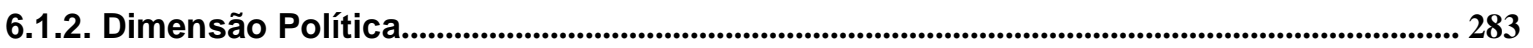

6.1.2.1. Instrumentos Políticos................................................................................................................... 284

6.1.2.2. Licenciamento Ambiental e Autorização de Construção ................................................... 285

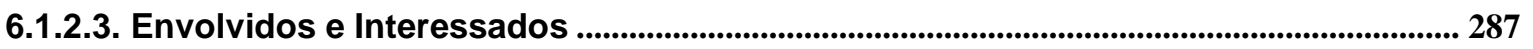

6.1.2.4. Propriedade e Integração Energética ............................................................................................. 292

6.1.3. Dimensão Ambiental .............................................................................................................................. 292

6.1.3.1. Poluição do Meio Aéreo …………………….................................................................. 292

6.1.3.2. Produção de Gases de Efeito Estufa ................................................................................. 293

6.1.3.3. Ocupação do Solo................................................................................................................................. 293

6.1.3.4. Produção de Resíduos Sólidos .................................................................................................. 294

6.1.3.5. Caracterização do uso e consumo de água ................................................................................ 295

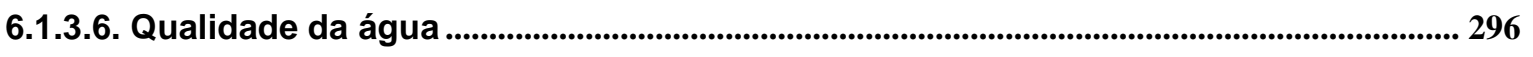

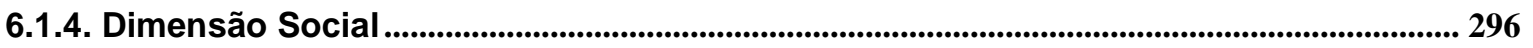

6.1.4.1. Geração de Empregos .............................................................................................................................. 297

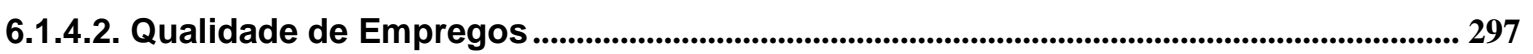

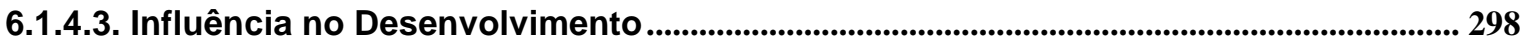

6.1.4.4. Alteração de Conforto......................................................................................................................... 299

6.1.4.5. Impacto Humano Decorrente do Espaço Ocupado.................................................................. 301

6.1.4.6. Influência de Impactos Ambientais à Saúde Humana .......................................................... 302

6.2. Cômputo e Valoração de Potenciais Completos de Cogeração a Bagaço de Cana-deAçúcar ................................................................................................................................................................ 304

6.2.1. Dimensão Técnico-Econômica ...................................................................................................... 304

6.2.1.1. Potencial Energético Teórico................................................................................................................ 304

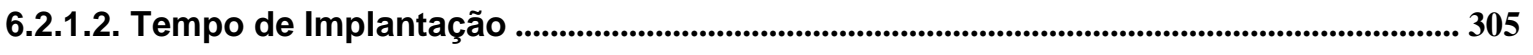




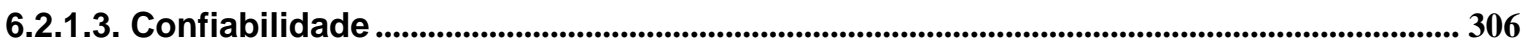

6.2.1.4. Distância de recurso energético a centro de consumo .......................................................306

6.2.1.5. Valoração de Domínio Tecnológico ................................................................................................ 307

6.2.1.6. Custo unitário de Geração de Energia ...............................................................................307

6.2.1.7. Qualidade de Energia ............................................................................................................................. 308

6.2.2. Dimensão Política................................................................................................................................................ 308

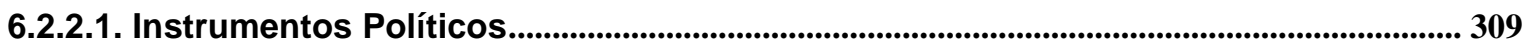

6.2.2.2. Licenciamento Ambiental e Autorização de Construção ...................................................... 310

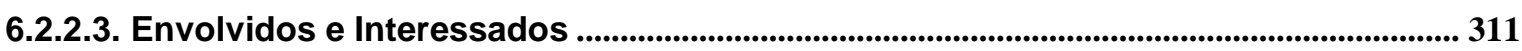

6.2.2.4. Propriedade e Integração Energética ...................................................................................... 315

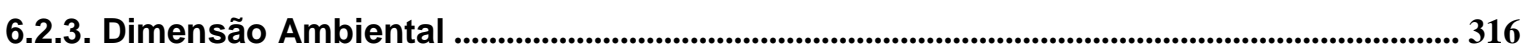

6.2.3.1. Poluição do Meio Aéreo ……………………….................................................................................... 316

6.2.3.2. Produção de Gases de Efeito Estufa ................................................................................. 317

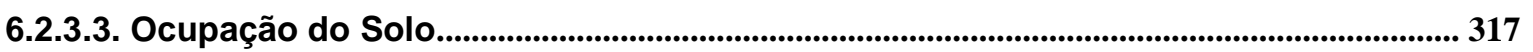

6.2.3.4. Produção de Resíduos Sólidos .......................................................................................................... 318

6.2.3.5. Caracterização de uso e consumo de água ............................................................................. 318

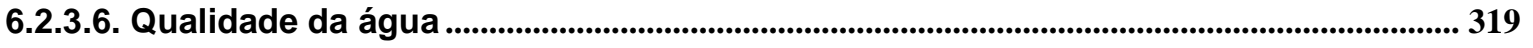

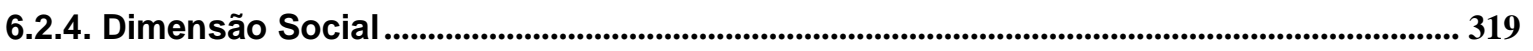

6.2.4.1. Geração de Empregos ..................................................................................................................... 320

6.2.4.2. Qualidade de Empregos .................................................................................................... 320

6.2.4.3. Desenvolvimento Econômico e Humano .................................................................................. 321

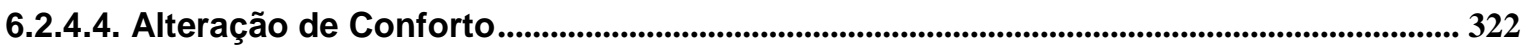

6.2.4.5. Impacto Humano Decorrente do Espaço Ocupado................................................................ 322

6.2.4.6. Influência de Impactos Ambientais à Saúde Humana ............................................................ 322

6.3. Substituição de Chuveiros Elétricos por Sistema com Aquecimento Solar....................... 323

6.3.1. Dimensão Técnico-Econômica ......................................................................................................323

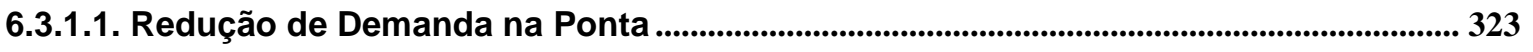

6.3.1.2. Energia Economizada ................................................................................................................................. 324

6.3.1.3. Investimento Total ................................................................................................................................... 325

6.3.1.4. Custo da Energia Conservada ........................................................................................................... 325 


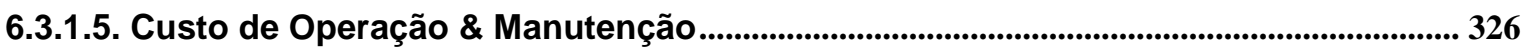

6.3.1.6. Tempo de Implantação ...................................................................................................................... 326

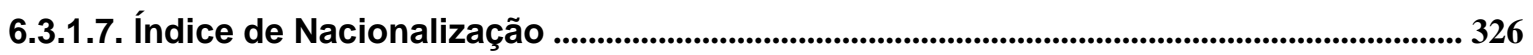

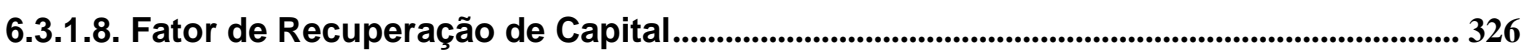

6.3.1.9. Custo da Demanda Evitada ................................................................................................................. 327

6.3.1.10. Qualidade de Energia............................................................................................................................... 327

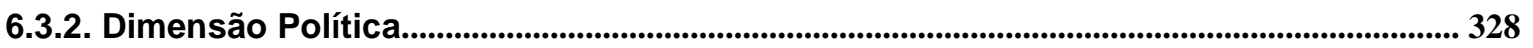

6.3.2.1. Instrumentos Políticos................................................................................................................... 328

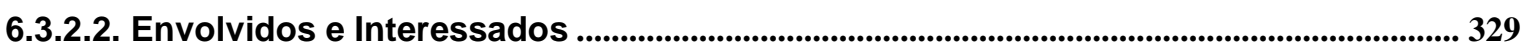

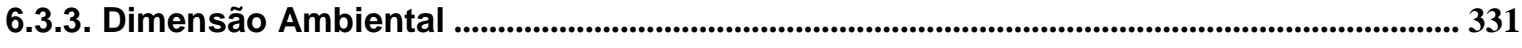

6.3.3.1. Alteração da Vazão ............................................................................................................................ 331

6.3.3.2. Qualidade da água ................................................................................................................................ 332

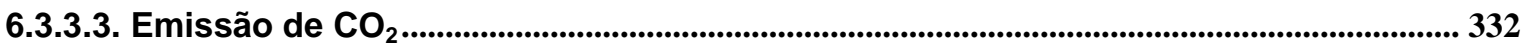

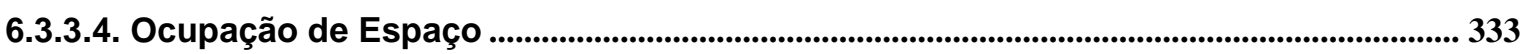

6.3.4. Dimensão Social ............................................................................................................................................ 333

6.3.4.1. Geração de Empregos ............................................................................................................. 333

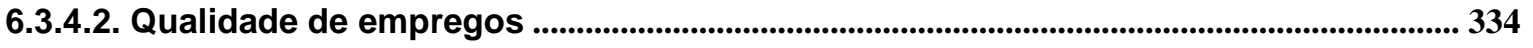

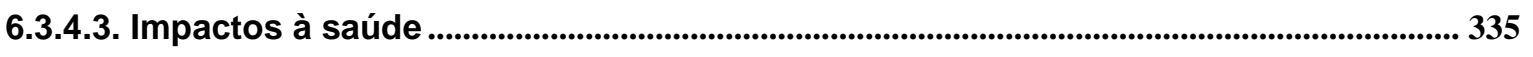

6.3.4.4. Alteração de conforto ......................................................................................................................... 336

6.3.4.5. Influência no desenvolvimento ......................................................................................................... 336

6.4. Substituição de Lâmpada Incandescente por Lâmpadas Fluorescente Compactas..... 337

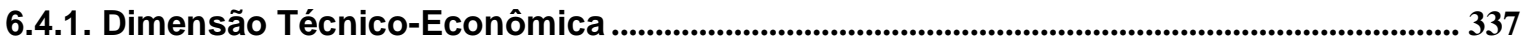

6.4.1.1. Redução de Demanda na Ponta .............................................................................................. 337

6.4.1.2. Energia Economizada ...................................................................................................................... 339

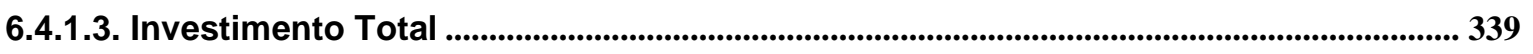

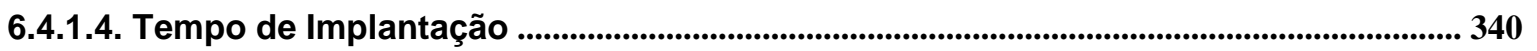

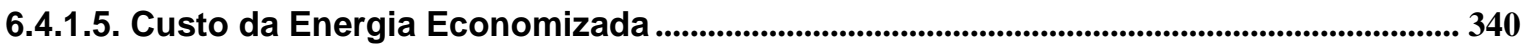

6.4.1.6. Custo de Operação \& Manutenção............................................................................................... 341

6.4.1.7. Índice de Nacionalização ....................................................................................................................... 341

6.4.1.8. Fator de Recuperação de Capital.................................................................................................. 341 


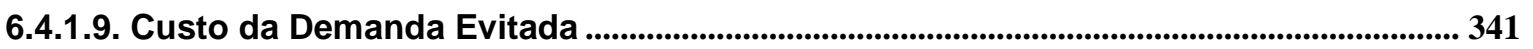

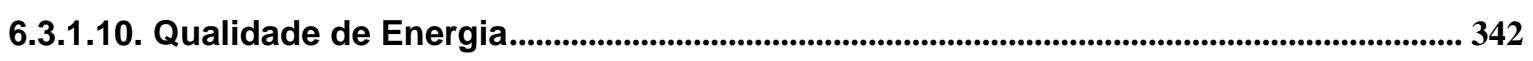

6.4.2. Dimensão Política..................................................................................................................................... 342

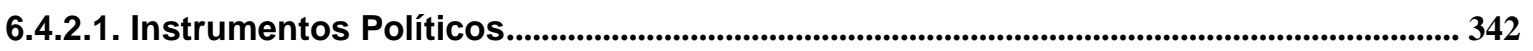

6.4.2.2. Envolvidos e Interessados .............................................................................................................. 343

6.4.3. Dimensão Ambiental ................................................................................................................................... 345

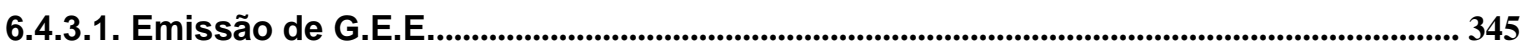

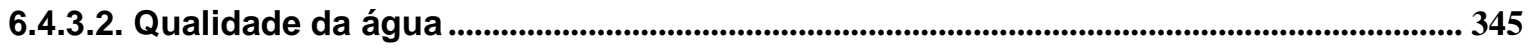

6.4.3.3. Produção de Resíduos Sólidos ........................................................................................................ 346

6.4.3.4. Ocupação de Espaço ........................................................................................................................ 347

6.4.4. Dimensão Social ..................................................................................................................................................... 347

6.4.4.1. Geração de empregos.......................................................................................................................... 347

6.4.4.2. Impactos à saúde humana .............................................................................................. 347

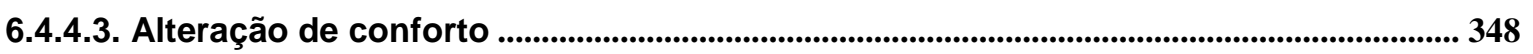

6.4.4.4. Influência no desenvolvimento local ............................................................................................. 348

6.5. Resultados do Estudo de Caso................................................................................................. 350

7. Considerações e Conclusões ......................................................................................................................... 354

Anexo 1: Tabelas de CVPC .................................................................................................................. 357

Anexo 2: Resultados do Fluxo de Caixa Descontado para RELO .................................................... 373

Anexo 3: Simulações de Erosão e Vazão de PCHs ..................................................................................... 379

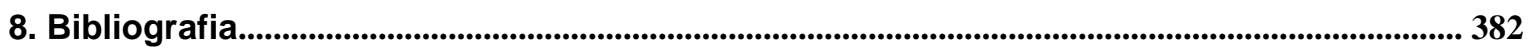




\section{Lista de Figuras}

Figura 1: Diagrama Esquemático do Planejamento Integrado de Recursos Energéticos ..... 23

Figura 2: Algoritmo geral de cômputo e valoração de potenciais completos de recursos....33

Figura 3: Árvore de atributos e subatributos da dimensão política 37

Figura 4: Algoritmo de cômputo e valoração do atributo Instrumentos Políticos de Apoio a RELOS.

Figura 5: Algoritmo de CVPC do atributo Procedimentos Legais

Figura 6: Análise de Poder do Setor Nuclear Brasileiro 57

Figura 7: Algoritmo de cômputo e valoração do atributo Envolvidos e Interessados 60

Figura 8: Algoritmo de valoração do atributo Posse e Integração Energética de Recursos 68

Figura 9: Árvore de atributos e subatributos da dimensão ambiental ............................................. 74

Figura 10: Algoritmo de cômputo e valoração do atributo Poluição Atmosférica...................... 78

Figura 11: Algoritmo de cômputo e valoração do atributo Gases de Efeito Estufa ................... 83

Figura 12: Algoritmo de valoração do atributo Ocupação do Solo 90

Figura 13: Algoritmo de cômputo e valoração do atributo Poluição e Degradação do Solo 97

Figura 14: Algoritmo de CVPC do atributo Consumo de Recursos Hídricos 103

Figura 15: Algoritmo de cômputo e valoração do atributo qualidade da água 109

Figura 16: Árvore de atributos e subatributos da dimensão social 114

Figura 17: Algoritmo de valoração do atributo Geração de Empregos. 120

Figura 18: Empregos diretos por tipo de atividade no setor eólico europeu 122

Figura 19: Algoritmo de valoração do subatributo Qualidade de Empregos 126

Figura 20: Algoritmo de cômputo e valoração do desequilíbrio ambiental no meio social 132

Figura 21: Algoritmo de cômputo e valoração de Deslocamento Humano em decorrência da implantação de empreendimentos energéticos 139

Figura 22: Algoritmo de cômputo e valoração da influência no desenvolvimento local ...... 146

Figura 23: Algoritmo de cômputo e valoração de alteração de percepção de conforto........ 153

Figura 24: Árvore de atributos e subatributos da dimensão Técnico-Econômica 157

Figura 25: Algoritmo de cômputo e valoração do atributo custo de geração de energia.... 169

Figura 26: Algoritmo de CVCP do atributo Domínio Tecnológico de Recursos. 174

Figura 27: Algoritmo de CVCP do atributo Tempo de Implantação de RELO 180 
Figura 28: Algoritmo de CVCP do atributo confiabilidade de RELO.

Figura 29: Arranjos de ICGs

Figura 30: Fluxo de Potência de Geradores em Instalações de Transmissão Compartilhada

Figura 31: Algoritmo de CVCP do atributo Transporte de Energia ................................................. 196

Figura 32: Algoritmo de cômputo e valoração do atributo Potenciais Energéticos................ 209

Figura 33: Tensão e corrente medidas em ventilador alimentado por um inversor de onda

Figura 34: Algoritmo de CVCP do atributo Qualidade de Energia................................................... 218

Figura 35: Segmentação de usos finais e medidas de RELD ........................................................... 220

Figura 36: Algoritmo de cômputo e valoração do atributo Alteração de Conforto RELDs.. 247

Figura 37: Algoritmo de valoração do atributo Posse e Integração Energética de RELDs . 257

Figura 38: Algoritmo de valoração do atributo Custos de RELDs .................................................. 262

Figura 39: Etapas de Projetos de Eficiência Energética ......................................................................... 264

Figura 40: Algoritmo de CVPC do tempo de implantação de RELDs ............................................. 266

Figura 41: Algoritmo de CVPC de confiabilidade de RELDs............................................................... 269

Figura 42: Algoritmo de CVPC de potenciais energéticos de RELDs ............................................ 274

Figura 43: Mapa Hidrológico das bacias e Sub-bacias Hidrográficas da RAA .......................... 277

Figura 44: Mapa Altimétrico ou Mapa com Curvas de Níveis da RAA.......................................... 277

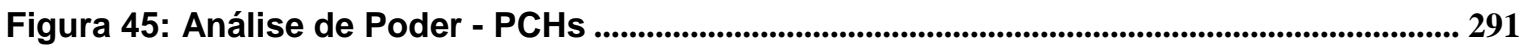

Figura 46: Análise de Poder - Cogeração a Biomassa ......................................................................... 315 


\section{Lista de Tabelas}

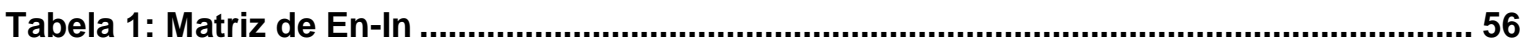

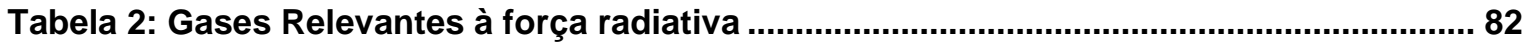

Tabela 3: Gases de Efeito Estufa e Potenciais de Aquecimento Global ................................. 82

Tabela 4: Relação entre Capacidade Instalada e Área ocupada de Recursos Energéticos.. 88

Tabela 5: Uso de água em sistemas energéticos .................................................................. 101

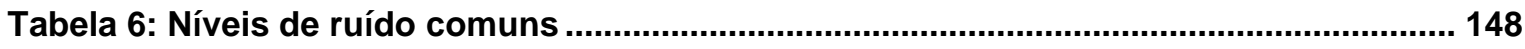

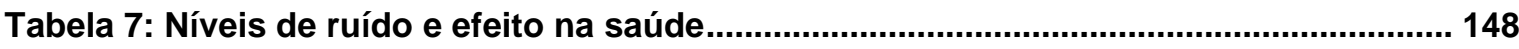

Tabela 8. Custos de Geração de Energia de Angra 3 …..................................................... 167

Tabela 9: Metodologia de cálculo tarifário de acordo com perfil de usuário ....................... 193

Tabela 10: Características de Qualidade de Energia em Eletrodomésticos ......................... 214

Tabela 11: Componentes Químicos de Eletrodomésticos..................................................... 227

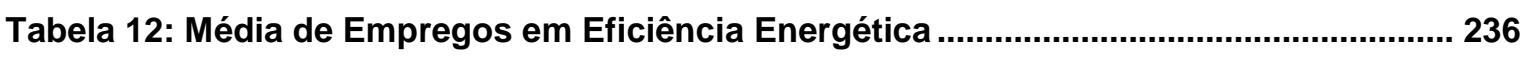

Tabela 13: Média de Empregos em Eficiência Energética ....................................................... 236

Tabela 14: Correlação entre energia economizada e custo.................................................... 261

Tabela 15: Duração de Medidas de Eficiência Energética .................................................... 268

Tabela 16: Locais Levantados e Faixas de Potência calculadas .......................................... 278

Tabela 17: Escolha das Tecnologias para o Aproveitamento do Potencial Teórico............. 279

Tabela 18 - Parâmetros e atributos técnico-econômicos ........................................................ 283

Tabela 19: Simulação dos Custos de Geração de PCHs ................................................. 283

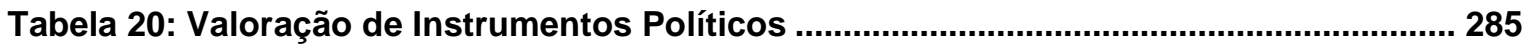

Tabela 21: Tempo médio de expedição de licenças ambientais ........................................... 286

Tabela 22: Potência gerada por área alagada em hidrelétricas e PCHs............................... 294

Tabela 23: Massa salarial produzida durante construção e operação de PCH .................... 298

Tabela 24: Parâmetros e atributos técnico-econômicos ..........................................................308

Tabela 25: Simulação dos Custos de Geração do RELO - Biomassa...................................... 308

Tabela 26: Valoração de Instrumentos Políticos .................................................................. 310

Tabela 27: Emissões aéreas de bagaço e palha de cana........................................................... 317

Tabela 28: CVPC Emissões aéreas de bagaço e palha de cana................................................ 317 
Tabela 29: Distribuição de lâmpadas por tipo na região sudeste.......................................... 338

Tabela 30: Matriz da Dimensão Técnico-Econômica (DTE) ................................................. 351

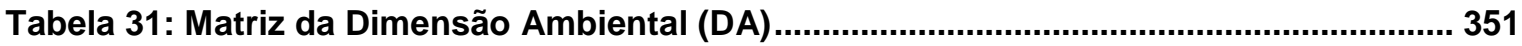

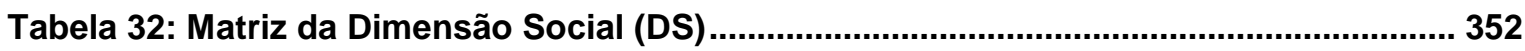

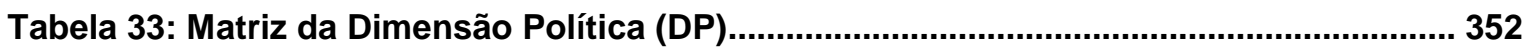

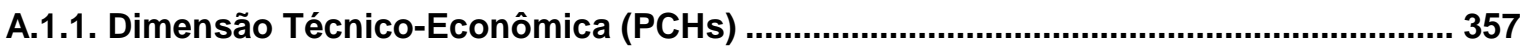

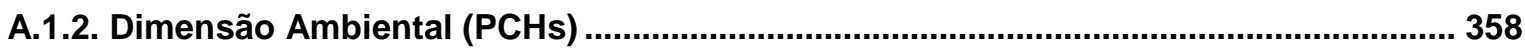

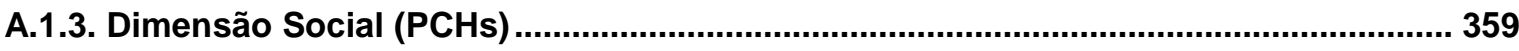

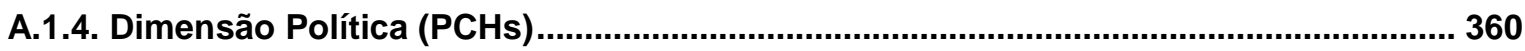

A.2.1. Dimensão Técnico-Econômica (Cogeração a Biomassa) ............................................ 361

A.2.2. Dimensão Ambiental (Cogeração a Biomassa) …....................................................... 362

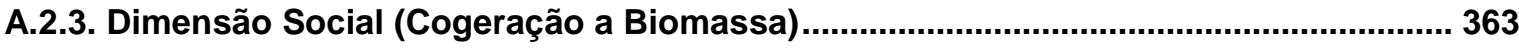

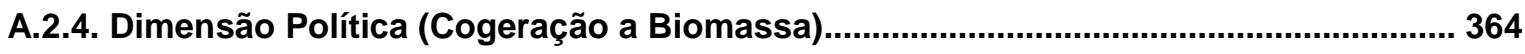

A.3.1. Dimensão Técnico-Econômica (Aquecedores Solares) …….........................................365

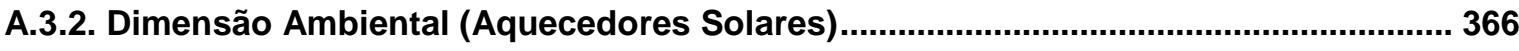

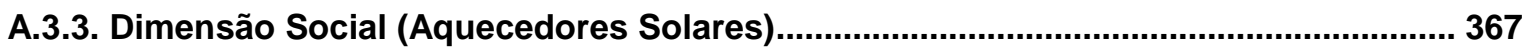

A.3.4. Dimensão Política (Aquecedores Solares) ……............................................................ 368

A.4.1. Dimensão Técnico-Econômica (Lâmpadas Fluorescentes Compactas) ..................... 369

A.4.2. Dimensão Ambiental (Lâmpadas Fluorescentes Compactas) .................................... 370

A.4.3. Dimensão Social (Lâmpadas Fluorescentes Compactas)............................................ 371

A.4.4. Dimensão Política (Lâmpadas Fluorescentes Compactas) …...................................... 372

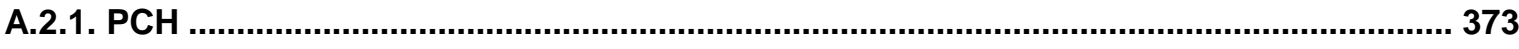

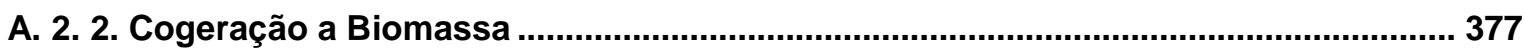

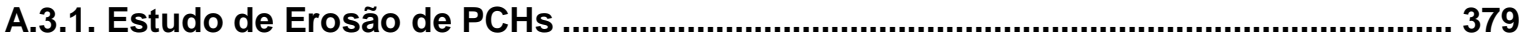

A.3.2. Iterações de Volume Médio, Área Inundada, Vazão.................................................... 380

A.3.3.Variação Anual Capacidade Média de Reservatórios em Função de Erosão .............. 381 


\section{Lista de Siglas e Abreviaturas}

ACC: Avaliação de Custos Completos;

AHP: Análise Hierárquica de Processos;

ANEEL: Agência Nacional de Energia Elétrica;

BIG-GT: Gaseificação da Biomassa Integrada por Turbina a gás;

BNDES: Banco Nacional de Desenvolvimento Econômico e Social;

BMU: Ministério do Meio Ambiente da Alemanha;

CCEE: Câmara de Comercialização de Energia Elétrica;

CEMIG: Companhia Energética de Minas Gerais AS;

CETESB: Companhia de Tecnologia de Saneamento Ambiental;

Cl: Capacidade Instalada;

CMMAD: Comissão Mundial sobre Meio Ambiente e Desenvolvimento;

CSP: Energia Solar Concentrada;

CVPC: Cômputo e Valoração de Potenciais Completos;

DOE: Department of Energy - EUA;

ELETROBRÁS: Centrais Elétricas do Brasil AS;

EIA: Estudo de Impacto Ambiental;

En-In: Envolvidos-Interessados (no processo de planejamento);

EPC: Engineering, Procurement and Construction;

EPE: Empresa de Pesquisa Energética;

FC: Fator de Capacidade da Usina;

FRC: Fator de Recuperação de Capital;

GEPEA: Grupo de Energia do Departamento de Engenharia de Energia e Automação Elétrica da Escola Politécnica da Universidade de São Paulo;

GLD: Gerenciamento pelo Lado da Demanda;

IBGE: Instituto Brasileiro de Geografia e Estatística;

IBAMA: Instituto Brasileiro do Meio Ambiente e dos Recursos Naturais Renováveis;

IDH: Índice de Desenvolvimento Humano;

IEA: International Energy Agency;

IPCC: Intergovernmental Panel of Climate Change;

IRENA: International Renewable Energy Agency; 
MDL: Mecanismos de Desenvolvimento Limpo;

MME: Ministério de Minas e Energia;

MP: Material Particulado;

MRE: Mecanismo de Realocação de Energia;

O\&M: Operação e Manutenção;

ONGs: Organizações Não Governamentais;

ONS: Operador Nacional do Sistema Elétrico;

ONU: Organização das Nações Unidas;

OSCIP: Organização da Sociedade Civil de Interesse Público;

PAH: Processo de Análise Hierárquica;

PCH: Pequena Central Hidrelétrica (capacidade instalada até $30 \mathrm{MW}$ );

PIB: Produto Interno Bruto;

PIR: Planejamento Integrado de Recursos Energéticos;

PL: Projeto de Lei;

PTC: Production Tax Credits;

PURPA: Public Utility Regulatory Policies Act;

PROINFA: Programa de Incentivo às Fontes Alternativas de Energia Elétrica;

RELO: Recurso Energético pelo Lado da Oferta;

RELD: Recurso Energético pelo Lado da Demanda;

RIMA: Relatório de Impacto Ambiental;

RPS: Renewable Portfolio Standard;

SAC: Serviço de Amortização Constante;

SIN: Sistema Interligado Nacional;

TdR: Termo de Referência;

TIR: Taxa Interna de Retorno;

TUSD: Tarifa pelo Uso do Sistema de Distribuição;

TUST: Tarifa pelo Uso do Sistema de Transmissão;

UHE: Usina Hidrelétrica (capacidade instalada superior a $30 \mathrm{MW}$ );

UNEP: United Nations Environment Programme;

UTE: Usina Termelétrica;

WWF: World Wildlife Fund. 


\section{Resumo}

Esta tese apresenta a metodologia de cômputo e valoração de potenciais completos de recursos energéticos no âmbito do Planejamento Integrado de Recursos. A metodologia é genérica a diferentes tipos de recursos - dos lados de oferta e demanda - e flexível a fim de permitir sua aplicação em diferentes regiões.

A etapa de cômputo e valoração de potenciais é de suma importância no processo de planejamento integrado de recursos e sua metodologia consiste na transformação de informações prévias relativas às dimensões de análise em potenciais completos. Para tanto, são confeccionados algoritmos de cômputo e valoração, capazes de converter o conteúdo qualitativo ou relativo de cada atributo em valores absolutos ou diagnósticos quantitativos. Estes potenciais alimentam as etapas subsequentes do PIR - tais como o Ranqueamento de Recursos e o Plano Preferencial Integrado de Recursos.

O Planejamento Integrado de Recursos Energéticos é, por natureza, uma metodologia de análise de implementação de recursos energéticos com base em seus potenciais holísticos, de acordo com variáveis espaciais e temporais. Para tanto, a metodologia do PIR parte de um conjunto de recursos energéticos disponíveis e aponta dentre estes quais devem ser preferencialmente aproveitados em um dado cenário, de modo a orientar a busca pela satisfação das necessidades energéticas dos diversos atores envolvidos. Esta implantação de recursos pode tanto ser regulamentada ou induzida pela atração de investimentos e políticas públicas.

O PIR diferencia-se do planejamento energético tradicional no que se refere à atenção dada a recursos do lado da demanda como alternativas factíveis de atendimento à demanda energética - ao lado das opções do lado da oferta -, e à ponderação equilibrada da análise destes recursos sob óticas sociais, ambientais e políticas, ao lado de parâmetros técnicos e econômicos. Esta análise holística insere em cada dimensão os diversos aspectos dos impactos associados a cada recurso energético, ou seja, busca contabilizar tanto os custos internos e tangíveis de empreendimentos energéticos, quanto custos externos marginalizados de análises técnico-econômicas.

A metodologia de cômputo e valoração de recursos energéticos é validada em Estudo de Caso com base em informações colhidas na Região Administrativa 
de Araçatuba. Quatro recursos energéticos foram escolhidos para o estudo de caso: pequenas centrais hidrelétricas e sistemas de cogeração a biomassa - do lado da oferta - e a implantação de sistemas de aquecimento solar de água e a substituição de lâmpadas incandescentes por iluminação fluorescente - do lado da demanda. Toda a informação referente a esses recursos foi processada pelos algoritmos de valoração e resultou em potenciais completos nas quatro dimensões de análise, dispostos em matrizes de valoração.

Estas matrizes alimentarão as etapas subsequentes do planejamento integrado de recursos - os processos de ranqueamento de recursos e formulação de plano preferencial integrado de recursos. 


\section{Abstract}

This thesis presents a methodology for the accounting and valuation of energy resources full potentials, within the Integrated Resource Planning (IRP). The methodology is generic to different types of resources - in both supply and demand sides - and flexible as to allow its application in different regions.

The calculation and assessment of potentials is of paramount importance in the energy planning process and its methodology consists of converting preliminary information from all areas of analysis into full potentials. For this purpose, algorithms are designed to convert the qualitative content of each attribute in figures or quantifiable diagnostics. These potentials fuel the subsequent steps of the IRP - such as the resource ranking and the Integrated Preferential Plan.

The Integrated Resources Planning is by nature a methodology for the assessment of energy resources based on their holistic potential, according to space and time variables. Therefore, the IRP methodology starts from a set of available energy resources and among these indicates the ones which should preferably be utilized in a given scenario in order to guide the demands of different involved stakeholders. The deployment of resources can be either regulated or induced by public policies and investment attraction.

The IRP differs from traditional energy planning with regard to attention given to demand-side resources as feasible alternatives energy to meet energy demand - along the options on the supply side - and the balanced consideration of the analysis of these resources through a social, environmental and political lens, alongside technical and economic parameters. This holistic analysis inserts in each dimension the various aspects of the impacts associated with each energy resource, that is, seeks to account both tangible and internal costs of energy enterprises and the external costs marginalized from technical-economic analysis.

The method for the calculation and valuation of energy resources is validated by a case study based on information collected in the Administrative Region of Araçatuba in the state of São Paulo. Four energy resources were chosen in the case study: small hydro plants and sugarcane biomass cogeneration - on the supply side - and installation of solar heating and replacement of incandescent lighting for fluorescent lamps - on the demand side. 
All the data concerning these resources was processed by the valuation algorithms and resulted in full potentials in all four analysis dimensions, displayed in valuation matrixes. These matrixes will be able to feed the subsequent steps of the integrated resources planning - the processes of resource ranking and the formulation of the integrated preferential plan. 


\section{Introdução}

O exercício de Cômputo e Valoração de Potenciais Completos constitui uma etapa básica e primordial para o desenvolvimento do Planejamento Integrado de Recursos (PIR). O processo trabalha informações prévias levantadas nos processos de Inventário Ambiental, Listagem e Seleção de Recursos e Identificação de Envolvidos e Interessados e as converte em valores absolutos $\mathrm{e}$ indicadores pertinentes às quatro dimensões de análise do planejamento - ambiental, social, política e técnico-econômica. Estes dados ou potenciais alimentam as etapas subsequentes do PIR - tais como 0 Ranqueamento de Recursos e o Plano Preferencial Integrado de Recursos - a partir do fornecimento de diagnósticos de variados parâmetros - desde o custo e o potencial energético de um recurso, até diferentes impactos socioambientais e a leitura das condições políticas capazes de viabilizá-lo.

Em suma, o Cômputo e a Valoração de Recursos Energéticos fornece às etapas de Ranqueamento e Plano Preferencial todas as informações referentes a esses recursos, quantificadas em seus potenciais completos. Esses potenciais e indicadores, referentes a todos os atributos analisados nas quatro dimensões, servem de informação básica à avaliação dos Envolvidos e Interessados - no processo de ranqueamento - e ao redimensionamento de potenciais recursos dos lados da oferta e demanda - integrados em carteiras e cenários energéticos.

O objetivo principal desta tese é, portanto, construir uma metodologia para o cômputo e a valoração de potenciais completos de recursos energéticos. Essa metodologia deve ser genérica a diferentes tipos de recursos - dos lados de oferta e demanda - e flexível a fim de permitir sua aplicação em diferentes regiões.

O texto deste documento está dividido em sete capítulos. O capítulo 2 explicita os objetivos da tese e sua contextualização na corrente pesquisa em Planejamento Integrado de Recursos.

O capítulo 3 defende a importância do tema abordado, as motivações para tanto e sua contextualização na realidade presente, considerando as necessidades de se conjugar as crescentes demandas energéticas a restrições de emissões de gases de efeito estufa e outros poluentes. Esse capítulo discute 
as premissas do desenvolvimento sustentável e as diferentes abordagens de planejamento energético propostas.

O capítulo 4 introduz o conceito de Planejamento Integrado de Recursos, sua motivação e origem, a estruturação, os principais aspectos desse processo e sua aplicação em exemplos práticos atuais e anteriores.

O capítulo 5 define a metodologia de Cômputo e Valoração de Potenciais Completos de Recursos Energéticos, justifica a escolha e os critérios da elaboração da metodologia empregada e traça um paralelo entre esta e diferentes procedimentos utilizados em linhas de pesquisa de outros institutos ou universidades.

O capítulo cobre também a conceituação do processo de cômputo e valoração de recursos energéticos para atributos nas dimensões Política, Ambiental, Social e Técnico-Econômica, respectivamente. Esse processo é construído e organizado por algoritmos de valoração, adaptados para recursos energéticos dos lados da oferta e demanda, descritos em detalhes.

O capítulo 6 descreve o estudo de caso da metodologia de cômputo e valoração de potenciais completos para recursos energéticos do lado da oferta (pequenas centrais hidrelétricas e usinas de cogeração a biomassa) e do lado da demanda (uso de sistemas de aquecimento solar e substituição de lâmpadas incandescentes por fluorescentes compactas).

O capítulo 7 coloca as considerações e conclusões pertinentes à pesquisa realizada e à tese proposta, delimitando as contribuições do trabalho às etapas e ferramentas desenvolvidas até o momento no PIR na USP e sinalizando as possibilidades de aprimoramento, evolução e continuação desses trabalhos.

Por fim, o capítulo 8 lista a bibliografia utilizada para a fundamentação e construção da tese e do estudo de caso, baseada em referências nacionais, internacionais, relatórios técnico-científicos do grupo de pesquisa e literatura relacionada ao planejamento energético e meio-ambiente. 


\section{Objetivos}

O objetivo desta Tese de Doutorado é a elaboração de um Modelo de Cômputo e Valoração de Potenciais Completos de Recursos Energéticos. Esses potenciais são construídos com base em informações prévias coletadas nas etapas de Inventário Ambiental, Levantamento de Envolvidos e Interessados e Listagem de Recursos Energéticos e convertidos em parâmetros absolutos - tais como custos e potenciais energéticos -, relativos - como indicadores referentes a condições ambientais e sociais - e qualitativos - como análises de mapeamento de atores energéticos e arcabouço político.

Os potenciais completos alimentam duas das etapas subsequentes do PIR: o Ranqueamento de Recursos e o Plano Preferencial Integrado de Recursos. O fornecimento de diagnósticos de variados parâmetros orienta a avaliação dos Envolvidos e Interessados no processo de Ranqueamento de Recursos e constitui a base de modelagem e integração desses recursos em carteiras que visem atender à demanda energética do local ou região objeto deste planejamento integrado de recursos.

A metodologia busca, portanto, estruturar a quantificação desses potenciais, definida dentro das premissas do Planejamento Integrado de Recursos, valendo-se, para tanto, da construção de algoritmos de Cômputo e Valoração.

Esse modelo pode ser adaptado e aplicado a qualquer região de estudo ou período definido e foi validada na Região Administrativa de Araçatuba, por meio da valoração de alguns dos recursos energéticos disponíveis na região. $O$ levantamento de informações referentes a esses recursos foi possível com base nos estudos de Planejamento Integrado de Recursos Energéticos realizados no local, apoiados no projeto de pesquisa em políticas públicas "Novos Instrumentos de Planejamento Energético Regional Visando o Desenvolvimento Sustentável”, da Fundação de Amparo à Pesquisa do Estado de São Paulo (Processo 03/06441-7).

Para consolidar a leitura dos potenciais energéticos locais, a metodologia de cômputo e valoração completa desses recursos buscou organizar e quantificar suas características multidimensionais, idealizadas de acordo com as premissas do PIR. 
Os objetivos específicos deste trabalho são:

- Caracterização dos Critérios de Avaliação de Recursos Energéticos: delimitação das dimensões técnico-econômica, ambiental, social e política de análise de recursos e a caracterização de seus atributos a fim de garantir a representatividade de diferentes grupos de custos e benefícios referentes à sua implantação;

- Qualificação de impactos socioambientais: locais, regionais e globais referentes às etapas da cadeia energética dos diferentes grupos de recursos energéticos de oferta e demanda. $O$ estudo desses impactos consiste em um elemento essencial para a formação e delimitação dos potenciais completos desses recursos;

- Formulação de Cômputo e Valoração de Potenciais Completos (CVPC): por meio de algoritmos de valoração específicos a cada atributo dentro das quatro dimensões de análise. O procedimento de formulação da valoração apresenta raciocínio paralelo entre recursos de oferta e demanda em alguns casos e estruturas particulares em outros;

- Formulação de Potenciais Energéticos: caracterização dos potenciais energéticos teóricos e discussão de potenciais realizáveis e de mercado de recursos energéticos com base na amplitude e abrangência de aplicação dos recursos, de acordo com os limites impostos pelas quatro dimensões de análise;

- Aplicação da Metodologia de CVPC: demonstração de Cômputo e Valoração de Potenciais Completos por meio de exercício de análise de recursos energéticos em estudo de caso aplicado à Região de Araçatuba. 


\section{Justificativa e Contextualização}

\subsection{Energia, Transformações e Consequências}

A utilização da energia pelo homem confunde-se com os primórdios da história da humanidade. O domínio do fogo, há cerca de 1,8 milhões de anos, transformou a linha evolutiva da espécie humana e abriu caminho para as conquistas territoriais e, posteriormente, intelectuais que se desdobrariam desse ponto até os dias atuais. Assim, a energia, inicialmente base da sobrevivência da raça humana, ganha importância crescente como aspecto de desenvolvimento humano.

Ao longo dessa evolução, observou-se o crescimento da demanda energética em proporção aos níveis de crescimento populacional. Além de condição básica para a sobrevivência da população mundial, a energia é um dos vetores determinantes para o atendimento de níveis mínimos de desenvolvimento humano - influenciando parâmetros como saúde, educação e segurança e, por consequência, contribuindo potencialmente para a redução da pobreza e de taxas de mortalidade - como também para o desenvolvimento econômico e social de diferentes regiões do globo, alterando, com isso, padrões demográficos e rotas migratórias, desigualdades sociais e pressões por urbanização nessas regiões.

Desde o início do período industrial, a oferta de energia mostra-se imprescindível ao crescimento de toda e qualquer infraestrutura de atividade econômica na realização de atividades de transformação e de produção e na locomoção cotidiana de milhões de habitantes, para o exercício das mais variadas funções.

Se, por um lado, a atual era da informação pode ter atenuado o aumento da demanda energética em decorrência da conexão direta de comunicação entre pessoas de todos os continentes, por outro lado, essa integração comercial global traz consigo novas demandas energéticas, que passam a satisfazer a crescentes necessidades humanas em diferentes níveis de conforto, bem estar e qualidade de vida.

De acordo com o Plano Nacional de Expansão de Energia PDE 20102019, o Brasil precisará de uma capacidade instalada adicional entre $3.500 \mathrm{MW}$ e 5.000 MW ao ano, a fim de atender ao seu crescimento econômico nesta 
década (EPE, MME, 2010). Segundo a edição de 2010 do anuário World Energy Outlook, a geração global de eletricidade aumentará em 87\% entre 2007 e 2035, crescendo de 18,8 mil TWh a 35,2 mil TWh nesse período (IEA, 2009).

Esse ritmo de crescimento vem se desdobrando em inúmeros impactos ao homem, a uma enorme variedade de seres vivos e ao meio ambiente que habitam. O planeta seguramente experimentou crises climáticas extremas, mas as suspeitas de que as transformações recentes não seriam provocadas por causas naturais têm sido progressivamente reforçadas pela ciência, de acordo com a atualização dessas avaliações pelo Painel Intergovernamental sobre Mudanças Climáticas da Organização das Nações Unidas - IPCC (IPCC, 2007).

\subsection{Mudanças Climáticas}

Segundo o IPCC, até o fim deste século, a temperatura média da Terra pode subir de $1,8^{\circ} \mathrm{C}$ - na melhor das hipóteses - até mais de $6^{\circ} \mathrm{C}$. Alguns desses efeitos poderão ser sentidos muito antes desse horizonte de tempo; em grandes centros urbanos já é possível observar mudanças climáticas em curso desde 0 século passado. Se o ritmo das emissões atuais for mantido, a temperatura média global romperá a barreira dos $1^{\circ} \mathrm{C}$ em 2040 (I PCC, 2007).

Considerando um aumento de $0,8^{\circ} \mathrm{C}$ registrado desde a Revolução Industrial até os dias atuais, somado ao aumento mínimo de $1,8^{\circ} \mathrm{C}$ previsto pelo IPCC até o final do século, o limite de 450 ppm de concentração de GEE na atmosfera já teria sido ultrapassado. Essa concentração de poluentes pode converter-se em consequências trágicas - colapso dos ecossistemas, fome, escassez de água, migrações em massa, enchentes, elevação do nível do mar, desertificação, aumento de doenças tropicais, além de grandes prejuízos econômicos (BAITELO, PIVA \& FURTADO, 2007).

Efeitos climáticos extremos como a intensificação de ondas de calor e tempestades tropicais, já vêm acontecendo em diferentes locais do globo nos últimos anos, com exemplos em Nova Orleans, no sudeste asiático e no sul e no norte do Brasil. Algumas das consequências desses eventos a longo prazo são o deslocamento da produção agrícola viável, o comprometimento de ecossistemas e habitats animais e alterações no suprimento de água (JACOBSON, 2008). 
De acordo com o IPCC, boa parte do incremento da temperatura média do planeta tem sido provocado por ações antropogênicas, com destaque, em ordem crescente, para o uso do solo, a conversão de florestas nativas e a produção e utilização de energia. As emissões de gases de efeito estufa provocadas pelo desmatamento e pelo uso de energia na indústria, no setor de transportes e na geração de eletricidade apresentam curvas de crescimento que, se não forem inflexionadas no curto e médio prazo, provocarão mudanças irreversíveis no clima global, trazendo consequências enormes para a humanidade, em termos econômicos, socioambientais e políticos.

Acredita-se que essas mudanças podem ser evitadas se a elevação da temperatura média do planeta se mantiver entre 1,5 e 2 graus Celsius até o final do século. Para tanto, as emissões globais deverão ser reduzidas, até 2050, em um valor entre 75 e $95 \%$ da média de emissões de 1990. Para tanto, estima-se que será preciso investir a cada ano entre 1 e 2,5 trilhões de dólares a fim de evitar um quadro ainda pior de impactos climáticos.

O desafio de redução de emissões valerá também para países em desenvolvimento, que deverão comportar a maior parte da população mundial em 2050. Neste sentido, estas nações emergentes devem almejar um modelo de desenvolvimento econômico alavancado pela valorização da biodiversidade e dos recursos naturais renováveis.

\subsection{Panorama Energético no Mundo e no Brasil}

A missão de redução de emissões de gases de efeito estufa envolve ações direcionadas ao controle da conversão de florestas em territórios para múltiplos usos agropecuários, e ações direcionadas à redução do uso de energéticos que impliquem essas emissões - notadamente combustíveis fósseis. Ainda que as atuais reservas comprovadas de petróleo e gás natural sejam suficientes para 0 atendimento de um consumo energético global superior a 30 anos, menos de um quarto dessas reservas de energias fósseis poderão ser utilizadas até 2050, a fim de que a redução necessária de gases de efeito estufa seja alcançada (MEINSHAUSEN, HARE, et al, 2009).

Essas fontes seriam substituídas em grande parte por fontes renováveis e por medidas de redução de consumo energético, ambas com um elevado potencial de implantação no país. Enquanto a participação dessas fontes vem 
sendo reduzida na matriz elétrica brasileira, o aumento da participação das termelétricas movidas a combustíveis fósseis vem sendo possibilitado em parte pela reestruturação do modelo do setor elétrico brasileiro, iniciada no final da década de 90 . O novo modelo ${ }^{1}$ promoveu a desverticalização das atividades de geração, transmissão e distribuição de energia, trouxe a venda de energia por leilões e, por consequência, dificultou a abertura de oportunidades para o desenvolvimento da indústria de energias renováveis. Cerca de $60 \%$ da energia negociada nos certames realizados entre 2004 e 2010 vieram de termelétricas com base em combustíveis fósseis, principalmente, óleo combustível, diesel e carvão. Além do grande impacto ambiental dessas usinas, o impacto econômico das tarifas é considerável, por conta dos elevados custos operacionais de parte dessas termelétricas, que podem superar os R\$400/MWh (SOARES et al, 2009a).

A recente ampliação da participação de usinas termelétricas a combustíveis fósseis na matriz elétrica nacional tem-se balizado na justificativa da redução do risco de novos racionamentos de energia no futuro e na dificuldade de licenciamento de novos projetos hidrelétricos.

Some-se a essa conjuntura, as recentes descobertas das reservas petrolíferas da camada pré-sal e a atenção na fundamentação de um marco regulatório para sua exploração e divisão de lucros, que podem retardar a ampliação das energias renováveis na matriz elétrica nacional dos próximos anos. Os trabalhos legislativos da comissão especial de energias renováveis foram interrompidos durante o ano de 2010, entre outros fatores, por conta da tramitação dos projetos de lei do pré-sal.

Em termos financeiros, ainda que as receitas do pré-sal possam auxiliar o desenvolvimento de pesquisas e subsidiar os custos das fontes renováveis, a quantidade de investimentos mobilizados para a exploração do petróleo e,

\footnotetext{
${ }^{1} \mathrm{O}$ novo marco regulatório de reestruturação do setor elétrico brasileiro foi transformado em lei em fevereiro de 2004, por meio das leis 10.847/04 e 10.848/04 e do decreto regulamentador 5.163/04 (BRASIL, 2004). Foram desverticalizados os ativos dos segmentos da cadeia produtiva do setor elétrico, ou separadas as atividades de geração, transmissão, distribuição e comercialização de energia (UDAETA\&GRIMONI, 2004). A expansão da geração de energia passou a depender de ação empresarial e concorrencial. A partir do Decreto no 5.163/2004, foram instituídos leilões de energia elétrica, com o objetivo de vender a eletricidade de empreendimentos existentes para atendimento às necessidades de mercado das distribuidoras.
} 
posteriormente, para a pesquisa e implantação da captura de carbono pode retardar parte dos investimentos nacionais em energias renováveis ${ }^{2}$.

\subsection{Perspectivas Energéticas e Crescimento de Baixo Carbono}

O contexto de urgência na redução de emissões do setor energético global, aliado ao crescente custo das energias fósseis no longo prazo aponta a necessidade de busca de novas opções energéticas por abordagens alternativas de planejamento.

No âmbito brasileiro, as condições geográficas e climáticas - índices de radiação solar de até $2.300 \mathrm{kWh} / \mathrm{m}^{2} / \mathrm{ano}$, potenciais hidrológico e eólico altamente favoráveis - colocam o país em posição privilegiada para a transformação desses recursos em geração de energia renovável.

Além de recursos energéticos do lado da oferta, há um grande potencial a ser explorado do lado da demanda. O desafio do planejamento energético atual é empreender uma revisão conceitual de metodologias de avaliação baseadas na expansão da oferta de energia, incorporando a inclusão de alternativas representadas por medidas de gerenciamento de carga, eficiência energética e uso consciente e racional da energia nos diversos setores de consumo.

A análise imparcial de ambos os grupos de recursos energéticos - dos lados da oferta e da demanda - estende-se além do custo econômico dessas opções, ao tratar de múltiplos impactos e benefícios de sua implantação nas diferentes áreas política, social e ambiental.

Os exemplos observados na Alemanha e na Espanha mostram que ambos os grupos de recursos devem ser trabalhados em conjunto. $O$ aumento de participação de energias renováveis na matriz elétrica desses países não tem sido suficiente para reduzir a emissão de poluentes atmosféricos locais. A crescente capacidade instalada eólica e solar desses países é compensada pela elevada participação de termelétricas a carvão em suas matrizes elétricas. Por mais que o crescimento da geração renovável supere o avanço das térmicas movidas a combustíveis fósseis, resultados significativos de redução de emissões

\footnotetext{
${ }^{2}$ O cenário de abundância de petróleo pode facilitar a ampliação de combustíveis fósseis na matriz energética em detrimento da exploração de novas opções energéticas e tecnológicas, haja vista a intenção do MME de estudar a implantação do diesel em carros de passeio, que indica a opção por um combustível poluente, ao invés de investimentos na pesquisa de outras opções energéticas para uso veicular, como tecnologias de veículos híbridos, elétricos, entre outros.
} 
nacionais apenas serão obtidos em um quadro de políticas que incluam a implantação de programas e ações de redução de consumo de energia.

\subsection{Desenvolvimento Sustentável e Ecodesenvolvimento}

O estudo de estratégias para o equacionamento entre o crescimento econômico e o incremento de impactos socioambientais vem sendo caracterizado há mais de vinte anos sob o amplo conceito de desenvolvimento sustentável. 0 termo foi definido no relatório Nosso Futuro Comum da Comissão Mundial sobre Meio Ambiente e Desenvolvimento (CMMAD) da Organização das Nações Unidas (ONU), como "o desenvolvimento que satisfaz as necessidades presentes, sem comprometer a capacidade das gerações futuras de suprir suas próprias necessidades" (CMMAD, 1987).

No decorrer desses anos, porém, a expressão tem sido crescentemente rechaçada por grupos de atores climáticos e ambientalistas, entre acadêmicos e especialistas, por ter sido arbitrariamente massificada nos mais diferentes setores da sociedade, sem que o significado semântico da expressão tenha sido convertido na efetiva concretização do desenvolvimento econômico e social aliado ao equilíbrio do deplecionamento de recursos naturais. De acordo com Vieira, o cruzamento das diferentes interpretações do conceito de sustentabilidade e das opções possíveis para colocá-lo em prática tem instaurado um confuso debate até os dias de hoje (SACHS, VIEIRA, 2007).

Paralelamente, o conceito de Ecodesenvolvimento, a partir de 1972, também passa a designar um novo estilo de desenvolvimento com enfoque participativo de planejamento e gestão, norteado por postulados éticos como o atendimento de necessidades humanas fundamentais e o cultivo da prudência ecológica, por um lado, e o apontamento das limitações de esquemas convencionais de planejamento, por outro. O princípio passava a apoiar avaliações participativas e estratégias integradas de harmonização de objetivos socioeconômicos, sociopolíticos e socioambientais de desenvolvimento, por meio da valorização de potenciais subutilizados de recursos naturais em cada contexto socioecológico (BERKES, 1989, apud SACHS, VIEIRA, 2007).

$\mathrm{Na}$ Cúpula Mundial sobre Desenvolvimento Sustentável, realizada em Johanesburgo em 2002, o conceito de desenvolvimento sustentável era ainda definido dentro do trinômio de viabilidade econômica, justiça social e equilíbrio 
ecológico. O equacionamento dessas três variáveis vem-se revelando, contudo, mais uma aspiração estratégica de longo prazo dos países-membros do que um critério concreto para a seleção, aplicação e utilização de recursos naturais e energéticos atualmente disponíveis.

De acordo com Carlos Nobre, pesquisador científico do INPE, O Brasil ainda apresenta muitos resquícios do desenvolvimentismo da era militar e pouca percepção de que uma trajetória sustentável é possível ${ }^{3}$.

O desafio presente de governos e grupos de planejadores e tomadores de decisão persiste na alteração de parâmetros de avaliação econômica e social, no remodelamento de sistemas de produção e consumo e na conciliação da sustentabilidade em múltiplas dimensões.

\subsection{Planejamento Tradicional e Propostas Alternativas}

O planejamento energético adotado pela administração federal mostra que os preceitos da linha tradicional continuam sendo seguidos. O Plano Decenal de Expansão da Energia, produzido pelo Ministério de Minas e Energia, é um dos exemplos de planejamento norteado por metodologias de desenvolvimento tradicional. $O$ documento, que traça as metas energéticas para o setor no período 2010-2019, prevê, em sua última versão, a expansão de termelétricas a combustíveis fósseis e o aumento de praticamente $100 \%$ das emissões do setor elétrico nesse período. Ainda que o plano preveja a expansão de fontes renováveis como biomassa e eólica, os resultados contradizem as propostas de redução de gases de efeito estufa contidas no Plano Nacional de Mudanças Climáticas e as mais recentes metas de redução de emissões de gases de efeito estufa - entre 36 e 38\% - levadas à Conferência das Partes 15, em Copenhague.

O documento projeta que a capacidade total de geração do país saltará dos atuais 112,4 mil megawatts (MW) para 167,1 mil MW em 2019. O potencial será atendido em praticamente $70 \%$ por grandes hidrelétricas e $12,9 \%$ por fontes renováveis complementares. A eficiência energética contribui com apenas 3,2\% da redução do consumo projetado para o horizonte final de análise.

A geração termelétrica será ampliada de 16.420 para $25.438 \mathrm{MW}$. O resultado dessa expansão é o crescimento do volume de emissões de $\mathrm{CO}_{2}$ no

\footnotetext{
${ }^{3}$ LOURENÇO, L. "Cientista quer combate ao avanço da pecuária sobre floresta para diminuir desmatamento da Amazônia". Agência Brasil, publicado em 15 de julho de 2008.
} 
setor elétrico, dos atuais 25 milhões de toneladas por ano para cerca de 51 milhões em 2019 (EPE, MME, 2010).

A obtenção de energia com base nesses recursos implica diversos tipos de impactos negativos, em diferentes escalas, de acordo com a fonte energética explorada e a tecnologia empregada. Esses impactos são frequentemente considerados marginais sob uma análise técnico-econômica e não são integralmente abordados dentro do paradigma tradicional de planejamento energético.

Como opções suplementares, diferentes cenários de atores políticos e energéticos mundiais propõem o aumento da utilização de fontes renováveis e a adoção de medidas de eficiência energética, acompanhados, em alguns casos, pela ampliação da geração nuclear e pelo sequestro e armazenamento de carbono emitido em termelétricas movidas a combustíveis fósseis.

A crítica ao planejamento energético conduzido em âmbito federal é compartilhada por organizações da sociedade civil e instituições acadêmicas, ilustrada em exemplos de cenários energéticos elaborados em parceria. $\mathrm{O}$ cenário [r]evolução energética do Greenpeace mostra que é possível manter, em um horizonte de longo prazo, a participação de $92 \%$ de energias renováveis, na matriz elétrica aliada à redução de $26 \%$ da projeção do consumo de eletricidade. O cenário prevê a diversificação entre as fontes eólica, solar, biomassa e hidrelétricas (em pequenas centrais), aproveitadas em diferentes tecnologias. A geração elétrica a carvão, óleo diesel e nuclear é totalmente eliminada da projeção para o ano de 2050.

O estudo Agenda Elétrica Sustentável 2020 da WWF-Brasil considera um potencial de redução de consumo de $40 \%$ e a participação de $88 \%$ de energias renováveis na matriz elétrica nacional de 2020.

Como reflexo desses estudos, aponta-se, desde 2008, a projeção de metas de redução de emissões de gases de efeito estufa no World Energy Outlook da Agência Internacional de Energia (IEA, da sigla em inglês) e a intenção da recém fundada IRENA (Agência Internacional de Energias

\footnotetext{
${ }^{4} \mathrm{O}$ aumento de emissões de gases de efeito estufa projetados para a matriz elétrica brasileira não seguem proporção linear em relação à ampliação da capacidade instalada termelétrica justamente por conta da variabilidade de despacho dessas usinas.
} 
Renováveis, do inglês) de desenvolver e propor um cenário energético de baixas emissões.

O equacionamento e a análise das melhores opções energéticas, capazes de atender ao crescimento econômico com a minimização de impactos socioambientais e políticos, começou a ser respondido há algumas décadas, com o surgimento do Planejamento Integrado de Recursos, na América do Norte. 


\section{Planejamento Integrado de Recursos}

\subsection{Introdução}

O Planejamento Integrado de Recursos Energéticos (PIR), originado como processo de planejamento energético de concessionárias e distribuidoras norteamericanas é, por natureza, uma metodologia de seleção da expansão da oferta de energia elétrica. Para tanto, a metodologia do PIR parte de um conjunto de recursos energéticos disponíveis em uma região ou local e aponta, dentre essas opções, aqueles que devem ser preferencialmente aproveitados, de modo a orientar a busca pela satisfação das necessidades dos diversos agentes do setor, seja por uma implementação regulamentada ou por direcionamentos preferenciais de investimentos e políticas.

Sua evolução em pesquisas no Brasil e no mundo tem-se caracterizado pela diferenciação do planejamento energético tradicional no que se refere, principalmente, à indiscriminação de recursos do lado da demanda no elenco de alternativas energéticas e à inclusão de aspectos ambientais, sociais e políticos na análise de viabilidade desses recursos.

\subsection{Origem do PIR}

O processo de planejamento de concessionárias norte-americanas nos anos 60 era diretamente concentrado na expansão da oferta energética. $O$ crescimento constante na demanda de eletricidade permitia a manutenção da economia de escala para a construção contínua de usinas, reduzindo o custo marginal de implantação de novos empreendimentos. As tarifas de eletricidade eram estáveis e o planejamento consistia, principalmente, em determinar o cronograma de adição de grandes empreendimentos capazes de atender ao crescimento da carga elétrica. Técnicas simples de projeção eram suficientes para atender a demandas energéticas futuras.

$\mathrm{Na}$ década de 1970, diferentes acontecimentos políticos e ambientais, como o embargo árabe do petróleo, o início da implantação de procedimentos de controle de emissões de usinas termelétricas e o acidente da usina nuclear de Three Mile Island afetam a incerteza do custo estrutural do setor elétrico, com o aumento das tarifas e a redução do crescimento da carga. 
A competição de venda de eletricidade passa a ser estimulada como resultado do PURPA ${ }^{5}$ - Lei Regulatória de Concessionárias, da sigla em inglês. Ações de eficiência energética evoluem para o conceito de gerenciamento pelo lado da demanda e o planejamento de mínimo custo evolui para o planejamento integrado de recursos, definido na Lei Nacional de Políticas Energéticas de 1992. (TVA, 2009)

Essas mudanças drásticas criam a necessidade de ferramentas mais sofisticadas de planejamento para orientar decisões de concessionárias referentes à implantação de recursos energéticos. Assim, surge a possibilidade de formular o atendimento à variação da demanda energética por meio de mecanismos mais elaborados como carteiras energéticas, capazes de diversificar o suprimento da oferta com a redução de riscos técnicos e econômicos.

O PIR atual é um aperfeiçoamento do conceito de planejamento de menor custo, introduzido em meados da década de 1980. Essa evolução inclui a escolha das melhores opções energéticas dos lados da oferta e da demanda por meio de análises multicriteriais, por meio do envolvimento de atores do setor energético no processo de planejamento e por meio da projeção de cenários energéticos de médio e longo prazo como forma de minimizar os riscos do oferecimento de serviços energéticos.

Ainda que os exemplos mais claros do PIR estejam concentrados na América do Norte, há exemplos de aplicações de PIR ou derivações próximas em diferentes regiões do mundo.

Nos Estados Unidos, o arcabouço regulatório do PIR foi adotado ou explorado em 41 estados no ano de 1992 (Mitchell, 1992, apud D`Sa, 2005). O processo de planejamento fomentou a competição de diferentes opções energéticas de oferta e de demanda nos planos de concessionárias.

A desverticalização de mercados de energia iniciada no final desta década enfraqueceu o conceito de planejamento regional de longo prazo com envolvimento público, uma vez que a desregulamentação do setor passou a favorecer a tomada individual de decisão de investidores e empreendedores

\footnotetext{
5 A lei de 1978 é vista como um marco na história da desregulamentação dos estados americanos, com a permissão de produção e comercialização de energia pelas concessionárias, em competição com monopólios naturais. Sobre estas, portanto, recaía a pressão competitiva por setores de mercado e pela busca de melhores preços para disponibilizar estes novos potenciais (TVA, 2009).
} 
(Northwest Power Planning Council, 1998, apud D`Sa, 2005). Ainda assim, mais da metade dos estados norte-americanos manteve o PIR, convertendo o processo obrigatório para concessionárias em opcional, ou transformando-o em termo de compromisso de metas de investimentos em medidas de gerenciamento de demanda e geração renovável. O PIR, em alguns casos, passou a ser um processo informativo de concessionárias, sem caráter aprovativo. Vale ressaltar que, em todos esses casos, as premissas teóricas do planejamento foram mantidas.

Experiências européias em PIR podem ser exemplificadas pela Dinamarca - cuja lei de eletricidade de 1994 continha a obrigação de um processo de PIR, concretizado em um plano de 20 anos, coordenado pelo ministério de energia -, e por programas focados no gerenciamento do lado da demanda na Holanda, Reino Unido e Alemanha (Wuppertal Institute et al., 2000).

À maneira da experiência norte-americana, em que pese a desverticalização das atividades do setor elétrico, as premissas do PIR foram mantidas na diretiva de Técnicas de Planejamento Racional ${ }^{6}$. Em alguns países, a reestruturação do setor elétrico trouxe a figura do operador nacional do sistema, a quem cabia desenvolver um panorama de opções de oferta que possibilitassem que consumidores e investidores avaliassem oportunidades futuras ${ }^{7}$.

Antes da onda de reformas do setor elétrico, países em desenvolvimento registraram experiências relacionadas a planejamento de custo mínimo, que, por não incluírem uma análise integrada da oferta com o lado da demanda, ou por não estarem incluídas em planos energéticos federais ou estaduais, não poderiam ser denominadas de PIR. Citam-se exemplos na África do Sul (Planejamento Integrado e Estratégico de Eletricidade, conduzido pela concessionária Eskom) e na Tailândia (com a criação do escritório de Gerenciamento pelo Lado da Demanda em sua distribuidora Nacional) (D'Sa, 2005). Em outros casos, foram conduzidos inúmeros exercícios acadêmicos de

\footnotetext{
${ }^{6}$ A diretiva de Técnicas de Planejamento Racional (ou RPT, da sigla em inglês) da Comissão Européia, consistiu na avaliação integrada de opções de oferta e demanda. Foi considerada pelo parlamento europeu como um complemento à diretiva que estabelecia a competição da oferta de eletricidade (Wuppertal Institute et al., 2000).

${ }^{7}$ No Reino Unido e na Austrália, os órgãos responsáveis pelo gerenciamento da rede e do mercado de eletricidade preparam planos de oportunidades de 7 e 10 anos, respectivamente (D`SA, 2005).
} 
PIR na Índia (Reddy et al., 1991 apud D’Sa, 2005) e no Brasil, que serão detalhados no próximo item.

Após as reformas do setor elétrico, surgiram mudanças de legislação e organização para apoio a programas e ações de eficiência energética, mas estas não foram integradas ao processo de planejamento energético principal. Como exemplos, citam-se a Índia, a Tailândia e mesmo o Brasil. Exceção se fez à África do Sul, no qual o PIR foi desenvolvido em 2002 (NER-SA, 2002 apud D'Sa, 2005). ${ }^{8}$

A planificação do atendimento à demanda energética por meio de ações conjuntas entre a ampliação da oferta e a eficientização de usos finais tem exemplos ainda em Cuba (HERNANDEZ, 2007). A proposição de um planejamento integrado de recursos para a China foi sugerida por Bradford (BRADFORD, 2005) e em caráter de IRSP (Planejamento Integrado e Estratégico de Recursos), para mercados liberalizados (HU, et al, 2010).

\subsection{PIR no Brasil}

As experiências de PIR no Brasil consistem em iniciativas realizadas em instituições de ensino superior e institutos de pesquisa, exemplificadas em publicações de Jannuzzi (JANNUZZI, 1995; JANNUZZI et al, 1997; SWISHER et al, 1997); Bajay (1996), e no estudo de aplicação de ações integradas de oferta e demanda em Roraima (SAUER, 1996). Somam-se a esses esforços a proposta de PIR elaborada pela CEMIG (UDAETA, 1997), a única iniciativa de planejamento proposta por concessionárias, ainda que não tenha sido colocada em prática ou tornada publicamente disponível ${ }^{9}$.

A fundamentação teórica da metodologia desenvolvida no GEPEA (UDAETA et al, 2003) e trabalhada na USP desde a segunda metade da década de 1990 foi feita por Udaeta (UDAETA, et al, 1997).

\footnotetext{
${ }^{8} \mathrm{Na}$ África do Sul, o PIR foi recomendado em documento oficial de políticas energéticas, vinculado à exigência para o licenciamento de novas plantas e (D'Sa, 2005, apud DME-SA, 1998), incluído na nova Lei de Energia e desenvolvido em 2002 em cooperação com a divisão de Planejamento da Eskom (D'Sa, 2005, apud NER-SA, 2002).

${ }^{9}$ A iniciativa mostrava indícios do plano de atuação futura da empresa na direção de aliar a diversificação da geração de energia a diferentes formas de gerenciamento da demanda a fim de atender à sua crescente carga.
} 
Esse PIR na USP apresenta caráter amplo de aplicação, não se restringe a instrumento governamental ou ferramenta empresarial ou corporativa. O PIR estudado e aprimorado desde então é manuseável e adaptável a diferentes entidades (estatais, associações não-governamentais, locais, entre outras), a diferentes espaços geográficos e períodos temporais, ao trabalhar cenários e não apenas demanda de mercado. Sua primeira aplicação foi na região do Médio Paranapanema, no Estado de São Paulo (UDAETA et al, 1999) e a segunda experiência foi proposta na região Amazônica (UDAETA et al, 2001).

Após essas aplicações, os trabalhos concentraram-se na Região Administrativa de Araçatuba, divididos em duas etapas. O PIR realizado na Região de Araçatuba foi desenvolvido no âmbito do projeto "Novos Instrumentos de Planejamento Energético visando o Desenvolvimento Sustentável do Oeste Paulista", inserido no Programa de Pesquisas em Políticas Públicas da FAPESP (Fundação de Amparo à Pesquisa do Estado de São Paulo). O projeto foi coordenado pelo GEPEA (Grupo de Energia do Departamento de Energia e Automação da Escola Politécnica da USP) e pelo IEE/USP (Instituto de Eletrotécnica e Energia da USP) e realizado em parceria com a Cooperhidro (Cooperativa do Pólo Hidroviário de Araçatuba) e a Agência de Desenvolvimento Regional, que auxilou os trabalhos de pesquisa na região do Oeste Paulista e desenvolveu atividades de fomento ao aproveitamento da infraestrutura e recursos da região do Oeste Paulista.

\subsection{Metodologia do PIR}

O PIR segue diretrizes comuns de processos de planejamento energético e faz uso de etapas conhecidas de análise, às quais agregam-se diferenciações conceituais e filosóficas.

Das principais particularidades, ressaltam-se a abrangência da análise de recursos energéticos - extendida a fontes energéticas, tecnologias de conversão e a cadeia energética envolvida na disponibilização do recurso-, a inclusão de opções de recursos energéticos de diferentes perfis e origem no processo de planejamento e a caracterização de recursos energéticos em caráter multicriterial, dentro de diferentes dimensões de análise. 
Ao longo do horizonte de pesquisa, o PIR apresentou estruturas de diferentes graus de complexidade. A pesquisa desenvolvida na USP tem aprimorado as etapas existentes e agregado modificações à estrutura e à complexidade do processo geral.

Pode-se dizer que o Planejamento Integrado de Recursos Energéticos trabalhado atualmente na USP tem funcionalidade modular e suas etapas podem ser aplicadas separadamente, servindo de ferramenta a diferentes grupos de tomadores de decisão.

A estrutura atual do PIR está dividida nas seguintes etapas fundamentais: estruturação de informações prévias, caracterização de recursos energéticos, cômputo e valoração dos potenciais completos, ranqueamento de recursos energéticos, previsão da demanda energética, mapeamento energoambiental, plano preferencial integrado de recursos energéticos e plano de ação.

\subsubsection{Informações Prévias}

Inventário Energoambiental: Análise de variáveis de natureza ambiental, social e política do planejamento energético, com base na descrição de parâmetros relacionados ao meio ambiente, dentro dos domínios biofísicos do solo, da água e da atmosfera, contemplando o levantamento do domínio antrópico. A análise apóia-se em bancos de dados existentes e disponíveis nas regiões de estudo.

Listagem e Seleção de Recursos Energéticos: etapa de pesquisa e determinação de recursos energéticos locais, dos lados da oferta e demanda. Esses recursos são descritos em termos de fontes energéticas, segmentadas por diferentes formas de utilização - em tecnologias associadas, medidas e ações de gerenciamento e eficientização do uso de energia, e setores de geração ou consumo.

Identificação dos En-In: o mapeamento dos agentes e atores energéticos é realizado por meio da troca de experiências em pesquisas e entrevistas locais, reuniões, treinamentos técnicos de PIR - específicos para cada dimensão de análise de recursos energéticos - e na realização de dinâmicas de avaliação de custos completos desses recursos energéticos nas quatro dimensões. 


\subsubsection{Caracterização de Recursos Energéticos}

Metodologia utilizada para consolidar o levantamento e o estudo dos recursos e tecnologias energéticas dos lados da oferta e da demanda. Com tal metodologia, é feita a pesquisa e a organização das características holísticas dos recursos, dentro das esferas técnico-econômicas, ambiental, social e política de análise. Essas dimensões pautam a caracterização de seus atributos - ou representações de impactos inerentes à utilização e implantação de recursos resultando na avaliação completa dos recursos energéticos quanto a custos e benefícios provenientes de seu emprego.

\subsubsection{Cômputo e Valoração dos Potenciais Completos (CVPC)}

O processo de Cômputo e Valoração de Potenciais Completos de Recursos Energéticos (CVPC) abrange a valoração - em termos relativos e absolutos - de todos os atributos referentes aos recursos energéticos nas quatro dimensões do PIR. Esses valores são balizados pelos potenciais energéticos teóricos, realizáveis e de mercado - aplicáveis na região. A formulação e a delimitação desses potenciais valem-se das possibilidades naturais locais, bem como de limitações de diferentes ordens impostas pelas quatro dimensões de análise.

\subsubsection{Ranqueamento de Recursos Energéticos}

O conjunto de informações trabalhadas na etapa de CVPC forma matrizes de valoração de potenciais específicas para cada recurso energético. A comparação desse conjunto de informações entre recursos possibilita 0 ranqueamento ou classificação dos recursos energéticos em função de seu desempenho na somatória de todos esses atributos.

O processo aplica a metodologia de Análise de Custos Completos (ACC) baseada no Processo de Análise Hierárquica (PAH).

O Ranqueamento Final indica a priorização de recursos energéticos. Tal ranqueamento é obtido por meio do cruzamento das ACCs Qualitativa e Determinística, com base em dados numéricos coletados no processo da 
valoração e da avaliação inferida entre os envolvidos e interessados - da região de estudo - e os especialistas de PIR.

\subsubsection{Previsão da Demanda Energética}

A classificação de recursos permite seu ordenamento, e sua implementação é realizada pela previsão das necessidades de energia, modelada por meio de cenários energéticos. Os cenários incluem diferentes premissas e condicionantes econômicas, políticas e socioambientais em sua modelação e constituem ferramenta fundamental para a formulação da previsão de demanda energética local e sua conjugação à disponibilidade local e regional de recursos energéticos.

\subsubsection{Mapeamento Energoambiental}

O objetivo essencial do Mapeamento Energoambiental é construir os indicadores ambientais que podem influenciar e delimitar a implementação dos projetos de expansão energética elaborados pelo cenário. Dessa forma, 0 processo de mapeamento atribui um filtro de avaliação holística às diretrizes formuladas pelos cenários energéticos, influenciando 0 resultado do planejamento que será proposto no plano preferencial integrado.

O propósito do trabalho de confecção de indicadores para aplicação no processo de PIR é estabelecer intervalos entre a situação atual (fotografia dos meios terrestre, aquático, aéreo e antrópico no tempo e na geografia específicos à região estudada) e os parâmetros encontrados na legislação e normas internacionais de qualidade ambiental. As variáveis definidas fazem parte de metodologias já utilizadas por companhias e instituições de monitoramento ambiental.

\subsubsection{Plano Preferencial Integrado de Recursos Energéticos}

O plano preferencial é composto pelas etapas de integração de recursos energéticos seguida da formação de carteiras energéticas por grupos de recursos energéticos implementados posteriormente em um plano de ação.

A Integração de Recursos Energéticos concilia o atendimento da demanda prevista pelos diferentes cenários ao longo do tempo por meio da inserção dos 
recursos energéticos previamente ranqueados. Essa inserção resulta no refinamento dos potenciais realizáveis previamente calculados à luz dos parâmetros vigilantes determinados na etapa de mapeamento energoambiental.

A formação de carteiras energéticas organiza os recursos resultantes da integração energética em conjuntos capazes de atender a diferentes requisitos de mínimo custo, segurança de investimentos ou benefícios sociais e ambientais.

\subsubsection{Plano de Ação}

Etapa final do PIR em que grupos de recursos selecionados na etapa de plano preferencial são analisados em termos de atratividade financeira. Em outras palavras, o plano determina o potencial de mercado dos recursos selecionados a serem implantados localmente.

Segue, na Figura 1, o diagrama atualizado das etapas do Planejamento Integrado de Recursos Energéticos. 


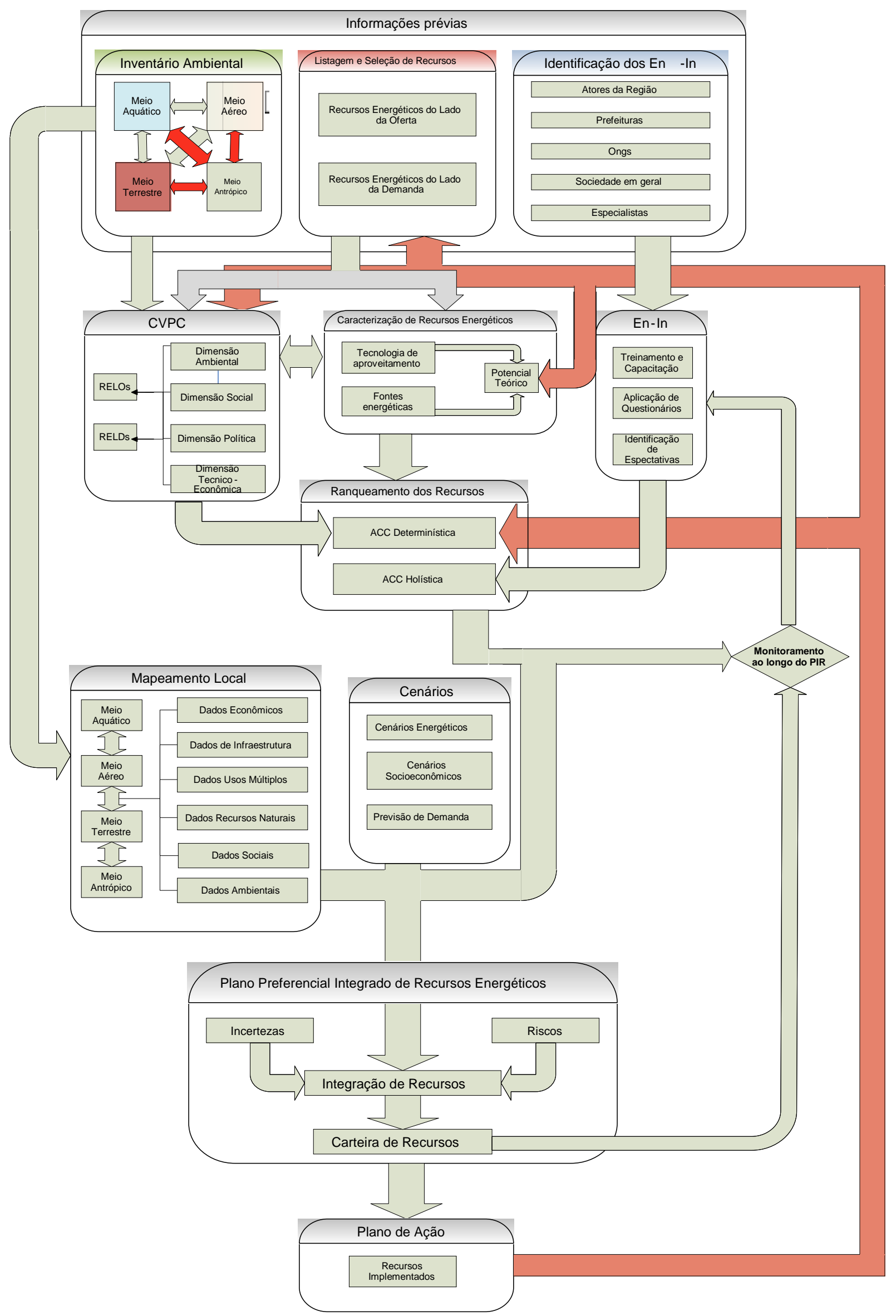

Fonte: UDAETA et al, 2009

Figura 1: Diagrama Esquemático do Planejamento Integrado de Recursos Energéticos 


\section{Cômputo e Valoração dos Potenciais Completos de Recursos Energéticos}

\subsection{Conceito e Justificativa}

O custo de um serviço energético é composto por diferentes atributos técnicos e econômicos relacionados à cadeia de produção do energético, à tecnologia utilizada para sua conversão em eletricidade e à estrutura necessária para a construção do sistema de geração. $O$ arranjo de composição desse custo equaciona diferentes parâmetros de funcionamento visando conferir economicidade ao valor final do projeto. A formação desse preço final, ainda que busque incluir gastos relacionados a compensações por impactos socioambientais, não alcança o desafio de incorporar integralmente esses custos.

O cômputo e a valoração completa dos potenciais de recursos energéticos (CVPC) busca mensurar esses impactos e incorporar diferentes externalidades à avaliação e mensuração de atributos relacionados à análise desses recursos. Esse exercício representa uma das principais etapas do planejamento integrado de recursos e deve ser considerado como parte imprescindível de qualquer processo de planejamento energético que intencione analisar preocupações socioambientais.

Essa contabilização pretende ir além da monetarização de impactos socioambientais no preço da energia e da análise qualitativa desses impactos, considerando as limitações desses processos e as exigências impostas aos planejadores energéticos em estabelecer limites de custos socioambientais à energia ofertada.

Assim, a elaboração desses custos ou potenciais completos pretende valer-se, além de fatores técnicos, de restrições socioambientais e políticas a essa ponderação.

Para tanto, são levantados e concebidos indicadores representativos a cada atributo do recurso analisado, computados ou traduzidos em valores relativos e absolutos. Essa contabilização parte da determinação e do cálculo de potenciais teóricos e realizáveis referentes a cada recurso energético que, por sua vez, assimilam limitações de utilização e conversão de energia impostas por fatores das quatro dimensões de análise. 
O objetivo desse processo de cômputo e valoração é a definição e construção precisa de potenciais completos de cada recurso - considerando fonte energética e tecnologia utilizada para sua conversão. A valoração de recursos energéticos no âmbito do PIR aproxima-se de metodologias de análises multicriteriais tradicionais, assumindo o desafio de quantificação dos impactos considerados e incorporando ao processo a variável política, de extrema importância para a viabilidade de recursos energéticos ${ }^{10}$.

O cômputo de potenciais completos dos recursos transcende a análise completa de um recurso ao não se valer apenas de fatores usualmente contemplados para a composição de tarifas energéticas - abordando benefícios técnicos, econômicos, sociais e ambientais no processo de CVPC ${ }^{11}$. Assim, os indicadores produzidos e levantados não se restringem à monetarização de impactos sociais, ambientais e políticos.

Esse raciocínio justifica-se ao se observar o desafio cada vez mais presente na agenda de planejadores energéticos - concessionárias, governo federal, grandes consumidores e geradores - em incluir em suas análises a contabilização de atributos energéticos menos tangíveis. Um exemplo deste desafio é representado na prática pela recente imposição de limites de emissão de gases de efeito estufa em empreendimentos energéticos, observada em exemplos em diferentes partes do mundo ${ }^{12}$.

No PIR, os valores quantificados e qualificados são explicitados em diferentes atributos em todas as dimensões de análise. A formatação se justifica pelo argumento de que a implementação de um determinado recurso deve se basear nos múltiplos potenciais de uma tecnologia em atender à solução de uma

\footnotetext{
${ }^{10}$ Como exemplos de fatores políticos, citam-se o apoio governamental na construção de políticas de incentivo a determinados tipos de recursos ou a decisão estratégica de privilegiar o desenvolvimento de uma determinada fonte.

${ }^{11} \mathrm{Na}$ primeira fase do PIR conduzido na Região de Araçatuba, optou-se por realizar a caracterização de recursos energéticos utilizando-se a ferramenta de Avaliação de Custos Completos, em sua forma holística, como instrumento de ranqueamento de recursos. A determinação de indicadores quantitativos não foi possível para a análise de parte dos atributos do processo.

${ }^{12}$ A restrição norte-americana de índices de emissões de usinas a carvão para a liberação do licenciamento ambiental destes empreendimentos é acompanhada no Brasil pela proposição da Instrução Normativa número 7 do IBAMA, que propõe compensações ambientais a termelétricas movidas a combustíveis fósseis, o que restringe sua implantação por conta da alteração da economicidade desses projetos.
} 
demanda energética, considerando custos completos derivados de diferentes dimensões de análise.

O critério de decisão instantânea por um determinado recurso restrito ao seu custo ou valor monetário mostra-se limitado para a resolução de problemas que transcendem o objetivo de atendimento energético ao menor custo possível $^{13}$. Mesmo em termos econômicos, observa-se o risco dessa decisão diante da variação desse parâmetro ao longo do tempo, em taxas tendencialmente crescentes para combustíveis fósseis - dada a progressiva redução de suas reservas - e tendencialmente decrescentes para energias renováveis - como reflexo da curva de aprendizado tecnológico desses recursos.

Outra limitação dessa análise unidimensional é a dificuldade de incorporar aos valores monetários benefícios decorrentes da aplicação combinada entre diferentes recursos energéticos. A complementaridade entre fontes energéticas, como é o caso da atuação das gerações eólica e de biomassa no atendimento da oferta de sistemas energética em períodos de baixa geração hídrelétrica, não pode ser tecnicamente representada nas tarifas referentes a cada um desses recursos.

\subsection{Estado da Arte de Procedimentos Correntes de Valoração}

A fim de estudar a incorporação de aspectos sociais e ambientais no processo de planejamento energético, foram desenvolvidas diferentes metodologias de precificação, valoração e internalização de impactos.

Como técnicas econômicas de valoração, figuram: a atribuição de valor econômico de recursos ambientais em valores de uso e de não uso (considerando o valor do consumo do recurso ou, por outro lado, o valor de existência e preservação desse recurso); o custo de perda de produção (agrícola, pesqueira, entre outras); o conceito de disposição para pagar por um recurso (em uma tentativa de atribuir valor a produtos em mercados hipotéticos, paralelos aos mercados reais); e a quantificação de dano (como resultado da contabilização de funções Dose-Resposta de um recurso, aplicadas a um caso particular).

\footnotetext{
${ }^{13}$ Em 1970, as Emendas Norte Americanas de Ar Limpo (U.S. Clean Air Act Amendments) proibiram o emprego do fator de custo como base para a determinação de regulamentações de padrões de poluição aérea.
} 
A internalização desses custos em empreendimentos reais tem sido praticada em diferentes métodos, entre os quais a taxação (pagamento proporcional ao custo da degradação provocado pelo uso do recurso), o oferecimento de subsídios (como incentivo à redução ou eliminação da poluição na implantação de um recurso), a fixação de padrões e normas máximas de poluição e a negociação de licenças de poluição ou emissão que equilibrem o alcance dessas metas entre diferentes agentes ou empreendedores (MARIANO, 2001).

Alguns desses métodos e técnicas são aplicados a diferentes linhas de metodologias voltadas à análise de impactos e externalidades de recursos energéticos. Dentre tais linhas, apontam-se: a análise de ciclo de vida (que analisa a utilização de materiais envolvidos na cadeia energética de um determinado recurso desde sua extração até o descarte final), a abordagem de trajetória de impacto (ou Impact Pathway Approach, desenvolvida pela ExternE, que monetariza externalidades relacionadas à saúde pública avaliadas em termos físicos) e a metodologia de Insumo-Produto (Input-Output, que monetariza, para um período de tempo, o fluxo de produtos fabricados e utilizados em uma região de estudo como consequência da implantação de um recurso energético).

Ainda que essa linha de pesquisa seja extremamente importante para a discussão de impactos socioambientais em projetos energéticos, não se pode deixar de notar um considerável grau de discrepância entre os resultados observados na literatura científica, por conta da abrangência de premissas adotadas e do inevitável grau de subjetividade associado a elas.

O ponto comum a esses métodos é a quantificação econômica dos impactos ocorridos nas diferentes dimensões em consequência da implementação de um recurso energético. A objeção ao método não se restringe à dificuldade técnica de tradução de um grande número de atributos à variável econômica, mas, principalmente, à incompatibilidade entre o processo econômico e a realidade ecológica e aos problemas dos efeitos de irreversibilidade de impactos da utilização de recursos sobre o meio ambiente (SACHS, 2007). 


\subsection{Metodologia para Cômputo e Valoração de Potenciais Completos do Lado da Oferta}

O processo de cômputo e valoração de recursos é crucial na estrutura metodológica do PIR, uma vez que recolhe os recursos energéticos inventariados e caracteriza seus diferentes parâmetros técnico-econômicos, sociais, ambientais e políticos, a fim de uniformizar a avaliação das diferentes condições de cada recurso energético para as etapas subsequentes do planejamento: o ranqueamento de recursos e sua inserção no atendimento da demanda energética projetada para a região de estudo.

O processo de CVPC é executado no PIR por meio de algoritmos de valoração. Neste caso, entende-se por algoritmo uma rotina ou série de processos que definem a maneira de resolver uma tarefa ou um cálculo. Desta forma, algoritmos podem ser representados por fórmulas matemáticas ou instruções em um programa, produzindo como respostas parâmetros quantitativos, qualitativos ou holísticos

O procedimento básico de operação dos algoritmos é a utilização de informações prévias referentes aos atributos das quatro dimensões dos recursos energéticos analisados e sua conversão em diferentes tipos de potenciais completos. Estes potenciais alimentarão o Ranqueamento de Recursos fornecendo uma matriz de valoração para orientar o processo de decisão dos Envolvidos e Interessados - e o Plano Preferencial Integrado de Recursos Energéticos - no qual os potenciais serão refinados em carteiras de recursos, de modo a atender à demanda energética local.

Como exemplos desses parâmetros, na dimensão técnico-econômica, citam-se os diferentes custos da cadeia energética, aliados à confiabilidade, à disponibilidade e à vida útil de uma usina, na formação do custo final de geração de energia.

A dimensão política analisa a influência de condições políticas sobre parâmetros técnicos e econômicos a fim de traçar a projeção do desenvolvimento de um recurso. Essas condições incluem a interação dos atores energéticos envolvidos com o recurso em questão ou a disponibilização de instrumentos políticos capazes de favorecer sua implantação. 
$\mathrm{Na}$ dimensão ambiental, o volume de emissões ou rejeitos líquidos e sólidos é resultado de cada etapa da cadeia energética considerada, desde a produção de um combustível à sua queima na operação da usina. Essas emissões sofrem perturbações resultantes de diferentes condições naturais e meteorológicas, determinativas para a deposição das substâncias em uma dada região, ou seu arrasto a regiões externas ao entorno de análise.

A dimensão social quantifica diferentes impactos sobre o conforto e a saúde humana como consequência da implementação de um recurso energético, bem como efeitos positivos relacionados à geração de emprego e renda em uma região, projetados com base em diferentes indicadores técnicos.

As quatro dimensões de análise - técnico-econômica, política, social e ambiental - representam um ângulo prioritário pelo qual se enxerga a questão energética e os diferentes agentes envolvidos no processo (FUJII, UDAETA, 2006). As duas primeiras dimensões abrangem parâmetros que influenciam o custo, a qualidade e a viabilidade de ampliação de utilização de um recurso energético. Já as duas últimas analisam os impactos desse recurso energético sobre o meio ambiente e sua repercussão sobre a sociedade.

Os potenciais completos dos atributos das quatro dimensões de análise são obtidos por diferentes métodos básicos. Parte-se da obtenção de indicadores relativos a esses atributos, em função de energia gerada ou potência instalada. Essa informação pode ser levantada ou aferida na região de estudo, ou pesquisada junto a diferentes fontes de pesquisa.

Esses indicadores abrangem, em diversos casos, diferentes etapas da cadeia energética do recurso avaliado. A ponderação de indicadores de cada etapa em um único fator relativo ao recurso passa, em alguns desses casos, por diferentes avaliações qualitativas ou quantitativas - com a aplicação de restritores a esses indicadores. Os valores relativos desses indicadores são então multiplicados pelos potenciais energéticos teóricos (cuja contabilização maximizando a utilização de parâmetros naturais, geográficos e energéticos), realizáveis (considerando a eficiência de tecnologias e processos, perdas e restrições técnicas) e de mercado, (incluindo condicionantes macroeconômicas, financeiras, políticas e diferentes riscos) originando potenciais completos, diferenciados para cada atributo.

Assim, uma série de funções de valoração segue o exemplo da valoração das emissões aéreas, obtida com base na multiplicação desse potencial energético pelo 
índice ou fator de emissões $(F(a))$ em $\mathrm{g} / \mathrm{kWh}$ ou kg/MWh. A equação padrão abaixo ilustra o procedimento:

\section{CVPCa(RELO)=F(a) x Pot(RELO) (1)}

Onde:

CVPCa(RELO): valoração de atributo a de recurso energético do lado da oferta (RELO) (em diferentes unidades);

$F(a)$ : fator do atributo (diferentes unidades em função de Energia, MWh, ou Potência, MW);

Pot (RELO): potencial de oferta do recurso RELO (em unidades por Energia, MWh, ou Potência, MW).

Outros grupos de atributos são quantificados em valores relativos, medidos pelo gradiente ou variação de alteração em relação ao seu estado anterior, em decorrência da implantação do recurso energético avaliado. Este é o caso de atributos como alteração de qualidade da água e alteração de desenvolvimento humano e econômico de uma região, de acordo com a equação abaixo:

\section{CVPC DH $($ RELO) $=\Delta f(P I B, I D H, E E R)=\Delta f($ IND) (2)}

Onde:

CVPC DH (RELO): valoração de atributo de Desenvolvimento Humano de Recursos do Lado da Oferta (em diferentes unidades);

IND: indicadores que representam o atributo, como variação de PIB, Efeito Emprego-Renda, IDH.

Outro grupo de atributos é valorado pela soma ou inter-relação de parcelas independentes referentes a diferentes etapas temporais ou geográficas. Essa contabilização aplica-se, entre outros casos, ao tempo de construção ou ao custo de conexão total de um empreendimento, de acordo com a equação abaixo:

CVPC Con (RELO) $=\sum_{i=i}^{n} \operatorname{TST}_{i}($ etapa) (3)

Onde:

CVPC Con (RELO): cômputo e valoração de atributo de conexão (em R $\$ / M W h$ ); TST: Tarifas do sistema de transporte de energia (em $R \$ / M W h$ ) 
i: trecho do sistema de transmissão e/ou distribuição de energia

n: número de trechos ou etapas de transporte de energia

Já os atributos da dimensão política recebem uma avaliação essencialmente qualitativa, que parte do mapeamento e da análise de forças e tendências políticas, por meio do levantamento e da extratificação de En-Ins, de políticas de incentivo a recursos energéticos. Esses valores brutos são refinados por simulações ou estimativas de interação ou projeção em diferentes condições políticas e econômicas. O resultado é medido em termos qualitativos, por meio do nível de consenso entre En-Ins, aprovação de licenciamentos para empreendimentos, execução de políticas de integração energética ou alcance de metas de programas de incentivo a recursos energéticos. Assim, não seguem funções matemáticas e, sim, rotinas, como as mostradas a seguir:

\section{Mapeamento - Estratificação - Interações (Simulações)}

\section{- Aferição de Metas - Resultado (4)}

A figura 2 apresenta a estrutura geral de CVPC para os atributos das quatro dimensões do PIR.

O resultado do processo de CVPC é a produção de uma matriz de valoração contendo os potenciais completos referentes a todos os atributos das quatro dimensões de análise. Esta matriz serve de base para a avaliação dos EnIn e o posterior ranqueamento de recursos, bem como para o processo de integração de recursos e formação de carteiras energéticas.

Uma estrutura geral dessa matriz, considerando-se cada coluna para uma dimensão de análise e cada linha para um grupo de recursos (de oferta e de demanda), pode ser vista abaixo:

$$
\varphi=\left[\begin{array}{llll}
\mathbf{D}_{\text {tec-ec }} & \mathbf{D}_{\text {amb }} & \mathbf{D}_{\text {soc }} & \mathbf{D}_{\text {pol }} \\
\mathbf{D}_{\text {tec-ec }} & \mathbf{D}_{\text {amb }} & \mathbf{D}_{\text {soc }} & \mathbf{D}_{\text {pol }}
\end{array}\right]
$$

Onde $\varphi$ é a matriz geral resultante da integração das matrizes das dimensões dos recursos de oferta e demanda; a linha superior representa os RELO e a inferior, os RELD. Cada elemento da matriz constitui uma submatriz específica, que computa a valoração de todos os atributos de cada dimensão. 
Expandindo-se a estrutura em matrizes específicas para as quatro dimensões de análise, explicitando os atributos e alguns recursos energéticos analisados, tem-se:

$$
\operatorname{DTE}_{i, n}=\left[\begin{array}{cccccc}
\text { CUG } & \text { IN } & \text { Qual.En } & \text { Conf } & \text { Fac.Tec. Pot.En. } \\
" & " & " & " & " & " \\
" & " & " & " & " & " \\
" & " & " & " & " & "
\end{array}\right]
$$

$$
\mathbf{D A}_{i, n}=\left[\begin{array}{ccc}
\text { Meio Aéreo } & \text { Meio Aquático } & \text { Meio Terrestre } \\
" & " & " \\
" & " & " \\
" & " & "
\end{array}\right]
$$

$\mathrm{DS}_{\mathrm{i}, \mathrm{n}}=\left[\begin{array}{ccccc}\text { Emp } & \text { Desl.Pop. } & \text { Des.Ec./Hum } & \text { Alt.Conforto } & \text { Saúde/Agric. } \\ " & " & " & " & " \\ " & " & " & " & " \\ " & " & " & " & "\end{array}\right]$

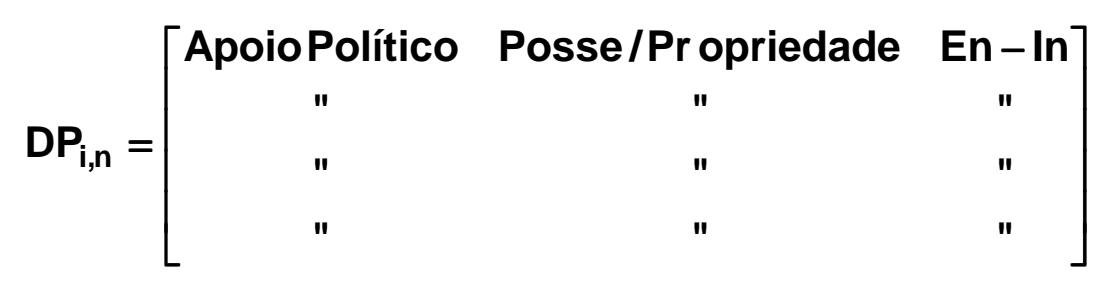

\section{Onde:}

DTE: matriz específica da dimensão técnico-econômica;

DA: matriz específica da dimensão ambiental;

DS: matriz específica da dimensão social;

DP: matriz específica da dimensão política;

i: varia em função do número de recursos;

$\mathrm{n}$ : varia em função do número de atributos.

Os itens seguintes apresentam 0 detalhamento da construção de algoritmos de cômputo e valoração de recursos energéticos dos lados da oferta e demanda, para cada um dos atributos das quatro dimensões de análise. 


\section{Algoritmo Geral CVPC}

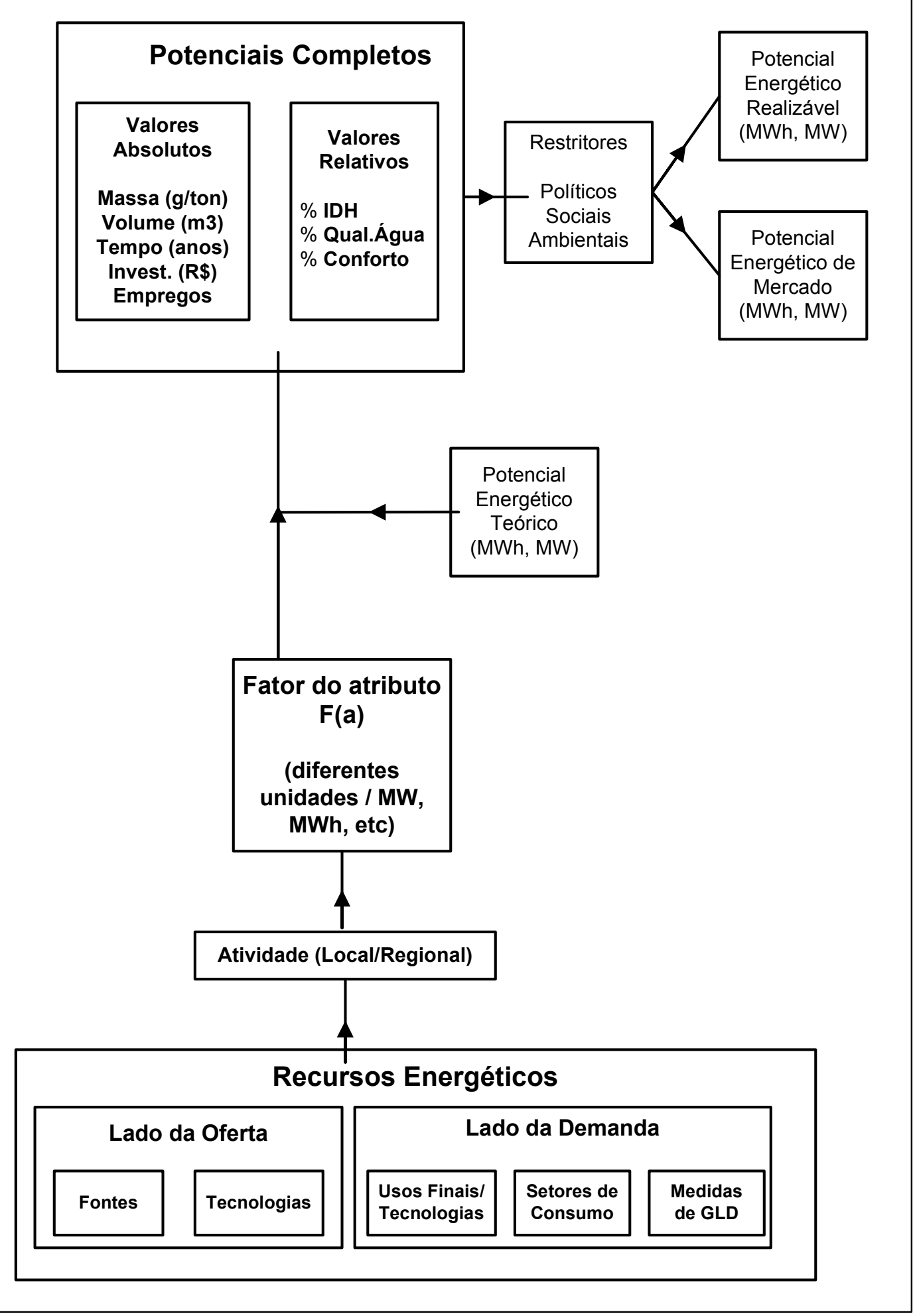

Figura 2: Algoritmo geral de cômputo e valoração de potenciais completos de recursos 


\subsection{Cômputo e Valoração da Dimensão Política}

\subsubsection{Conceituação da Dimensão Política para o PIR}

A dimensão política do planejamento energético analisa um conjunto de fatores capazes de orientar e avaliar a provisão, o desenvolvimento e a implementação de um determinado recurso energético. Em uma análise isonômica, a decisão pela implementação de cada recurso caberá à convergência de anseios dos diferentes interessados e envolvidos em toda a cadeia de produção e utilização desse energético - desde empreendedores de projetos, fornecedores de equipamentos, concessionárias responsáveis pela venda e transmissão dessa energia, cidadãos consumidores de eletricidade ou habitantes do entorno de áreas afetadas por grandes usinas.

Verifica-se, porém, que, em um processo tradicional de planejamento energético, a decisão pela construção de um empreendimento ou pela abertura de uma linha de expansão de um determinado energético é conduzida de forma central pelo governo e por grupos privados, com motivações, em inúmeros exemplos práticos, que transcendem a ponderação de impactos ambientais e suas possíveis consequências à sociedade e relativizam a priorização da economicidade tarifária. A avaliação informal desses processos é correntemente medida em função de seu "custo político", cuja compreensão demanda a ponderação de diretrizes estratégicas à expansão energética de cada Estado, como a soberania e a segurança energéticas em territórios nacionais, e a extensão desse status, tanto entre regiões adjacentes quanto entre países distantes - com o estabelecimento de acordos de cooperação ou a formação de

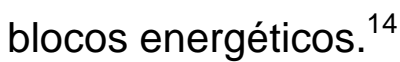

Identifica-se a sinalização de estratégias de desenvolvimento de um recurso energético em planos e iniciativas de diferentes tipos, como políticas públicas de estímulos financeiros, acordos voluntários, instrumentos regulatórios, fixação de fundos destinados à pesquisa e ao desenvolvimento tecnológico, ou programas de educação e conscientização de uso racional de energia ou de combustíveis limpos.

${ }^{14}$ Citam-se diversos exemplos de cooperações históricas entre países, como a construção da usina hidrelétrica binacional de Itaipu, entre Brasil e Paraguai, e a cooperação nuclear entre 0 Brasil e a França ou o projeto Desertec, que pretende gerar cerca de $20 \%$ da demanda energética da Europa no Norte da África por meio da tecnologia de Energia Solar Concentrada. 
A dimensão política abrange todos esses fatores descritos, divididos em atributos que quantificam, para cada recurso energético, os seguintes aspectos:

- a origem e a posse de fontes energéticas, considerando sua disponibilidade local, regional ou nacional e o grau de conhecimento técnico e econômico associado aos processos de extração (quando aplicável) e conversão em energia. Esse atributo também avalia o estado da propriedade de utilização e comercialização de cada fonte, em âmbito público, estatal ou privado;

- a política de integração energética regional, analisada pela qualificação de suas linhas de comercialização inter-regional e internacional de commodities energéticas, determinante para o direcionamento da dinâmica entre a utilização de recursos locais - maximizando-se seus benefícios - e recursos exógenos - passíveis de eventuais riscos geopolíticos;

- o apoio político à implementação de um empreendimento ou da expansão estratégica de um recurso, representado, em âmbito regulatório, por diferentes mecanismos de políticas ou programas de incentivo e em âmbito legal, pelos procedimentos de expedição de licenciamentos de projetos $^{15}$;

- e, principalmente, a análise da interação entre os envolvidos e interessados (En-In $)^{16}$ nas problemáticas energéticas da região estudada. O exame dos interesses particulares de cada um desses grupos e a leitura de sua interação constituem um atributo decisivo para as perspectivas de viabilização de um recurso energético. A análise categorizará os grupos de En-In de acordo com níveis geográficos e setoriais, considerando diferentes grupos de consumidores de energia, comunidades impactadas por empreendimentos, cadeias de suprimento energético e de

\footnotetext{
${ }^{15}$ A complexidade do procedimento de licenciamento ambiental tem sido experimentada na prática, na duração da expedição de licenças para as usinas hidrelétricas da região Norte do Brasil. Nos Estados Unidos, foram identificados exemplos mais extremos, com diferentes casos de licenciamento indeferidos para usinas termelétricas a carvão.

${ }^{16} \mathrm{O}$ envolvimento público no gerenciamento de recursos caracterizado pela inclusão dos En-In no processo de planejamento energético constitui, conforme mencionado previamente, uma das etapas ou premissas básicas do PIR e não se restringe à valoração da Dimensão Política; seu envolvimento está incluído em diversas outras etapas práticas da realização do PIR, por meio de participação popular em diferentes meios informativos (pesquisas de opinião, oficinas, workshops) ou participativos (audiências públicas, integração em ONGs, conselhos e comitês).
} 
infraestrutura, órgãos federais, estaduais e municipais e organizações governamentais e não-governamentais (MALLON, 2006).

\subsubsection{Procedimento da Valoração de Atributos Políticos}

Em que pese a influência de variáveis políticas na condução de processos de planejamento energético tanto no nível federal, quanto local, a proposta de valoração de atributos políticos dentro do escopo dos trabalhos de planejamento integrado de recursos energéticos é pautada pelo compromisso de que todas as dimensões integrantes do processo sejam equacionadas com a mesma incidência e influência analítica (FUJII, UDAETA, 2006).

A presença de complicadores à avaliação de atributos políticos tem sido identificada nos trabalhos prévios de PIR (USP, FAPESP, 2009c). Propõe-se, na valoração dessa dimensão, reduzir o grau de subjetividade desta análise, por meio da proposição de indicadores híbridos - utilizados em diferentes dimensões - capazes de mensurar satisfatoriamente o potencial de conversão desses esforços políticos na implementação de recursos energéticos. $O$ desafio persiste na metodologia de análise dos En-In, dada a complexidade da quantificação das inter-relações humanas e sociais em parâmetros de viabilidade de recursos energéticos. $O$ trabalho de valoração política realizado na Região de Araçatuba (USP, FAPESP, 2009c) formalizou a análise retórica e descritiva de atributos e serve de base para a elaboração das estruturas algorítmicas de mensuração desses atributos (e sua representação em valores minimamente discretos) apresentadas neste texto.

A valoração política procurou quantificar a intensidade ou volume de apoio a recursos energéticos em função de metas numéricas de implementação, previstas e/ou alcançadas ao longo do tempo. A posse e o potencial de utilização de cada energético são medidos pelo grau de nacionalização de empreendimentos e pela determinação geográfica de localização das respectivas fontes.

A valoração dos En-In segue linha qualitativa, ao ponderar as relações de poder e influência dentro das diferentes redes de atores. A mesma abordagem é utilizada para a análise da composição de blocos energéticos de cooperação e 
sua magnitude é determinada pela significância do vínculo político firmado entre países ou regiões.

Segue, na Figura 3, a estrutura da árvore da dimensão política, com os respectivos atributos e subatributos utilizados como indicadores de valoração.

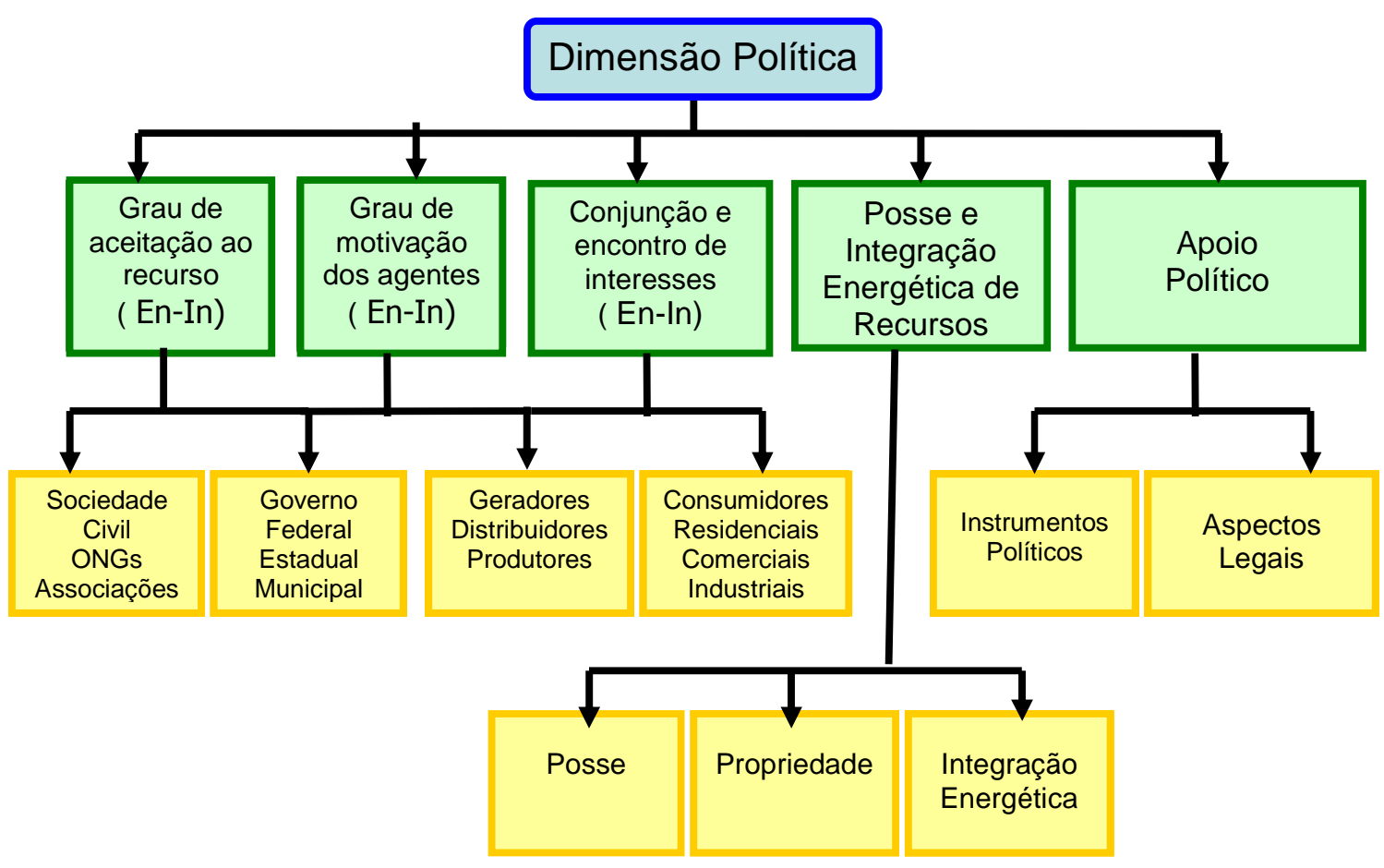

Fonte: USP, FAPESP, 2009c

Figura 3: Árvore de atributos e subatributos da dimensão política

\subsubsection{Apoio Político}

\subsubsection{Instrumentos Políticos de Incentivo}

A análise institucional dos principais mercados de energias alternativas mostra que os principais casos de sucesso de mercados energéticos internacionais são fruto de incentivos que, ao garantirem uma remuneração justa aos geradores, valorizam e anteveem benefícios diretos e indiretos de cada fonte à matriz energética e efeitos periféricos resultantes da criação e da sustentação de mercados.

Os próximos itens descrevem os principais instrumentos políticos de incentivo para energias renováveis e fósseis. Observa-se que esses instrumentos frequentemente incorporam características de outras ações fomentadoras de 
energias renováveis ou eficiência energética, implantadas separada ou conjuntamente. Como exemplos, citam-se o emprego de estratégias de educação e disseminação de informação, o uso de investimentos públicos para a construção de projetos e o estabelecimento de linhas de pesquisa e desenvolvimento de recursos energéticos.

\subsubsection{Tarifas Feed-in}

A tarifa feed-in é um preço especial pago pelas concessionárias de energia para a eletricidade proveniente de fontes renováveis. A tarifa é capaz de suportar grandes mercados de energia renovável a um custo pulverizado entre todos os consumidores de eletricidade e tem sido apontada como o vetor de sucesso do desenvolvimento dos mercados de energia eólica e solar em diferentes países da Europa e Ásia, como Alemanha, Espanha, China e Índia. Recentemente, tem-se cogitado a extensão dessas tarifas especiais para energias fósseis, como a geração termelétrica a carvão na Espanha.

As tarifas feed-in podem ser fixas (com a definição de um preço mínimo da energia elétrica gerada, independentemente do mercado de eletricidade) ou prêmio (ao remunerar geradores com um valor prêmio adicional ao preço de mercado). A regulamentação impõe obrigações contratuais entre as concessionárias e os produtores de energia de fontes renováveis, entre as quais figura o pagamento de valores fixos em contratos vigentes por períodos entre 15 e 30 anos. O nível da tarifa é geralmente mantido fixo durante um número variável de anos para dar segurança aos investidores, garantindo, assim, parte da receita ao longo da vida útil do investimento ${ }^{17}$.

O mecanismo feed-in conta com outras variações, como tarifas que condicionam a obrigação da aquisição da eletricidade apenas à quantidade de energia perdida na transmissão e distribuição ou sua complementação com subsídios do Estado (KLEIN, 2006).

Alguns países optaram por uma combinação entre instrumentos de incentivo por meio de subsídios e flexibilização de impostos relacionados a

\footnotetext{
${ }^{17}$ A redução gradual da tarifa visa seguir o comportamento da curva de aprendizado de cada tecnologia e evitar sobrecompensação na evolução de seu preço. Nesse modelo, as tarifas são revistas regularmente para mantê-las em linha com os objetivos da política energética e acompanhar as variações no preço da energia.
} 
equipamentos e serviços da cadeia de geração de energias renováveis. A China vem sendo um exemplo de país que alia tarifas prêmio a políticas industriais, obtendo resultados expressivos no desenvolvimento da indústria eólica do país: nos dois últimos anos, a capacidade eólica da China foi multiplicada de 5.910 MW para 25.805 MW (GWEC, 2010), colocando o país entre os três maiores produtores desse tipo de energia.

Em outros casos, tanto na Europa como no Brasil, provou-se que o mecanismo feed-in aplicado de maneira incorreta, sem o acompanhamento de medidas industriais aliada a políticas complementares de incentivo e o aprimoramento dos procedimentos de obtenção de licenças tampouco garante resultados consistentes em curto ou mesmo médio prazos (BAITELO, 2009).

\subsubsection{Sistema de Cotas e Certificados Verdes}

O sistema de cotas é uma política de incentivo que estabelece um mínimo de contratação da demanda das concessionárias em energias renováveis, como forma de protegê-las da competição de outras fontes de baixo custo. A meta, instituída pelo governo, pode ser cumprida baseada na produção da energia necessária, na compra de energia de geradores ou na aquisição de certificados verdes. A obrigação da aquisição desses certificados, em proporção à geração e consumo de energia são a garantia de que a energia será consumida e que a diferença entre o preço de mercado praticado e o custo da geração renovável será coberta, já que o valor dos certificados é adicionado à tarifa de eletricidade.

Entre os países que adotaram esse sistema figuram Bélgica, Romênia, Suécia, Itália e, até recentemente, o Reino Unido, além de vários estados norteamericanos, onde o sistema é conhecido como Padrão de Carteira Renovável, ou Renewable Portfolio Standard (RPS). ${ }^{18}$ O Proinfa adotou também premissas do Sistema de Cotas, determinando limites de potência contratada para cada tecnologia. A proposta se repete no substitutivo do PL 630/03, da Câmara dos Deputados, que inclui, no artigo 7, a obrigatoriedade de compra anual de 100 MWmédios de energias alternativas pelas concessionárias (FERRO, 2009).

\footnotetext{
${ }^{18}$ Nesse país, o setor de energias renováveis pede por um Renewable Portfólio Standard nacional, como forma de oficializar em lei o pedido de Barack Obama de que $10 \%$ de toda a eletricidade seja proveniente de energias renováveis até 2012 e $25 \%$ até 2020.
} 
O sistema de cotas também pode beneficiar-se com sucesso do uso da tarifa feed-in (RICKERSON \& GRACE, 2007). Essa combinação é comum na Europa; já nos Estados Unidos, o mecanismo mais utilizado dentro do sistema RPS é o de licitação (veja próximo item).

\subsubsection{Sistema de Licitação e Leilão}

O sistema de licitação é utilizado para fomentar investimentos em recursos energéticos implementados em regiões específicas e é capaz de apoiar geradores em termos de investimento, produção ou outros direitos limitados. Os critérios para avaliar as ofertas são determinados antes de cada rodada de licitação, quando o governo decide o nível desejado de energia gerada, a potência instalada em cada fonte e as taxas de crescimento, entre outros fatores.

Em processos mais competitivos, como sistemas de leilões, o regulador define as reservas de mercado para um determinado montante de energia renovável e organiza o processo de competição entre os produtores a fim de alcançar um resultado de contratação próximo a esse volume. As propostas são classificadas em ordem crescente de custo até que se atinja o total a ser contratado. Na sequência, elabora-se um contrato de longo prazo como garantia de pagamento da energia para cada produtor de fontes renováveis. Os valores dos contratos são baseados nos preços finais dos leilões.

Os sistemas de leilão envolvem ofertas competitivas de contratos para a construção e a operação de um projeto específico, ou uma quantidade fixa de capacidade renovável em um país ou estado. Esse sistema tem sido utilizado para a promoção da energia eólica em países como Irlanda, Reino Unido, França, e Brasil. No caso do Reino Unido, o sistema de Non-Fossil-Fuel Obligation (ou Obrigação de Combustíveis Não-Fósseis), que vigorou entre 90 e 98, permitia que empreendedores oferecessem lances para diferentes tecnologias renováveis. Já nos casos da França e do Brasil, o sistema é empregado em uma versão híbrida, incorporando elementos de tarifas feed-in.

Em algumas políticas, o sistema competitivo é usado para empreendimentos de grande porte, e o esquema feed-in é empregado para projetos de pequena escala. Essa proposta funciona em estados norteamericanos como Califórnia e Washington (COUTURE \& CORY, 2009) e também 
consta do texto substitutivo do projeto de lei PL 630/03, apresentado na Comissão Especial de Energias Renováveis (FERRO, 2009).

As experiências nacionais e internacionais ${ }^{19}$ têm mostrado que o sistema, por si só, é ineficiente para desenvolver indústrias de renováveis. Apesar de ter a vantagem de reduzir os custos das fontes renováveis ao estabelecer e estimular um preço competitivo, esse preço tem resultado em uma contratação limitada de projetos em leilões exclusivos para fontes ou na competição entre fontes em leilões de fontes compartilhadas.

Mesmo assim, a regularidade na realização de leilões, proposta no artigo 2 do substitutivo do PL 630/03 em uma quantidade mínima de 600 MW médios para as fontes eólica, biomassa e pequenas centrais hidrelétricas (com 200 MW médios para cada), nos próximos dez anos, pode dar uma visão de longo prazo ao mercado - desde que o preço de referência das energias negociadas no leilão viabilize, economicamente, as usinas de geração renovável e a quantidade de energia negociada tenha um volume capaz de estimular o mercado.

\subsubsection{Subsídios e Medidas Fiscais}

Subsídios representados por taxas de retorno especiais para investimentos ou medidas fiscais na forma de créditos ou desoneração de impostos são um mecanismo importante para superar um alto custo inicial de investimento em empreendimentos de tecnologias menos econômicas. Ainda que, sob uma perspectiva política, o impacto de uma cobrança sobre um contribuinte ou diretamente sobre um consumidor de eletricidade seja diferente, em termos econômicos, o efeito de um incentivo na forma de renúncia de impostos produtivos ou na redução de pagamentos tem efeito similar (TESKE, 2005).

O sistema fiscal é utilizado no apoio a fontes renováveis em diferentes modalidades de redução ou abatimento em impostos especiais aplicados na geração, isenção tributária para fundos verdes e utilização de fundos específicos para geração de eletricidade renovável. Um exemplo de medida fiscal são os créditos de impostos de produção ou Production Tax Credits (PTC), utilizados nos EUA e no Canadá, desde 1992.

\footnotetext{
${ }^{19} \mathrm{O}$ insucesso dos leilões na Califórnia - onde empreendedores fecharam contratos por meio de lances baixos, sem ter as condições financeiras de desenvolver os projetos - tem suscitado análises sobre as vantagens da atuação das tarifas feed-in inclusive na implementação de projetos de grande porte (GRACE, RICKERSON, et al, 2008).
} 
O PTC concede descontos no imposto de renda para cada unidade de energia produzida por fontes renováveis ${ }^{20}$, mas apresenta como deficiência 0 efeito de ciclos de expiração/extensão do programa, que têm comprimido as demandas por energias renováveis em períodos exíguos, comprometendo o desenvolvimento da cadeia produtiva e a redução gradual de preços de energias renováveis (WISER, BOLINGER, BARBOSE, 2007). Como exemplo, cita-se a opção temporária de crédito oferecida pelo ARRA (Lei Americana de Recuperação e Reinvestimento), válida apenas para projetos que iniciem sua construção entre 2009 e 2010 (ZINDLER, 2009).

No Brasil, a Associação Brasileira de Energia Eólica (Abeeólica) propõe estímulos fiscais para as obras eólicas, similares às medidas fiscais aplicadas internacionalmente. A carga tributária representa uma parcela entre $25,7 \%$ e $30,2 \%$ do gasto total para a construção de um parque eólico. A associação propõe incentivos via PIS/COFINS, IPI, ICMS e ISSQN para bens de capital de toda a cadeia produtiva (ABEEÓLICA, 2009). Com os incentivos fiscais, os parques eólicos podem oferecer tarifas inferiores a $R \$ 140 / \mathrm{MWh}$, a exemplo do ocorrido nos leilões de energia renovável em agosto de 2010, em que a geração eólica recebeu parte desse pacote de desonerações. O resultado positivo de contratação de geração eólica nesses certames fortalece a intenção do MME de não mais realizar leilões exclusivos para grupos de fontes ou limitar a contratação de fontes renováveis complementares a leilões de reserva ${ }^{21}$.

A combinação entre as tarifas feed-in e as concessões de crédito também é possível; os incentivos fiscais reduzem o capital inicial dos projetos e, com isso, os valores de tarifa necessários para viabilizar esses empreendimentos (COUTURE \& CORY, 2009).

\footnotetext{
${ }^{20}$ Originalmente programado para expirar ao final de 2008, o PTC foi prorrogado, dentro do pacote anticrise aprovado pelo governo norte-americano (Ato de Recuperação e Investimento ARRA - da sigla em inglês), que acrescentou uma nova opção de concessão de crédito, ao fornecer pagamentos de $30 \%$ dos custos totais de investimentos em projetos.

${ }^{21}$ A capacidade de contratação deverá ser restrita nos próximos anos - com a entrada da energia no sistema interligado de grandes empreendimentos hidrelétricos como as usinas do rio Madeira e de Belo Monte e está alinhada com a inclinação do Ministério de Minas e Energia em defender a participação dos empreendimentos renováveis em certames comuns como o A-3 e A-5, à medida que ganhem competitividade.
} 


\subsubsection{Algoritmo de Cômputo e Valoração}

A avaliação de apoio político a um recurso mensura a efetividade de instrumentos políticos para a implementação de um recurso energético, orientada por parâmetros como ágio entre o valor tarifário oferecido e o custo energético do recurso, a meta absoluta de programas, a duração de programas (e perspectivas de renovação), a duração de contratos com empreendedores e o volume previsto de contratação. Esses parâmetros refletem-se, diretamente. na capacidade instalada anual de cada recurso energético e no cálculo de seu potencial completo.

A estrutura do algoritmo de valoração desse atributo analisa os principais tipos de instrumentos políticos energéticos. Estes se dividem em diferentes categorias: financeiros (tarifas feed-in, medidas fiscais, créditos e financiamentos), regulatórios (estabelecimento de cotas, mandatos ou padrões mínimos), licitações e leilões (para a contratação de empreendimentos energéticos) e comercialização de licenças (certificados verdes, créditos de carbono). À parte desses instrumentos, figuram ações fomentadoras de novas opções energéticas vinculadas ou independentes desses instrumentos de incentivo, divididas em âmbito educativo (disseminação de informação por guias, etiquetagem de produtos), de investimentos públicos (Programa de Aceleração do Crescimento, do Governo Federal) e do estabelecimento de linhas de pesquisa e desenvolvimento tecnológico.

A avaliação desses instrumentos analisa a faixa de potência dos recursos energéticos contemplados na política e a jurisdição do programa (local, regional, nacional ou internacional). O potencial teórico de um instrumento é medido pela meta de instalação proposta pelo recurso energético (se aplicável) ou sua projeção baseada nas condições iniciais do instrumento (atratividade da tarifa energética oferecida e duração dos contratos) e sua duração - analisada como indicador da intenção de desenvolvimento de um recurso. Essa projeção pode basear-se em cenários e experiências anteriores de implementação do referido instrumento.

O potencial realizável de cada recurso é medido pela quantidade efetivamente implementada (no caso de programas finalizados) ou projetada (de 
acordo com a prorrogação ou expiração do programa) de um recurso energético, com base em experiências anteriores de aplicação dos instrumentos.

O algoritmo de valoração desse atributo segue abaixo, na Figura 4.

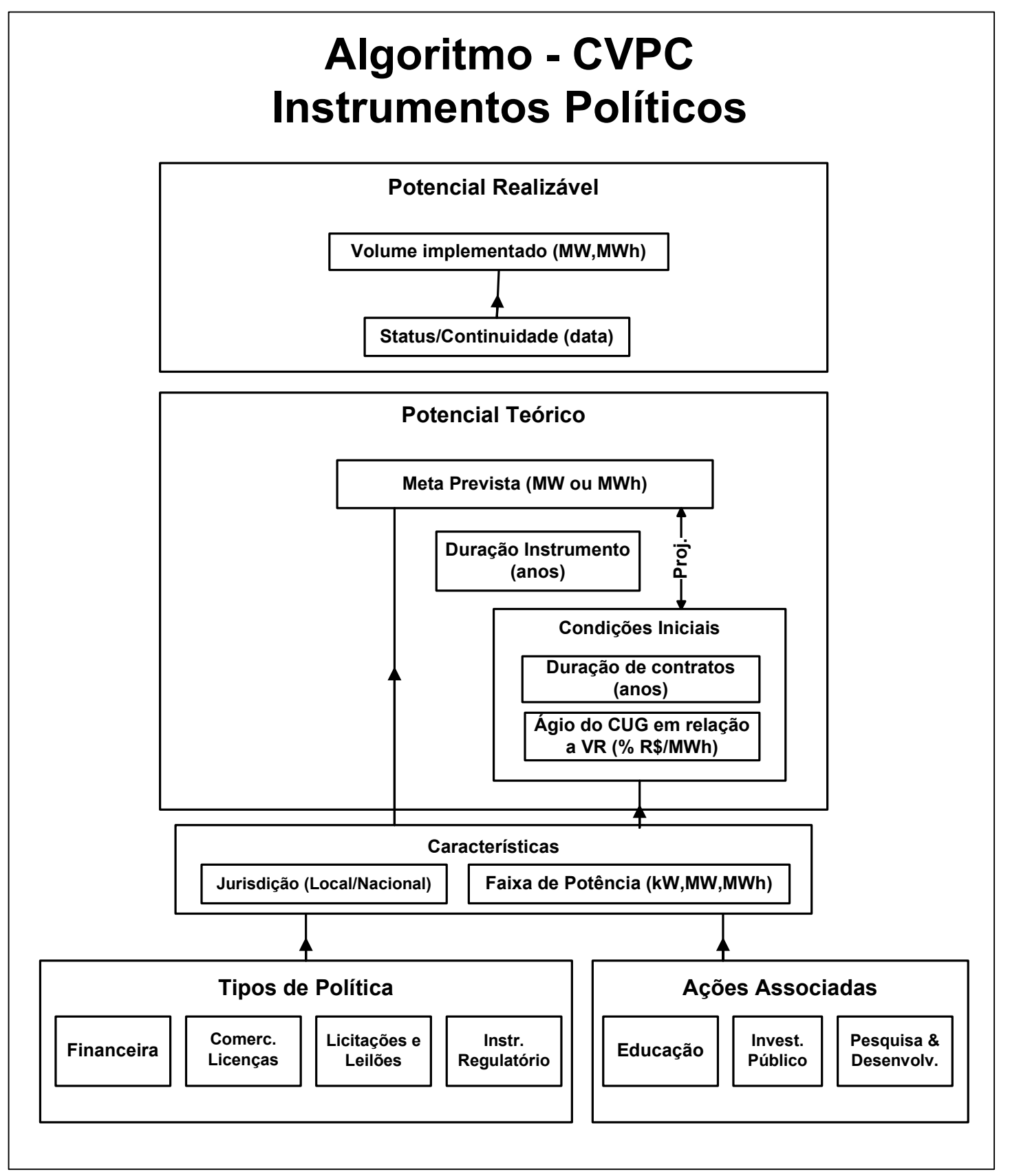

Fonte: Elaboração Própria

Figura 4: Algoritmo de cômputo e valoração do atributo Instrumentos Políticos de Apoio a RELOS 


\subsubsection{Procedimentos de Aspectos Legais}

O licenciamento de empreendimentos energéticos é um dos instrumentos legais que mais recebe atenção do poder público, em função de sua importância na aceleração ou retardamento desses projetos e consequentemente para investimentos relacionados a eles.

Dessa forma, o processo de licenciamento deve ser avaliado em paralelo ao atributo de políticas de incentivo para a implementação de recursos energéticos, considerando seu potencial em influenciar a viabilização de um recurso, de acordo com a estrutura do licenciamento, o conjunto de processos técnicos e legais conduzido em sua análise, bem como o contexto político, histórico e social dessa análise.

O licenciamento de um empreendimento é precedido do EIA (Estudo de Impacto Ambiental) e de seu respectivo RIMA (Relatório de Impactos ao Meio Ambiente) quando previstos significativos impactos ambientais, conforme estabelecido na Constituição Federal. No caso do Brasil, o processo de emissão de licenças é dividido nas licenças prévia, de instalação e de operação ${ }^{22}$. Estas são organizadas em procedimentos divididos em diferentes estágios contribuindo para o aumento do grau de incerteza quanto à estimativa da duração total do processo.

De acordo com relatório do Banco Mundial (2008), a maioria das deficiências associadas ao licenciamento ambiental de hidrelétricas no Brasil ocorre na fase de licença prévia, como combinação de diferentes fatores, entre os quais: falta de planejamento adequado do governo, falta de clareza sobre a esfera governamental com autoridade legal para emitir licenças ambientais, atrasos na emissão dos termos de referência (TdRs) para o estudo de impacto

\footnotetext{
${ }^{22}$ Licença Prévia - LP - concedida na fase preliminar de planejamento do empreendimento por um prazo máximo de 5 anos; aprova sua localização e concepção, atesta a viabilidade ambiental e estabelece os requisitos básicos e condicionantes atendidos nas fases seguintes da implantação.

Licença de Instalação - LI - autoriza a instalação do empreendimento ou atividade de acordo com as especificações dos planos, programas e projetos aprovados, incluindo medidas de controle ambiental e condicionantes.

Licença de Operação - LO - autoriza a operação da atividade ou empreendimento após a verificação do cumprimento das exigências das licenças anteriores, conforme as medidas de controle ambiental e condicionantes determinadas para a operação. A Licença de Operação do empreendimento é renovada a cada período de 4 a 10 anos, de acordo com o órgão ambiental competente.
} 
ambiental (EIA) exigido pela legislação, qualidade e avaliação dos EIAs e falta de regras claras para a compensação social.

Em outros casos de licenciamento, como o da usina hidrelétrica de Jirau, o processo teve sua duração estendida por envolver uma série de disputas judiciais resultantes de imprecisões e alterações técnicas da versão de projeto inicialmente prevista.

O setor de Pequenas Centrais Hidrelétricas acusa a demora na aprovação de projetos pela Aneel e complicações para a obtenção de licenças ambientais, com consequências sobre o aumento do custo dos projetos. Ainda que a capacidade instalada de usinas outorgadas pela Aneel entre 1998 e 2010 seja de 2.073 MW (ANEEL, 2010, apud CANAZIO, 2010), a quantidade de projetos com licença ambiental de instalação não chega à metade deste número. Ainda que somente a licença prévia seja exigida para a participação de empreendimentos em leilões, as complicações e o período de tempo para a emissão da licença prévia e da licença de instalação influenciam o aporte de investidores. Por outro lado, usinas eólicas e usinas de cogeração a biomassa contam com processos rápidos de aprovação.

Em relação a usinas termelétricas a carvão, a recente experiência norteamericana mostra que a pressão pela redução de emissões domésticas de gases de efeito estufa tem resultado na recusa de licenciamento de um número considerável de usinas nos últimos anos. Apenas no ano de 2007, foram 59 usinas cujos licenciamentos foram negados ou projetos foram abandonados, em estados como Flórida e Texas. Posteriormente a Agência de Proteção Ambiental norte-americana (Environment Protection Agency ou EPA, da sigla em inglês) foi proibida por recurso por seu Conselho de Apelos Ambientais de conceder a licença de operação para uma termelétrica a carvão em Utah sem a delimitação de limites de emissões de gases de efeito estufa. A medida compromete a expedição do licenciamento de outras cem usinas, decidido pela EPA e agências que seguem suas diretrizes.

No caso do licenciamento de projetos eólicos, o tempo de concessão foi recentemente estimado por um estudo da Associação Européia de Energia Eólica (EWEA, 2009). O documento avaliou o tempo médio em 3,5 anos para parques instalados em terra, com grande variação entre países - de 8 meses para a Finlândia até 58 meses no caso de Portugal. Esse tempo é afetado pelo número 
de autoridades contatadas pelo empreendedor durante o processo, identificado entre 5 e 41.

Todos esses fatores influenciam o ritmo de concessão das licenças. Observam-se efeitos positivos em casos em que os projetos recebem avaliações mais precisas e compensações sociais e ambientais condizentes com os impactos projetados; por outro lado, atrasos na obtenção de licenças podem aumentar o custo das obras e comprometer a implementação de alguns projetos $^{23}$.

A diferenciação no ritmo do processo de licenciamento ambiental de alguns tipos de empreendimentos é capaz de influenciar a disponibilidade de implantação de outros recursos, haja vista a redução do número de aproveitamentos hidráulicos competitivos em alguns dos leilões anteriores de energia, tendo resultado na contratação de um maior número de usinas térmicas entre 2006 e 2008. O mesmo efeito foi observado no adiamento da liberação da licença ambiental da hidrelétrica de Belo Monte, dando oportunidade para a contratação de um número considerável de parques eólicos no leilão de reserva de 2009 e favorecendo a realização de outro leilão de energias renováveis em 2010.

O relatório do Banco Mundial traça um conjunto de recomendações para minimizar os problemas existentes de licenciamento, entre os quais o esclarecimento de responsabilidades da União e dos Estados em relação ao licenciamento, a adoção de mecanismos de resolução de conflitos para o processo de licenciamento - a fim de minimizar a transferência para o Poder Judiciário de questões que deveriam ser resolvidas dentro do escopo do processo administrativo de licenciamento ambiental - e o fortalecimento do processo de EIA baseado na formação de equipes multidisciplinares para preparação dos TdR, grupos multissetoriais para preparação de manuais operacionais e capacitação técnica e diversidade profissional aos órgãos envolvidos no processo de licenciamento.

${ }^{23}$ De acordo com o Banco Mundial, os custos diretos do licenciamento ambiental (sociais, ambientais e incertezas regulatórias) representam, em média, cerca de $15 \%$ do custo total da obra. No caso da hidrelétrica de Belo Monte, os custos de mitigações e compensações ambientais contemplados na licença ambiental do empreendimento totalizam 1,5 bilhão de reais diante de um custo anunciado de 16 bilhões para o projeto. 
Por fim, o documento aponta ausência de regras setoriais sobre compensação social - obrigando que empreendedores equacionem demandas não derivadas do potencial impacto social ou ambiental direto do empreendimento proposto - e problemas no fluxo de informações entre os diferentes órgãos envolvidos no processo de licenciamento ${ }^{24}$.

Por outro lado, é importante ressaltar que essas críticas também devem ser analisadas sob a perspectiva da avaliação e contabilização de custos socioambientais. A inclusão desses elementos no processo de licenciamento, ainda que reflita sobre o aumento de sua duração e de seus custos finais, contribui para o equilíbrio da análise de impactos incorridos em cada empreendimento.

Em suma, a valoração de aspectos legais como processos de licenciamento ambiental de usinas complementa a análise de instrumentos políticos de incentivo a recursos energéticos. Esta é medida em termos de verificação da concessão ou não de licenças ambientais e a duração desse processo, como será explicado no próximo item.

\subsubsection{Algoritmo de Cômputo e Valoração}

O algoritmo analisa o tempo e os custos necessários para a aprovação do licenciamento de projetos e as variáveis envolvidas na alteração desses parâmetros. A análise é baseada nos parâmetros numéricos de custo e tempo de aprovação médio de projetos similares, que se influenciam mutuamente no processo de aprovação do licenciamento ambiental de empreendimentos. A análise incorpora também diferentes fatores qualitativos determinantes à expedição de licenças, como contextos político, histórico, estratégico e social.

Como primeiro fator do algoritmo, analisa-se o tempo do processo, incluindo o tempo de emissão dos termos de referência para o estudo de impacto ambiental (EIA) e os tempos de elaboração de documentos referentes a cada uma das licenças ambientais, suscetíveis aos corpos técnicos envolvidos em sua formulação e à qualidade de estudos e documentos produzidos.

\footnotetext{
${ }^{24}$ Cita-se o caso de Aimorés, no qual o IBAMA aceitou a proposta de apoio ao Parque Estadual de Sete Salões, cuja criação e implementação ficariam a cargo do empreendedor. Ao longo do processo, a FUNAI identificou a área como terra indígena, do povo Krenak, o que a tornaria não elegível a receber recursos da compensação ambiental.
} 
O segundo fator considera os custos totais das etapas de licenciamento, incluindo os custos de estudos e documentos apresentados, custos de atraso ou interrupção dos trabalhos e, principalmente, os custos de compensação ambiental e social. A margem de variação desses valores é novamente influenciada pelo conjunto de regras estabelecidas para compensações sociais, além de diferentes riscos de natureza social e ambiental.

Como variáveis macroscópicas modificadoras do comportamento desse processo, inclui-se o marco legal e institucional que rege o licenciamento, responsável, direta e indiretamente, pela identificação da esfera governamental autorizada a emitir cada licença e pelo número de autoridades envolvidas em cada processo.

O algoritmo contempla esse conjunto de fatores e variáveis restritivas e sua comparação empírica com casos e exemplos de projetos realizados, fornecerá um indicativo da probabilidade de aprovação ou reprovação do empreendimento analisado. A fórmula abaixo e a figura 5 , a seguir, mostram 0 algoritmo do subatributo:

O cômputo e a valoração do licenciamento ambiental e da outorga de autorização de empreendimentos são contabilizados pela duração desses processos e seus custos associados, de acordo com as equações abaixo:

\section{CVPC leg $(R E L O)=f(T, C)$}

$T($ leg) = $T(L P)+T(L I)+T(L O)+T(O A)$

Onde:

$\mathrm{T}(\mathrm{leg})$ : Tempo de procedimentos legais;

$\mathrm{T}(\mathrm{LP})$ : Licença Prévia;

$\mathrm{T}(\mathrm{LI})$ : Licença de Instalação;

T(LO): Licença de Operação;

$\mathrm{T}(\mathrm{OA})$ : Outorga de Autorização.

\section{C $($ leg $)=\operatorname{Cpr}($ RELO) + Ccomp $($ RELO)+Catr $($ RELO)}

Onde:

$\mathrm{C}$ (lic): Custos de procedimentos legais $(\mathrm{R} \$)$;

$\mathrm{Cpr}(\mathrm{RELO})$ : Custo de Processos (R\$);

Ccomp(RELO): Custo de compensação (R\$);

Catr(RELO): Custos por atrasos $(R \$)$. 


\section{Algoritmo - CVPC Procedimentos Legais}

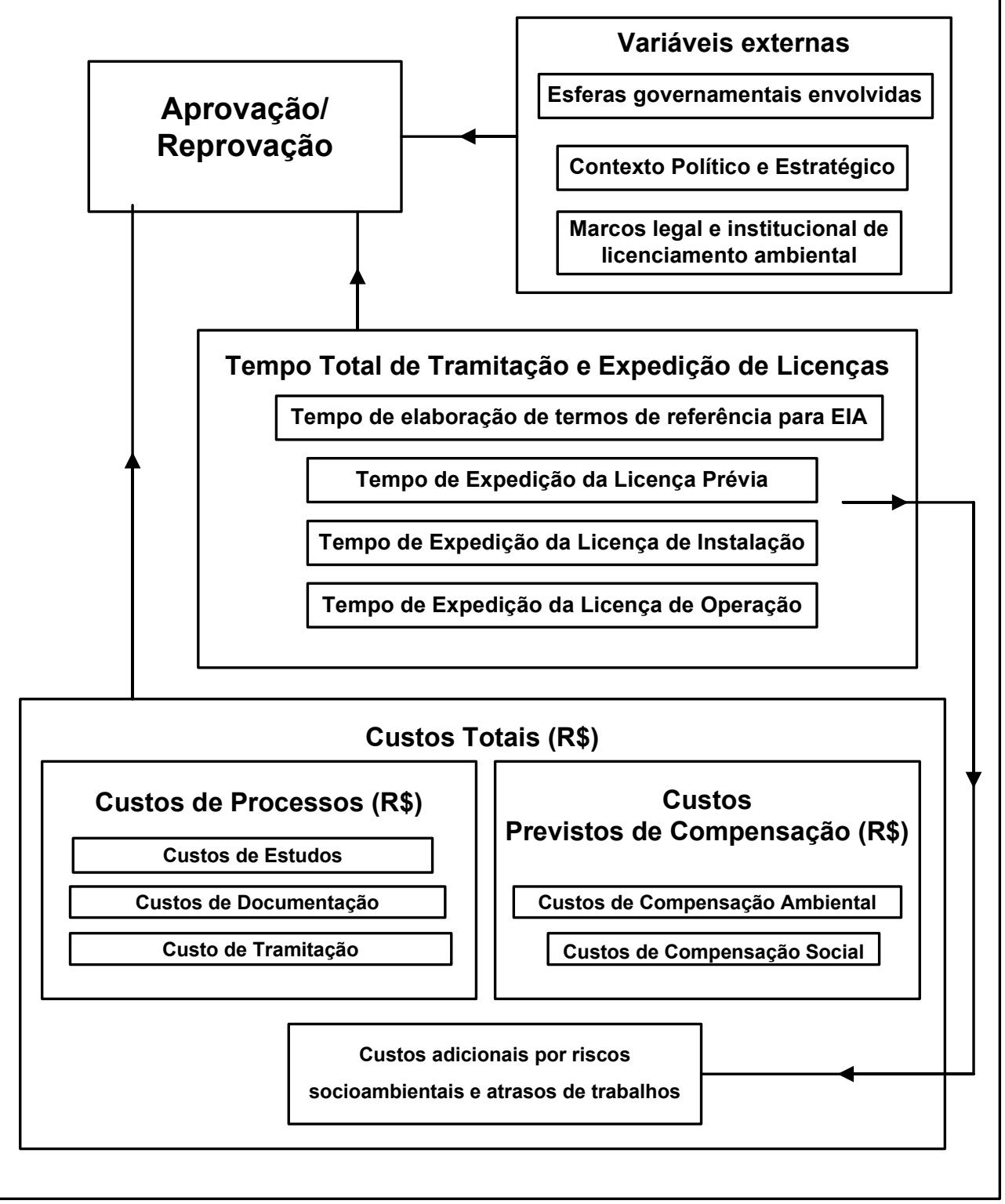

Fonte: Elaboração Própria

Figura 5: Algoritmo de CVPC do atributo Procedimentos Legais

\subsubsection{Envolvidos e Interessados (En-In)}

Conforme comentado anteriormente, a análise de atributos da dimensão política apresenta particularidades por conta de dificuldades de quantificação e 
relativização desses elementos, vulneráveis a instabilidades de ordem humana, cultural, social e política, bem como temporal e geográfica.

Essa observação cabe especialmente para a análise dos Envolvidos e Interessados (En-In) em um determinado recurso energético. Essa terminologia é utilizada pelo grupo de estudos de PIR, na USP, para caracterizar os diferentes atores ou stakeholders em diferentes graus de envolvimento em problemáticas energéticas locais ou regionais. Assim, o universo de En-Ins inclui empreendedores e geradores de um dado recurso, populações impactadas, positiva ou negativamente, por esse empreendimento, associações que defendem interesses de ambas as partes. Sob uma perspectiva macroscópica, inclui ainda a sociedade civil organizada em movimentos, e diferentes esferas governamentais. Todos esses atores ${ }^{25}$ são determinantes, em maior ou menor escala, para a implantação de recursos energéticos - ou para a decisão de sua não utilização -, ao influenciar esses processos por diferentes tipos de ações ou estratégias públicas, políticas e legais.

De forma sintética, os principais grupos de Envolvidos e Interessados para recursos energéticos do lado da oferta são:

- Governo (federal, estadual, municipal), representado por diferentes ministérios e secretarias, bem como comissões parlamentares;

- agências reguladoras de eletricidade e energéticos;

- empresas do setor elétrico e coordenação de atividades, nas áreas de geração, transmissão e distribuição;

- entidades responsáveis pela operação e planejamento do sistema energético brasileiro;

- setor industrial: representado por produtores e fabricantes de equipamentos;

- setor privado: representado por empreiteiras, construtores e financiadores de empreendimentos;

- geradores de energia: empreendedores de projetos ou sistemas;

- associações setoriais energéticas: de diferentes energéticos e atividades da cadeia energética;

\footnotetext{
${ }^{25} \mathrm{O}$ fato de demais grupos interessados na problemática de um dado empreendimento terem uma participação marginal menos atuante, seja ela por representação de associações ou outros grupos, não necessariamente implica que seu papel seja menos decisivo na discussão.
} 
- produtores independentes e autoprodutores: consumidores industriais que produzem a energia consumida;

- concessionárias e permissionárias: distribuidoras de energia gerada em plantas e transportada pelo sistema de transmissão até consumidores de diferentes setores energéticos;

- consumidores de energia: grupos de consumidores em diferentes tensões, de grandes consumidores industriais a consumidores dos setores comercial, residencial, público e rural;

- sociedade: OSCIPs, Associações de diferentes classes, sindicatos, organizações não-governamentais (focadas em áreas ambientais, energéticas, "econômicas" ou de negócios, sociais, entre outras);

- Ministério Público Federal: atuante na defesa de determinados grupos de cidadãos contra eventuais abusos e omissões do Poder Público ${ }^{26}$;

- sociedade em geral (cidadãos);

- academia: grupos de pesquisa, docentes, especialistas em questões energéticas socioambientais, corpos estudantis, entre outros;

- Mídia: jornais, revistas, televisão, rádio, periódicos, mídia especializada, veículos de internet.

Esses e outros Envolvidos e Interessados são os agentes determinantes para a implantação de recursos energéticos por diferentes meios; entre orientadores de políticas públicas, influenciadores da opinião pública ou negociadores do custo político dos reais tomadores de decisão, as estratégias e ações disponíveis diferenciam-se para cada grupo e tem eficácia diferenciada de acordo com diversos fatores analisados mais adiante neste atributo.

Assim, a identificação e o mapeamento de En-Ins ou stakeholders, independentemente do grupo em que o planejador se classifica, é uma tarefa imprescindível para aqueles que desejam atingir o objetivo de desenvolver um empreendimento energético baseado em negociações que visem ao alcance de

\footnotetext{
${ }^{26}$ O Ministério Público é autônomo em relação aos três poderes Executivo, Legislativo e Judiciário e seus procuradores e promotores têm independência assegurada na Constituição. Atua também na defesa do patrimônio público contra ataques de particulares de má-fé.
} 
um mínimo consenso ${ }^{27}$. O aprimoramento dessas condições afeta diretamente o tempo total de aceitação e posterior desenvolvimento desse projeto; a demonstração emblemática de resistência ao projeto inicial de Belo Monte resultou na postergação e posterior alteração da obra a fim de se alcançar um maior grau de aprovação entre os diferentes grupos afetados pelo empreendimento $^{28}$. O grande repúdio da sociedade de diferentes países à energia nuclear após o acidente na usina de Chernobyl resultou no adiamento dos planos de programas nucleares de grande parte dos países europeus - a decisão foi legitimada por plebiscitos em alguns deles.

É concedida participação à sociedade em processos de construção de empreendimentos ou negociações gerais por meio de representação em audiências públicas, contribuições e questionamentos a informações de projetos expostos em relatórios de impactos socioambientais, intervenções e participação em reuniões de comitês ou órgãos de políticas energéticas ${ }^{29}$.

Demonstrações de repúdio a projetos ou mesmo processos de planejamento energético têm sido vistos com frequência crescente nos últimos anos. Os maiores atos de desobediência civil em discordância das atuais políticas climáticas foram registrados em Washington, nos Estados Unidos e, posteriormente, em Copenhague, na Conferência das Partes, na forma de marchas e manifestações. Acusações criminosas a ações de ativistas em oposição à construção de usinas termelétricas fósseis - ligadas diretamente à poluição do ar e à emissão de gases de efeito estufa - têm recebido avaliações inéditas da justiça, com menção especial ao caso ocorrido no Reino Unido ${ }^{30}$. Nos

\footnotetext{
${ }^{27}$ Empreendedores de projetos energéticos têm recorrido à experiência de profissionais de relações públicas para intermediar o processo de relacionamento com grupos afetados por esses projetos. Estes recorrem a diferentes táticas para ganhar o apoio das comunidades, tais como a criação de bases de apoio e a identificação de agentes-chave primordiais para o ganho da causa ou o processo de construção de entendimento (ou convencimento) acerca dos objetivos e consequências da construção.
}

${ }^{28}$ O 1ํ Encontro dos Povos Indígenas do Xingu, realizado em fevereiro de 1989, em Altamira (PA), ficou marcado pelo gesto de advertência da índia kaiapó Tuíra, que tocou com a lâmina de seu facão o rosto do então diretor da Eletronorte, José Antônio Muniz Lopes.

${ }^{29}$ Cabe registrar, porém, que as cadeiras reservadas aos representantes da sociedade civil da Comissão Nacional de Políticas Energéticas (CNPE) por vezes não são preenchidas.

${ }^{30}$ Seis ativistas do Greenpeace foram, criminalmente, acusados por provocar danos a uma termelétrica a carvão em Kent. Com o apoio do climatologista James Hansen, da NASA (Administração Nacional do Espaço e da Aeronáutica, da sigla em inglês), e outros ambientalistas, a defesa argumentou que a ação foi feita em nome de locais impactados por mudanças 
Estados Unidos, ações conjuntas contra cerca de 150 projetos de usinas a carvão contribuíram para a redução de metade do número de usinas construídas.

A avaliação do potencial desses envolvidos e interessados vale-se de singularidades metodológicas para a mensuração desses diferentes grupos humanos, por conta da análise de variáveis interdependentes entre atores. Assim, além da leitura do posicionamento de cada grupo e de sua motivação de atuação ou resistência, o terceiro fator chave contemplado neste algoritmo é a ponderação de perdas e ganhos resultante da interação entre os grupos.

As consequências de relações entre os diferentes atores são avaliadas em função de seu grau de equilíbrio, determinado pela combinação de valores como a força e a influência de cada grupo e os recursos materiais e intelectuais dos quais cada um dispõe. A análise é inexata e imprevisível tanto por conta da relatividade desses fatores em determinar o alcance de objetivos de cada parte, como também pelo dinamismo do centro de convergência dessas discussões, resultantes da pluralidade de argumentos, culturas e crenças dos atores envolvidos e, principalmente, pelas constantes mudanças de fatores políticoeconômicos inerentes às discussões ${ }^{31}$.

Novamente, essa análise política é essencialmente qualitativa, ainda que passível de tradução em metas ou resultados de potência instalada. Um exemplo desse raciocínio é o potencial estimado de instalação de empreendimentos hidrelétricos ou nucleares no plano decenal de expansão 2010-2019. O valor ainda teórico poderá ser comparado em termos práticos à capacidade construída até o final da década, como um exercício para inferir a quantidade não construída de empreendimentos, decorrente de diferentes fatores como o tensionamento de atores locais, regionais ou nacionais envolvidos nesses projetos.

Outro exemplo de mensuração de resultados de grupos de En-ln é sugerido por dois estudos de caso da Universidade de Administração de Harvard, que analisaram índices de sucesso das organizações ambientalistas internacionais Greenpeace e WWF (CASADESUS-MASANELL et al, 2007).

climáticas, em especial a ilha de Tuvalu, no Pacífico, a calota polar do Ártico e o Rio Amarelo na China. O júri determinou que a ação implicava a preservação de propriedade na Inglaterra e ao redor do globo, inocentando os ativistas de qualquer tipo de condenação.

${ }^{31}$ Como exemplo desse cenário, cita-se a cisão da tribo dos índios Juruna por decorrência de divergências a respeito da construção da usina de Belo Monte. 
O processo de identificação de En-In inicia-se pela organização dos diferentes grupos relacionados ao recurso energético analisado, em categorias de grandes grupos como governo, empreendedores, populações atingidas e sociedade organizada. Esses grupos são compostos por diferentes representações e ramificações de acordo com a jurisdição ou o escopo geográfico da região contemplada (municipal, regional, estadual ou nacional).

A segunda etapa de organização de En-Ins lista os grupos afetados pelo recurso analisado, em função de impactos econômicos, ambientais e sociais. A lista a seguir exemplifica algumas dessas possibilidades:

\section{Impactos Econômicos (Diretos e Indiretos):}

- Ganho de empreiteiras por prestação de serviços na construção de usinas e ganho de geradores com a venda da energia;

- Ganho de comércio e indústrias com o aumento da renda e a movimentação da economia local;

- Perdas em atividades comerciais como turismo ou pesca;

\section{Impactos Ambientais:}

- Desmatamento na área construída;

- Alteração da qualidade da água de rios próximos;

- Poluição atmosférica de material particulado e/ou gases de efeito estufa;

\section{Impactos Sociais:}

- Deslocamento populacional;

- Geração de empregos;

- Impactos à saúde de população próxima.

Assim, com base na identificação dos impactos provocados por um recurso energético, constrói-se a matriz de En-In, considerando os impactados dentro dos grupos analisados. O exemplo abaixo, adaptado de Mallon (2006), aplica-se genericamente a recursos de fontes renováveis: 
Tabela 1: Matriz de En-In

\begin{tabular}{|c|c|c|c|c|}
\hline $\begin{array}{l}\text { Setores/Grupos } \\
\text { Impactados }\end{array}$ & Governo & Empreendedores & Cidadãos & $\begin{array}{l}\text { Sociedade } \\
\text { Organizada }\end{array}$ \\
\hline $\begin{array}{l}\text { Impactos } \\
\text { Econômicos } \\
\text { Diretos }\end{array}$ & $\begin{array}{c}\text { Secretarias de } \\
\text { Infraestrutura, } \\
\text { Agências de } \\
\text { Desenvolvimento, } \\
\text { Autoridades locais }\end{array}$ & $\begin{array}{c}\text { Fabricantes de } \\
\text { equipamento, indústria } \\
\text { de suprimento, agentes } \\
\text { financeiros }\end{array}$ & $\begin{array}{l}\text { Empregados em } \\
\text { indústrias, } \\
\text { Contratantes de } \\
\text { projetos }\end{array}$ & $\begin{array}{l}\text { Associações } \\
\text { Industriais, } \\
\text { Organizações de } \\
\text { Desenvolvimento }\end{array}$ \\
\hline $\begin{array}{l}\text { Impactos } \\
\text { Econômicos } \\
\text { Indiretos }\end{array}$ & $\begin{array}{l}\text { Ministérios e } \\
\text { Agências de } \\
\text { Economia e } \\
\text { Desenvolvimento }\end{array}$ & $\begin{array}{l}\text { Consumidores de } \\
\text { energia, } \\
\text { Comercializadores, } \\
\text { Distribuidores }\end{array}$ & $\begin{array}{l}\text { Consumidores de } \\
\text { energia, População } \\
\text { Local }\end{array}$ & $\begin{array}{c}\text { Associações de } \\
\text { consumidores, } \\
\text { geradores e outros } \\
\text { grupos }\end{array}$ \\
\hline $\begin{array}{l}\text { Impactos } \\
\text { Ambientais }\end{array}$ & $\begin{array}{c}\text { Ministério do Meio } \\
\text { Ambiente, Agências } \\
\text { de Licenciamento } \\
\text { Ambiental }\end{array}$ & $\begin{array}{l}\text { Arrendadores de } \\
\text { terrenos }\end{array}$ & $\begin{array}{l}\text { Impactados por } \\
\text { poluição ambiental } \\
\text { ou mudanças } \\
\text { climáticas }\end{array}$ & $\begin{array}{c}\text { Grupos } \\
\text { ambientalistas, } \\
\text { Institutos } \\
\text { Especializados }\end{array}$ \\
\hline $\begin{array}{l}\text { Impactos } \\
\text { Sociais }\end{array}$ & $\begin{array}{l}\text { Autoridades de } \\
\text { Planejamento, } \\
\text { Autoridades de } \\
\text { Conservação }\end{array}$ & $\begin{array}{l}\text { Residentes locais, } \\
\text { visitantes }\end{array}$ & $\begin{array}{l}\text { Impactados por } \\
\text { alteração da } \\
\text { qualidade de vida }\end{array}$ & $\begin{array}{c}\text { Grupos Sociais de } \\
\text { Populações Afetadas } \\
\text { por } \\
\text { Empreendimentos }\end{array}$ \\
\hline
\end{tabular}

Fonte: Mallon, 2006

O terceiro passo da análise de En-Ins é a valoração de subatributos internos aos grupos, tais como:

- Instrução ou conhecimento (técnico, político ou de diferentes ordens);

- Recursos Humanos (qualidade e habilidade de cada grupo);

- Recursos Financeiros (volume de recursos - $\mathrm{R} \$$ - para financiar medidas e ações de diferentes tipos);

- Representatividade (numérica ou relativa de cada grupo);

- Opinião (em relação ao recurso analisado, avaliada em diferentes níveis entre aprovação e repúdio);

- Poder de Ação (mobilização, persuasão de opinião pública ou política, potencial de alteração de resultados de negociação).

A análise individual de cada grupo de En-Ins pela sua organização e quantificação nos parâmetros citados é fundamentada, inicialmente, pela leitura qualitativa desses diferentes grupos e seus posicionamentos e ambições. Esse processo foi realizado e descrito no Relatório Técnico Científico de Valoração da Dimensão Política do PIR (USP, FAPESP, 2009c). O resultado da análise política 
é a configuração do panorama de posicionamento e atuação social específicos a cada recurso analisado, diante de suas peculiaridades locais referentes ao equilíbrio de poderes e à atuação de agentes.

A análise interativa de En-Ins parte da ponderação de riscos, perdas e benefícios de cada agente participante em uma problemática energética. Uma alternativa qualitativa para esse mapeamento é uma análise de poder (Power Analysis), nos quais os grupos de En-Ins são posicionados em um plano de eixos em função de sua inclinação/reprovação ao recurso energético analisado e o poder/influência de cada grupo. Mais dimensões ou eixos - tais como recursos financeiros - podem ser acrescentadas ao método, a fim de aumentar seu grau de detalhamento. As posições cartesianas de cada agente podem ser vetorizadas e a soma destes vetores indicaria a tendência do resultado da interação entre esses agentes, em cada instante de tempo analisado.

O exemplo abaixo (figura 6 ) mostra uma análise para o recurso energia nuclear no Brasil:

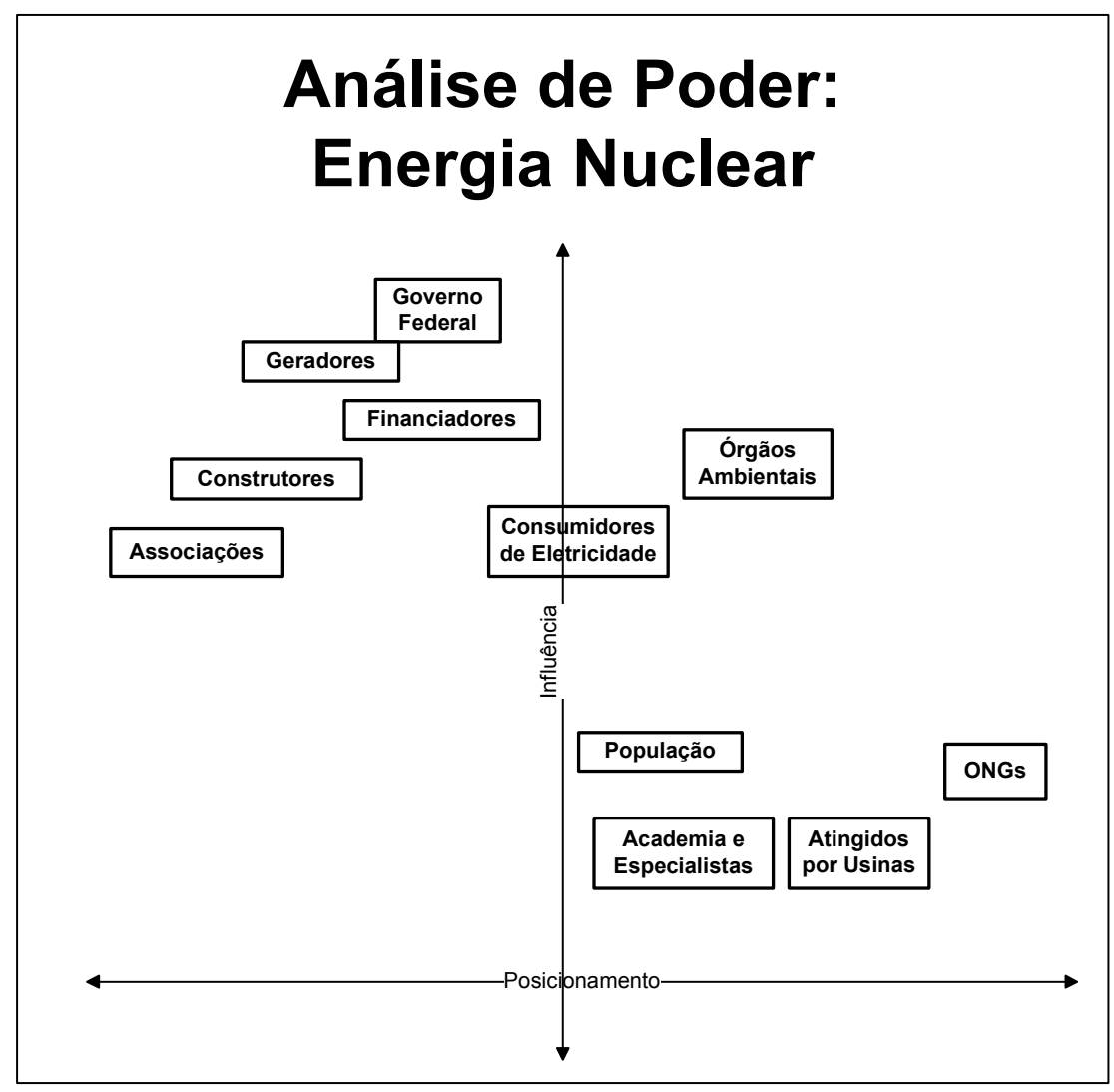

Fonte: Elaboração Própria

Figura 6: Análise de Poder do Setor Nuclear Brasileiro 
A quantificação das perdas e ganhos de diferentes En-Ins envolvidos em processos energéticos pode valer-se da metodologia da teoria de jogos (FONSECA, 2010). O uso da Teoria da Decisão para o gerenciamento de conflitos $^{32}$ foi proposto por Fisher, Ury e Patton (FISCHER et al, 1983) e Nijkamp (NIJKAMP et al, 1980) para a combinação de critérios e pesos a fim de mensurar as possibilidades de estratégias de compromissos entre partes conflitantes (BREDARIOL, 2001).

O resultado numérico que analisa diferentes possibilidades de negociação entre dois ou mais agentes auxilia tanto o processo de cômputo de potencial na estimativa de aferição de realização prática de potenciais teóricos de um determinado recurso, quanto o processo subsequente do PIR, o ranqueamento de recursos $^{33}$, especificamente na composição de atributos relacionados à avaliação de Envolvidos e Interessados.

\subsubsection{Algoritmo de cômputo e valoração}

Sintetizando a sequência de etapas para a valoração do potencial de envolvidos e interessados em um recurso energético, inicia-se o processo pelo mapeamento e caracterização de En-Ins, por diferentes processos de inferência, de pesquisas de campo a reuniões e entrevistas ${ }^{34}$. Em seguida, a extratificação de En-Ins é facilitada por matrizes de diferentes grupos em função de seus impactos e jurisdição.

O processo de análise individualizada de En-Ins acontece de forma qualitativa em levantamentos possibilitados por pesquisas bibliográficas em diferentes meios, pela ponderação de potenciais impactos sofridos por eles em diferentes dimensões de análise.

\footnotetext{
${ }^{32}$ Políticos, economistas e matemáticos têm usado a teoria dos jogos para analisar um vasto leque de fenômenos envolvendo disputas e interesses, de oligopólios a disputas territoriais.

${ }^{33} \mathrm{O}$ exercício do ranqueamento de recursos hídricos proposto por Fonseca (2010) utiliza a valoração prévia de atributos desse recurso na dimensão política, aplicado a um algoritmo semelhante ao utilizado por Bernard Marchand (1997), do Instituto Francês de Urbanismo, para a simulação de negociações de decisões do desenvolvimento urbano (MARCHAND, 1997, apud BREDARIOL, 2001).

${ }^{34}$ Como exemplos genéricos desses levantamentos, destacam-se o EGI (Iniciativa para a Governança em Eletricidade) e o Bem Estar, conduzidos, respectivamente, pelo WRI (World Resources Institute) e pelo Movimento Nossa São Paulo.
} 
Como terceiro passo, a interação entre agentes pode ser ilustrada graficamente por ferramentas como o power analysis - ou análise de poder - ou novamente por inferências qualitativas (USP, FAPESP, 2009c).

Por fim, a simulação de resultados dessas interações em diferentes cenários pode ser conduzida em metodologias tais como a Teoria de Jogos.

A demonstração de resultados práticos do relacionamento entre envolvidos e interessados é, na maioria dos casos, extremamente imprecisa dada a gama de resultados possíveis. De qualquer forma, sugere-se a inferência de potenciais energéticos concretizados em relação a potenciais inicialmente propostos em planos governamentais ou mesmo a obtenção de condicionantes socioambientais em documentos de licenciamentos ambientais para empreendimentos energéticos como forma de mensurar a relação de ganhos e perdas de cada agente envolvido.

A figura 7 ilustra a sequência de procedimentos para a avaliação de Envolvidos e Interessados: 


\section{Algoritmo - CVPC de Envolvidos e Interessados}

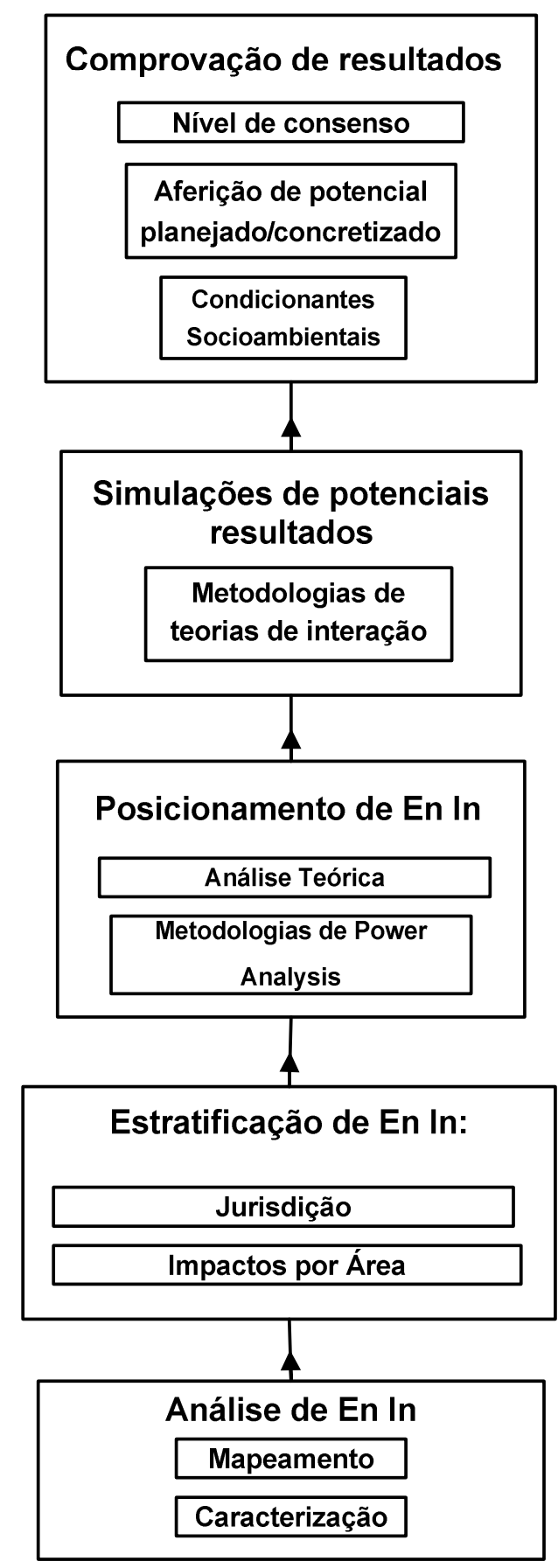

Fonte: Elaboração Própria

Figura 7: Algoritmo de cômputo e valoração do atributo Envolvidos e Interessados 


\subsubsection{Posse de Fonte Energética e Integração Transfronteiriça}

\subsubsection{Introdução}

Esse atributo analisa a origem e a posse de fontes energéticas, considerando sua disponibilidade local, regional ou nacional e o prolongamento da utilização de recursos via acordos internacionais e medidas de integração energética. $\mathrm{O}$ estado da propriedade de utilização e comercialização de cada fonte também é analisado - no entanto, o domínio tecnológico necessário para a conversão dessas fontes energéticas é abordado separadamente, na dimensão técnico-econômica.

A análise da propriedade de uma fonte energética é determinante para a viabilidade de sua exploração e implementação em uma região ou país; a disponibilidade de recursos naturais e energéticos significa o aumento da segurança energética local e a possibilidade de desenvolvimento econômico e social como decorrência de seu aproveitamento.

A análise da disponibilidade local ou nacional de um recurso abrange aspectos como o impacto do transporte dessa fonte até a região de estudo e, no caso de recursos estrangeiros, aspectos político-econômicos como acordos internacionais, que serão discutidos mais adiante.

Dentro do conceito de posse ou propriedade, há diferentes possibilidades e características de acordos para a exploração e utilização das fontes, cujo uso é classificado como livre ou público - como as energias solar e eólica-, de propriedade da união ou estatal, como os recursos hídricos, nucleares e petrolíferos, ou particulares ou privados, no caso de culturas de biomassa ou em determinados tipos de exploração de petróleo.

A viabilidade de desenvolvimento e implantação de recursos energéticos é fortemente vinculada ao modelo de apropriação empregado - principalmente no caso de exploração estatal ou privada de recursos. Grandes projetos costumam contar com auxílio majoritário do governo, ainda que envolvam empresas privadas em diferentes etapas.

No que se refere à metodologia de CVPC, a análise dos atributos de posse e propriedade de um recurso energético contribui à mensuração de seu potencial energético teórico (ao ponderar a extensão ou volume de reservas locais e/ou importação desse recurso) e de seu potencial de mercado (ao considerar a 
viabilidade comercial desse recurso à luz de acordos de concessão e comercialização previstos).

\subsubsection{Disponibilidade e Propriedade de Fontes Energéticas}

A mensuração do potencial de utilização de um recurso baseia-se nas condições de contorno naturais e geográficas relacionados à sua posse (analisada em domínio local, regional ou nacional) e é delimitada, em seguida, de acordo com seu modelo de concessão.

Em outras palavras, a estimativa teórica de utilização de um recurso é sucedida pela avaliação de restrições comerciais e políticas. Nesse exercício, a fonte energética pode ser avaliada como de livre acesso (como a energia eólica, solar e biomassa), destinada a usos múltiplos (hídrica), de posse da União (como nos casos do petróleo e gás natural brasileiro) ou estrangeira.

Esta última classificação abrange a utilização do recurso por acordos bilaterais de integração energética, possibilitada pelo compartilhamento de fontes e tecnologias ou mesmo a transmissão de eletricidade. A disponibilidade energética é balizada pela qualidade dessas relações do ponto de vista diplomático e geopolítico, repercutindo na instabilidade de fornecimento, por um lado, ou na segurança energética como efeito do cumprimento de contratos, por outro.

Fontes renováveis que não dependem de matéria prima para a geração de energia, como as gerações solar e eólica, representam recursos livres do ponto de vista do insumo energético, mas ainda dependentes do compartilhamento ou nacionalização de tecnologias importadas para a geração de energia.

Outras fontes renováveis como a hídrica, já apresentam um modelo diferenciado de utilização. A legislação vigente determina que os rios brasileiros são patrimônio da União Federal, que concede o uso do potencial hídrico por um tempo determinado mediante o pagamento pelo uso do bem público. Assim, ainda que os potenciais hídricos brasileiros sejam um recurso natural público, sua utilização para a geração de energia é firmada em contrato de concessão entre a União e o empreendedor (público ou privado). Este paga a compensação pelo uso de recursos hídricos a município e estado nos quais o recurso hídrico se 
localiza, em proporções iguais de $45 \%{ }^{35}$ (BRASIL, 2009). Em relação à biomassa, a fonte energética pertence ao local onde é desenvolvida, mas a propriedade, tanto do produto como da terra na qual é plantada, é particular. Nesse caso, a possibilidade de utilização de recursos naturais para a produção de combustíveis sólidos ou líquidos permite o transporte desses recursos e sua exportação a outros locais ${ }^{36}$.

Nesse sentido, o controle de uma fonte energética e a opção pelo seu uso nacional ou exportação representam prioridades de políticas energéticas nacionais. A disponibilidade de um determinado recurso garante a segurança energética para o desenvolvimento econômico do país e seu superávit permite a geração de divisas para sua balança comercial. A disponibilidade energética é um fator de alta relevância não apenas em termos técnicos e econômicos, como também de uso político, na promoção da legitimidade de governos, como será visto a seguir.

\subsubsection{Questões Políticas Pertinentes à Posse de Fontes Energéticas}

O Gás Natural, enquanto combustível fóssil de disponibilidade geográfica restrita a algumas regiões do globo, permite o estabelecimento de estratégias de comercialização que fortalecem ou sustentam a posição política de países detentores do recurso perante países importadores. Ainda que a concessão de sua exploração possa ser dividida entre agentes privados, tal concessão é obtida junto ao Estado detentor do recurso energético.

Parte do gás natural utilizado pelo Brasil é importado da Bolívia, país detentor de uma das maiores reservas mundiais do combustível. A relação diplomática entre ambos sofreu tensões na década passada, por conta de impactos sobre a segurança energética brasileira em decorrência da nacionalização das operações de petróleo e gás na Bolívia e restrições diretas à

\footnotetext{
${ }^{35}$ A redistribuição da verba destinada à compensação pelo uso dos recursos hídricos está sendo proposta pelo Projeto de Lei Complementar 315, no qual os municípios passariam a receber $65 \%$ dos recursos enquanto os estados teriam sua participação reduzida a $25 \%$. O projeto está no Congresso desde 2003 e ainda deve tramitar pelas Comissões do Meio Ambiente e Infraestrutura.

${ }^{36} \mathrm{O}$ etanol brasileiro teve sua viabilidade ambiental recentemente validada pela Agência de Proteção Ambiental Norte Americana (ou EPA, na sigla em inglês) e deve ser comercializado para diferentes países do mundo, contribuindo para metas nacionais de redução de combustíveis fósseis e consequentemente emissões de carbono.
} 
operação da Petrobrás no país. A medida teve como riscos diretos a possibilidade de interrupções no fornecimento de gás natural boliviano e aumento desse custo ao Brasil. A minimização desses riscos técnicos, políticos e econômicos implica a priorização do uso do combustível nacional, com o aproveitamento de bacias regionais e o reforço de investimentos de infraestrutura de portos para a importação de gás natural liquefeito (GNL).

Em relação ao petróleo, inúmeros exemplos de divergências e disputas por posse ou direito de exploração dessa fonte têm sido registrados na história política mundial. A importância da disponibilidade estratégica desses energéticos pode ser demonstrada pelo grau dos conflitos comerciais, políticos e bélicos travados entre países detentores de reservas, principalmente do Oriente Médio e os maiores consumidores, fundamentalmente países da OECD.

O Brasil deve imunizar-se de riscos associados à importação de derivados de petróleo com o início da exploração das reservas do Pré Sal nos próximos anos. O recurso é de posse da união, mas a divisão de royalties com municípios e estados produtores rendeu ampla discussão política nos anos de 2009 e 2010. O mesmo pode ser dito sobre a concessão da exploração de blocos dessas áreas a agentes internacionais. Grandes consumidores energéticos como os Estados Unidos e a China devem participar desse mercado a fim de utilizar parte desses recursos. O interesse norte-americano fundamenta-se na redução de riscos de suprimento do combustível obtido de regiões e países com os quais mantém relacionamento político delicado, como o Oriente Médio e a Venezuela. Neste último caso, a alteração das condições de vendas do combustível do país produtor compromete a segurança energética dos Estados Unidos e o atendimento à sua enorme demanda energética (SULLIVAN, 2008).

O recurso nuclear apresenta distribuição restrita no que se refere à posse do energético; as reservas identificadas de urânio restringem-se a um número limitado de países, como Austrália, Cazaquistão, Canadá, Rússia, África do Sul, Namíbia e o Brasil, que ocupa a sétima posição em termos de reservas recuperáveis (WNA, 2009). Ainda que o urânio de cada um desses países seja nacional e de propriedade da União, a distribuição do uso desse combustível e sua viabilidade para geração nuclear envolvem o compartilhamento de tecnologia de enriquecimento de urânio. 
Brasil tem o acordo de enriquecimento com nações como o Canadá e a Holanda, para onde o yellow cake é enviado e convertido em UF6 e, posteriormente, em urânio enriquecido. Diferentes acordos bilaterais ou multilaterais desse tipo têm a atenção constante da ONU, uma vez que domínios nacionais sobre o processo de enriquecimento de urânio pode conduzir ao desenvolvimento de armamentos atômicos, com exemplo no Paquistão (LANGEWIESCHE, 2007). O Brasil participou de tratativas para um acordo de enriquecimento de urânio entre a Turquia e o Irã, a fim de evitar que novas sanções fossem aplicadas ao país pelo Conselho de Segurança da $\mathrm{ONU}^{37}$.

Por outro lado, a parte tecnológica de construção de reatores é dominada por diferentes países, dentre os quais a maior parte não conta com reservas de urânio, como é o caso da França, Japão e Estados Unidos, que registram as maiores participações de geração nuclear em suas matrizes elétricas. Nesse sentido, a construção das usinas nucleares brasileiras de Angra 1 e 2 foi amparada por um acordo nuclear com a Alemanha, que previa, originalmente, a construção de oito reatores $^{38}$. O acordo atual tem sido mantido com a França; a empresa alemã Siemens, encarregada de suprir equipamentos para a usina de Angra 3, fundiu-se com a francesa Framatome, repassando o compromisso para a estatal francesa Areva.

\subsubsection{Integração Energética}

Os exemplos anteriores mostram que a distribuição de fontes de recursos energéticos tanto renováveis quanto não-renováveis não é, geograficamente, uniforme ao redor do mundo. Assim, a integração energética entre regiões e países é fundamental para permitir o acesso a essas fontes, seja por meio do transporte de combustíveis fósseis ou biomassa, pelo compartilhamento de

\footnotetext{
${ }^{37} \mathrm{O}$ acordo, não fechado, entre Brasil, Irã e Turquia previa que urânio iraniano levemente enriquecido fosse enviado ao território turco e, posteriormente, devolvido em um nível de enriquecimento superior, de $20 \%$. A medida ajudaria a evitar que o Conselho de Segurança da ONU aprovasse novas sanções contra o Irã por conta do desenvolvimento de sua capacidade interna de enriquecimento.

${ }^{38}$ O Acordo nuclear Brasil-Alemanha foi assinado em 1975, com a intenção de construção de oito reatores. Além da construção e operação das usinas, o acordo possibilitou a transferência de tecnologia nuclear para o Brasil, resultando no domínio sobre praticamente todas as etapas de fabricação do combustível nuclear. A transferência de tecnologia alemã para o enriquecimento de urânio foi a única etapa não permitida pelos Estados Unidos, o que incentivou o desenvolvimento de um sistema próprio nacional, que atingiu capacidade comercial de produção a partir de 2004.
} 
usinas hidrelétricas em rios fronteiriços ou, indiretamente, por meio da construção de linhas de transmissão que permitam o envio de energia do ponto de geração até outros mercados consumidores.

Nesse sentido, a mensuração da integração energética é medida empiricamente pela qualidade de relações firmadas entre países, considerando a segurança de comercialização de energéticos entre eles - medida por riscos contratuais (COSTA et al, 2007). Em termos numéricos, a integração é medida pela ampliação do uso de recursos energéticos importados (redefinindo o total de potenciais teóricos) ou pelo compartilhamento de usinas ou importação de tecnologias (aumentando o potencial realizável desses recursos). Essa equação inclui a consideração de limitações de fontes e sistemas de infraestrutura, que influenciam capacidades máximas e mínimas de geração e transporte de energia.

Como exemplo de fatores adicionais à mensuração da integração energética entre países, citam-se:

- o adiamento de investimentos em geração, como resultado da interconexão entre países, e a consequente redução de tarifas para consumidores;

- o aumento da carga média por compartilhamento de energias de diferentes perfis (como a complementação entre hidrelétricas e eólicas ou entre hidrelétricas e térmicas) ou por gerações com base em uma mesma fonte considerando diferenças climáticas locais (em casos de hidrelétricas com regimes hidrológicos diferenciados entre nordeste e sudeste ou eólicas com regimes de vento diferenciados por região).

- a gestão ótima e integrada desses sistemas na América Latina pode trazer benefícios como a economia anual de 1 bilhão de dólares nas tarifas praticadas no continente e o adiamento de investimentos de 9,4 bilhões de dólares em geração de eletricidade (apud CIER, 2010, apud GAMA, 2010). Somam-se a esses valores benefícios à segurança energética e à infraestrutura de transmissão de eletricidade nesses países. A integração deve acontecer por diferentes ações como o compartilhamento de hidrelétricas com o Peru e linhas de transmissão com a Argentina.

Por outro lado, diferentes episódios registrados entre esses países na última década ilustram, de forma prática, as diferentes restrições ao cômputo do potencial de integração energética. Os principais foram interrupções de 
fornecimento (de 2 mil MW da Argentina, em 2007 e de termelétricas da Venezuela a Roraima por conta de racionamento), a nacionalização de empresas da Petrobrás na Bolívia, em 2006 - e oscilações no fornecimento do gasoduto boliviano nos anos seguintes - e a renegociação do contrato da usina de Itaipu (INSTITUTO ACENDE BRASIL, 2010).

Por fim, a identificação de riscos e conflitos de suprimento de combustíveis e problemas de integração pode conduzir países à adoção de modelos alternativos de exploração energética. Os exemplos mais notórios decorreram das crises de petróleo na década de 70 - que abriram espaço à pesquisa e ao desenvolvimento de novas fontes de energias renováveis na America do Norte - e da insegurança de suprimento de gás natural russo à Alemanha - que fomentou 0 desenvolvimento de fontes alternativas para a produção de eletricidade e calor, como o biogás (BMU, 2009). Obviamente a tendência de globalização amplia interações econômico-financeiras e, com isso, diversifica provedores de fontes ou recursos energéticos e minimiza o risco de controle de recursos por poucos Estados.

\subsubsection{Algoritmo de Cômputo e Valoração}

Os algoritmos de atributos de valoração da posse de recursos energéticos e da integração energética entre regiões e países são construídos conjuntamente, uma vez que ambos interagem com a valoração de potenciais energéticos de recursos.

Se o potencial teórico de um recurso é moldado por sua propriedade nacional, o modelo de concessão e utilização pública ou privada estabelecido para esse recurso interfere em seu potencial de mercado. Já a integração energética determina a complementação do potencial realizável local pela importação de combustíveis ou eletricidade proveniente de outras regiões.

A localização de fontes energéticas pode ser aferida em levantamentos de bancos de dados locais, nacionais e internacionais. Já a posse e a propriedade de recursos energéticos podem ser pesquisadas em marcos legais locais e regionais dos recursos energéticos. Já acordos e compromissos de integração energética são informações constantemente atualizadas por periódicos, jornais ou publicações oficiais de órgãos governamentais. 
Essa informação utilizada para o refinamento de potenciais energéticos é essencialmente teórica e pode ser quantificada em termos de benefícios a países e regiões, conforme sua variação de potenciais de mercado - de acordo com sua forma de comercialização - e conforme a variação de seu potencial realizável de acordo com o compartilhamento do recurso com outras regiões.

A esquematização dessa valoração pode ser vista na figura 8 abaixo:

\section{Algoritmo - CVPC de Posse e Integração Energética de Recursos}

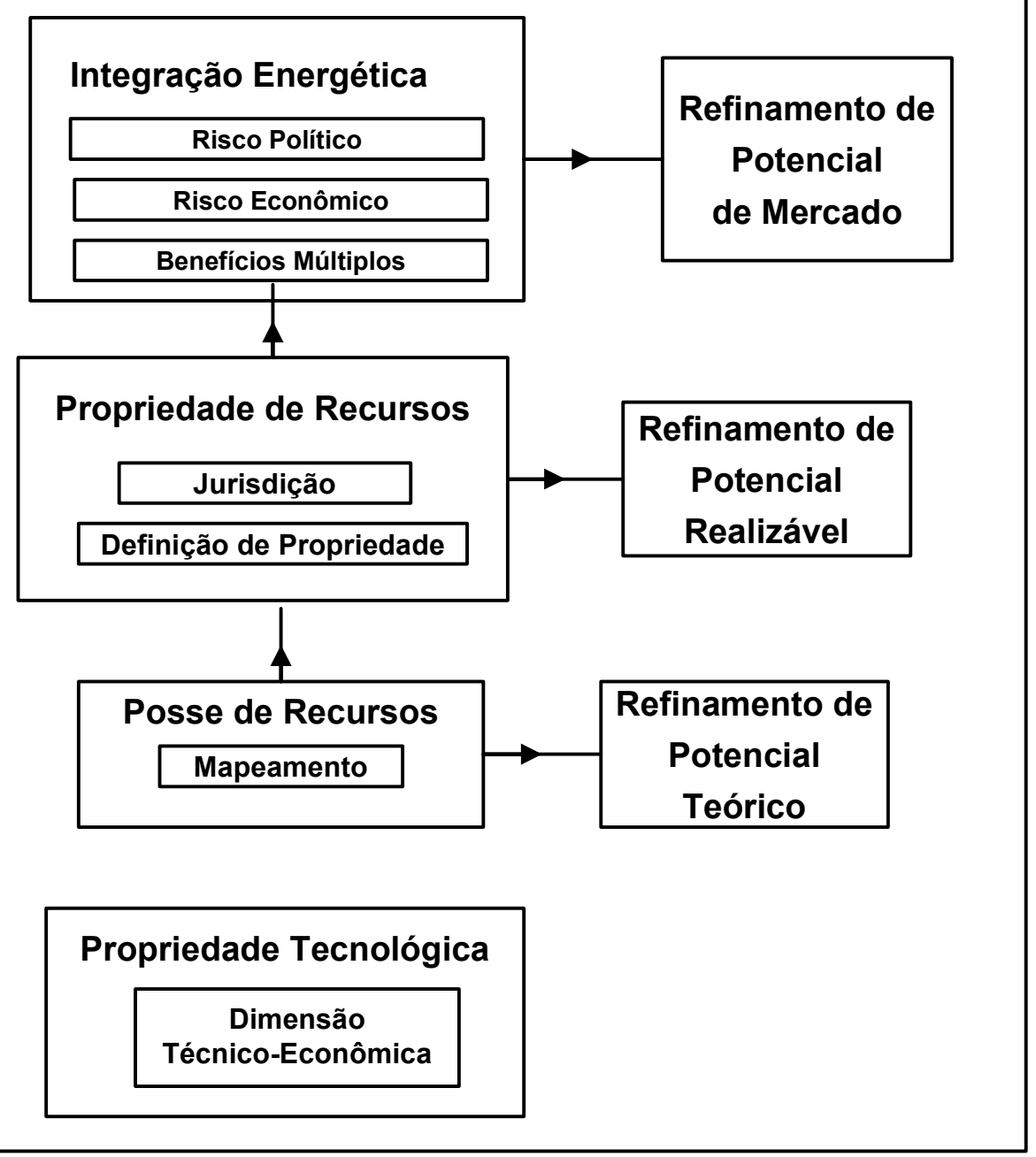

Fonte: Elaboração Própria

Figura 8: Algoritmo de valoração do atributo Posse e Integração Energética de Recursos 


\subsection{Cômputo e Valoração da Dimensão Ambiental}

\subsubsection{Definição da Dimensão Ambiental para o PIR}

A dimensão ambiental do planejamento integrado de recursos relaciona os diferentes impactos dos sistemas energéticos sobre o meio ambiente. Se a dimensão política do planejamento energético estuda a efetividade de ações antropogênicas para a implantação de sistemas de energia, as dimensões ambiental e social analisam a interferência dessas decisões na ponderação de impactos e benefícios a esses meios.

O meio ambiente é definido como o conjunto de fatores que afetam e determinam o comportamento e a sobrevivência dos seres vivos que o habitam. Faz sentido, portanto, organizar a análise das perturbações de atividades energéticas sobre esse meio nas áreas que representam suas matérias fundamentais - os meios aéreo, terrestre e aquático.

De acordo com a Resolução $001 / 86^{39}$ do Conama (Conselho Nacional de Meio Ambiente), um impacto ambiental é definido como "qualquer alteração das propriedades físicas, químicas e biológicas do meio ambiente, causada por qualquer forma de matéria e energia, resultante das atividades humanas que, direta ou indiretamente, afetam: a saúde, a segurança e o bem estar da população; as atividades sociais e econômicas; a biota; as condições estéticas e sanitárias do meio ambiente; e a qualidade dos recursos ambientais" (CONAMA, 1986).

Essas alterações sobre o meio ambiente interferem diretamente sobre a qualidade de vida de toda a sociedade - de populações habitantes do meio urbano a comunidades no entorno de grandes empreendimentos. Assim, da mesma forma que os recursos naturais atendem, na forma de produtos e commodities, a inúmeras necessidades da sociedade, a sobreutilização e a limitação de recuperação de estoques desses recursos comprometem sua provisão futura.

\footnotetext{
39 A resolução CONAMA № 001 , de 23 de janeiro de 1986 estabelece as definições, as responsabilidades, os critérios básicos e as diretrizes gerais para uso e implementação da Avaliação de Impacto Ambiental como um dos instrumentos da Política Nacional do Meio Ambiente.
} 
A alteração da qualidade de parâmetros ambientais e a transformação desses recursos acontecem em diferentes etapas das cadeias energéticas, desde a extração e produção de combustíveis fósseis e nucleares, a construção de usinas para a geração de energia, até a transmissão dessa energia aos centros de consumo e seu uso final em diferentes setores.

Como exemplos de impactos de empreendimentos energéticos sobre os meios aéreo, aquático e terrestre, citam-se:

- Impactos da construção de barragens sobre os múltiplos usos de recursos hídricos, como abastecimento, irrigação e controle de cheias por conta de sedimentação e assoreamento de reservatórios hidrelétricos (REIS, 2001). A modificação da vazão do Rio Xingu e de seus afluentes no projeto de construção da Usina Hidrelétrica de Belo Monte deve resultar na alteração da disponibilidade de recursos hídricos da Volta Grande do Xingu - com consequências sobre a diminuição do lençol freático, mudanças nos trechos navegáveis, perda de fauna aquática e terrestre, escassez de água, entre outros impactos. (SANTOS e HERNANDEZ, 2009)

- Impactos sobre o solo em atividades de mineração de carvão, representados pela alteração da superfície terrestre, deposição de rejeitos, contaminação, alterações morfológicas e erosão em Criciúma (PIAZZA, 2006). A extração, o processamento e a combustão do carvão produzem uma grande quantidade de resíduos sólidos, como cinzas e ganga. Essa é uma das maiores fontes de resíduos sólidos na China, comprometendo grandes áreas de terra - aráveis, em alguns $\operatorname{casos}^{40}$ (YUSHI, HONG e FUQIANG, 2008).

- As emissões atmosféricas provenientes da produção de combustíveis derivados de petróleo em refinarias - incluindo emissões fugitivas de compostos voláteis de óleo cru e suas respectivas frações em bombas, válvulas e tanques -, emissões potenciais de $\mathrm{CO}$, SOx, NOx, material particulado e hidrocarbonetos pela queima de combustíveis em aquecedores de processo e caldeiras e emissões de sulfeto de hidrogênio, óxidos de enxofre e nitrogênio para a recuperação de enxofre nas unidades de processo (MARIANO, 2001).

${ }^{40} \mathrm{O}$ peso da ganga no carvão produzido a cada ano é equivalente a dez por cento do carvão extraído (YUSHI, HONG e FUQIANG, 2008). 
Dentro desse contexto, a mensuração dos impactos desses sistemas energéticos para o meio ambiente e para a sociedade torna-se imprescindível em qualquer metodologia de planejamento energético.

\subsubsection{Procedimento da Valoração de Atributos Ambientais}

A valoração de impactos ambientais no planejamento energético é extremamente complexa; a quantificação da alteração das condições físicas, químicas e biológicas de uma região em função da implantação de um empreendimento energético requer o equacionamento de diferentes variáveis de estado desse processo - como a localização, a extensão e a duração desses impactos e os fenômenos de propagação dessas perturbações no sistema definido como meio ambiente.

A determinação da relevância desses fenômenos e dos limites de sua perturbação em efeitos de segunda ordem demandam conhecimentos específicos que validem sua mensuração. Esses parâmetros foram levantados nos relatórios de Inventário Ambiental (USP, FAPESP, 2008a) e Mapeamento Ambiental (USP, FAPESP, 2009b) do Estudo de Caso de PIR realizado em Araçatuba. Somado a eles, a elaboração da caracterização de recursos energéticos (BAITELO, 2006; FUJII, UDAETA 2006; USP, FAPESP, 2008) fundamentou o desenvolvimento da árvore de atributos empregada para o cômputo e a valoração completa dos potenciais energéticos dessa dimensão.

Os impactos da cadeia energética ao meio ambiente são divididos em atributos aéreo, aquático e terrestre. Dentro de cada um deles, consideram-se ramificações em análises mais específicas.

Os impactos ao meio aéreo consideram a variação da concentração de diferentes substâncias poluentes na atmosfera, dentre elas os gases causadores de efeito estufa. Esse fator é mensurado em função do peso das emissões produzidas para cada unidade de energia gerada, ou gramas por kWh. O cálculo dessas emissões deve levar em conta a procedência do consumo de energia nos processos envolvidos desde a sua produção até seu uso final. As emissões finais de gases são proporcionais às etapas conduzidas localmente, em função do combustível e da tecnologia de conversão utilizados para cada recurso energético nas etapas de produção, transporte, geração e tratamento de resíduos (quando aplicável). A produção de poluentes secundários, como o ozônio e particulados 
secundários, formados por transformações químicas de poluentes diretos (como compostos orgânicos voláteis) na atmosfera, também é contabilizada, em função de seus impactos aos ecossistemas terrestres. Essa poluição é condicionada a condições climáticas específicas como intensidade de luz solar, temperatura, velocidade do vento local, entre outros.

A tradução dessas emissões em potencial medida de geração de efeito estufa segue os índices de conversão de cada poluente em emissões de CO2 equivalente, de acordo com a metodologia do Painel Intergovernamental de Mudanças Climáticas - IPCC, da sigla em inglês (IPCC, 2007).

Os impactos ao meio terrestre incluem a deposição de poluentes aéreos no solo, resultando em sua degradação - e efeitos colaterais como a infiltração desses poluentes em lençóis freáticos -, a geração de resíduos sólidos tóxicos como subproduto da geração de energia e o uso e degradação do solo pelo efeito da ocupação de empreendimentos energéticos.

Esses atributos analisam as diferentes etapas da cadeia energética. No caso da deposição de poluentes, as emissões finais de gases são proporcionais aos processos energéticos conduzidos localmente, como a geração de energia ou a produção local de tecnologias pertencentes a essa cadeia. A geração de resíduos sólidos para produção e geração de energia, bem como a ocupação e degradação do solo por empreendimentos energéticos consideram, nas condições de contorno da região estudada, impactos locais e regionais. Nesses casos, pode-se ilustrar como exemplos dessas atividades a mineração de urânio, a produção de etanol - com implicações ao uso do solo e produção de resíduos finais - e a queima de combustíveis fósseis como óleo combustível ou gás natural.

A medição desses impactos na valoração, para resíduos sólidos, é função de seu peso em proporção à energia produzida no processo. A avaliação da ocupação e degradação do solo por empreendimentos é medida em pela área ocupada em função da capacidade instalada do empreendimento ou do volume de produção de energéticos ou tecnologias de conversão.

Por fim, o meio aquático divide-se em dois grupos fundamentais: a demanda de recursos hídricos e a geração de efluentes líquidos. 
A demanda de recursos hídricos é avaliada em função de sua captação e consumo para fins energéticos, segundo os procedimentos da gestão de recursos hídricos.

A captação contabiliza os volumes derivados de um corpo d'água, em função do tempo; o consumo refere-se à fração do volume captado (USP, FAPESP, 2008c). O uso desses recursos é novamente computado em todas as etapas da cadeia energética conduzidas localmente, como a produção fabril de equipamentos e tecnologias de conversão de energia, a extração de combustíveis energéticos como petróleo, carvão e urânio e o cultivo da cana-deaçúcar e outras oleaginosas para a produção de biocombustíveis.

A análise da geração de efluentes líquidos considera condicionantes de emissão em corpos d'água e alteração de parâmetros de qualidade das águas $\mathrm{pH}$, temperatura e variáveis microbiológicas, hidrobiológicas e ecotoxicológicas. A análise desses parâmetros é expressa na forma de concentrações por volume de água e o cômputo de potencial dos indicadores é ponderado pelo volume de efluentes líquidos por unidade de energia gerada. Ressalta-se a limitação dessa análise para situações em que o despejo de efluentes em processos industriais não é realizado em corpos d'água, comprometendo a validade da medição de qualidade de água

A alteração desses parâmetros nos três meios da dimensão ambiental exerce inegável impacto sobre a fauna, a flora e o bioma afetado. Diferentemente das implicações de alterações ambientais sobre a sociedade, analisadas na dimensão social, esses impactos estão inseridos no meio natural afetado e integram, portanto, a dimensão ambiental. Porém, a análise desses parâmetros é realizada em diferentes etapas do PIR, como o inventário e o mapeamento ambientais.

Segue, na figura 9, a estrutura da árvore da dimensão ambiental, com os respectivos atributos e subatributos utilizados como indicadores de valoração. 


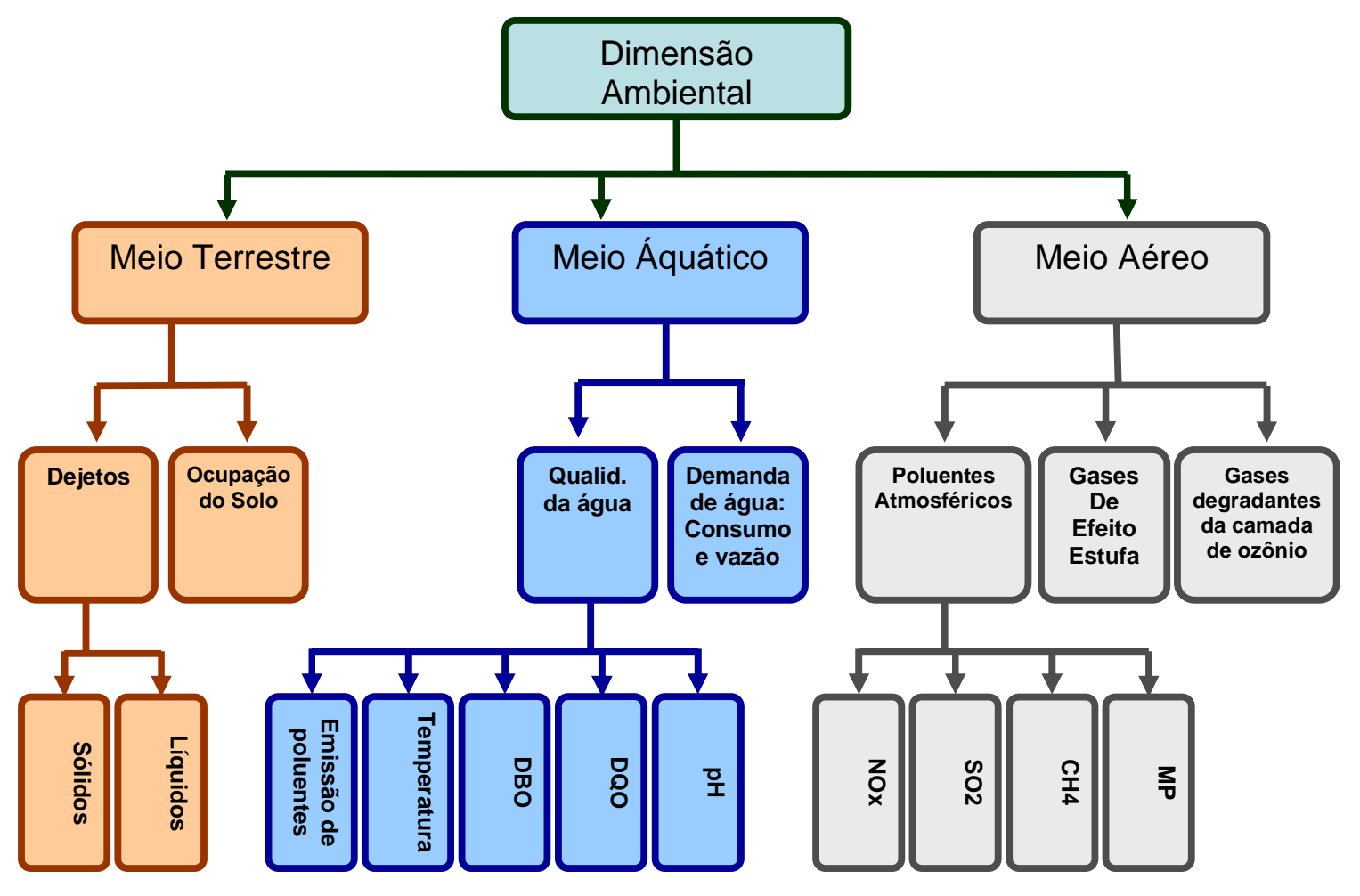

Fonte: USP, FAPESP 2009e

Figura 9: Árvore de atributos e subatributos da dimensão ambiental

\subsubsection{Poluição Atmosférica}

As mudanças climáticas decorrentes da poluição atmosférica pela emissão de gases causadores de efeito estufa são atualmente uma das maiores ameaças à vida humana e animal. Podem, futuramente, causar graves impactos à economia global e à estabilidade sociopolítica das nações.

Esse atributo trata do acréscimo de emissões de poluentes à atmosfera provocada por atividades relacionadas à cadeia energética, na forma de diferentes substâncias químicas, como óxidos de enxofre e de nitrogênio, monóxido e dióxido de carbono, metano e compostos orgânicos voláteis, material particulado, entre outros. Essas substâncias emitidas em fontes móveis e estacionárias são responsáveis por impactos ambientais globais, como o efeito estufa, e regionais - como a chuva ácida e o smog.

Diferentes impactos ambientais e tipos de emissões aéreas ocorrem em cada etapa da cadeia energética, de acordo com as características das fontes energéticas e das tecnologias empregadas em sua conversão. Usinas termelétricas com base em combustíveis fósseis registram as maiores emissões absolutas; gerações a carvão, diesel e óleo combustível resultam em cerca de 
$1000 \mathrm{~g}$ de CO2 equivalente para cada kWh gerado (UNECE, 2007). Em outro extremo, tecnologias de geração com base em fontes renováveis livremente disponíveis na natureza, como a eólica, registram emissões reduzidas, inferiores a $10 \mathrm{~g}$ de CO2 equivalente para o mesmo kWh produzido (JACOBSON, 2008).

Entre esses extremos, localiza-se a energia nuclear, que não produz emissões na operação da usina, mas demanda uma alta quantidade de energia para a extração e tratamento do combustível utilizado na geração, resultando em emissões indiretas (SOVACOOL, 2008c).

A emissão total de cada recurso energético pode ser quantificada por uma análise das interações entre todos os processos envolvidos desde a obtenção do combustível até a geração de energia. A análise de custo de vida contabiliza todos os custos energéticos desses processos, por meio da coleta $\mathrm{e}$ processamento de uma ampla gama de dados como implicações geográficas dos processos energéticos, a qualidade do combustível utilizado nesses processos e a logística envolvida ${ }^{41}$. Obviamente a metodologia gera diferentes resultados de acordo com os fatores considerados; alguns estudos deixam de cobrir todos os aspectos da cadeia energética de uma fonte específica; no caso específico da geração nuclear, o custo energético de toda a cadeia é frequentemente subestimado no cômputo das emissões ${ }^{42}$.

Os pontos comumente minimizados referem-se aos custos energéticos da mineração, do processo de conversão do urânio em combustível nuclear, do armazenamento de rejeitos nucleares após a geração de energia e do descomissionamento dos sítios de mineração de urânio - com sua restauração às condições ambientais originais - e das usinas nucleares após sua vida útil incluindo as fases de manutenção após o fechamento da usina, limpeza dos componentes antes do desmonte, demolição de componentes radioativos e empacotamento e descarte de resíduos (BAITELO, 2007).

O estudo "Nuclear power - The Energy Balance" (STORM, SMITH, 2007) contabiliza as emissões de $\mathrm{CO} 2$ em cada uma dessas etapas da cadeia de

\footnotetext{
41 Diversos institutos de pesquisa realizam esse tipo de trabalho, como o Öko-Institut, da Alemanha. O software GEMIS (Modelo de Emissões Globais para Sistemas Integrados) compila e atualiza dados utilizados na Análise de Ciclo de Vida.

${ }^{42}$ Ainda que a World Nuclear Association indique uma escala de emissões entre 6 e $26 \mathrm{~g} / \mathrm{kWh}$, outros estudos internacionais demonstram níveis de emissão de CO2 entre 30 e $60 \mathrm{~g} / \mathrm{kWh}$ (IEA, 1994; CRIEPI 1995) e 130 g/kWh (ISA, Universidade de Sidney).
} 
geração nuclear, produzindo um resultado final, em condição limite, de emissões próximas às de uma termelétrica a gás natural ${ }^{43}$.

\subsubsection{Algoritmo de Cômputo e Valoração}

O atributo poluição atmosférica computa as emissões aéreas de todas as etapas da cadeia energética realizadas na região estudada. Considera-se o consumo energético e suas proporcionais emissões por fontes móveis e estacionárias para as etapas energéticas de produção de combustíveis (incluindo extração e processamento), transporte, construção de empreendimentos, geração de energia, tratamento e condicionamento de resíduos e descomissionamento (se aplicável).

O uso energético nessas etapas provoca emissões por fontes móveis e estacionárias dos seguintes grupos de substâncias químicas: óxidos de enxofre e de nitrogênio, monóxido e dióxido de carbono, hidrocarbonetos, compostos orgânicos voláteis e material particulado (ODONGO, 2008). A essas emissões, soma-se a produção de poluentes secundários formados por transformações químicas de poluentes diretos na atmosfera, como o ozônio, o ácido nitroso $\left(\mathrm{HNO}_{2}\right)$ e o ácido nítrico $\left(\mathrm{HNO}_{3}\right)$.

O potencial de formação e dispersão desses poluentes para diferentes zonas urbanas e rurais é proporcional às diferentes condições meteorológicas locais, topografia do terreno, velocidade e direção do vento, radiação solar, umidade relativa e temperatura do ar e poluição preexistente (MIRANDA, 2001).

Assim, o algoritmo parte da identificação dos processos energéticos realizados para a obtenção de cada recurso energético e dos volumes de energia demandados para cada um deles - considerando as características e a procedência da energia utilizada nos mesmos, gerada localmente ou suprida por uma rede energética integrada e regional - medidos em kWh e tep (toneladas equivalentes de petróleo).

Em seguida, contabilizam-se as emissões atmosféricas relativas a cada processo energético empregado na obtenção do recurso analisado. Esses

\footnotetext{
${ }^{43}$ Storm e Smith consideram que a exploração futura de minérios de urânio mais pobres (entre 0,1 e $1 \%$ de concentração) deverá aumentar o gasto de energia nesse processo, na medida em que as reservas de urânio diminuam. Segundo a análise, o custo energético de toda a cadeia nuclear é capaz de repercutir em emissões equivalentes de $\mathrm{CO} 2$ superiores à quantidade das emissões de termelétricas a gás, ou $400 \mathrm{gCO} / \mathrm{kWh}$, considerando a exploração futura de minérios pobres em urânio (abaixo de 0,01\%).
} 
valores são medidos em peso de poluentes em função da energia produzida em cada etapa, multiplicados pela energia gerada de acordo com a capacidade instalada do recurso energético analisado.

Por fim, a produção desse potencial teórico de emissões atmosféricas restringe-se na prática pela dispersão de poluentes e formação de produtos secundários com base na medição das condições naturais locais. Esse potencial realizável deriva, portanto, da correção das emissões teóricas em função dos diferentes parâmetros meteorológicos, representado pelo peso das emissões finais em função da energia gerada pela capacidade instalada de cada recurso. Ressalta-se que esse potencial realizável é determinado na prática apenas no processo de integração de recursos energéticos, com o auxílio dos vigilantes construídos no mapeamento ambiental.

O algoritmo de cômputo e valoração desse atributo segue abaixo, na figura 10 . 


\section{Algoritmo - CVPC Poluição Atmosférica}

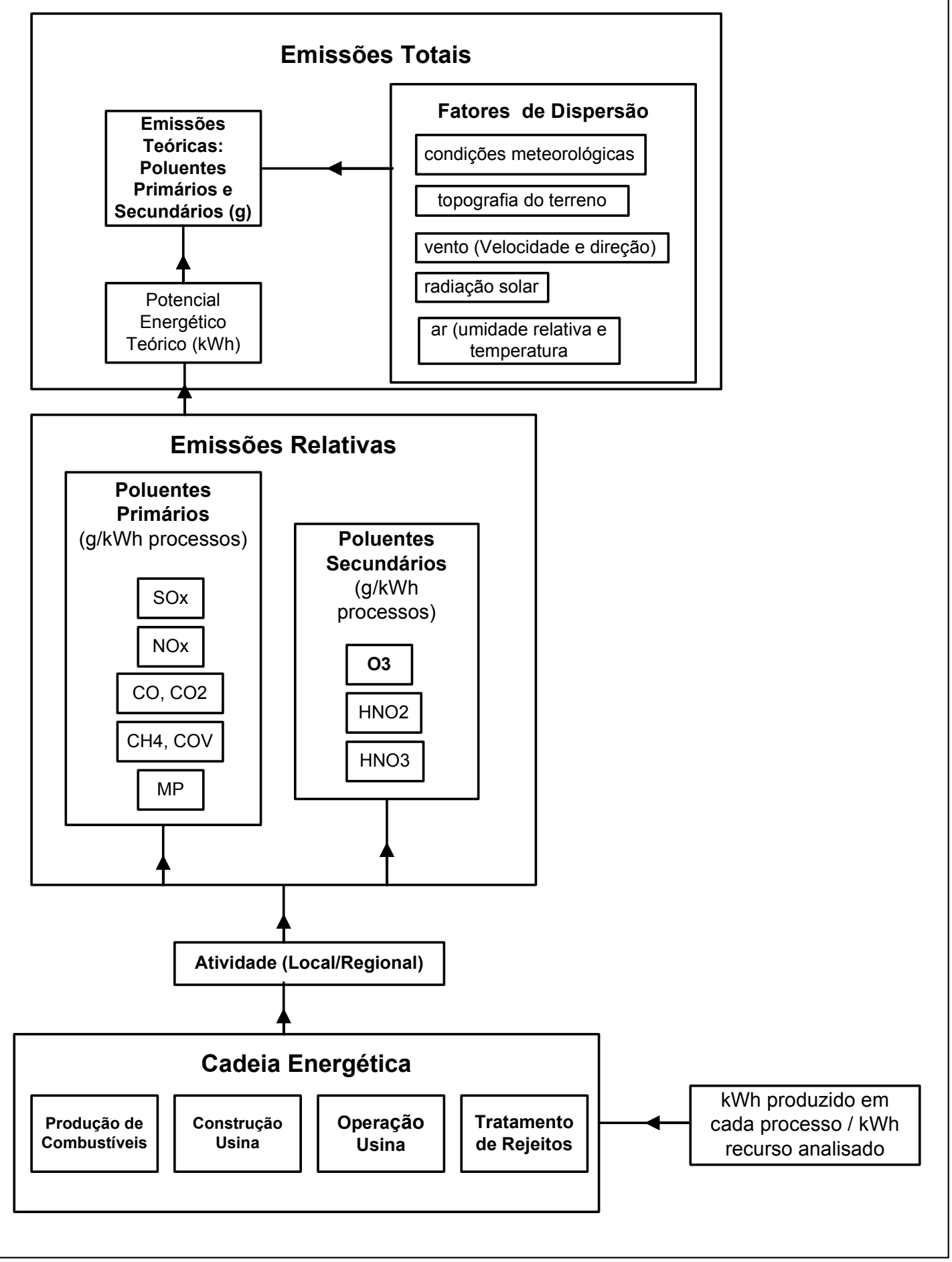

Fonte: Elaboração Própria

Figura 10: Algoritmo de cômputo e valoração do atributo Poluição Atmosférica 


\subsubsection{Produção de Gases de Efeito Estufa no Setor Energético}

Em paralelo à poluição atmosférica, quantifica-se, neste atributo, a emissão de gases de efeito estufa de recursos energéticos. Ainda que a emissão de gases seja quantificada no atributo de poluição atmosférica, a contabilização de tais gases em função de potenciais de aquecimento global justifica-se pelo nível de prioridade e urgência com a qual a discussão sobre o aquecimento global ${ }^{44}$ e a mitigação desses gases é tratada atualmente em fóruns nacionais e internacionais.

Os principais gases de efeito estufa são o vapor d'água e o dióxido de carbono. O primeiro responde pela maior participação no efeito estufa (entre $36 \mathrm{e}$ $66 \%$ ), mas não é alterado significativamente pela atividade humana. Desde a era industrial, atividades como o uso de combustíveis fósseis, a agricultura e a transformação do solo têm resultado no aumento da emissão, principalmente, dos seguintes gases de efeito estufa: dióxido de carbono (CO2), óxido nitroso (N2O), metano $(\mathrm{CH} 4)$ e halocarbonos (grupo de gases que inclui fluorina, clorina e bromina). Outros gases, como monóxido de carbono (CO), óxidos de nitrogênio (NOx) e compostos orgânicos voláteis não metânicos (NMVOC), ainda que não sejam classificados como gases de efeito estufa direto, influenciam reações químicas que ocorrem na atmosfera.

$\mathrm{O}$ aumento das emissões de $\mathrm{CO} 2$ tem sido provocado pelo uso de combustíveis fósseis no setor de transportes, aquecimento e refrigeração ${ }^{45}$. As emissões de NO2 também derivam do uso de combustíveis fósseis. Já as emissões de metano no setor energético derivam de fugas durante a extração, transporte e distribuição de petróleo e gás natural e do processamento destes energéticos em refinarias. Os processos de mineração e beneficiamento do carvão mineral provocam o mesmo efeito (MCT, 2009).

\footnotetext{
${ }^{44}$ Aproximadamente dois terços da energia solar que atinge os limites da atmosfera terrestre é absorvida pela superfície terrestre e pela atmosfera. Para equilibrar o fluxo dessa energia, a Terra deveria irradiar esta mesma quantidade de energia de volta para o espaço, mas grande parte dessa radiação térmica emitida pela terra e pelos oceanos é reabsorvida pela atmosfera e irradiada de volta à Terra. Este fenômeno é o chamado efeito estufa. Ainda que este efeito natural seja o responsável pela existência de vida no planeta, atividades humanas, principalmente a queima de combustíveis fósseis e o desmatamento de florestas, têm intensificado o efeito estufa além de seu funcionamento padrão, provocando o aquecimento global.

${ }^{45}$ Emissões anuais de $\mathrm{CO} 2$ provenientes da queima de combustíveis fósseis, produção de cimento e queima de gás natural em flares cresceram de 6,4 bilhões de toneladas nos anos 90 para mais de 7,2 bilhões de toneladas entre 2000 e 2005 (IPCC, 2007).
} 
Esse atributo trata do acréscimo de emissões antropogênicas de gases de efeito estufa à atmosfera provocada por atividades relacionadas à cadeia energética, incluindo emissões resultantes da queima de combustíveis e de fugas na cadeia de produção e transformação de energia. Assim como a valoração das emissões atmosféricas, a valoração da emissão total de gases de efeito estufa provocada por um recurso energético pode ser quantificada por uma somatória dos processos envolvidos desde a obtenção do combustível até a geração de energia, convertidos em carbono equivalente, a fim de mensurar seu potencial de geração de efeito estufa.

A diferença deste algoritmo é a contabilização de emissões das atividades realizadas dentro do entorno da região de estudo analisada. Assim, a produção local de combustíveis que sejam utilizados em outras regiões é considerada como emissão externa e, portanto, não é contabilizada dentro dessa área. Por outro lado, a emissão de gases de efeito estufa decorrentes da utilização de energia para a produção de recursos ou mercadorias exportados a outras regiões é internalizada nesta análise.

Os indicadores desse atributo são similares aos de valoração de poluição atmosférica; a emissão de substâncias químicas na fase gasosa acarretadas pela utilização do potencial de oferta do recurso energético valorado associa-se ao volume desse potencial por fatores de emissão existentes na literatura ${ }^{46}$. No entanto, as substâncias consideradas restringem-se aos gases de efeito estufa recorrentes de atividades do setor energético - CO2, CH4 e N2O - convertidos em unidade comum de potencial de efeito estufa.

\subsubsection{Algoritmo de Cômputo e Valoração}

O atributo computa o potencial de geração de efeito estufa dos gases envolvidos em atividades da cadeia energética realizadas no local de estudo. Considera-se, portanto, a geração de energia - para diferentes atividades econômicas - e suas proporcionais emissões locais.

\footnotetext{
${ }^{46}$ Dentre as fontes de referência utilizadas, estão a quinta edição da compilação de fatores de emissão AP42, produzida pela Agência de Proteção Ambiental dos Estados Unidos da América (USEPA); Emission Inventory Guidebook, versão 2007, publicado pela Agência Ambiental Européia (EMEP); e o Guia para Inventários Nacionais de Gases de Efeito Estufa, versão 2006, editado pelo Painel Internacional de Mudanças Climáticas (IPCC).
} 
Esses gases emitidos são o dióxido de carbono (CO2), o óxido nitroso (NO2) e o metano ( $\mathrm{CH} 4)$. Neste caso, contabilizam-se as emissões realizadas dentro dos limites da região estudada, com base em sua fonte - móvel ou estacionária - independentemente das condições de dispersão desses poluentes. Assim, o algoritmo parte da identificação dos processos energéticos realizados localmente para cada recurso energético. Essa energia é medida em MWh e dimensionada em função da quantidade final de energia gerada pelo recurso analisado. Em seguida, contabilizam-se as emissões atmosféricas de gases de efeito estufa relativas à geração do recurso analisado. Esses valores são medidos em peso de gases de efeito estufa em função da energia gerada, multiplicados pelo coeficiente ou potencial de efeito estufa de conversão do gás em $\mathrm{CO} 2$ equivalentes (potencial de efeito estufa - PEF - ou global warming potential - GWP) ${ }^{47}$. Por fim, o total é multiplicado pelo potencial de oferta do recurso energético analisado, a fim de obter-se um valor absoluto de emissão medido em massa de $\mathrm{CO} 2$ equivalente.

A dispersão das emissões atmosféricas não é incluída na valoração deste atributo uma vez que a análise de emissão de gases de efeito estufa leva em conta a somatória de emissões locais a fim de contabilizar números regionais de emissões. Estes números serão trabalhados em inventários e sua associação ao aquecimento global determinará a urgência de sua redução.

Os coeficientes de potencial de efeito estufa são extraídos do quarto relatório de avaliação do IPCC (2007) e são variáveis de acordo com os horizontes de tempo no qual o potencial é calculado. Assim, são apresentados coeficientes para períodos de 20, 100 e 500 anos. Cada período resulta em diferentes potenciais, em decorrência do decaimento da concentração desses gases na atmosfera. Os valores constam da tabela 3 .

\footnotetext{
${ }^{47}$ Deve-se ressaltar que a utilização do coeficiente de PAG (GWP) - que relativiza a importância dos gases de efeito estufa em relação ao dióxido de Carbono - ainda que utilizada internacionalmente, é criticada no inventário de emissão de gases de efeito estufa do MCT por não representar de forma adequada a contribuição relativa dos diferentes gases de efeito estufa à mudança do clima. O inventário afirma que a mudança do clima não é proporcional à energia, à exceção de períodos de tempo muito curtos e o uso do indicador enfatiza sobremaneira a importância de gases de efeito estufa de vida curta, especialmente o metano.
} 
Tabela 2 - Gases Relevantes à força radiativa

\begin{tabular}{|c|c|c|c|}
\hline Gás & $\begin{array}{c}\text { Crescimento desde era pré- } \\
\text { industrial }\end{array}$ & $\begin{array}{l}\text { Crescimento percentual } \\
\text { desde era pré-industrial }\end{array}$ & Força Radiativa \\
\hline $\mathrm{CO}_{2}$ & $105 \mathrm{ppm}$ & $38 \%$ & 1.53 \\
\hline $\mathrm{CH}_{4}$ & $1045 \mathrm{ppb}$ & $67 \%$ & 0.48 \\
\hline $\mathrm{N}_{2} \mathrm{O}$ & $44 \mathrm{ppb}$ & $16 \%$ & 0.15 \\
\hline
\end{tabular}

Tabela 3 - Gases de Efeito Estufa e Potenciais de Aquecimento Global

\begin{tabular}{|c|c|c|c|}
\hline \multirow{2}{*}{ Gás } & \multicolumn{3}{|c|}{ Potencial de Aquecimento Global (em Horizonte de Tempo) } \\
\cline { 2 - 4 } & 20 anos & 100 anos & 500 anos \\
\hline $\mathrm{CO}_{2}$ & 1 & 1 & 1 \\
\hline $\mathrm{CH}_{4}$ & 62 & 23 & 7 \\
\hline $\mathrm{N}_{2} \mathrm{O}$ & 275 & 296 & 156 \\
\hline
\end{tabular}

Fonte: IPCC, 2007

O potencial de efeito estufa de cada gás emitido por um recurso energético é dado pela equação:

\section{CVPC GEE (G) = FEm(G) x PAG(G) x Pot (RELO) (8)}

Onde:

CVPC GEE (G): cômputo e valoração de potencial de efeito estufa de cada gás emitido por um RELO (em Gg ou tonelada equivalente de $\mathrm{CO}_{2}$ );

FEm (G): fator de emissão do gás $\mathrm{G}$ (em gCO2eq/kWh);

PAG $(G)$ : potencial de aquecimento global do gás $G$ (adimensional);

Pot(RELO): potencial de oferta do RELO (em MWh ou MW) .

E o potencial total de geração de gases de efeito estufa para um recurso energético é calculado pela seguinte fórmula:

$\operatorname{CVPC}$ GEE $(\operatorname{RELO})=\sum_{\mathrm{i}=1}^{\mathrm{n}} \operatorname{CVPCEm_{i}}(\mathrm{G})$

CVPC GEE (RELO): cômputo e valoração de emissões totais de gases de efeito estufa para um RELO (em Gg ou tonelada equivalente de $\mathrm{CO}_{2}$ );

CVPC Em (G): cômputo e valoração de potencial de efeito estufa de cada gás emitido por um RELO (em Gg ou tonelada equivalente de $\mathrm{CO}_{2}$ ).

$\mathrm{n}$ : etapas da cadeia energética envolvidas na valoração do RELO.

O algoritmo de cômputo e valoração do atributo segue na figura 11. 


\section{Algoritmo - CVPC Gases de Efeito Estufa}

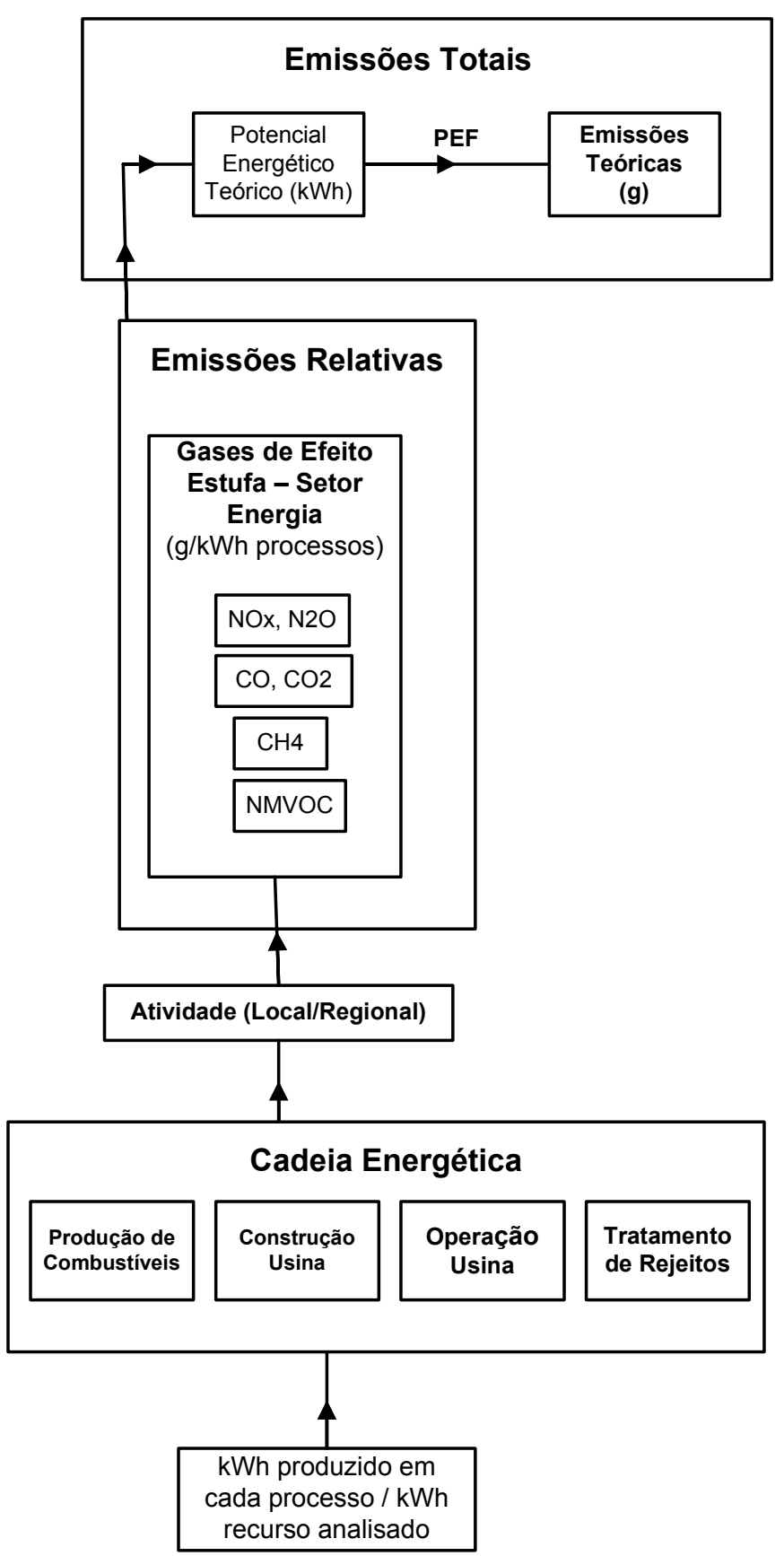

Fonte: Elaboração Própria

Figura 11: Algoritmo de cômputo e valoração do atributo Gases de Efeito Estufa 


\subsubsection{Ocupação do Solo}

A ocupação de extensões territoriais constitui um dos principais impactos de recursos energéticos ao meio ambiente, proporcional às características naturais e à sensibilidade do local ocupado e dos impactos decorrentes dessa ocupação. A avaliação da ocupação do solo por empreendimentos é medida pela relação entre a capacidade instalada ou a energia produzida pelo sistema e a área ocupada.

Para tanto, o atributo considera as diferentes etapas da cadeia energética; contabiliza-se não somente a área ocupada por conta da construção de usinas, reservatórios ou sistemas de geração, como também a área utilizada para subestações, gasodutos, mineração e produção de combustíveis, além do espaçamento entre áreas construídas ${ }^{48}$. Demais impactos de recursos energéticos ao solo, como sua degradação e erosão ou o despejo ou descarte de resíduos, são tratados no próximo subatributo.

A relação entre espaço ocupado e capacidade instalada de empreendimentos varia de acordo com as condições naturais do local - potencial de vento para geração eólica ou queda d'água para geração hidrelétrica - e costuma apresentar relação linear em uso de áreas construídas para usinas termelétricas.

A área ocupada no solo ou fundo do mar por uma fundação de torre eólica varia entre 13 e $20 \mathrm{~m}^{2}$. Entretanto, o espaçamento entre as torres, que contribui para um maior aproveitamento energético das turbinas, prevê uma área total de cerca de $0,5 \mathrm{~km}^{2}$ para torres com turbinas de $5 \mathrm{MW}^{49}$. No entanto, a comparação dessa área com extensões territoriais utilizadas em outros empreendimentos energéticos envolve outros parâmetros como impactos à área e sua utilização para outros fins ${ }^{50}$.

\footnotetext{
${ }^{48}$ Como exemplos, citam-se a área de proteção requerida como parâmetro de segurança em complexos nucleares e as distâncias praticadas entre torres eólicas na construção de parques.

${ }^{49}$ Segundo a equação $A=4 D \times 7 D$, onde $D$ é o diâmetro do rotor, prevê-se que, para uma turbina de $5 \mathrm{MW}$ com um rotor de $126 \mathrm{~m}$ de diâmetro, demanda-se uma área de 0,44 km2 de espaçamento (JACOBSON, 2008).

${ }^{50}$ Neste caso, parques eólicos recebem avaliações positivas por conta de baixos impactos à área utilizada, haja vista seu compartilhamento com outras atividades como culturas agrícolas e pecuárias, como no caso do parque eólico de Osório.
} 
As usinas movidas a energia oceânica e maremotriz apresentam uma pegada maior: uma central oceânica de $750 \mathrm{~kW}$ ocupa $525 \mathrm{~m} 2$ na superfície do oceano e uma turbina maremotriz de $1 \mathrm{MW}$ ocupa $288 \mathrm{~m} 2$ no fundo do mar - a área não representa interferência à navegação, mas possíveis impactos à vida marinha (JACOBSON, 2008).

No caso das hidrelétricas, a relação entre a capacidade das usinas e a área utilizada para a formação de lagos artificiais mostra grande variação de acordo com cada projeto, em função da tendência de redução desses reservatórios e da construção de usinas a fio d'água, com alagamentos proporcionalmente inferiores em relação à energia gerada - a exemplo de projetos mais recentes de grandes obras como Belo Monte e as usinas do Rio Madeira. Em termos ilustrativos, projetos como a usina de Samuel apresenta relação de capacidade instalada de $0,39 \mathrm{MW} / \mathrm{km}^{2}$; já o índice para a usina de Belo Monte é de 21,8 MW/ km² ${ }^{51}$.

Plantas solares de painéis fotovoltaicos ou sistemas termossolares (CSP) apresentam áreas similares de ocupação: a área requerida para painéis fotovoltaicos é de 1,2 km2 para cada $100 \mathrm{MW}$ instalados, enquanto uma planta de CSP de $100 \mathrm{MW}$ utiliza entre 3,8 e 4,7 km2 incluindo a área adicional que abriga o sistema de armazenamento de energia (JACOBSON, 2008).

Usinas termelétricas apresentam áreas similares para a ocupação da usina; já a utilização do solo e de territórios para a extração ou produção de combustível - de carvão e urânio a cana-de-açúcar ou outras formas de biomassa - ou mesmo sua inutilização como área de evacuação, resulta em índices diferenciados de capacidade instalada por área ocupada.

No caso de termelétricas a carvão, o novo modelo com captura e armazenamento de carbono projetado nos Estados Unidos e Europa considera o uso das instalações da usina, o transporte do carvão e a área minerada em um total de 5,2 km2 para uma planta de $425 \mathrm{MW}$ ou $83 \mathrm{MW} / \mathrm{km} 2$ (JACOBSON, 2008).

\footnotetext{
${ }^{51}$ A tendência de redução da área alagada não se repete necessariamente para os próximos projetos na região amazônica: a previsão de construção de outras seis hidrelétricas de capacidade total de $10.907 \mathrm{MW}$ na bacia do Rio Tapajós deve provocar um alagamento total de $1.980 \mathrm{~km}^{2}$ (EPE, 2010). O índice de capacidade instalada por área alagada seria, nesse caso, de $5,5 \mathrm{MW} / \mathrm{km} 2$
} 
A implantação de usinas nucleares ocupa uma extensão de cerca de 90 mil m2 com as facilidades de geração, para uma capacidade instalada de 1350 MW, ou por volta de 15 mil MW por km2 de área utilizada. No entanto, a contabilização da zona de evacuação ${ }^{52}$ - um raio de $5 \mathrm{~km}$ isolado em função do risco de acidentes aumenta a área total em, praticamente, duas vezes. A área usada para a mineração e para o armazenamento de resíduos é de 0,6 km2/MWh e de 0,08 km2 para cada usina, respectivamente. Assim, de acordo com a média mundial, a área total utilizada é de 20,5 km2 (JACOBSON, 2008).

Por fim, a cogeração de eletricidade a bagaço de cana ocupa uma extensão territorial considerável em função da energia gerada, em comparação com as demais termelétricas. A produção de energia de $10 \mathrm{mil} \mathrm{MWh}$ por ano com base na cogeração com biomassa de cana demandaria uma área para cultivo de 300 a 1000 hectares (BOYLE, 2004). Assim, pode-se dizer que 2,5 MW necessitam entre 3 e $10 \mathrm{~km} 2$. A área seria comparativa às hidrelétricas de índices mais desfavoráveis de uso de terra por energia gerada.

A atividade de transmissão tem impacto diferenciado sobre o uso do solo de acordo com sua característica e com a área e o bioma atingidos. No caso de geração eólica, a transmissão apresenta um trecho subterrâneo ou submarino das torres à casa de força - ainda que o trecho entre o parque e a rede básica tenha transmissão aérea.

A análise da área ocupada por instalações de usinas ou sistemas energéticos deve considerar, além da extensão territorial, o impacto da utilização desse espaço, ou seja, a influência da implantação desses projetos sobre os biomas originais e sobre atividades econômicas e sociais conduzidas localmente. Como exemplo desses impactos, o planejamento da expansão hidrelétrica na região norte, especificamente com base na implantação de usinas nos rios Tapajós e Jamanxim, no Pará, deve afetar diretamente $871 \mathrm{~km}^{2}$ de áreas protegidas de floresta (ELETRONORTE, 2009) ${ }^{53}$

\footnotetext{
${ }^{52}$ Nos EUA, a área de evacuação é dividida em regiões de controle privado, áreas restritas a empregados da usina e áreas vitais com restrições adicionais. A primeira área é normalmente deixada como espaço aberto, a fim de minimizar riscos.

${ }^{53}$ Os estudos foram permitidos com base na publicação do Decreto 7.154/2010, que autoriza estudos e relatório de impacto ambiental (EIA-Rima) para hidrelétricas em quaisquer unidades de conservação, bem como a instalação de linhas de transmissão em unidades de uso sustentável.
} 
O acidente de Chernobyl expôs uma área de $55 \mathrm{mil} \mathrm{km2} \mathrm{(dos} \mathrm{quais} \mathrm{cerca}$ de 25 mil km2 de florestas) à contaminação radioativa, em cerca de 2.300 assentamentos na Ucrânia. O raio de $30 \mathrm{~km}$ de exclusão ao redor da usina provocou a evacuação de 91 mil pessoas; a ação era obrigatória em locais onde a medição de Césio 137 excedia o nível de 555 kBq/m2 (milhares de Becquerels por metro quadrado). ${ }^{54}$

Em outros casos, a área desocupada pode ser recuperada ou utilizada para diferentes fins. A instalação de parques eólicos aproveita parte do espaço entre as turbinas para outras culturas. No caso da abertura de estradas temporárias para a construção de parques, há exemplos de crescimento da vegetação após seu uso. As usinas hidrelétricas-plataforma planejadas para a região do Pará também preveem o abandono de canteiros de obras após sua construção, para permitir a regeneração da floresta. A indústria de mineração de carvão apresenta diversos casos de restauração de áreas de exploração em um ou dois anos após as atividades (DIAMOND, 2005). Já a recuperação de áreas degradadas pela mineração de urânio nem sempre é possível; em casos de alcance extenso da contaminação, a remoção de todo o solo torna-se inviável.

Com base no exercício realizado pelo Ministério de Minas e Energia, fixando a energia gerada em Belo Monte (40.039.399 MWh) para diferentes sistemas energéticos e comparando os valores médios de áreas utilizadas nesses sistemas, obteve-se a tabela 4, com a complementação de informação de outras fontes:

\footnotetext{
${ }^{54}$ A área comprometida para a produção agrícola e pecuária ainda é considerável. A monitoração realizada no Reino Unido apresenta a restrição de criação de ovelhas em um território de $\mathbf{7 5 0}$ $\mathrm{km} 2$.
} 
Tabela 4: Relação entre Capacidade Instalada e Área ocupada de Recursos Energéticos

\begin{tabular}{|c|c|c|c|}
\hline Fonte Energética /Usina & $\begin{array}{c}\text { Capacidade } \\
\text { Instalada (MW) }\end{array}$ & $\begin{array}{l}\text { Área utilizada } \\
(\mathrm{km} 2)\end{array}$ & $\begin{array}{l}\text { Relação } \\
\text { MW/km2 }\end{array}$ \\
\hline Hidrelétrica - Xingó $^{\text {a }}$ & 3.000 & 60 & 50 \\
\hline Hidrelétrica - Belo Monte ${ }^{b}$ & 11.233 & 516 & 21,8 \\
\hline Hidrelétrica - Jirau ${ }^{\mathrm{b}}$ & 3.300 & 258 & 12,5 \\
\hline Hidrelétrica - Itaipu $^{\text {a }}$ & 14.000 & 1.549 & 9,04 \\
\hline Hidrelétrica - Tucuruí $^{\mathrm{a}}$ & 4.240 & 2.430 & 1,74 \\
\hline Hidrelétrica - Balbina $^{c}$ & 250 & 2.360 & 0,11 \\
\hline $\mathrm{PCHs}^{*}(\mathrm{FC}=55 \%)^{\mathrm{b}}$ & 8.310 & $831-1.662$ & $5-10$ \\
\hline Biomassa* $(\mathrm{FC}=48 \%)^{b}$ & 9.522 & $12.000-80.000^{\mathrm{d}}$ & $0,12-0,8$ \\
\hline Eólicas $^{*}(\mathrm{FC}=43 \%) 5$ & 10.500 & $921-2.100$ & $5-11,4^{\dagger}$ \\
\hline Solar $\mathrm{PV}^{*}(\mathrm{FC}=16,5 \%)^{\mathrm{b}}$ & 28.000 & $277-336^{\dagger}$ & $83,3-101^{\dagger}$ \\
\hline Solar CSP (FC=25\%) 6 & 18.265 & $694-858$ & $21,3-26,3$ \\
\hline Termelétrica Carvão* $(\mathrm{FC}=85 \%)$ & 5.372 & $7,4-64,7^{\mathrm{t,g}}$ & $83-729^{\mathrm{f}, \mathrm{g}}$ \\
\hline Termelétrica Óleo* $(\mathrm{FC}=71,9 \%)$ & 6.350 & 4,4 & 1042 \\
\hline Nuclear* $^{*}$ & 5.400 & $25-111$ & $48,8-214,3$ \\
\hline
\end{tabular}

* Em geração elétrica equivalente à da usina de Belo Monte

${ }^{a}$ Fonte: MESQUITA \& MILAZZO, 2007; ${ }^{b}$ Fonte: MME, 2010; ${ }^{c}$ Fonte: WITTMANN, 2009; ${ }^{d}$ Fonte: BOYLE, 2004; ${ }^{e}$ Fonte: Elaboração Própria; ${ }^{\dagger}$ Fonte :JACOBSON, 2008; ${ }^{9}$ Fonte: ABCM, 2009;

${ }^{\text {h }}$ Fonte: DIÁRIO OFICIAL, 2008; ' Fonte: ELETRONUCLEAR, 2010.

\subsubsection{Algoritmo de Cômputo e Valoração}

A valoração da ocupação da área considera a razão entre a capacidade instalada do empreendimento e a área ocupada pela cadeia energética local do recurso. Assim, energéticos transportados até a região, como combustíveis fósseis, não têm a área considerada para as atividades de exploração e extração contabilizadas no território ocupado total do empreendimento.

A razão entre a capacidade gerada e a área ocupada em um sistema energético é particular a cada recurso energético, dados os diferentes métodos de conversão e aproveitamento energético. Com base nesse fator e no potencial energético teórico desse recurso, calcula-se a área ocupada total da região como resultado de sua implementação, de acordo com a fórmula:

CVPC Oc (RELO) $=$ Pot (RELO) $/$ FO (RELO)

Onde:

CVPC Oc (RELO): área ocupada pela implementação do RELO $\left(\mathrm{km}^{2}\right)$;

FO (RELO): fator de ocupação de área do RELO (MW/km²);

Pot (RELO): Potencial de oferta anual do RELO (MW). 
Conforme afirmado, o fator de ocupação de área deve considerar todas as etapas da cadeia do recurso energético conduzidas localmente, incluindo a construção e a geração do sistema e demais processos cabíveis.

A área ocupada associada à realização do potencial de cada recurso energético é avaliada de acordo com sua situação e utilização prévias à implementação do recurso - em termos ambientais e sociais. Obviamente essa informação, ainda que quantificável em termos de grau de impacto à área ou à população deslocada, não será internalizada no resultado da quantificação da área ocupada e sim utilizada como informação paralela relevante aos empreendedores e todos os envolvidos direta e indiretamente no projeto. Parte desses impactos é valorada no algoritmo de impactos ao solo, como a deposição de resíduos líquidos e sólidos.

A terceira etapa da valoração do espaço ocupado por recursos energéticos é o refinamento da mensuração do total da área impactada em termos de abrangência de impactos - como áreas de segurança ou áreas inutilizadas em decorrência de acidentes nucleares. É importante que a contabilização dessa área parta de médias históricas independentes dos fatores utilizados na valoração da área ocupada inicial. Considera-se na análise o reuso de áreas inicialmente ocupadas pela construção do empreendimento e o aproveitamento de áreas com atividades paralelas à geração de energia. Esse valor é subtraído da área ocupada calculada inicialmente.

O algoritmo de valoração da ocupação territorial de um recurso energético é ilustrada na figura 12: 


\section{Algoritmo - CVPC Ocupação do Solo}

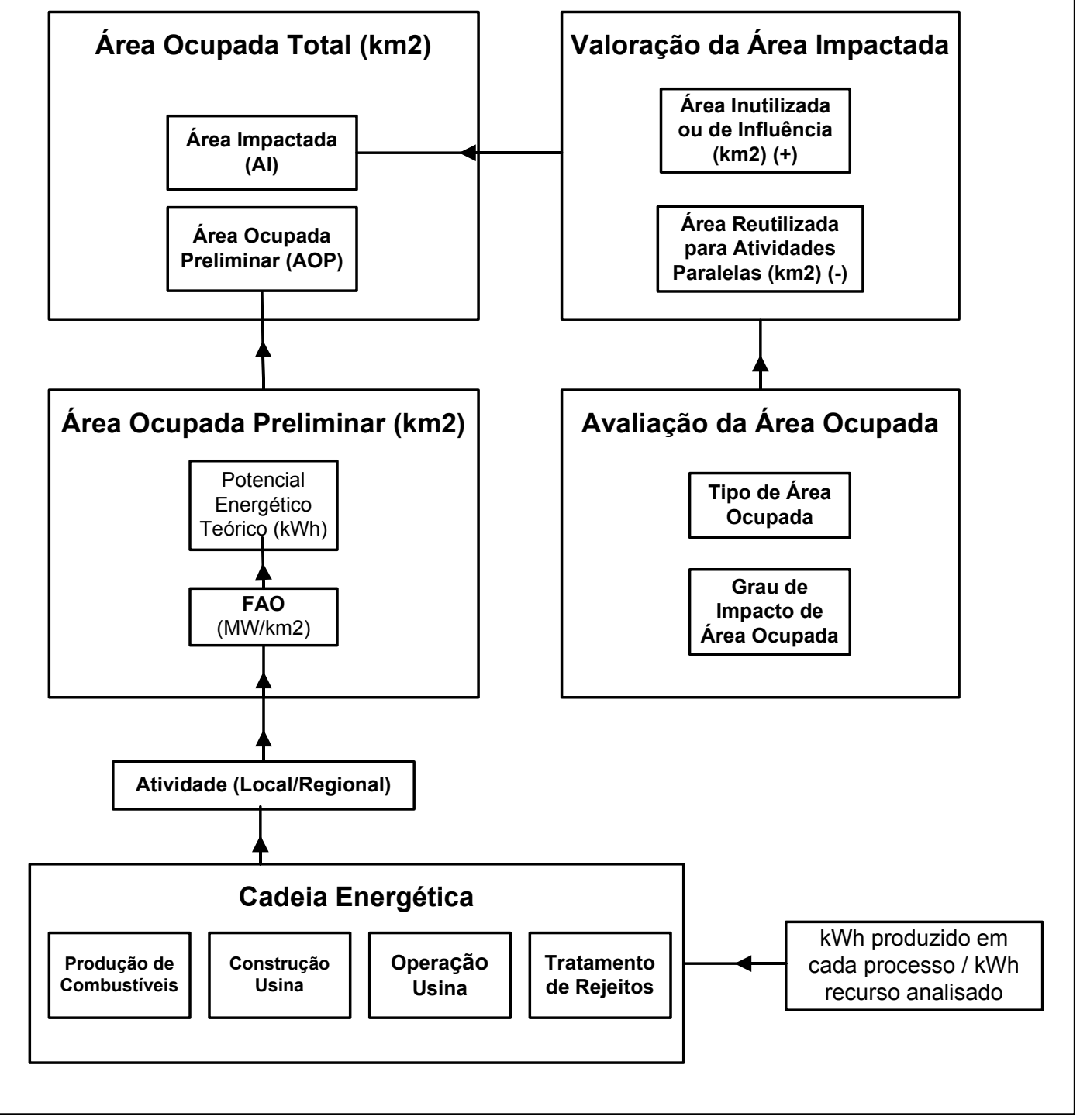

Fonte: Elaboração Própria

Figura 12: Algoritmo de valoração do atributo Ocupação do Solo

\subsubsection{Poluição e Degradação do Solo}

Os impactos ao meio terrestre incluem a deposição de poluentes ou dejetos no solo - por vezes implicando efeitos colaterais como a contaminação desses dejetos a corpos d’água ou lençóis freáticos -, a produção de resíduos 
sólidos, em alguns casos tóxicos ou perigosos, como subprodutos da geração de energia e a exploração e degradação do solo por efeito de ocupação de empreendimentos energéticos. Este último impacto foi parcialmente abordado no atributo anterior, avaliando a extensão da ocupação e a ocorrência de degradação do solo ou de matéria natural existente na área. O volume de matéria deslocada ou contaminada é avaliado neste atributo.

A deposição de poluentes, dejetos e resíduos no solo e em vegetais e materiais provoca desequilíbrios em ecossistemas naturais e urbanos, com efeitos sobre a saúde, a produção agrícola - com a acidificação dos solos e a redução de seus nutrientes -, a condição de edificações - com a degradação de construções, entre outros. Esse efeito é propagado quando a transferência de poluentes por cursos d'água ou lençóis freáticos amplia a área contaminada, ameaçando fauna, flora e comunidades próximas. Em alguns casos, o nível de impacto pode tornar o solo temporariamente impróprio para atividades agrícolas e sociais ou mesmo inutilizá-lo permanentemente.

A medição ou valoração de impactos de poluentes ao solo na dimensão ambiental é função do peso ou volume líquido ${ }^{55}$ dos dejetos ou resíduos produzidos pela aplicação de um determinado recurso em proporção à energia gerada por ele.

O processamento de diferentes fontes de energia e a fabricação de tecnologias para sua conversão resultam em diferentes tipos de contaminação ou poluição química dos solos por descargas acidentais ou voluntárias e deposição não controlada de substâncias tóxicas.

Em usinas de etanol, os processos de fermentação e destilação produzem efluentes como a vinhaça, organoclorados, cobre e outros contaminantes, que, por vezes são depositados no solo, alterando sua acidez e, posteriormente, alcançando lençóis freáticos e contaminando rios e mananciais próximos à área das plantações. A queima dos canaviais altera diferentes parâmetros do solo como umidade, taxa de transpiração, porosidade e repelência à água tornando-o mais impermeável e, consequentemente, sujeito a erosões (FERREIRA, 2006). Essa queima, bem como a do bagaço para a geração de eletricidade produz cinzas em fatores superiores a $5 \mathrm{~kg}$ por tonelada de processamento de cana

\footnotetext{
${ }^{55}$ Obtido pela diferença entre volumes de rejeitos produzidos em relação à quantidade de matéria utilizada na produção destes recursos energéticos.
} 
(LEME, 2005). Outras formas de cogeração com base na biomassa produzem resíduos sólidos em proporções diferentes, de acordo com o ciclo empregado; para o ciclo BIG-GT (Gaseificação da Biomassa Integrada por Turbina a gás, da sigla em inglês), a estimativa apresentada por fonte é de $0,224 \mathrm{~g} / \mathrm{kWh}$ (SPATH e MANN, 1997 e 2000).

A geração termelétrica por combustíveis fósseis produz altas emissões de poluentes aéreos e resíduos sólidos. A magnitude dessas emissões é influenciada pelo combustível e por tecnologias e processos empregados na combustão, e os consequentes impactos ao solo e ao meio ambiente variam de acordo com a gestão e o descarte desses resíduos e efluentes.

Térmicas a carvão apresentam emissões aéreas de $\mathrm{SO} 2, \mathrm{NO} 2$, monóxido de carbono, cinzas e dejetos líquidos contaminados com metais pesados como cromo, bário, arsênico e mercúrio. As emissões dependem da qualidade do combustível; o carvão brasileiro apresenta um alto conteúdo de impurezas, com teor de cinzas entre 40 e $55 \%$ e de enxofre entre 1 e 2,5\%, além de um baixo poder calorífico, entre 3.100 e $4.500 \mathrm{Kcal} / \mathrm{kg}$ (BORBA, 2001). Os óxidos sulfúrico e nítrico dissolvem-se na água, formando ácido sulfúrico, com impactos à vida aquática, alterações nos nutrientes do solo e aumento da solubilidade de metais. A produção de resíduos sólidos - como cinzas em decorrência da combustão do carvão - é condicionada aos processos empregados e às características do carvão queimado.

A produção de dejetos líquidos e sólidos acontece também na utilização de tecnologias de captura de carbono e termelétricas a óleo diesel, impactando espécies de plantas e animais na área atingida e implicando, por vezes, tempos de recuperação superiores a dois anos ${ }^{56}$.

Em relação à produção de combustível, a exploração de carvão por mineração guarda mais semelhanças com a mineração de outros metais do que com a cadeia de exploração e produção de petróleo. As minas de carvão revolvem uma quantidade de terra superior às minas de metais e, em alguns casos, desnudam o solo até o leito da rocha, despejando os resíduos em rios. No entanto, a proporção de rejeitos produzidos em relação ao produto extraído é

${ }^{56}$ A Companhia Energética de Petrolina (CEP) foi autuada pelo Instituto Brasileiro do Meio Ambiente e dos Recursos Naturais Renováveis (Ibama) em R\$ 100 mil por despejar cerca de 800 mil litros de resíduos de óleo combustível em oito hectares de caatinga, num local situado a $19 \mathrm{~km}$ de Petrolina (PE). 
comparativamente inferior à mineração de outros metais - em proporção 1 para 1 em massa, contra 1 para 400 em minas de cobre ou 1 para 5 milhões em minas de ouro - por conta de extração em filões puros de quilômetros de extensão (DIAMOND, 2005).

Analogamente, a mineração de urânio também provoca a liberação de resíduos químicos no solo e na superfície das águas. O exemplo nacional da mineração realizada na região de Caetité ilustra o empobrecimento do solo e a contaminação da água em decorrência de vazamentos durante o beneficiamento e o processamento de urânio. A operação de usinas nucleares produz rejeitos altamente radioativos, como varetas de elemento combustível, estocadas em piscinas por vários anos até seu transporte a depósitos permanentes ${ }^{57}$. Rejeitos de baixa e média radioatividade, como materiais de construção de usinas, embalagens de equipamentos e resíduos domésticos, são estocados de diferentes formas nas plantas.

Em relação à geração de energia renovável, a geração geotérmica, por conta de sua operação, tem impactos particulares ao solo, relacionados à indução de sismicidade e alteração da massa de fluido geotérmico (HUNT, 2001). Já as fontes solar fotovoltaica (PV) e heliotérmica (CSP) impactam o solo por meio da produção de efluentes químicos durante o processo produtivo das tecnologias e por descarte dos fluidos envolvidos na operação das usinas concentradoras de energia solar. A produção de painéis fotovoltaicos envolve o emprego de substâncias tóxicas como Cádmio, Arsênio e Selênio, que demandam uma série de cuidados de prevenção de controle ambiental, desde a intoxicação de trabalhadores até o descarte correto de resíduos (TOLMASQUIM, 2003). Em sistemas heliotérmicos, o vazamento de fluidos térmicos sintéticos utilizados nas usinas pode gerar danos aos ecossistemas locais. Observa-se que esse vazamento pode ser evitado com a utilização de bacias de contenção e tanques de armazenagem dessas substâncias.

Empreendimentos hidrelétricos exercem efeitos diferenciados sobre o solo; características de projeto das usinas - relacionadas à construção de

57 A problemática do desenvolvimento de depósitos permanentes de rejeitos nucleares, considerados seguros a longo prazo, é ilustrada pela controversa construção do depósito norteamericano de Yucca Mountain, comprometido por problemas de sobrecusto, oposição local da população de Nevada e riscos do transporte de material radioativo de outras regiões dos Estados Unidos até o local. 
reservatórios e barragens e a alterações das condições hidrológicas dos rios implicam o deslocamento de volumes de solo para sua construção ${ }^{58}$ e 0 transporte de sedimentos ao longo dos cursos d’água de cada empreendimento. A gestão incorreta de resíduos de rochas e materiais envolvidos na obra pode provocar impactos sobre a agricultura e outras atividades locais. A retenção de sedimentos em barramentos, reduzindo o transporte de nutrientes pelos rios, pode ser mensurada pela necessidade de gastos adicionais em fertilizantes industriais para a manutenção da produção agrícola da área afetada (REIS, 2001). A transferência de sedimentos pode provocar também a sedimentação e o assoreamento dos reservatórios ${ }^{59}$; a perda de seu volume útil traz como consequência prejuízos à provisão dos usos múltiplos da água.

\subsubsection{Algoritmo de Cômputo e Valoração}

A produção de subprodutos sólidos como resultado da geração de eletricidade ou produção de energéticos é valorada de acordo com a massa desse resíduo em função da energia ou eletricidade produzida no processo, com base na análise de fatores como poder calorífico e eficiência de conversão de combustíveis produzidos.

No caso de recursos energéticos fósseis, a composição em massa dos resíduos sólidos produzidos consiste na fração mineral não-volátil do combustível empregado na produção de energia, somada à massa de solo removida ou impactada durante sua extração e à massa de solo impactada pela deposição de emissões aéreas.

Já no caso de recursos renováveis, a massa de resíduos sólidos afetada por empreendimentos compreende o solo perdido em processos de erosão ou comprometido por contaminação química, a massa total de sedimentos retirada do solo ou de rochas para a construção de projetos e o volume de sedimentos transportado ao longo do curso de rios, no caso de hidrelétricas.

\footnotetext{
${ }^{58}$ A construção de canais de derivação no projeto da hidrelétrica de Belo Monte exigirá a escavação de 75,3 milhões de metros cúbicos de solo e outros 25,1 milhões de metros cúbicos em rocha. Entretanto, alterações na concepção do projeto podem reduzir o volume escavado em cerca de um terço, em função da eliminação de um dos canais de derivação (COSTA, 2010)

${ }^{59}$ No caso das usinas do Rio Madeira, a alta carga de sedimentação, estimada entre 257 e 306 milhões de toneladas anuais de sedimentos sólidos em suspensão (GUYOT, 1995) pode comprometer a vida útil das barragens.
} 
Os impactos da emissão e do transporte desses rejeitos à fauna, à flora e a regiões próximas como áreas de preservação, bem como o potencial de recuperação de áreas afetadas são fatores paralelos analisados no atributo de ocupação do solo.

A cadeia nuclear apresenta impactos ao solo e geração de resíduos sólidos diferentes dos grupos anteriores de fontes: nesse caso, os impactos relacionam-se à produção do combustível e ao gerenciamento de resíduos sólidos radioativos produzidos nas usinas. Assim, a avaliação da quantidade de solo removida ou impactada durante a extração do urânio e a formação de subprodutos resultantes de seu processamento e beneficiamento soma-se ao volume de resíduos de baixa, média e alta radioatividade derivados da operação e do posterior descomissionamento de usinas.

Deve-se ressaltar que, apesar de essa análise restringir-se à produção de resíduos sólidos resultantes de atividades energéticas, o levantamento dessa informação é complexo em função da ampla variação de abordagens e análises para estudos de inventário de ciclo de vida (FUJII,UDAETA, 2006).

Para efeito de organização, a contabilização de geração de resíduos sólidos divide-se nas diferentes etapas da cadeia energética. Assim, o algoritmo abrange etapas de valoração de resíduos da produção de energéticos (extração e mineração), volume de perda de solo (retirado para construção de empreendimento e impactado por erosão), volume de solo contaminado por rejeitos derivados da produção de combustíveis e tecnologias (subprodutos e poluentes químicos) e volume de solo afetado pela deposição de poluentes aéreos e, por fim, resíduos sólidos resultantes da sedimentação, da queima de combustíveis e resíduos radioativos derivados da operação e descomissionamento de usinas nucleares.

O cálculo de potenciais dessas etapas é ilustrado com exemplos de volume de perda de solo e de geração de resíduos sólidos pela sedimentação de barragens e combustão de energéticos fósseis.

A equação universal de perda do solo relaciona a erosão do solo aos diferentes tipos de solo e usos aplicados - desde culturas para a produção de biocombustíveis à construção de barragens. Assim, a perda do solo é função de fatores diretos, como gerenciamentos de usos do solo e controle de erosão, e fatores geográficos como ângulo de inclinação do território e densidade 
pluviométrica do local analisado (REIS, 2001). Diferentes tipos de solo são submetidos a equações especificas a fim de compor o total da perda anual.

No caso de usinas hidrelétricas, a estimativa do volume de material sólido perdido é obtida por meio da somatória do volume de solo deslocado com a construção do empreendimento com as variações anuais de depósito anual de solo no reservatório - compreendendo a somatória do solo carreado pela região a montante $(E)$, com a erosão dos canais $(C)$ e a erosão da ocupação do leito (B).

O volume que chega ao reservatório é função das partículas sólidas transportadas por erosão, da área do corpo d’água analisado (A) e da taxa de despejo de sedimentos levantada para o empreendimento $(R)$, de acordo com a equação 11 abaixo:

$S=(E+C+B) \times A \times R \quad(11)$

O volume de sedimentos retido no reservatório (SR) é o produto entre o volume que chega ao reservatório (S) e sua capacidade de retenção (RT), de acordo com a equação:

$\mathrm{SR}=\mathrm{S} \times \mathrm{RT}(12)$

A geração de resíduos sólidos resultantes da combustão de energéticos fósseis contabiliza a produção de cinzas e material particulado, variáveis de acordo com a eficiência do combustível e seu poder calorífico. Outros subprodutos podem ser obtidos de acordo com ciclos e combustores utilizados ${ }^{60}$.

O cálculo da valoração é apresentado a seguir:

CVPC RS $(R E L O)=\sum_{i=1}^{n} F R_{i}(R E L O) \times \operatorname{Pot}(R E L O)$

Onde:

${ }^{60}$ Em adição às cinzas, os resíduos sólidos gerados pela operação de combustores de leito fluidizado apresentam também produtos de reação da substância adsorvente empregada com o dióxido de enxofre formado pela oxidação exotérmica do carvão mineral; para o caso no qual o adsorvente é a calcita (CaCO3), as substâncias formadas são fundamentalmente gesso (CaSO4) e cal $(\mathrm{CaO})$. A produção dessas substâncias varia de acordo com a possibilidade da reação do enxofre com o adsorvente, formando gesso (CaSO4) ou do depósito do adsorvente na forma de $\mathrm{cal}(\mathrm{CaO})$. 
CVPC RS (RELO): valoração absoluta dos resíduos do RELO (em ton ou m3);

FR (resíduos): fator de produção de resíduos do RELO nas diferentes etapas da cadeia energética (m3/MWh);

Pot (RELO): potencial de geração de energia do recurso RELO em unidades por Energia (MWh) ou Potência (MW);

$\mathrm{n}$ : etapas da cadeia energética envolvidas na valoração do RELO.

A figura 13 ilustra o algoritmo de cômputo e valoração de resíduos sólidos para recursos energéticos do lado da oferta:

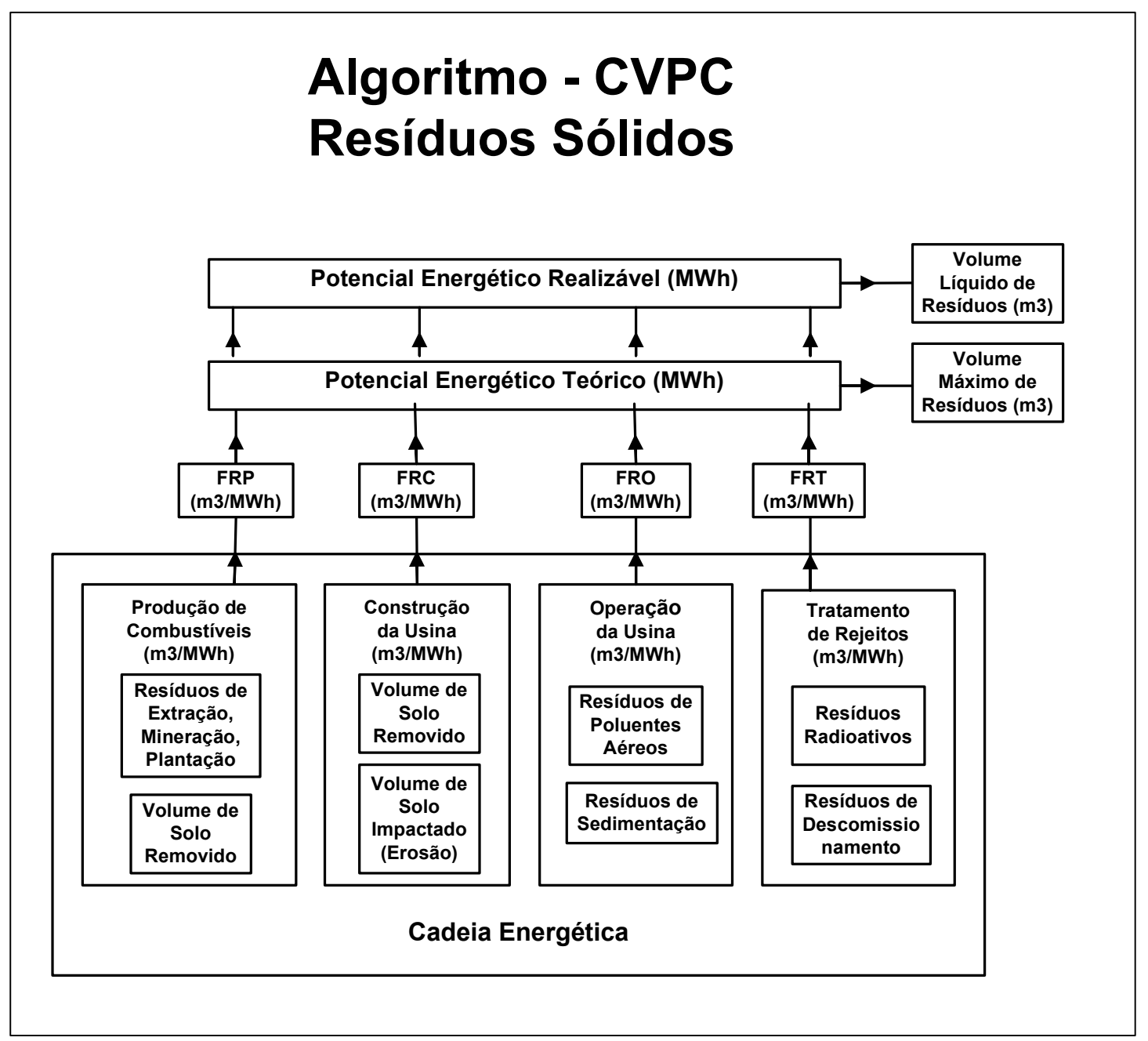

Fonte: Elaboração Própria

Figura 13: Algoritmo de cômputo e valoração do atributo Poluição e Degradação do Solo 


\subsubsection{Consumo de recursos hídricos}

A água é considerada o recurso mais essencial à vida, em seus múltiplos usos que asseguram a saúde humana e da fauna e flora de todos os biomas, e exerce papel fundamental em atividades econômicas como a agricultura, a indústria, os transportes e, obviamente, a geração de energia. Neste último setor, os recursos hídricos têm participação em todas as partes da cadeia energética, desde a extração e produção de energéticos, ao seu transporte até locais de consumo, a utilização da água propriamente dita para a geração de energia, a manutenção de sistemas energéticos e, por fim, o condicionamento e descarte de rejeitos sólidos e líquidos produzidos nestas atividades.

A avaliação da participação da água em atividades energéticas é organizada em função de seu uso - captação e consumo para cada recurso energético - e qualidade do recurso devolvido aos corpos d'água e mananciais medida em função de parâmetros como alteração de acidez, temperatura e demanda bioquímica de oxigênio. A oferta de recursos hídricos, já limitada em diferentes regiões do globo, tende a diminuir diante dos efeitos de mudanças climáticas nas próximas décadas. Daí a importância dessa avaliação, tanto em função da minimização do uso desses recursos quanto na manutenção da qualidade dos recursos utilizados.

Neste atributo, avalia-se a demanda de recursos hídricos, em relação à sua captação e consumo para fins energéticos. A depleção desses recursos é função da diferença entre o volume de água captado e o volume reposto após sua utilização. O uso desses recursos é contabilizado para todas as etapas da cadeia energética conduzidas no local ou região de estudo, desde a produção de equipamentos e combustíveis até o uso de água para ciclos de geração de energia até o gerenciamento de resíduos dessas operações, como colocado anteriormente.

A geração hidrelétrica consome água por ações como o controle de vazão ou a evaporação em superfícies de reservatórios. A água é também consumida em usos múltiplos como irrigação, navegação ou regulação de rios. De acordo com Jacobson, o consumo médio de água em reservatórios relacionado à geração de eletricidade, já deduzido dos demais usos da água, varia entre 17 e 28,8 litros/kWh (JACOBSON, 2008). 
Além do consumo, o aproveitamento hidrelétrico implica alterações hidrológicas dos rios utilizados em construções, tanto em nível quanto em vazão. A construção da Usina Hidrelétrica de Belo Monte e a alteração do ciclo hídrico do rio alterarão a vazão do Rio Xingu em uma extensão de 100 quilômetros. Como consequência, os níveis da água do rio Xingu e do lençol freático baixarão: a diferença entre séries históricas de níveis de água do rio e cenários considerando a implementação da usina apontam para diminuições que podem chegar a $5 \mathrm{~m}$ durante os meses úmidos (janeiro a maio).

Vários impactos biológicos e sociais têm sido associados à redução dos níveis da água, como os problemas para a navegação e os efeitos sobre a Floresta Aluvial e a fauna aquática em toda a área afetada pelo rebaixamento do lençol freático. A redução da vazão deve inviabilizar a navegação no Rio Xingu, reduzir o volume de pescado e áreas de plantio de agricultura familiar. $O$ Movimento Xingu Vivo para Sempre calcula que cerca de 50 mil pessoas da região serão atingidas pelos alagamentos e pela seca provocados pela usina.

As usinas do rio Madeira também devem sofrer redução da velocidade do fluxo da água: de 4,57 para $1,19 \mathrm{~m} / \mathrm{s}$ para vazão de $16.600 \mathrm{~m} 3 / \mathrm{s}$ ou 6,92 para $3,28 \mathrm{~m} / \mathrm{s}$ para vazões altas. As consequências são diversas, desde a elevação do nível da água em $5 \mathrm{~m}$ - novamente com impactos sobre navegação, pesca e agricultura - até impactos na qualidade da água, tratados no próximo atributo.

O uso da água em termelétricas movidas a combustíveis fósseis começa no processo de extração e produção do combustível. No caso de derivados de petróleo, todas as operações de refino requerem grandes volumes de água para circuitos de resfriamento e alimentação das caldeiras (MARIANO, 2007).

A mineração de carvão segue a mesma lógica, grandes volumes de água são consumidos na pesquisa mineral, na lavra, no beneficiamento e no transporte em minerodutos.

A operação das termelétricas demanda quantidades abundantes de água limpa e fria, razão pela qual são comumente localizadas na margem de rios. $O$ consumo pode atingir 1.200 metros cúbicos de água por hora, dos quais apenas 700 retornam ao manancial (TOMAZELA, 2001). A maior parte desse volume é utilizado no sistema de resfriamento, para a condensação do vapor de exaustão das turbinas; parte desse volume é perdido, principalmente, nas etapas de evaporação e arraste. Tecnologias de geração caracterizam-se por consumos de 
água e eficiência específicos. Tecnologias similares podem utilizar diferentes sistemas de resfriamento - por torre úmida ${ }^{61}$, seca e mista, ou em circulação aberta, sem o uso de torres ${ }^{62}$.

$O$ consumo de água em termelétricas a carvão é de 1,49 m3/MWh (UDAETA, KATAYAMA, et al, 2008) para carvão pulverizado em sistema semiaberto e de $1,85 \mathrm{~m} 3 / \mathrm{MWh}$ para plantas com tecnologia de sequestro e armazenamento de carbono (CCS da sigla em inglês) (JACOBSON, 2008). Em térmicas a gás natural, o uso se reduz a intervalos entre 0,38 a 0,76 m3/MWh, de acordo com a tecnologia de resfriamento.

Reatores nucleares seguem o mesmo princípio, o uso da água é necessário para produzir vapor a alta pressão para a geração de energia por turbinas e para o sistema de resfriamento desse vapor. A maior parte da água é devolvida à fonte a temperaturas superiores à água captada, mas parte dela é perdida por evaporação. A demanda de água, superior a termelétricas que utilizam combustíveis fósseis, é proporcional à tecnologia de resfriamento, variando entre 1,51 a 2,73 m3/MWh (JACOBSON, 2008). Já a demanda de captação de água pode ser superior àquela necessária para a produção de energia com base na biomassa, que envolve volumes de até $227 \mathrm{~m} 3 / \mathrm{MWh}^{63}$ (YOUNOS et al, 2009).

Usinas heliotérmicas de energia solar concentrada (CSP) apresentam consumos diferenciados de água de acordo com a tecnologia e com os sistemas de resfriamento empregados. O sistema de calha parabólica emprega água fria para recondensar o vapor utilizado na produção de energia. Assim, há perda de água por evaporação e para a manutenção dos espelhos, resultando em um alto

\footnotetext{
${ }^{61} \mathrm{O}$ primeiro projeto da termelétrica de Carioba II, que utilizaria resfriamento por torres úmidas, provocaria perdas consideráveis de água: do consumo de $1.069 \mathrm{~m} 3 / \mathrm{h}$ para resfriamento e reposição das perdas na caldeira, apenas $219 \mathrm{~m} 3 / \mathrm{h}$ seriam repostos ao corpo d'água (TEIXEIRA, 2003).

${ }^{62}$ A maior parte das termelétricas operantes no país ainda utilizam o sistema de resfriamento em circulação semiaberta. Atualmente, é exigida a adoção do sistema de torre seca em usinas termoelétricas recentemente construídas. Essa tecnologia minimiza o consumo de água, evitando perdas por evaporação e o surgimento de plumas de vapor.

${ }^{63} \mathrm{~A}$ grande demanda por captação de água forçou a redução de capacidade de 17 reatores durante uma onda de calor extremo na França, em 2003. De acordo com relatório do Departamento de Saúde Pública do Parlamento australiano, de 2006, os requerimentos de utilização de água são entre 20 e $83 \%$ superiores aos de outras usinas.
} 
consumo de 2,94 m3/MWh. Tecnologias de receptores de torres centrais apresentam valores levemente inferiores, em 2,94 m3/MWh. Esse consumo é reduzido significativamente com o uso de resfriamento por ar; o resfriamento a seco reduz o consumo de água a menos de 0,3 m3/MWh (US DOE, 2007).

A geração solar por painéis fotovoltaicos utiliza água nos processos de construção e lavagem das placas, totalizando o consumo de cerca de 0,025 $\mathrm{m} 3 / \mathrm{kWh}$. Dentre as demais tecnologias renováveis, as gerações de energia geotérmica, eólica, oceânica e maremotriz apresentam consumos extremamente baixos de água durante sua construção e operação. As geotérmicas consomem cerca de $0,02 \mathrm{~m} 3 / \mathrm{kWh}$ enquanto as demais opções consomem cerca de um quinto desse valor (JACOBSON, 2008).

Por fim, a cadeia de produção de álcool e açúcar consome volumes de água mais altos do que as demais opções energéticas analisadas. $O$ valor é de mil m3 de consumo de água e captação de quatro vezes esse valor para 500 mil toneladas de cana moídos (RODRIGUES et al, 2003). É importante ressaltar que essa quantidade é empregada, essencialmente, na etapa de lavagem da cana $(60 \%)$ e no abastecimento de caldeiras (30\%). Assim, a colheita da cana crua e a eficientização de caldeiras e sistema de resfriamento de tanques pode reduzir os gastos desse processo.

A fim de sintetizar os valores discutidos, segue a tabela 5, com intervalos de consumo de água para diferentes recursos energéticos.

Tabela 5: Uso de água em sistemas energéticos

\begin{tabular}{|c|c|c|c|c|c|}
\hline \multirow{3}{*}{ Tipo de Usina } & \multirow{3}{*}{ Processo } & \multicolumn{4}{|c|}{ Intensidade de Água (I/MWh) } \\
\hline & & \multicolumn{2}{|c|}{ Condensação de Vapor } & \multicolumn{2}{|c|}{ Outro Uso } \\
\hline & & Captado & Consumido & Captado & Consumido \\
\hline Carvão & Mineração & & & & $19-280$ \\
\hline \multirow{3}{*}{$\begin{array}{l}\text { Térmica Fóssil } \\
\text { Biomassa } \\
\text { Resíduos }\end{array}$} & $\mathrm{RCA}^{\mathrm{a}}$ & $75.708-189.270$ & 300 & \multirow{3}{*}{\multicolumn{2}{|c|}{114}} \\
\hline & Torre CF & $1136-2271$ & $1136-1817$ & & \\
\hline & Seco & 0 & 0 & & \\
\hline \multirow[t]{3}{*}{ Nuclear } & Mineração & & & & $170-568$ \\
\hline & $\mathrm{RCA}$ & $94.635-227.124$ & 400 & \multicolumn{2}{|r|}{114} \\
\hline & Seco & 0 & 0 & \multicolumn{2}{|c|}{0} \\
\hline Geotérmica & Torre CF & 7.571 & 1400 & \multicolumn{2}{|c|}{-} \\
\hline CSP (Calha Parabólica) & Torre CF & $2.877-3.483$ & $2.877-3.483$ & \multicolumn{2}{|c|}{30} \\
\hline CSP Torre & Torre CF & 2.839 & 750 & \multicolumn{2}{|c|}{30} \\
\hline Gás Natural CC & $\mathrm{RCA}$ & $28.391-75.708$ & 100 & \multicolumn{2}{|c|}{$26-38$} \\
\hline & Seco & 0 & 0 & 0 & 0 \\
\hline Carvão IGCC $^{\text {b }}$ & Torre CF & 946 & 200 & \multicolumn{2}{|c|}{$26-38$} \\
\hline Hidrelétrica & Evaporação & 0 & & 0 & 17.034 \\
\hline
\end{tabular}


${ }^{a}$ Refrigeração de ciclo aberto

${ }^{b}$ Ciclo combinado com gaseificação integrada

Fonte: Adaptado de U.S. DOE (2007).

\subsubsection{Algoritmo de Cômputo e Valoração}

O volume de água captada e consumida é função do recurso energético analisado, envolvendo o aproveitamento local de recursos hídricos - no caso de hidrelétricas ou geotérmicas - ou a produção de combustíveis - no caso de térmicas. Neste segundo caso, o maior consumo de água por evaporação deverá ocorrer na fase de operação, de acordo com o tipo de circulação do sistema de refrigeração e o tipo de ciclo de funcionamento da usina. Completa o cômputo deste atributo o uso de água para a manutenção dos sistemas.

Os algoritmos para ambos os indicadores que compõem o atributo valemse da formulação abaixo, considerada para as diferentes etapas da cadeia energética do recurso analisado:

\section{CVPC URH (etapa) $=[$ FCap (etapa) - FDev(etapa) $] \times$ Pot $($ RELO) $(14)$ \\ CVPC URH(RELO) $=\sum_{i=1}^{n}$ CVPC URH $_{i}$ (etapa)

Onde:

CVPC URH (etapas): cômputo e valoração de uso de recursos hídricos em etapas da cadeia energética do RELO (em litros ou $\mathrm{m} 3$ );

FCap (etapa): fator de captação de recursos hídricos para etapa da cadeia energética do RELO (em m3/MWh);

FDev (etapa): fator de devolução de recursos hídricos para etapa da cadeia energética do RELO (em m3/MWh);

CVPC URH (RELO): cômputo e valoração do uso de recursos hídricos de um RELO (em litros ou $\mathrm{m} 3)$;

n: etapas da cadeia energética envolvidas na valoração do RELO.

O algoritmo de cômputo e valoração de consumo de recursos hídricos segue abaixo na figura 14 . 


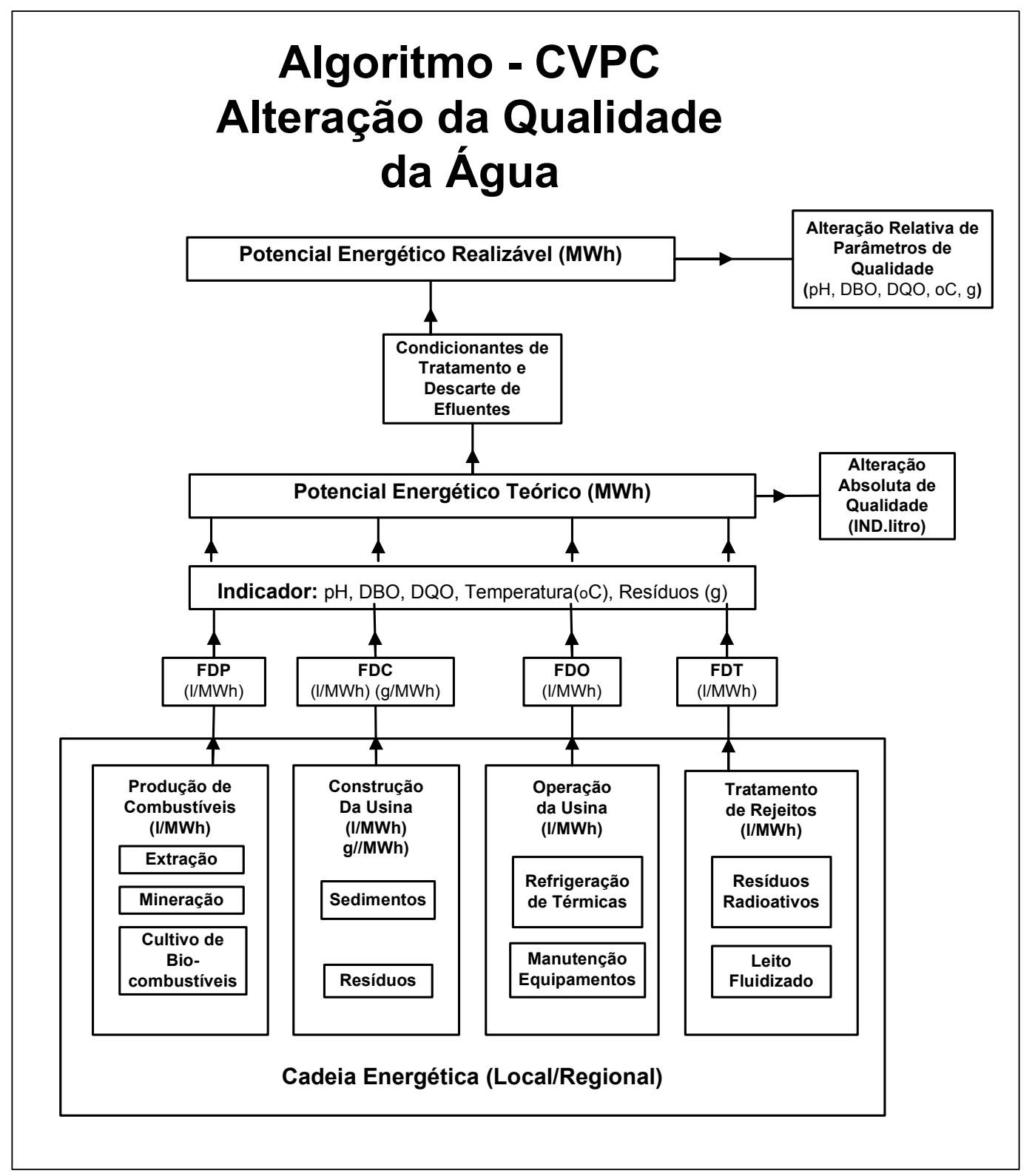

Fonte: Elaboração Própria

Figura 14: Algoritmo de CVPC do atributo Consumo de Recursos Hídricos

\subsubsection{Qualidade da Água}

A análise da qualidade da água utilizada em atividades da cadeia energética é um fator de enorme importância social e ambiental. A devolução desses volumes de água a corpos d’água, mananciais ou rios, implica mínima manutenção de suas condições originais de temperatura, acidez e outras variáveis microbiológicas, hidrobiológicas e ecotoxicológicas. A alteração desses parâmetros pode implicar diferentes desequilíbrios ecológicos e impactos à 
sociedade. A contaminação ou poluição de recursos hídricos pode impactar organismos aquáticos, provocar o assoreamento de mananciais e elevar o custo de tratamento da água. Já a restrição desse consumo pode causar enormes prejuízos a atividades industriais, agrícolas, comerciais e, principalmente, à saúde humana e à qualidade de vida de populações (MARIANO, 2007).

A poluição térmica da água provoca outros efeitos sobre sua qualidade como a redução do oxigênio dissolvido na água, por conta de impactos à fauna aquática decorrentes do desenvolvimento de algas. Os recursos energéticos que mais impactam a temperatura da água em rios e lagos são a energia solar concentrada (CSP) e a geração termelétrica por conta de sua utilização para resfriamento, e o etanol, por conta do cultivo de cana-de-açúcar.

A análise do atributo parte da medição ou cálculo da variação de fatores como temperatura (medida em graus Celsius), acidez (medida pelo $\mathrm{pH}$ ), demandas química e bioquímica de oxigênio (DQO e DBO) e demais poluentes, medidos por volume de dejetos líquidos despejados em corpos d’água. Todos esses fatores são racionalizados em função da energia empregada ou gerada em cada processo da cadeia energética.

Analisando o ciclo de geração elétrica por combustíveis fósseis, o refino de petróleo produz uma série de efluentes - resultantes do contato de água ou vapor em contato com óleo ${ }^{64}$ - com efeito direto sobre a acidez do meio aquático que os recebe. Esses efluentes costumam apresentar altas DBO e/ou DQO ${ }^{65}$ (MARIANO, 2007). O consumo desse oxigênio apresenta impactos diretos à vida aquática do local afetado. A produção de efluentes hídricos em refinarias varia em função do tipo de petróleo processado e da tecnologia e eficiência desse processamento. No Brasil, as refinarias do sistema Petrobras geram entre 0,40 e 1,60 de $\mathrm{m} 3$ de efluente por $\mathrm{m} 3$ de óleo refinado na planta. $O$ fator se reduz para refinarias mais modernas ou de maior capacidade de refino (MARIANO, 2007).

\footnotetext{
${ }^{64}$ Dentre efluentes, citam-se soluções ácidas, soda exausta, águas de lavagem do petróleo cru e derivados, água proveniente da etapa de dessalinização, condensados resultantes da retificação a vapor e da destilação, condensados resultantes da limpeza ou regeneração com vapor dos catalisadores de processo, fenol resultante das etapas de craqueamento catalítico, produção de lubrificantes e de solventes e em águas de lavagem da gasolina, seguintes aos tratamentos cáusticos (MARIANO, 2007).

${ }^{65}$ A matéria orgânica de um líquido é decomposta por bactérias aeróbias, que utilizam oxigênio dissolvido no meio aquático. $\mathrm{O}$ aumento de efluentes ou matéria orgânica aumenta, portanto, a demanda de oxigênio para realizar sua decomposição.
} 
As temperaturas desses dejetos variam entre 22 e 41 graus, o $\mathrm{pH}$ entre 6,2 e 10,6 e DBO e DQO entre 17 e 280 mg/l e 140 e 3.340 mg/l, respectivamente.

Adicionalmente à poluição da água pelo descarte de efluentes, vazamentos acidentais de petróleo nas etapas de extração e transporte - como a recente ocorrência no Golfo do México ${ }^{66}$ - exemplificam os riscos e impactos da utilização desse energético.

A mineração de recursos fósseis implica impactos semelhantes à qualidade da água - com a alteração de pH, DBO e DQO - e perda de áreas de ecossistemas nativos.

A operação de termelétricas a combustíveis fósseis produz águas residuais por diferentes processos: soluções derivadas da limpeza química de equipamentos térmicos, líquidos residuais dos sistemas de tratamento de água e da limpeza de geradores de vapor, água do sistema de remoção de cinzas - em centrais que utilizam combustíveis sólidos - e água de resfriamento, responsável pela poluição térmica de reservatórios de água (SALOMON, 2003).

Sistemas de refrigeração de termelétricas com ciclo aberto produzem água superaquecida, cujo despejo resulta em um aumento de cerca de $10^{\circ} \mathrm{C}$ na temperatura média dos rios que a recebem, causando um desequilíbrio no ecossistema aquático com a perda de oxigênio pelos rios, e a mortalidade de fauna e flora aquática (TEIXEIRA, 2003). Esse efeito é observado também em termelétricas a combustível nuclear, cujos descartes também incluem metais pesados e sais. A Usina de Angra I, situada na praia de Itaorna, no município de Angra dos Reis, descarrega cerca de $30 \mathrm{~m} 3 / \mathrm{s}$ de água utilizada para a refrigeração do sistema de geração de energia elétrica no Saco de Piraquara de Fora, baía da llha Grande, no Estado do Rio de Janeiro (ANEEL, 2009).

O fator de geração de efluentes líquidos de termelétricas a carvão varia entre 0,26 a 0,57 $\mathrm{m}^{3}$ por MWhe (USP, FAPESP, 2008c). Em adição a estes, a operação de termelétricas fósseis contribui com a deposição de emissões aéreas

\footnotetext{
${ }^{66}$ O maior vazamento de petróleo da história dos EUA, ocorrido no Golfo do México em abril de 2010, originou-se por conta da explosão de uma plataforma da Petrolífera British Petroleum. O acidente provocou a morte de 11 trabalhadores e um vazamento de óleo, cuja dificuldade de contenção provocou um vazamento acumulado de 4,9 milhões de barris de petróleo até setembro desse mesmo ano. Os principais problemas identificados impactam a fauna aquática local, pássaros migratórios, a indústria pesqueira de Lousiana e o turismo no Golfo da Flórida. (BRITISH PETROLEUM, 2010).
} 
de gases como SO2, NOx e mercúrio em corpos d’água, provocando sua acidificação.

No campo de recursos renováveis, a energia solar apresenta a produção de resíduos químicos na produção de painéis fotovoltaicos e na operação de usinas heliotérmicas. No primeiro caso, a produção de polisilício para as placas resulta em resíduos líquidos de tetraclorido, em proporção quatro vezes superior. A quebra dessa substância pode produzir clorina e ácido hidroclórico - cujo descarte em meio aquático aumenta sua acidez e toxicidade. $\mathrm{O}$ uso de água de resfriamento em usinas heliotérmicas produz efluentes de alta concentração de sais e substâncias químicas de tratamento. O descarte (chamado de blowdown) é uma fonte potencial de impacto a meios aquáticos (U.S. Department of Energy, 2007).

A geração de energia geotérmica aproveita calor a elevadas temperaturas, convertendo vapor em eletricidade. Em alguns casos, esse calor é obtido por meio da injeção de água em campos geotérmicos. Os efeitos colaterais dessa operação incluem o lançamento de água com compostos minerais, como ácido sulfúrico em aquíferos, além da possibilidade de vazamento de dióxido de carbono de perfurações profundas ao ambiente (SCHIERMEIER ET AL, 2008).

A alteração da qualidade da água em projetos hidrelétricos é observada, principalmente, em parâmetros como a acidez e o aumento de substâncias tóxicas como o mercúrio, por consequência da sedimentação - como no caso das usinas do Rio Madeira - e do despejo de resíduos de rocha e outros materiais em reservatórios e rios. A mudança de regime hidráulico também exerce consequências sobre a diminuição do oxigênio dissolvido e a qualidade da água nos trechos inundados (SWITKES, 2008).

O impacto da utilização da biomassa à alteração da qualidade da água concentra-se, no caso da cana-de-açúcar, na etapa de cultivo e produção do etanol. O tratamento e a devolução da água utilizada em usinas de etanol são divididos em diferentes etapas. O tratamento da água utilizada para o resfriamento nas usinas, refrigerada em sistemas de troca de calor com ar por aspersão e descanso, reutiliza totalmente a água. A água captada em poços para o uso em caldeiras ${ }^{67}$ e a água de lavagem de cana ${ }^{68}$ apresentam tratamento

\footnotetext{
${ }^{67}$ A água captada para o uso nas caldeiras é clarificada geralmente por floculação com sulfato de alumínio e soda cáustica, abrandada com uma resina especial e tem o $\mathrm{pH}$ regulado para um
} 
adequado para sua devolução (RODRIGUES et al, 2003). O maior problema encontra-se na falta de tratamento da água utilizada para a irrigação da lavoura e de destinação à vinhaça, resultando em infiltrações em lençóis freáticos (RODRIGUES et al, 2003) $^{69}$.

\subsubsection{Algoritmo de Cômputo e Valoração}

A valoração da qualidade da água baseia-se na medição de alteração dos parâmetros acidez, temperatura, demanda de oxigênio e concentração de poluentes químicos, medidos, respectivamente, em $\mathrm{pH}$, graus Celsius, DBO, DQO e gramas por litro. A pesquisa de campo ou bibliográfica ilustra a alteração desses parâmetros em função do volume de água impactado por quantidade total de energia produzida em cada etapa da cadeia energética do recurso analisado.

A alteração desses indicadores é verificada com base em padrões de emissão ou concentração de poluentes ${ }^{70}$. A qualidade final da água, avaliada por essas diferentes especificações, dependerá de condições de tratamento de impactos, amplamente diferenciada de acordo com recurso energético e região analisada.

O algoritmo de cálculo desse potencial pondera as características do efluente líquido em função do volume total de efluente produzido na aplicação do potencial de geração do recurso energético analisado, de acordo com a equação 12 abaixo:

melhor desempenho na produção de vapor nas caldeiras. No geral, esaa água é captada de poços o que facilita o tratamento.

${ }^{68}$ A água de lavagem de cana, somada às demais águas de limpeza da indústria, é tratada em tanques e lagoas de decantação, em um circuito semifechado onde se recicla $2 / 3$ do total, havendo, portanto, captação e devolução constantes. O lodo das lagoas é utilizado na fertilização das lavouras, assim como a fração mais suja dessa água.

${ }^{69}$ A vinhaça é produzida durante a fermentação e destilação do etanol e contém xarope, clorido, cobre e outros contaminantes. Seu descarte na superfície de solos pode contaminar lençóis freáticos, com impactos a populações e fauna local.

\footnotetext{
${ }^{70}$ A Resolução CONAMA n`20/86 adotou o sistema de cl assificação qualitativa da água baseada em seu uso (art. $1^{\circ}$, "caput", e art. $2^{\circ}$, "a"), esse enquadramento prevê que os rios sejam classificados em 4 classes distintas de acordo com algumas características físico-químicas e biológicas. Os principais parâmetros avaliados são: o oxigênio dissolvido (OD), a demanda bioquímica de oxigênio (DBO) e o número de coliformes fecais e totais. A classe 1 é a melhor e a classe 4, a pior em termos de qualidade de água (USP, FAPESP, 2009b). Já efluentes devem se enquadrar em padrões de emissão definidos pela resolução CONAMA no357.
} 


\section{CVPC alt (RELO) = IND (RELO) x FD (RELO) $\times$ Pot (RELO) (16)}

Onde:

CVPC alt (RELO): alteração absoluta de parâmetros de qualidade i do recurso energético RELO $(\mathrm{pH}$, graus, DBO, DQO, g);

IND: indicador do parâmetro de qualidade i do efluente líquido do recurso energético RELO $(\mathrm{pH}$, graus, DBO, DQO, $\mathrm{g}$ - medidos em função do volume de efluentes gerados);

FD: fator de descarga de efluentes líquidos do recurso energético RELO (medido em volume de efluentes em função da energia produzida pelo recurso);

Pot (RELO): potencial de oferta do RELO.

Indicadores relativos a parâmetros do efluente que não são expressos em concentrações merecem particular cuidado, como no caso do indicador referente à temperatura ${ }^{71}$. Dessa forma, diferentemente de grande parte dos demais atributos valorados, nesse caso a valoração absoluta não apresenta uma caracterização palpável do atributo. Assim, o valor final recupera a alteração da qualidade de água (medida inicialmente apenas para o efluente produzido) para todo o corpo d’água considerado na análise. A equação abaixo ilustra 0 processo:

\section{CVPC alt rel $($ RELO $)=$ CVPC alt $($ RELO $) /$ Vol tot $(17)$}

Onde:

CVPC alt rel (RELO): alteração relativa de parâmetros de qualidade i do RELO, em função de $(\mathrm{pH}$, graus, DBO, DQO, g) por MWh;

CVPC alt (RELO): alteração absoluta de parâmetros de qualidade i do RELO (pH, graus, DBO, DQO);

Vol tot: volume total do corpo d’água que recebe o efluente.

Segue a figura 15, com o procedimento do algoritmo de cômputo e valoração dos potenciais de alteração à qualidade da água:

\footnotetext{
${ }^{71} \mathrm{~A}$ análise dimensional do valor do indicador referente à temperatura, obtido pelo algoritmo sugerido, revela a unidade ${ }^{\circ} \mathrm{C} \cdot \mathrm{m}^{3} / \mathrm{MWhe}$; assim, permi te-se que o indicador possa fornecer $\mathrm{o}$ mesmo resultado para grandes despejos à temperatura ambiente e pequenos despejos com temperatura elevada, para quantidades iguais de energia (UDAETA, KATAYAMA et al, 2008).
} 


\section{Algoritmo - CVPC Alteração da Qualidade da Água}

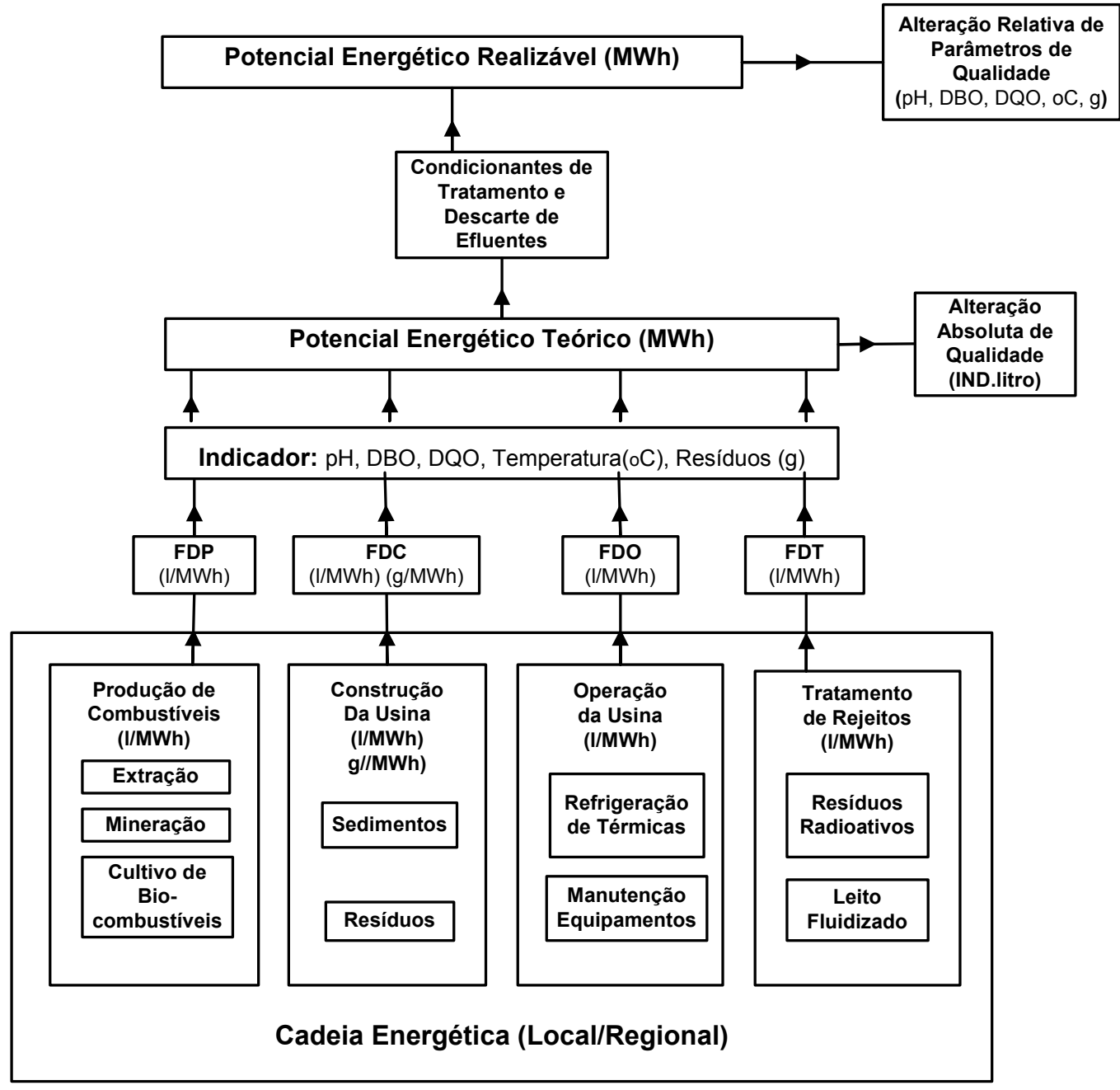

Fonte: Elaboração Própria

Figura 15: Algoritmo de cômputo e valoração do atributo qualidade da água 


\subsection{Cômputo e Valoração da Dimensão Social}

\subsubsection{Definição da Dimensão Social para o PIR}

A dimensão social do planejamento integrado de recursos relaciona as consequências dos diferentes impactos de sistemas energéticos sobre a sociedade. Algumas delas relacionam-se diretamente à influência da alteração de fatores ambientais sobre o meio social, representadas por impactos sobre a saúde e interferências positivas e negativas sobre a qualidade de vida de populações afetadas por empreendimentos energéticos.

Como exemplos de impactos de empreendimentos energéticos sobre 0 meio social, como consequência de alterações sobre o meio ambiente, citam-se:

- a previsão da influência da construção das usinas hidrelétricas de Santo Antônio e Jirau no Rio Madeira sobre a pesca comercial local. A construção de barragens no trecho entre Porto Velho e Guajará-Mirim tem um impacto de valor de mercado sobre a pesca comercial estimado entre US\$800 milhões e 1,3 bilhões, abrangendo áreas na Bolívia e regiões brasileiras rio abaixo (BARNES, 2008). O impacto sobre o potencial pesqueiro afeta diretamente a subsistência das famílias e a economia da região;

- a contaminação ambiental à qual estão expostos habitantes dos municípios de Caetité, Lagoa Real e Igaporã (Bahia), onde se localiza a maior jazida de urânio do país. O elevado índice de radioatividade medido em amostras de água e inferido com base nos níveis de incorporação do radionuclídeo pelos habitantes da região representa um grau de contaminação ambiental por urânio cerca de cem vezes superior à média mundial. Essa condição tem ocasionado sérios problemas de saúde como a ocorrência de neoplasias (PRADO, 2008).

A dimensão social analisa também a interferência de empreendimentos energéticos sobre habitantes dos meios urbano e rural, tanto em eventos extremos - como o deslocamento de populações para a construção de grandes usinas - quanto na intervenção de projetos energéticos na qualidade de vida de moradores próximos - representada, entre outros fatores, pela alteração da 
percepção de conforto como resultado de poluição sonora, visual e outras perturbações.

A quantificação desses atributos, de juízo essencialmente subjetivo, será aprofundada no próximo item. Como exemplo de impacto negativo de recursos energéticos sobre populações afetadas, cita-se:

- O deslocamento populacional pela construção de empreendimentos energéticos: a construção de aproximadamente 150 usinas hidrelétricas em todo o país provocou o desalojamento de cerca de 200 mil famílias de ribeirinhos por conta do alagamento de 34 mil quilômetros quadrados de terras (BERMANN, 2007).

Outros atributos da dimensão social analisam o impacto de recursos energéticos sobre o desenvolvimento humano de uma região, representado por parâmetros como a geração de empregos local - como fator positivo - e influências sobre a saúde ocupacional desses trabalhadores - como fator negativo. Neste segundo item, não se pode deixar de incluir a contabilização de acidentes no setor energético entre trabalhadores dos referidos empreendimentos e a população próxima às ocorrências.

Seguem exemplos ilustrativos de impactos positivos e negativos estudados nesses atributos:

- De acordo com o Programa das Nações Unidas para o Meio Ambiente (PNUMA), cerca de 2,33 milhões de pessoas estavam empregadas no setor de energias renováveis em 2006. A maior parte dos empregos está nos setores de biomassa e termossolar. O potencial de crescimento é significativo: os setores de energia eólica e solar fotovoltaica podem gerar, respectivamente, cerca de 2,1 milhões e 6,3 milhões de empregos até 2030 (PNUMA, 2008).

- O impacto sobre a saúde ocupacional dos cortadores de cana, remunerados em função de sua produtividade; na região de Ribeirão Preto, o índice médio de produção dobrou de 6 toneladas por dia nos anos 80 para 12 toneladas atualmente (ALVES, 2006). A constante pressão por aumento da produtividade tem provocado inúmeros casos de esgotamento e morte nos canaviais do sudeste do país (ASSIS, ZUCARELLI et al, 2007). 
- O levantamento de grandes acidentes energéticos entre 1907 e 2007, considerando sistemas energéticos de petróleo, carvão, gás natural, nuclear, hidrelétricas e renováveis, registrou 279 ocorrências, resultando em 182 mil mortes e um prejuízo de propriedade de 41 bilhões de dólares $^{72}$. As hidrelétricas respondem por $94 \%$ das fatalidades, enquanto as usinas nucleares foram responsáveis por $41 \%$ dos prejuízos provocados (SOVACOOL, 2008a).

A análise de elementos de ordem sociocultural, comumente realizada no âmbito social do planejamento energético, é trabalhada no PIR na dimensão política. Nesta, analisa-se o posicionamento dos atores envolvidos na questão energética e a repercussão dos efeitos destes sistemas sobre os meios ambiental e social.

\subsubsection{Cômputo e Valoração da Dimensão Social para o PIR}

A valoração de impactos do meio social no planejamento energético é um processo heterogêneo quanto à produção e cálculo de indicadores.

O cálculo de atributos que analisam as consequências de impactos ambientais ao meio social - representados por problemas de saúde em decorrência da poluição atmosférica ou contaminação de água e alimentos - é possibilitado pela construção de indicadores baseados em dados disponíveis na literatura, levantados por diferentes pesquisas nacionais e internacionais e verificados pelos trabalhos do PIR. A medição desses impactos é representada por índices que quantificam a população afetada por empreendimentos energéticos, representados por internações hospitalares em decorrência de contato com substâncias tóxicas ou alteração na produção de alimentos em função de contaminação do solo e da água.

A valoração de impactos de recursos energéticos sobre o desenvolvimento humano de uma região, apesar da dificuldade de aferição, pode ser estimada por meio de indicadores econômicos e projeções desses parâmetros para cada recurso energético. $O$ mesmo se aplica à estimativa de impactos de recursos à

\footnotetext{
${ }^{72}$ O levantamento adotou os seguintes critérios para o cômputo dos acidentes: a contabilização de pelos menos uma vítima ou o prejuízo de, pelo menos, 50 mil dólares na propriedade em questão, bem como a comprovação do caráter não-intencional dos acidentes, identificados apenas no setor civil.
} 
saúde ocupacional, ainda que a disponibilidade de pesquisas nesse campo seja até certo ponto limitada.

Exemplos dessas valorações estão na contabilização do volume de recursos financeiros provenientes de royalties e bônus oriundos da exploração de recursos energéticos - e sua influência sobre a infraestrutura local -, na mensuração de geração de empregos para cada recurso energético e no cômputo de variação da qualidade de vida de populações envolvidas em empreendimentos energéticos.

As maiores dificuldades recaem sobre a análise de atributos referentes à alteração de percepção de conforto como consequência da implantação de um recurso energético, representados por fatores como poluições visual, sonora, alteração de padrões de odor. Em relação aos recursos do lado da demanda, essa alteração pode ser significativa no caso de medidas de eficiência energética que resultem na mudança de hábitos ou costumes de diferentes ordens e na adoção de equipamentos e tecnologias alternativas mais modernas.

O teor subjetivo desses elementos dificulta sobremaneira sua formatação em parâmetros numéricos ou técnicos. A quantificação desses parâmetros, em diversos casos, vale-se apenas de levantamentos e pesquisas de opinião realizadas junto aos cidadãos lesados.

Essas pesquisas podem aferir o índice de aprovação ou rejeição de uma população amostral impactada por um dado recurso. O levantamento desse tipo de manifestação por meio de audiências públicas, ainda que constitua prática corrente dos processos de planejamento energético nacional, apresenta limitações de manifestação e expressão de todos os envolvidos e interessados.

Em suma, a quantificação dos atributos dessa dimensão em valores numéricos não é plenamente satisfeita em todos os casos. Segue, na Figura 16, a estrutura da árvore da dimensão social, com os respectivos atributos e subatributos utilizados em sua valoração. 


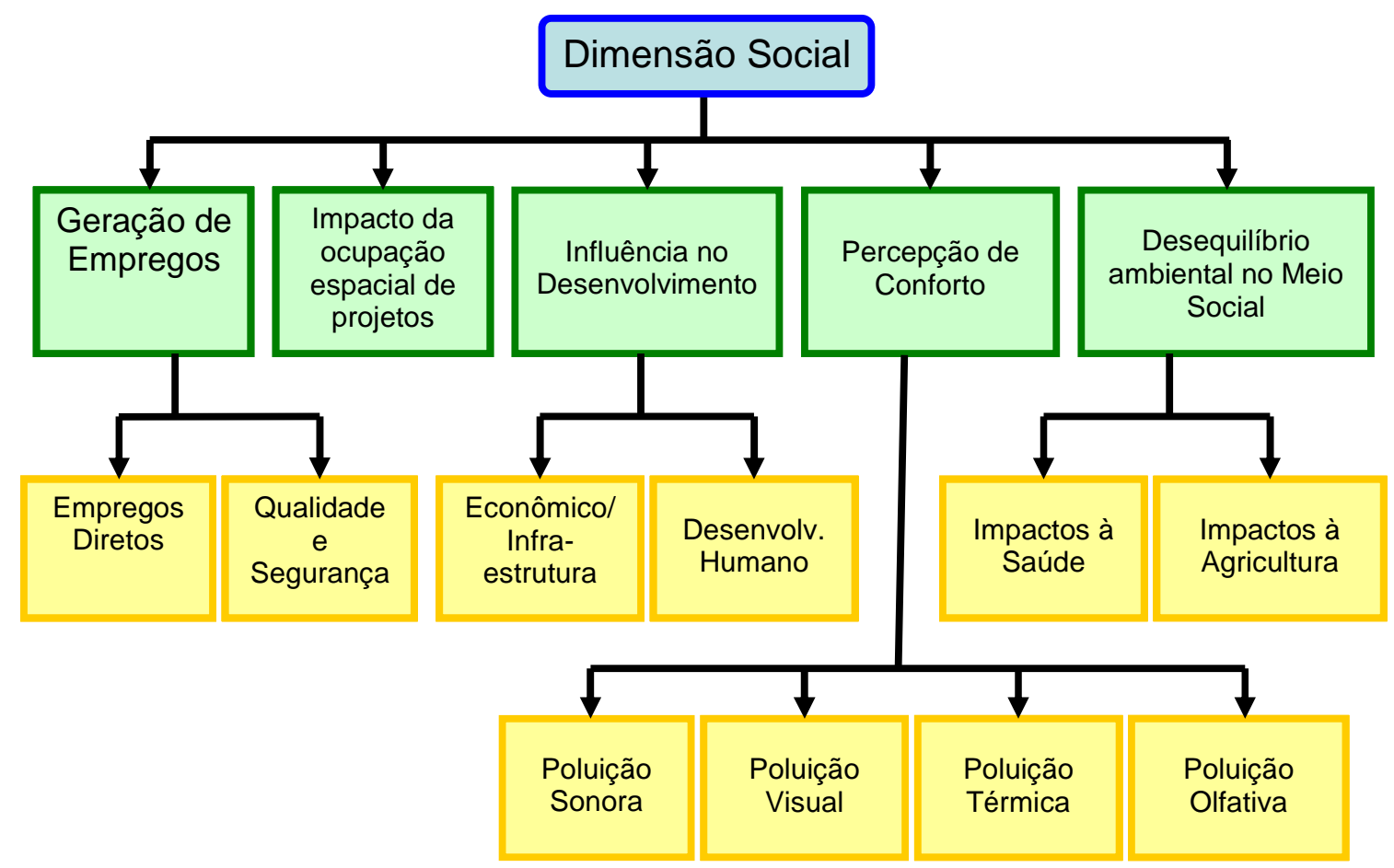

Fonte: USP, FAPESP, 2009b

Figura 16: Árvore de atributos e subatributos da dimensão social

\subsubsection{Geração de Empregos}

\subsubsection{Subatributo: Quantidade de Empregos}

Esse atributo mensura a geração de empregos como decorrência da implantação ou expansão de um recurso energético. Diferentemente da maior parte dos impactos estudados nas dimensões ambiental e social, a criação de empregos é um dos claros benefícios provocados pelos sistemas energéticos, com repercussões sobre outros atributos analisados, como a qualidade de vida de populações afetadas - representada pela reversão da geração de riqueza em ganhos de saúde, educação e infraestrutura.

Mercados de trabalho não apenas geram riquezas, mas melhoram sua distribuição - a geração de renda é importantíssima na redução da pobreza e no compartilhamento dos benefícios de crescimento econômico. Essa distribuição tem grande urgência no cenário atual, em que 1,3 bilhões de pessoas - ou $40 \%$ da força mundial de trabalho - estão relegados à economia informal e 190 milhões de pessoas estão desempregadas. Empregar essas pessoas proporciona, além dos ganhos econômicos, o benefício da inclusão social dessa população, contribuindo para a formação de uma sociedade estável e coesa 
(PNUMA, 2008). Nesse sentido, países com políticas para a promoção de diferentes formas de energias renováveis já experimentam um grande aumento na criação de empregos nesse setor, como é o caso da Alemanha, onde esse índice quadruplicou em dez anos, atingindo o número de 260 mil empregos.

É importante ressaltar que cada recurso energético apresenta um potencial de geração de empregos diferente, com características e qualidade de trabalhos diferenciadas ${ }^{73}$ de acordo com cada cadeia energética e a distribuição desses postos em diferentes atividades.

Essas etapas dividem-se, fundamentalmente, nas fases de estudos e projetos, produção e processamento de combustíveis (se aplicável), construção do empreendimento - incluindo a fabricação e instalação de equipamentos operação e manutenção e descomissionamento (se aplicável).

Os índices de geração de emprego para cada etapa são, normalmente, específicos a cada projeto de implantação de recurso energético, mesmo para o caso de indústrias estabelecidas como a das usinas hidrelétricas. Em todo caso, há exemplos de estudos de compilação de dados internacionais para a estimativa de empregos globais em fontes renováveis e fósseis (GOLDEMBERG, 2004). Mesmo assim, o levantamento não é trivial; como alternativa à análise particular de cada situação de empreendimento, pode-se modelar projeções de geração de empregos, cujo resultado final é comprometido pela variação não-linear e nãoprevisível de parâmetros exógenos como taxas de crescimento econômico e curvas de aprendizado particulares a cada recurso.

Essas taxas de aprendizado, também conhecidas como fatores de declínio, determinam a quantidade de empregos necessária para a instalação de uma quantidade de potência. A redução de postos de trabalho é consequência de maior eficiência dos processos produtivos, resultando na queda dos custos finais dos recursos. Por outro lado, a análise local deve ser específica em relação a esse fator, considerando o estágio de desenvolvimento tecnológico e econômico local para cada recurso (RUTOVITZ et al, 2009).

O fator de importação e exportação de recursos deve ser considerado na análise. $O$ emprego de tecnologias importadas para a construção de sistemas

\footnotetext{
${ }^{73}$ Um exemplo é a bioenergia, de enorme potencial de criação de empregos, mas de grande variação da qualidade destes postos, oferecendo tanto posições qualificadas quanto tipos de trabalho que registram casos de violação de direitos humanos e trabalhistas.
} 
energéticos certamente reduz a utilização de mão de obra local. Por outro lado, a produção de recursos que atendam a outras regiões contempla a criação de postos de trabalho superiores à quantidade necessária para a produção de recursos energéticos destinados ao atendimento da demanda local.

A variação de empregos relacionados a cadeias energéticas repercute na geração de empregos indiretos em diferentes setores que fornecem insumos para as obras civis, como os setores de equipamentos e siderurgia. Um exemplo de potencial geração de empregos indiretos é a exploração das reservas do pré-sal, cujo planejamento projeta que 656 mil empregos seriam gerados em sua cadeia produtiva até 2013.

Por fim, aponta-se um fator essencial à análise temporal de geração de empregos para a implementação de um conjunto de recursos energéticos: a dinâmica de transição de empregos em novas tecnologias e recursos em substituição a empregos previamente existentes. Essa ponderação deve naturalmente considerar o potencial econômico de investimento necessário para a criação desses empregos em função da capacidade instalada e da energia gerada para cada recurso. O exemplo da cana-de-açúcar no Estado de São Paulo é significativo; de acordo com a Única (União da Indústria de Cana-deAçúcar), até 2014, estima-se que cerca de 180 mil cortadores de cana deixem seus empregos por conta da mecanização da colheita. Essa atividade, por sua vez, somada à expansão da produção, irá absorver cerca de 75 mil empregos nas fases agrícola e industrial (JANK,NEVES, 2009).

\subsubsection{Algoritmo de Cômputo e Valoração}

O ponto inicial da valoração de geração de empregos é a discriminação dos potenciais postos de trabalho nas diferentes etapas da cadeia energética envolvida em cada recurso analisado. A instalação de um empreendimento energético abrange as fases de estudos e projetos, produção e processamento de combustíveis (se aplicável), construção do empreendimento - incluindo a fabricação e instalação de equipamentos, operação e manutenção e descomissionamento (se aplicável).

A definição de implantação de um projeto passa pelos levantamentos de campo para engenharia e meio ambiente, estudos energéticos e ambientais e 
elaboração de plano ambiental e projeto básico do empreendimento (TIAGO, et al, 2008).

A produção e o processamento de combustível são representados por uma cadeia particular para cada energético. Como exemplos, citam-se a produção de combustível nuclear $^{74}$ e de óleos derivados de petróleo ${ }^{75}$.

A fase de construção de um empreendimento inclui a definição da localização do canteiro de obras, o comissionamento do canteiro, a montagem dos equipamentos mecânicos e elétricos (previamente fabricados) e a limpeza da área após a construção.

A atribuição de um número de funcionários para as atividades de operação e manutenção de um projeto consideram a otimização das práticas conhecidas para essas atividades, construída com base nos indicadores referentes ao grau de modernização das instalações, idade dos equipamentos e custos administrativos gerais.

Por fim, registra-se o descomissionamento como etapa final da vida útil de uma usina. No entanto, a falta de experiências comerciais e, consequentemente, exemplos práticos do processo dificultam a atribuição de um valor minimamente preciso de geração de emprego para essa etapa.

O fator de empregos para cada uma dessas fases, representado em número de trabalhadores por capacidade instalada, pode ser aferido em experiências práticas para cada tipo de projeto implantado localmente. $\mathrm{Na}$ falta dessa informação, os dados podem ser consultados em estudos nacionais e internacionais e modelados para a situação da região estudada.

O fator de emprego também é influenciado pela produtividade e eficiência de processos específica em empreendimentos locais, com base no nível de desenvolvimento tecnológico e econômico local. Essa variação é representada por um multiplicador regional ou local de empregos, que pode ser calculado localmente - em função da experiência de empreendimentos implantados - ou utilizar indicadores de produtividade de diferentes estudos, adaptados para a realidade da região estudada.

\footnotetext{
${ }^{74}$ As etapas produtivas de combustível nuclear incluem as etapas de mineração de urânio, beneficiamento, enriquecimento e produção de elemento combustível.

${ }^{75}$ A produção de combustíveis derivados do petróleo abrange uma cadeia que inclui a exploração, o transporte e o refino do óleo para a obtenção dos diferentes produtos.
} 
O volume de produção local também depende da utilização de tecnologias importadas em equipamentos de empreendimentos. Um conteúdo totalmente nacional utiliza a taxa de emprego estimada para um recurso enquanto tecnologias importadas diminuem os empregos relacionados à etapa de fabricação.

Dessa forma, o potencial teórico de geração de empregos de um recurso energético é obtido pela somatória da multiplicação das taxas de emprego para cada etapa produtiva pela capacidade instalada do referido empreendimento. Cada etapa é recalculada em função de seu conteúdo de produção nacional.

O cálculo do potencial realizável de geração de empregos incorpora a influência de fatores técnicos e econômicos na reavaliação da estimativa teórica.

O primeiro desses fatores é a correção da taxa de emprego em cada etapa produtiva em função do tempo, por um fator de declínio ou curva de ajuste de aprendizado. Esse fator internaliza a maturação das tecnologias e processos produtivos no cômputo final da geração de empregos. Outro fator é o multiplicador de exportação energética - a alteração da produtividade em função de produção de energia para exportação a outras regiões.

Ambos os fatores são regidos de forma não previsível por fenômenos político-econômicos, como a expansão e retração de crédito financeiro, crises internacionais e cenários de racionamento energético.

Esses estímulos impactam diretamente o planejamento e a projeção de demanda energética de uma região ou país, para a implantação de capacidade adicional de recursos energéticos. Como consequência, registra-se variação na criação de empregos indiretos, oriundos dos setores provedores de insumos e serviços que alimentam a cadeia energética desses recursos. Esses empregos indiretos são modelados por coeficientes técnicos fixos que relacionam a produção de um setor ao consumo intermediário ao longo de toda a sua cadeia.

Em síntese, o cálculo do potencial realizável de geração de empregos resulta de duas componentes: a multiplicação da capacidade instalada de cada recurso pela correção das taxas de emprego de cada etapa produtiva (de acordo com os fatores de declínio e multiplicador de exportação energética) e a geração de empregos indiretos, estimada pela produção de setores provedores da cadeia energética analisada. 
O cômputo e a valoração do total de empregos gerado por um recurso energético de oferta é calculado pelas seguintes equações:

CVPC Emp(etapa) $=\sum_{\mathrm{i}=1}^{\mathrm{n}}\left[\mathrm{FEmp} \mathrm{i}_{\mathrm{i}}(\right.$ etapa $\left.) \times \mathrm{IN}_{\mathrm{i}} \times \mathrm{MR}_{\mathrm{i}}\right] \times \operatorname{Pot}(\mathrm{RELO})$

CVPC Emp (RELO) $=\sum_{i=i}^{n} C_{i P C} E_{i p}($ etapa $)$

Onde:

CVPC Emp (etapas): cômputo e valoração de empregos para cada etapa da cadeia energética do RELO (em número de empregos);

FEmp (etapa): Fator de empregos de RELOs por etapa da cadeia energética (em empregos/MW); $\mathrm{n}$ : etapas da cadeia energética envolvidas na valoração do RELO;

IN: Índice de nacionalização de produção e/ou serviços (\%);

MR: Multiplicador regional (adimensional);

CVPC Emp(RELO): Cômputo e valoração de empregos para RELOs (em número de empregos).

O algoritmo de cômputo e valoração é apresentado a seguir, na figura 17. 


\section{Algoritmo - CVPC Geração de Empregos}

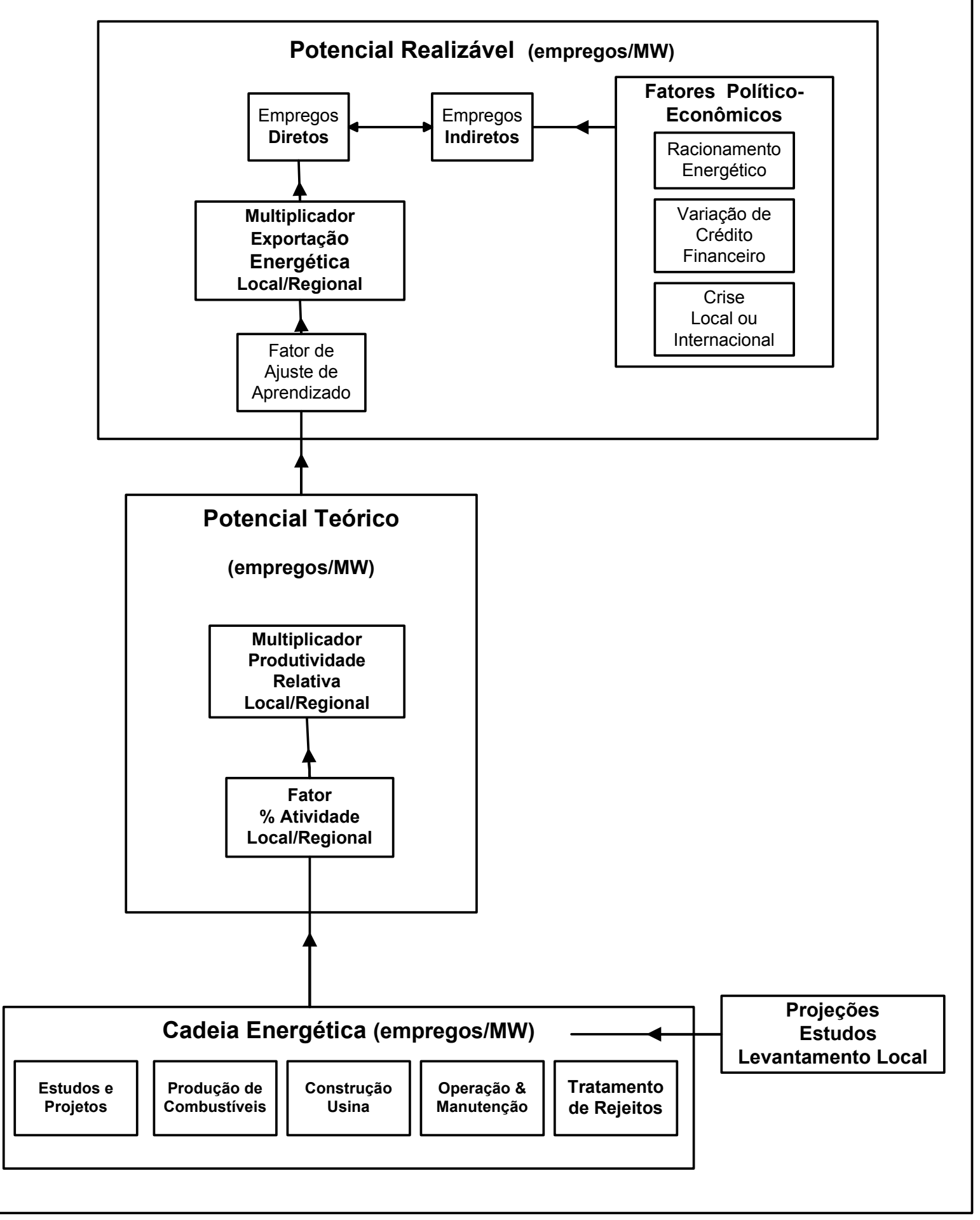

Fonte: Elaboração Própria

Figura 17: Algoritmo de valoração do atributo Geração de Empregos 


\subsubsection{Subatributo: Qualidade de Empregos}

A implantação ou expansão de um recurso energético é capaz de gerar um volume de empregos, distribuídos em toda a cadeia de produção. O cômputo e valoração completa desses empregos é dividido nos subatributos de quantificação de empregos, medida no atributo anterior, e qualidade desses empregos, medida nesse atributo.

Conforme colocado no atributo de geração de empregos, cada recurso energético apresenta um potencial de geração diferente, com características e qualificações diferenciadas de acordo com a distribuição desses postos de trabalho ao longo de cada cadeia energética.

Essas etapas dividem-se fundamentalmente nas fases de estudos e projetos, construção, fabricação e instalação de sistemas ou empreendimentos, operação e manutenção e produção de combustíveis (se aplicável).

A avaliação de um posto de trabalho e a estratificação desse potencial utiliza diferentes critérios, como a qualificação da função, a faixa salarial, as condições humanas e sociais associadas ao trabalho - refletidas em saúde ocupacional e ocorrência de acidentes - e características do contrato laboral.

Optou-se por utilizar os critérios relacionados à temporalidade e condições do trabalho na avaliação desse atributo. Nesse sentido, empregos relacionados aos setores de construção e instalação são considerados trabalhos temporários (ainda que a temporariedade esteja vinculada às obras e não à função propriamente dita), enquanto empregos na cadeia de manufatura e manutenção são tidos como empregos de duração mais longa (PNUMA, 2008). Os setores de produção de energéticos como bioenergia, carvão e combustível nuclear apresentam, em diversos casos, condições de trabalho questionáveis.

Em relação à saúde ocupacional e à contabilização de acidentes de trabalho, levantamento realizado por Sovacool coloca a geração hidrelétrica como responsável pelo maior número de fatalidades nos últimos 100 anos (com 171 mil mortes na barragem chinesa de Shimantam, seguidas pelo acidente nuclear de Chernobyl e pela ruptura de um duto de petróleo na Nigéria). Em termos de frequência de acidentes, o maior número de ocorrências concentra-se nas fontes gás natural, petróleo, nuclear e carvão (SOVACOOL, 2008a). 
A indústria de energias renováveis tem uma demanda alta por força de trabalho com altos níveis de educação e oferece maior segurança de empregos em contratos de longo prazo; entretanto, verifica-se uma proporção considerável de empregos temporários entre subcontratantes (PNUMA, 2008).

Por outro lado, a indústria extrativista de mineração de combustíveis fósseis tem reduzido a taxa de emprego nas últimas décadas, com o crescimento da mecanização. A indústria de carvão tem-se caracterizado pelo predomínio de companhias de grande porte e redução de mão de obra - em 2002, o total de empregos contabilizava menos de 1\% da força de trabalho. Entre 1995 e 2005, a queda foi de $20 \%$ e deve cair outros $23 \%$ até 2014 , com o aprimoramento de técnicas de extração e processamento de combustível. A tendência repete-se no setor de petróleo - houve redução de $40 \%$ dos empregos da cadeia de refino entre 1980 e 1999 e outros 8\% entre 2001 e 2006. Na Europa, a diminuição de postos na indústria de petróleo e gás natural foi de 150 mil na segunda metade dos anos 90 e de outros 200 mil empregos entre 2000 e 2004 (PNUMA, 2009).

A estratificação detalhada de empregos é feita no estudo "Wind at Work" (EWEA, 2009), que contabiliza empregos diretos nos setores de fabricação de turbinas eólicas, promoção de geração eólica, concessionárias, serviços de engenharia e área de pesquisa e desenvolvimento.

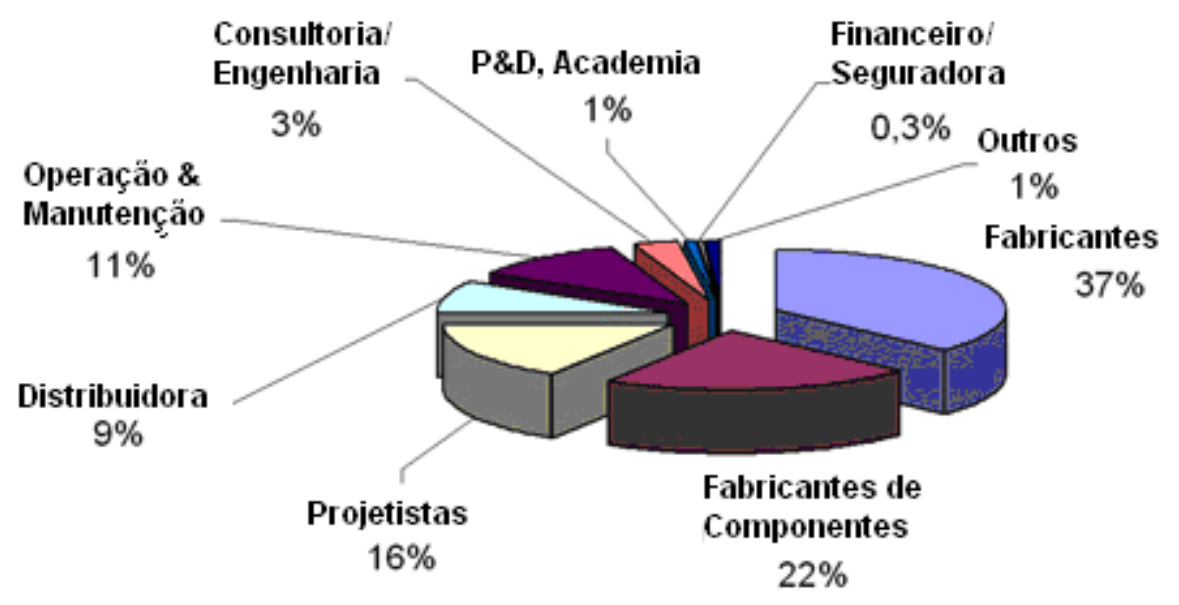

Fonte: EWEA (2009)

Figura 18: Empregos diretos por tipo de atividade no setor eólico europeu

O mesmo estudo lista de forma detalhada os tipos de empregos envolvidos em cada ramo do setor eólico. Essa listagem pode ser replicada para outros energéticos e é sintetizada a seguir. 
Fabricação de Equipamentos:

- pesquisa \& desenvolvimento, projeto de produtos, controle de qualidade e gerenciamento de processos produtivos: engenheiros químicos, elétricos e mecânicos de alta qualificação;

- especialistas de saúde e segurança;

- cadeia de produção: trabalhadores com média e baixa expertise;

- operação \& manutenção: equipe técnica para O\&M e reparo de equipamentos;

- setores administrativo, de vendas, marketing e contabilidade: equipe de apoio.

Desenvolvimento de Projetos:

- gerenciamento de projetos: engenheiros e economistas para coordenação;

- impactos ambientais: engenheiros ambientais e especialistas;

- modelos de previsão: programadores e meteorologistas para previsão do tempo (no caso de energias renováveis);

- aspectos legais e financeiros de desenvolvimento de projetos: advogados e economistas;

- setores administrativo, de vendas, marketing e contabilidade: equipe de apoio.

Construção, Reparo, Operação e Manutenção:

- construção: engenheiros elétricos e civis;

- especialistas de saúde e segurança;

- especialistas em transporte de materiais pesados;

- equipe técnica especializada em instalação de equipamentos;

- operação \& manutenção: equipe técnica para O\&M e reparo de equipamentos;

- eletricistas;

- cadeia de produção: trabalhadores com média e baixa expertise;

- setores administrativo, de vendas, marketing e contabilidade: equipe de apoio. 
Produtores independentes e concessionárias:

- gerenciamento de plantas: Engenheiros elétricos, ambientais e civis;

- especialistas de saúde e segurança;

- venda de eletricidade: agentes financeiros, equipe de vendas e marketing;

- equipe técnica: O\&M de usinas (contratada ou subcontratada);

- setores administrativo, de vendas, marketing e contabilidade: equipe de apoio.

Consultorias, entidades legais, instituições de direito e engenharia, seguradoras, centros de P\&D e outros:

- pesquisa e desenvolvimento: engenheiros especializados;

- engenheiros ambientais;

- especialistas em política energética;

- especialistas em pesquisas sociais, treinamento e comunicação;

- modelos de previsão: programadores e meteorologistas;

- agentes financeiros e economistas;

- advogados especializados em energia e questões ambientais;

- pessoal de marketing, organizadores de eventos.

Verifica-se que os casos de trabalhadores de menor exigência de qualificação e ou temporários concentram-se nas áreas de construção e fabricação de equipamentos. Somam-se a tais áreas as de suprimento de combustíveis, principalmente no caso das indústrias de mineração e de biocombustíveis. No caso da indústria de cana-de-açúcar, verificam-se diferentes práticas trabalhistas, desde denúncias de trabalho escravo e semiescravo até a adoção de projetos de requalificação de cortadores de cana para funções mais complexas de mecanização ou mesmo a migração a outros setores da economia (UNICA, 2010) $^{76}$.

Em relação à saúde ocupacional, verificam-se maiores ocorrências de acidentes nas fases de construção e operação, no caso de empreendimentos

\footnotetext{
${ }^{76}$ O maior projeto é o Renovação, implementado pela UNICA (União da Indústria de Cana-deAçúcar), que tem o objetivo de requalificar anualmente 7 mil trabalhadores funcionários e exfuncionários do corte de cana, provenientes de usinas associadas à União (ÚNICA, 2010).
} 
hidrelétricos ${ }^{77}$. Já no caso da cadeia do gás natural, os acidentes distribuem-se nas fases de prospecção, extração, construção e operação de plataformas, gasodutos e usinas ${ }^{78}$.

\subsubsection{Algoritmo de Cômputo e Valoração}

A valoração da qualidade de empregos gerados é a discriminação dos potenciais de perfis de trabalho nas diferentes áreas relacionadas à oferta de energia. Esses perfis foram listados no item anterior dentro das áreas de fabricação de equipamentos, desenvolvimento de projetos, construção, operação e manutenção de usinas ou sistemas, comercialização de energia, pesquisa e desenvolvimento, entre outros.

O cálculo do algoritmo parte do potencial de empregos extratificado dentro dessas áreas - obtido de forma análoga ao atributo geração de empregos, com base no uso de indicadores e fatores de restrições locais - e a distribuição desse potencial para cada perfil de trabalho, de acordo com o recurso energético considerado.

A distribuição desses potenciais é avaliada de acordo com a qualificação necessária para a função, a temporalidade dos contratos, impactos sobre a saúde ocupacional e a faixa salarial. Dessa forma, dentro do universo de empregos gerados por um determinado recurso energético, o potencial de empregos qualificados excluiria um conjunto de postos de trabalho de baixa e média experiência, contratos temporários, impactos à saúde ocupacional, probabilidade média ou alta de acidentes de trabalho e remuneração baixa.

O algoritmo de valoração do atributo segue na figura 19.

\footnotetext{
77 Estatísticas de acidentes no setor elétrico disponíveis no Grupo de Intercâmbio e Difusão de Informações sobre Engenharia de Segurança e Medicina do Trabalho (GRIDIS) da Eletrobras e nos Anuários Estatísticos da Previdência Social (REIS, 2001).

${ }^{78}$ Dados de acidentes do trabalho disponíveis junto a estatísticas de acidentes da Petrobras e da Comissão Européia (REIS, 2001).
} 


\section{Algoritmo - Valoração Qualidade de Empregos}

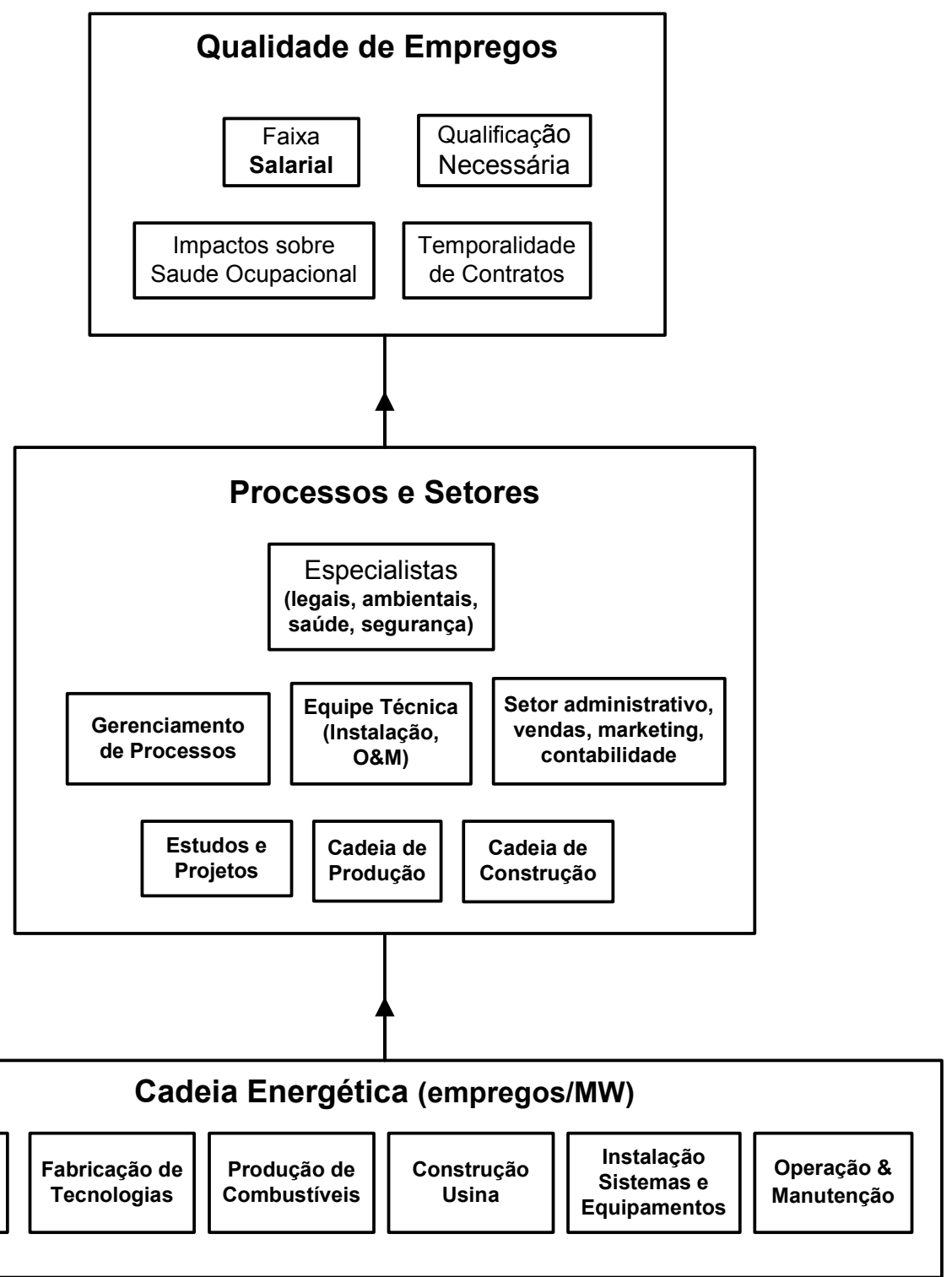

Fonte: Elaboração Própria

Figura 19: Algoritmo de valoração do subatributo Qualidade de Empregos 


\subsubsection{Atributo: Impactos de Desequilíbrio Ambiental no Meio Social}

A valoração de impactos de empreendimentos energéticos ao meio social como decorrência de alterações ao meio ambiente mensura danos à saúde humana como consequência da contaminação ambiental da água, solo e ar e suas implicações sobre o cultivo de alimentos, a provisão de água potável e a qualidade do ar.

Conforme colocado anteriormente, o cálculo de algoritmos que analisam as consequências de impactos ambientais ao meio social vale-se do uso de indicadores baseados em dados disponíveis na literatura, levantados por diferentes pesquisas nacionais e internacionais e verificados pelos trabalhos do PIR. Esses índices retratam a população afetada ou atingida por atividades da cadeia energética, por meio de taxas de mortalidade e frequência de internações hospitalares como decorrência de fatores como a contaminação da água ou de alimentos, a alteração na qualidade do ar, entre outros.

Os impactos ao meio social provocados por alterações ambientais dividemse em seus principais meios aéreo, terrestre e aquático.

A poluição do ar pela emissão de gases e poluentes em fontes móveis e estacionárias produz impactos conhecidos à saúde humana como asma, bronquite e enfisema pulmonar, como resultado da penetração desses poluentes no aparelho respiratório. De acordo com a Faculdade de Medicina da USP, estima-se que a exposição a material particulado, expelido em veículos e usinas termelétricas que utilizam combustíveis fósseis, seja responsável por aproximadamente 800 mil mortes anuais causadas por doenças cardiorrespiratórias em todo o mundo, das quais 35 mil ocorreriam na América Latina (SALDIVA et al, 2006).

A emissão de radiação pelo meio aéreo também é apontada como causadora de casos de câncer e leucemia em crianças que habitam áreas próximas de centrais nucleares, de acordo com o estudo alemão "Câncer Infantil em proximidades de usinas nucleares", ou Kikk (FAIRLIE, 2009). O estudo de 2008 verificou um crescimento de $60 \%$ de ocorrências de câncer e $120 \%$ de leucemia entre crianças que vivem em um raio de cinco quilômetros de usinas, como efeito da incorporação de radionuclídeos por radiação direta de reatores, 
emissão de vapor de água radioativo (contendo trítio) de torres de resfriamento de reatores e emissões radioativas de $\mathrm{C} 14$ e gases nobres radioativos como isótopos de $\mathrm{Kr}$, Ar e Xe ao ambiente (FAIRLIE, 2009). O acidente de Chernobyl afetou milhões de pessoas, por conta do contato com radiação liberada na usina. O total de afetados, entre a população de áreas evacuadas, contaminadas, são profissionais que trabalharam no controle do acidente e seus descendentes, contabilizou 2,65 milhões de pessoas (FAIRLIE, 2006).

No meio aquático, atividades da cadeia energética podem ocasionar, além de poluição da água por substâncias tóxicas ou radiativas, a transmissão de doenças de veiculação hídrica, por ingestão ou contato direto com água contaminada por bactérias, vírus e parasitas. Esse caso acontece na construção de hidrelétricas, quando a formação do lago resulta na eutrofização possibilitando condições ideais para a reprodução de insetos transmissores de doenças ou agentes biológicos.

O caso de contaminação de água mais recente é o da zona rural de Caetité, a $757 \mathrm{~km}$ de Salvador, Bahia. A área é utilizada para a mineração de urânio, e uma série de poços artesianos foram interditados, com índices de radiação alfa e beta acima dos limites recomendados pela Portaria ํㅜ 518/04, de potabilidade de água, do Ministério da Saúde. O elevado índice de radioatividade inferido pelos níveis de incorporação do radionuclídeo pelos habitantes da região provoca sérios problemas de saúde como neoplasias.

Outro exemplo de contaminação de água em decorrência de atividades de mineração ${ }^{79}$ é retratado no artigo "Integridade ecológica de córregos relacionada a taxas de mortalidade de câncer em humanos" (HITT, HENDRYX, 2010). estudo sugere uma forte correlação entre o aumento da mineração de carvão, a diminuição da integridade ecológica de córregos e o aumento de taxas de ocorrência de câncer ${ }^{80}$.

A contaminação do solo interfere, além do solo propriamente dito, em diferentes ambientes da área afetada - em águas superficiais e subterrâneas, no ar, na fauna e na vegetação - com consequências diretas sobre a saúde pública.

\footnotetext{
${ }^{79}$ A contaminação das águas ocorre com o descarte de resíduos de mineração, metais e outros poluentes em correntes, afetando aquíferos e, consequentemente, outras comunidades.

${ }^{80}$ Identificaram-se diferentes tipos de câncer nos sistemas respiratório, digestivo, urinário, e câncer de mama.
} 
O acréscimo de concentrações atmosféricas de substâncias emitidas em etapas da cadeia energética e sua deposição no solo, nos vegetais e nos materiais, além de danos à saúde, provoca a redução na produção agrícola, danos a florestas e degradação de construções e edificações. A acidificação dos solos pela emissão de poluentes resulta na redução de nutrientes e na liberação de substâncias prejudiciais às plantas, reduzindo, consequentemente, a produtividade de culturas.

A contaminação do solo nas áreas rurais também acontece por determinadas técnicas de produção de etanol e açúcar e do descarte indevido de seus subprodutos como a vinhaça.

O descarte inadequado de rejeitos radioativos provoca a infertilização do solo e a improdutividade da terra, com impactos diretos sobre a contaminação de alimentos. Esse caso acontece mais de duas décadas depois do acidente na usina nuclear de Chernobyl, transcendendo a área da ocorrência até países vizinhos à Ucrânia. Restrições de produção, transporte e consumo de alimentos contaminados pelo acidente estendem-se da Suécia e Finlândia até regiões da Alemanha, Áustria, Itália e Polônia, onde determinados frutos e peixes atingem níveis radioativos de milhares de Bequerels por quilo de Césio 137, dez vezes superiores ao limite de 600 Bq/kg (FOOD STANDARD AGENCY, 2009).

\subsubsection{Algoritmo de Cômputo e Valoração}

A valoração de impactos de desequilíbrio ambiental no meio social, ou dessas alterações à saúde humana, é medida pela ocorrência de doenças e taxas de mortalidade contabilizadas na cadeia energética de cada recurso - e pela produção de alimentos - representada por perdas de produção e comercialização decorrentes de restrições de contaminação.

Assim, o potencial de populações afetadas por impactos ambientais de empreendimentos energéticos é medido pela quantidade de internações e taxas de mortalidade e morbidade referentes a cada recurso energético, multiplicadas pelo potencial de implantação do referido recurso ${ }^{81}$.

\footnotetext{
${ }^{81}$ Adicionalmente à contabilização total de casos de mortalidade e morbidade pode-se calcular o valor associado ao aumento do risco de doenças ou fatalidades, por meio do método de custo de doença, contabilizando gastos totais com tratamento e o valor de dias perdidos de trabalho (REIS, 2001).
} 
O impacto à produção de alimentos é representado pela restrição à comercialização e uso de produtos agrícolas e pecuários, como decorrência de contaminação por substâncias poluentes tóxicas e/ou radioativas produzidas em etapas da cadeia energética para cada recurso avaliado.

Para a valoração de pessoas afetadas por impactos ambientais de empreendimentos, é necessário o estabelecimento de uma função entre a construção de tais empreendimentos e taxas de morbidade e mortalidade associadas a eles ${ }^{82}$. Essas taxas são condicionadas a funções dose-resposta que analisam a variação de agentes patogênicos e exposição a substâncias tóxicas e/ou radioativas transmitidas pelo ar e absorvidas pelo corpo humano por contato físico, ou ingeridas por vias respiratória ou oral ${ }^{83}$.

A aferição dessas substâncias parte da verificação de emissões atmosféricas por fontes pontuais, pelo consumo local de combustível ou energia gerada. Em seguida, determina-se a concentração do poluente ao nível do solo, por meio de modelos de dispersão que simulem o transporte e as reações químicas desses poluentes na atmosfera, considerando quantidades emitidas e condições meteorológicas existentes (REIS, 2001).

A concentração de poluentes no solo impacta o nível de adequação de culturas de alimentos para o consumo humano e, consequentemente, as perdas agrícolas referentes à proporção inutilizada da produção. As restrições a alimentos são também determinadas pela detecção de níveis máximos de radioatividade estipulados por organizações de saúde.

A utilização de funções dose-resposta e/ou dados de vulnerabilidade com base nos níveis considerados de concentração desses poluentes produz os indicadores de risco individual de morbidade e mortalidade.

\footnotetext{
${ }^{82}$ Uma dificuldade para o estabelecimento dessas funções é a disponibilidade de uma base confiável de dados, verifica-se a falta de diagnósticos, por falta de precisão da causa das doenças, da origem de quadros de saúde e da causa mortis. Soma-se a essa dificuldade a regionalização de vetores dessas doenças (REIS, 2001).

${ }^{83}$ Esses estudos epidemiológicos podem acompanhar a saúde de uma amostra de pessoas identificadas no tempo ou basear-se em dados estatísticos para uma população. O acompanhamento pode ser feito por séries temporais, que observam variações das taxas dos efeitos dentro de uma área específica ao longo do tempo, ou estudos cruzados, nos quais são observadas diferenças nos efeitos em diferentes localidades durante um período de tempo (SZKLO, 1997).
} 
No caso de contaminação radioativa por fontes próximas ou de contração de doenças recorrentes de alterações no fluxo de rios, típicas de empreendimentos hidrelétricos ${ }^{84}$, os dados associados de morbidade e mortalidade são medidos pela verificação da variação de ocorrências no local, após a construção dos empreendimentos, em relação à média histórica de casos nessa região ${ }^{85}$.

. O algoritmo de valoração do atributo segue na figura 20.

84 As principais doenças que podem ter incidência sobre populações ribeirinhas são esquistossomose, febre amarela, malária, leishmaniose, dengue, filariose, chagas e oncocerose, cólera, tifo, disenterias e parasitas.

${ }^{85}$ Esse procedimento é aplicado em casos de dificuldade de obtenção, na literatura especializada, de funções dose-resposta que relacionem a construção de usinas nucleares e hidrelétricas com o aumento do número de casos de doenças. 


\section{Algoritmo - CVPC Desequilíbrio Ambiental no Meio Social}

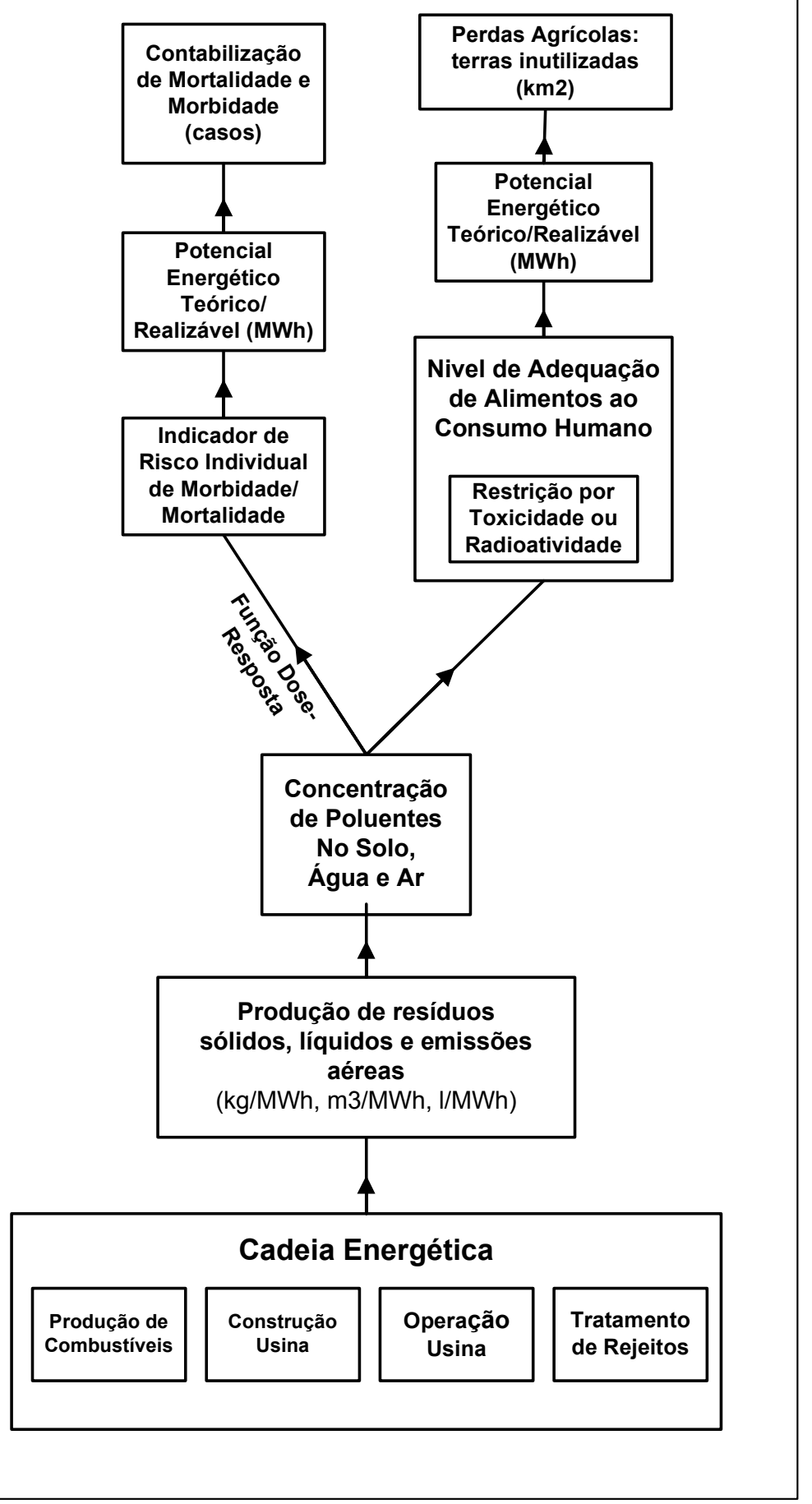

Fonte: Elaboração Própria

Figura 20: Algoritmo de cômputo e valoração do desequilíbrio ambiental no meio social 


\subsubsection{Atributo: Impacto Humano decorrente da Ocupação Espacial de Empreendimentos}

Esse atributo da dimensão social avalia a interferência de empreendimentos energéticos sobre o espaço ocupado, com consequências sobre habitantes dos meios urbano e rural, em eventos extremos como o deslocamento de populações para atividades como a extração e a produção de energéticos, a transmissão de energia, a construção de grandes usinas e a evacuação de população próxima a elas, como resultado de acidentes.

Essas ocorrências têm exemplos em diferentes tipos de atividades do setor energético, desde a mineração de carvão e o cultivo de cana-de-açúcar, à construção de usinas hidrelétricas e parques eólicos, além de acidentes relacionados a usinas nucleares e extração de petróleo e consequências diferentes sobre essas populações, entre danos psicológicos resultantes da realocação, a perdas econômicas, sociais - como inviabilização de moradias ou espaços utilizados para diferentes fins -, culturais e históricas dos locais danificados ou modificados.

A desapropriação de populações é um procedimento comum do poder público, de transferência compulsória de imóveis pertencentes a terceiros, no atendimento a interesses sociais, ou de utilidade ou necessidade pública. A medida, ainda que seja realizada mediante pagamento de justa e prévia indenização, não contempla o ressarcimento de todos os impactos acima citados e incorre na transferência forçada dos proprietários originais - por meio de decretos, quando necessário -, a despeito de comprovação de justo título e boafé do bem expropriado.

O exemplo nacional mais palpável de deslocamento populacional como resultado da construção de empreendimentos energéticos vem do histórico de projetos hidrelétricos. Cerca de 200 mil famílias foram desalojadas para a construção de aproximadamente 150 usinas hidrelétricas em um período que compreende os anos de 1950 e 2005 (BERMANN, 2007). Esse deslocamento acontece por conta de grandes áreas necessárias para a construção de reservatórios e barramento de rios.

Ainda que a condução do processo tenha apresentado evolução nos últimos anos em relação a maiores investimentos socioambientais nos custos de 
usinas e de melhorias na relação entre empreendedores e atingidos, a construção de projetos futuros gera discussão e questionamentos de diferentes atores sociais e ambientais e, principalmente, da população afetada. O projeto da hidrelétrica de Belo Monte tem a previsão de deslocar entre 20 e 30 mil pessoas e conta com a oposição de mais de 60 lideranças indígenas, em decorrência dos múltiplos impactos futuros do empreendimento. Tais impactos estendem-se além da área de construção da barragem, implicando a redução de recursos hídricos e a expansão do desmatamento regional - resultante da pressão local por recursos naturais e econômicos.

Usinas termelétricas, ainda que ocupem áreas reduzidas em proporção às hidrelétricas, têm exemplos de impactos à saúde de populações próximas e consequentes deslocamentos humanos. Na Tailândia, houve a decisão jurídica favorável a famílias no vilarejo de Mae Moh impactadas pela termelétrica de Egat, a maior usina a carvão do país. A usina a carvão, abastecida por uma mina de 135 km2 a céu aberto, provocou doenças respiratórias e mortes em 16 vilarejos por conta de emissões de dióxido de enxofre.

A corte de Chaing Mai decidiu também pelo deslocamento de famílias afetadas em pelo menos cinco quilômetros de distância da usina. Trinta mil pessoas já foram deslocadas como resultado da operação da térmica (GREENPEACE, 2006).

A desapropriação de terras e populações não acontece apenas em atividades de geração. Entre Minas Gerais e Rio de Janeiro, terras ao longo de $525 \mathrm{~km}$ serão desocupadas para a construção de um mineroduto que deverá escoar a produção até o Porto de Açu.

Ao lado dos recursos hídricos, a geração nuclear apresenta alto número de pessoas afetadas e população deslocada por empreendimentos, principalmente por conta da ocorrência de acidentes. De acordo com a legislação da Ucrânia sobre "Situação e Proteção Social de cidadãos afetados pela catástrofe de Chernobyl", em torno de $7 \%$ da população ucraniana foi afetada pelo acidente, excluindo moradores de Kiev. Em 2005, o número chegava a 2,6 milhões de cidadãos, entre 165 mil residentes de áreas evacuadas e 1,5 milhões de pessoas em cerca de 2.300 assentamentos em áreas contaminadas.

A biomassa é outro recurso de grande impacto sobre reordenação do espaço e consequentes deslocamentos de populações por monoculturas como a 
cana-de-acúcar, utilizada para a produção de etanol e bioeletricidade e de soja, na produção de biodiesel. Ambas as produções apresentam exemplos de impactos sobre a manutenção da agricultura familiar e mudanças no padrão de produção agrícola, conforme apontado em trabalho de campo realizado em regiões do Triângulo Mineiro e Zona da Mata, em Minas Gerais; Oeste Paulista, em São Paulo; Sul e Leste do Mato Grosso do Sul; e Noroeste do Rio Grande do Sul (ASSIS, ZUCARELLI et al, 2007).

O aumento da produção da agroindústria canavieira está relacionado à expansão do cultivo em novas áreas, exercendo pressão sobre modos de vida e atividades rurais. A expansão de canaviais tem estimulado o arrendamento de terras por longos prazos - e a provável renovação dessas terras após o fim desses períodos - e expulsado agricultores do campo. Em áreas circunvizinhas a assentamentos de reforma agrária dedicados à reprodução da agricultura familiar, como Iturama no Triângulo Mineiro, as plantações de cana ilharam o Assentamento Água Vermelha e moradores recebem constantes propostas para arrendamento ou plantio (ASSIS, ZUCARELLI et al, 2007).

A necessidade de realocação de populações situadas em áreas de empreendimentos energéticos é, obviamente, mínima em casos de sistemas energéticos descentralizados, como a geração solar fotovoltaica, quando realizada essencialmente de forma distribuída, utilizando a área útil de telhados de edificações. A geração eólica, por sua vez, registra exemplos de compartilhamento de terras com outras finalidades como pastagens e agricultura, como no exemplo do parque eólico de Osório, no Rio Grande do Sul. Desapropriações de faixas de terra são previstas para a implantação de linhas de transmissão conectando elas e futuras centrais, como a de Tramandaí a subestações.

Entretanto problemas relacionados ao uso de territórios têm ocorrido nos estados do Ceará e do Rio Grande do Norte. No primeiro caso, o processo de instalação de um parque eólico na praia de Parajuru levantou questionamentos de proprietários de terrenos por conta dos valores recebidos e do procedimento da ação de desapropriação. No litoral e em outras regiões do Rio Grande do Norte, verificam-se ações de especulação imobiliária de territórios para parques eólicos; a secretaria de energia do estado assegura que não há ação ou 
programa governamental que obrigue um proprietário de terra a ceder direitos ou uso de sua terra sem que se Ihe satisfaçam condições remuneratórias.

Entre efeitos colaterais do deslocamento de famílias por conta de empreendimentos energéticos, aponta-se a queda na qualidade de vida de tais famílias, como decorrência de sua fixação em bairros e locais com ofertas precárias de serviços públicos ${ }^{86}$.

Outro impacto óbvio é a pressão sobre a infraestrutura urbana no caso da migração temporária de trabalhadores para a construção de projetos hidrelétricos ou culturas de biocombustíveis. No projeto de Belo Monte, é prevista a duplicação da população de Altamira e, no projeto da termelétrica Sul Catarinense em Treviso, o volume esperado é similar, com a expectativa de que a cidade passe de 3 para 6 mil habitantes durante a construção da usina.

De forma análoga, o arrendamento de terras para a ampliação dos plantios de cana desencadeia uma complexa alteração nos tipos de produção, na disponibilidade de empregos, no fluxo migratório para cidades, na oferta de alimentos e na possibilidade de demarcação de terras que, originalmente, seriam destinadas à reforma agrária.

Ainda em relação à qualidade de vida por conta do deslocamento, na Ucrânia, 9.500 pessoas em 1.337 famílias ainda permanecem em zonas de evacuação compulsória após o acidente de Chernobyl. Essa população carece de infraestrutura, serviços básicos, direito ao uso da terra e cuidados médicos, além da alta exposição a radiação. Essa situação, somada à perda de referenciais espaciais e sociais, repercute em efeitos mentais, psicológicos e estresse.

Esses impactos são discutidos nos atributos seguintes, que medem a influência de empreendimentos energéticos sobre a infraestrutura e a economia dos locais impactados e alterações de conforto e qualidade de vida dessas populações.

Outros impactos relacionam-se a perdas estéticas culturais e históricas de territórios, desde a transformação de rios e montanhas para a geração hidrelétrica ou a mineração, até a ocupação e danificação de sítios arqueológicos.

\footnotetext{
${ }^{86}$ De acordo com a aplicação de 46 questionários em locais impactados (63\% com proprietários e $37 \%$ com não proprietários), verificou-se que $29,5 \%$ dos afetados sentiram queda na qualidade de vida, contra $23,5 \%$ dos entrevistados que tiveram melhorias na qualidade de vida. Nesse mesmo grupo, $41 \%$ declararam redução de renda, enquanto $35 \%$ tiveram melhorias de renda (BERMANN, 2004).
} 
O alagamento do reservatório pode provocar o desaparecimento de quedas d'água, remansos e outras paisagens. A formação desses lagos ou mesmo a construção de parques eólicos podem resultar na perda de objetos e artefatos arqueológicos enterrados nesses locais, base da história e cultura de civilizações preexistentes nessas regiões. A valoração dessas perdas, ainda que possa ser mensurada por captação dos bens perdidos, dificilmente será capaz de considerar o valor psicológico, histórico e sentimental dos recursos perdidos.

Em suma, a valoração de impactos humanos relacionados à ocupação territorial para fins energéticos considera, além do volume de pessoas deslocadas, o impacto sofrido por essa população em termos de perdas sociais, culturais e econômicas - também avaliadas em outros atributos dessa dimensão a adaptação das populações a novos locais ou mesmo desses locais a novos usos $^{87}$ e, principalmente, a condução do processo de desapropriação territorial pacífica ou não - e em condições justas de indenização aos afetados.

As opções de indenização às famílias deslocadas por empreendimentos costumam ser em dinheiro, carta de crédito, autorreassentamento ${ }^{88}$ ou reassentamento rural coletivo ${ }^{89}$ (INSTITUTO ACENDE BRASIL, 2010). O bom encaminhamento dessa negociação depende da definição prévia de critérios socioeconômicos para as indenizações e da padronização das regras dessas práticas.

\subsubsection{Algoritmo de Cômputo e Valoração}

A valoração de impactos humanos à ocupação espacial de recursos energéticos considera, em essência, a quantidade total de pessoas deslocadas com base na densidade populacional da área afetada.

Em seguida, avaliam-se as condições do processo de desapropriação, em termos de critérios de indenização e características da remoção - forçada ou

\footnotetext{
${ }^{87} \mathrm{O}$ alagamento de reservatórios causa interferência em atividades como pesca, caça e banho; por outro lado, pode criar condições para a prática de outras atividades como esportes náuticos, por conta da criação de lagos artificiais.

${ }^{88}$ Famílias que optam por soluções individuais de busca de imóveis, com o valor da indenização recebida.

${ }^{89}$ A família recebe um lote de terra preparado para exploração agrícola, com abastecimento de água, energia elétrica e estrada de acesso à propriedade
} 
acordada. Como consequência desses critérios, avaliam-se também as perdas gerais do deslocamento, entre prejuízos culturais, sociais, históricos ou arqueológicos decorrentes da alteração espacial.

Como terceira etapa, o algoritmo avalia as condições do processo de reassentamento, considerando a readaptação das populações transferidas e alterações de qualidade de vida e fatores de desenvolvimento humano.

A avaliação do reuso da área desapropriada e da valoração da modificação da área de influência são feitas, respectivamente, nos atributos de impactos de empreendimentos ao solo (na dimensão ambiental) e de influência no desenvolvimento local como resultado da implantação de projetos energéticos (atributo da dimensão social).

O algoritmo pode ser visualizado na figura 21 , a seguir: 


\section{Algoritmo - CVPC Deslocamento Humano}

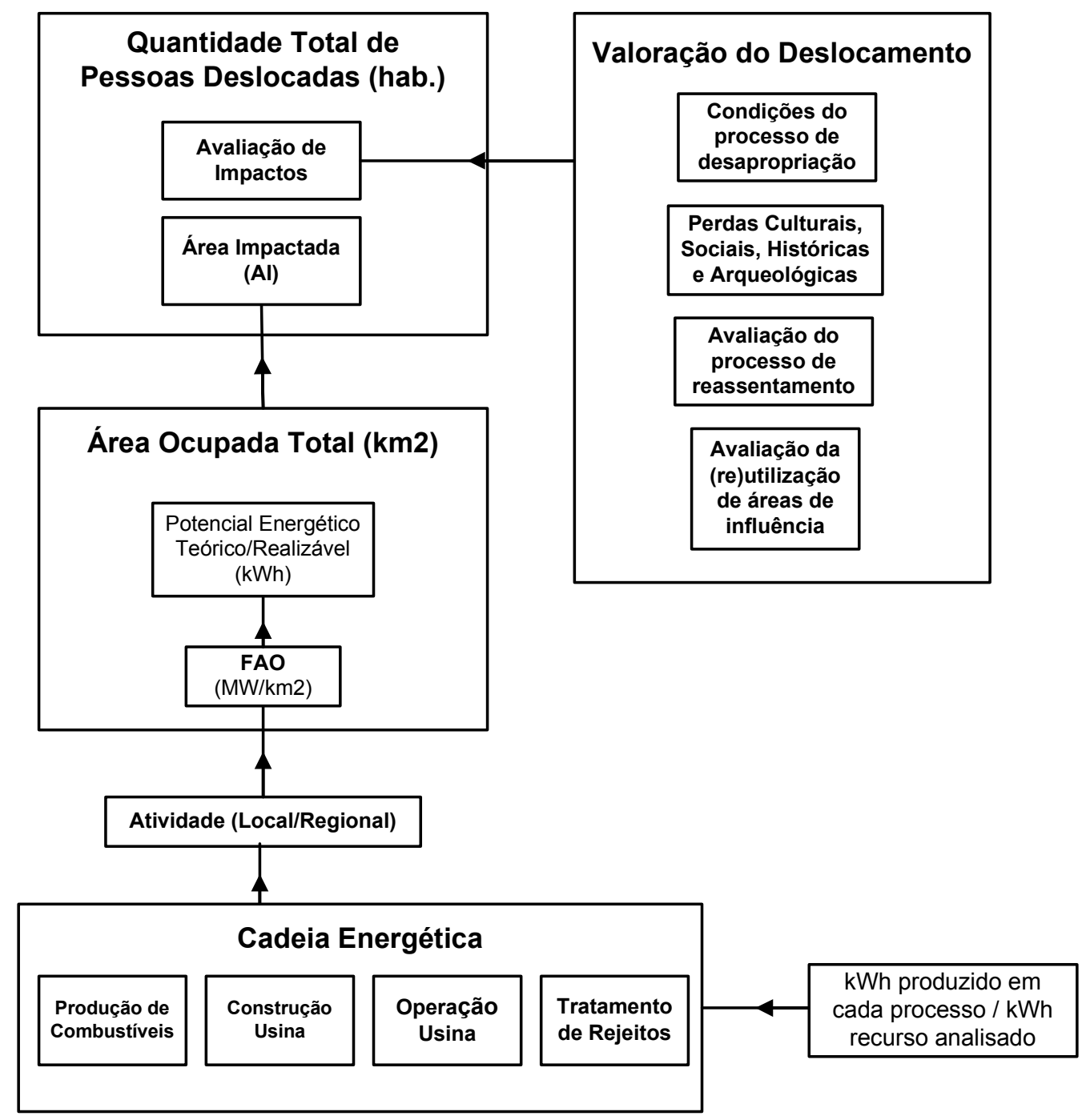

Fonte: Elaboração Própria

Figura 21: Algoritmo de cômputo e valoração de Deslocamento Humano em decorrência da implantação de empreendimentos energéticos

\subsubsection{Influência no Desenvolvimento Local}

Dentre os atributos valorados nessa dimensão, merece atenção especial a análise das interferências positivas e negativas de empreendimentos energéticos sobre o desenvolvimento das regiões que os recebem. Esse desenvolvimento 
reflete-se sobre a sociedade em três perspectivas: econômica, estrutural e humana.

A contribuição de recursos energéticos ao desenvolvimento econômico pode ser medida por diferentes fatores como a variação do produto interno bruto ou da receita obtida por recolhimento de impostos e taxas específicos a atividades relacionadas ao setor, a redução de importação na balança comercial, entre outros. A indústria eólica representa um exemplo desse desenvolvimento para os números macroeconômicos da Espanha, contribuindo com 3,27 bilhões de euros ao PIB do país em $2008^{90}$. O reflexo desses fatores sobre a sociedade é a criação de empregos diretos e indiretos por consequência da implantação de atividades energéticas (analisada em outro atributo) e da conversão desses empregos em maior renda para a região. O aquecimento econômico traduz-se no aumento de atividades industriais e comerciais, estimulando a demanda energética local e, por consequência, contribuindo a esse efeito econômico circular.

Essa variável é medida em função da geração de empregos diretos, indiretos e de efeito-renda criados por investimentos em empreendimentos energéticos. O emprego efeito-renda é obtido pela incorporação do consumo privado no cômputo de consumos da cadeia energética ${ }^{91}$; representa o estímulo do aumento da conversão da renda de trabalhadores e empresários à produção de outros setores da economia, realimentando, assim, o processo de geração de empregos.

No caso espanhol, estima-se que, para cada unidade de $\mathrm{PIB}$, a indústria eólica tenha criado mais empregos $(0,42)$ que a média do setor energético $(0,34)$, justificando as despesas (de 991 milhões de euros) em garantir uma tarifa prêmio para esse tipo de energia. Esses resultados são contestados por Álvares (et al,

\footnotetext{
${ }^{90}$ Além de participar com $10 \%$ da demanda elétrica espanhola, a geração eólica contribui com 3,27 bilhões de euros ao PIB da Espanha ( $0,35 \%$ do total em 2008 e projeção de alcançar $0,42 \%$ em 2010), com importante efeito de alavancagem a companhias auxiliares de produção e infraestrutura (1,38 bilhões de euros). Outros efeitos foram a arrecadação de 189 milhões de euros em impostos e 2,55 bilhões de euros em produtos exportados e a redução de importação de 5,7 milhões de toneladas equivalente de petróleo de combustíveis fósseis (DELOITTE, 2008).

${ }^{91}$ A quantificação de empregos indiretos considera o número de postos de trabalho criados em decorrência do aumento de demanda na cadeia produtiva de equipamentos, obras civis, meio ambiente e serviços. Essa produção envolve tanto o consumo intermediário (incluindo bens e matérias-primas necessários para a produção de insumos) quanto 0 valor adicionado (representando o que foi acrescentado ao conjunto de bens intermediários).
} 
2009), esse autor alega que a criação de empregos verdes implica perda de empregos em outras áreas da economia, considerando que o alto custo de eletricidade por fontes renováveis tende a inibir a implantação de indústrias eletrointensivas. ${ }^{92}$

O desenvolvimento econômico indica a perspectiva de aprimoramento da infraestrutura da região que recebe um determinado recurso energético. Se o aumento do PIB local pode se reverter em melhorias de planejamento e condições de serviços públicos como rede de saneamento e transporte, deve-se ressaltar que esta não é uma relação nexo-causal; por diferentes motivos legais e/ou administrativos, a renda advinda de recursos energéticos não necessariamente reverte-se em benefícios à região impactada.

Um exemplo prático é a distribuição de royalties e participações especiais associadas à produção de petróleo e gás natural no Brasil. A eficiência no emprego de recursos públicos, ainda que exerça efeito inegável sobre economias locais, não implica a minimização de demandas sociais e econômicas. No caso da distribuição orçamentária de Campos, uma parcela significativa dos royalties recebidos pelo município em 1999 e 2000 não foi aplicada em investimentos de infraestrutura, indicando um desvio da função socioeconômica legalmente prevista para esse recurso (SERRA et al, 2007). Na região da hidrelétrica de Itaipu, de acordo com Sterliche, não há política definida para o investimento dos royalties na maior parte dos municípios contemplados (STERLICHE, 2008) ${ }^{93}$. Em outras situações, a arrecadação de receitas originalmente destinadas a garantir 0 suprimento energético de localidades da região Norte acaba sendo revertida a outras finalidades, apesar da previsão de conexão dessas regiões à rede ${ }^{94}$.

\footnotetext{
92 O estudo "Study of the Effects on Employment of Public Aid to Renewable Energy Sources" calcula que cada emprego nas áreas de energias renováveis ou eficiência energética criado na Espanha resultou na redução de 2,2 empregos em outros setores da economia, com impactos principais à metalurgia, mineração de não-metais e indústrias de alimento, bebidas e tabaco.
}

${ }^{93}$ A legislação dos royalties beneficiou o Governo do Paraná e 15 municípios paranaenses, os principais atingidos pelo alagamento de terras para a formação do reservatório, além do município de Mundo Novo, no Estado do Mato Grosso do Sul. O valor recebido em royalties pelo Tesouro Nacional do Brasil é superior a 3,7 bilhões de dólares (STERLICHE, 2008).

${ }^{94}$ A Conta de Consumo de Combustíveis para os sistemas isolados, criada originalmente para cobrir os custos de combustíveis de geração térmica constantes dos planos de operação dos sistemas isolados sofreu alterações com a lei 12.111/09 e passou a reembolsar também os custos de contratação de energia e potência associada, geração própria, encargos e impostos associados. O encargo deveria ser descontinuado após a conexão dessas regiões ao sistema 
Outro exemplo da limitação da associação do PIB à implementação de políticas de promoção social é o fato de a legislação nacional não exigir obrigatoriedade de utilização da totalidade da renda de royalties recebida ${ }^{95}$. A possível mudança nas regras de distribuição de royalties de atividades petrolíferas, equalizando benefícios entre municípios produtores e não-produtores pode agravar esse quadro ${ }^{96}$.

Por outro lado, a mudança de legislação tenta sanar os efeitos de desigualdade regional provocados pela atual distribuição de riquezas de atividades de petróleo. De acordo com Serra, entre 2002 e 2007, as receitas públicas dos Municípios Petrolíferos Fluminenses, em conjunto, experimentaram uma elevação de cinco vezes, em comparação a um aumento de apenas 2,2 vezes para os demais municípios. A consequência dessa distribuição é um quadro de polarização espacial dessa riqueza, com hiperdeslocamentos de pessoas e capitais no interior dessa região ${ }^{97}$ e custos sociais associados (SERRA et al, 2007). Assim, ainda que, para economias fechadas, o PIB represente uma boa indicação da renda apropriada pela população de um município, o indicador não reflete o desenvolvimento local, uma vez que parte da renda gerada é alocada à remuneração de indivíduos residentes em outras cidades.

Em outros casos, regiões que recebem projetos energéticos e têm expectativa de desenvolvimento econômico podem sofrer com efeitos colaterais como o estrangulamento da infraestrutura local. O sinal econômico dado por empreendimentos energéticos nem sempre é acompanhado por um planejamento

interligado, mas será mantido até pelo menos o ano de 2012 a fim de compensar a perda de arrecadação de ICMS pela circulação de diesel nesses estados.

${ }^{95}$ Entre 2002 e 2007, R $\$ 3,2$ bilhões de royalties de petróleo, recursos hídricos e minerais vinculados ao meio ambiente foram contingenciados para o superávit primário. O Ministério do Meio Ambiente deveria receber $R \$ 3,8$ bilhões de royalties, mas ficou com apenas $R \$ 606$ milhões; o desvio de finalidade foi possível porque a legislação não impede o governo de não utilizar o dinheiro dos royalties. (CNM, 2008).

${ }^{96}$ De acordo com a legislação brasileira, os royalties do petróleo são divididos entre a União $(40 \%)$, Estados produtores $(22,5 \%)$ e municípios produtores $(30 \%)$. Os $7,5 \%$ restantes são distribuídos para todos os municípios e Estados da federação. A emenda aprovada na Câmara dos Deputados em março de 2010 prevê que $30 \%$ dos royalties sejam destinados aos Estados, $30 \%$ aos municípios e $40 \%$ à União, sem tratamento diferenciado aos produtores.

${ }^{97}$ Uma vez que os municípios não podem utilizar as rendas petrolíferas para quitação de dívidas e pagamento de pessoal direto, observa-se a multiplicação da contratação de pessoas físicas e jurídicas, de forma terceirizada, por muitos dos municípios beneficiários. 
adequado do atendimento à demanda de serviços criada com o crescimento desordenado da população urbana da área afetada, por conta da migração de trabalhadores e famílias à região. Esse fenômeno pode acontecer na região de Altamira, com a construção da hidrelétrica de Belo Monte ${ }^{98}$.

Alternativamente ao uso de receitas provenientes de royalties, a compensação ou melhoria de condições de infraestrutura de regiões impactadas ou hospedeiras de empreendimentos energéticos pode ser assegurada, ainda que teoricamente, por condicionantes impostas no processo de licenciamento ambiental dessas usinas. No caso da construção da usina nuclear de Angra 3, a licença prévia prevê uma série de medidas em relação à infraestrutura de saúde, educação, segurança pública e transporte em Angra dos Reis e municípios vizinhos.

A interferência positiva de empreendimentos energéticos ao desenvolvimento humano pode ser vinculada à análise e variação de índices como o IDH (índice de desenvolvimento humano) nas regiões afetadas. Ressaltase que essa análise deve ser conduzida com precaução, por diferentes motivos. Em primeiro lugar, conforme mostrado anteriormente, 0 desenvolvimento econômico e a abundância da produção material não apresentam vínculo direto a melhorias de qualidade de vida (SACHS, 2007). Em segundo lugar, a construção de índices capazes de medir satisfatoriamente o desenvolvimento humano de países, regiões e municípios tem sido amplamente discutida desde a origem do IDH, questionado por suas limitações metodológicas e contabilísticas ${ }^{99}$, por diferentes autores. Dentre as propostas, incluem-se sugestões de inclusão de componentes de degradação ambiental (NEUMAYER, 2001), a reavaliação da aritmética simples de atribuição do índice (obtido pela média entre renda, longevidade e taxa de alfabetização), com base na vetorização desses

\footnotetext{
${ }^{98}$ Altamira atrai muitos migrantes da região norte da bacia do Rio Xingu. Há tendência de maior urbanização também para outros municípios da bacia do rio Xingu; entretanto, identifica-se nessas cidades a carência de instrumentos de planejamento e gestão para atender às necessidades que surgem com o aumento da população (ELETROBRÁS, 2009).

${ }^{99}$ Propõe-se o aprofundamento de análise e inclusão de indicadores capazes de mensurar a diversidade de desenvolvimento de diferentes países em condições sociais, políticas e econômicas, refletido em parâmetros de medição de necessidades humanas, tendências demográficas, energia e meio ambiente.
} 
elementos, ou mesmo a comparação do IDH a outros indicadores como o MHDI ou o BORDA (NOORBAKHSH, 1998).

\subsubsection{Algoritmo de Cômputo e Valoração}

O algoritmo de valoração do desenvolvimento local é, portanto, composto de três parcelas: variação do produto interno bruto e diferentes indicadores econômicos como a variação da balança comercial e a geração de empregos como consequência da implementação de recursos energéticos - esta última já contabilizada em outro atributo, mas, dessa vez, contemplando postos indiretos de trabalho e o efeito renda em decorrência da variação de produção e consumo - alteração de condições gerais de infraestrutura pela implementação de recursos arrecadados com royalties ou condicionantes previstas em processos de licenciamento ambiental, e por fim, o uso de indicadores para a medição de alteração de indicadores sociais referentes aos setores de educação, saúde, saneamento, transporte e segurança, entre outros.

A respeito da avaliação de alteração da infraestrutura local por consequência direta de empreendimentos energéticos, observa-se que não se pode estabelecer relação linear ou comportamento similar de evolução ou proporção entre os parâmetros, seja ela para casos diferentes contemplando um mesmo recurso ou a mesma região de análise. Assim, essa avaliação deve basear-se qualitativamente na concretização de condicionantes estipuladas em processos de licenciamento ou outros meios legais relacionados à autorização de empreendimentos e, principalmente, ao uso líquido de recursos advindos de encargos, royalties e participações de empreendimentos em atividades voltadas à melhoria de infraestrutura geral da região impactada.

Essa alteração, seja ela positiva ou negativa, deve impactar o terceiro indicador desse atributo, o desenvolvimento humano, medido por diferentes critérios locais relacionados à variação de níveis de saúde, educação, condições de habitação, entre outros. Vale lembrar que a avaliação de parâmetros relacionados à qualidade de vida de habitantes afetados por empreendimentos em relação à percepção de diferentes tipos de conforto e bem estar é aprofundada no próximo atributo. 
O cômputo e valoração de desenvolvimento econômico e humano de recursos energéticos de oferta, bem como a medição de suas variações percentuais, são obtidos pelas seguintes equações:

CVPC DE(RELO) $=$ FRenda $\times$ Pot(RELO)

$\Delta$ CVPC DE (RELO) $=$ CVPC DE $($ RELO)/PIBlocal (21)

Onde:

CVPC DE (RELO): Cômputo e valoração de desenvolvimento econômico de RELO (R\$); FRenda: Massa salarial anual de um determinado empreendimento ( $R / M W)$.

$\triangle$ CVPC DE (RELO): Variação de cômputo e valoração de desenvolvimento econômico de RELO $(\%)$.

\section{$\Delta \mathrm{CVPC}$ DH $=\Delta \mathrm{CVPC}$ DE (RELO) $/ 3(22)$}

Onde:

$\triangle$ CVPC DH (RELO): Variação de cômputo e valoração de desenvolvimento humano de RELO $(\%)$.

A figura 22 ilustra 0 algoritmo de valoração de influência ao desenvolvimento local: 


\section{Algoritmo - CVPC Desenvolvimento Local}

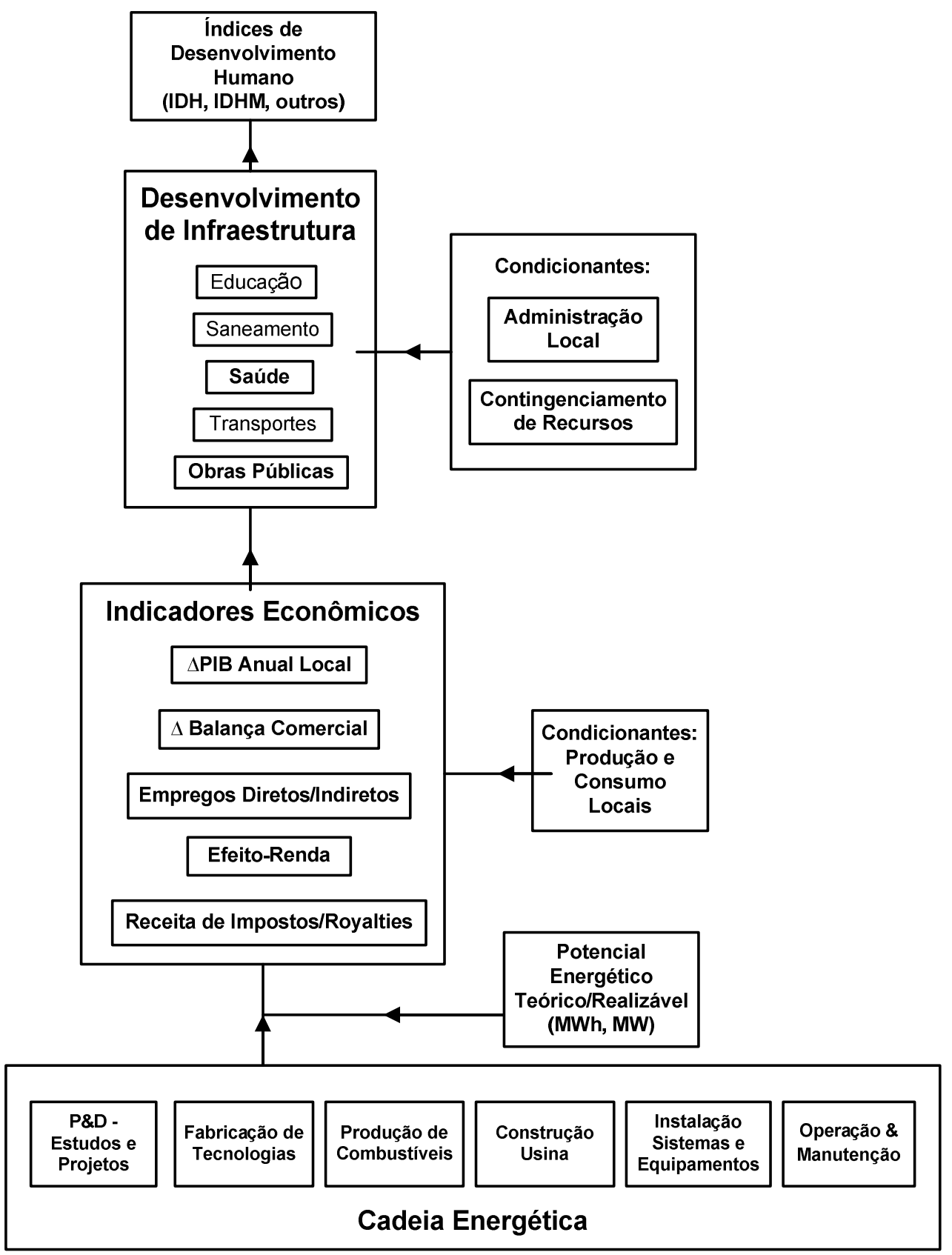

Fonte: Elaboração Própria

Figura 22: Algoritmo de cômputo e valoração da influência no desenvolvimento local 


\subsubsection{Alteração de percepção de conforto}

A percepção de conforto de um indivíduo ou uma comunidade em relação à utilização de um recurso energético analisa fatores de impactos particulares a esses grupos, distintos de impactos diretos à saúde ou à qualidade de vida de populações em termos de prosperidade e educação. Esses fatores consideram diferentes tipos de poluição que retratam alterações de conforto associadas a recursos - comparadas a padrões médios de tolerância quando possível.

Os tipos de poluição valoradas são a visual - representada por alteração de sistemas energéticos no campo de visão de populações próximas a estes -, sonora - provocada pelo impacto de ruídos de usinas ou geradores a comunidades vizinhas -, olfativa - resultante de emissões químicas em plantações de biocombustíveis ou emissões aéreas em usinas termelétricas - e térmica - pela alteração de temperatura ou calor em zonas próximas a grupos geradores ou sistemas energéticos térmicos.

A poluição visual é mensurada pela alteração estética provocada por um sistema energético em relação à situação anterior. Dessa forma, o impacto é analisado pela área do elemento introduzido na paisagem ou campo visual e seu contraste com os demais elementos desse campo. Este efeito pode ser provocado por instalações de painéis e aquecedores solares em telhados de conjuntos residenciais, torres eólicas em locais no campo ou pela construção de usinas em áreas de paisagens naturais. No caso de grandes projetos, a avaliação de impacto visual vale-se de mapeamento em sistemas de informação geográfica ou GIS (da sigla em inglês geographical information system).

No exemplo de turbinas eólicas, mede-se, para uma distância predeterminada, a poluição visual por percepção relativa de tamanho, análise de imagem para determinação de seu nível de contraste e os efeitos de espalhamento sobre esse contraste (Hurtado, Fernandez, et al, 2004).

A poluição sonora em sistemas energéticos é associada ao excesso de ruído de operação de máquinas, turbinas e outros equipamentos. O nível de ruído varia segundo potência e tamanho de equipamentos. Em grupos geradores, por exemplo, identifica-se ruído mecânico proveniente do motor a diesel, ruído aerodinâmico gerado pelo ventilador do radiador para refrigeração da água, e ruído da saída dos gases de combustão (Araújo, 2004). Nesse caso, a redução 
de ruído passa por tratamento acústico e redução de abertura de troca de ar, com restrições por conta do risco de danificação do equipamento.

Os principais impactos de ruído ao ser humano relacionam-se à audição, habilidade de comunicação e comportamento; sons acima de 65 dB (decibéis) podem contribuir para aumentar casos de insônia e irritabilidade. Níveis superiores a $75 \mathrm{~dB}$ podem provocar problemas mais sérios de saúde como surdez e hipertensão arterial. As tabelas 6 e 7 abaixo mostram alguns níveis de ruído e suas consequências na saúde humana (PAULA, ALENCAR, 2002).

\section{Tabela 6: Níveis de ruído comuns}

\begin{tabular}{l|c} 
Descrição & $\begin{array}{c}\text { Nível Sonoro } \\
\text { (dBA) }\end{array}$ \\
\hline Limiar de dor & 120 \\
Discoteca, volume alto, & 110 \\
Broca pneumática a dois metros & 105 \\
Ambiente industrial ruidoso & 90 \\
Piano a um metro & 80 \\
Carro quieto que passa a dois metros & 70 \\
Conversação normal & 60 \\
Ruído de centros urbanos (noturno) & 50 \\
Dentro de quarto (dia) & 40 \\
Dentro de quarto (noite) & 30 \\
Estúdio gravação & 20 \\
Quarto com bom isolamento sonoro & 10 \\
Limiar ouvindo a um kHz & 0
\end{tabular}

Tabela 7: Níveis de ruído e efeito na saúde

\begin{tabular}{l|lr}
\hline $\begin{array}{l}\text { Pressão } \\
\text { sonora } \\
\mathbf{1 5 0} \mathbf{d B}\end{array}$ & $\begin{array}{l}\text { Descrição } \\
\mathbf{1 2 0} \mathbf{d B}\end{array}$ & $\begin{array}{l}\text { Causa perda } \\
\text { instantaneamente. }\end{array}$ \\
$\mathbf{1 0 0} \mathbf{d B}$ & $\begin{array}{l}\text { Fisicamente doloroso e deve ser evitado. } \\
\text { Curtos períodos de exposição causam um } \\
\text { deslocamento temporário do limiar de } \\
\text { audição, e a exposição mais prolongada } \\
\text { pode causar danos irreparáveis nos } \\
\text { órgãos auditivos. } \\
\text { Longos períodos de exposição a este } \\
\text { nível normalmente causam perda } \\
\text { permanente de audição. } \\
\text { Longos períodos de exposição causam } \\
\text { cansaço mental e físico. }\end{array}$ \\
$\mathbf{6 5} \mathbf{d B}$
\end{tabular}


A implantação de usinas ou sistemas energéticos deve prever a alteração do ambiente sonoro local, a fim de controlá-lo e minimizá-lo. Duas resoluções foram estabelecidas pelo Conselho Nacional do Meio Ambiente - CONAMA - a fim de definir normas de emissão de ruídos em diferentes atividades ${ }^{100}$.

O nível de ruído em sistemas energéticos é determinado pela medição dos níveis de pressão sonora em diferentes pontos. No caso de geração eólica, os níveis sonoros registraram entre 41,1 e 48,2 dB(A) em estudo de caso de Zambujo e Churro (2004); já o nível de ruído em grupos geradores é consideravelmente mais elevado - entre 109,9 dB (para potencias de $60 \mathrm{kVA}$ ) e 115,8 dB (para potências de 300 kVA) (Araújo, 2004). Em seguida, calcula-se o nível de ruído equivalente contínuo, para diferentes pontos, produzindo um mapa de área de maior impacto sonoro (Cruz, Melo, et al, 2007).

Assim, a mensuração da poluição sonora em um sistema energético ocorre pela diferença entre níveis de ruído medidos e limites de ruído estipulado para a região considerada. No caso da legislação de Portugal (Regime Legal sobre a Poluição Sonora ou RLPS), essa diferença não pode exceder $5 \mathrm{~dB}(\mathrm{~A})$ no Período Diurno e 3dB(A) no Período Noturno (Zambujo e Churro, 2004). Essa tolerância varia também em função do tempo de exposição a esse ruído.

A poluição olfativa é parte da poluição atmosférica provocada pela alteração de odor de ambientes ou espaços abertos. O odor é uma resposta sensorial a substâncias químicas inaladas pelo ar. Ainda que o principal efeito dessa poluição seja o incômodo, em casos mais sérios, de acordo com o tempo de exposição, pode causar sensação de náusea e dor de cabeça, além de sintomas ligados ao stress.

Muitos compostos com alto teor de odor resultam de atividade biológica ou estão presentes em emissões de processos químicos. A ocorrência desse tipo de poluição em processos energéticos relaciona-se à produção de diferentes tipos de biomassa (biocombustíveis como etanol ${ }^{101}$ ou biogás derivado de dejetos

\footnotetext{
${ }^{100}$ A norma NBR 10151 define os limites de níveis de ruído - de $40 \mathrm{~dB}(\mathrm{~A})$ no período diurno e 35 $\mathrm{dB}(\mathrm{A})$ no período noturno, para áreas de sítios e fazendas, e de $50 \mathrm{~dB}(\mathrm{~A})$ no período diurno e 45 $\mathrm{dB}(\mathrm{A})$ no período noturno, para áreas residenciais urbanas. Já o tempo de exposição ao ruído no ambiente de trabalho é determinado pela NR-15 - que estabelece o nível máximo de $85 \mathrm{~dB}(\mathrm{~A})$ para uma jornada de $8 \mathrm{~h}$.

101 No caso de culturas de cana-de-açúcar, a destilação do álcool gera como subproduto a vinhaça, líquido de natureza ácida, cheiro desagradável, poluente e corrosivo.
} 
animais $^{102}$ ) e à emissão de diferentes poluentes químicos em termelétricas movidas a combustíveis fósseis.

A medição de odor pode ser feita por meio dos seguintes indicadores:

- Índice de odor: razão adimensional entre a pressão de evaporação e o limiar de reconhecimento total de odor, que expressa o potencial total de um composto em liberar odor em condições de evaporação. Nos extremos da escala, estão o etanol, com índice 11 e o m-butil-mercaptan, com 49.340.000.

- Detectabilidade de odor: concentração mínima que produz resposta olfatória ou sensação. Essa concentração é medida em razão de diluição, relacionada ao número de diluições necessárias para tornar o ar com odor não detectável $(\mathrm{D} / \mathrm{T})$.

- Intensidade de odor: a força da sensação de odor acima de limiares de reconhecimento. É exponencialmente proporcional à concentração de odor, de acordo com a fórmula: $I=k(C)^{n}$.

A medição de odor pode ser feita por métodos instrumentais, sensoriais, análise química e olfatometria, realizada em amostras de emissões ou ar ambiente nos locais impactados. Todos eles são analisados de acordo com limites de concentração e intensidade (Central Pollution Control Board, 2007).

Por fim, o quarto tipo de alteração de conforto associado a recursos energéticos é a poluição térmica ou produção de calor. Fator normalmente avaliado para equipamentos de uso final, como iluminação, esse tipo de poluição aplica-se à alteração desconfortável de temperatura por equipamentos de geração de energia. Normalmente o estudo da poluição térmica relacionada à operação de termelétricas direciona-se ao impacto da produção de calor sobre a temperatura da água usada para restabelecer o equilíbrio térmico de ciclos. Assim, não foram identificados registros de impactos de alteração de temperatura local por operação de grupos geradores ou outros sistemas de geração de energia.

\footnotetext{
${ }^{102} \mathrm{O}$ metano, principal componente do biogás, não tem cheiro, mas os demais gases presentes conferem-Ihe um ligeiro odor desagradável.
} 


\subsubsection{Algoritmo de Cômputo e Valoração}

A valoração desses diferentes tipos de poluição segue uma metodologia básica de medição local e posterior cálculo seguindo formulações especificas. A quantificação da alteração de conforto em cada um desses fatores é, portanto, a diferença percentual entre valores calculados e valores máximos permitidos por legislação para cada caso ou local estudado.

Assim, a poluição sonora pondera o nível de pressão sonora (NPS) medido em diferentes pontos, considerando o erro-padrão da série de medidas (para garantir que o número de medições caracteriza o nível de ruído emitido) (Behar, Plener, 1984, apud SILVA et al, 2008). O cálculo é executado pela seguinte equação:

NPS $=x+/-t x(\sigma / \sqrt{n})(23)$

Onde:

$\mathrm{x}=$ média dos níveis de pressão sonora $[\mathrm{dB}(\mathrm{A})]$ da distribuição amostral;

$\mathrm{t}=$ valor da distribuição $\mathrm{t}$;

$\mathrm{n}=$ número de amostras;

$\sigma=$ desvio padrão da distribuição amostral

O potencial de danos à audição depende também de sua duração. O nível de exposição normalizada (NEN) considera os parâmetros de pressão e duração sonora, com base na equação:

\section{NEN=NE $+10 \log (\mathrm{Te} / 480)(24)$}

Onde:

$\mathrm{NE}=$ Nível de Exposição referente à atividade realizada, representado pela média dos valores calculados $(\mathrm{dB}(\mathrm{A}))$;

$\mathrm{Te}=$ tempo de exposição ao ruído sob análise (em minutos).

Mede-se, ainda, o nível de ruído ambiental Lra em diferentes pontos externos à usina. A valoração da poluição é mensurada com base na comparação entre estes níveis NEN e Lra em relação a limites sonoros estipulados por legislação. 
No caso da poluição visual, a metodologia também considera a medição de diferentes pontos a fim de compor uma média de impacto visual. Este é obtido como uma função proporcional à multiplicação dos seguintes fatores:

(1) coeficiente de visibilidade a da usina ou sistema energético desde um ponto ou local m;

(2) coeficiente de visibilidade $b$ de local $m$ visível desde a usina;

(3) população do ponto ou local m;

(4) total de pessoas impactadas.

$\mathrm{CPA}=(\operatorname{axbxPA}) / \mathrm{PTA}$

Onde:

CPA: coeficiente de pessoas afetadas;

PTA: número total de pessoas na área analisada/impactada;

$\mathrm{a}=\Sigma \mathrm{PCH} / \mathrm{n}$ (coeficiente de visibilidade da usina desde o local);

b: coeficiente de visibilidade de local desde a usina;

PA: população afetada.

A poluição olfativa pode ser medida pelos índices de odor, detectabilidade de odor e intensidade de odor, de acordo com as fórmulas:

$10=\mathrm{D} / \mathrm{T}(26)$

Onde:

IO= Índice de odor;

$\mathrm{D}=$ pressão de evaporação;

$\mathrm{T}=$ limiar de reconhecimento total de odor.

$\mathrm{I}=\mathrm{k}(\mathrm{C})^{\mathrm{n}}(27)$

$\mathrm{I}=$ Intensidade de odor;

$\mathrm{C}=$ concentração de odor;

$\mathrm{n}=$ expoente de odor.

O algoritmo de valoração para alteração de conforto em decorrência da implantação de recursos energéticos do lado da oferta pode ser visualizado na figura 23 a seguir: 


\section{Algoritmo - CVPC Alteração de Conforto}

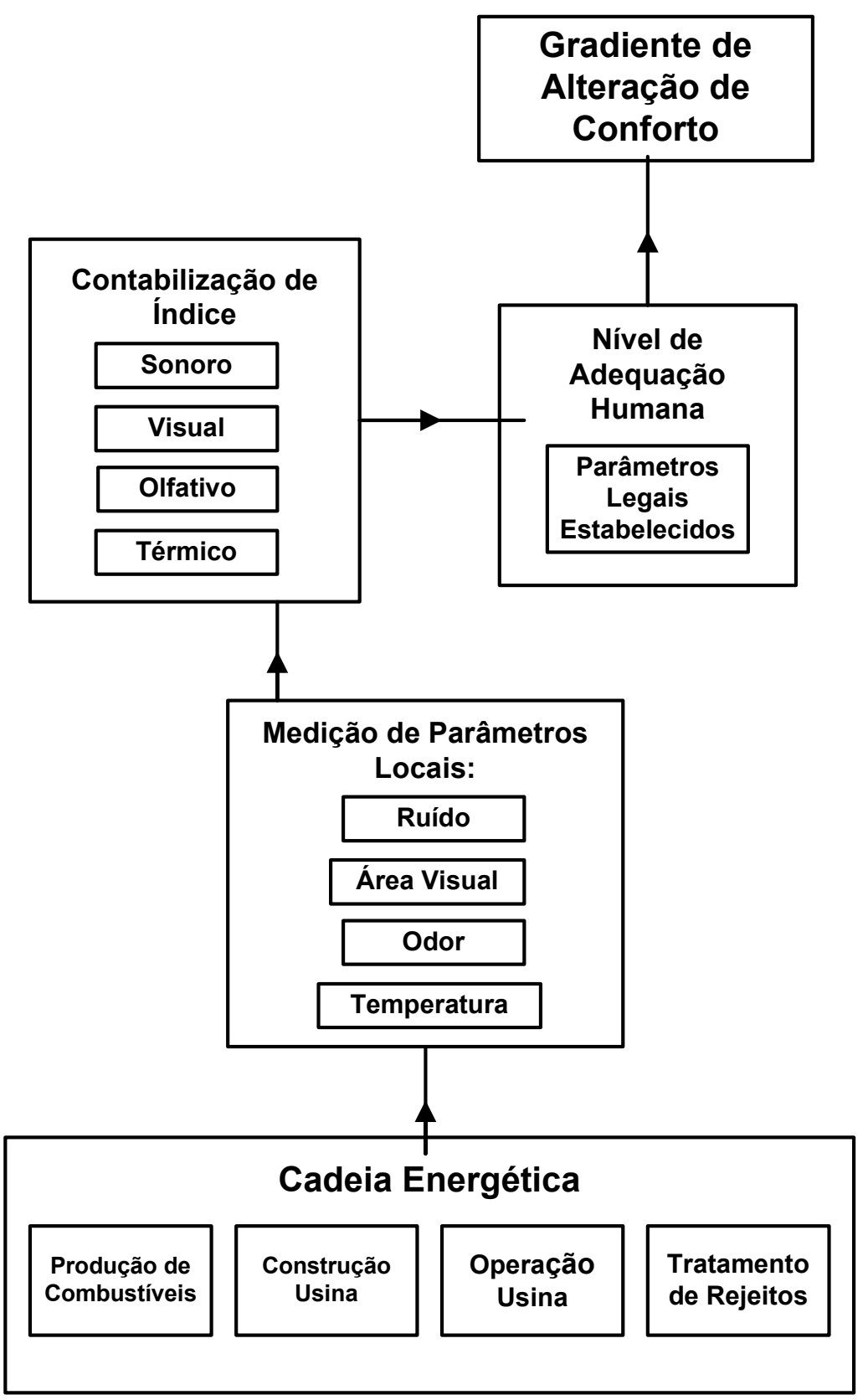

Fonte: Elaboração Própria

Figura 23: Algoritmo de cômputo e valoração de alteração de percepção de conforto 


\subsection{Cômputo e Valoração da Dimensão Técnico- Econômica}

\subsubsection{Definição da Dimensão Técnico- Econômica}

A dimensão técnico-econômica abrange a maior parte dos parâmetros mensuráveis e quantificáveis relacionados à precificação de atributos técnicos de recursos energéticos. Ao contrário da dificuldade de valoração identificada em diversos atributos das demais dimensões de análise do PIR, os fatores de análise dessa dimensão são calculados em diferentes ferramentas e utilizados correntemente em análises de viabilidade de planejamento energético.

O atributo central de análise é o custo de geração de um recurso, ao qual se associam uma série de outros custos - de investimento e implantação, de operação e manutenção e de produção de combustíveis, cada qual incorporando diferentes componentes técnicos - como vida útil e fator de capacidade - e econômicos - como taxa interna de retorno, tempo de retorno do investimento e taxa de desconto.

Essa composição almeja a minimização dos custos incorridos durante o desenvolvimento do recurso para o empreendedor, por meio das melhores condições de retorno do capital investido e custo de geração. O resultado da otimização de custos é a composição de tarifas energéticas mais baixas para 0 consumidor. Entretanto, o valor final repassado às residências inclui outras componentes como custos de transmissão e distribuição de energia e diferentes encargos relativos ao sistema elétrico, que absorvem custos adicionais de operação de diferentes fontes e sistemas energéticos. O mérito de utilização de cada uma dessas opções e da cobrança de encargos é, frequentemente, discutido pela academia, por institutos e consultorias ${ }^{103}$.

O cálculo de custo de geração de empreendimentos apresenta limitações quanto à inclusão de seus impactos ou externalidades ambientais, sociais e políticas. Ainda que alguns desses impactos sejam minimizados sob a forma de condicionantes e compensações para a concessão de licenças ambientais, sua

${ }^{103}$ Como exemplos, citam-se análises constantes da PSR Consultoria e do Instituto Acende Brasil. 
internalização no custo final dos projetos é marginal e não afeta a composição final da tarifa - um exemplo prático é o projeto de construção de Angra $3^{104}$.

Em suma, ainda que o custo final da energia auxilie o planejador na escolha de recursos energéticos economicamente viáveis, apresenta limitações à capacidade de incorporar alguns parâmetros técnicos e mesmo financeiros relevantes para a viabilidade de empreendimentos.

Para tanto, analisam-se essas características em atributos diferenciados da dimensão técnico-econômica, tais como: a dificuldade de manutenção de equipamentos, a distância entre a usina e o centro de consumo, o tempo médio de construção de um empreendimento ${ }^{105}$, a confiabilidade de suprimento energético - representada pela intermitência da geração e pela disponibilidade do combustível utilizado ${ }^{106}$-, o domínio tecnológico do recurso e a qualidade da energia gerada.

A análise também cobre a componente financeira do projeto; a viabilização econômica de um empreendimento envolve a conjunção entre condições de financiamento, aporte de garantias e seguros. A estas, somam-se pré-requisitos socioambientais, incluídos na formação de critérios de sustentabilidade em bancos e instituições financeiras. A crescente sensibilidade de empreendedores agentes financeiros a condições socioambientais que aumentam o risco de implementação de empreendimentos tem resultado em posições contrárias ao financiamento de projetos de alto impacto ambiental e social, como usinas termelétricas movidas a combustíveis fósseis e nucleares.

Ressalta-se que, na composição de atributos de valoração do PIR, optouse por transferir alguns desses parâmetros à dimensão política, compreendidos

\footnotetext{
${ }^{104}$ A licença de operação da usina foi concedida em março de 2009, com a imposição de 44 condicionantes. Alguns dos pontos principais referem-se à obrigatoriedade de um cronograma para o projeto de depósito de rejeitos nucleares, o tratamento de rejeitos líquidos produzidos durante a construção e a apresentação de um projeto de monitoramento atmosférico da área da usina. Essas exigências representam um baixo custo adicional ao projeto e não são computadas no valor final do custo de geração da usina.

${ }^{105}$ Diferentes problemas técnicos na construção da usina nuclear de Olkiluoto, na Finlândia, contribuíram para o atraso de 3 anos e 2 meses no cronograma planejado em 4,5 anos, resultando em um aumento de 2,5 bilhões de euros no custo inicialmente projetado em 3 bilhões de euros.

${ }^{106}$ Por um lado, a confiabilidade de suprimento das fontes renováveis é questionada por sua natural intermitência - negligenciando-se a complementação entre estas fontes. A confiabilidade de grandes centrais, por outro lado, é afetada pela interrupção causada por diferentes motivos técnicos ou mesmo pela redução da disponibilidade de combustível.
} 
como instrumentos político-financeiros capazes de estimular a penetração de um determinado recurso energético.

No próximo item, discutem-se os principais atributos analisados na valoração de potenciais da dimensão técnico-econômica.

\subsubsection{Procedimentos de cômputo e valoração de atributos técnico-econômicos}

A valoração da dimensão técnico-econômica, conforme colocado anteriormente, vale-se de diferentes índices técnicos relacionados a equipamentos e empreendimentos energéticos, amplamente disponíveis ou calculáveis por meio de diferentes metodologias consolidadas.

O objetivo principal desse processo é o cálculo de potenciais energéticos completos dos recursos analisados, utilizando diferentes parâmetros para a elaboração dos algoritmos desses potenciais. Dentre eles, citam-se os custos de instalação, de combustível e de operação e manutenção - que formam o custo de geração -, os custos de transporte e distribuição da energia, as faixas de potência do recurso analisado - caracterizando o perfil da geração energética -, a vida útil de equipamentos e empreendimentos, fatores de potência e de capacidade, tempo de instalação e qualidade da energia gerada.

Esses atributos cobrem três áreas principais na análise técnico-econômica de cada recurso energético - economicidade, capacidade energética, e fatores técnicos. A figura 24 mostra a estrutura da árvore da dimensão técnicoeconômica, com os respectivos atributos e subatributos considerados. $\mathrm{Na}$ sequência, as principais áreas são descritas, com o auxílio de informações da base científica de bibliografias do PIR na USP (USP, FAPESP, 2009d, USP, FAPESP, 2008c) e referências externas (EXCELÊNCIA ENERGÉTICA, 2010). 


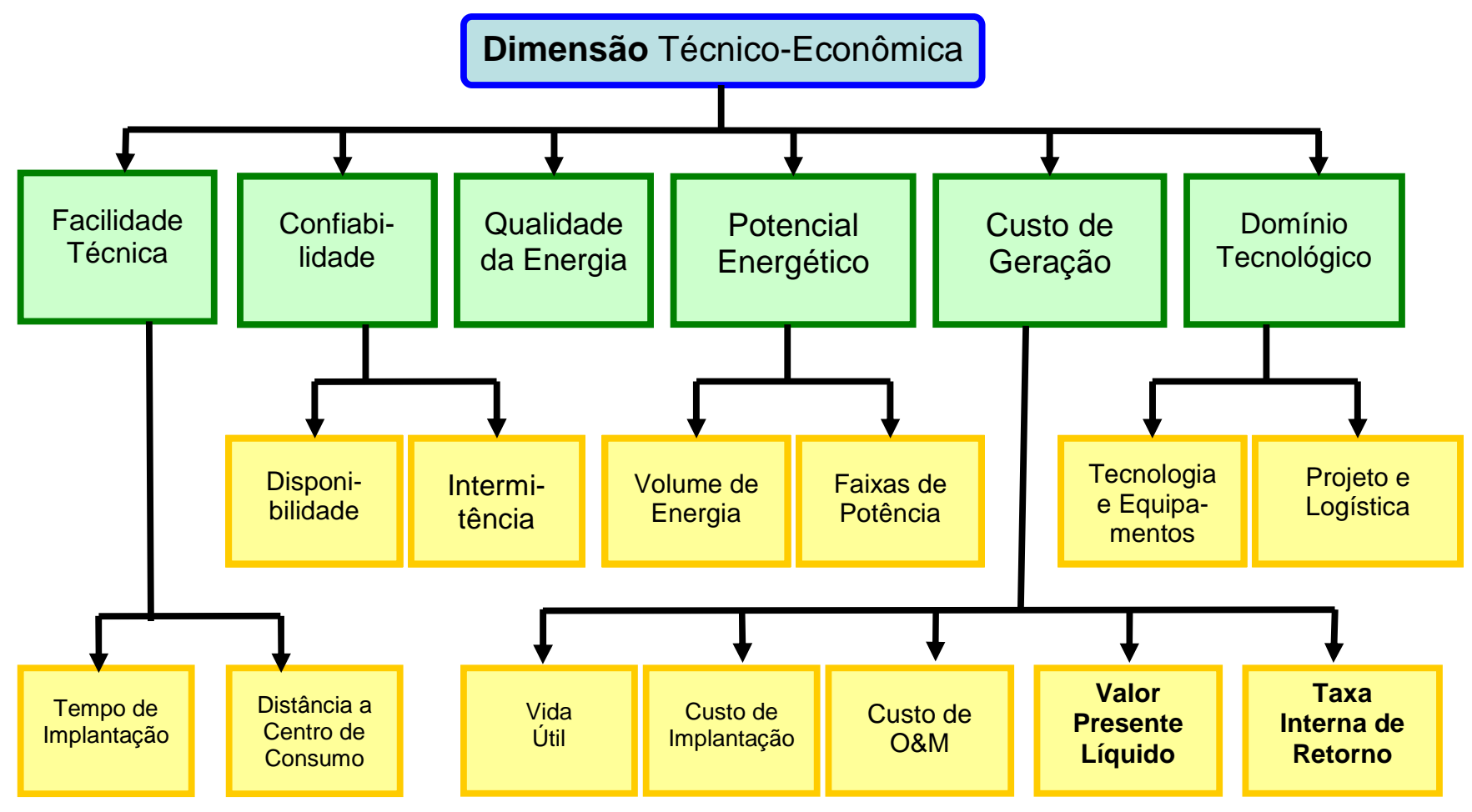

Fonte: Elaboração Própria

Figura 24: Árvore de atributos e subatributos da dimensão Técnico-Econômica

\subsubsection{Métodos de Avaliação de Viabilidade de Recursos Energéticos}

O custo de geração de um sistema energético é determinado por variáveis econômicas, distribuídas em diferentes subatributos.

Em primeiro lugar, a avaliação de viabilidade desses projetos pode ser conduzida por diferentes metodologias de indicadores de retorno, métricas de lucro, custo de capital e fluxo de caixa ${ }^{107}$ (REGO, 2009).

A avaliação de fluxo de caixa permite o uso de diferentes metodologias como payback, valor presente líquido e taxa interna de retorno. O payback indica o número de anos necessários para a recuperação do investimento em um empreendimento, medido em tempo de retorno. Ainda que seja capaz de medir a liquidez de um projeto, não contabiliza o fluxo de caixa gerado após a

\footnotetext{
${ }^{107}$ O fluxo de caixa representa a atividade econômica ou a capacidade de criação de valor de uma empresa. É composto pelos fluxos operacionais (venda da energia gerada, custos e despesas incorridas e tributos recolhidos), de atividades financeiras (evolução do endividamento do empreendimento) do projeto e dos investimentos.
} 
recuperação do investimento, mostrando-se desaconselhável para projetos de longa duração (STALLA, 2000, apud REGO, 2009).

O Valor Presente Líquido é uma técnica matemático-financeira para mensurar a lucratividade de um projeto, utilizando o cálculo das diferenças entre as entradas de caixas convertidas em valores presentes e o investimento inicial realizado. O método pode ser aplicado a diferentes situações com base na previsão de fluxos de caixa futuros do investimento. Este é traçado de acordo com informações como investimento inicial, vida útil do empreendimento, taxa esperada de juros e dos demais lucros e despesas operacionais e administrativas anualizadas. A lucratividade de cada empreendimento é proporcional ao seu VPL.

$$
V P L=\sum_{t=0}^{n} F C_{t} /(1+k)^{t}-I . I .
$$

Onde:

FC: Fluxo de Caixa (em R\$);

t: Horizonte de tempo da análise (em anos);

K: Taxa de Capital Próprio (em \%);

I.I.: investimento inicial realizado (em $\mathrm{R} \$$ ).

A Taxa Interna de Retorno (TIR) é a taxa que desconta os fluxos de caixa líquidos de um projeto e iguala sua rentabilidade ao custo de oportunidade do capital (ke), igualando o VPL desse investimento a zero, ou seja, o valor presente das entradas iguala-se ao investimento inicial do projeto (GITMAN, 1997) ${ }^{108}$.

$$
0=\sum_{t=0}^{n} F C_{t} /(1+T I R)^{t}-I . I .
$$

Onde:

FC: Fluxo de Caixa (em R\$);

TIR: Taxa Interna de Retorno (em \%);

t: Horizonte de tempo da análise (em anos);

${ }^{108}$ Segundo Gitman, o VPL é a melhor técnica para análise de orçamento de capital, por conta de suposições de taxas de reinvestimento de entradas de caixa mais conservadoras. Administradores prefirem usar a TIR por uma maior aceitação a taxas de retorno do que a valores monetários. De acordo com Stalla, a TIR ignora diferenças de escala de projetos, por ser uma unidade adimensional. 
I.I.: investimento inicial realizado (em $\mathrm{R} \$)$.

A análise de viabilidade de investimentos em novos projetos e o cálculo de seu preço de comercialização utiliza majoritariamente o método de avaliação pelo Fluxo de Caixa Descontado, com determinação do valor presente líquido (VPL). Essa ferramenta é a mais utilizada pelo mercado de capitais e recomendada pela bibliografia especializada como a que melhor revela a efetiva capacidade de geração de riqueza de determinado empreendimento, trazendo a valor presente os benefícios futuros esperados a uma taxa de desconto apropriada (EXCELÊNCIA ENERGÉTICA, 2010).

Essa taxa de retorno é diferenciada de acordo com cada recurso energético analisado e seus diferentes subsetores (geração, transmissão, distribuição e comercialização) no Modelo de Precificação de Capitais Próprios $(\mathrm{CAPM})^{109}$. A taxa de retorno ou atratividade mínima é representada pelo custo de capital do empreendimento, ou sua remuneração mínima, que precifica os riscos específicos a cada recurso energético. Com base no modelo de precificação de ativos financeiros, o custo de capital próprio do investidor é igual ao "retorno sobre títulos livres de risco" somado ao "risco sistêmico da empresa" multiplicado pelo "preço de mercado do risco", de acordo com a fórmula:

$$
\mathrm{Ke}=\mathrm{R}_{\mathrm{I}}=\mathbf{R}_{\mathrm{F}}+\boldsymbol{\beta} \cdot\left(\mathbf{R}_{\mathrm{M}}-\mathbf{R}_{\mathrm{F}}\right)
$$

Onde:

Ke: Custo de capital do investidor;

Rı: Taxa de retorno do investimento;

$\mathbf{R F}_{\mathbf{F}}$ : Taxa de retorno do ativo livre de risco;

$\mathbf{R}_{\mathbf{M}}$ : Taxa média de retorno do mercado;

$\boldsymbol{\beta}$ : Risco sistêmico do empreendedor.

Nessa metodologia, o impacto de alavancagem de um recurso energético não considera apenas o risco sistêmico da empresa como também as opções de financiamento desse empreendimento.

Alternativamente ao Fluxo de Caixa Descontado, o Fator de Recuperação de Capital (FRC) também é utilizado para a conversão do valor presente de um investimento em um custo fixo anual durante um período de tempo especificado

\footnotetext{
${ }^{109}$ A premissa da aversão ao risco e sua valoração em prêmios deriva da aplicação do Modelo de Precificação de Ativos Financeiros (CAPM ou Capital Asset Pricing Model, da sigla em inglês), considerado o mais tradicional no campo das finanças.
} 
(normalmente a vida útil do projeto), a uma taxa de juros anual especificada. $O$ FRC determina a viabilidade econômica de um empreendimento ao auxiliar a avaliação de receitas necessárias para enfrentar os custos de capital upfront de projetos, com base em pressupostos de financiamento típicos para a indústria de energia elétrica. É dado pela expressão:

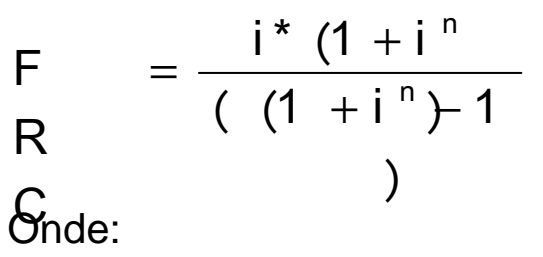

FRC: Fator de Recuperação de Capital (adimensional);

I: Taxa anual de juros (em \% ou adimensional);

n: vida útil do aproveitamento (em anos).

Ainda que seja utilizado como metodologia para a determinação do custo de geração de empreendimentos, o FRC peca em considerar variações anuais do fluxo de caixa de um projeto decorrentes da amortização de dívidas de financiamento ${ }^{110}$.

\subsubsection{Atributos Econômicos}

O Custo de Instalação de um empreendimento, medido em função do kW instalado, inclui a contabilização das despesas de todo o ciclo de construção de um empreendimento - de estudos de viabilidade e engenharia, preparo do sítio e construção da usina - incluindo os juros de financiamento da obra. É disponível em inúmeras fontes de empresas e institutos de pesquisa, mas apresenta variações de acordo com as condições técnicas e financeiras de cada projeto. É calculado pela fórmula 23 , a seguir:

\section{$\mathrm{Cl}=$ Investimento Total /Potência Instalada (32)}

Onde:

$\mathrm{Cl}$ : Custo de Instalação por unidade monetária em função de kW instalado (US\$/kW ou R\$/kW); Investimento Total: Volume do Capital Investido, em unidade monetária (US\$ ou R\$);

\footnotetext{
${ }^{110}$ No caso de sistemas de amortização constante, utilizados pelo BNDES, os juros decrescentes não podem ser contemplados pela metodologia de FRC, produzindo resultados distorcidos para 0 custo de geração.
} 
Os Custos Operacionais abrangem custos de operação e manutenção, custos administrativos, custos de combustível, seguros ${ }^{111}$, custos de arrendamento, custos ambientais, uso de sistemas de transmissão e constituição de fundo de descomissionamento e tratamento de rejeitos, quando aplicável. Dessas parcelas, os custos ambientais, de uso de sistemas de transmissão e de constituição de fundo de descomissionamento são incorporados à tarifa de eletricidade por meio de diferentes encargos ${ }^{112}$.

Os custos de operação e manutenção abrangem ações de caráter preventivo e corretivo ao longo da operação da usina ou sistema energético. Possuem uma componente fixa dependente da potência instalada, calculada em $\mathrm{R} \$ / \mathrm{kW}$.ano e uma componente variável dependente da energia gerada, em $\mathrm{R} \$ / \mathrm{MWh}$. A componente fixa incorpora custos de peças e serviços de terceiros; a variável inclui custos de administração e custos de mão de obra (engenharia e pessoal técnico). É calculada pela seguinte fórmula:

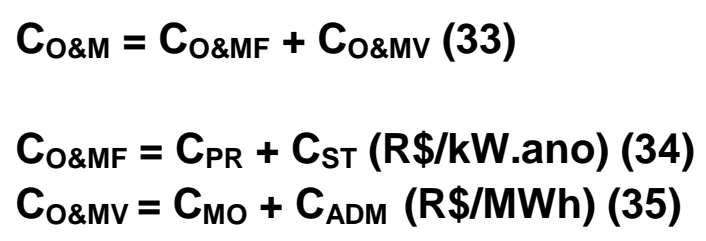

Onde:

$\mathbf{C}_{\mathrm{ST}}$ : Custo de serviços de terceiros $(\mathrm{R} \$ / \mathrm{kW})$;

$\mathrm{C}_{\mathrm{PR}}$ : Custo de peças de reposição $(\mathrm{R} \$ / \mathrm{kW})$;

$\mathbf{C}_{\text {MO: }}$ Custo de mão de obra $(\mathrm{R} \$ / M W h)$;

$\mathbf{C}_{\mathrm{ADM}}$ : Custos Administrativos (R $\left.\$ / \mathrm{MWh}\right)$.

O Custo de Combustível é aplicável a usinas termelétricas que utilizem em sua operação energéticos fósseis - como óleo combustível, diesel, carvão e gás natural -, renováveis - como diferentes modalidades de biomassa sólida e

111 O seguro operacional, por vezes incluído no custo operacional de empreendimentos, varia de 0,25 e $0,3 \%$ sobre o valor anual do investimento (EPE, 2008) até $0,5 \%$ da receita bruta operacional (EXCELÊNCIA ENERGÉTICA, 2010).

${ }^{112}$ Dentre os encargos incluídos na tarifa de energia elétrica, citam-se: o TFSEE (Tarifa de Fiscalização de Serviços de Energia Elétrica), a Contribuição associativa da Câmara de Comercialização de Energia Elétrica, a Taxa de Administração do ONS, Investimentos em Pesquisa e Desenvolvimento, COFURH (Compensação Financeira pela Utilização de Recursos Hídricos), Custos de Distribuição e Transmissão, Instrução Normativa IBAMA n07/2009 e o REIDI (Regime Especial de Desenvolvimento de Infraestrutura) (EXCELÊNCIA ENERGÉTICA, 2010). 
biogás -, ou combustível nuclear. Esse custo é calculado em $R \$ / M W h$ e inclui as diferentes etapas dessa cadeia, entre produção, processamento e transporte. Pode variar de $R \$ 20 / \mathrm{MWh}$, no caso de uma termelétrica com cogeração com base na biomassa de cana-de-açúcar (EPE, 2008) até valores superiores a $\mathrm{R} \$ 400 / \mathrm{MWh}$, custo previsto para a aquisição de óleo combustível em termelétricas (SOARES et al, 2009b).

O Custo Unitário de Geração é a componente do custo de energia por unidade gerada, incluindo o custo de implantação de um recurso - vinculados a diferentes condições de financiamento -, os custos de operação e manutenção e os custos de combustível.

\section{$\mathrm{CUG}=(\mathrm{PI} \times \mathrm{Cl} \times \mathrm{FRC}+\mathrm{PI} \times \mathrm{Co} \& \mathrm{~m}+\mathrm{PI} \times \mathrm{Ccomb} \times \mathrm{FC} \times 8,76) / \mathrm{EFA}(36)$}

Onde:

$\mathrm{PI}$ : potência instalada $(\mathrm{kW})$;

$\mathrm{Cl}$ : custo de instalação (US\$/kW);

$\mathrm{FRC}^{113}$ : fator de recuperação do capital, para uma vida útil $\mathrm{N}$ e taxa de atualização do capital i.

$\mathrm{C}_{\mathrm{O \& M}}$ :custo unitário de operação e manutenção (US $\left.\$ / M W h\right)$;

$\mathrm{C}_{\mathrm{COMB}}$ : custo do combustível

FC: fator de capacidade médio na vida útil do gerador;

EFA: energia firme anual do gerador (MWh).

Como EFA $=\mathrm{PI} / 8,76 * \mathrm{FC}(37)$

$\mathrm{CUG}=(\mathrm{Cl} \times \mathrm{FRC}+\mathrm{Co \& m}) / \mathrm{FC} \times 8,76+\mathrm{Ccomb}$

A Vida Útil de um projeto é o período de funcionamento conjunto de empreendimento e equipamentos empregados, em condições padrão de rendimento de conversão e geração de energia. A estimativa da vida útil de um empreendimento fundamenta-se pela probabilidade de degradação dos componentes e materiais utilizados na construção do sistema energético ao longo do tempo. Vale-se, para tanto, de ensaios e médias históricas particulares a cada recurso, incorporando evoluções tecnológicas e condições técnicas e ambientais locais.

A vida útil de sistemas energéticos varia de 20 a 25 anos para sistemas fotovoltaicos até 40 anos para termelétricas nucleares (ainda que esse tempo

\footnotetext{
${ }^{113}$ De acordo com as condições de financiamento, utilizam-se formulações alternativas ao FRC para o tratamento de juros variáveis.
} 
possa ser prorrogado em mais 20 anos). Usinas hidrelétricas contam com os tempos mais longos de vida útil; registram-se, no Brasil, usinas em operação há mais de 60 anos.

Uma vez que a duração da vida útil de cada empreendimento influencia sua rentabilidade, são comuns casos de perpetuidade e extensões de tempo de operação de usinas, a fim de maximizar esses benefícios. Observam-se práticas como o retrofitting e a repotenciação de usinas, com a substituição de turbinas, caldeiras e outros equipamentos, a fim de aumentar a potência e o tempo de funcionamento desses empreendimentos.

\subsubsection{Atributos Técnicos}

O Domínio Tecnológico representa o índice de nacionalização de um empreendimento energético, em função dos equipamentos e serviços envolvidos no projeto. Estes podem ser nacionais, mistos ou inteiramente importados. Essa informação é particular a cada empreendimento, sendo composta pela origem de cada insumo da cadeia energética analisada. A evolução desse parâmetro depende do estágio de desenvolvimento tecnológico de cada fonte e de eventuais restrições de matéria prima para fabricação de componentes tecnológicos. O domínio tecnológico é discutido no item 5.7.4 e completa a análise do atributo de propriedade de um recurso energético, juntamente com a análise da posse de fontes energéticas, tratada na dimensão política.

O Tempo de Implantação de um empreendimento, um item fundamental para a formação do custo final, é variável de acordo com as condições de financiamento, a tecnologia empregada, a qualidade do projeto e a capacitação dos serviços contratados. Depende, principalmente, do porte e da localização do empreendimento energético. A informação também é particular a cada empreendimento; séries históricas baseadas em períodos médios são disponíveis em diferentes estudos e publicações. O tempo final de implantação é resultado da concatenação de tempos previstos para etapas de construção específicas a cada empreendimento.

O Fator de Capacidade permite aferir a energia efetivamente gerada por determinada tecnologia, relacionando a produção média da usina geradora e sua produção de pico, ou seja, calculando a razão entre a produção total e sua 
produção potencial, se operada constantemente a plena capacidade. $O$ resultado é um valor inferior a 1, expresso também em porcentagem.

$$
F C=\frac{E F A}{8.760{ }^{*} \mathrm{PI}_{\mathrm{i}}}
$$

\section{Onde:}

FC: fator de capacidade (adimensional ou em \%);

EFA: Energia Firme Anual (em MWh/ano);

$\mathbf{P}_{\mathbf{i}}$ : Potência Instalada, MW.

A confiabilidade varia de acordo com a faixa de potência do empreendimento, resultante de fatores como a intermitência de alguns recursos e a indisponibilidade de combustíveis ou equipamentos, comuns a usinas de grande porte. Os fabricantes das referidas tecnologias constituem fonte de informação para valores médios de disponibilidade e geração média de recursos. O atributo é discutido em mais detalhes no item 5.7.6.

A distância do recurso energético ao centro de consumo determina 0 custo de transmissão e distribuição necessário para o transporte de energia ao consumidor final e o índice médio de perdas na rede durante esse trajeto. A distância é proporcional ao desafio técnico de garantir a estrutura de transporte e também de operação e manutenção de sistemas, no caso de unidades geradoras remotas ou de geração descentralizada em comunidades isoladas. É, portanto, elemento essencial para a tomada de decisão de implantação de um recurso, especialmente em função de seu potencial energético. O atributo é discutido em mais detalhes no item 5.7.7.

A qualidade da energia: atributo que mede a variação de parâmetros técnicos de provisão de energia e o atendimento mínimo dessas condições a fim de garantir o funcionamento correto e contínuo de equipamentos de uso final. Estes, por sua vez, podem provocar na rede elétrica a geração de harmônicos e transitórios ou afetar parâmetros como fator de carga e fator de potência. A aferição da qualidade de energia é realizada pela identificação de níveis padronizados de tensão, fator de potência, entre outros. $O$ atributo é discutido em mais detalhes no item 5.7.9. 


\subsubsection{Atributos de Capacidade Energética:}

A Potência de um recurso caracteriza a máxima capacidade de operação fornecida por uma unidade de geração dentro de cada tecnologia em estudo. A faixa de potência trabalhada facilita a análise de recursos em faixas e perfis de geração, de sistemas isolados à geração distribuída e de grande porte.

O Volume de Energia gerada varia de acordo com a potência e o fator de capacidade de cada recurso. A valoração é novamente dividida por faixas de potência, dentro das quais identifica-se variação decorrente do fator de capacidade de cada tecnologia. O cálculo do volume de energia é dado por:

\section{VE $=$ PC $\times$ Pn $\times 8760(40)$}

Pn = Pmáx x N (41)

Onde:

$\mathrm{VE}=$ Volume de Energia (em MWh);

$\mathrm{FC}=$ Fator de Capacidade (em \% ou adimensional);

$\mathrm{Pn}=$ Potência Nominal (em MW);

Pmax = Potência máxima fornecida por cada um dos componentes de geração (em MW);

$\mathrm{N}=$ número de unidades geradores de uma usina.

Potencial energético: o cálculo dos parâmetros de volume de energia, fatores de capacidade e disponibilidade - por meio de medições ou obtenção de parâmetros por referências bibliográficas - permite a formulação dos potenciais energéticos dos recursos dos lados da oferta e demanda. O potencial teórico abrange o aproveitamento de recursos sem restrições geográficas ou técnicas, 0 potencial realizável refina esse valor incluindo limitações de utilização e conversão de energia impostas por atributos das dimensões de análise e 0 potencial de mercado considera condições temporais econômicas, financeiras e políticas temporais. A formulação e o cálculo desses potenciais energéticos são detalhados no item 5.7.8. 


\subsubsection{Custo de geração de energia}

A valoração do custo unitário de geração incorpora diferentes parâmetros técnicos e econômicos em sua composição. O primeiro grupo de fatores tem seu desempenho determinado pela evolução tecnológica e grau de desenvolvimento de sistemas energéticos. Os parâmetros econômicos dividem-se em componentes de custos fixo e variável. Os custos fixos, ou o capital investido, incluem as despesas oriundas durante o ciclo completo de implantação de um empreendimento; os custos variáveis consideram despesas de operação e manutenção e combustível utilizado na usina (SAUER et al, 2009).

O custo final, conforme colocado anteriormente, busca equacionar todas essas despesas de forma a garantir tanto o retorno de investimento do empreendedor quanto o pagamento de uma tarifa justa pelo consumidor. Ainda que o estabelecimento desses índices seja capaz de garantir a racionalidade econômica da tarifa paga ao consumidor final, a composição desse valor muitas vezes deixa de incorporar custos e impactos do recurso energético ao meio ambiente - no caso da extração de combustíveis, por exemplo - e a habitantes do entorno do empreendimento - no caso do subdimensionamento de seguros contra acidentes para usinas com vidas úteis extensas.

A composição de custos varia de acordo com o tipo de recurso energético e o porte do projeto. Os custos de capital são os mais representativos na maior parte dos projetos. Os demais custos variam de acordo com o recurso analisado. A geração de energia por combustíveis fósseis despende grandes gastos de combustível, especialmente em termelétricas a óleo combustível e diesel. No caso da geração nuclear, verifica-se, proporcionalmente, maior mobilização de custos na etapa final de funcionamento de uma usina, por conta do tratamento de resíduos radioativos e do descomissionamento do empreendimento após a conclusão de sua vida útil ${ }^{114}$.

A maximização dos lucros obtidos com um empreendimento energético é proporcional ao período de seu funcionamento. A extensão desses ciclos, embora

\footnotetext{
114 Os custos de descomissionamento de usinas devem ser traduzidos em valor presente líquido e incluídos nos custos de geração. No Reino Unido, foi atribuído um orçamento de £2,47 bilhões ( $R \$ 7,07$ bilhões) no ano fiscal $2007 / 2008$ para o órgão público responsável pelo trabalho. No Brasil, a composição de um fundo para o descomissionamento das usinas existentes é planejada, mas não se concretizou na prática.
} 
garanta uma maior margem de ganhos econômicos aos empreendedores, maximiza o risco de acidentes nessas usinas e compromete a garantia de segurança de populações habitantes nesses entornos.

Em suma, a valoração do custo de geração de um recurso energético incorpora os seguintes custos e fatores:

- Custo de geração

- Custo de implantação;

○ Vida útil;

- Impostos, encargos e seguros;

- Fator de capacidade;

- Custo de combustível

- Preço do combustível (cadeia de extração e produção);

- Preço do transporte;

- Custo de operação e manutenção

- Custos fixos;

- Custos variáveis.

Como exemplo, segue a precificação do custo de geração de energia para a usina de Angra 3 (SAUER et al, 2009).

Tabela 8. Custos de Geração de Energia de Angra 3

\begin{tabular}{|c|c|}
\hline Capacidade Instalada & $1.345 \mathrm{MW}$ \\
\hline Custos excluindo juros durante construção (JDC) - $\mathrm{C}_{1}$ (US\$) & 4.660 .000 .000 \\
\hline Despesas de investidores $\left(8 \%\right.$ de $\left.\mathrm{C}_{1}\right)$ & 327.800 .000 \\
\hline Custo direto- $\mathrm{C}_{2}$ & 4.987 .800 .000 \\
\hline JDC (6 anos, $7.5 \%$ a. a. de $70 \%$ de $\mathrm{C}_{2}+8 \%$ a.a de $30 \%$ de $\left.\mathrm{C}_{2}\right)$ & 2.775 .081 .000 \\
\hline Capital de Investimento $-\mathrm{C}_{3}$ & 7.762 .881 .000 \\
\hline \multicolumn{2}{|c|}{ Custos Anuais (US\$) Depreciação em 40 anos, com TIR=10\% a.a. $\rightarrow$ FRC $=0.1022$} \\
\hline Anuidade de retorno de caixa & 793.367 .000 \\
\hline Seguro (1\% de $\mathrm{C}_{3}$, ao ano) & 79.337 .000 \\
\hline Manutenção ( $3 \%$ de $\mathrm{C}_{1}$, ao ano) & 139.800 .000 \\
\hline Despesas administrativas e salários & 25.294 .000 \\
\hline Custos anuais totais & 1.037 .801 .000 \\
\hline \multicolumn{2}{|l|}{ Custos de Geração de Energia (em US\$/MWh) } \\
\hline Efeitos de custos anuais (fator de capacidade $=87 \%$ ) & $101,2 / \mathrm{MWh}$ \\
\hline Combustível & $10,4 / \mathrm{MWh}$ \\
\hline $\begin{array}{l}\text { Custos esperados de descomissionamento e deposição final de rejeitos } \\
\text { de alta radioatividade }\end{array}$ & $1,76 / \mathrm{MWh}$ \\
\hline Soma $\Rightarrow$ Custo de geração de Angra 31 & U\$ 113,36/ MWh \\
\hline
\end{tabular}

Fonte: SAUER et al, 2009. 


\subsubsection{Algoritmo de Cômputo e Valoração}

O cálculo do Custo Unitário de Geração considera três componentes fundamentais: custo de investimento, custo de operação e manutenção e custo de combustível.

\section{$\mathrm{CUG}=(\mathrm{Cl} \times \mathrm{FRC}+\mathrm{Co \& m}) / \mathrm{FC} \times 8,76+\mathrm{Ccomb}$}

A primeira parcela, o custo de investimento, é função do custo de implantação do empreendimento $(\mathrm{Cl})$, corrigido de acordo com o fator de capacidade $(F C)$, que determina a real disponibilidade de potência do empreendimento e o fator de recuperação de capital (FRC) - ou outras condições diferenciadas de financiamento - empregado no recurso. O fator referente à contabilização de juros depende das condições de financiamento e do horizonte de fluxo de caixa acordadas com o agente financeiro responsável pela construção do empreendimento.

A segunda componente do custo de geração é o custo de operação e manutenção, função da mão de obra empregada por capacidade instalada, do custo de peças de reposição utilizadas e de custos gerais administrativos, de acordo com as equações:

$$
\begin{aligned}
& C_{O \& M}=C_{O \& M F}+C_{O \& M V}(33) \\
& C_{O \& M F}=C_{P R}+C_{S T}(R \$ / k W . a n o)(34) \\
& C_{O \& M V}=C_{M O}+C_{A D M}(R \$ / M W h)(35)
\end{aligned}
$$

A terceira componente do custo de geração é o custo do combustível, empregada em empreendimentos termelétricos fósseis e nucleares. O custo expresso em unidade monetária por peso ou volume de combustível e convertido em unidade monetária por quantidade de energia gerada ou $R \$$ por $M W h$. $O$ algoritmo de valoração desse atributo segue na figura 25. 


\section{Algoritmo - CVPC Custo de Geração de Energia}

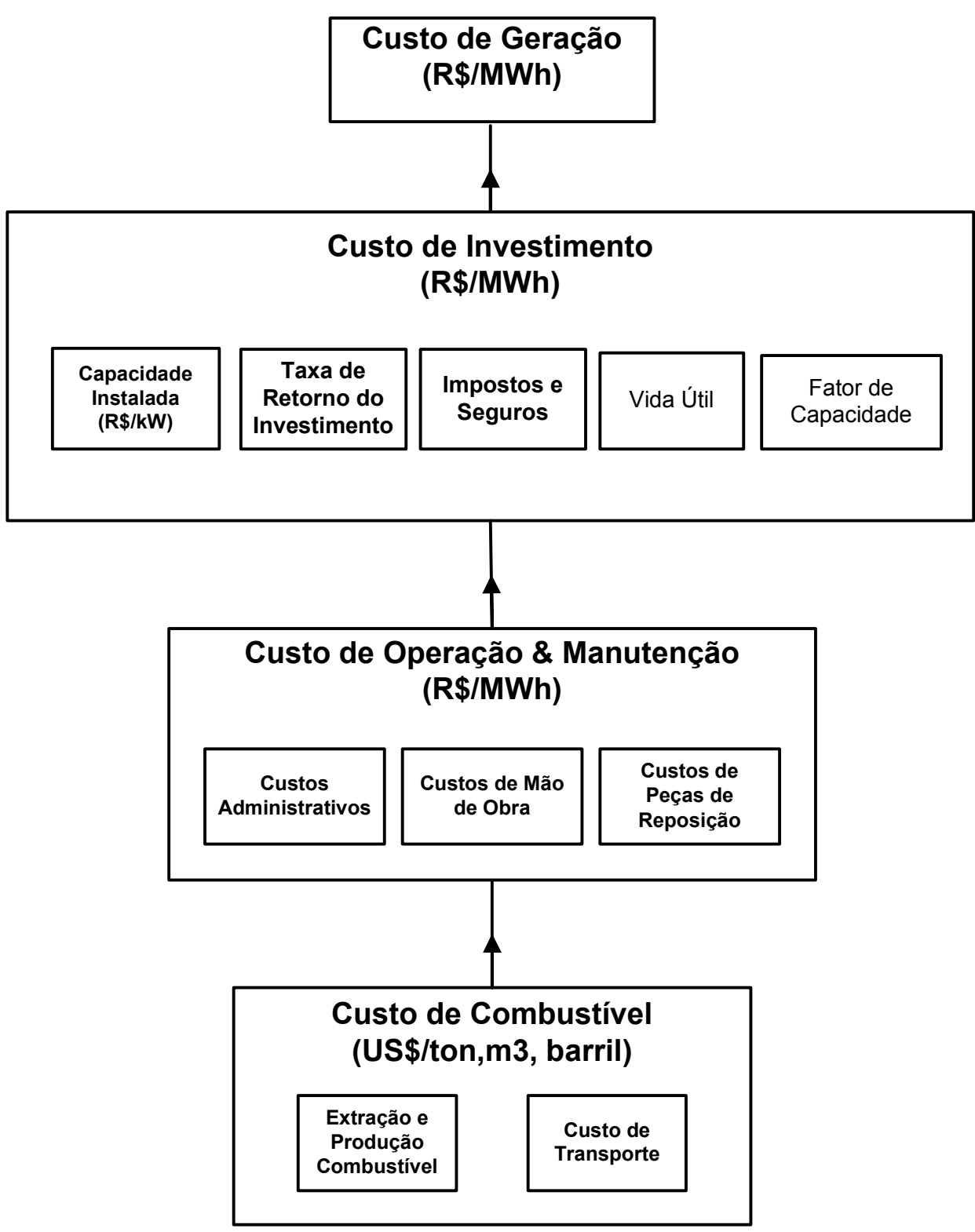

Fonte: Elaboração Própria

Figura 25: Algoritmo de cômputo e valoração do atributo custo de geração de energia 


\subsubsection{Domínio Tecnológico}

O domínio tecnológico de um recurso energético em uma dada região envolve o conhecimento sobre os processos produtivos da tecnologia de conversão energética e da infraestrutura relacionada ao empreendimento desse recurso. Esse conhecimento é medido pela proporção de equipamentos e serviços de procedência nacional ou regional envolvidos no empreendimento, considerando tanto o uso de peças e equipamentos, quanto a especialização necessária para a condução desses projetos. O grau desse domínio tecnológico pode ser representado pelo índice de nacionalização de equipamentos e serviços relacionados a um empreendimento energético.

Em diferentes casos de programas de incentivo a fontes energéticas, como - Proinfa e o projeto de lei PL 630/03, estipula-se um índice mínimo de nacionalização de equipamentos e serviços aos participantes de chamadas públicas. A intenção do índice é de aumentar o grau de domínio tecnológico de recursos energéticos usados no Brasil, protegendo a indústria de componentes e serviços e reduzindo o volume de importação dos mesmos.

A medida, estabelecida em projetos industriais desde 1970, vem sendo questionada desde então (MARTINS, 1976). No caso do Proinfa, o índice de nacionalização foi criticado por dificultar o estabelecimento de parques eólicos, ainda dependentes de aerogeradores e outros equipamentos importados da Europa, Estados Unidos e Ásia. Ainda que a indústria eólica de componentes tenha crescido nacionalmente nos últimos anos, a fabricação nacional pode chegar atualmente até $60 \%$. Entretanto, a compra dos equipamentos e materiais com esse índice encarece o projeto e compromete sua economicidade, segundo a Abeeólica (Associação Brasileira de Energia Eólica).

Por esse motivo, optou-se por não fixar um índice mínimo de nacionalização para os projetos cadastrados nos leilões de energia eólica. A intenção de não impor essa obrigação visa atrair empresas fabricantes internacionais ao país e possibilitar que a posterior nacionalização de sua produção barateie o custo desses componentes.

Medida similar foi tomada na China, que eliminou o limite no uso de peças importadas para a montagem de turbinas para aerogeradores, como mecanismo de incentivo à geração renovável no país. A decisão foi tomada pela Comissão 
Nacional de Reforma e Desenvolvimento, que revogou a exigência de $70 \%$ de índice de nacionalização sobre as peças das turbinas, a fim de abrir um mercado de concorrência racional no país. A China já é o segundo país com maior capacidade instalada de energia eólica no mundo (25.805 MW), posicionando-se entre Estados Unidos (35.064 MW) e Alemanha (25.777 MW) (GWEC, 2010).

A classificação de domínio tecnológico de um empreendimento varia, portanto, do regional ou local, ao nacional, passando por projetos híbridos entre recursos locais e estrangeiros. A evolução desse parâmetro não depende da disponibilidade de uma fonte energética e sim do estágio de desenvolvimento tecnológico e aprendizado em pesquisas referentes a tecnologias utilizadas para cada fonte energética. A título de ilustração, o enorme potencial solar brasileiro não se reflete em seu aproveitamento energético, uma vez que ainda há barreiras econômicas e tecnológicas para a fabricação nacional de painéis fotovoltaicos. $O$ enorme potencial de silício utilizado nesse processo depende de seu refino, realizado em poucos países do mundo e que também demanda alta tecnologia industrial.

Ainda que o status de pesquisa em desenvolvimento em um determinado recurso energético seja um indicador de potencial domínio tecnológico desse recurso, a aferição desse domínio poderá ser mensurada apenas com a concretização dessa pesquisa em produção real de equipamentos $e$ disponibilização de serviços e a análise do comportamento de curvas de aprendizado de recursos energéticos.

A análise do atributo de propriedade de um recurso energético é, portanto, resultado da análise da posse de uma fonte energética, tratada na dimensão política e completada com a análise do atributo de grau de domínio tecnológico.

\subsubsection{Algoritmo de Cômputo e Valoração}

A Portaria n. 86, do Ministério de Minas e Energia estabelece critérios e instruções para o cálculo de índice de nacionalização de equipamentos e serviços de empreendimentos do Proinfa. Esses procedimentos são incorporados na construção do algoritmo de valoração do grau de domínio tecnológico de recursos energéticos.

O Índice de Nacionalização, em valor, $\left(I_{V}\right)$ é calculado pela seguinte fórmula: 
$I v=(1-x / y) .100(\%)(42)$

Onde:

$X$ = valor dos componentes importados, composto pelo somatório das seguintes parcelas:

a) valor $\mathrm{FOB}^{115}$ dos componentes importados diretamente pelo fabricante e pela compradora e incorporados ao equipamento, acrescido do frete (exceto em caso de transporte nacional), do seguro de transporte (exceto em caso de seguradora nacional) e do Imposto de Importação, convertido em reais pela taxa de câmbio;

b) valor dos componentes importados por terceiros e adquiridos no mercado interno, excluindo-se IPI e ICMS:

c) valor dos serviços contratados no exterior, em moeda estrangeira, excluídos os impostos; e

d) Taxas e outras despesas pagas em moeda estrangeira, excluídos os impostos.

\section{$\mathbf{Y}=$ Valor composto pelo somatório das seguintes parcelas:}

a) valor dos componentes importados $(X)$;

b) valor dos componentes nacionais, adquiridos no mercado interno, excluindo-se IPI e ICMS;

c) valor dos serviços contratados no Brasil, em moeda nacional, excluídos os impostos; e

d) taxas, aluguéis e demais despesas em moeda nacional, excluídos os impostos.

A equação pode ser reescrita em função dos componentes nacionais e importados. Decompondo a parcela $Y$ em componentes importados (X) e nacionais $(Z)$, tem-se:

IV $=(1-x / y) \cdot 100=(1-x /(x+z)) \cdot 100=(z /(x+z)) \cdot 100(43)$

Onde:

$X=$ valor dos componentes importados,

$\mathrm{X}+\mathrm{Z}=$ valor total dos componentes importados e nacionais.

Para a composição desse valor, são considerados todos os custos diretos, indiretos e juros relacionados a equipamentos e serviços de empreendimentos energéticos. Como exemplo, os projetos do Proinfa listam, em custos diretos, componentes relacionadas a terrenos, relocações e ações ambientais, obras civis

${ }^{115}$ Preço sem frete incluso, ou free on board, do inglês. 
de estruturas e benfeitorias ${ }^{116}$, equipamentos principais (turbinas e geradores), elétricos e eletromecânicos e linhas de transmissão e conexão. Os custos indiretos relacionam-se a construções e manutenção de canteiro e acampamento, engenharia e administração do proprietário, serviços básicos e especiais de engenharia e estudos e projetos ambientais. $O$ custo total inclui os custos diretos, indiretos e os juros durante a construção do empreendimento.

O algoritmo de cômputo e valoração do atributo segue na figura 26 .

${ }^{116}$ Incluindo casas de força, de comando, subestação, torres eólicas, reservatório e barragens, de acordo com a energia contemplada. 


\section{Algoritmo CVPC Domínio Tecnológico}

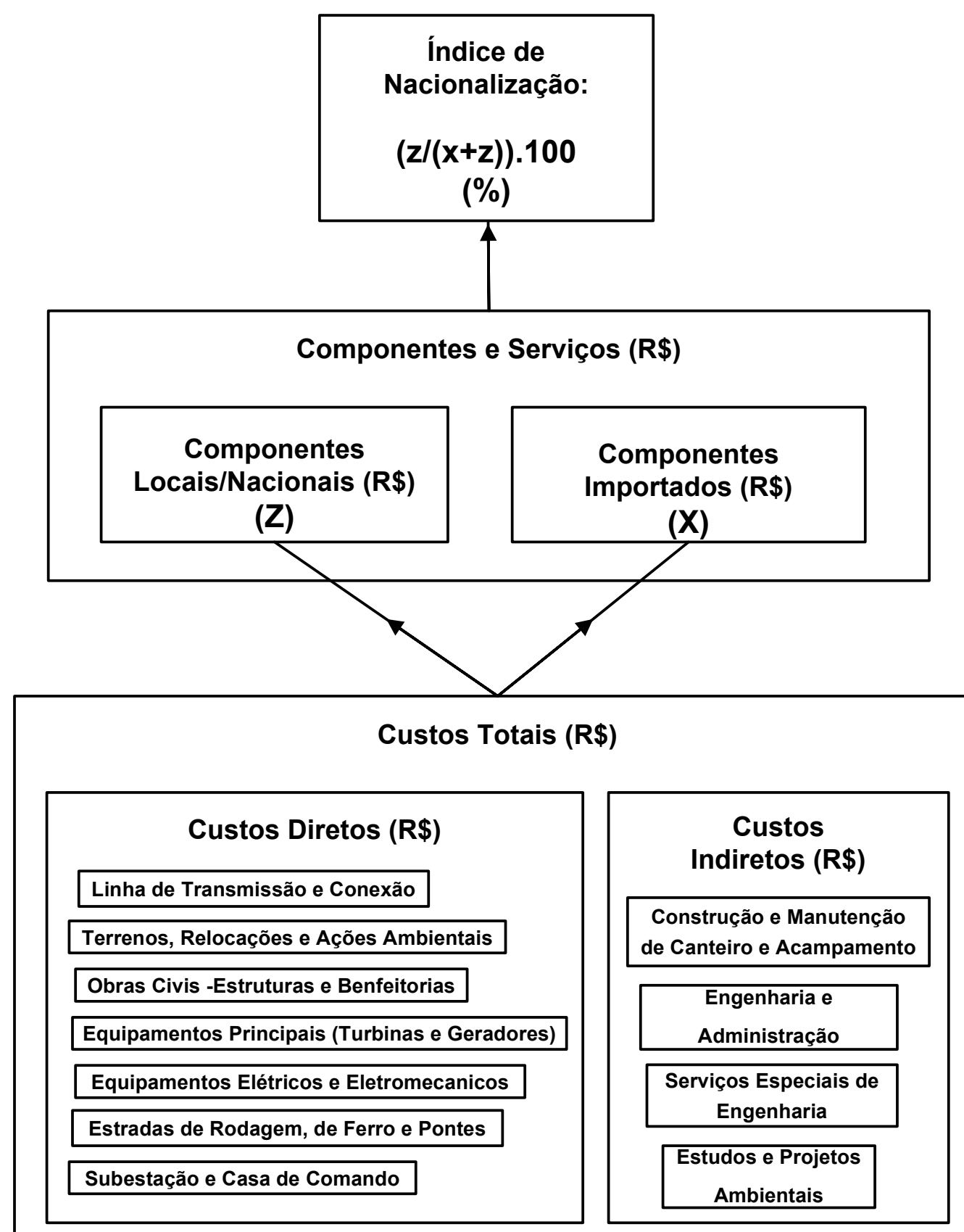

Fonte: Elaboração Própria

Figura 26: Algoritmo de CVCP do atributo Domínio Tecnológico de Recursos 


\subsubsection{Tempo de Implantação}

O tempo de implantação considera todo o período de construção de um empreendimento, desde a fase de projetos até o início de funcionamento, como resultado de uma somatória de horizontes de planejamento consecutivos e/ou paralelos entre si.

$\mathrm{O}$ andamento desses períodos influencia diretamente o tempo total de conclusão e o início de operação de um determinado projeto; o custo final do empreendimento é diretamente proporcional ao seu período de construção. $O$ capital mobilizado para a construção dessas usinas está sujeito a taxas de juros acordadas com as condições de financiamento.

O planejamento de construção é influenciável por um grande número de variáveis. Dentre estas, citam-se as tecnologias empregadas, a qualidade dos projetos, a capacitação dos serviços contratados e, principalmente, a localização e o porte do empreendimento.

Nesse sentido, sistemas de menor porte e menores tempos de construção levam vantagem em relação a grandes projetos por conta da redução do risco de variação de custo ao longo do tempo de construção. Podem, ainda, em algumas situações, beneficiar-se da utilização das tecnologias mais eficientes no momento da construção, ao passo que grandes empreendimentos, em alguns casos, estão sujeitos à obsolescência das tecnologias escolhidas ao final de grandes horizontes de construção, como é o caso da usina de Angra 3.

O horizonte de tempo de construção é proporcional à capacidade instalada da usina. O tempo de construção é também proporcional aos riscos de alterações não previstas no projeto - tais como taxas de retorno, custos de mão de obra, regulação ambiental, entre outros. A duração do tempo total de construção e a imprecisão dos prazos finais representam um alto risco ao sistema elétrico. Extensos períodos de construção são observados em diferentes casos brasileiros de grandes centrais elétricas como Itaipu - no caso das hidrelétricas - e Angra $2^{117}$ - no caso das nucleares. Ambas as obras levaram mais de uma década para serem concluídas.

\footnotetext{
${ }^{117}$ Angra 2 levou 17 anos para entrar em operação e custou o equivalente a US $\$ 12$ bilhões (em valores de 2001), cerca de cinco vezes mais que o orçamento previsto.
} 
O atraso na construção de empreendimentos resulta em uma grande variação entre os custos projetados e os custos finais de usinas, principalmente em experiências de construção de usinas nucleares ${ }^{118}$ (JACOBSON, 2008).

Segundo a Agência Internacional de Energia Atômica, o prazo médio de construção de reatores nucleares passou de 64 meses em 1976 para 146 meses em 2008 (IAEA, 2009).

A distância dessas obras até as principais linhas de transmissão ou aos principais centros de consumo - subatributo integrante do atributo facilidade técnica dentro da dimensão técnico-econômica de análise, ao lado do tempo de construção - demandam grandes custos e logística de transporte de equipamentos, como se verifica nos projetos das hidrelétricas de Belo Monte e do Rio Madeira, na região Norte.

Períodos mais curtos de construção são verificados em empreendimentos de ordem de grandeza de $100 \mathrm{MW}$, como termelétricas ou parques eólicos. No caso de usinas termelétricas movidas a combustíveis fósseis, o tempo médio de construção verificado, variável com o porte da usina, tem sido entre dois e três anos. Já as usinas eólicas em construção no país, com parques entre 25 e 100 MW contratados pelo Proinfa e no oitavo leilão de energia de reserva, têm estimativas médias de dois anos de construção ${ }^{119}$.

No caso de geração distribuída, a construção de instalações solares fotovoltaicas ou de sistemas de biodigestão e aproveitamento do biogás, na ordem de dezenas de $\mathrm{kW}$, é normalmente inferior a um ano e minimiza a estrutura técnica de transporte de energia, considerando seu consumo local.

Instalações solares - em diferentes disposições e aplicações, entre plantas centralizadas, sistemas conectados a rede ou isolados - podem requerer tempos de construção inferiores aos parques eólicos, posto que o material utilizado é préfabricado e modularizado - sistemas fotovoltaicos podem entrar na rede em apenas dois meses se os painéis estiverem disponíveis RAVIS (2007).

\footnotetext{
118 Os custos de construção podem alcançar 6.000 dólares por kW instalado. Angra 1 custou US $\$ 2.874 / \mathrm{kW}$, enquanto o reator argentinio Atucha, de $698 \mathrm{MW}$, custou US $\$ 6.017 / \mathrm{kW}$.

${ }^{119}$ A concessionária Florida Power \& Light estima que pode colocar novos parques eólicos em operação em um intervalo de tempo entre 3 e 6 meses (FLAVIN et al., 2006).
} 
Alterações no cronograma de construção de usinas ou sistemas de geração relacionados a questões tecnológicas e qualidade técnica de projetos e pessoal envolvido têm sido observados no setor nuclear, em diferentes exemplos. O grande intervalo entre a construção dos últimos reatores e a retomada atual de cerca de vinte anos - na Europa e nos Estados Unidos resultou em perda de experiência e prática dos diferentes agentes responsáveis pela sua construção, entre reguladores, operadores, fornecedores e subcontratadores.

A perda de experiência, aliada a inovações tecnológicas dos reatores resultando na diferenciação de materiais e projetos dos componentes - além do aumento dos níveis mínimos de segurança e qualidade requisitados para a construção das usinas são o conjunto de fatores que justificam o atraso dos EPR (Reator Europeu a Água Pressurizada, da sigla em inglês) em construção na França e na Finlândia ${ }^{120}$.

O atraso da usina finlandesa de Olkiluoto-3 traz ainda como consequência aos investidores o impacto econômico da compra em mercado spot da energia prevista pelo empreendimento, como forma de atender à demanda coberta pelo reator, que já deveria estar em operação em $2010^{121}$.

\subsubsection{Algoritmo de Cômputo e Valoração}

O tempo total de construção de uma central ou sistema de geração de energia é resultado da somatória ou concatenação dos diferentes períodos de tempo estipulados para cada etapa desse processo. O cronograma de construção de uma usina divide-se, costumeiramente, em atividades preparatórias à construção - considerando o estudo e a preparação do local - e atividades de construção, divididas na preparação da infraestrutura necessária à construção da obra, montagem elétrica e mecânica, comissionamento e testes de operação.

A duração de cada um desses intervalos é particular a cada tipo de empreendimento e projeto, incluindo variáveis técnicas e econômicas locais

\footnotetext{
${ }^{120}$ Ambos os projetos têm tido atrasos consideráveis de construção por conta de documentação e certificação relacionada à segurança das usinas, problemas de construção relacionados à concretagem, soldagem e fabricação de componentes, além de diferenciação de projetos em relação ao padrão de construção utilizado em outras partes do mundo.

${ }^{121}$ A concessionária PVO comprou eletricidade no mercado nórdico de energia, para compensar a capacidade instalada que deveria vir da usina de Olkiluoto-3. Estima-se que o preço pago por MWh no mercado spot tenha sido entre 24 e 37 euros.
} 
específicas a cada um deles. De qualquer forma, a estimativa destes períodos de tempo para a obtenção do tempo total de construção de uma usina pode ser aferida com base em séries históricas baseadas em períodos médios de cada etapa, corrigidas de acordo com a curva de aprendizagem de cada recurso considerado, disponíveis em diferentes estudos e publicações.

De forma geral, a definição de implantação de uma usina, observados os aspectos de engenharia, passa pela análise do potencial energético local e da viabilidade do sítio escolhido, seguida da elaboração do projeto básico do empreendimento e da elaboração de estudos de inventário ambiental.

A primeira fase de estudos e projetos inclui estudos do recurso energético, de engenharia, gestão de terrenos (quando aplicável) e estudos ambientais. Os estudos do recurso energético incluem estudos locais de potencial do recurso energético - com a medição da fonte energética e a elaboração e aferição de históricos de energia produzida -, estudo da viabilidade de instalação de estruturas e de construção de elementos técnicos do empreendimento. Os estudos de engenharia consideram o estudo do projeto básico, incluindo o estudo da topografia da locação escolhida e estudos de conexão à rede. A gestão dos terrenos identifica os proprietários dos territórios e inclui procedimentos de assinatura de contratos de cessão para a construção da obra. Os estudos ambientais incluem a elaboração de relatórios de impactos ambientais, a indicação de alternativas de recuperação das áreas afetadas, projetos de manuseio de controle de impactos ao solo, fauna e flora locais e estudo de levantamento arqueológico do sítio utilizado para a obra.

Após a fase de estudos e projetos, seguem as atividades preparatórias à construção, com a realização de obras civis e estradas internas para possibilitar a logística de transporte de insumos e material de construção. A preparação do sítio é iniciada com as atividades de fundação.

A construção propriamente dita é dividida nas etapas de concretagem, montagem elétrica e mecânica, comissionamento da usina e testes de operação. A concretagem conta com períodos e tarefas diferenciados de acordo com 0 porte e a característica da usina, incluindo a construção de barragens e outras estruturas no caso de hidrelétricas, ou de domos para a contenção de reatores para as usinas nucleares. No caso de parques eólicos, o erguimento das torres 
tem caráter modular e pode ser feito em etapas, até que o empreendimento seja completado.

Em seguida é realizada a montagem dos equipamentos mecânicos - como turbinas e caldeiras - e elétricos - incluindo geradores, transformadores, sistemas de proteção e controle, instalações elétricas e sistemas de transmissão.

Como última etapa da construção, faz-se o comissionamento da central, que consiste em inspecionar e testar os componentes físicos do empreendimento, entre equipamentos e sistemas.

A operação comercial do empreendimento é precedida por um período de testes pré-operacionais, envolvendo testes de operação e potência da usina, para aferição do funcionamento correto e do alcance da potência de turbinas utilizadas.

O algoritmo de tempo de implantação de um empreendimento energético resulta, portanto, na seguinte equação:

Tempo de Implantação $=\mathrm{T}($ Projeto\&Estudos $)+\mathrm{T}($ preparação do sítio $)+$ T(fundação\&concretagem + T (montagem eletromecânica) + $\mathrm{T}$ (comissionamento) + $\mathrm{T}$ (testes de potência)

O resultado do tempo total de implantação é função, em primeiro lugar, do porte do empreendimento. No caso de pequenos sistemas, etapas ligadas a infraestrutura e testes operacionais são obviamente encurtadas; o mesmo se aplica ao tempo de projeto e estudos.

No caso de usinas de grande porte, cada um desses elementos está sujeito a um desvio de tempo, como consequência de diferentes fatores complicadores à realização do projeto.

A figura 27 a seguir ilustra o algoritmo de valoração do tempo de implementação. 


\section{Algoritmo - Valoração Tempo de Implantação de Recurso Energético}

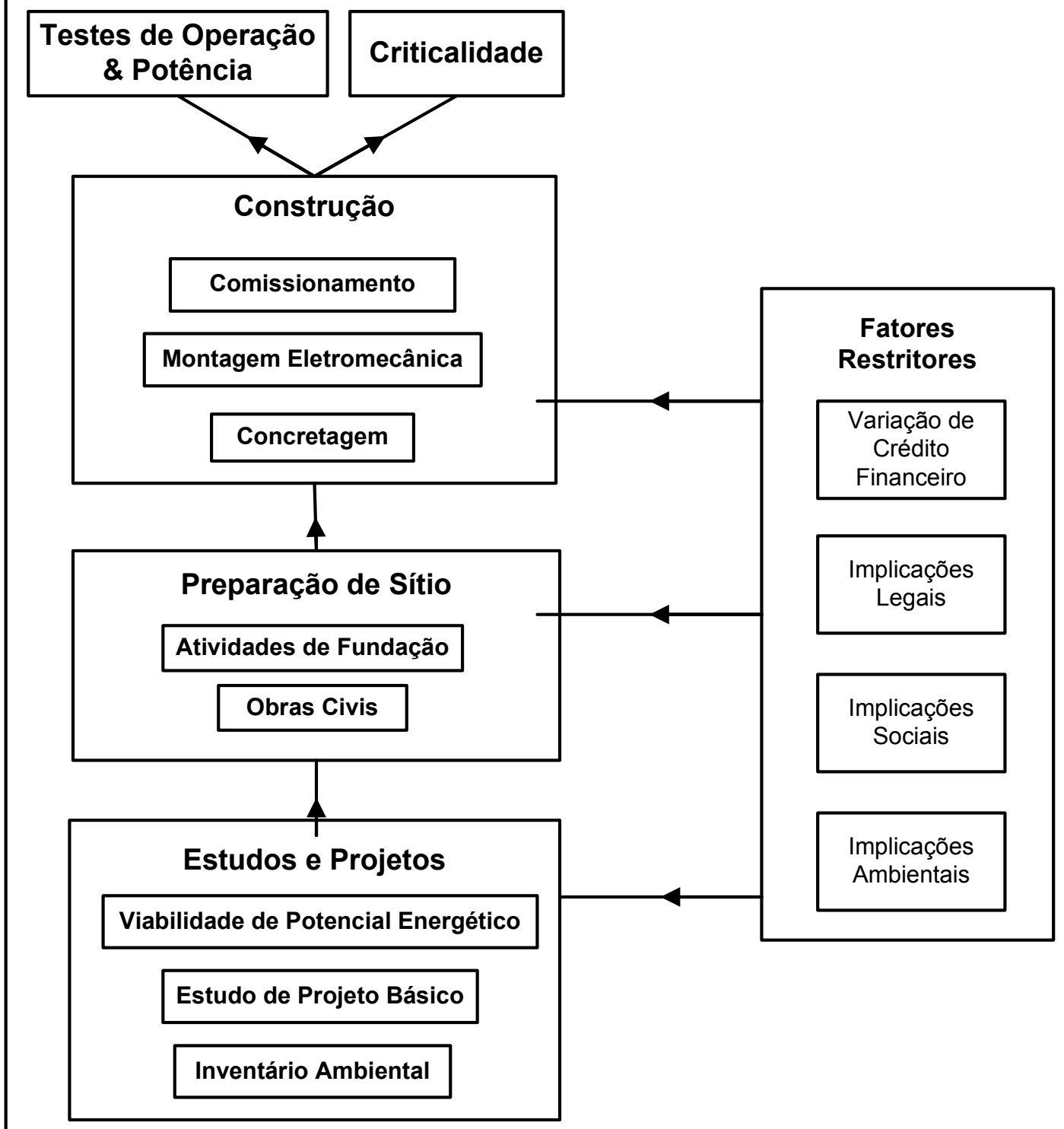

Fonte: Elaboração Própria

Figura 27: Algoritmo de CVCP do atributo Tempo de Implantação de RELO 


\subsubsection{Confiabilidade}

A análise da confiabilidade de um recurso energético é resultado da combinação da intermitência de sua geração - representada pelo seu fator de capacidade $^{122}$ - aliada à disponibilidade da fonte energética utilizada e da tecnologia empregada em sua conversão.

Historicamente, a evolução no emprego de uma tecnologia reduz seu custo e aumenta seu fator de capacidade ao longo do tempo. Essa tendência é verificada em todos os tipos de geração; mais recentemente em sistemas solares e aerogeradores.

A confiabilidade varia consideravelmente de acordo com a faixa de potência do recurso analisado e, principalmente, de acordo com as características do energético. Recursos renováveis costumam apresentar índices maiores de intermitência, regidos por fenômenos naturais. Já empreendimentos de grande porte como termelétricas movidas a combustível nuclear ou fóssil, apesar de teoricamente gerarem energia firme capaz de atender à base da demanda elétrica, têm sua disponibilidade regida pelas condições técnicas de funcionamento da usina, somadas à oferta do combustível utilizado em sua operação.

A intermitência e a previsibilidade de geração de recursos renováveis são particulares, em duração e regime, a cada fonte energética. A geração eólica varia de acordo com os regimes de vento e gradiente de pressão, em função de fatores meteorológicos e da época do ano. A geração solar depende da incidência de radiação solar de acordo com a hora do dia, estações do ano e fatores meteorológicos, como nebulosidade. Já a geração maremotriz registra maior previsibilidade por conta do regime das ondas e marés, em função dos campos gravitacionais da lua e do sol. A cogeração a biomassa é sazonal, de acordo com a safra da cultura agrícola utilizada no processo. Por fim, a geração hidrelétrica é função do regime pluviométrico, e da vazão das usinas, ainda que o despacho seja orientado em função do porte dos reservatórios.

\footnotetext{
${ }^{122} \mathrm{O}$ fator de capacidade é a relação entre a produção real de uma usina e sua produção teórica, considerando uma operação a máxima eficiência. O fator de capacidade médio nacional no ano de 2009 considerando a capacidade instalada- 106,57 GW (ANEEL, 2010) - e a energia gerada nesse ano (EPE, MME, 2010) - 466,2 TWh - foi de 49,9\%.
} 
A intermitência desses recursos contribui para a crença de que a geração renovável - principalmente solar e eólica - não é confiável e não poderia contribuir com uma participação significativa da oferta de eletricidade ou gerar energia de base, necessitando de geração de backup para atender à demanda em períodos de baixa geração renovável. Em adição a isso, argumenta-se que os períodos de maior geração renovável não coincidiriam necessariamente com os picos de maior demanda elétrica ${ }^{123}$. Esta visão de que alguns recursos renováveis não são despacháveis é compartilhada pelo setor elétrico de quase todo o mundo (SOVACOOL, 2008b).

Por outro lado, exemplos de Dinamarca e Espanha têm mostrado que é possível incorporar grandes quantidades de energia eólica no sistema. No segundo caso, a geração representa $11 \%$ da capacidade instalada e chega a gerar mais de $40 \%$ da energia instantânea do país, em períodos de fortes ventos, provocando o desligamento de usinas termelétricas a fim de aproveitar a geração eólica de eletricidade nessas situações.

Diferentes estudos vêm mostrando que a implantação de grandes quantidades de geração renovável, combinada entre diferentes recursos em diferentes áreas, tem sua intermitência reduzida consideravelmente ${ }^{124}$ - ainda que não se possa deixar de lado o cômputo de custos de transmissão e a complexidade dessa integração (SOVACOOL, 2008b).

O fator de capacidade combinado de cada recurso cresce em função de sua capacidade instalada total, não apenas com a combinação de geração entre diferentes pontos geográficos, como também como consequência do ganho de aprendizado adquirido com o aumento da escala de fabricação de equipamentos. A geração eólica registrou um avanço no fator de capacidade de iniciais $15 \%$ para valores superiores a $40 \%$ nos últimos dez anos. Para a geração solar,

\footnotetext{
${ }^{123}$ Em estados norte-americanos como a Califórnia, a variação da carga máxima entre o inverno e o verão chega a ser de mais de $50 \%$ do total - de 29 mil MW em janeiro, a carga salta para 45 mil MW no verão.

${ }^{124}$ A confiabilidade do sistema aumenta, assim, em função de sua descentralização. É princípio geral na engenharia de sistemas energéticos que quanto maior o sistema, menor sua necessidade de capacidade de reserva. A redução de uma demanda conjunta entre consumidores individuais é obtida com sua interligação, provocando com que as variações individuais sejam atenuadas. O mesmo acontece com a variação de geração de parques eólicos interconectados (SOVACOOL, 2008b).
} 
índices de $7 \%$, nos anos 80 , subiram a mais de $20 \%$ para algumas tecnologias nos últimos anos (IEA, 2009).

A intermitência da geração solar é criticada por concessionárias, não apenas por sua restrição ao atendimento de energia de base, como também para energia de ponta. No entanto, essa limitação é minimizada na modalidade de geração solar concentrada, na qual é possível armazenar parte do calor concentrado em espelhos na forma de sais ou fluidos, antes que ele gere eletricidade por meio de uma turbina.

Os recursos energéticos de suprimento teoricamente contínuo, com base em combustíveis fósseis como carvão, derivados de petróleo e energia nuclear, não são suscetíveis a intermitência resultante de fenômenos naturais ${ }^{125}$, mas têm sua disponibilidade relacionada à oferta desses combustíveis. Essa oferta é condicionada a fatores técnicos - grau de complexidade de extração e transporte desses recursos - e geopolíticos - como resultado de conflitos e desacordos diplomáticos internacionais, no suprimento desses combustíveis. Este último componente é discutido na dimensão política de análise de recursos.

A disponibilidade dessas fontes pode ser afetada em cenários de racionamento - nos quais a demanda concorrencial por energéticos pode restringir sua disponibilidade -, e em conjunturas de alta de preços - como o do gás natural, resultante da falta de um modelo de regulação para o transporte do insumo.

Além da intermitência da fonte energética analisada, a tecnologia empregada na conversão dessa fonte em energia tem grande participação na confiabilidade global de um recurso energético.

Para a geração tradicional de grande porte, de acordo com estudo do setor elétrico britânico, há uma chance de $10 \%$ de que falhas inesperadas em usinas ou redes de transmissão resultem na indisponibilidade de geração. (GROSS et al., 2006, apud SOVACOOL, 2008b).

Entretanto os prejuízos de interrupções, previstas ou não, podem ser graves para os geradores, principalmente, no caso de a energia não entregue ser adquirida no mercado spot, a custos dezenas ou centenas de vezes superiores

\footnotetext{
${ }^{125}$ Exceto no caso de terremotos, especialmente comuns no Japão. Uma dessas ocorrências vitimou o complexo nuclear de Kashiwazaki; Kariwa, que resultou no vazamento de 1,2 litros de rejeito nuclear ao mar e na desativação temporária das usinas.
} 
aos da venda de energia gerada pela usina. Esse exemplo é recorrente; no Japão, a usina nuclear de Kashiwazaki Kariwa, desativada por um terremoto foi obrigada a repor a energia que estaria gerando com base em compras no mercado spot, resultando em aumento de gastos e racionamento energético.

As usinas nucleares podem também ser afetadas pela disponibilidade de água, uma vez que a operação demanda uma diferença de temperatura entre o vapor e a água de rios ou lagos utilizada no condensador, altas temperaturas da água já afetaram o funcionamento de usinas. Em 2004, uma forte onda de calor na Europa forçou o desligamento de uma série de reatores na França (JACOBSON, 2008).

Outros fenômenos naturais podem interromper a oferta de energia, ao afetar não apenas a geração, como também a transmissão de eletricidade. Um exemplo desse caso foi o exaustivamente estudado blecaute ocorrido em novembro de 2009, que deixou 18 estados brasileiros, temporariamente, sem eletricidade por conta da interrupção do suprimento de energia nas linhas de Itaipu, provocada por um curto-circuito triplo.

Além de fenômenos naturais, conflitos políticos como guerras ou atos de terrorismo podem afetar o suprimento de energia de usinas. Nesse caso, a geração renovável de forma descentralizada, realizada por tecnologias como painéis fotovoltaicos, aerogeradores e usinas maremotrizes, são menos suscetíveis a interrupção do que usinas de grande porte de geração centralizada como termelétricas, hidrelétricas ou mesmo plantas de energia solar concentrada (JACOBSON, 2008).

O risco de ações terroristas é extremamente sensível à região geográfica analisada - e o contexto político em que se insere - e seu prejuízo é proporcional ao porte da usina. Impactos colaterais podem incluir vazamento radioativo (no caso de usinas nucleares), inundações (centrais hidrelétricas) ou vazamento de efluentes químicos, no caso de fontes de geração termelétrica, como o carvão.

Interrupções previstas relacionadas à manutenção de equipamentos e reabastecimento variam de 5 a 20\% do tempo de funcionamento, o que significa que as usinas geram na prática entre 80 e 95\% da capacidade instalada teórica, sem contar seu fator de capacidade.

Para o carvão, a média de interrupções anuais para manutenções programadas é de $6,5 \%$ e a média de interrupções não programadas é de $6 \%$. A 
disponibilidade de usinas a carvão nos EUA registra limites entre 79 e 92\% (NERC, 2005). A interrupção programada de usinas nucleares é de 39 dias a cada 17 meses, ou 7\%, produzindo uma disponibilidade de cerca de 93\% (LOVINS, 2009).

As médias são elevadas em comparação ao tempo de indisponibilidade de aerogeradores - entre 0 e $2 \%$ para geradores em terra e entre 0 e $5 \%$ para torres offshore - e painéis fotovoltaicos - entre 0 e $2 \%$. Ressalta-se que essa média refere-se a unidades individuais de geração e representa um impacto reduzido no sistema total ${ }^{126}$.

Essa pequena variação de geração em relação à oferta total contrapõe-se com a indisponibilidade de 500 a 1000 MW de potência de usinas termelétricas. Pesa ainda a favor das tecnologias renováveis a melhoria do fator de capacidade e a redução de interrupções não previstas.

\subsubsection{Algoritmo de Cômputo e Valoração}

Conforme visto no item anterior, o cálculo da confiabilidade real de um recurso energético é função da intermitência de sua geração - representada pelo seu fator de capacidade - aliada à disponibilidade da fonte energética utilizada e da tecnologia empregada em sua conversão.

Os fabricantes das referidas tecnologias e diversos levantamentos acadêmicos constituem fonte de informação para valores médios de fatores de capacidade e geração média de tecnologias. Já a avaliação de interrupções não previstas, como consequência de variáveis políticas e econômicas ou fenômenos naturais, pode ser marginalmente estimada, dentro de altos graus de imprevisibilidade, por cenários ou levantamentos de médias históricas.

Assim, o cálculo de confiabilidade de recursos energéticos apresenta uma parcela de fator de capacidade - variável de acordo com o desenvolvimento da tecnologia e o arranjo do sistema de geração -, o fator de disponibilidade de combustíveis - regido por variáveis econômicas e políticas - e o fator de

\footnotetext{
${ }^{126}$ No caso de um parque eólico, problemas em uma torre não afetarão o funcionamento do conjunto. Tomando por base o parque eólico de Osório, a indisponibilidade de uma torre de 2MW terá um impacto de 1,33\% sobre a geração total do parque. Dessa forma, a indisponibilidade do sistema é uma fração do índice verificado para cada turbina.
} 
disponibilidade de usinas ou sistemas - teoricamente analisado por documentos técnicos, mas suscetível a fenômenos naturais e fatores político-econômicos.

É importante ressaltar que a análise individualizada de recursos energéticos nessa etapa de valoração impede que a complementaridade entre fontes energéticas - como é o caso da complementação entre a geração hidrelétrica e a cogeração a biomassa ou a complementação entre as gerações eólica e solar em sistemas híbridos - com o intuito de diminuir índices de flutuação da geração de eletricidade seja medida e possa favorecer a avaliação de um recurso em aplicações específicas.

A formulação e o algoritmo da valoração da confiabilidade de recursos energéticos são retratados nas equações abaixo e na figura 27 a seguir:

CVPC Conf $\left(\right.$ RELO) $=$ FC (RELO) ${ }^{\star}$ FD (RELO) (45)

$\mathrm{FD}(\mathrm{RELO})=(\mathrm{FDComb})^{\star}($ FDUsina $)$

Onde:

CVPC conf (RELO): cálculo da confiabilidade de um recurso de oferta em função de seu fator de capacidade (FC) e sua disponibilidade (FD) (adimensional);

FD (RELO): fator de disponibilidade de um recurso, calculado em função da disponibilidade de obtenção de combustível (FDComb) (se aplicado) e de operação da usina (FDUsina). 


\section{Algoritmo - CVPC Confiabilidade de Recurso Energético}

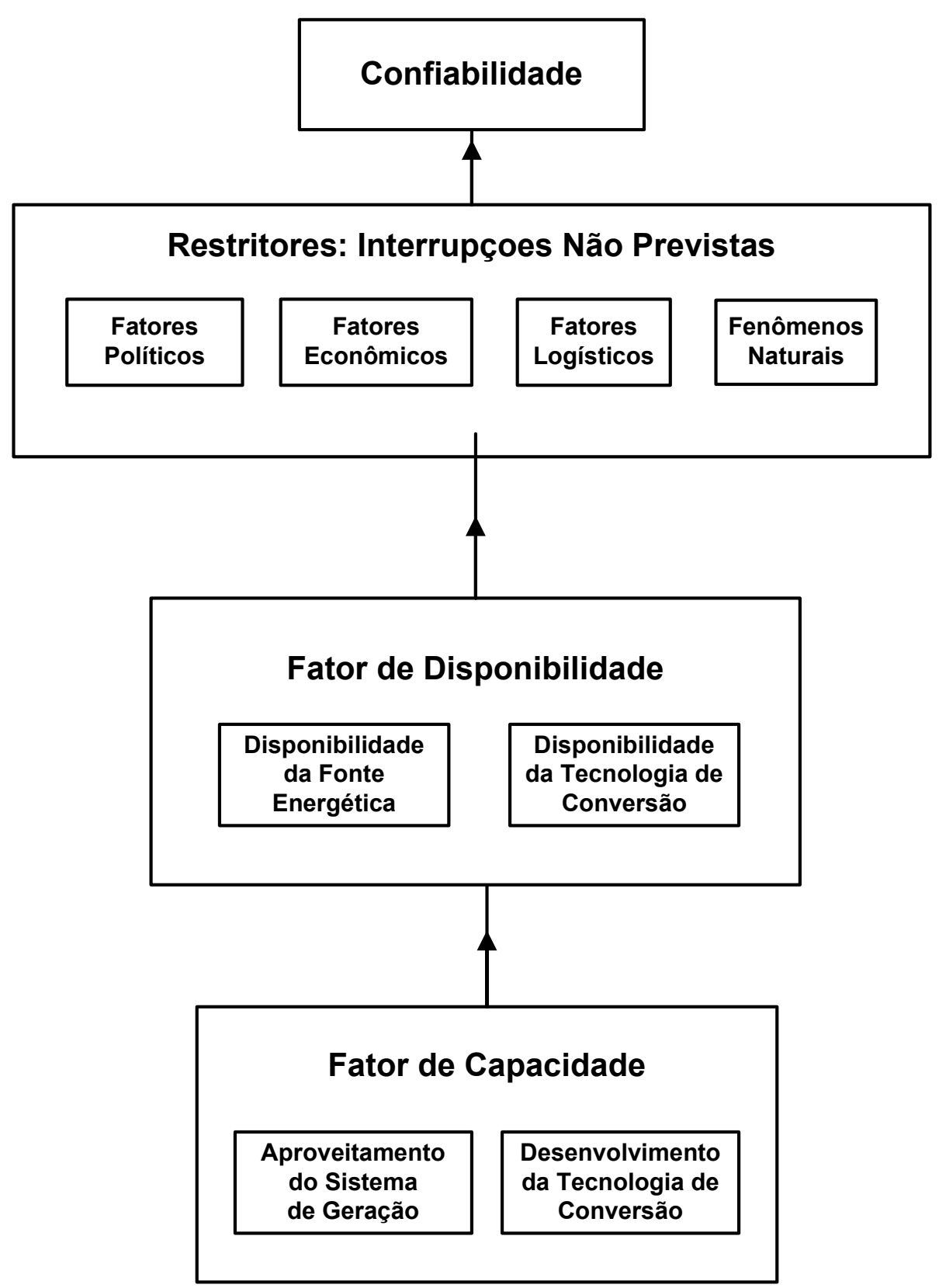

Fonte: Elaboração Própria

Figura 28: Algoritmo de CVCP do atributo confiabilidade de RELO 


\subsubsection{Distância de Geração de Recurso Energético a Centro de Consumo}

A distância de um recurso energético até os centros onde a energia gerada é consumida é um importante atributo de avaliação da viabilização desse recurso, tanto para geradores quanto para consumidores de energia. Para geradores, o ponto ideal de conexão da usina à rede repercute em termos logísticos, técnicos e econômicos - a avaliação da distância de projetos ao sistema de carga é ponderada em conjunto com restrições de custos e disponibilidade local da fonte energética.

Já para os consumidores, a utilização ótima dos sistemas resulta na minimização do custo de uso dessa rede e, consequentemente, na coerência das tarifas aplicadas a esses geradores.

Em relação à questão logística, há diferentes disposições ou configurações de transmissão de energia do ponto de geração até o centro de consumo ou de carga. Usinas hidrelétricas são distantes dos centros de carga, em função da localização dos maiores potenciais de aproveitamento hidrelétrico. Isso se aplica a centrais nucleares, costumeiramente localizadas próximas a corpos d'água, utilizados para o resfriamento dos circuitos internos e distantes de concentrações populacionais por conta dos riscos de acidentes nessas usinas. As demais termelétricas localizam-se mais próximas aos centros de carga, enquanto a geração distribuída - representada por pequenos grupos geradores e painéis fotovoltaicos - pode situar-se próxima aos centros de carga quando conectada à rede ou distante desses centros, no caso de comunidades isoladas do sistema elétrico. Em relação a projetos de energia eólica, de biomassa e de pequenas hidrelétricas, os arranjos de conexão podem ser diferentes dos demais, conforme será discutido a seguir.

É importante ressaltar que a distância de um recurso energético até seu centro de consumo ou centro de carga e as modalidades de conexão entre esses pontos conduzem a índices proporcionais de perdas dessa energia durante esse processo. Nesse sentido, os custos de transporte ou transmissão e distribuição de energia até o consumidor final aumentam em função dos desafios técnicos de garantir uma estrutura confiável para que essa energia atinja os centros de consumo. 
Nesse sentido, a descentralização da produção de energia proporciona um maior aproveitamento de recursos energéticos locais, com o consumo de energia mais próximo à fonte geradora e a redução das grandes perdas de transmissão de energia do sistema nacional. Porém, no caso de unidades geradoras remotas ou de geração em comunidades isoladas da rede elétrica, identificam-se dificuldades técnicas relacionadas à operação contínua desses sistemas. Há situações nas quais a manutenção é dificultada por limitações técnicas dos En-In locais - como em painéis fotovoltaicos ou pequenos geradores - ou casos em que a geração de eletricidade é provida por combustíveis trazidos de longas distâncias - como o diesel utilizado na região Norte - cujo custo e tempo de transporte impactam a regularidade do suprimento de energia às comunidades atendidas.

A distância de um recurso energético aos centros de consumo é, portanto, um elemento essencial para a tomada de decisão na implantação de um empreendimento, especialmente em função de seu potencial energético - que pode constituir um fator prioritário nesse processo, a despeito de dificuldades logísticas de transmissão.

A distância entre usinas e pontos de consumo é valorada pelo arranjo de conexão dessas usinas ao sistema interligado nacional, com base em instalações de distribuição ou diretamente à rede básica de transmissão, os dois ambientes de tarifação do uso da rede. Esses arranjos seguem algumas formas principais, que determinam a estrutura técnica de transporte dessa energia $e$, consequentemente, a composição do custo do transporte na tarifa de energia.

A rede de distribuição pode ser acessada pelos geradores por barramentos maiores que 88kV (de acordo com a Resolução 166, de 2005, da Aneel) ou menores que 69 kV (de acordo com a Resolução 349, de 2009 da Aneel).

Há três tipos de instalação de transmissão, de acordo com o artigo 17 da Lei 9.074/1995: as que formam a rede básica de sistemas interligados (com nível de tensão igual ou superior a $230 \mathrm{kV}$ ), as de âmbito próprio da distribuidora (com nível de tensão inferior a $230 \mathrm{kV}$ ) e as de interesse exclusivo dos geradores. Os dois primeiros tipos são de serviço público enquanto o último tipo, de interesse particular, é disponibilizado aos geradores por transmissoras ou distribuidoras mediante o pagamento de encargos de conexão de instalações de uso exclusivo. 
O acesso de geradores a instalações de transmissão de Interesse Exclusivo de Centrais de Geração para Conexão Compartilhada (ICG) permite o compartilhamento dos custos de acesso à rede básica entre dois ou mais geradores (KELMAN, 2009). Esse arranjo vem sendo utilizado por novas centrais geradoras eólicas, pequenas hidrelétricas e de cogeração a biomassa, motivadas pela falta de capacidade de absorção no sistema das distribuidoras a até $69 \mathrm{kV}$ e pela possibilidade de maior agilidade de conexão. As ICGs são rateadas até certo ponto, a partir do qual são construídas as IEGs, ou instalações exclusivas do gerador, em que cada unidade de geração distribuída é conectada no pórtico de acesso da ICG.

Assim, a transmissão pode ser feita sem o auxílio de ICGs $^{127}$ (de acordo com a Resolução 320, de 2008, da Aneel (2008b) ou com o auxílio de ICGs (de acordo com a Resolução 267, de 2007, da Aneel (2007a). Dentre os arranjos possíveis contemplando as ICGs, de acordo com a figura 29 abaixo, um gerador pode acessar a rede básica diretamente em uso exclusivo (G6). Pode também custear o trafo elevador e o Sistema de Medição para Faturamento (G1 a G4, G5, G7, G8 e G9). Desse grupo, usinas mais distantes, além do trafo, podem ratear as linhas de transmissão e a $\mathrm{SE}^{128}$ subcoletora (G1 a G4). O mesmo se aplica aos exemplos de G7 e G8. Outra possibilidade para geradores é o rateio da ICG do acesso à subestação coletora (G9).

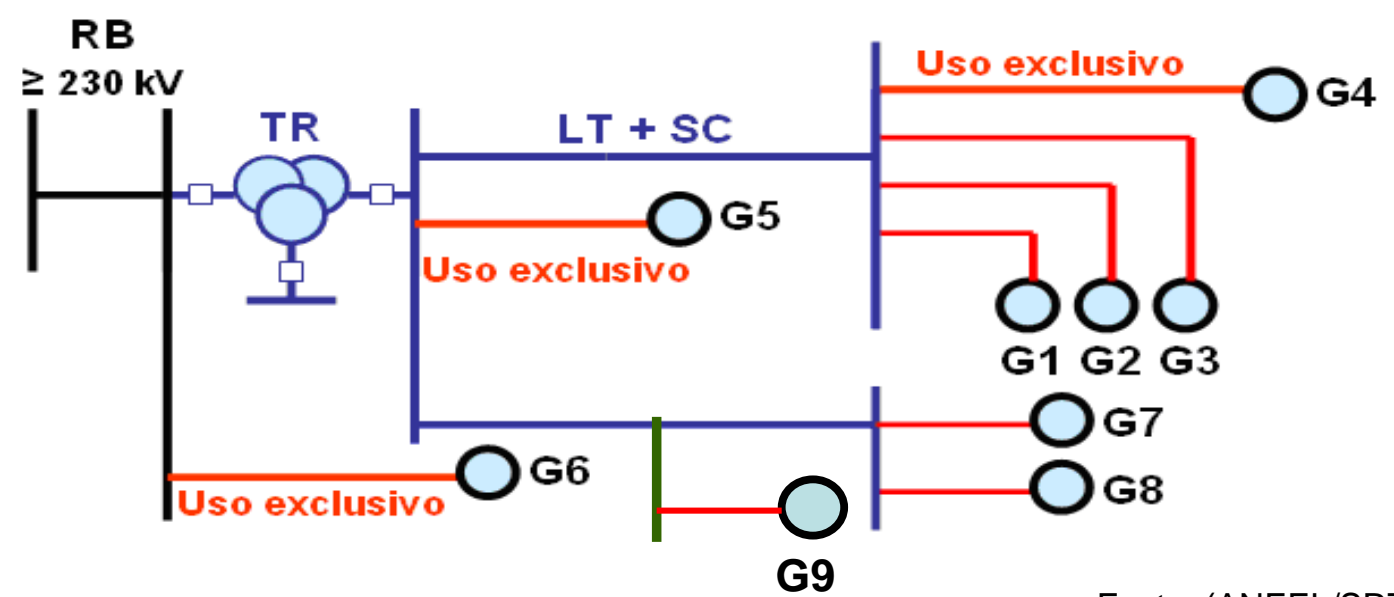

Fonte: (ANEEL/SRT, 2007)

Figura 29: Arranjos de ICGs

\footnotetext{
${ }^{127}$ ICG - Instalação Compartilhada de Geração: possibilita o acesso de mais de uma unidade de geração distribuída num mesmo ponto de conexão na rede básica.

${ }^{128}$ SE Coletora: instalação de rebaixamento de tensão da rede básica $(230 \mathrm{kV})$ para tensão de distribuição (138 kV), para possibilitar acesso da geração distribuída.
} 
Em resumo, em função dos diferentes arranjos de conexão de geradores à rede elétrica, optou-se por valorar a distância de um recurso energético de oferta até os pontos de carga e consumo por meio da somatória de custos envolvidos em cada etapa desse processo.

Os custos envolvidos são relacionados - para usinas conectadas ao sistema interligado nacional - aos encargos da TUST (tarifa de uso do sistema de transmissão, valor pago pelo Gerador, correspondente ao montante de uso do sistema de transmissão, em função da potência injetada), da TUSD (tarifa de uso dos sistemas de distribuição, tanto por unidades geradoras quanto por consumidores livres ou outras distribuidoras), da ICG (tarifa de uso das instalações compartilhadas, pagas pelo gerador a fim de viabilizar a instalação do trecho exclusivo de conexão) e da IEG (instalação exclusiva do gerador, pago pelo gerador para viabilizar a instalação do trecho exclusivo de conexão do Gerador na ICG), aplicáveis ou não a cada configuração analisada.

Para o caso de geração distribuída, a conexão de usinas inferiores a 30 MW é feita ao sistema de distribuição. No caso de geração local de energias renováveis como pequenas torres eólicas ou painéis fotovoltaicos, a distância de geração a consumo é considerada irrisória em casos de geração domiciliar e não se consideram custos ou encargos de transporte dessa energia.

Para usinas isoladas do sistema, a distância de geração até os pontos de consumo pode ser aferida pela estruturação de redes ou mini-redes em atendimento a indústrias ou comunidades.

No caso de geração descentralizada feita por combustíveis fósseis, o custo de transporte é composto pelas despesas envolvidas com a entrega do combustível utilizado até esses pontos de consumo.

Em outro extremo, a projeção de super-redes para viabilizar a conexão de diferentes tipos de geração renovável já vem sendo projetada na Europa. A conjunção entre o uso de turbinas eólicas offshore na costa da Grã-Bretanha à energia das ondas das costas escandinavas e o aproveitamento solar fotovoltaico do continente, por uma estrutura de cabeamento submarino, é estimada em 30 bilhões de euros e deverá aumentar a taxa de confiabilidade dessas energias na região.

Faz-se uma observação final à estrutura de transmissão de energia utilizando o sistema interligado nacional. Dentro dessa lógica, é importante 
considerar que ainda que opções locais sejam analisadas como viáveis logística e tecnicamente, é comum a prevalecência de opções energéticas mais distantes, transportadas até a região, desde que sua economicidade seja comprovada.

\subsubsection{Algoritmo de Cômputo e Valoração}

A Nota Técnica no 053/2007-SRT/ANEEL indica que existem, conforme preconizado em Lei, apenas dois ambientes tarifários para o uso das redes de serviço público: o da transmissão (Rede Básica) e o da distribuição (DIT + instalações de distribuição). As tarifas para remunerar os custos dos serviços de transmissão deverão ser pagas às transmissoras, enquanto as tarifas para remunerar os custos de distribuição serão pagas às distribuidoras, mesmo que os usuários estejam conectados às DIT (instalações de transmissão disponibilizadas às distribuidoras) (ANEEL, 2007b).

De acordo com o site da ANEEL (2010), todo agente do setor elétrico que produza ou consuma energia elétrica tem direito à utilização da Rede Básica rede de linhas de transmissão de grandes quantidades de energia elétrica por longas distâncias em tensão igual ou superior a $230 \mathrm{kV}$. As tarifas de uso do sistema de transmissão - TUST - são calculadas com a metodologia nodal, que dá um sinal econômico locacional.

A parcela principal da TUST, a TUST-RB refere-se às instalações de transmissão integrantes da Rede Básica com tensões iguais ou superiores a 230 kV. Seu cálculo é realizado por simulações com o Programa Nodal, que utiliza como dados de entrada a configuração da rede - representada por suas linhas de transmissão, subestações, geração e carga - e uma receita total a ser arrecadada - composta da RAP a ser paga às transmissoras, de uma Parcela de Ajuste (correspondente às diferenças de arrecadação do período anterior) e de uma previsão de receita para pagamento de instalações de transmissão que irão entrar em operação ao longo do período considerado.

A partir de junho de 2004, a Rede Básica passou a contemplar as instalações de transformação necessárias para rebaixar as tensões da transmissão iguais ou superiores a $230 \mathrm{kV}$ - para as tensões de distribuição (Resolução Normativa no 067). O serviço de transmissão prestado por essas unidades transformadoras passou a ser pago pelas distribuidoras, por meio da parcela TUST- FR, que incorpora, ainda, os custos de transporte associados às 
Demais Instalações de Transmissão (DITs) compartilhadas entre as distribuidoras. Todos os barramentos de subestações com tensão inferior a 230 kV passaram a ser classificados como DIT, ou instalações de transmissão de âmbito da distribuição, mediante o pagamento de tarifa de uso do sistema de distribuição - TUSD.

Em resumo, geradores que se conectarem ao ambiente da transmissão (instalações de Rede Básica) ou ao ambiente de distribuição (DIT + instalações de distribuição) deverão ter suas tarifas de uso calculadas com base em metodologia que promova a sinalização locacional - ou a composição de custo proporcional à distância dos geradores até a rede de transmissão ou distribuição de eletricidade.

Tabela 9: Metodologia de cálculo tarifário de acordo com perfil de usuário

\begin{tabular}{|c|c|c|c|c|}
\hline \multirow{2}{*}{$\begin{array}{c}\text { Tipo de } \\
\text { usuário }\end{array}$} & \multicolumn{2}{|c|}{$\begin{array}{c}\text { Ambiente da Transmissão } \\
\text { (Rede Básica) }\end{array}$} & \multicolumn{2}{c|}{$\begin{array}{c}\text { Ambiente da Distribuição (DIT } \\
\text { + instalações de distribuição) }\end{array}$} \\
\cline { 2 - 5 } & Tipo de tarifa & Metodologia & Tipo de tarifa & Metodologia \\
\hline Gerador & TUST & $\begin{array}{c}\text { Nodal } \\
\text { (locacional) }\end{array}$ & TUSDg & $\begin{array}{c}\text { Nodal } \\
\text { (locacional) }\end{array}$ \\
\hline
\end{tabular}

Fonte: Nota Técnica no. 053/2007-SRT/ANEEL

Assim, o gerador que se conecta no ambiente de distribuição deveria pagar apenas a TUSDg. No entanto, se o gerador for despachado centralizadamente pelo ONS, pagará também a TUST, mesmo que toda a energia gerada por ele seja totalmente absorvida pela carga situada na rede de distribuição.

A metodologia locacional para o cálculo da TUSDG considera o sentido dos fluxos de potência nos transformadores de fronteira da rede básica, contemplando assim as situações de DIT importadoras ou exportadoras de potência. Dessa forma, um pequeno gerador cuja potência seja absorvida pela carga não utiliza a Rede Básica, enquanto um grande gerador, na situação de DIT exportadora, faz uso tanto da distribuição quanto da transmissão, conforme mostra a figura 30 , a seguir: 


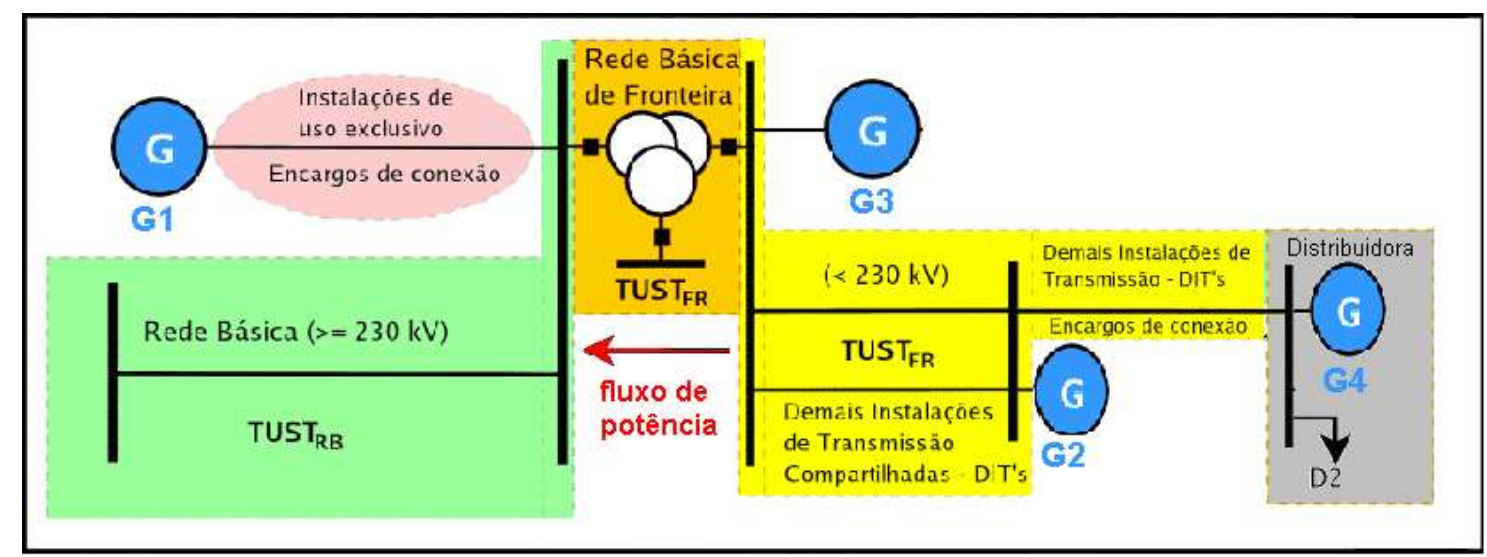

Fonte: Nota Técnica 053/2007-SRT/ANEEL

Figura 30: Fluxo de Potência de Geradores em Instalações de Transmissão Compartilhada

Nessa metodologia, todo despacho, centralizado ou não, será custeado pelo encargo da TUSDg, acrescentado à parcela de custo da rede básica para geradores exportadores de potência.

Para fontes renováveis como eólicas e usinas a biomassa, bem como termelétricas a óleo, o custo total de transmissão e distribuição é formada pela Tarifa de Uso do Sistema de Transmissão (TUST), acrescido do encargo de Interesse Exclusivo de Centrais de Geração para Conexão Compartilhada (ICG) (ANEEL, 2008).

Assim, de forma genérica, o custo de transporte de energia de um gerador aos centros de carga é uma somatória das seguintes parcelas: encargo de uso do sistema de transmissão, encargo de uso do sistema de distribuição, encargo de uso de instalações compartilhadas de geração, encargo de uso das instalações exclusivas de geração e conta de consumo de combustíveis (embutida na TUST e TUSD). As duas primeiras parcelas são função de diferentes componentes, mencionados anteriormente.

\section{Custo total $=$}

TUST(parcelas) $^{129}$ (desconto se aplicável) $^{130}+$

${ }^{129}$ Para determinação da TUST média, foi considerada a Resolução Homologatória n 907/2009, ANEXO II. Esse anexo refere-se às Tarifas de Uso das Instalações de Transmissão componentes da rede básica do Sistema Interligado Nacional, aplicáveis às centrais de geração com ponto de conexão alterado para ICG de Rede Básica em razão eventual Chamada Pública e Participações do Leilão de Reserva de 2009. 


\author{
+TUSD(importação/exportação) (desconto se aplicável) + \\ ICG (se aplicável) ${ }^{131}+$ \\ IEG (se aplicável) + \\ Transporte de Combustível (CCC) ${ }^{132}$

Além da metodologia nodal, discutida na NT 053 (ANEEL, 2007b), há diferentes propostas de metodologias para cálculo de tarifas de sistemas de transmissão e distribuição, exploradas por Medeiros (2006) e Soares (SOARES et al, 2009b). 130 A Resolução Normativa no 77 , de 18 de agosto de 2004 , estabelece os procedimentos
vinculados à redução de $50 \%$ das tarifas de uso dos sistemas elétricos de transmissão (TUST) e
de distribuição (TUSD), aplicáveis aos empreendimentos hidrelétricos com potência igual ou
inferior a $1.000 \mathrm{~kW}$ e àqueles com base em fontes solar, eólica, biomassa ou cogeração
qualificada, cuja potência injetada nos sistemas de transmissão ou distribuição seja menor ou
igual a $30.000 \mathrm{~kW}$.

131 Para determinação do encargo da ICG médio, considera-se o Anexo II da Resolução Homologatória n681/2008, que estabelece os encargos de custeio das ICGs para as centrais geradoras interessadas e habilitadas na Chamada Púbica 01/2008.

${ }^{132}$ A Conta de Consumo de Combustíveis (CCC) é um encargo cobrado nas tarifas de uso dos sistemas elétricos de distribuição e transmissão para cobrir os custos anuais da geração termelétrica produzida no país, principalmente em áreas isoladas do sistema interligado nacional. A CCC foi instituída pela Lei no 5.899 , de 05 de julho de 1973. Aplicada inicialmente nas regiões Sul, Sudeste e Centro-Oeste, foi posteriormente estendida também aos sistemas interligados das regiões Norte e Nordeste, visando dar continuidade ao suprimento de energia elétrica aos sistemas distribuidores, garantindo o fornecimento de combustíveis utilizados nas centrais geradoras termelétricas. 


\section{Algoritmo CVPC Distância de Geração a Consumo de Energia}

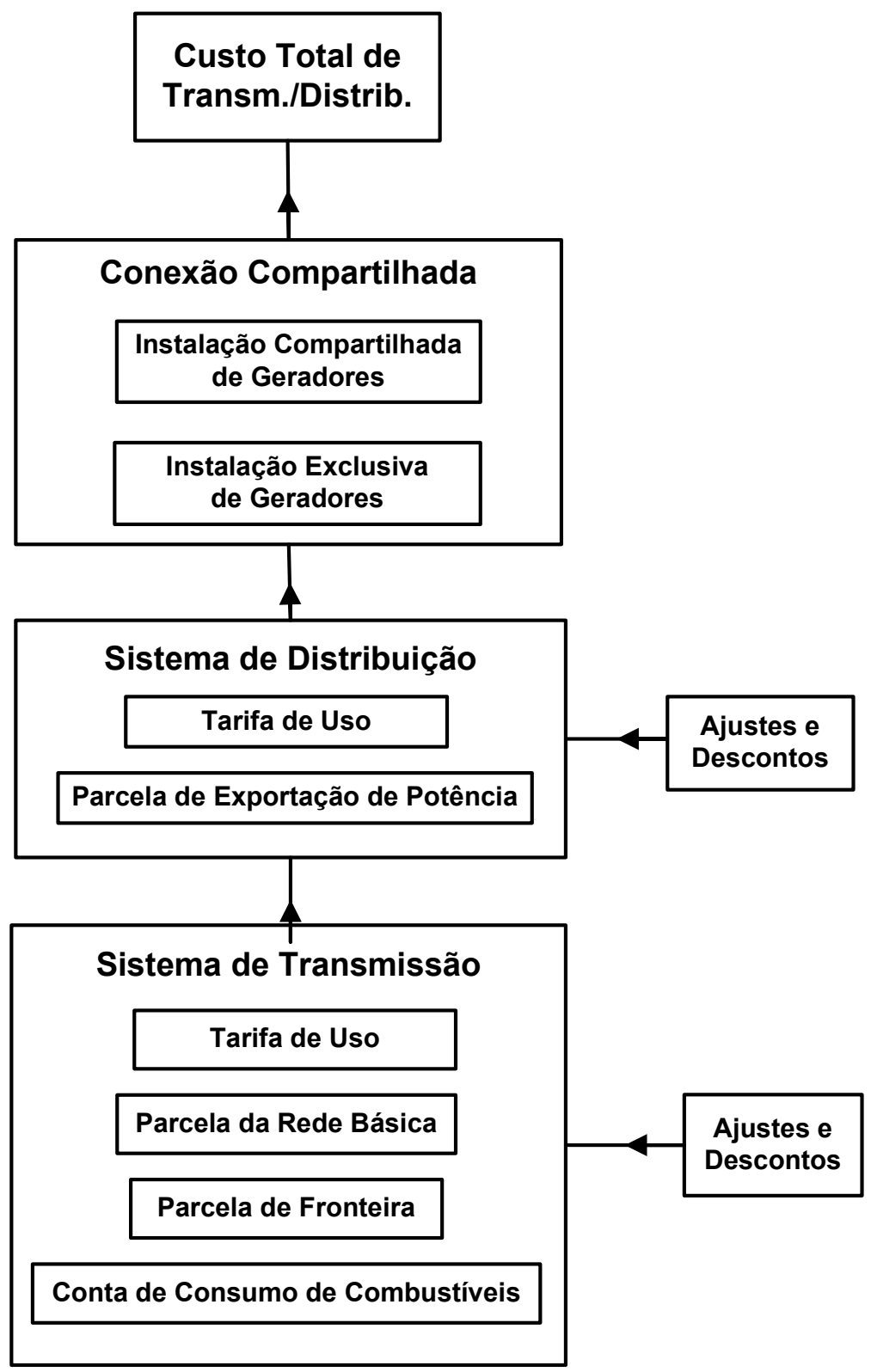

Fonte: Elaboração Própria

Figura 31: Algoritmo de CVCP do atributo Transporte de Energia 


\subsubsection{Cômputo e Valoração de Potenciais Energéticos}

Em atributos anteriores, foram analisados diferentes aspectos que contribuem para a tomada de decisão pela implementação de um recurso energético em uma região. Ainda que, na lógica do PIR, todos eles representem a mesma importância, em uma estrutura de mercados, o potencial de exploração e conversão de um recurso em energia representa um dos fatores primordiais para apoiar sua implementação, ao lado de sua atratividade econômica.

O potencial energético é caracterizado como a capacidade de operação de cada tecnologia e o volume de energia convertido de fontes energéticas, de acordo com diferentes fatores de eficiência e rendimentos.

A segurança do suprimento energético é um objetivo prioritário de políticas energéticas internacionais - tanto em termos de oferta física quanto de custo dos recursos. De acordo com o mais recente World Energy Outlook, 81,3\% da demanda energética global é atendida por combustíveis fósseis (IEA, 2010). Diversos são os motivos para preocupação, uma vez que a crescente demanda é predominantemente atendida por recursos finitos e mal distribuídos regional e globalmente - muitos países e regiões dependem de grandes volumes de importação de energéticos. Por outro lado, fontes renováveis provêm de uma variedade de estoques naturais constantemente repostos e não esgotáveis.

De acordo com a Associação de Pesquisa à Energia Solar, energias renováveis são capazes de produzir cerca de 2.850 vezes a quantidade de energia demandada no mundo. Ainda que apenas uma pequena quantidade desse potencial seja tecnicamente acessível, a energia seria suficiente para atender o sêxtuplo da demanda que o mundo necessita atualmente. A discussão sobre os limites desse potencial, de extrema importância, é feita no próximo item.

\subsubsection{Tipos de Potenciais Energéticos}

O potencial energético teórico é a quantidade de energia que pode ser produzida com base em reservas e estoques de recursos primários considerando seu potencial físico máximo, negligenciando restrições geográficas - como ocupação territorial de um recurso - e perdas técnicas - de conversão e rendimento de tecnologias. 
Essas restrições são incorporadas no cálculo do potencial técnico ou realizável, que considera a eficiência de conversão de cada tecnologia - variável ao longo do tempo - demais restrições técnicas e estruturais - como uso de espaço -, sociais e ambientais.

A análise desse potencial técnico varia consideravelmente de acordo com a fonte. O potencial técnico de energias renováveis é estimado em até $15.857 \mathrm{EJ}$ por ano (UBA 2009), representando cerca de 32 vezes a demanda energética primária mundial, de 503 EJ por ano (IEA, 2009). Esse potencial não pode ser plenamente utilizado em função de diferentes restrições de ordem econômica e política. O novo potencial realizável resultante desse refinamento é chamado de potencial de mercado e contabiliza recursos viáveis de implantação em comparação a outras opções energéticas.

A valoração de potenciais pode ser dividida por faixas de potência, dentro das quais se identificam particularidades referentes a fatores de eficiência e custos de implantação e geração.

Os próximos itens abordam o estado da arte da avaliação de potenciais dos principais recursos energéticos, avaliadas por diferentes metodologias de levantamento e contabilização conduzidas por diferentes entidades e instituições.

\subsubsection{Potencial Teórico de Recursos Energéticos}

O cálculo dos potenciais teóricos fundamenta-se em duas premissas básicas: o levantamento da quantidade de fontes primárias disponíveis e a consideração da tecnologia mais eficiente de conversão (FUJII, UDAETA, 2006).

O levantamento da quantidade de fontes primárias determina a quantidade de energia conversível e aproveitável na região analisada, de acordo com o grupo de tecnologias empregadas. Além do estoque energético anual de cada fonte, outro atributo essencial à avaliação é sua característica renovável, a fim de mensurar sua disponibilidade e grau de reposição - se houver - em médio e longo prazo. A disponibilidade de fontes primárias também pode ser categorizada por critérios como a facilidade de acesso e extração. Para fontes energéticas fósseis e nucleares, em particular, deve-se analisar a durabilidade de reservas. 
A energia útil convertida com base nesse potencial bruto é função da eficiência das diferentes tecnologias de conversão consideradas para cada recurso.

Como premissas particulares ao cálculo de potenciais teóricos de cada recurso, listam-se a disponibilidade de áreas (para o cultivo de biomassa e o aproveitamento e instalação de sistemas de energias eólica, solar e oceânica), o estudo de bacias hidrográficas (para aproveitamentos hidrelétricos), entre outros.

As maiores potencialidades teóricas nacionais são representadas pela energia solar, eólica e hídrica, respectivamente.

De acordo com o Atlas Solarimétrico do Brasil (TIBA et al, 2003), o país apresenta média anual de radiação global entre 1642 e $2300 \mathrm{kWh} / \mathrm{m}^{2} / \mathrm{ano}$, o que significa que se apenas $5 \%$ de toda essa energia fosse aproveitada, toda a demanda brasileira atual por eletricidade poderia ser atendida. A radiação pode ser convertida em eletricidade por dois grupos principais de tecnologias: painéis fotovoltaicos e usinas de energia solar concentrada.

Em seguida, a energia eólica tem um potencial nacional estimado em 143 mil MW, segundo o Atlas Eólico Nacional (AMARANTE et al, 2001) e reavaliado para valores superiores a $300 \mathrm{mil} \mathrm{MW}$ de acordo com levantamentos estaduais em curso. Esse número considera apenas turbinas onshore; o potencial offshore entre os estados do Rio Grande do Sul e Rio de Janeiro é estimado em outros 102 mil MW (PIMENTA et al, 2008). Seu aproveitamento ocorre pela conversão da energia cinética de translação em energia cinética de rotação, com o emprego de turbinas eólicas ou aerogeradores.

O aproveitamento da energia hidráulica se dá pela conversão da energia mecânica de águas em desníveis naturais (a fio d’água) ou artificiais (produzidos por barragens e/ou reservatórios. O potencial brasileiro teórico para a geração hidrelétrica em usinas de grande porte supera os 260 mil MW (EPE, MME, 2010), dos quais boa parte se concentra na região norte do país. Adicionalmente à implantação de grandes usinas, o espaço para a utilização de pequenos aproveitamentos hidrelétricos - até $30 \mathrm{MW}$ - é estimado em 25.913 MW no Brasil (TIAGO et al, 2007), com melhor distribuição entre as regiões do país e $27 \%$ na região sudeste, região de maior demanda energética no país.

A energia de biomassa vale-se de diferentes processos para a conversão de energia, entre sistemas térmicos, que envolvem a combustão direta de 
sólidos, líquidos ou gases por pirólise ou gaseificação ou sistemas biológicos, que envolvem a decomposição de biomassa sólida em combustíveis líquidos ou gasosos por processos de fermentação ou digestão anaeróbica. Destes, o potencial mais notável para a geração de energia elétrica é o calculado pela cogeração a bagaço e da palha de cana-de-açúcar. Considerando uma produção estimada de 1 bilhão de toneladas de cana-de-açúcar até a safra de 2020/21, pode produzir cerca de 14 mil MW médios de eletricidade, segundo a União da Indústria de Cana-de-Açúcar (ÚNICA) (2009).

Por fim, a energia oceânica representada pela energia das ondas poderia atender a uma parcela significativa do suprimento de eletricidade mundial no futuro, podendo gerar cerca de 90 mil TWh por ano. Considerando a extensão da costa brasileira, estima-se que o potencial teórico nacional poderia atender até 15\% da demanda elétrica do país (COPPE, 2009, apud EPE, 2010).

O potencial de obtenção de energias térmicas fósseis e nucleares está vinculado às tecnologias de conversão em eletricidade, mas, primordialmente, ao volume do estoque natural disponível para esses combustíveis - localmente ou não. A geração de energia elétrica por derivados de petróleo como óleo combustível e diesel ocorre por meio da queima direta desses combustíveis em caldeiras, turbinas e motores de combustão interna ou da cogeração de energia térmica desses combustíveis em diferentes processos.

A estimativa de reservas de combustíveis fósseis apresenta grande variação de acordo com fontes consultadas, por diferentes motivos políticos, técnicos e comerciais. Alguns números são divulgados por empresas e governos sem análise ou verificação, com diferenças físicas e conceituais. As reservas recuperáveis de petróleo são estimadas em 2,67 trilhões de barris. Adiciona-se a esse volume a participação de reservas não convencionais de petróleo. De elevados custos de exploração e custos ambientais de recuperação, esse potencial é estimado em até 6 trilhões de barris de petróleo.

O gás natural, combustível fóssil de maior expansão nas últimas duas décadas, apresenta reservas de 182 trilhões de metros cúbicos perspectivas de utilização mais longas que derivados de petróleo, por conta de suas reservas recuperáveis - o campo de gás mais extenso do mundo guarda cerca de $15 \%$ das reservas recuperáveis mais recentes, comparado a $6 \%$ para o caso do petróleo. A questão sobre a qualidade de dados repete-se nesse caso, com 
ambiguidade sobre volumes produzidos dada a não contabilização de gás queimado em flares - cuja média no Brasil chega a 30\%.

Antes de ser superado pelo petróleo, o carvão era a maior fonte de energia primária global. As reservas globais recuperáveis, estimadas em 847 bilhões de toneladas, são as mais elevadas dentre combustíveis fósseis e grandes consumidores de energia como Estados Unidos, China e Índia permanecerão autossuficientes em carvão por um longo horizonte de tempo ${ }^{133}$.

Encerrando o grupo de recursos energéticos não renováveis para a geração termelétrica, o urânio, utilizado em usinas nucleares, é um recurso finito de distribuição global extremamente limitada; cinco países - Canadá, Austrália, Cazaquistão, Rússia e Niger - controlam três quartos da oferta mundial. O Brasil é apontado como o sétimo potencial energético em termos de reservas provadas. Estima-se que as reservas de urânio e combustíveis nucleares derivados devem atender às usinas nucleares atuais por menos de 70 anos ${ }^{134}$.

\subsubsection{Potencial Realizável}

O potencial realizável corresponde ao refinamento do potencial teórico de um recurso energético, incorporando restrições de ordem social, ambiental, bem como demais restrições técnicas identificadas no aproveitamento desse recurso. O potencial realizável indica, portanto, a capacidade energética implantável de um recurso, independentemente de sua viabilidade econômica.

Restrições político-econômicas são posteriormente incorporadas na análise de potenciais de mercado, que analisa esse potencial economicamente viável de cada recurso energético.

As restrições técnicas e socioambientais são particulares a cada tipo de recurso e projeto e concretizam-se na forma de licenças e determinações de órgãos ambientais. Essas medidas selecionam, de forma natural, a implantação de recursos e contribuem para a aferição do potencial realizável. A conceituação

\footnotetext{
${ }^{133}$ Extrapolando projeções de demanda, o mundo deve consumir cerca de $20 \%$ das reservas atuais de carvão até 2030 e $40 \%$ até 2050. Assim, com a manutenção desta tendência, o carvão ainda estará disponível por alguns séculos.

${ }^{134} \mathrm{Um}$ relatório conjunto entre a Agencia de Energia Nuclear (NEA) da OECD e a Agencia Internacional de Energia Atômica estima que as usinas nucleares existentes terão utilizado seu combustível, com base em tecnologia atual, em menos de 70 anos. A previsão inclui o uso de combustível de óxido misto (MOX), uma mistura de urânio e plutônio.
} 
dessas restrições, ou vigilantes, é trabalhada na etapa de mapeamento ambiental.

A geração solar apresenta baixa restrição de instalação e utilização de espaço, mesmo em coberturas de edifícios. Exceção é feita a áreas com ocorrência de sombreamento e tempo usualmente nublado. Usinas heliotérmicas apresentam restrições mais rigorosas; sua viabilidade restringe-se a áreas áridas e semiáridas, com incidência de radiação solar perpendicular aos painéis. Restrições socioambientais concentram-se no caso de geração solar concentrada por conta da utilização de água e da oposição de grupos da sociedade civil à ocupação de áreas desérticas para a implantação de sistemas.

A energia eólica é a fonte renovável de maior crescimento mundial. A capacidade instalada vem crescendo a taxas anuais próximas a $30 \%$ nos últimos 5 anos. Restrições técnicas concentram-se em gargalos de suprimento de tecnologias de turbinas por conta do boom de demanda de construção de parques, na redução progressiva de sítios com fatores de capacidade e aproveitamento eólico favoráveis ${ }^{135}$, ou restrições socioambientais de implantação indevida em áreas de proteção ambiental, dunas ou sítios arqueológicos.

No Brasil, a geração hidrelétrica aproveita atualmente cerca de $30 \%$ do potencial técnico. O restante está inventariado (38\%) ou estimado (32\%) (EPE, 2007). A região norte apresenta o menor aproveitamento desse potencial (9\%), por conta de restrições de exploração de utilização de territórios indígenas e unidades de conservação e de maiores dificuldades técnicas de transmissão dessa energia até os principais centros de consumo do país. O processo de licenciamento ambiental também contribui para o atraso de diferentes projetos, principalmente, no caso de pequenas centrais hidrelétricas. O potencial de 25 mil MW traduz-se em um total instalado de 4 mil MW (EPE, 2010); muitos projetos planejados estão atrasados por conta de dificuldades na obtenção de licenças ambientais e outros entraves técnicos burocráticos.

A capacidade instalada de geração de eletricidade por biomassa no Brasil é superior a 7,5 mil MW (ANEEL, 2010). O potencial desse recurso poderia ser

\footnotetext{
${ }^{135}$ A tendência pode ser observada em mercados mais saturados como o europeu; a oferta por disponibilidade de áreas com elevados potenciais permanece em regiões com alto índice de potencial terrestre não explorado na América do Sul e do Norte.
} 
mais aproveitado se fossem superadas algumas limitações técnicas como a estrutura de conexão entre usinas e a rede básica, a necessidade de substituição de caldeiras de baixa para alta pressão em usinas para a cogeração a bagaço de cana. Outra porção desse potencial poderia ser aproveitada com o uso da palha para geração de energia ${ }^{136}$. Atualmente, ainda detecta-se o desperdício desse potencial por conta da queima a céu aberto para facilitação da colheita manual da cana-de-açúcar $^{137}$. Outras limitações óbvias relacionam-se à utilização de territórios livres de implicações sobre fronteiras agropecuárias ou prejuízos à conversão de florestas.

Ainda que o limite energético teórico de fontes fósseis possa ser potencializado para utilização local com a importação de combustíveis, os potenciais realizáveis são condicionados a diferentes limites técnicos e ambientais. No caso do gás natural, o limite de utilização local do combustível é proporcional à sua exploração ou, no caso de regiões que recebem o combustível de outros locais, à estrutura de distribuição até eles. No caso do carvão, limitações de custo de transporte favorecem o consumo local da fonte. Mais recentemente o teto de emissões para termelétricas movidas a combustíveis fósseis, implantados em estados norte-americanos, tem restringido parte de sua crescente utilização global $^{138}$.

Por fim, o aproveitamento do urânio e outros combustíveis para a geração nuclear dependem de fatores relacionados à cadeia de produção do combustível. Em primeiro lugar, citam-se a qualidade e a proporção de urânio obtida em minérios e o aumento em sua dificuldade de extração. Tal desafio técnico aumentará ao longo das décadas ${ }^{139}$, quando o urânio poderá ser extraído de fontes secundárias como minas de grandes profundidades, subterrâneas

\footnotetext{
${ }^{136} \mathrm{O}$ aproveitamento da palha e pontas da planta é determinado pelo coeficiente de disponibilidade, que varia em função da condição de topologia da área plantada, do tipo de colheita, se mecanizada ou manual, sem queima e da disponibilidade de tecnologias e infraestrutura de processamento e transporte.

${ }^{137}$ Estima-se que o potencial da palha seja igual ao do bagaço, pois cada tonelada de cana apresenta $280 \mathrm{~kg}$ de palha com $50 \%$ de umidade.

${ }^{138} \mathrm{O}$ carvão foi a maior fonte de energia primária no mundo até ser superado pelo petróleo nos anos 60. Atualmente, sua participação na matriz energética mundial é de cerca de $42 \%$ (IEA, 2009).

${ }^{139}$ Estima-se que a capacidade de mineração de urânio terá que ser duplicada nos próximos anos a fim de atender à crescente demanda de reatores operantes e em construção.
} 
(debaixo de florestas) ou mesmo submarinas. Em segundo lugar, o potencial realizável é função da reutilização e do reprocessamento de combustíveis utilizados, que ainda não tem viabilidade técnica, logística e comercial comprovada.

\subsubsection{Potencial de Mercado}

O potencial energético de mercado concentra-se na discriminação, dentro de um universo de empreendimentos energéticos, daqueles que demonstram sustentabilidade econômica e financeira, avaliando-se, em cada projeto, seu modelo de captação de recursos, esquemas de financiamento, formação competitiva e atrativa de preços - em relação a outros projetos similares e projetos em outras fontes energéticas - e garantia de venda de energia. Além do mérito econômico, outros fatores que balizam a dinâmica de avaliação do potencial de mercado são riscos político-econômicos, exemplificados por inclinações de apoio governamental, oscilações de investidores e diferentes riscos geopolíticos como variação de suprimento de combustíveis fósseis e variação da taxa de câmbio internacional - com sérios reflexos sobre componentes tecnológicos importados.

O potencial de mercado deriva-se do potencial energético teórico em paralelo ao potencial realizável. Essa estruturação ocorre, pois o potencial de mercado analisa as implicações decorrentes de custos de opções energéticas, sem necessariamente considerar todo o conjunto de implicações analisadas no potencial realizável, como questões socioambientais. Dessa forma, observam-se situações de projetos economicamente viáveis, como pequenas centrais hidrelétricas que não são construídos por dificuldades de obtenção de licenças ambientais e oposição de comunidades afetadas pelo empreendimento.

Em relação a energias renováveis, o potencial de mercado tem-se mostrado altamente favorável nos últimos cinco anos; no ano de 2009, o setor movimentou 162 bilhões de dólares, cifra superior à quantidade movimentada em novos investimentos fósseis (PNUMA, 2010). O crescimento das energias eólica e solar desde 2004 , de $600 \%$ e $250 \%$, respectivamente, foi possível com medidas e programas de incentivos e pacotes de estímulo econômico, que apoiarão a não interrupção dessa tendência de crescimento nos últimos anos, apesar da redução de crédito no mercado financeiro como consequência da crise financeira global. 
As restrições ambientais impostas pelas mudanças climáticas e pelo reforço de tratados climáticos internacionais indicam a projeção de investimentos ainda maiores no futuro.

O mercado mundial de painéis fotovoltaicos tem crescido a mais de $35 \%$ ao ano nos últimos anos. O desenvolvimento está concentrado em aumentar a eficiência energética e reduzir o uso de matéria prima em sistemas e módulos. As células fotovoltaicas têm registrado considerável queda de preço nos últimos anos, seguindo uma redução aproximada de $20 \%$ a cada duplicação da capacidade instalada. A meta de custo de US\$1/W deve ser alcançada nos próximos dez anos, tornando as células competitivas em relação aos preços de tarifas elétricas praticadas atualmente. Tendência parecida é observada na energia solar concentrada, cuja grande expansão internacional acompanhada do desenvolvimento tecnológico de armazenamento de calor projeta seus custos futuros em patamares competitivos, entre $\mathrm{R} \$ 100$ e 180/MWh.

O mercado eólico tem-se diversificado nos últimos anos. O domínio alemão já foi superado pelos Estados Unidos (maior capacidade instalada desde o final de 2009) e pela China (maior número de fabricantes e próximo de superar o parque instalado alemão). Assim, os custos devem cair como consequência da maior disponibilidade física e geográfica da cadeia produtiva ${ }^{140}$.

A situação brasileira é análoga. A sinalização da realização de leilões para a fonte eólica tem trazido diferentes fabricantes internacionais ao país e condições oferecidas a projetos em termos de isenção e redução de impostos reduziu drasticamente o preço da energia ${ }^{141}$.

A viabilidade futura da geração de eletricidade a biomassa está relacionada às condições oferecidas a esse recurso, em termos de reduções e isenções de encargos e impostos e condições de financiamento de substituição de caldeiras de baixa pressão em usinas. A formação de preço depende ainda das condições de distribuição de energia acordadas entre usinas e o operador do sistema - este componente pode ser responsável pelo aumento significativo do preço final disponibilizado por usinas distantes da linha básica de transmissão.

${ }^{140} \mathrm{Em} \mathrm{2009}$, mais de 70\% do Mercado anual de energia eólica situavam-se em regiões fora da Europa, tendência que deve expandir-se no futuro.

${ }^{141}$ A redução de $\mathrm{R} \$ 280 / \mathrm{MWh}$ de projetos participantes do Proinfa para $\mathrm{R} \$ 148 / \mathrm{MWh}$ para projetos participantes do leilão de energia eólica tornam esse tipo de geração competitiva com os demais tipos de geração termelétrica, a biomassa ou de PCHs. 
Já a biomassa líquida, ou biocombustível, tem seu potencial de mercado vinculado à evolução do preço do petróleo, podendo tanto acompanhar a tendência de alta de preços, quanto retardar a inserção de combustíveis de segunda geração em um cenário de lucratividade dos energéticos correntes. A taxa cambial também exerce influência sobre esse potencial, com a variação da disponibilidade de álcool para exportação e consequentemente para consumo veicular (HUAYLLAS, 2006).

No campo dos combustíveis fósseis, o potencial de mercado do petróleo varia em função do preço do barril, condicionado a exequibilidade e recuperabilidade de reservas atuais e futuras. Essa equação, por sua vez, está atrelada à viabilidade econômica desse óleo - por conta dos preços do barril neste momento - e à manutenção de baixos padrões ambientais de produção de combustível e emissões de gás carbônico. Vale lembrar que a tendência política aponta para restrições crescentes à utilização de combustíveis fósseis e o acompanhamento dessas restrições na imposição de crescentes taxas progressivas sobre a emissão de carbono.

O carvão pode, por um lado, acompanhar a tendência de alta de preços e redução de potencial de mercado, de acordo com a evolução da economia internacional e a taxação da energia fóssil. Por outro lado, o crescimento da demanda por aço em países em desenvolvimento, atendido por indústrias eletrointensivas, ainda oferece boas opções de mercado a um carvão a preços baixos e reservas abundantes. Essa viabilidade pode ser comprometida por dificuldades logísticas de escoamento da produção e gargalos de infraestrutura de mineração e transporte, cuja expansão em países em desenvolvimento ainda é lenta e custosa ${ }^{142}$.

Em relação aos recursos energéticos fósseis, o potencial de mercado contabiliza também a tecnologia de conversão, ou seja, as termelétricas, e sua viabilidade é diretamente associada às condições tarifárias oferecidas à instalação das usinas. No Brasil, o baixo custo de instalação de termelétricas a gás e óleo combustível e a transferência do preponderante custo do combustível para uma componente de custo variável resultou na aprovação de um grande

\footnotetext{
142 OSTER, S. et al, "China Spurs Coal-Price Surge", Publicado no Wall Street Journal em 12 de fevereiro de 2008.
} 
número de usinas termelétricas nos leilões A-3 e A-5 dos últimos anos (PRADO, HEIDEIER, 2008).

O potencial de mercado do recurso nuclear está vinculado tanto ao custo das usinas quanto do combustível urânio. $O$ custo de reatores vem registrando tendência de subidas, em decorrência do aumento de custo de materiais e da perda progressiva de know how tecnológico para a construção de usinas ${ }^{143}$. A incerteza quanto ao custo final de reatores tem minado o potencial de mercado desse recurso diante de investidores privados e o risco de construção é arcado pelo setor público em todas as regiões do globo.

O custo de combustível também afeta o custo do recurso nuclear, com tendência de grande oscilação nos últimos anos. O suposto renascimento nuclear nos Estados Unidos foi contido pela crise financeira e o potencial de mercado do recurso deve consolidar-se apenas após a implantação dos primeiros reatores entre 2016 e 2018, que deve dar uma sinalização mais clara em relação ao tempo de construção e à estimativa de orçamento desses projetos ${ }^{144}$.

\subsubsection{Algoritmo de Cômputo e Valoração}

O algoritmo de valoração de potenciais energéticos parte da construção do potencial teórico, função de diferentes variáveis para a conversão de potencial bruto mecânico, térmico ou químico das diferentes fontes energéticas em energia elétrica.

Assim, as possíveis variáveis de entrada dessa função são: velocidade (de fluidos, da água ou do ar), vazão (da água), queda bruta (de rios), temperatura e pressão (de vapor), densidade (do ar ou de outros gases), peso específico (do ar, da água ou de outros elementos), volume (de ar, água e combustíveis), poder calorífico (de combustíveis), radiação incidente (solar), latitude, área (extensão territorial de culturas naturais ou área de canais), entre muitos outros.

A conversão desse potencial em energia depende ainda da eficiência e do rendimento das tecnologias e processos envolvidos nessa transformação, medidos em porcentagens ou aproveitamentos fracionários.

\footnotetext{
${ }^{143}$ O exemplo da usina Olkiluoto na Finlândia é o mais emblemático, demonstrando uma sequência de equívocos de projeto, com repercussão sobre o tempo de construção e o custo final da usina.

144 WOODALL et al, "Economic Woes delay U.S. nuclear Power expansion", publicado em http://www.reuters.com em 17 de março de 2009.
} 
O potencial realizável refina o valor teórico em vista de diferentes restrições técnicas e socioambientais. Assim, considera-se para esse cômputo, perdas técnicas e restrições como dificuldades de acesso e extração de combustíveis ou aproveitamentos energéticos renováveis, a simultaneidade de usos energéticos em um mesmo espaço - resultando diversas vezes na opção de uma sobre a outra - ou a progressiva redução de sítios para o aproveitamento ótimo de recursos renováveis e não renováveis. Ainda na área técnica, considera-se também a limitação de recursos energéticos de usos múltiplos, como a água (para transporte, irrigação e geração de eletricidade) ou o gás natural (para calor e eletricidade em diferentes setores).

O potencial realizável trabalha, ainda que de forma preliminar, restrições socioambientais à implantação de usinas ou sistemas energéticos em áreas nãoapropriadas por diferentes justificativas ambientais, sociais, culturais históricas ou éticas ou restrições ambientais decorrentes de limites de emissões ou contaminação dos meios aéreo, terrestre ou aquático local. Essas restrições são aferidas na etapa de mapeamento ambiental, que precede a integração de recursos energéticos.

Como segunda derivação do potencial teórico, o potencial de mercado infere a proporção, da energia gerada teoricamente, comercializável dentro de regras de mercado e em condições de atratividade econômica determinadas por empreendedores ou mesmo incentivos governamentais. Assim, as variáveis trabalhadas nessa função retratam as condições econômicas e financeiras de cada projeto, entre elas: faixas de preço, risco, taxas de retorno, além de variáveis mais abstratas como fatores geopolíticos e internacionais como taxas de câmbio ou cotações do barril de petróleo.

Esse potencial bruto é equiparado à função indexada a tarifas energéticas médias (como preço teto de leilões de energia) e demais preços de mercado (mercado livre, por exemplo), a fim de determinar o potencial de mercado.

Assim, o potencial final é um algoritmo variável em função do tempo: o potencial teórico apresenta variação técnica de eficiência, rendimento e disponibilidade de sítios; o potencial realizável percebe o aumento de restrições em função da diminuição da disponibilidade de recursos; e o potencial de mercado oscila de forma considerável de acordo com condições econômicas em 
cada cenário político e seu aprimoramento de acordo com evoluções tecnológicas.

A figura 32 ilustra o processo de cômputo de potenciais energéticos.

\section{Algoritmo CVPC Potenciais Energéticos}

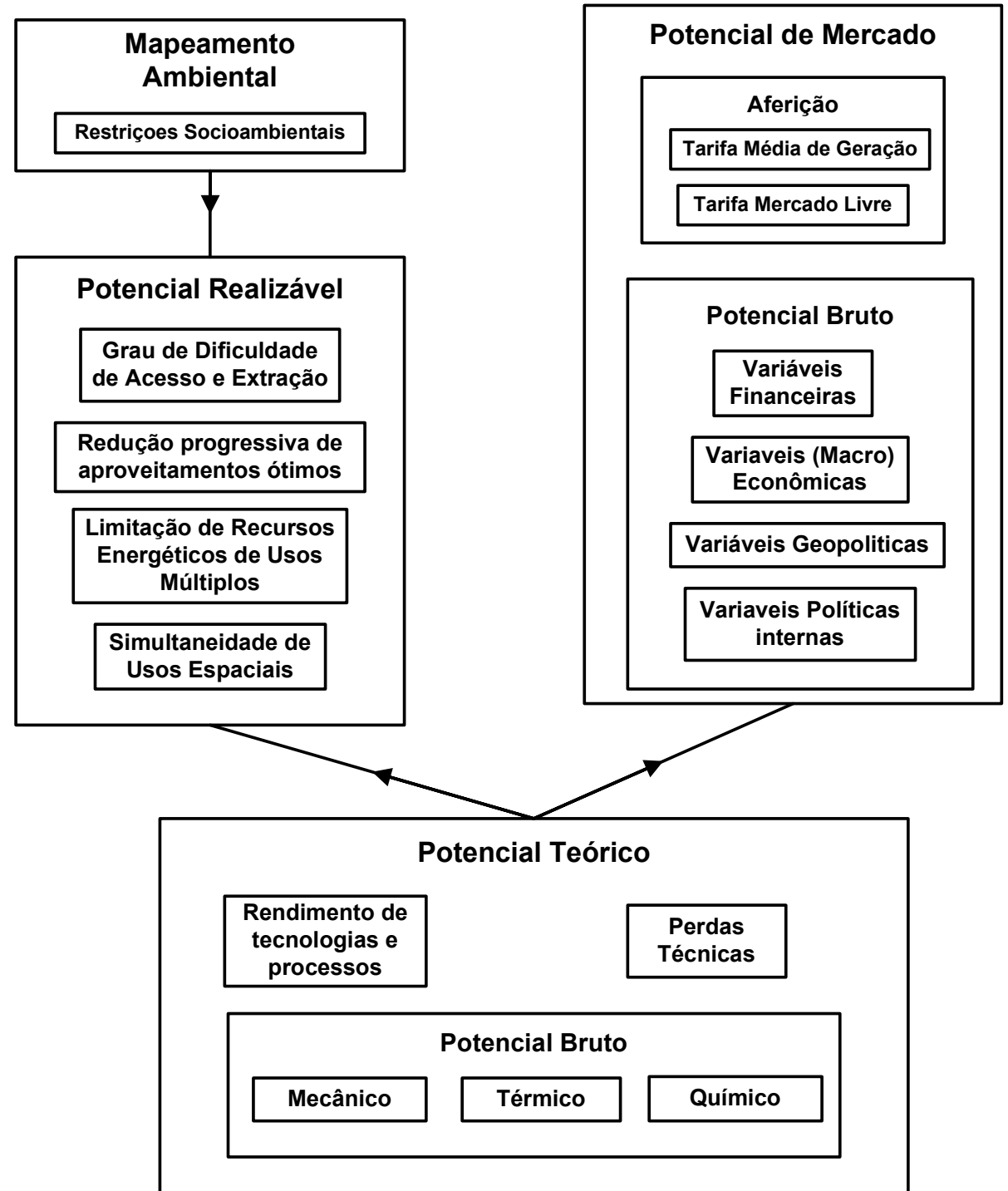

Fonte: Elaboração Própria

Figura 32: Algoritmo de cômputo e valoração do atributo Potenciais Energéticos 


\subsubsection{Qualidade de Energia}

O conceito de qualidade de energia abrange uma série de parâmetros que devem ser cumpridos a fim de evitar a alteração ou perturbação de sistemas e redes elétricas e garantir o funcionamento adequado, contínuo e seguro de equipamentos elétricos (DUGAN, 2002).

De acordo com BOLLEN (2003), a qualidade de energia abrange conceitos como qualidade de tensão (desvios de tensão considerando a forma senoidal como referência), qualidade de corrente (análogo à tensão, considerando desvios de referência senoidal), qualidade de potência (por meio da análise de potências ativa e reativa e fator de potência) e qualidade de fornecimento (envolve a qualidade técnica da energia bem como aspectos relacionados à qualidade do atendimento de energia ao consumidor).

Os problemas de qualidade de energia dependem essencialmente da sensibilidade e da vulnerabilidade dos equipamentos envolvidos, tanto do lado da oferta, conectados à rede para a produção de energia, quanto da demanda, consumindo energia da rede elétrica. Assim, o atributo analisa de forma integrada a alteração da qualidade de energia gerada por recursos energéticos dos lados da oferta ou alterada por recursos do lado da demanda.

Do lado da oferta, a análise da qualidade de geração de grande porte relaciona-se, de forma geral, a parâmetros que medem confiabilidade, disponibilidade e intermitência de cada tipo de fonte e tecnologia empregada para sua conversão - tópicos já abordados neste texto. Dessa forma, o atributo concentra a análise da qualidade de energia em gerações de pequeno porte em sistemas desconectados da rede - representados como recursos energéticos do lado da oferta - e em alterações provocadas por sistemas ou equipamentos finais conectados à rede - representados como recursos energéticos do lado da demanda.

Em sistemas de pequeno porte, a conexão à rede pode demandar reforço da rede para lidar com a alteração de parâmetros da energia. Já no caso da demanda, o uso de equipamentos de uso final pode trazer implicações sobre a qualidade da energia de residência, edifícios e mesmo à rede de distribuição. Em casos mais graves, o desvio ou o furto de eletricidade da rede, conhecido popularmente como gato, tem implicações sobre questões de segurança, 
aumentando o risco de acidentes, além de prejudicar a qualidade técnica da energia para demais consumidores no mesmo subsistema.

Demais perdas que impactam a qualidade da energia oferecida a consumidores relacionam-se a perdas em equipamentos como medidores e cabos condutores e perdas não técnicas, como erros de medição e calibração. Entretanto, a análise do atributo, conforme indicado anteriormente, é focada nos lados da oferta e demanda, e, portanto, não abrange a avaliação da qualidade de energia relacionada a sistema de transmissão e distribuição - ainda que essas etapas sejam responsáveis por parte dos problemas de perda e interrupções ${ }^{145}$.

Os fatores analisados na valoração da qualidade de energia referem-se aos distúrbios manifestados na energia da rede elétrica em decorrência da utilização de sistemas de pequeno porte ou equipamentos de uso final. Os principais problemas associados à qualidade de energia elétrica, de acordo com PIRES (2006) apud DUGAN (2002) são:

- transitórios: transitório impulsivo (impulso unidirecional sem alteração na frequência de estado permanente da tensão e corrente, sendo unidirecional) e oscilação (positiva e negativa, sem alteração na frequência de estado permanente da tensão e corrente);

- variações de tensão: sobretensão (aumento no valor eficaz da tensão em 10\% ou mais para uma duração mínima de 1 minuto), subtensão (diminuição no valor eficaz da tensão em $10 \%$ ou mais para uma duração mínima de 1 minuto), flutuação (variações entre 0,9 e 1,1 pu do valor eficaz de tensão) e interrupção (sustentada por um período maior que 1 minuto ou de curta duração, abaixo de 0,1 pu por menos de 1 minuto);

- desbalanceamento: Desvio máximo da média de cada tensão ou corrente de fase dividido pela média das tensões ou correntes de fase (expresso em porcentagem);

- distorção da forma de onda: presença de tensão ou corrente contínua no sistema elétrico, harmônicos (tensões ou correntes de frequências

\footnotetext{
145 A avaliação da interrupção de energia conta com diferentes indicadores utilizados por concessionárias, como Duração ou Frequência Equivalente de Interrupção por Consumidor (DEC e FEC, respectivamente) ou Duração ou Frequência Equivalente individual por unidade consumidora (DIC e FIC, respectivamente). Esses parâmetros não são trabalhados neste atributo por restringirem sua análise de qualidade ao suprimento de energia a consumidores finais.
} 
múltiplas ou derivadas da frequência fundamental presentes na forma de onda de tensão ou corrente), notching (distúrbio periódico de tensão causado pela operação de componentes eletrônicos de potência durante comutação de fase), ruído (sinais indesejáveis superpostas a tensão ou corrente, em frequências até $200 \mathrm{kHz}$ );

- variações na frequência da rede: desvios na frequência fundamental, com resultados como o flickering (flutuação na iluminação).

\subsubsection{Alteração de Qualidade de Energia em Sistemas de Geração de Pequeno Porte (RELO)}

Sistemas de geração de pequeno porte são comumente implementados em locais isolados da rede de distribuição de energia elétrica e, portanto, armazenam a energia gerada, proveniente de uma ou mais fontes renováveis, em bancos de baterias.

A configuração típica do sistema estudado é constituída por um gerador, um banco de baterias, um regulador de carga (para o controle dos limites de carga no banco de baterias) e um inversor estático (para a conversão da tensão CC em tensão CA). Assim, a forma de onda dessa tensão dependerá da qualidade do inversor e dos métodos de conversão e filtragem utilizados para suavizá-la e eliminar os harmônicos indesejáveis, que resultam do processo de conversão (BONFIM et al., 1998).

Em suma, os fatores de alteração da qualidade de energia observados em sistemas de geração são:

- Suscetibilidade a interrupções no fornecimento: sistemas renováveis de pequeno porte são suscetíveis a interrupção do fornecimento de energia elétrica às cargas, em casos de projetos com bancos de bateria, destinados ao atendimento de energia restrito a um determinado período do dia. Nessas situações, a geração renovável pode se mostrar insuficiente para repor a energia demandada pela carga no banco de bateria, por conta de fatores como a sazonalidade da geração.

- Variação do valor eficaz da tensão de saída do inversor: A variação da tensão de saída de inversores de pequeno porte em equipamentos é proporcional ao valor da tensão instantânea do banco de baterias. Assim, 
o decaimento da tensão do banco de baterias em decorrência de consumo de energia ou a entrada de cargas novas resulta na redução da tensão eficaz de saída do inversor, com impacto direto à vida útil das cargas alimentadas pelo inversor.

- Desequilíbrios em sistemas monofásicos e trifásicos: Os desequilíbrios de tensão acontecem, principalmente, no atendimento a cargas monofásicas (em alguns casos, maioria em sistemas de pequeno porte) e cargas não-lineares (como os casos de equipamentos de iluminação fluorescente, televisores, entre outros).

- Harmônicos: Correntes com conteúdo harmônico produzida por cargas não-lineares introduzem componentes harmônicas na tensão de alimentação. A influência é maior em sistemas de geração de pequeno porte, de baixa capacidade de curto-circuito e demanda próxima à potência de suprimento do sistema. Conteúdo harmônico pode resultar também de alimentações feitas por inversores de onda não senoidal.

A influência da geração de fontes de pequeno porte em cargas resistivas, como lâmpadas incandescentes, ferro elétrico e chuveiro elétrico, analisada por Galhardo e Pinho, mostra formas de onda semelhantes para corrente e tensão, com taxas de distorção harmônica iguais (TDHi e TDH da tensão de alimentação). Já a alimentação de motores por inversores de onda não senoidal (onda quadrada) provocam perdas no ferro e no cobre e presença de harmônicos no fluxo magnético, com alterações sobre seu acionamento.

Esse tipo de tensão provoca também a redução de rotação, potência máxima e vida útil de aparelhos. A tensão e a corrente medidas em um ventilador alimentado por um inversor de onda quadrada são mostradas na figura 33. 


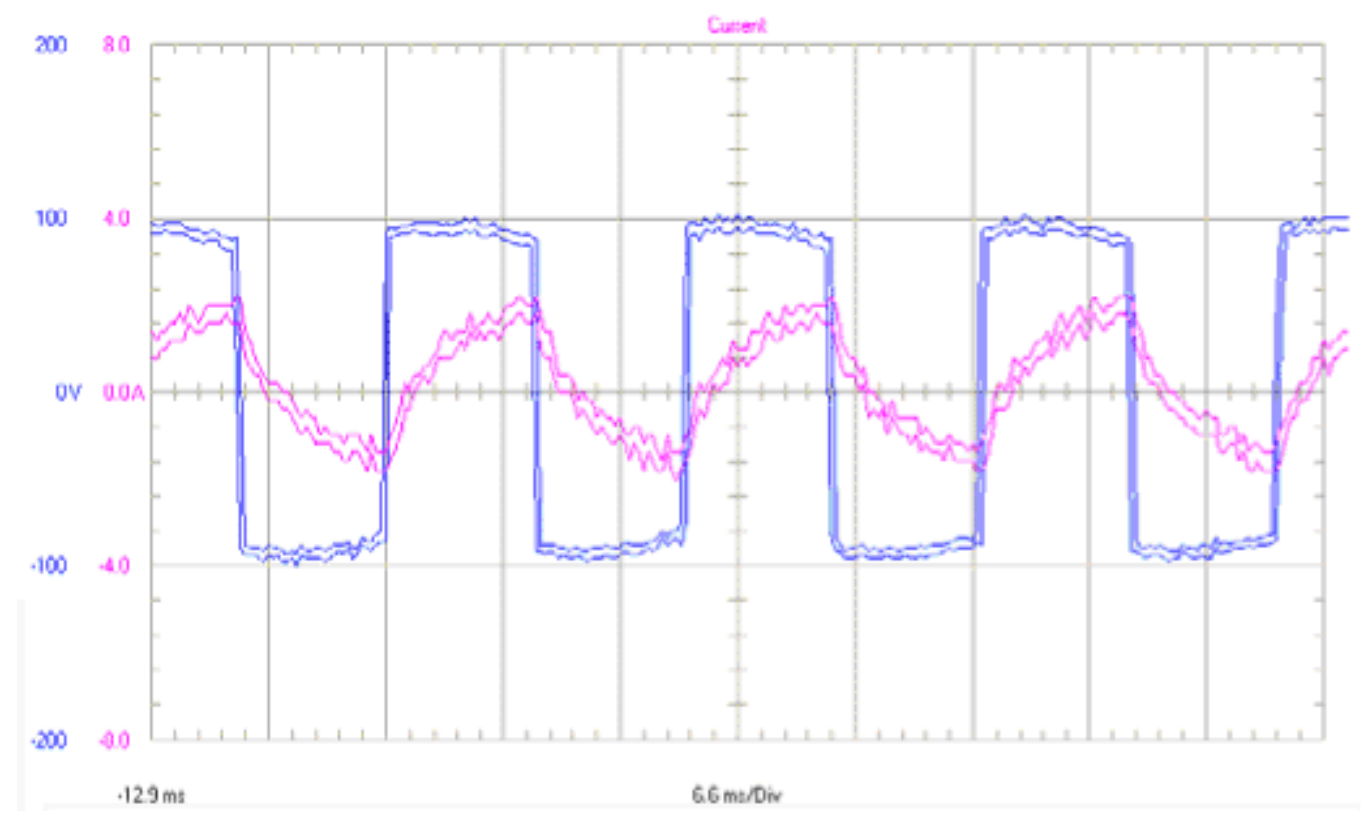

Figura 33: Tensão e corrente medidas em ventilador alimentado por um inversor de onda quadrada

A utilização de fontes não senoidais para a alimentação de cargas com fontes chaveadas, como computadores, impressoras e aparelhos de TV, apresenta variação de harmônicos, corrente de pico e demanda de energia reativa, em relação à alimentação senoidal. Estes números podem ser vistos na tabela a seguir:

Tabela 10: Características de Qualidade de Energia em Eletrodomésticos

\begin{tabular}{|c|c|c|c|c|c|c|}
\hline Equipamento & \multicolumn{4}{|c|}{ Microcomputador } & \multicolumn{3}{c|}{ Televisão } \\
\hline Parâmetros & Senoidal & Quadrada & Quadr.Modif. & Senoidal & Quadrada & Quadr.Modif. \\
\hline Tensão eficaz (V) & 118 & 108 & 117 & 120 & 112 & 117 \\
\hline Corrente eficaz (A) & 1.177 & 789 & 1.166 & 598 & 478 & 536 \\
\hline TDHv (\%) & 2,9 & 41,9 & 28,6 & 3,47 & 42,4 & 27,28 \\
\hline TDHi (\%) & 106,93 & 59,91 & 104,44 & 125,64 & 59,73 & 56,99 \\
\hline Corrente de pico (mA) & 3.831 & 2.823 & 8.266 & 2.621 & 2.016 & 1.600 \\
\hline Fator de potência & 0,67 & 0,94 & 0,63 & 0,59 & 0,93 & 0,86 \\
\hline
\end{tabular}

Fonte: Galhardo e Pinho, 2003

Os demais parâmetros são pouco afetados. Para as cargas chaveadas, os inversores de onda quadrada modificada e onda quadrada apresentam 
praticamente a mesma forma de onda de corrente ${ }^{146}$. A medição da carga de um computador e 4 lâmpadas PL de 25W mostrou um valor de potência de distorção pequeno (4,933 VA), valores de taxa de distorção harmônica de tensão e corrente próximos ( $\mathrm{TDHv}=40,295 \%$ e TDHi $=41,697 \%$ ) e um fator de potência próximo da unidade $(0,995)$ (GALHARDO, PINHO, 2003).

\subsubsection{Alteração de Qualidade de Energia por RELDs}

Analisando a utilização de equipamentos de uso final com o intuito de redução de consumo energético - como a substituição de lâmpadas incandescentes por lâmpadas fluorescentes compactas - identificam-se efeitos negativos à qualidade da energia elétrica da rede à qual estejam conectados.

De acordo com Gama (GAMA et al, 1999) e Pires (2006, apud Procel, 2001), diferentes medidas adotadas pelo Procel (Programa Nacional de Conservação de Energia Elétrica) de gerenciamento pelo lado da demanda resultaram em impactos à qualidade de energia de sistemas. As principais medidas responsáveis por essa ocorrência foram:

- substituição de iluminação: a substituição de lâmpadas incandescentes por lâmpadas fluorescentes compactas, visando o ganho de eficiência e economia de energia, introduz níveis substanciais de harmônicos nos sistema de distribuição secundária e contribui para a diminuição do fator de potência dessa energia, com a redução das potências ativa, reativa e aparente (SILVEIRA, et alli, 2004). Identifica-se também perda na qualidade de energia elétrica, sobretudo na corrente circulante na instalação (ASTORGA, 2001). A opção por lâmpadas de vapor de sódio para a iluminação pública, apesar de reduzir o consumo energético, apresenta maior distorção harmônica de corrente (35\%) em comparação a lâmpadas de vapor metálico e vapor de mercúrio $(25 \%$ e $20 \%$, respectivamente) (TOSTES et al, 2002). O uso do reator eletrônico (em lâmpadas fluorescentes compactas) apresenta a distorção da forma de onda em comparação ao reator eletromagnético (em lâmpadas

\footnotetext{
146 Grande parte dos equipamentos eletrônicos possui na entrada um retificador com filtro capacitivo; logo a tensão após a ponte retificadora (tensão sobre o capacitor de entrada), para uma alimentação puramente quadrada, é uma tensão CC, que faz com que esse capacitor esteja sempre carregado em regime permanente e se comporte como um circuito aberto (Galhardo e Pinho, 2003).
} 
incandescentes), resultando na geração de harmônicos de corrente e no aumento da corrente de neutro em sistemas trifásicos (LUZ, et al, 1999);

- uso de controladores de velocidade variável: o controle dos fluxos de potência resulta em economia de energia, mas podem apresentar harmônicos significativos. $O$ crescente uso de inversores de frequência para o controle de velocidade de motores elétricos tem provocado uma tendência de aumento anual de $0,1 \%$ na distorção de tensão em ambientes industriais nos Estados Unidos (NEJDAWI et alli, 1999);

- instalação de bancos de capacitores: a melhoria do fator de potência pode ser comprometida no caso de instalações mal executadas, deficientes na análise de harmônicos circulantes no sistema, pode resultar em problemas como a amplificação do conteúdo harmônico e ressonância harmônica no sistema, e consequências como o aquecimento e a queima prematura desses bancos de capacitores;

- controladores de intensidade luminosa: visando, também, à economia na energia utilizada para a iluminação, dispositivos como o dimmer podem reduzir o fator de potência e aumentar a injeção de harmônicos no sistema elétrico, quando aplicados em lâmpadas incandescente e fluorescente com reator eletromagnético e, em alguns casos, em lâmpadas fluorescentes com reator eletrônico (DATTA, 1991).

\subsubsection{Algoritmo de Cômputo e Valoração}

A valoração da qualidade de energia, tanto para recursos energéticos do lado da oferta quanto para recursos do lado da demanda parte da medição de fatores básicos de qualidade da energia entregue à rede, resultante de geração de pequeno porte ou do emprego de diferentes medidas de redução de consumo de energia, como a substituição de equipamentos de uso final.

Assim, a frequência da rede, as correntes de cada fase (la, lb e lc) e neutro (In) e a tensão da carga são medidas nas aplicações citadas anteriormente. Com esses dados, pode-se determinar a variação de parâmetros como tensão (em $\Delta \mathrm{V})$, corrente de fase, corrente neutra, e a distorção de formas 
de onda de tensão e corrente com base nas fórmulas abaixo, de distorção harmônica para corrente (THDi) e tensão (THDv) e fator de crista $(F C)$ :

THD = Raiz de $\Sigma$ fn $_{2}(\mathrm{n}$ de 2 a k $) / f 1 \times 100 \%$

Onde:

f1: módulo da grandeza na frequência fundamental;

$\mathrm{n}$ : ordem harmônica;

k: último harmônico considerado;

fn: módulo da grandeza na frequência harmônica.

FC = Onda pico / Onda eficaz (49)

A variação ou queda do fator de potência é determinada pela variação das potências ativa e reativa, também medida pela variação de tensões e corrente entre a energia fornecida pelo sistema e a energia da rede. $\mathrm{O}$ algoritmo para $\mathrm{O}$ cômputo e valoração da qualidade de energia pode ser visto na figura 33 , a seguir. 


\section{Algoritmo - CVPC Qualidade de Energia}

Alteração de Potência

Potência Ativa $\Delta P$

Potência Reativa $\Delta P$

Potência Harmônica $\Delta D$

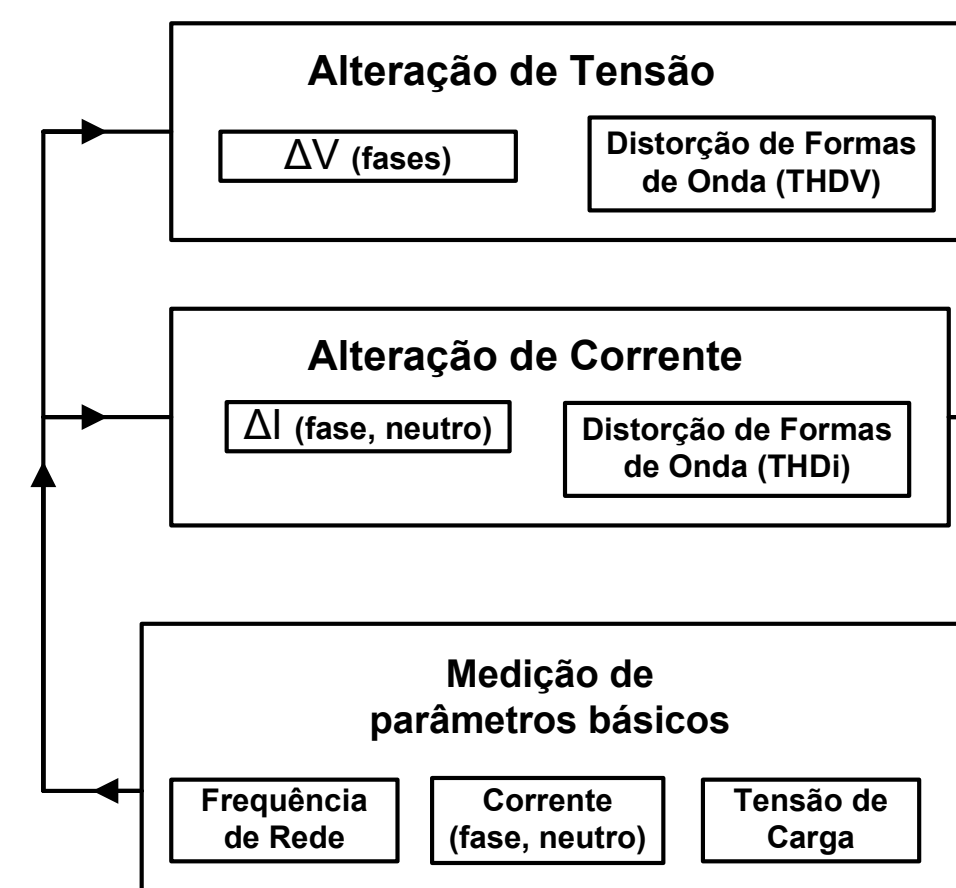

Fonte: Elaboração Própria

Figura 34: Algoritmo de CVCP do atributo Qualidade de Energia 


\subsection{Metodologia para Cômputo e Valoração de Potenciais Completos do Lado da Demanda}

A avaliação de recursos energéticos do lado da demanda trata da mensuração dos diferentes custos e impactos, envolvidos com a redução de energia por ações de eficientização energética - em sistemas e equipamentos - e por medidas de gerenciamento da energia pelo lado da demanda - em atividades de controle de demanda elétrica, direcionadas ao consumidor de usos finais de energia e à distribuição da energia das concessionárias. Essas ações podem ser realizadas em diferentes setores de consumo - industrial, residencial, comercial, público e rural -, em ações ou programas coordenados por agentes como o governo federal, governos municipais, empresas de serviços energéticos (ESCOS), organizações não-governamentais, entre outros.

A caracterização, valoração e planificação de Recursos Energéticos do Lado da Demanda (RELD) são processos fundamentais ao PIR e ao planejamento energético como um todo, por incorporarem, ao processo de ampliação da oferta de energia, a gestão energética e de projeção de demanda, perspectivas de reduções de impactos socioambientais e otimização técnica e econômica. Assim, a importância dos RELD justifica-se como instrumento de minimização de riscos de suprimento e como forma de disponibilização de energia com menores custos econômicos e socioambientais.

Os RELDs são compostos pela aplicação de medidas de eficiência energética e/ou gerenciamento pelo lado da demanda a uma tecnologia de uso final em um determinado setor de consumo. Cada grupo de tecnologias pode ser combinado a diferentes medidas de eficientização ou GLD, aplicados a diferentes setores, gerando uma enorme combinação de recursos do lado da demanda.

Os três blocos são listados na figura 34 a seguir: 


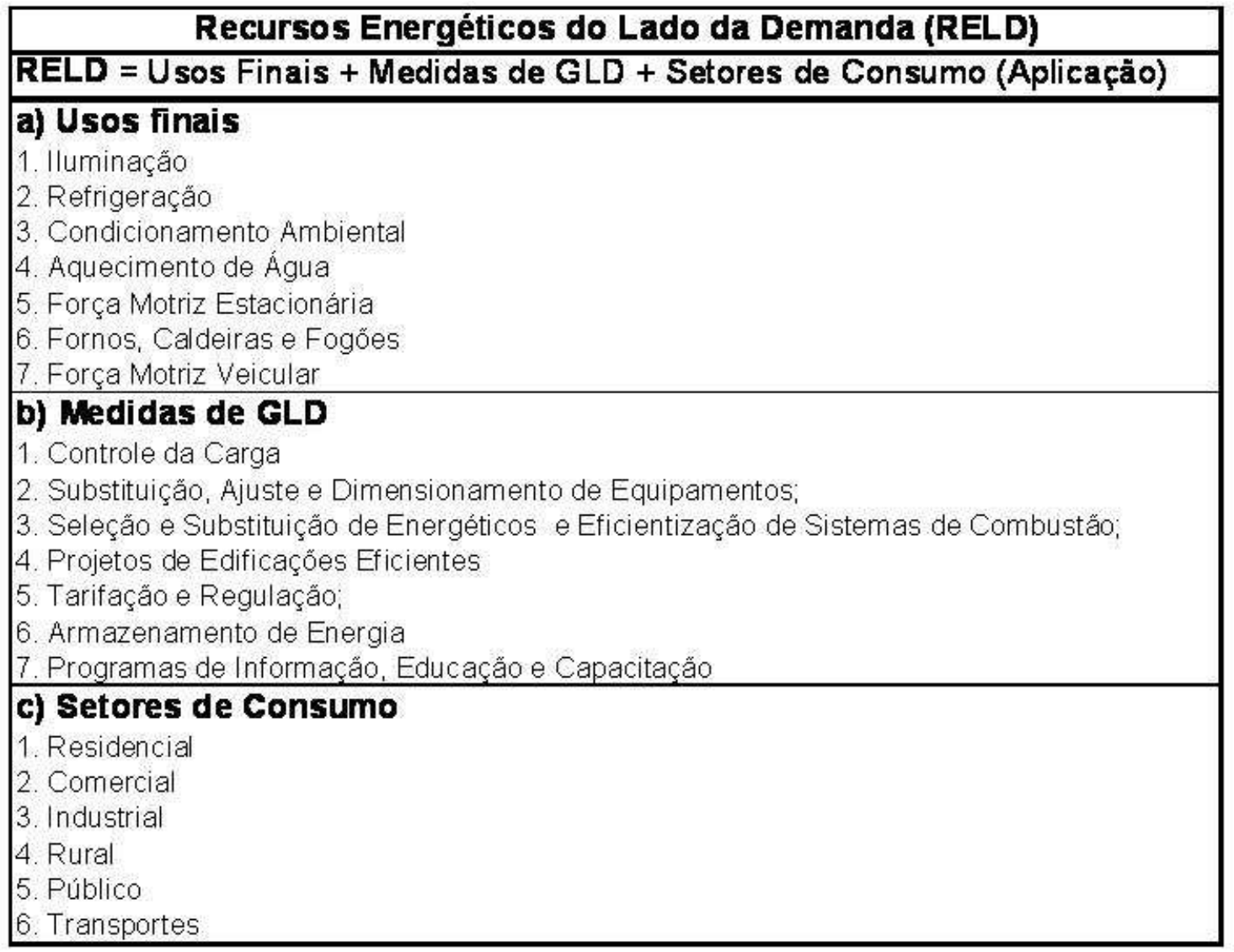

Figura 35: Segmentação de usos finais e medidas de RELD

Fonte: BAITELO et al, 2006.

O cômputo e a valoração de potenciais completos do lado da demanda têm como objetivo analisar as implicações das quatro dimensões de análise do PIR à implantação desses recursos, bem como seus respectivos custos e benefícios em caráter socioambiental, político e técnico-econômico.

A valoração desses potenciais é estabelecida de forma análoga ao processo proposto para recursos energéticos do lado da oferta, em patamares máximos, ou teóricos, e refinados, ou realizáveis e de mercado. A quantificação desses valores condiciona-se a diferentes variáveis inerentes a cada dimensão de análise.

A valoração política vincula-se fundamentalmente ao potencial de instrumentos políticos de apoio ao estabelecimento de recursos do lado da demanda - por acordos locais, nacionais ou internacionais - e à convergência de interesse de atores energéticos na implementação desses recursos.

Por um ângulo macroeconômico, a implementação de recursos do lado da demanda é influenciada pela conjuntura econômica local e nacional e as 
respectivas respostas de mercado a cada situação, e interage com diferentes parâmetros-chave como a geração de renda e de produto interno bruto local e nacional e a intensidade energética de diferentes atividades produtivas, relacionados à variação do consumo de energia e ganhos ou perdas de eficiência decorrentes dessas tendências.

Os fatores técnicos associados à mensuração e concretização de planos ou medidas de eficiência energética consideram a análise de monitoração de continuidade de programas e verificação de suas respectivas metas, a evolução de eficiência de tecnologias de uso final e a operação desses equipamentos em diferentes setores.

A realização de potenciais de recursos energéticos do lado da demanda reverte-se em benefícios ambientais reais, na medida em que reduções reais e constantes de consumo de energia podem resultar na otimização ou postergação da ampliação de recursos energéticos do lado da oferta e, consequentemente, em impactos ambientais associados à sua implementação. A redução real de impactos aos meios aéreo, terrestre e aquático acontecerá em situações em que a operação de usinas ou sistemas energéticos poluentes for reduzida como resultado de alteração da demanda de uma região. Em outros casos, a redução de consumo corrige a ampliação energética de uma dada região, minimizando os potenciais impactos ambientais futuros resultantes dessa nova capacidade instalada.

Em âmbito social, a implementação desses recursos acontece de forma natural, com o aumento da disponibilização de tecnologias e procedimentos de eficientização do consumo de energia, desde que tais procedimentos não comprometam a percepção de diferentes parâmetros de conforto, saúde e qualidade de vida do consumidor.

Ao lado de benefícios técnicos e socioambientais, o aproveitamento de recursos do lado da demanda pode contribuir à segurança energética e ao aumento da independência energética local, regional ou mesmo nacional, ao oferecer ao processo de planejamento energético maior proporção de recursos energéticos localmente disponíveis.

Em suma, a contabilização de potenciais de valoração de recursos energéticos do lado da demanda conjuga parcelas utilizadas no equacionamento do cômputo de potenciais de recursos do lado da oferta a fatores particulares a 
recursos de demanda. Em outras palavras, a quantificação de diferentes impactos referentes a recursos de oferta é tratada em função de sua redução, com a aplicação de recursos do lado da demanda. Adicionalmente a essa parcela, a aplicação dos RELD deve prever a ocorrência de outros impactos específicos, exemplificada na utilização de equipamentos de usos finais que impliquem na liberação de poluentes tóxicos ao ambiente ou na alteração de conforto de consumidores de energia e da sociedade como um todo.

Com base na equação 44, a primeira parcela da valoração de RELD calcula valores absolutos resultantes da implantação de recursos do lado da demanda, derivados de fatores relativos, pertencentes às dimensões de avaliação.

A segunda parcela diferencia-se do processo empregado para os RELO, ao mensurar o impacto da redução de consumo de energia local ou regional em termos de variação de atributos das dimensões de análise. Em outras palavras, essa parcela avalia os impactos positivos da implementação de RELD, em relação às dimensões de análise - notadamente as dimensões ambiental e social - subtraindo-o da valoração final de potenciais ou impactos. Para tanto, parte-se de fatores de cada atributo atrelados a uma média ou linha de base local, considerando que a redução de consumo de energia resultará na redução de uma média de impactos referente à composição da matriz energética da região estudada.

As equações abaixo ilustram o procedimento de cômputo e valoração dos RELDs:

CVPC (RELD)= Fa(RELO) $\times$ Pot(RELD) - F(base) $\times$ Pot(RELO) (50)

$F($ base $)=\sum_{i=1}^{n} \quad(P \%(R E L O) \times F a(R E L O))(51)$

Onde:

CVPC (RELD): valoração absoluta de recurso RELD, medida em diferentes unidades;

Fa (RELO): fator do atributo, em diferentes unidades divididas por Energia (MWh) ou Potência (MW);

Pot (RELD): potencial de redução de energia ou demanda do recurso RELD em unidades por Energia (MWh) ou Potência (MW);

F (base): fator relativo do atributo em relação à linha de base da capacidade instalada local ou regional, representada por diferentes unidades em função da Energia ( $M W h$ ) ou Potência ( $M W)$;

n: etapas da cadeia energética envolvidas na valoração do RELO. 
Cabe mencionar que a consideração de cada uma das duas parcelas é particular a cada grupo de recursos avaliado. Em alguns casos, a implantação de um RELD envolverá custos técnico-econômicos sem necessariamente repercutir em benefícios nesse campo, eliminando a segunda parcela da equação. Em outros casos, a aplicação de um RELD trará a redução de custos ambientais, sem a ampliação de qualquer custo ambiental adicional, dispensando a primeira parcela da equação.

\subsection{Cômputo e Valoração da Dimensão Ambiental}

A valoração de recursos energéticos do lado da demanda em diferentes atributos da dimensão ambiental do PIR analisa impactos positivos e negativos de sua implementação. Diferentemente da valoração de recursos energéticos de oferta, o cômputo e a valoração de RELDs pode produzir potenciais negativos, em situações nas quais a redução de consumo de energia repercute comprovadamente na diminuição de impactos ambientais. Esse caso é identificado quando a redução de consumo resulta na redução da geração de energia ou da ampliação do parque energético da região analisada, minimizando impactos ambientais relativos a essas atividades.

A configuração dessa redução de impactos deve ser quantificada em função do tempo, de acordo com a região estudada e com seu perfil energético e econômico. Regiões e países em desenvolvimento apresentam curvas elevadas de crescimento econômico e energético. Nesse caso, a redução de consumo energético em um determinado setor pode retardar temporariamente a expansão do parque energético e seus impactos ambientais resultantes. Em outros exemplos, países e regiões desenvolvidas com moderado crescimento econômico e baixa expansão energética podem prescindir de usinas poluentes e, assim, reduzir, de forma definitiva, seus impactos ambientais com a adoção de planos de gerenciamento energético pelo lado da demanda.

Dentre os grupos de impactos potencialmente minimizáveis pela redução da geração de energia, figuram a poluição atmosférica de gases de efeito estufa e material particulado - de usinas movidas a combustíveis fósseis-, impactos relacionados ao uso e exploração do solo - em grandes usinas hidrelétricas ou cultivo de biocombustíveis - e impactos relacionados ao consumo e à alteração 
de parâmetros de qualidade da água - em sistemas que utilizam ciclos de refrigeração como usinas de energia solar concentrada ou termelétricas nucleares.

Já a parcela de impactos ambientais decorrentes da implantação de RELDs, quando aplicável, avalia a produção de poluentes aos meios aéreo como vapor de mercúrio de lâmpadas fluorescentes compactas e gases de alto potencial de efeito estufa utilizados em refrigeradores e sistemas de condicionamento ambiental -, resíduos sólidos - resultantes do descarte indevido de tecnologias de uso final substituídas por equipamentos mais eficientes - e impactos ao meio aquático - como a possibilidade do aumento de consumo de água por medidas de substituição de combustíveis no setor de transportes ou como resultado da utilização de aquecedores solares para aquecimento de água em residências ou estabelecimentos comerciais.

Ressalta-se que esse grupo de impactos decorrente da implantação de RELDs é de difícil comprovação e verificação, uma vez que o estabelecimento de uma relação nexo causal entre o processo de modernização - e consequente eficientização - de tecnologias de uso final no mercado ${ }^{147}$ e seu emprego específico em ações de gerenciamento do lado da demanda pode ser considerado extremamente complexo, se não imponderável.

Os próximos itens abordam os impactos de RELDs aos meios ambientais aéreo, aquático e terrestre e desenvolvem algoritmos de cômputo e valoração de potenciais referentes a esses impactos.

\footnotetext{
${ }^{147}$ A renovação do parque de equipamentos em um determinado setor de usos finais deve ser revista anualmente, de forma a definir ciclos para permitir sua discriminação de acordo com a eficiência das tecnologias e, assim, permitir o exercício de avaliação de desempenho e consumo. A revisão tem o intuito de corrigir diagnósticos incoerentes ao final de um determinado horizonte de tempo, como a conclusão de que todos os equipamentos de um dado uso final, a despeito de níveis diferenciados de eficiência, tenham atingido um patamar mínimo de consumo e dispensem substituição.
} 


\subsubsection{Poluição Aérea}

Esse atributo trata do acréscimo de emissões de poluentes à atmosfera provocada por atividades relacionadas ao gerenciamento pelo lado da demanda e do possível decréscimo desses poluentes provocado pela redução de atividades relacionadas à cadeia energética.

A parcela que contabiliza o aumento de emissões considera substâncias como gases refrigerantes, conhecidos como f-gases, ou gases compostos de flúor - utilizados em equipamentos como refrigeradores e ar condicionado - e vapor de mercúrio derivado do descarte inadequado de lâmpadas fluorescentes. O vazamento de gases refrigerantes é responsável pela depleção da camada de ozônio e pelo aquecimento global ${ }^{148}$ (LU, 2007). Cerca de $90 \%$ desses gases são usados em refrigeradores e sistemas de ar condicionado. As emissões são resultado de uso de equipamentos antigos, manutenção, falha, escape ao final da vida útil do produto e vazamentos rotineiros - este último caso responde por $60 \%$ das emissões (GREENPEACE, 2008).

Outras emissões devem-se a gastos energéticos com programas e campanhas de eficiência energética e reforma de edifícios visando a sua eficientização por meio de melhor aproveitamento bioclimático.

Já a parcela que quantifica a potencial redução de emissões de poluentes aéreos avalia o impacto de RELDs na redução de emissão de poluentes como óxidos de enxofre e de nitrogênio, monóxido e dióxido de carbono, metano, compostos orgânicos voláteis, material particulado, entre outros, produzidos em diferentes atividades energéticas. Cabe ressaltar que o cálculo de emissões diferentes de $\mathrm{CO} 2$ é mais complexo por depender, além do tipo de combustível, também de condições de combustão e tecnologia envolvida no processo de conversão (HANLEYA, 2009).

Em alguns RELDs, como a substituição de combustíveis nos usos finais de aquecimento ou transporte, a redução de emissões pode ser calculada de forma direta. Já no caso de outras medidas de GLD, a mensuração do aumento ou diminuição de impactos referentes à poluição atmosférica é complexa. Em

\footnotetext{
$148 \mathrm{O}$ potencial de efeito estufa destes gases é milhares de vezes superior ao CO2. Para o PFC (perfluorcarbono), varia entre 6.500 a 9.200 vezes e para o HFC (hidrofluorcarbono), entre $9.400 \mathrm{e}$ 10.000, de acordo com o horizonte de tempo avaliado.
} 
primeiro lugar, em grande parte das análises, não é possível apontar o perfil da geração energética que será subtraída ou postergada como resultado da economia de energia em um determinado local. Assim, assume-se o perfil dessa energia e de suas emissões atmosféricas como a média da matriz energética da região analisada. $O$ procedimento merece ressalvas em relação à atualização temporal dessa linha de base - em função da ampliação da matriz energética avaliada - e à variação da mesma conforme a importação ou exportação de energia a outros mercados.

\subsubsection{Algoritmo de Cômputo e Valoração}

A contabilização das emissões inclui, em duas parcelas, a quantidade de poluentes gerados e evitados em decorrência da adoção de programas de GLD, medidos em gramas de poluentes por $\mathrm{kWh}$ de energia economizada. A formulação dessa contabilização segue abaixo:

CVPC Em (RELD) = F Em (RELD) x Pot(RELD) - F Em(base) $\times$ Pot(RELO) (52)

$F($ base $)=\sum_{i=1}^{n} \quad(P \%($ RELO) $x$ F Em (RELO) $)$

CVPC Em GEE (RELD) $=\sum_{\mathrm{i}=1}^{\mathrm{n}}$ CVPC Em (RELD) $\times$ Pot GEE (54)

Onde:

CVPC Em (RELD): valoração absoluta das emissões do RELD (em g);

F Em (RELD): fator de emissões do RELD (em g/kWh);

n: etapas da cadeia energética envolvidas na valoração do RELO;

Pot (RELD): potencial de redução de energia ou demanda do recurso RELD (em unidades de energia, MWh, ou Potência, MW);

F Em (base): fator de emissões relação à linha de base da capacidade instalada local ou regional, representada por $\mathrm{g}$ de poluentes em função da Energia ( $\mathrm{g} / \mathrm{MWh}$ );

CVPC Em GEE (RELD): valoração absoluta das emissões de gases de efeito estufa do RELD, (em g de $\mathrm{CO} 2$ equivalente);

Pot GEE: Potencial de gases de efeito estufa, unidade adimensional, proporcional ao $\mathrm{CO} 2$. 


\subsubsection{Impactos ao Solo}

Os impactos da cadeia energética ao meio terrestre incluem a deposição de poluentes ou dejetos no solo, sua degradação e sua ocupação em diferentes atividades de produção, geração ou transporte de energia. Dessa forma, analisando-se a implantação de RELDs, esses impactos negativos relativos à poluição do solo podem, em alguns casos, ser minimizados por ações de eficientização energética e gerenciamento do lado da demanda. Impactos negativos poderiam ser reduzidos por meio da substituição de recursos que impliquem impactos ao solo, sejam eles a substituição da produção de biocombustíveis por outros energéticos ou o adiamento da expansão de infraestrutura de transmissão de energia que possa atingir a cobertura florestal de um determinado bioma.

Já a impactação do solo em decorrência de atividades de eficientização energética pode ser provocada pela produção de resíduos, com o descarte indevido de equipamentos como lâmpadas fluorescentes eficientes - que podem contaminar o solo com a liberação de vapor de mercúrio e outros elementos tóxicos como chumbo ${ }^{149}$ - ou diferentes equipamentos relacionados ao gerenciamento do lado da demanda, como coletores solares ou controladores de carga.

Os principais componentes químicos identificados nos eletrodomésticos mais comuns são apresentados abaixo, de acordo com tabela resumida, adaptada de Barba-Gutierrez et alli (2008):

Tabela 11: Componentes Químicos de Eletrodomésticos

\begin{tabular}{|c|c|c|c|}
\hline Componentes & Geladeira (40 kg) & Televisão (15,6 kg) & Computador (23 kg) \\
\hline Alumínio & 1,98 & 0,16 & 0,32 \\
\hline Cobre & 0,32 & 0,47 & 1,42 \\
\hline Ferro & 25,66 & 1,72 & 7,62 \\
\hline Chumbo & - & - & 0,05 \\
\hline
\end{tabular}

Fonte: Barba-Gutierrez, et alli, 2008.

${ }^{149}$ A concentração de mercúrio em lâmpadas fluorescentes compactas varia entre 3 e $5 \mathrm{mg}$ de acordo com o fabricante. Vapor de mercúrio e argônio são identificados em tubulações de lâmpadas fluorescentes e a presença de chumbo é detectada no reator do equipamento (PARSON, 2006). 
Atividades como a fabricação de equipamentos, a reforma de edifícios e programas de eficiência que impliquem gastos energéticos, podem produzir impactos ambientais diretos e indiretos, como emissões aéreas e geração de resíduos sólidos, nos locais de origem dessas atividades. Em relação ao aumento de gastos energéticos por conta da reciclagem e do manuseio de resíduos eletrônicos provenientes da substituição de equipamentos de uso final, ainda de acordo com Barba-Gutierrez et alli, a atividade pode passar a aumentar o grau de impactos ambientais de acordo com o gasto energético da logística de reciclagem, comumente apoiada em caminhões e transportes movidos a combustíveis fósseis.

A ocupação de extensões territoriais constitui um dos principais impactos de recursos energéticos ao meio ambiente. $O$ impacto varia de acordo com as características socioambientais do local ocupado e do processo dessa ocupação.

No caso de RELDs, a redução ou adiamento de atividades da cadeia energética pode repercutir na redução desse impacto, na região original desses processos. Por outro lado, a adição de impactos de ocupação territorial por conta de atividades como a fabricação de tecnologias eficientes ou mesmo a reforma ou construção de edifícios eficientes não pode ser considerada como adicional a esse tipo de impacto por dois motivos: em primeiro lugar, a área ocupada pode ser considerada desprezível ${ }^{150}$ em relação à extensão de impactos análogos observados em recursos do lado da oferta; em segundo lugar, verifica-se novamente uma enorme dificuldade em se estabelecer uma relação direta entre essas atividades produtivas e um plano específico de eficiência energética - 0 propósito essencial da produção de equipamentos mais modernos e da reforma de edifícios seguirá em primeiro lugar à lógica e demandas do mercado.

\subsubsection{Algoritmo de Cômputo e Valoração}

A produção de subprodutos sólidos como resultado da geração de eletricidade ou produção de energéticos é valorada de acordo com o volume desse resíduo em função da energia ou eletricidade produzida no processo, com

\footnotetext{
${ }^{150}$ No caso de ocupação de espaço individual ou dentro de cidades para medidas de RELD relacionadas como o uso de sistemas de aquecimento de água ou calor residenciais, o espaço é ocupado em telhados de edifícios existentes ou pequenas quantidades de área no caso de sistemas comunitários (KAYGUSUZ, 2009).
} 
base na análise de fatores como poder calorífico e eficiência de conversão de combustíveis produzidos.

Assim, a contabilização dos resíduos sólidos divide-se nas parcelas, de subprodutos sólidos gerados ou evitados em decorrência da adoção de programas de GLD, em gramas para cada MWh de energia economizada. A formulação dessa contabilização segue abaixo:

$\operatorname{CVPC}\left(\right.$ Res RELD) $=\sum_{\mathrm{i}=1}^{\mathrm{n}}$ FR (RELD) $x \operatorname{Pot}\left(\right.$ RELD) $-\sum_{\mathrm{i}=1}^{\mathrm{n}}$ FR(base) $x$
$\operatorname{Pot}($ RELO) (55)

$F($ base $)=\sum_{i=1}^{n} \quad(P \%($ RELO) $\times$ FR(RELO) $)$

Onde:

CVPC (Res RELO) valoração absoluta dos resíduos do RELD (em g);

FR (RELD): fator de produção de resíduos do RELD nas diferentes etapas da cadeia energética (em $\mathrm{g} / \mathrm{kWh}$ ou $\mathrm{kg} / \mathrm{MWh}$ );

n: etapas da cadeia energética envolvidas na valoração do RELO;

Pot (RELD): potencial de geração de energia do recurso RELO (em unidades de energia, MWh, ou potência, MW);

FR(base): fator de resíduos em relação à linha de base da capacidade instalada local ou regional, (em m3 por energia, MWh, ou potência, MW).

Já a valoração da área ocupada por RELDs considera as parcelas de área ocupada ou evitada por estes recursos sem, contudo, entrar no mérito de avaliação preliminar de ocupação de espaço proposto para RELOs. Esta perde o sentido no caso dos RELDs, pois se considera, neste caso, uma linha de base ao invés de análises particulares a empreendimentos. A valoração da ocupação de espaço é feita em função de área, medida em km2; ao invés de considerar-se a energia economizada em MWh, utiliza-se, nesse caso, a demanda economizada ou postergada, em MW, por uma questão de analogia à metodologia de RELOs. Seguem abaixo as equações:

CVPC (Oc RELD) = Pot (RELD) / FO(RELD) - Pot(RELO)/FO(base) 
$F($ base $)=\sum_{i=1}^{n} \quad(P \%($ RELO) $\times$ FO(RELO) $)$

Onde:

V(Oc RELD): área ocupada pela implementação do RELD (km²);

FO (RELD): fator de ocupação de área do RELD (MW/km²);

n: etapas da cadeia energética envolvidas na valoração do RELO;

Pot (RELD): Potencial de demanda do RELD (MW);

FO(base): fator de ocupação médio de RELOs em relação à linha de base da capacidade instalada local ou regional, representada por km2 em função da Potência (MW).

\subsubsection{Impactos à Água}

A avaliação da participação da água em atividades energéticas é dividida em função de seu consumo e qualidade do recurso devolvido aos corpos d'água e mananciais. A demanda de recursos hídricos é analisada em função da diferença entre o volume de água captado e o volume reposto após sua utilização. Na implantação de RELDs, esse consumo pode ser minimizado ou postergado quando for possível comprovar o adiamento ou cancelamento de empreendimentos ou atividades da cadeia energética que exerçam impactos sobre o consumo de água.

O consumo de água pode ser reduzido com a postergação ou cancelamento da construção de usinas termelétricas ou hidrelétricas como resultado de programas de GLD ou mesmo pela construção de edifícios sustentáveis que minimizem esse consumo, por meio da coleta e reuso de água

Por outro lado, algumas atividades de eficientização energética podem consumir água, como a seleção de usos finais - representada pela opção na utilização de aquecedores solares para aquecimento de água ou resfriadores evaporativos em substituição a ar condicionado - ou seleção de combustíveis como a substituição de combustíveis fósseis por etanol de cana-de-açúcar no setor de transportes.

O segundo impacto relevante ao meio aquático é a análise da alteração da qualidade da água, por fatores como temperatura, acidez, concentração de 
poluentes, entre outros. Esses fatores são racionalizados em função da energia empregada ou gerada em cada processo da cadeia energética, assim, a participação de RELDs pode alterar esse impacto.

A poluição das águas, na implantação de recursos energéticos de demanda, está relacionada à estimativa de impactos causados ou evitados por medidas de GLD como a substituição de combustíveis ou a substituição do uso da rede por geradores ou outros equipamentos. O adiamento da construção de uma hidrelétrica como resultado da implementação de RELDs pode evitar temporariamente a queda desses parâmetros em rios que seriam utilizados nesses projetos. Por outro lado, medidas como a eficientização de iluminação pode implicar impactos negativos à água, uma vez que o lançamento de vapores de mercúrio provenientes do descarte indevido de lâmpadas fluorescentes compactas em aterros pode contaminar o solo e, subsequentemente, os cursos d’água.

Dessa forma, o potencial de valoração de impacto ao meio aquático de RELDs apresenta uma parcela positiva, resultante de impactos diretos de consumo e alteração de qualidade de recursos hídricos, e a parcela negativa, derivada da redução desses impactos, com base na variação do uso de recursos energéticos de oferta potencialmente poluentes às águas, por conta de ações de GLD.

\subsubsection{Algoritmo de Cômputo e Valoração}

O volume de água captada e consumida em RELOs é função do recurso energético analisado, envolvendo diferentes etapas da cadeia energética. Para RELDs, a valoração adota uma média de fatores de consumo de água ou alteração de parâmetros - referente à linha de base da matriz energética local - e utiliza fatores de consumo e alteração de qualidade específicos para cada recurso do lado da demanda.

Os algoritmos para ambos os indicadores que compõem o atributo valemse das formulações abaixo, replicadas para as etapas da cadeia energética de cada recurso analisado: 
CVPC cons.liq (RELD) $=\left[\sum_{i=1}^{n}\right.$ FCap(RELD) $-\sum_{i=1}^{n}$ FCons(RELD) $] \times \operatorname{Pot}($ RELD)

- [ $\sum_{\mathrm{i}=1}^{\mathrm{n}}$ FCap (base) - $\sum_{\mathrm{i}=1}^{\mathrm{n}}$ FCons(base) $] \times$ Pot(RELO)

FCap(base $)=\sum_{i=1}^{n} \quad(P \%($ RELO) $\times$ FCap(RELO) $)(60)$

FCons $($ base $)=\sum_{\mathrm{i}=1}^{\mathrm{n}} \quad(\mathrm{P} \%(\mathrm{RELO}) \times \mathrm{FCons}(\mathrm{RELO}))(61)$

Onde:

CVPC cons.liq: consumo líquido absoluto de RELDs (em m3);

Cap: captação de recursos hídricos associada ao potencial de demanda do RELD (em m3);

Cons: consumo de recursos hídricos associada ao potencial de demanda do RELD (em m3);

FCap: fator de captação de recursos hídricos do RELD (em m3/MWh);

FCons: fator de consumo de recursos hídricos do RELD (em m3/MWh);

FCap (base): fator de captação médio de RELOs em relação à linha de base da capacidade instalada local ou regional, representada por $\mathrm{m} 3$ em função da energia gerada (MWh);

FCons (base): fator de consumo médio de RELOs em relação à linha de base da capacidade instalada local ou regional, representada por $\mathrm{m} 3$ em função da energia gerada (MWh);

n: etapas da cadeia energética envolvidas na valoração do RELO.

O algoritmo de cálculo de alteração de qualidade da água, de forma análoga ao apresentado para RELOs, trata o parâmetro de forma relativa, ao quantificar a alteração em função do volume de água impactado, de acordo com as equações abaixo:

CVPC alt $($ RELD $)=$ IND (RELD) $\times$ FD (RELD) $\times$ Pot (RELD)

- IND (base) x FD (base) x Pot (RELO)

CVPC alt rel $($ RELD) $=$ CVPC alt $($ RELD) $/$ Vol tot $(63)$

FCap $($ base $)=\sum_{i=1}^{n} \quad(P \%($ RELO) $\times$ FCap(RELO) $)(64)$ 
Onde:

CVPC alt (RELO): alteração absoluta de parâmetros de qualidade i do recurso energético $\mathrm{Re}(\mathrm{pH}$, graus, DBO, DQO, g);

IND: indicador do parâmetro de qualidade i do efluente líquido do RELD

( $\mathrm{pH}$, graus, DBO, DQO, $\mathrm{g}$ - medidos em função do volume de efluentes gerados);

FD: fator de descarga de efluentes líquidos do RELD (medido em função de volume de efluentes por energia economizada pelo recurso);

Pot (RELD): potencial de oferta do RELD;

CVPC alt rel (RELD): alteração relativa de parâmetros de qualidade i do RELD, em função de ( $\mathrm{pH}$, graus, DBO, DQO, g) por MWh economizado;

CVPC alt (RELO): alteração absoluta de parâmetros de qualidade i do RELD (pH, graus, DBO, $\mathrm{DQO}, \mathrm{g})$;

Vol tot: volume total do corpo d água que recebe o efluente;

n: etapas da cadeia energética envolvidas na valoração do RELO. 


\subsection{Cômputo e Valoração da Dimensão Social}

A dimensão social analisa impactos provocados por recursos energéticos na qualidade de vida e no bem-estar da sociedade como um todo - avaliados em atributos como a geração de empregos, o desenvolvimento econômico e humano, alteração de conforto e impactos à saude.

Em relação à valoração de recursos energéticos do lado da demanda, identificam-se impactos positivos, negativos ou mesmo neutros de sua implementação. Assim, pode-se identificar impactos positivos, em situações nas quais o emprego de medidas de eficiência energética contribui ao desenvolvimento local com a criação de empregos, melhorias de produtividade nos setores industrial e comercial e realocação de investimentos para áreas sociais prioritárias em situações de comprovada postergação de ampliação da oferta de eletricidade. Há um segundo grupo de valorações positivas, quando o adiamento de empreendimentos energéticos socialmente impactantes cria uma situação de postergação de impactos sociais relacionados à saúde humana principalmente resultantes de impactos ambientais de empreendimentos energéticos ao ar e à água - e/ou à ocupação territorial e consequente deslocamento de populações - em grandes usinas hidrelétricas ou no cultivo de biocombustíveis.

Já a parcela de impactos sociais decorrentes da implantação de RELDS, quando aplicável, avalia impactos de substâncias tóxicas de equipamentos de uso final à saúde e ao conforto humano - como vapor de mercúrio de lâmpadas fluorescentes compactas ou a alteração desse tipo de iluminação na produtividade e bem estar humanos. Por outro lado, o uso da arquitetura bioclimática em edificações, além de render reduções de consumo de energia, pode oferecer melhorias de conforto a trabalhadores e moradores, com o aproveitamento de recursos naturais e a consequente harmonização de espaços internos e externos.

A configuração desses impactos deve ser quantificada em função do tempo, de acordo com a região estudada e com seu perfil energético e econômico, considerando tanto tendências de crescimento econômico e energético e a real influência e durabilidade de ações de eficiência energética nesses locais. 
Ressalta-se novamente que a comprovação de alguns dos impactos decorrente da implantação de RELDs é complexa e inexata, considerando a dificuldade de enquadramento e classificação de ações como substituição de equipamentos ou construção de edifícios eficientes como medidas intencionais de eficiência energética.

Os próximos itens abordam os impactos de RELDs nos atributos da dimensão social e desenvolvem algoritmos de cômputo e valoração de potenciais referentes aos mesmos.

\subsubsection{Geração de Empregos}

Esse atributo mensura a geração de empregos como decorrência da implantação de recursos energéticos do lado da demanda. A criação de empregos é um dos claros benefícios provocados pelos sistemas energéticos, com repercussões sobre outros atributos analisados, como a qualidade de vida das populações locais, representada pela reversão da geração de riqueza em ganhos de saúde, educação e infraestrutura local.

A análise de RELDs contabiliza os empregos, em diferentes níveis de capacitação, gerados em atividades de GLD, sejam eles no setor de condução de programas governamentais ou ações de empresas de serviços energéticos, em setores de arquitetura e construção ou na fabricação de coletores solares e controladores de demanda. Já indicadores de desenvolvimento relacionados aos benefícios da eficiência energética à economia - como a criação de empregos indiretos e efeito-renda - são analisados no próximo atributo.

Ressalta-se que a avaliação da geração de empregos em RELDs é complexa por conta da diversidade do setor e da discriminação de ações associadas de $G L D^{151}$. Soma-se a esses, a questão da discriminação de melhorias de eficiência energética decorrentes de fenômenos naturais de ciclos de reposição de equipamentos (RUTHERTON et al, 2009). A valoração da geração de empregos e outros fatores concentra-se, portanto, em ações específicas de eficiência energética e não contempla casos de ciclos de reposição ou retrofitting convencional.

${ }^{151}$ Como exemplo desse caso, cita-se a criação de esquemas tarifários e de programas de comunicação associados à substituição de equipamentos de uso final. 
De acordo com Rutherton, a forma mais comum de exprimir a criação de empregos em eficiência energética é por investimentos anuais, como nos exemplos de Dupressoir et al, 2007, ACEEE 2008 e Access Economics 2009.

Tabela 12: Média de Empregos em Eficiência Energética

\begin{tabular}{|c|c|c|c|c|}
\hline Setor & País & $\begin{array}{c}\text { Energia } \\
\text { Economizada } \\
\text { Total (GWh) }\end{array}$ & $\begin{array}{c}\text { Empregos } \\
\text { por GWh }\end{array}$ & Fonte \\
\hline Média & EUA & 363.408 & 0,19 & ACEEE, 2008 \\
\hline Média & Austrália & 22.410 & 0,19 & Access Economics, 2009 \\
\hline Média & Alemanha & 75.000 & 0,60 & Dupressoir, 2007 \\
\hline
\end{tabular}

Fonte: Rutherton et al, 2009

Ainda de acordo com Rutherton, a análise mais abrangente da indústria de eficiência energética é mostrada no estudo "The Size of the U.S. Energy Efficiency Market: Generating a More Complete Picture", de Ehrhardt-Martinez e Laitner (ACEEE 2008). Nele, a eficiência energética líquida ou "prêmio" é identificada por setor, para o ano de 2004, e associada à criação de empregos. Com base nesta, pode-se estabelecer índices de geração de empregos em relação a energia economizada, para diferentes setores de consumo, de acordo com a tabela abaixo. Estes podem ser adaptados a diferentes países ou regiões, por meio de multiplicadores regionais.

Tabela 13: Média de Empregos em Eficiência Energética

\begin{tabular}{|c|c|c|c|c|}
\hline Setor & Residencial & Comercial & Industrial & Média \\
\hline $\begin{array}{c}\text { Empregos por US\$ } \\
\text { milhão investido }\end{array}$ & 8,1 & 5,9 & 4,6 & 5,4 \\
\hline $\begin{array}{c}\text { Economia de Energia } \\
\text { (GWh) }\end{array}$ & 96.713 & 73.268 & 193.427 & 1.532 .762 \\
\hline Emprego por GWh & 0,49 & 0,62 & 0,27 & 0,35 \\
\hline
\end{tabular}

Fonte: ACEE, 2008, apud Rutherton et al, 2009.

Para o lado da demanda, a diferenciação entre recursos em relação a potenciais de geração de empregos é significativa, de acordo com características e qualidades de trabalhos, diferenciadas em setores de consumo e etapas da cadeia de GLD. Essas etapas, não aplicáveis a todos os grupos de recursos, dividem-se fundamentalmente nas fases de estudos e projetos, pesquisa e 
desenvolvimento, produção de equipamentos, construção de edificações e gerenciamento de programas.

Assim, cada tipo de recurso envolverá uma quantidade de pessoal empregado, em função de diferentes níveis de complexidade e remuneração. Vale mencionar que, em alguns casos, a adoção de medidas de GLD pode repercutir negativamente, reduzindo, de forma indireta, o número de empregos que seriam disponibilizados por conta de uma hipotética ampliação da geração energética, bem como em atividades de transmissão e distribuição de energia.

A qualidade de empregos, de forma análoga à metodologia para os RELDS, é mensurada do lado da demanda em função da capacitação, da especialização, da remuneração de cada trabalho e de impactos de saúde ocupacional envolvidos.

\subsubsection{Algoritmo de Cômputo e Valoração}

A geração de empregos em RELDs segue o procedimento aplicado a recursos de oferta, partindo da discriminação dos potenciais postos de trabalho nas diferentes etapas da cadeia energética de GLD, envolvida em cada recurso analisado.

O fator de empregos para cada uma dessas fases, representado do lado da demanda em número de trabalhadores por energia economizada, pode ser aferido em experiências práticas para cada tipo de projeto implantado localmente e em estudos nacionais e internacionais, modelados para a situação da região estudada.

Assim como no algoritmo dos RELOs, o fator de emprego também é influenciado pela produtividade e eficiência de processos específica em empreendimentos locais, representada por um multiplicador regional ou local de empregos. Um segundo multiplicador é utilizado para discriminar a participação nacional em tecnologia e serviços dos RELDs, revertida em empregos locais.

O refinamento do potencial teórico de empregos, além de considerar a implantação de potenciais realizáveis de RELDs, incorpora a influência de fatores técnicos e econômicos como a correção da taxas de emprego em função do tempo por um fator de declínio ou curva de ajuste de substituição de equipamentos obsoletos por tecnologias mais eficientes. 
A segunda parcela de valoração, ainda que não aplicável em muitos casos, refere-se à quantidade de empregos retirada em decorrência da implantação de medidas de GLD, considerando a linha de base da capacidade instalada regional e a hipótese de seu incremento com base nessa distribuição.

O algoritmo de valoração desse atributo segue abaixo.

\section{Emp (RELD) = F Emp (RELD) $x$ MR x FD x Pot(RELD) $-F$ Emp (base) $x$ MR(base) x FD(base) x Pot(RELO) (66)}

$F$ emp (base) $=\sum_{i=1}^{n} \quad(P \%(R E L O) \times F$ Emp (RELO)) (67)

Onde:

V Emp (RELD): valoração absoluta de empregos de RELD, medida em postos de trabalho;

F Emp (RELD): fator de empregos do RELD, em postos de trabalho/MWh economizado;

MR: multiplicador regional;

FD: fator de declínio ou curva de aprendizado;

Pot (RELD): potencial de redução de energia ou demanda do RELD (por MWh ou MW);

F Emp (base): fator de empregos em relação à linha de base da capacidade instalada local (em postos de trabalho por MWh economizado);

n: etapas da cadeia energética envolvidas na valoração do RELO.

A valoração da qualidade de empregos para RELDs segue metodologia análoga ao lado da oferta, que pode ser vista na figura 19, no item 5.6.3.3.

\subsubsection{Influência no Desenvolvimento Local}

A influência de projetos energéticos em uma região abre oportunidades de desenvolvimento econômico e melhorias na infraestrutura de diferentes setores como a educação e a saúde. Constrói-se, portanto, uma relação direta entre o aporte de investimentos energéticos - e o consequente aumento de consumo de energia em uma região ou país - e o desenvolvimento econômico e humano, representados pelos indicadores $\mathrm{PIB}$ e IDH, respectivamente.

Por outro lado, o aprendizado de setores produtivos em direção à eficientização de processos e ao emprego de tecnologias progressivamente mais eficientes tem feito com que a relação entre PIB e consumo de energia, ou intensidade energética tenda a diminuir, ou seja, o desenvolvimento econômico ou o aumento percentual do PIB demanda cada vez uma quantidade menor de energia para ser alcançado. Segundo Goldemberg, a relação direta entre PIB e consumo energético pode ser quebrada com rotas alternativas de crescimento a 
base de tecnologias mais limpas e eficientes e o aumento da eficiência energética de usos finais e processos.

Exemplo claro do desacoplamento de parâmetros econômicos e energéticos foi dado na Califórnia, cujo crescimento econômico foi mantido durante duas décadas, sem afetar significativamente o aumento do consumo energético para a realização dessas atividades (BERNSTEIN et al, 2000).

Defensores da eficiência energética sugerem que a melhoria de parâmetros de eficiência pode provocar aumentos de produtividade, receita e PIB. Modelos econômicos de input-output mostram que consumidores e estabelecimentos comerciais utilizam a receita economizada com eficiência energética em áreas da economia mais trabalho-intensivas e mais produtivas do que a comercialização de energia (GELLER et al, 2005). A redução do consumo de energia primária dos Estados Unidos em 15\% entre 1995 e 2010 em decorrência de medidas de eficiência energética resultaria na criação de 770.000 empregos adicionais, o equivalente a um crescimento de 0,44\% na taxa geral de empregos e 14 bilhões de dólares em renda salarial anual, ou um aumento de 0,27\% em 2010 (ENERGY INNOVATIONS 1997). ${ }^{152}$

Portanto, adicionalmente à eficientização de processos produtivos e ganhos econômicos diretos, a implementação de diferentes programas de GLD em uma dada região pode gerar uma série de oportunidades de desenvolvimento de novas frentes de negócio, resultando em benefícios positivos para a economia local como um todo - em termos de geração de empregos diretos, indiretos e empregos de efeito-renda - investimentos em infraestrutura e em desenvolvimento humano.

$\mathrm{O}$ incentivo parcial ou total à venda de equipamentos eficientes ou a substituição e seleção de fontes energéticas é igualmente capaz de promover o desenvolvimento dos setores comercial e industrial. Esse desenvolvimento pode ser medido por diferentes fatores, como a variação do produto interno bruto e da receita obtida por recolhimento de impostos e taxas específicos a atividades relacionadas ao setor, de forma análoga à valoração proposta para os RELOs.

\footnotetext{
${ }^{152}$ Por outro lado, algumas estimativas deixam de considerer o efeito rebote, ainda que reduzido, associado à reducao eventual de preços e custos de energia, aumento de renda ou aumento do PIB induzido por melhorias de eficiência energética.
} 
Obviamente a análise dessa eficiência energética deve ser separada do fenômeno de melhorias autônomas de eficiência energética, resultante de inovação tecnológica. Hogan and Jorgenson (1991) estimam que apenas a evolução tecnológica pode reduzir a intensidade energética geral nos Estados Unidos em $0,34 \%$ ao ano, independente de variações de preços e tarifas energéticas (GELLER et al, 2005).

Em relação ao desenvolvimento humano, o racionamento voluntário de energia pode trazer benefícios em situações nas quais o suprimento é limitado, como em comunidades isoladas do sistema elétrico. Nesse caso, o uso racional e administrado de recursos energéticos, ainda que, por um lado, possa restringir o desenvolvimento econômico de uma comunidade, por outro, resulta na reserva de energia para o atendimento de serviços de saúde e educação, principalmente em exemplos de escolas ou postos com funcionamento noturno. Melhorias em outros setores de infraestrutura como habitação podem ser obtidos com a alocação de superávit de recursos oriundos da economia de gastos energéticos públicos municipais ou regionais.

\subsubsection{Algoritmo de Cômputo e Valoração}

O algoritmo de valoração do desenvolvimento local é, portanto, composto das parcelas: variação de indicadores econômicos, como produto interno bruto e geração de empregos indiretos e efeito-renda, e a alteração de indicadores sociais referentes aos setores de educação, saúde, saneamento, transporte e segurança, entre outros.

A dificuldade em se mensurar a influência de RELDs sobre alterações da infraestrutura local ou do desenvolvimento humano é ainda maior do que na valoração de recursos do lado da oferta.

Assim, a alteração de desenvolvimento econômico e humano como consequência da implantação de RELDs é calculada, à maneira dos demais atributos de demanda, em parcelas relacionadas à influência da eficiência nesses fatores, por um lado, e à influência da redução da implantação de RELDs, por outro.

As equações que valoram esse atributo seguem abaixo:

CVPC D(RELD) $=\Delta F D(R E L D) \times$ Pot(RELD) $-\Delta F D($ base $) \times$ Pot(RELO) 
$\Delta \mathrm{FD}(\mathrm{RELD})=\mathrm{f}(\Delta \mathrm{PIB}, \Delta$ empregos, $\Delta \mathrm{IDH})(69)$

$\Delta \mathrm{FD}$ (base) $=\sum(\mathrm{P} \%($ RELO) $\times \mathrm{FD}(\mathrm{RELO}))(70)$

Onde:

CVPC D (RELD): Valoração de desenvolvimento econômico e social de RELDs (em variação percentual de PIB, IDH, empregos, efeito-renda);

$\triangle F D(R E L D)$ : Fatores de variação de desenvolvimento econômico $(E)$ e humano $(H)$ (em variação de PIB, Empregos, IDH e variantes);

$\triangle F D$ (base): fator de variação de desenvolvimento de RELOs em relação à linha de base da capacidade instalada local ou regional (medida pela variação de PIB, empregos e IDH em função da energia gerada em MWh).

\subsubsection{Impactos de Desequilíbrio Ambiental no Meio Social}

A utilização de recursos de eficientização energética é capaz de minimizar impactos negativos referentes à repercussão da implantação de RELOs em impactos à saúde pública e à agricultura - decorrentes da poluição do ar, da contaminação da água e da geração de resíduos tóxicos. Assim, a perspectiva de redução de geração termelétrica, do adiamento ou cancelamento da construção de termelétricas, ou mesmo da seleção de recursos energéticos do lado da oferta pode trazer impactos positivos ou retardar impactos negativos à saúde e à alimentação de populações afetadas por esses empreendimentos.

Por outro lado, a substituição de equipamentos de uso final ou a prática da arquitetura sustentável pode implicar efeitos à saúde humana, em decorrência do gerenciamento incorreto de resíduos provenientes dessas atividades - desde vapor de mercúrio a gases refrigerantes.

De acordo com Parsons (PARSONS, 2006), a comparação entre lâmpadas incandescentes e fluorescentes compactas em relação à alteração da saúde humana - medida no indicador DALY, ou variação de anos de vida por doenças, em inglês - favorece 0 uso das últimas nas condições experimentais australianas $^{153}$. O estudo levanta a influência de parâmetros como elementos carcinogênicos e compostos orgânicos e inorgânicos presentes nas LFC, em função do indicador DALY em todo o ciclo da cadeia da lâmpada, obtendo uma alteração de respectivamente 0,000000604, 0,000000015 e 0,000102 de anos de vida para cada lâmpada considerada.

\footnotetext{
153 Ao considerar a economia de eletricidade altamente poluente baseada em termelétricas fósseis a carvão, a concentração de mercúrio e outras substâncias tóxicas nas lâmpadas fluorescentes pode ser facilmente compensada.
} 


\subsubsection{Algoritmo de Cômputo e Valoração}

A valoração de impactos de RELDs à saúde humana é medida pela ocorrência de doenças e taxas de mortalidade contabilizadas na cadeia energética de cada recurso - e à alteração na produção de alimentos.

Novamente, a valoração apresenta duas parcelas, a primeira referente a impactos adicionais à saúde e alimentos provocados por RELDs, e a segunda a impactos evitados pela implantação de RELDs, em decorrência da redução da geração de energia.

As equações referentes à valoração do atributo seguem abaixo:

CVPC Saúde (RELD) = $\sum_{\mathrm{i}=1}^{\mathrm{n}} \mathrm{FR}(\mathrm{RELD}) \times \mathrm{FDR}(\mathrm{RELD}) \times \operatorname{Pot}(\mathrm{RELD})$

- $\sum_{\mathrm{i}=1}^{\mathrm{n}} \mathrm{FR}($ base) $\times \mathrm{FDR}(\mathrm{RELO}) \times \operatorname{Pot}(\mathrm{RELO})$

$F R($ base $)=\sum_{i=1}^{n} \quad(P \%(R E L O) \times$ FR(RELO) $)$

Onde:

CVPC Saúde (RELD): Valoração absoluta de ocorrências de doenças ou mortalidade de RELDs (medidas em morbidade ou mortalidade);

FR (RELD): Fator de resíduos dos meios ambientais por ocorrência de RELDs;

FDR (RELD): função dose resposta que associa fatores de resíduos à ocorrência de doenças ou mortalidade e à contaminação alimentar de RELDs;

Pot(RELD): potencial de geração de energia do recurso RELO em unidades por Energia (MWh) ou Potência (MW);

$\mathrm{FR}$ (base): fator de resíduos em relação à linha de base da capacidade instalada local ou regional, representada por m3 em função da Energia (MWh) ou Potência (MW).

\subsubsection{Impacto Humano pela Ocupação Espacial de Empreendimentos}

$O$ atributo avalia a interferência de empreendimentos energéticos sobre 0 espaço ocupado, com consequências sobre habitantes dos meios urbano e rural, em eventos extremos como o deslocamento de populações para atividades como a extração e a produção de energéticos, a transmissão de energia, a construção de grandes usinas e a evacuação de população próxima a elas, como resultado de acidentes. 
A valoração da influência de RELDs sobre esse parâmetro é extremamente subjetiva. Por um lado, o adiamento da expansão da oferta energética como resultado de aumento de medidas de GLD não pode assegurar a eliminação desse impacto a populações potencialmente afetadas. Em outros casos, mostra-se impossível associar o sucesso de metas de GLD ao adiamento de empreendimentos específicos de oferta e, consequentemente, a seus impactos sociais diretos.

No cômputo de impactos de ocupação territorial por RELDs, a valoração tampouco faz sentido, uma vez que a utilização de espaço para a construção de fábricas de equipamentos de uso final ou edifícios, além de desprezível em comparação ao espaço ocupado por empreendimentos energéticos, não pode ser inequivocamente associada a ações ou programas de GLD. Assim, o cômputo e valoração desse atributo pode não ser aplicável a recursos energéticos do lado da demanda.

\subsubsection{Alteração de Percepção de Conforto}

A percepção de conforto de um indivíduo em relação à utilização de um recurso energético é determinante ao seu comportamento, bem-estar e qualidade de vida. A valoração desse atributo considera impactos particulares para os lados da oferta e demanda. Se para RELOs, os índices avaliados relacionam-se a diferentes tipos de poluição apresentados por sistemas energéticos, como visual, sonora, térmica e olfativa, no caso de RELDs, os fatores de alteração de conforto referem-se fundamentalmente à influência de equipamentos de uso final e construções eficientes em ambientes internos.

Os principais padrões de conforto relacionados ao lado da demanda são 0 visual ou luminoso - representado por índices adequados de iluminação para o desempenho de diferentes tarefas -, acústico - provocada pelo impacto de ruídos de equipamentos de uso final - e térmica - pela sensação de conforto provocada pelo condicionamento ambiental, ventilação natural ou isolamento de ambientes (GRAÇA, et al, 2003).

O uso de lâmpadas eficientes pode proporcionar um aumento de qualidade de iluminação, nível de satisfação e aumento de produtividade no caso de funções que demandem alto grau de visão (FISK, 2000). 
Já a avaliação dos efeitos da iluminação - eficiente ou não - sobre o comportamento humano, humor e bem-estar é considerado limitado, a despeito de esforços científicos em inúmeras pesquisas e publicações (McCOLL et al, 2001). Ainda assim, evidências comprovam que variações nas características espectrais de fontes luminosas em termos de intensidade, variabilidade, flicker influenciam a iluminação de um ambiente e, consequentemente, produtividade, humor e saúde humana. É importante ressaltar que essa influência varia de acordo com a população analisada - alguns grupos podem ser particularmente mais sensíveis à presença ou ausência de partes do espectro visível ou variações na distribuição de luz (McCOLL et al, 2001).

Ainda sobre a iluminação, uma das principais diferenças entre fontes naturais e artificiais é a ocorrência de flickering. No caso das lâmpadas fluorescentes compactas, há uma variação de até $60 \%$ na produção de luz a uma taxa de 100 ou $120 \mathrm{~Hz}^{154}$.

$\mathrm{Na}$ área térmica, o isolamento de janelas, além de resultar em ganhos de eficiência energética de edificações, aumenta o conforto térmico de ambientes, por conta da redução de correntes de ar e troca de calor radiante entre 0 habitante $\mathrm{e}$ as janelas. $\mathrm{O}$ isolamento reduz ainda a condensação em janelas $\mathrm{e}$ riscos associados de proliferação de microorganismos (FISK, 2000).

Adicionalmente a essas áreas, o conforto estético de ambientes - avaliado em termos pessoais e subjetivos de decoração ou praticidade - pode ser impactado pela substituição de equipamentos de uso final, como eletrodomésticos ou a utilização de controladores da demanda elétrica ou medidores inteligentes. A avaliação desse tipo de conforto, ainda que minimamente técnica e influenciada pelo fator sócio-psicológico do consumidor de energia, não pode ser minimizada, considerando seu grande impacto na escolha de equipamentos modernos e eficientes.

\footnotetext{
${ }^{154}$ Este efeito é maior em lâmpadas de espectro complete do que em fluorescentes comuns por conta da maior proporção de fósforos na porção azul do espectro visível (WILKINS, WILKINSON, 1991).
} 


\subsubsection{Algoritmo de Cômputo e Valoração}

A valoração desse diferentes tipos de conforto considera diferentes indicadores aos utilizados para a valoração de RELO. Assim, a variação de conforto visual, acústico e térmico pode ser mensurada para diferentes ambientes internos e comparada em relação à situação anterior à implementação de melhorias de eficiência nesses ambientes - ou a parâmetros médios no caso da avaliação de edificações novas.

Para o caso do conforto estético, diferentemente do procedimento para RELDs, dada a subjetividade e a variação de resultados de acordo com grupos amostrais, a valoração deve ser conduzida por meio de consultas e pesquisas de opinião.

Assim a metodologia seguida é a medição local de indicadores e o posterior cálculo comparativo em relação a uma situação média. A quantificação da alteração de conforto em cada um desses fatores é, portanto, a diferença percentual entre valores calculados e valores médios anteriores à implantação de RELDs.

Assim, o conforto acústico calcula o nível de pressão sonora médio e a potência sonora de um ambiente, de acordo com as equações abaixo:

\section{$\Delta \mathrm{La}=\mathrm{Lpa}{ }^{\prime}-\mathrm{Lpa}{ }^{\prime \prime}(73)$}

\section{Lwa=Lpfa + 10.log (S/So) (74)}

O conforto luminoso é medido, principalmente, pelos índices de iluminação de flickering e de espectro visual das fontes utilizadas. A avaliação em pesquisas em escolas feita por Blanco (BLANCO, 2007) e Damato (DAMATO et al, 2009) valeu-se da medição e do cálculo de iluminância, de acordo com a equação:

$i=109 \times 0,85 d(75)$

Onde:

I= iluminância, em lux

$\mathrm{D}=$ distância lateral para a fonte, em $\mathrm{m}$ 
O conforto térmico é medido pela identificação da variação de temperatura interior e detecção de correntes de ar em relação a situação anterior à implementação do isolamento térmico. Essa aferição pode ser considerada perceptiva e, portanto, optou-se por não defini-la por formulações matemáticas.

Mesmo caminho segue a valoração estética de RELDs, cuja aferição pode apenas ser obtida por pesquisas de opinião e sensibilidade junto a grupos amostrais afetados.

Em síntese, a valoração de conforto para RELDs segue parte da metodologia aplicada aos RELOs, mas é complementada com a identificação da variação desses indicadores em relação à situação prévia à implementação desses recursos. Nesse caso, dispensa-se a comparação de resultados medidos ou obtidos em relação a níveis máximos de poluição permitidos, aplicada à valoração de RELOs.

A figura 36 ilustra o algoritmo de cômputo e valoração: 


\section{Algoritmo - CVPC Alteração de Conforto}

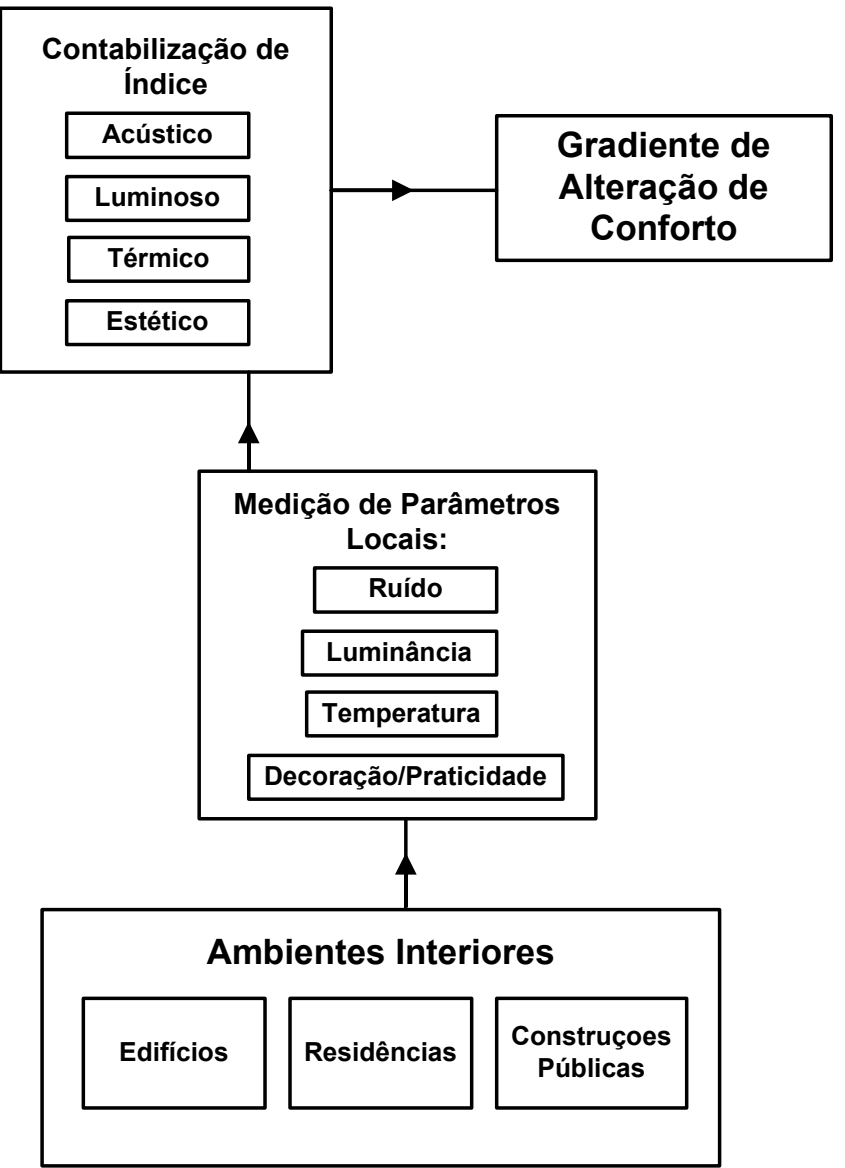

Fonte: Elaboração Própria

Figura 36: Algoritmo de cômputo e valoração do atributo Alteração de Conforto RELDs

\subsection{Cômputo e Valoração da Dimensão Política}

De forma análoga à valoração de recursos energéticos de oferta, a dimensão política de recursos energéticos do lado da demanda, representados por diferentes possibilidades de ações - desde a substituição de equipamentos a programas de educação para o uso racional de energia - analisa um conjunto de fatores capazes de orientar e avaliar o desenvolvimento e a implementação de um determinado recurso energético. O sucesso dessas ações depende, portanto, da coordenação entre fomentadores e implantadores (governo, concessionária, 
universidades) e o setor ou público ao qual se direciona (consumidores finais residenciais, industriais, entre outros).

Em síntese, os atributos valorados nessa dimensão, referentes aos RELDs, tratam da interação entre os diferentes atores do setor de eficiência energética e gerenciamento do lado da demanda, bem como a avaliação dos instrumentos políticos e legais disponíveis para a aplicação dessas medidas ou mesmo a ausência desses instrumentos, configurada como obstáculo à realização de ações ou programas. A avaliação política de RELDs é completada pela aferição do domínio nacional científico e tecnológico ao gerenciamento de programas e à projeção e construção de equipamentos eficientes. Parte dessa análise cabe à dimensão técnico-econômica, especificamente no atributo que mede o índice de nacionalização de tecnologias; a dimensão política trata do compartilhamento desse conhecimento, possibilitado por meio de acordos ou convênios regionais ou internacionais.

A avaliação da dimensão política de RELDs divide-se, portanto, em atributos que buscam quantificar esse impacto de forma numérica sempre que permitida essa possibilidade. No caso da avaliação de instrumentos políticos, mensura-se a intensidade ou volume de apoio a recursos energéticos em função de metas numéricas de implementação, previstas e/ou alcançadas ao longo do tempo; a posse e o potencial de utilização de cada energético são medidos pelo grau de nacionalização de empreendimentos e pelo perfil de acordos de compartilhamento técnico.

O maior desafio persiste na valoração de En-In do lado da demanda, cuja avaliação permanece essencialmente qualitativa, por conta da complexidade e imprevisibilidade das relações entre os atores. A dificuldade da análise aumenta quando se analisam particularidades inerentes a En-Ins de RELDs, como a indiferença ou a neutralidade de posicionamento de alguns atores.

Os próximos itens abordam os impactos de fatores políticos aos RELDs, e desenvolvem algoritmos de cômputo e valoração de potenciais referentes a esses impactos. 


\subsubsection{Instrumentos Políticos de Incentivo}

Esse atributo pretende avaliar o apoio à implementação de RELDs por meio de instrumentos políticos, em termos de objetivos, estrutura e desenvolvimento de programas.

A experiência brasileira em projetos de eficiência energética remete aos anos 80, com a criação do Programa Nacional de Conservação de Energia Elétrica (Procel), do Programa Brasileiro de Etiquetagem (PBE) e do Programa Nacional de Racionalização do Uso dos Derivados do Petróleo e do Gás Natural (Conpet). Os resultados obtidos ao longo dessas décadas - com 9.538 MW reduzidos de demanda na ponta para o Procel - são significativos; contudo, a ampliação desses programas poderia render resultados mais positivos e garantir a postergação de investimentos necessários à ampliação da oferta de energia. $O$ governo federal busca atualmente alcançar novos ganhos e propor metas nacionais em eficiência energética por meio do Plano Nacional de Eficiência Energética, cujas linhas gerais foram divulgadas ao final de 2010.

A avaliação de RELDs divide-se em diferentes áreas, que podem tanto ser cobertas por variadas ações quanto por um único programa. As áreas cobertas por instrumentos políticos são, portanto, legislação, educação e capacitação, financiamento e campanhas de diferenciação de equipamentos de uso final (ALVES, 2007).

A área de legislação inclui a regulação e controle, com a possibilidade de alteração de legislações vigentes ou de códigos de obra, de forma a beneficiar a instalação de equipamentos eficientes de uso final ou alterações em obras que possibilitem a seleção de recursos energéticos, como o uso de aquecedores solares. Dentro dessa área, inclui-se o próprio estabelecimento do PIR em concessionárias, equilibrando a importância do GLD no processo de planejamento energético de distribuidoras.

A área de educação e capacitação refere-se ao compartilhamento de informações de uso racional de energia para diferentes setores de consumo, em diferentes formatos educativos, de disciplinas, cursos e seminários a informativos, cartilhas e outras publicações.

$O$ incentivo à venda e utilização de equipamentos pode ser fomentado com base em mecanismos de mercado - como classificações de eficiência e 
priorização de incentivos para tecnologias em níveis mínimos de eficiência, etiquetagem de produtos, estabelecimento de leilões de eficiência energética ou de instrumentos financeiros, como a aquisição de equipamentos eficientes por meio da facilitação de financiamentos, criação de linhas de crédito específicas como é o caso das opções disponíveis para aquecedores solares - ou fornecimento de subsídios para esses equipamentos.

Por fim, citam-se mecanismos de apoio, considerando acordos de metas voluntárias para eficiência energética em empresas, a criação de organizações empreendedoras de eficiência energética e de ESCOs.

Avalia-se, portanto, a efetividade de políticas de eficientização energética, quanto a mecanismos regulatórios, financeiros e educativos. A análise não se restringe apenas aos pontos positivos de cada tipo de instrumento, mas abrange também restrições e barreiras à sua aplicação.

Essas barreiras concentram-se na área política e técnica, em relação a características e deficiências de programas. De modo geral, a principal deficiência que pode impactar a implementação de RELDs é a falta de atenção e consciência de governos e formuladores de políticas a essas oportunidades. Com base nisso, derivam-se deficiências regulatórias ${ }^{155}$ e econômicas ${ }^{156}$.

As primeiras referem-se à falta de planejamento com perspectivas de curto e longo prazo, com a valorização coerente de medidas de eficiência e GLD dentro dessa projeção (VINE, 2003). Já as barreiras econômicas que prejudicam programas de GLD são baixas tarifas de energia para consumidores finais desestimulando o uso racional e econômico de energia -, alto custo inicial e capital de investimento limitado para programas, alto risco financeiro de programas e prazos de retorno elevados ${ }^{157}$.

Complementando esses grupos de barreiras, citam-se dificuldades técnicas à execução de programas de GLD, como o excesso de capacidade instalada do lado da oferta e a formação inadequada de preços de energia ambos os fatores desestimulantes à eficiência energética (VINE, 2003).

\footnotetext{
155 A obrigatoriedade de programas de eficiência energética é um exemplo de fomento ao ambiente regulatório para a sua execução, analisado extensivamente por Alves (2007).

157 Ainda em relação a barreiras econômicas, ressalta-se a falta de instrumentos legais para incentivar a promoção de ações de eficiência energética por concessionárias, para as quais 0 único negócio previsto por lei é a venda de energia e essa economia representa perda de receita. (VINE, 2003).
} 


\subsubsection{Algoritmo de Cômputo e Valoração}

A avaliação de apoio político a um RELO mensura a efetividade de cada instrumento político de acordo com sua capacidade de implementação de um recurso energético, orientada pela identificação de barreiras à sua implantação e na aferição da capacidade anual de economia de energia de cada recurso energético.

A estrutura do algoritmo de valoração desse atributo analisa os principais tipos de instrumentos políticos energéticos, divididos nas categorias: instrumentos regulatórios (estabelecimento de cotas, mandatos ou padrões mínimos), de mercado (licitações e leilões, medidas fiscais, créditos e financiamentos) e diferentes tipos de instrumento de apoio (ao desenvolvimento de Escos, estabelecimento de acordos voluntários, entre outros). À parte desses instrumentos, figuram ações fomentadoras de novas opções energéticas vinculadas ou independentes desses instrumentos de incentivo, divididas em âmbito educativo (disseminação de informação por guias, etiquetagem de produtos), de investimentos públicos (Programa Minha Casa, Minha Vida, do Governo Federal) e do estabelecimento de linhas de pesquisa e desenvolvimento tecnológico.

A avaliação desses instrumentos segue metodologia análoga à proposta para os RELOS, partindo da jurisdição e da adaptabilidade do programa avaliado (local, regional, nacional ou internacional) e de sua flexibilidade na superação de barreiras técnicas, econômicas e políticas.

O potencial teórico de um instrumento é medido pela meta de redução de energia ou demanda proposta pelo recurso energético (se aplicável) ou sua projeção com base nas condições iniciais do instrumento (atratividade de condições e contratos e efetividade prévia demonstrada pelo instrumento) e sua duração e manutenção - analisada como indicador da intenção de desenvolvimento de um recurso. A projeção pode basear-se em cenários e experiências anteriores de implementação do referido instrumento.

O potencial realizável de cada recurso é medido pela quantidade efetivamente economizada (no caso de programas finalizados) ou projetada (de acordo com a prorrogação ou expiração do programa), com base em experiências anteriores de aplicação de instrumentos. 
O algoritmo de cômputo e valoração desse atributo é análogo ao modelo proposto para RELOs e pode ser visto na figura 4 do item 5.4.3.6.

\subsubsection{Envolvidos e Interessados (En-In)}

O peso da aceitação ou oposição de um determinado setor energético ou social ao uso de um RELO, análise em atributo anterior, no caso de RELDs, mostra-se mais diluído, mas não menos preponderante à sua implantação. Ainda que não se verifique a mobilização de um determinado En-In em relação a um RELD - uma vez que tais recursos não são capazes de influenciar um grupo social de forma tão negativa aos exemplos levantados para RELOs - a baixa aceitação ou capilarização de tecnologias mais eficientes ou de adesão a programas e ações de uso racional por parte da sociedade ou de setores públicos tem o poder de comprometer o alcance de metas ou o aproveitamento de potenciais energéticos de RELDs.

O universo de En-Ins do lado da demanda tem representação e distribuição particulares. De um lado, identificam-se agentes responsáveis por programas do lado da demanda, como órgãos governamentais e empresas de serviços de eficiência energética e, de outro, concessionárias e distribuidoras de energia, participantes ou não dessa iniciativa. Completam o quadro geral, a sociedade civil organizada, enquanto proponente de ações de eficiência energética e os diferentes setores de consumo energético - incluindo 0 residencial e o industrial, e os setores comercial e público, dos quais toda a sociedade participa direta ou indiretamente. Todos esses atores são determinantes, em maior ou menor escala, na decisão de utilização ou não desses RELDs, influenciando esses processos por diferentes tipos de ações ou estratégias públicas, políticas e legais ou pela transposição de barreiras que dificultam a implementação adequada desses recursos.

De forma sintética, os principais grupos de envolvidos e interessados de recursos energéticos do lado da demanda repetem diversos atores apontados na análise de RELOs. Seguem os principais grupos:

- governo (federal, estadual, municipal), representado por diferentes ministérios e secretarias, bem como comissões parlamentares;

- agências reguladoras de eletricidade e energéticos; 
- empresas do setor elétrico e coordenação, nas áreas de geração, transmissão e distribuição;

- associações setoriais energéticas, de diferentes energéticos e atividades da cadeia energética;

- concessionárias e permissionárias: distribuidoras da energia e responsáveis pela otimização desse serviço a consumidores de diferentes setores energéticos, cujo processo decisório equilibra pontos conflitantes $^{158}$;

- setor industrial, representado por fabricantes de equipamentos de uso final;

- consumidores residenciais, cujo comportamento se condiciona a estímulos à adoção de equipamentos eficientes ou mudança de hábitos de consumo;

- consumidores industriais e comerciais - perfil de consumidores diferenciado, considerando a complexidade ${ }^{159}$ da condução de medidas de GLD e sua influência em processos produtivos e atividades comerciais;

- sociedade civil organizada, representada por OSCIPs, associações de diferentes classes, organizações não-governamentais;

- sociedade em geral (cidadãos);

- academia, grupos de pesquisa, docentes, especialistas em questões energéticas socioambientais, corpos estudantis, entre outros;

- Mídia, jornais, revistas, televisão, rádio, periódicos, mídia especializada, veículos de internet - a influência desses veículos sobre alterações de GLD

\footnotetext{
${ }^{158}$ A implantação dessas ações pondera, por um lado, impactos positivos, tais como:

- Melhorias de ordem técnica e eficiência operacional no uso da energia;

-Comercialização de novos serviços ao consumidor;

-Gerenciamento, ainda que indireto, do risco de ampliação do sistema energético a partir da construção de novas usinas diante de incertezas quanto à projeção da demanda;

Por outro lado, aspectos negativos à implementação de RELDs para concessionárias referem-se essencialmente à possibilidade de diminuição de receita de venda de energia, ou da inviabilidade de programas de GLD diante das diversas opções de aquisição de energia mencionadas anteriormente, da autoprodução do lado da demanda.

${ }^{159}$ A complexidade refere-se basicamente às seguintes condicionantes (BAITELO, 2006):

- Modificação de construções ou processos referentes a usos finais;

- Tomada de decisão em grupos hierárquicos representando interesses de diferentes áreas internas a empresas;

- Limitações quanto ao redirecionamento de recursos e pessoal à execução e monitoramento de atividades de gerenciamento de demanda;

- Perspectiva da energia elétrica como um custo gerenciável e otimizável conforme o tipo de contrato acordado com a concessionária ou alternativas de autogeração ou cogeração.
} 
acontece por meio de reportagens ou veiculação de campanhas ou propagandas.

A identificação e mapeamento de En-Ins do lado da demanda energética é igualmente importante a empreendedores e gestores de RELDs, como forma de ambicionar o consenso entre atores preponderantes dos setores envolvidos, sem o qual o sucesso dessas ações de GLD é comprometido.

A avaliação do potencial desses envolvidos repete a metodologia aplicada aos RELOs no tocante à leitura do posicionamento de cada grupo, sua motivação de atuação ou resistência e a ponderação de perdas e ganhos resultante da interação entre os grupos.

Assim, novamente, a identificação de En-In inicia-se com a organização dos diferentes grupos relacionados a um dado RELD, em categorias de grupos como governo, empreendedores, atingidos e sociedade organizada e respectivas jurisdições. A segunda etapa lista os grupos considerados, de acordo com diferentes impactos econômicos, ambientais e sociais decorrentes do RELD analisado. A análise é completada com a valoração de atributos internos a grupos - como representatividade, recursos humanos, financeiros e intelectuais e poder de ação.

A análise interativa de En-Ins por meio da ponderação de riscos, perdas e benefícios de cada agente pode ser novamente conduzida por uma análise de poderes ou de metodologias como a teoria de jogos (FONSECA, 2010).

\subsubsection{Algoritmo de Cômputo e Valoração}

Em síntese, o algoritmo de valoração de En-Ins de RELDs repete a sequência proposta para os RELOs, com o mapeamento e caracterização de EnIns e a extratificação em matrizes de diferentes grupos em função de sua jurisdição.

A interação entre agentes pode ser ilustrada graficamente por ferramentas como análise de poder ou inferências qualitativas e a simulação de resultados dessas interações em diferentes cenários pode ser conduzida em metodologias tais como a Teoria de Jogos ou outras (FONSECA, 2010). 
Assim, a sequência de procedimentos para a avaliação de Envolvidos e Interessados repete o procedimento sugerido para os RELOs, mostrado na figura 6.

\subsubsection{Posse de Recursos e Integração Energética Transfronteiriça}

A análise da posse de um recurso energético do lado da demanda é particular ao procedimento proposto para os RELOs. A viabilidade de implantação de programas ou ações de GLD não depende de privilégios geográficos e naturais; a posse de um RELD é determinada essencialmente pela detenção do domínio tecnológico necessário à eficientização de usos finais e processos analisado na dimensão técnico-econômica - e dos recursos financeiros e intelectuais para sua execução, disponíveis localmente ou compartilhados com outras regiões ou nações.

A análise da propriedade de fontes energéticas não se aplica aos RELDs, uma vez que o direito e o poder de eficientização de usos finais - seja pela aquisição de novos equipamentos ou de mudanças em hábitos de consumo está sob controle da sociedade, em âmbito residencial ou em estabelecimentos comerciais e industriais ${ }^{160}$. Assim, a discussão da propriedade de RELDs não contribui à viabilidades de desenvolvimento e implantação desses recursos.

Portanto, o atributo analisa essencialmente a influência da posse de tecnologia e conhecimento em RELDs para a concretização de potenciais energéticos desses recursos. A posse tecnológica de fabricação de equipamentos eficientes, controladores de demanda ou medidores inteligentes é analisada na dimensão técnico-econômica dos RELDs. Já o domínio experimental e intelectual sobre medidas de GLD é analisado nesse atributo, por meio da integração e o compartilhamento de conhecimento em acordos entre regiões ou países.

Em relação a acordos de cooperação bilateral e internacional em eficiência energética, a experiência brasileira atual, registrada no site do Itamaraty, aponta o lançamento, no Simpósio das Américas sobre Energia e Clima, em Lima, do projeto "Desenvolvimento urbano em áreas de baixa renda com eficiência

\footnotetext{
${ }^{160}$ Não obstante, cabe mencionar que a concretização desse potencial depende da disponibilização de informação a consumidores e expertises específicas a empreendedores.
} 
energética: prédios sustentáveis e transporte público", a fim de orientar o debate de eficiência energética para as demandas dos países em desenvolvimento, com enfoque na construção de casas para pessoas de baixa renda (CONTRIBUIÇÃO DAS AMÉRICAS PARA O FÓRUM URBANO MUNDIAL, 2010, apud ITAMARATY, 2010).

Outra iniciativa apontada no site é a participação do país na fundação da Parceria Internacional para Cooperação em Eficiência Energética (IPEEC), juntamente com a União Européia. O compromisso da cooperação é de "desenvolver alternativas mais seguras, eficientes e sustentáveis aos combustíveis fósseis (ITAMARATY, 2010).

\subsubsection{Algoritmo de Cômputo e Valoração}

Os algoritmos de atributos de valoração da posse de recursos energéticos e da integração energética entre regiões e países são construídos conjuntamente, assim como a valoração proposta para os RELOs. A valoração dos RELDs conta, porém, com adaptações em relação à avaliação de posse e propriedade de recursos.

A posse tecnológica de recursos é avaliada na dimensão técnicoeconômica e a avaliação da propriedade desses recursos não se aplica ao lado da demanda.

Assim, a valoração desse atributo é concentrada na integração energética inter-regional ou internacional, como forma de potencializar a concretização de potenciais realizáveis e de mercado de RELDs. A propriedade intelectual e experimental de recursos, tanto individual, quanto setorial, também pode balizar em termos restritivos - o potencial realizável e de mercado de RELDs.

A esquematização da valoração pode ser vista na figura 37 abaixo: 


\section{Algoritmo - CVPC Posse e Integração Energética de RELDs}

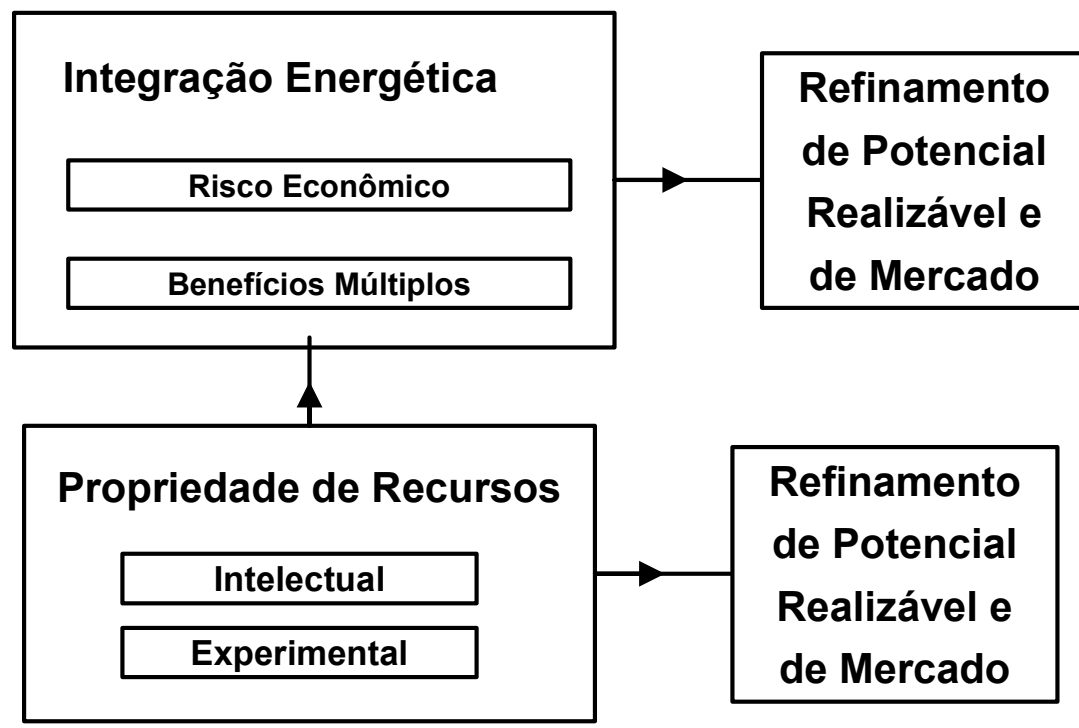

\section{Propriedade Tecnológica}

Dimensão

Técnico-Econômica

Fonte: Elaboração Própria

Figura 37: Algoritmo de valoração do atributo Posse e Integração Energética de RELDs 


\subsection{Cômputo e Valoração da Dimensão Técnico- Econômica}

A dimensão técnico-econômica de recursos do lado da demanda analisa aspectos técnicos, tecnológicos e econômicos da análise de cômputo e valoração de recursos. A exemplo da valoração dessa dimensão do lado da oferta, vários desses aspectos compõem o grupo de custos e potenciais comumente mensuráveis e quantificáveis em análises de viabilidade de recursos energéticos.

O atributo central de análise é novamente o custo da energia economizada e o custo de redução da demanda evitada por meio de ações e programas de GLD, formado por parâmetros como custos de implantação, de operação e manutenção, e componentes técnicos, como vida útil destas ações e redução de demanda em horário de ponta.

Para tanto, analisam-se essas características em atributos diferenciados da dimensão técnico-econômica, tais como: o tempo médio de implantação e duração de uma ação ou programa, a confiabilidade e a monitoração dessas ações - representada pela intermitência do gerenciamento do lado da demanda, a manutenção e a vida útil de equipamentos de uso final e o domínio tecnológico local do recurso utilizado.

A valoração de recursos energéticos do lado da demanda apresenta particularidades em relação a esses atributos. O tempo de implantação e duração de empreendimentos apresenta escalas de tempo bastante diferentes daquelas de sistemas energéticos analisados do lado da oferta. A confiabilidade dos RELD em comparação aos RELO também se diferencia, por ser função de diferentes parâmetros como a monitoração e manutenção de programas, entre outros. Por fim, o atributo que mais se diferencia entre os lados da oferta e da demanda é o custo da energia: no caso da demanda, o balanço entre o custo da energia economizada e a redução de gastos energéticos do edifício ou local considerado pode produzir valores negativos e, com isso, oferecer tempos de retorno atraentes para empreendedores. Obviamente, a decisão pela implementação de RELDs é diferenciada de acordo com setores de consumo, considerando fatores como a urgência, o retorno econômico e diferentes impactos às atividades realizadas na indústria ou edificação considerada.

No próximo item, discutem-se os atributos analisados na valoração de potenciais da dimensão técnico-econômica. 


\subsubsection{Custos de RELDs}

\subsubsection{Custo de Energia Economizada}

A valoração do custo de energia economizada incorpora diferentes parâmetros técnicos e econômicos em sua composição. O primeiro grupo de fatores tem seu desempenho determinado pela evolução tecnológica e grau de desenvolvimento de sistemas energéticos.

Já o segundo grupo conta com análises financeiras, ao avaliar a viabilidade de um empreendimento do ponto de vista do empreendedor ou investidor, considerando aspectos de mercado (SAUER et al, 2009).

A composição de custos varia de acordo com o tipo de recurso energético e o porte da ação ou projeto de eficiência energética. Algumas das ferramentas utilizadas para sua medição são a contabilidade, o fluxo de caixa, o valor desse custo no tempo, figuras de mérito econômico, entre outros.

Dentre essas, optou-se por utilizar nesta análise o custo da energia economizada, ou "Custo da Energia Conservada", para comparar projetos de geração com projetos de eficiência energética. O CEC é calculado como ALCC ${ }^{161}$ não energético (investimento e operacional) de projetos em eficiência, dividido pela expectativa de energia economizada.

Esse atributo, medido em unidade monetária por energia, difere basicamente do custo de energia gerada (atributo presente em avaliações de recursos de oferta) porque os custos vinculados à redução do consumo podem tanto ser positivos quanto negativos. O caso de custos negativos representa, portanto, um ganho econômico referente à economia de energia, se for incorporado na avaliação.

O cálculo do CEC segue a fórmula abaixo:

$C E C=\left(F R C\left(d, n_{E}\right) \times C E-F R C\left(d, n_{C}\right) \times C C+C A_{C \& M}\right) /(E C-E E) \quad(76)$

\footnotetext{
161 Anualized LCC (ALCC) - "Custo Anualizado" - pagamento uniforme, em valor presente, necessário anualmente (ou nos períodos considerados) para cobrir todos os custos de investimento e operacionais ao longo de sua vida.
} 
Onde:

CEC: Custo de Energia Conservada ( $\$$ \$ $/ \mathrm{MWh})$;

FRC: fator de recuperação de capital;

d: taxa de desconto;

$\mathrm{nE}$ : vida útil de tecnologia convencional (anos);

nC: vida útil de tecnologia eficiente (anos);

$\mathrm{CC}$ : custo convencional $(\mathrm{R} \$ \mathrm{MWh})$;

CE: custo eficiente $(R \$ / M W h)$;

EC: energia convencional (MWh);

EE: energia eficiente (MWh);

CAO\&M: custo adicional anual de operação e manutenção $(R \$)$.

O cálculo desse custo é aplicado a medidas de GLD relacionadas à substituição de equipamentos. Para a estimativa de custos de programas gerais de GLD, que contabilizam o levantamento energético e a capacitação e informação de agentes locais, preveem-se em linhas gerais os seguintes custos diretos e indiretos (ANEEL, 2008a):

Capacitação de Técnicos Locais:

- custos diretos - custos de equipamentos e material, custos de transporte, alimentação e hospedagem, remuneração de instrutores;

- custos indiretos - custos administrativos.

Organização de Dados Energéticos:

- custos diretos - custos de formatação mensal dos dados das contas de energia de cidades ou regiões, custos de transporte, alimentação e hospedagem de equipes técnicas;

- custos indiretos - custos administrativos.

Gerenciamento do Consumo de Energia Elétrica:

- custos diretos - custos de deslocamento de equipe técnica;

- custos indiretos - custos administrativos, custos de medição e verificação de redução de consumo energético.

\subsubsection{Custo Evitado de Demanda (CED)}

Esse fator considera o custo total da implantação de um RELD em função de sua demanda evitada, com base em valores da tarifa horosazonal azul, para cada subgrupo tarifário e concessionária/permissionária, homologada pela ANEEL (2008a). O cálculo desse custo segue a seguinte equação:

$$
C E D=\left(12 \times C_{1}\right)+\left(12 \times C_{2} \times L P\right)
$$

Onde:

C1: custo unitário da demanda no horário de ponta (R\$/kW.mês); 
C2: custo unitário da demanda fora do horário de ponta (R\$/kW.mês);

LP: constante de perda de demanda no posto fora de ponta, por kW de perda de demanda no horário de ponta.

O valor da constante LP é calculado com base nos horários da tarifa horosazonal azul, Fatores de Carga (FC) e Fatores de Perdas (Fp), segundo a fórmula a seguir (ANEEL, 2008a):

$\mathrm{Fp}=\mathrm{k} \times \mathrm{FC}+(1-\mathrm{k}) \times \mathrm{FC}_{2}$

Onde:

$\mathrm{K}$ : constante entre 0,15 e 0,30 ;

FC: Fator de Carga médio do segmento elétrico considerado.

Para consumidores que não contam com tarifa diferenciada, o valor do CED deve ser multiplicado por diferentes fatores ${ }^{162}$.

O estudo de Jannuzzi (et al, 2005) indica a faixa de custos e investimentos médios em programas de eficiência e redução de demanda energética, levantado junto às distribuidoras, com base em uma análise de 8 anos.

Tabela 14: Correlação entre energia economizada e custo

\begin{tabular}{|c|c|c|c|c|c|c|}
\hline Ciclo & $\begin{array}{c}\text { Empresas } \\
\text { Participantes }\end{array}$ & $\begin{array}{c}\text { Energia } \\
\text { Economizada } \\
\text { (GWh/ano) }\end{array}$ & $\begin{array}{c}\text { Demanda } \\
\text { Evitada } \\
\text { (MW) }\end{array}$ & ROL (\%) & $\begin{array}{c}\text { Investimentos } \\
\text { Previstos (R\$) }\end{array}$ & $\begin{array}{c}\text { Investimentos } \\
\text { Realizados } \\
\text { (R\$) }\end{array}$ \\
\hline $\mathbf{9 8 / 9 9}$ & 17 & 672 & 167 & 1,00 & 200.883 & 214.784 \\
\hline $\mathbf{9 9 / 0 0}$ & 42 & 672 & 169 & 0,75 & 322.729 & 173.264 \\
\hline $\mathbf{0 0 / 0 1}$ & 63 & 630 & 167 & 0,50 & 169.643 & 109.211 \\
\hline $\mathbf{0 1 / 0 2}$ & 61 & 90 & 23 & 0,50 & 165.943 & 44.831 \\
\hline $\mathbf{0 2 / 0 3}$ & 61 & 222 & 54 & 0,50 & 154.000 & ND \\
\hline $\mathbf{0 3 / 0 4}$ & 61 & 489 & 110 & 0,50 & 313.000 & ND \\
\hline $\mathbf{0 4 / 0 5}$ & 61 & 925 & 275 & 0,50 & 175.000 & ND \\
\hline $\mathbf{0 5 / 0 6}$ & 61 & 569 & 158 & $0,50 / 0,25$ & 311.000 & ND \\
\hline
\end{tabular}

Fonte: Jannuzzi, 2005.

\subsubsection{Algoritmo de Cômputo e Valoração}

O cálculo dos Custos referentes aos RELDs inclui Custos de Energia Economizada, Custos de Demanda Evitada e Custos Gerais de Programa. Cada

\footnotetext{
${ }^{162}$ Para projetos em Baixa Tensão de Sistema Aéreo, deve-se multiplicar o valor do custo unitário de demanda evitada no subgrupo A4 por 1,2. Para o custo unitário de energia evitada, deve-se multiplicar o valor do custo unitário de energia evitada no subgrupo A4 pelo fator $(1+\mathrm{leBT})$, onde leBT é o índice de perdas de energia no segmento de baixa tensão. Para Projetos nas Tensões de Distribuição em Sistema Térmicos Isolados, o custo unitário de demanda evitada é dado pelo produto entre a demanda evitada na ponta e custo marginal de média ou baixa tensão (ANEEL, 2008a).
} 
componente incorpora diferentes fatores, que podem ser visualizados no algoritmo a seguir:

\section{Algoritmo - CVPC Custo de Energia Economizada}

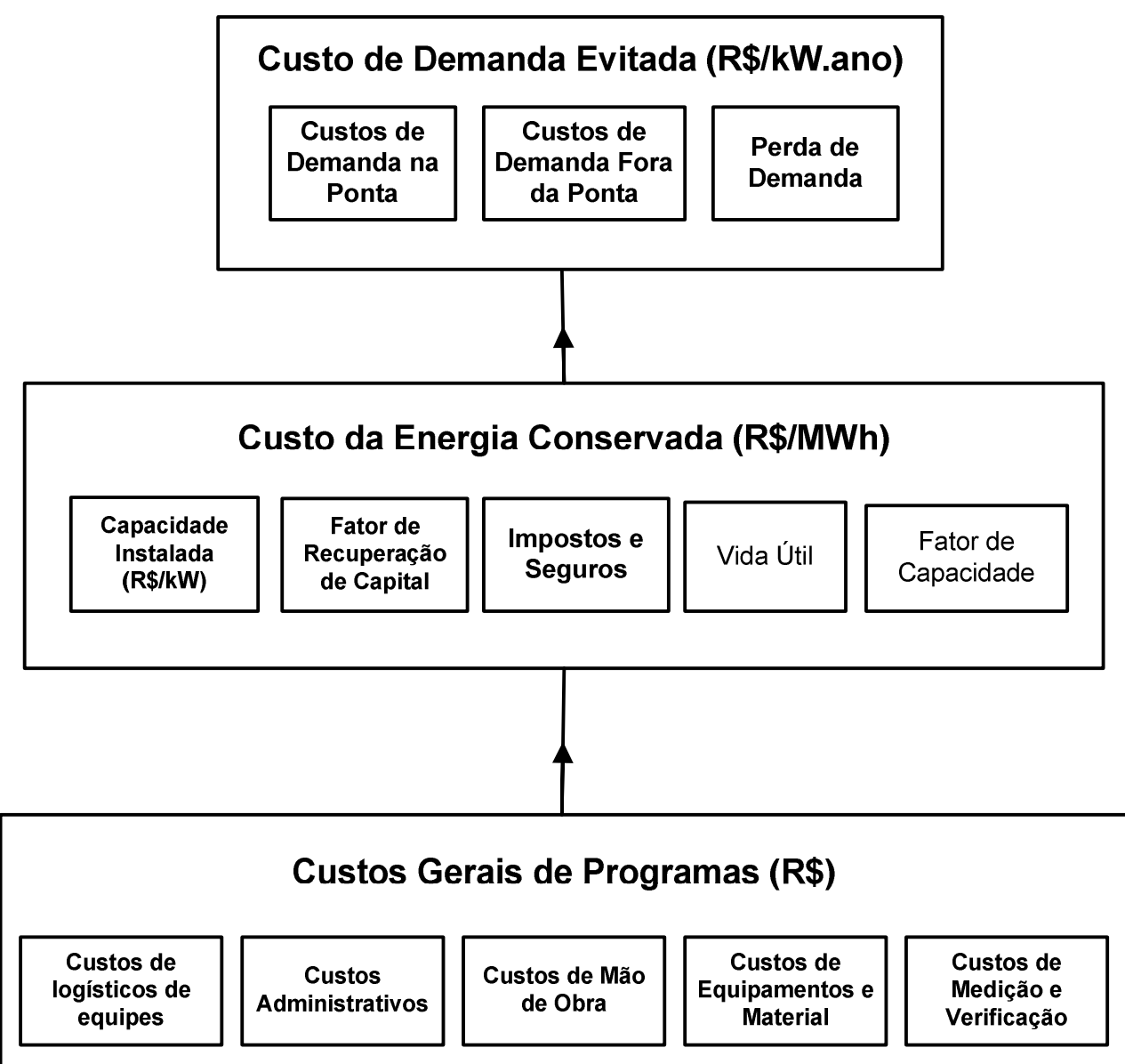

Fonte: Elaboração Própria

Figura 38: Algoritmo de valoração do atributo Custos de RELDs 


\subsubsection{Valoração de Domínio Tecnológico}

O domínio tecnológico de um recurso energético em uma dada região envolve o conhecimento sobre os processos produtivos da tecnologia de conversão energética e da infraestrutura relacionada ao empreendimento desse recurso. Esse conhecimento é medido pela proporção de equipamentos e serviços de procedência nacional ou regional envolvidos no empreendimento, considerando tanto o uso de peças e equipamentos, quanto a especialização necessária para a condução desses projetos. O grau desse domínio tecnológico pode ser representado pelo índice de nacionalização de equipamentos e serviços relacionados a um empreendimento energético.

Subatributos como o conhecimento teórico e prático em administração e gestão de linhas de ação requisitadas pelo recurso de GLD avaliado, representados pela existência de um corpo técnico e profissional capacitado para atuar na área de implantação e desenvolvimento do recurso analisado são avaliados na dimensão política.

Analisa-se, nesse subatributo, a procedência da tecnologia e dos equipamentos utilizados em medidas de GLD, sejam eles controladores de demanda, equipamentos de alto rendimento ou projetos eficientes de conservação de calor ou arquitetura bioclimática.

\subsubsection{Algoritmo de Cômputo e Valoração}

A valoração do domínio tecnológico de um recurso energético do lado da demanda segue exatamente a metodologia proposta para recursos do lado da oferta, com base no cálculo do índice de nacionalização, pela seguinte fórmula:

IV $=(z /(x+z)) .100(43)$

Onde:

$X=$ valor dos componentes importados,

$\mathrm{X}+\mathrm{Z}=$ valor total dos componentes importados e nacionais.

Para a composição desse valor, são considerados todos os custos diretos, indiretos e juros relacionados a equipamentos e serviços de empreendimentos energéticos. 
O algoritmo de cômputo e valoração desse atributo é análogo ao apresentado para o recurso do lado da oferta, na figura 25.

\subsubsection{Tempo de Implantação}

O tempo de implantação considera todo o período de aplicação de um RELD, desde a fase de projetos até a validação de seus resultados. Assim, esse tempo total contabiliza uma somatória de períodos consecutivos de planejamento.

O atributo procura analisar intervalos de tempo médios de ações e programas, considerando seus diferentes alcances para a obtenção de resultados de alteração de demanda e consumo energético. Como o escopo de recursos de GLD é muito amplo, o tempo de implantação considera tanto medidas de rápida implantação e resultados - como a substituição de equipamentos ou a utilização de novas tarifas, como medidas de difícil avaliação e horizontes mais longos de implantação - como a difusão de informação quanto a hábitos de uso racional e a capacitação de profissionais no ramo da eficiência energética.

$\mathrm{Na}$ figura 39 abaixo, são mostradas, em linhas gerais, as etapas envolvidas em um projeto de eficiência energética.

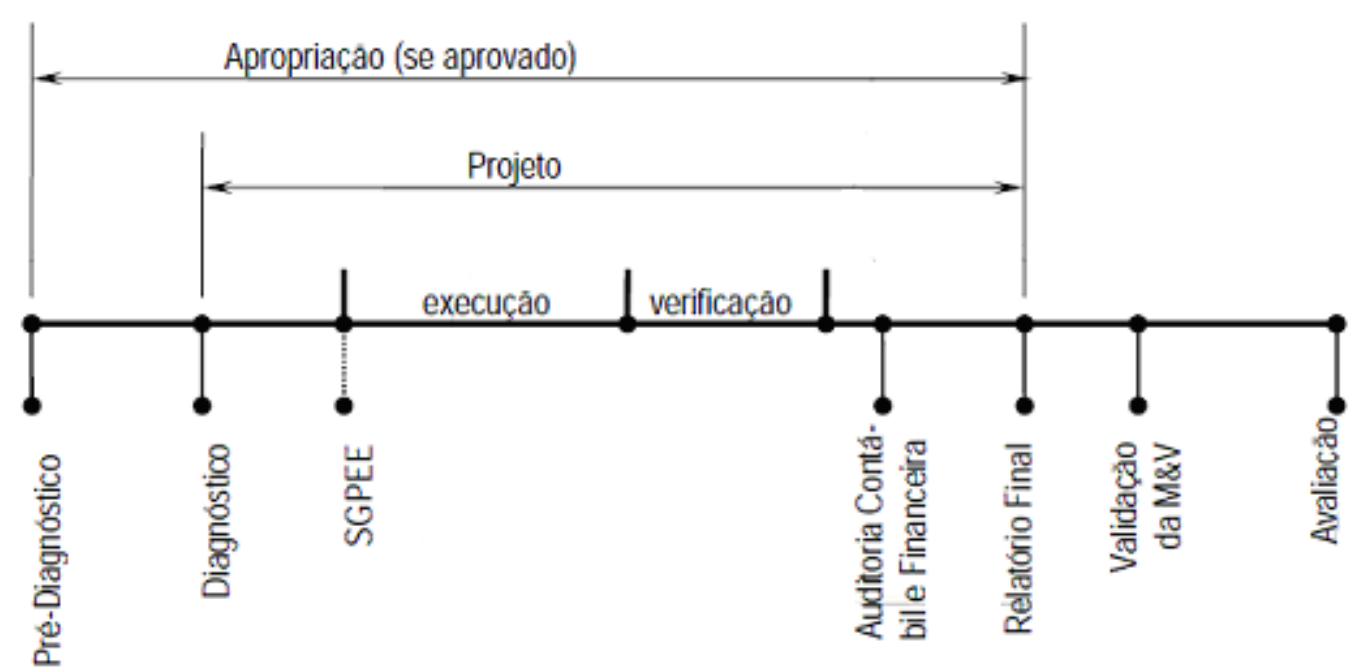

Fonte: ANEEL, 2008a.

Figura 39: Etapas de Projetos de Eficiência Energética

A primeira etapa de pré-diagnóstico considera a identificação de potenciais de economia de energia. Em seguida, a etapa de diagnóstico define a linha de base do projeto. A terceira etapa é a execução, que compreende atividades de 
engenharia e obras. Em seguida, acontece a etapa de verificação, para a contabilização dos reais ganhos de economia de energia e redução de demanda na ponta em relação ao estabelecido na linha de base.

Sucederá essa etapa a validação dos critérios de medição e verificação $(M \& V)$, realizada pela ANEEL. Por fim é iniciada a avaliação dos resultados obtidos no projeto.

Um segundo fator extremamente importante à avaliação de RELDs é a duração do impacto da redução de energia ou demanda. Uma vez que esse parâmetro lida com a constância e confiabilidade de cada recurso, optou-se por analisá-lo em outro item.

\subsubsection{Algoritmo de Cômputo e Valoração}

O tempo total de implantação e realização de um RELD é resultado da somatória ou concatenação dos diferentes períodos de tempo estipulados para cada etapa desse processo. Esse processo pode ser visualizado na figura 40 a seguir. 


\section{Algoritmo - CVPC Tempo de Implantação de RELD}

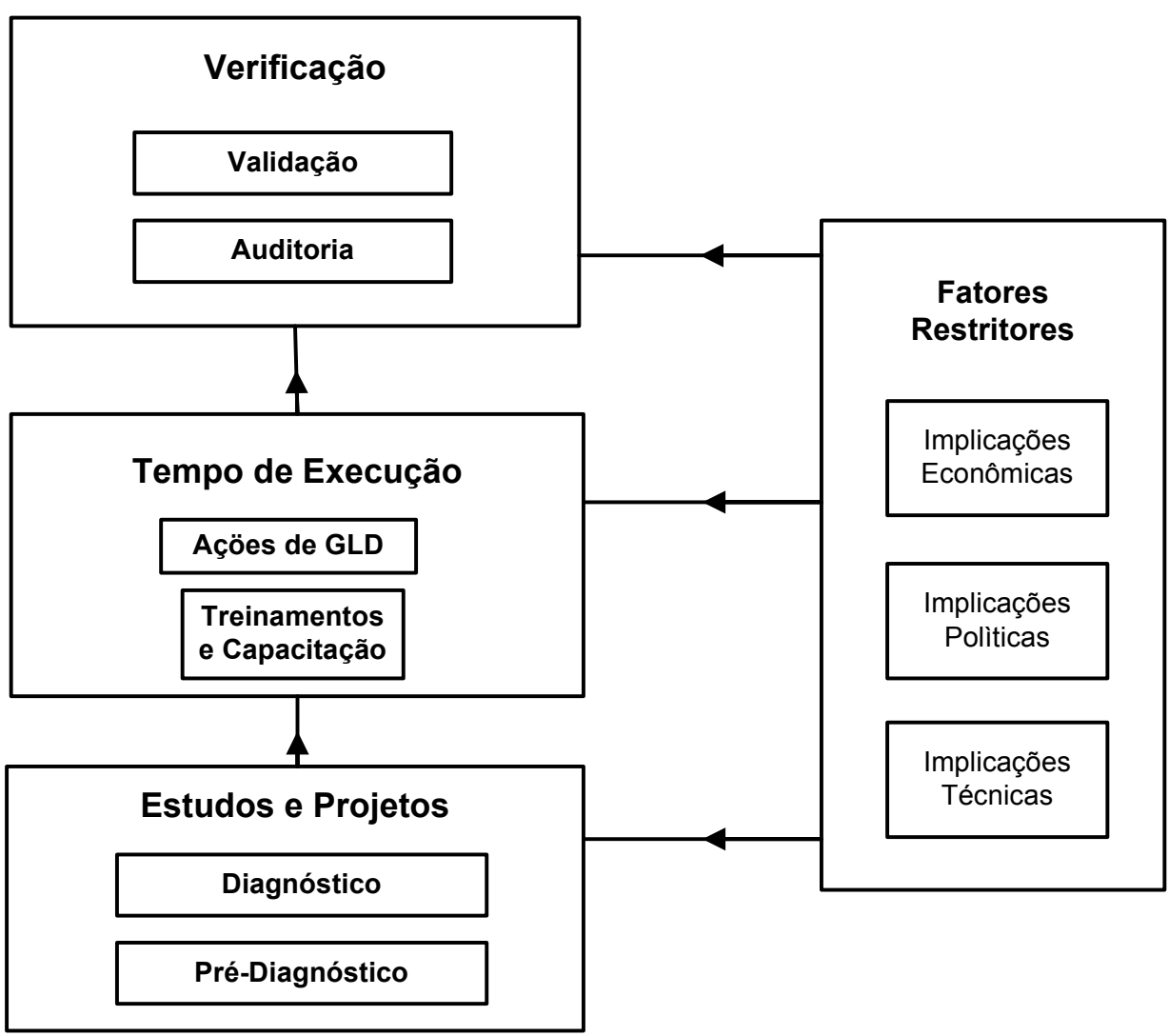

Fonte: Elaboração Própria

Figura 40: Algoritmo de CVPC do tempo de implantação de RELDs

\subsubsection{Confiabilidade}

Procura-se avaliar, neste atributo, a capacidade de um RELD em atingir as metas propostas de acordo com a ação adotada. A análise da confiabilidade de um recurso energético é resultado da combinação da regularidade ou intermitência de sua redução de consumo aliada à duração do efeito dessa 
economia. É medida pela monitoração de ações e/ou programas, processos que variam em decorrência da ampla gama de recursos analisados, em termos de aplicação, finalidade e linha de ação.

A frequência de monitoração e avaliação de RELDs depende também de variáveis e métodos utilizados, como regularidade da monitoração de usos finais, que, em alguns casos, podem durar mais tempo que a implementação do projeto; no caso da instalação de lâmpadas fluorescentes, a ação pode durar três anos, mas a energia economizada resultante deve permanecer por mais tempo. $\mathrm{Na}$ Califórnia, a avaliação de programas realizados entre 2004 e 2005 foi totalmente concluída em $2009^{163}$ (Blumstein, 2010).

A tabela 15, a seguir, explicita a durabilidade de projetos de eficiência energética, seguidos por protocolos de procedimento de medição e verificação (Jannuzzi et al, 2007):

\footnotetext{
${ }^{163} \mathrm{Na}$ Califórnia, sao conduzidos dois tipos de estudos de persistência para a avaliacão de medidas de eficiência energética: estudos de retenção e de desempenho (CPUC 1998). Os primeiros analisam a proporção de medidas implementadas no primeiro ano do programa ainda em vigor até o final do estudo; já os estudos de desempenho medem a eficiência de equipamentos ou ações in loco, a cada quatro ou cinco anos (Blumstein, 2010).
} 
Tabela 15: Duração de Medidas de Eficiência Energética

\begin{tabular}{|c|c|c|c|}
\hline Tipo de projeto & Segmento & Duração & Comentários \\
\hline $\begin{array}{l}\text { EFICIENTIZAÇÃO } \\
\text { INDUSTRIAL }\end{array}$ & INDUSTRIAL & 15 A 25 ANOS & $\begin{array}{c}\text { Troca de equipamentos antigos por outros } \\
\text { mais eficientes ou mudança de processo. A } \\
\text { redução de consumo dura por toda a vida úti } \\
\text { do equipamento. }\end{array}$ \\
\hline $\begin{array}{l}\text { EFICIENTIZAÇÃO } \\
\text { COMERCIAL }\end{array}$ & COMERCIAL & 10 A 15 ANOS & $\begin{array}{l}\text { Troca de equipamentos antigos por outros } \\
\text { mais eficientes. A redução de consumo dura } \\
\text { por toda a vida útil do equipamento. }\end{array}$ \\
\hline $\begin{array}{l}\text { EFICIENTIZAÇÃO EM } \\
\text { PRÉDIOS PÚBLICOS }\end{array}$ & $\begin{array}{l}\text { SETOR } \\
\text { PÚBLICO }\end{array}$ & 10 A 15 ANOS & $\begin{array}{l}\text { Troca de equipamentos antigos por outros } \\
\text { mais eficientes. A redução de consumo dura } \\
\text { por toda a vida útil do equipamento. }\end{array}$ \\
\hline $\begin{array}{c}\text { ILUMINAÇÃO } \\
\text { PÚBLICA: } \\
\text { SUBSTITUIÇÃOO DE } \\
\text { VM POR VS }\end{array}$ & $\begin{array}{l}\text { SETOR } \\
\text { PÚBLICO }\end{array}$ & INDEFINIDA & $\begin{array}{l}\text { A mudança de tecnologia é absorvida pela } \\
\text { concessionária, garantindo sua perpetuidade }\end{array}$ \\
\hline $\begin{array}{l}\text { DOAÇÃO DE } \\
\text { LÂMPADAS } \\
\text { FLUORESCENTES } \\
\text { COMPACTAS }\end{array}$ & RESIDENCIAL & $1 \mathrm{~A} 3 \mathrm{ANOS}$ & $\begin{array}{c}\text { Os projetos ocorrem em classes de baixa } \\
\text { renda não havendo continuidade após a } \\
\text { queima da lâmpada. }\end{array}$ \\
\hline $\begin{array}{l}\text { REBATE - LINHA } \\
\text { BRANCA }\end{array}$ & RESIDENCIAL & 3 A 5 ANOS & $\begin{array}{l}\text { O projeto atinge grande parcela da classe } \\
\text { média. }\end{array}$ \\
\hline $\begin{array}{l}\text { MARKETING } \\
\text { INSTITUCIONAL }\end{array}$ & TODOS & $\begin{array}{c}\text { NÃO } \\
\text { DETERMINADO }\end{array}$ & $\begin{array}{l}\text { Projeto de característica educacional, para } \\
\text { melhorar o nível de conscientização sobre a } \\
\text { economia obtida. }\end{array}$ \\
\hline $\begin{array}{l}\text { PROCEL NAS } \\
\text { ESCOLAS }\end{array}$ & RESIDENCIAL & $\begin{array}{c}\text { NÃO } \\
\text { DETERMINADO }\end{array}$ & $\begin{array}{c}\text { Apresenta excelentes resultados. } \\
\text { A amostra estatística revela um Recall } \\
\text { (lembrança) muito bom e uma redução } \\
\text { sensivel de consumo nas residências das } \\
\text { crianças. }\end{array}$ \\
\hline
\end{tabular}

Fonte: Jannuzzi, 2007

A confiabilidade é também suscetível a fatores como disponibilidade de equipamentos de uso final ou controle de demanda e aos serviços de acompanhamento e monitoração dessas ações.

\subsubsection{Algoritmo de Cômputo e Valoração}

Conforme visto no item anterior, o cálculo da confiabilidade real de um recurso energético é função da intermitência de sua economia de energia quantificada pela sua medição e verificação durante a duração dessa economia, aliada à eficiência e a disponibilidade técnica da tecnologia que possibilita essa economia.

Essa intermitência é função de diferentes fatores como o comportamento de consumidores em termos temporais e sazonais e influências externas técnicas, econômicas e políticas. 
O algoritmo de confiabilidade de recursos energéticos é retratado na figura 41 a seguir:

\section{Algoritmo - CVPC Confiabilidade de RELDs}

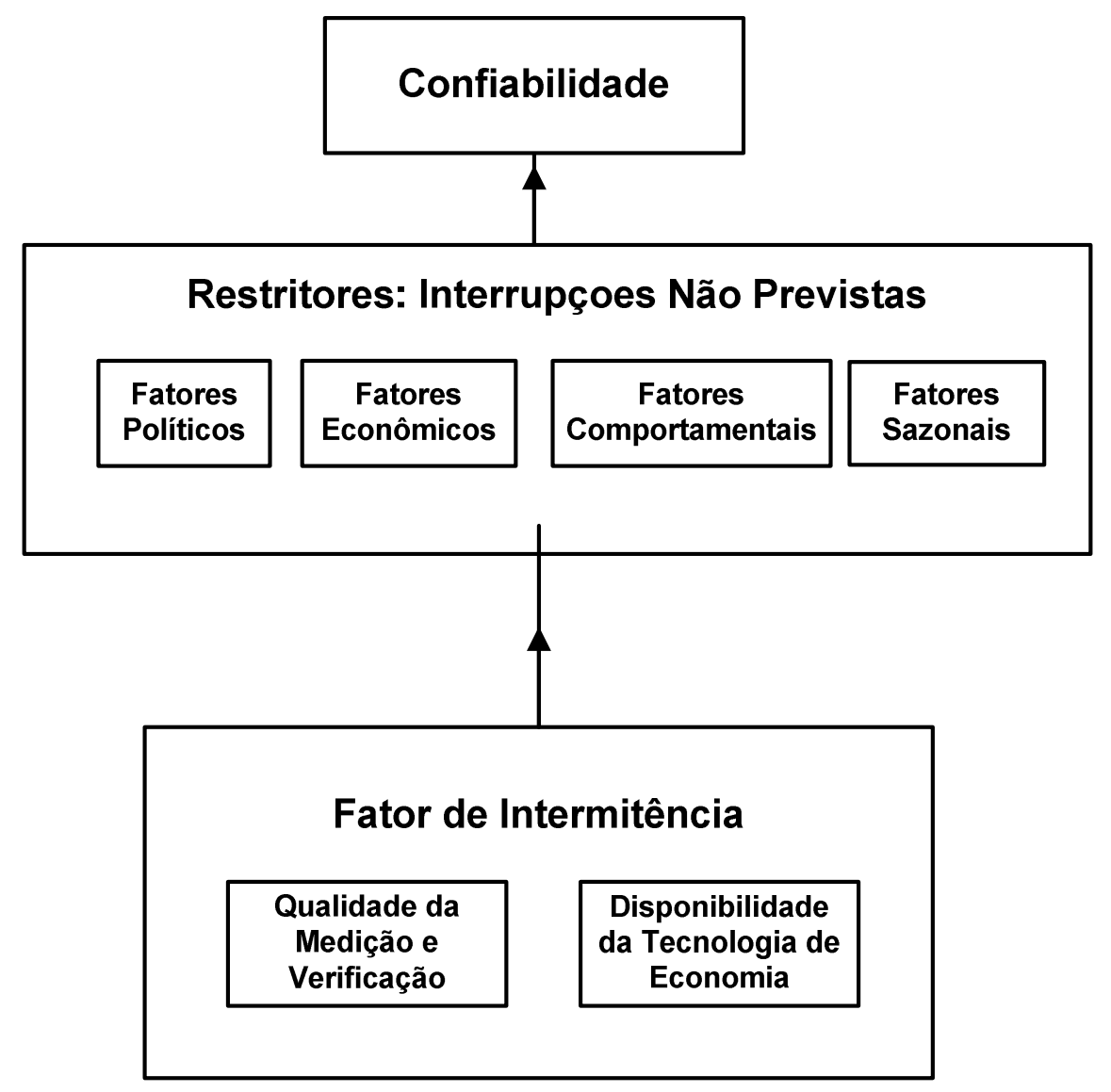

Fonte: Elaboração Própria

Figura 41: Algoritmo de CVPC de confiabilidade de RELDs 


\subsubsection{Valoração de Potenciais Energéticos}

O potencial energético do lado da demanda é caracterizado como a capacidade de economia de energia de um recurso aplicado a um determinado setor de consumo. De acordo com a divisão de recursos do lado da demanda, essa economia pode concretizar-se pela substituição de um uso final específico ou pela aplicação de medidas gerais de alterações de consumo por controle de demanda, reeducação de consumidores ou eficientização de processos e edificações.

O potencial dos RELDs pode ser analisado de forma top down ou bottom up. A primeira metodologia considera, de forma geral, o montante de energia ou demanda que pode ser evitado pela aplicação de um recurso, em relação ao consumo padrão de um determinado setor ou de uma região analisada. Já a avaliação bottom up mensura a quantidade de redução de energia ou demanda obtida pela somatória de medidas de eficiência - constituindo um recurso energético de demanda - comparada novamente a uma linha de base de consumo desse recurso.

Os potenciais de economia ou conservação de energia, a exemplo desses atributos do lado da oferta, figuram entre os fatores mais importantes para a avaliação de recursos energéticos. Os demais atributos da dimensão técnicoeconômica, bem como alguns atributos de outras dimensões, contribuem direta ou indiretamente ao refinamento dos diferentes tipos de potenciais analisados.

A seguir, analisam-se os três principais tipos de potenciais energéticos do lado da demanda. Os potenciais teóricos consideram parâmetros máximos de eficientização e aplicação de RELDs e os potenciais realizáveis e de mercado representam refinamentos desses valores para condições reais técnicas e de mercado.

\subsubsection{Potencial Teórico de Recursos Energéticos}

O cálculo dos potenciais teóricos fundamenta-se em parâmetros máximos de eficiência e possibilidades técnicas, logísticas e geográficas ilimitadas de utilização.

Assim, o valor desse potencial é obtido com base na formulação teórica de energia economizada (em MWh por ano) e da redução de demanda (em kW) 
para diferentes usos finais - considerando uma análise bottom-up - ou reduções máximas de consumo por medidas de GLD - em um modelo top-down.

A formulação de economia de energia e de reduções de demanda compara usos medidos de energia ou demanda antes e após a implementação de ações ou programas de economia de energia. A metodologia base de cálculo desses fatores é apresentada no item algoritmo de valoração (ANEEL, 2008a).

\subsubsection{Potencial Realizável}

O potencial realizável toma como base a energia e a demanda teoricamente economizáveis, incorporando a esses cálculos refinamentos decorrentes de restrições e reajustes de diferentes ordens.

Entre essas restrições, cita-se a correção do potencial pela dedução da economia de energia, atingida por efeitos independentes da implantação de RELDs. Há dois tipos de fenômenos, conhecidos como free riders e spillover. Os free riders são os grupos de consumidores que contribuem a uma redução de economia de energia independentemente de incentivos ou da participação em programas, ou seja, têm motivação pessoal para essa redução e não devem, portanto, ter resultados de redução de consumo vinculados a programas ou ações realizados. Já o spillover considera efeitos de alteração de mercado ou outros fatores prévios à implantação de programas e que perduram durante a ação de GLD, distorcendo resultados de economia de energia.

Além dessas restrições, contabilizam-se ajustes referentes à variação do uso de energia. De acordo com a Aneel, "as condições que geralmente afetam o uso de energia são o clima, ocupação, turnos de trabalho, produtividade total da planta e operações do equipamento requeridas por essas condições" (ANEEL, 2008b). Esses ajustes podem tanto resultar no aumento quanto na diminuição de eficiência energética em comparação a projeções estimadas por potenciais teóricos de economia de energia e demanda.

A validação desses ajustes vale-se de diferentes métodos de análise e coleta de dados, com base em cálculos, pesquisas, modelagens, medidas de usos finais, auditorias e inspeções locais (VINE, 1999). 


\subsubsection{Potencial de Mercado}

O potencial energético de mercado de RELDs, a exemplo da definição utilizada do lado da oferta, concentra-se na discriminação, dentro de um universo de empreendimentos energéticos, daqueles que demonstram sustentabilidade econômica e financeira, avaliando uma série de fatores econômicos e financeiros, mas, acima de tudo, a competitividade de programas ou ações de GLD diante de custo e viabilidade de opções do lado da oferta.

Além do mérito econômico, outros fatores que balizam a dinâmica de avaliação do potencial de mercado são riscos político-econômicos, exemplificados por inclinações de apoio governamental, oscilações de investidores e diferentes riscos geopolíticos como variação de suprimento de combustíveis fósseis e variação da taxa de câmbio internacional - que afetam diretamente a disponibilidade de recursos de oferta e, consequentemente, a viabilidade de medidas de GLD.

\subsubsection{Algoritmo de Cômputo e Valoração}

O algoritmo de valoração de potenciais energéticos parte da construção do potencial teórico, função de diferentes variáveis de equipamentos eficientes e padrões para a contabilização de economia de energia e redução de demanda energética na ponta.

As duas equações gerais para esses cálculos, adaptáveis a diferentes usos finais, seguem abaixo:

$$
\begin{aligned}
& \text { EE }=(\text { NEqex } \times \text { PotEqex }- \text { NEq. ef. } x \text { PotEqef. }) \times t \quad(79) \\
& \text { RDP }=(\text { NEqex } \times \text { PotEqex }- \text { NEq. ef. } \times \text { PotEqef. }) \times F(C P, D, U)
\end{aligned}
$$

Onde:

- NEqex: quantidade de equipamentos existentes;

-NEqef: quantidade de equipamentos eficientes;

- PotEqex: potência de equipamento existente (W);

-PotEqef: potência de equipamento eficiente $(\mathrm{W})$;

- $t$ - tempo de utilização de equipamento, em horas por ano;

- FCP,FU,FD - Fator de Coincidência na Ponta, Fator de Utilização de equipamento ou Fator de diversidade de equipamentos, aplicáveis de acordo com o uso final. 
De acordo com o uso final considerado, a conversão desse potencial em energia depende ainda da eficiência e do rendimento das tecnologias e processos envolvidos.

O potencial realizável refina o valor teórico em vista de diferentes refinamentos técnicos - como a contabilização dos efeitos de free riders $e$ spillovers - e ajustes técnicos em função de condições diversas capazes de afetar o uso da energia. Assim, a equação capaz de exprimir da melhor forma possível o cálculo do potencial realizável é:

\section{Potencial realizável de Economias de Energia = Uso da energia consumo- base - Uso da energia pós-retrofit + Refinamentos \pm Ajustes

Como segunda derivação do potencial teórico, o potencial de mercado infere a proporção da energia teoricamente economizável, aproveitável dentro de regras de mercado e em condições de atratividade econômica determinadas por empreendedores ou mesmo incentivos governamentais. Assim, as variáveis trabalhadas nesta função retratam as condições econômicas e financeiras de cada projeto, entre elas: faixas de preço, risco, taxas de retorno, além de variáveis técnico-econômicas como previsão de oferta da energia em horizontes de curto e médio prazo e decisões políticas decorrentes da conjuntura econômica do momento analisado.

Esse potencial bruto é equiparado à função indexada a tarifas energéticas médias (como preço de liquidação das diferenças) e outros preços de mercado (mercado livre, por exemplo), a fim de determinar esse potencial energético de mercado.

Em suma, o potencial final de um RELD é um algoritmo variável em função do tempo: o potencial teórico apresenta variações técnicas de eficiência de equipamentos e disponibilidade de usos finais; o potencial realizável incorpora ajustes e refinamentos técnicos não previstos na contabilização teórica; e o potencial de mercado oscila de forma considerável de acordo com condições econômicas em cada cenário político e seu aprimoramento de acordo com evoluções tecnológicas. RELDs.

A figura 42 ilustra o processo de cômputo de potenciais energéticos de 


\section{Algoritmo - CVPC Potenciais Energéticos de RELDs}

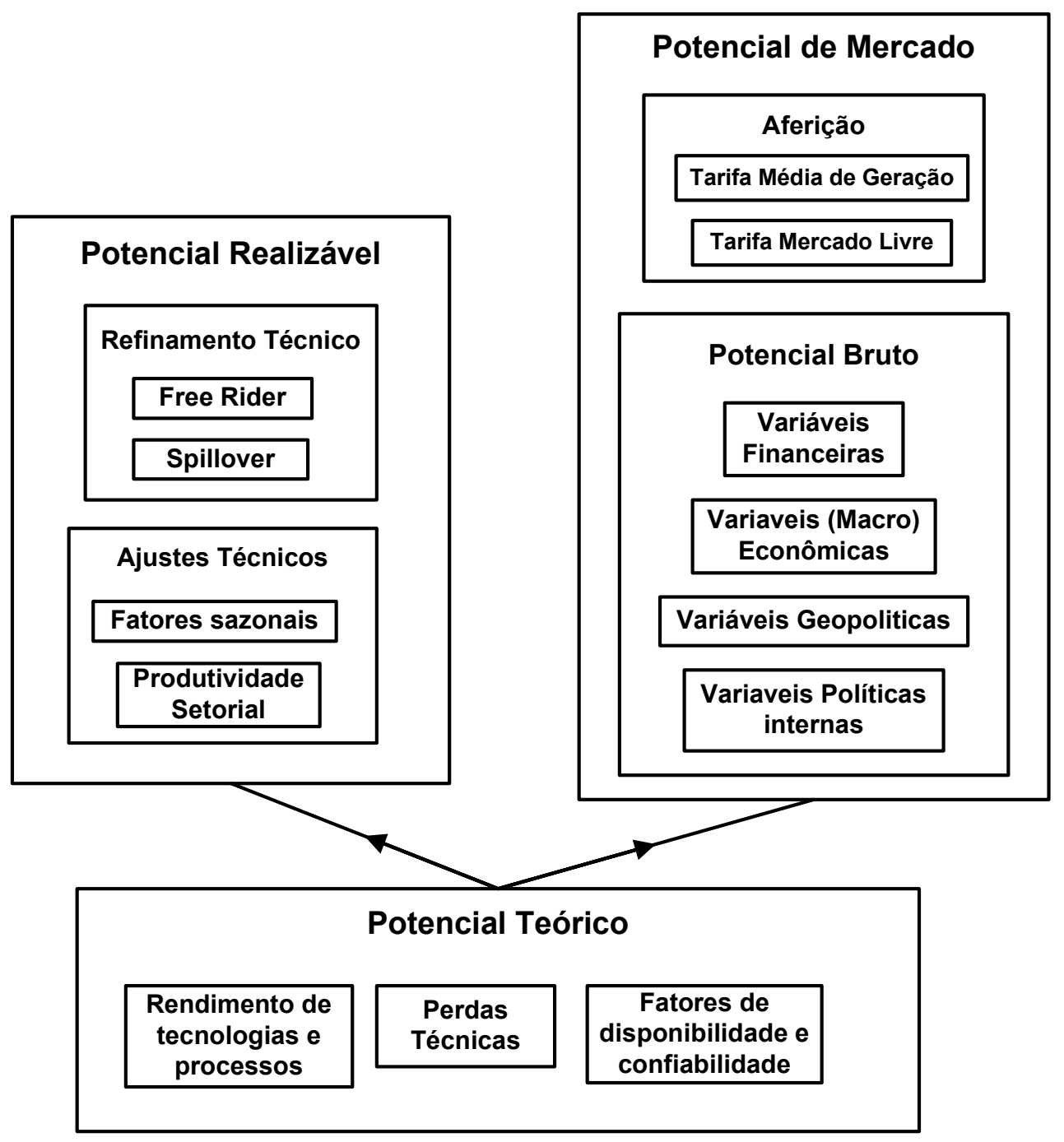

Fonte: Elaboração Própria

Figura 42: Algoritmo de CVPC de potenciais energéticos de RELDs 


\section{Estudo de Caso}

O Estudo de Caso da Metodologia de Cômputo e Valoração de Recursos Energéticos apresentada nesta tese tem como objetivo aplicar os algoritmos elaborados e aferir os potenciais completos de alguns recursos energéticos analisados com base em informações da Região Administrativa de Araçatuba.

Os critérios para a seleção de recursos energéticos foram essencialmente:

- Aplicabilidade futura ou presente na região de estudo, aferida por potenciais teóricos em exercícios anteriores (USP, FAPESP, 2008c);

- Aplicabilidade de recursos ao estudo e observação de impactos estudados e adaptabilidade aos algoritmos elaborados;

- Diversidade de recursos, de forma a abranger comportamentos e características de resultados diferenciados entre eles;

- Disponibilidade suficiente de dados e informações referentes ao recurso nas quatro dimensões de análise.

Os recursos selecionados, respeitando os critérios supramencionados, foram, dos lados da oferta e demanda:

- Pequenas Centrais Hidrelétricas;

- Usinas de Cogeração a Biomassa;

- Substituição de Chuveiros Elétricos por Aquecedores Solares;

- Substituição de Lâmpadas Incandescentes por Fluorescentes Compactas.

Como restrições a esse processo, apontam-se a limitação de cômputo e levantamento de alguns dos atributos considerados, em decorrência da dificuldade de obtenção de dados atualizados para a região, bem como a não aplicabilidade de alguns dos atributos aos recursos energéticos selecionados para o exercício.

Os potenciais obtidos valem-se de índices e informações coletadas no Projeto de Pesquisa de PIR em Araçatuba, coletadas e organizadas entre os anos de 2006 e 2009 e hierarquizada na Mina de Dados (USP, FAPESP, 2008d). Alguns desses números são complementados e/ou atualizados com informações de bibliografia consolidada interna ao grupo, bem como referências nacionais e estrangeiras de grupos de pesquisa e literatura relacionada aos temas estudados.

Segue, nas próximas seções, o Cômputo e Valoração de Potenciais Completos (CVPC) dos recursos contemplados. 


\subsection{Cômputo e Valoração de Potenciais Completos de Pequenas Centrais Hidrelétricas}

A escolha por PCHs para o exercício de CVPC deve-se ao potencial energético levantado para o recurso em relatórios anteriores (2006 e 2008) e às boas possibilidades de concretização desse potencial na região, detalhadas na dimensão técnico-econômica. O exercício busca ainda levantar a relação antagônica entre impactos ambientais de escala aparentemente reduzida e potenciais impactos sociais equilibrados. $\mathrm{O}$ momento atual vivido pelas $\mathrm{PCH}$ em termos de instrumentos de incentivo político e legislação de autorização de construção e instalação é discutido na dimensão política.

\subsubsection{Dimensão Técnico Econômica}

A valoração da dimensão técnico-econômica para recursos energéticos do lado da oferta concentra-se essencialmente em atributos voltados aos cálculos de potencial energético e custos de geração de energia, trabalhados por metodologias conhecidas.

\subsubsection{Potencial Energético}

O cômputo e valoração do potencial energético teórico valeu-se da caracterização dos recursos hídricos na Região Administrativa de Araçatuba, com base em dados do estudo das Unidades de Gerenciamento dos Recursos Hídricos UGRHI-16, UGRHI- 19 UGRHI- 20 (USP, FAPESP, 2006).

Utilizou-se mapas hidrológicos e altimétricos (figuras 43 e 44) para determinar as cotas nas bacias já delimitadas pela Unidade de Gerenciamento dos Recursos Hídricos da Região e, assim, selecionar as tecnologias adequadas para o aproveitamento do recurso hídrico.

As tecnologias de aproveitamento apropriadas para cada queda foram escolhidas de acordo com os valores de diferenças de cotas. Em seguida, determinou-se o número de usinas com possibilidades de construção em cada local escolhido. A somatória delas resultou no potencial explorável ou aproveitável desse recurso para a Região (USP, FAPESP, 2008c). 


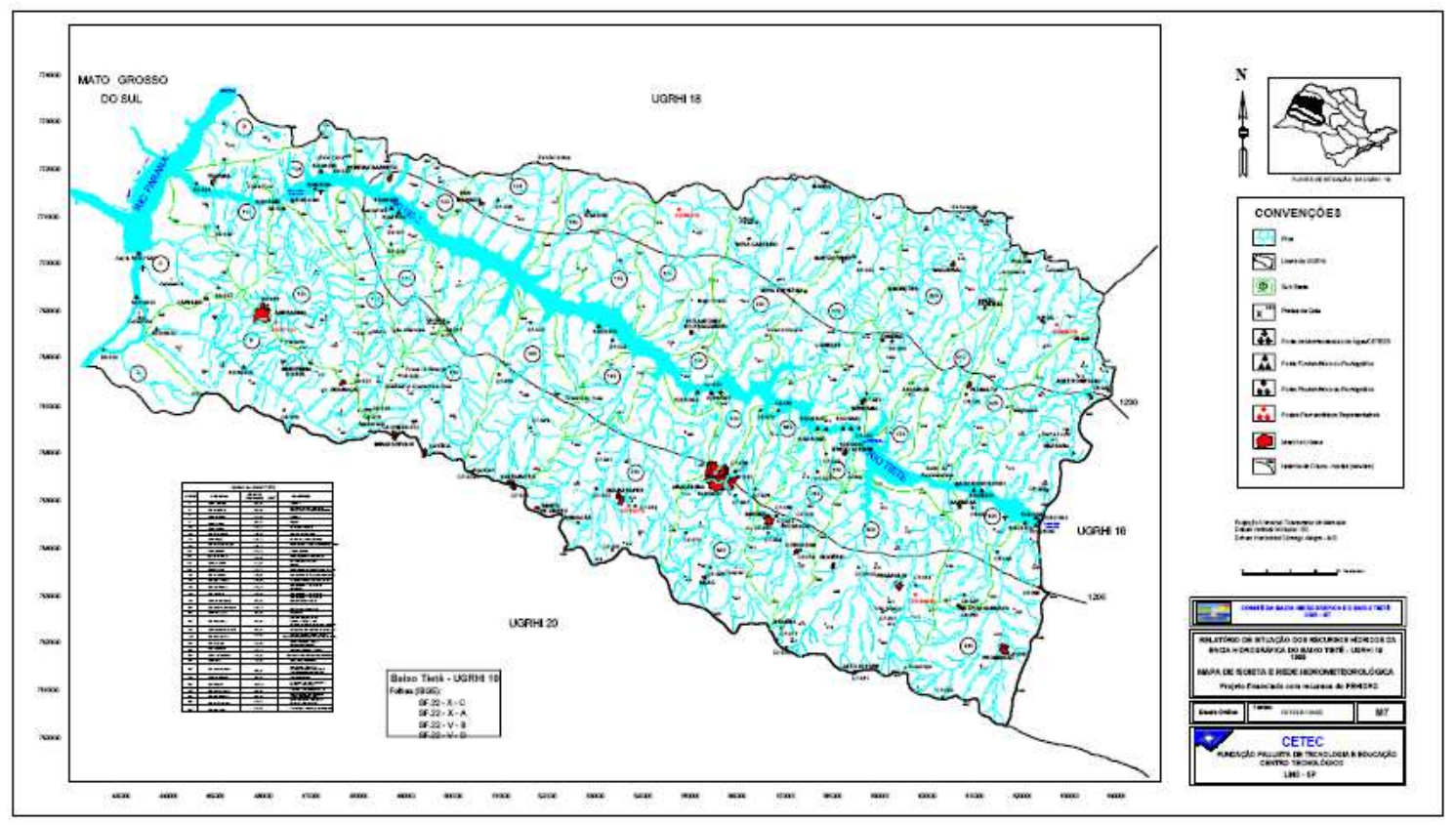

Figura 43: Mapa Hidrológico das bacias e Sub-bacias Hidrográficas da RAA

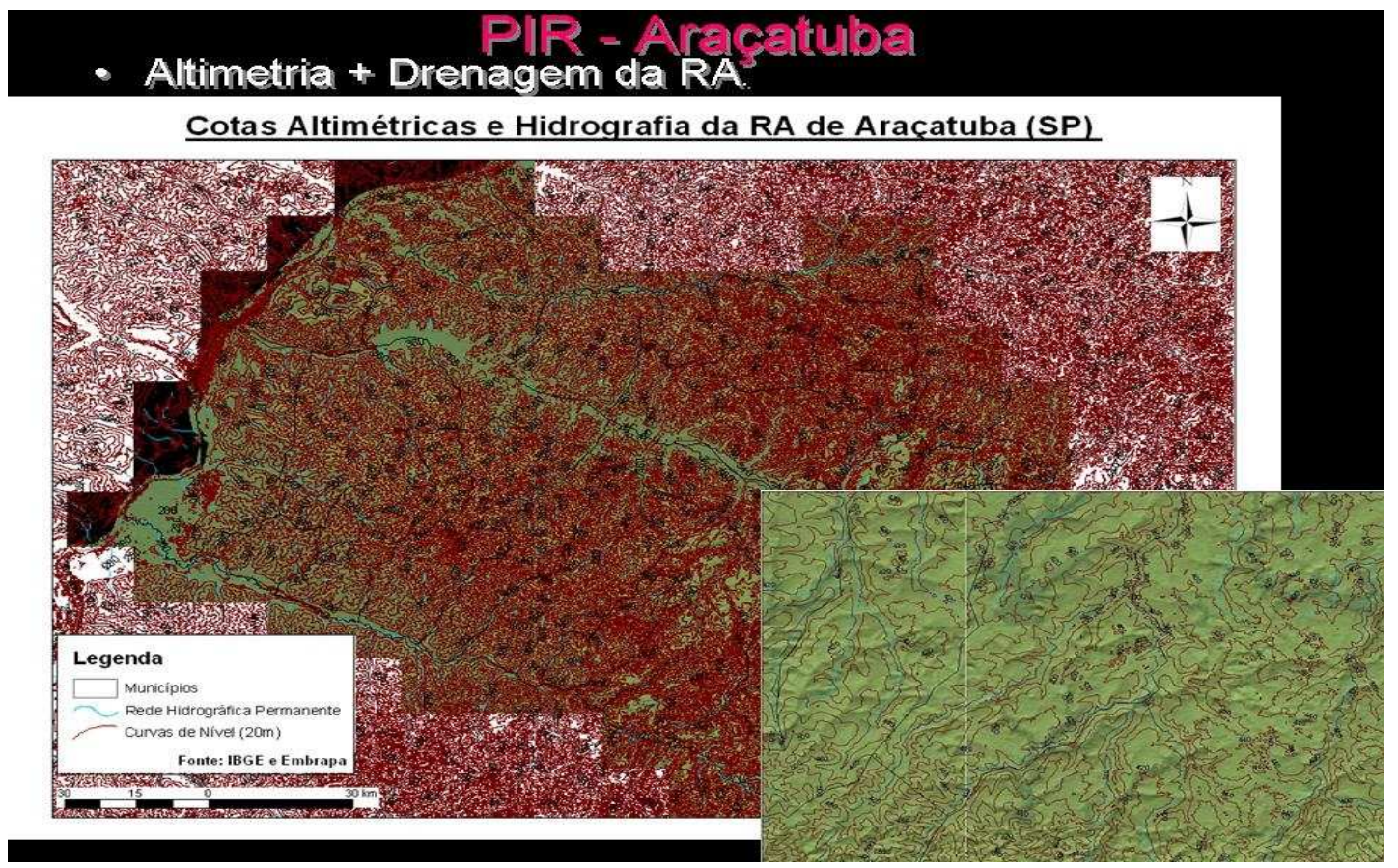

Figura 44: Mapa Altimétrico ou Mapa com Curvas de Níveis da RAA

Fonte: Udaeta, Telles et al, 2007.

O levantamento das cotas em sub-bacias delimitadas pela UGRHI-19 possibilitou o cálculo da diferença entre as cotas para a determinação do potencial teórico desse recurso, utilizando as fórmulas a seguir:

$P=\rho \times g \times Q \times H \times \eta$ 
$H=\Delta Z=Z 2-Z 1$

Onde:

P: Potência instala da usina $(\mathrm{kW})$;

$\rho$ : Peso específico da água $(\mathrm{g} / \mathrm{cm} 3)$;

$\mathrm{g}$ : Aceleração da gravidade $\left(\mathrm{m} / \mathrm{s}^{2}\right)$;

Q: Vazão $\left(\mathrm{m}^{3} / \mathrm{s}\right)$;

$\mathrm{H}$ : Queda Bruta $(\mathrm{m})$;

$\eta$ : Rendimento

$\mathrm{V}$ : Velocidade do escoamento no canal $(\mathrm{m} / \mathrm{s})$;

S: Área do canal $\left(\mathrm{m}^{2}\right)$;

$\mathrm{Z}_{1}$ e $\mathrm{Z}_{2}$ : Desníveis em um canal ou rio $(\mathrm{m})$;

$\Delta Z$ : Diferença de desníveis em canal ou rio $(m)$.

Os níveis foram determinados pelas figuras 44 e 45, resultando nos valores de $\Delta Z$ apresentados (USP, FAPESP, 2008c).

Além dos mapas hidrológico e altimétrico, o levantamento dos locais com potenciais apresentados na tabela 16 abaixo utilizou dados de postos de medição de vazões e pluviometria, que possibilitaram o cálculo das vazões das sub-bacias hidrográficas em toda a região administrativa de Araçatuba.

Conceitualmente, a classificação de PCHs abrange usinas de potência instalada entre 1 e $30 \mathrm{MW}$. De acordo com os resultados de faixas de potência apresentados na tabela 16, a soma dos potenciais referentes a este intervalo resulta em um potencial teórico de 397,73 MW.

Tabela 16: Locais Levantados e Faixas de Potência calculadas

\begin{tabular}{|c|c|c|c|c|}
\hline \multirow[b]{2}{*}{ Parâmetros } & \multicolumn{3}{|c|}{ Tipo de Geração } & \multirow[b]{2}{*}{$\begin{array}{l}\text { Peq. Geração, } \\
10<P<30 \mathrm{MW}\end{array}$} \\
\hline & $\begin{array}{c}\text { Pico Geração, } \\
1<P<100 \mathrm{~kW}\end{array}$ & $\begin{array}{l}\text { Micro Geração, } \\
100 \mathrm{~kW}<\mathrm{P}<1 \mathrm{MW}\end{array}$ & $\begin{array}{c}\text { Mini Geração, } \\
1<\mathrm{P}<10 \mathrm{MW}\end{array}$ & \\
\hline Potencial Total & $933 \mathrm{~kW}$ & $48,60 \mathrm{MW}$ & $373,64 \mathrm{MW}$ & $24,09 \mathrm{MW}$ \\
\hline Locais Identificados & 6 & 86 & 160 & 2 \\
\hline Baixa Queda, $0<\mathrm{H}<15 \mathrm{~m}$ & 6 & 25 & 1 & - \\
\hline $\begin{array}{c}\text { Média Queda, } \\
15<\mathrm{H}<50 \mathrm{~m}\end{array}$ & - & 56 & 55 & - \\
\hline $\begin{array}{c}\text { Alta Queda, } \\
\mathrm{H}>50 \mathrm{~m}\end{array}$ & - & 5 & 104 & 2 \\
\hline
\end{tabular}

Fonte: USP, FAPESP, 2008c

O tipo de turbina hidráulica recomendado para cada aproveitamento é escolhido por meio de curvas características fornecidas pelos fabricantes, que 
orientam as faixas de utilização de cada turbina. $O$ processo de escolha das tecnologias é mostrado na tabela 17 abaixo.

Tabela 17: Escolha das Tecnologias para o Aproveitamento do Potencial Teórico

\begin{tabular}{|c|c|c|c|c|c|c|c|}
\hline \multirow{2}{*}{$\begin{array}{l}\text { Faixas de } \\
\text { Potencias }\end{array}$} & \multirow{2}{*}{$\begin{array}{l}\text { Potencial } \\
\text { (MW) }\end{array}$} & \multirow{2}{*}{$\begin{array}{l}\text { Locais } \\
\text { Identificados }\end{array}$} & \multicolumn{3}{|c|}{ Quedas } & \multirow{2}{*}{$\begin{array}{l}\text { Tipo de } \\
\text { Turbina } \\
\text { Francis } \\
\end{array}$} & Tecnologias \\
\hline & & & Baixa & Média & Alta & & $\begin{array}{l}\text { Turbina } \\
\text { Kaplan }\end{array}$ \\
\hline $\begin{array}{l}\text { Mini Geração, } \\
1 \mathrm{MW}<\mathrm{P}<10 \mathrm{MW}\end{array}$ & 373,64 & 160 & 1 & 55 & 104 & $X$ & $X$ \\
\hline $\begin{array}{l}\text { Pequena Geração, } \\
10<P<30 \mathrm{MW}\end{array}$ & 24,09 & 2 & - & - & 2 & $x^{164}$ & $X$ \\
\hline
\end{tabular}

Fonte: USP, FAPESP, 2008c

\subsubsection{Tempo de Implantação}

O processo de implantação de uma pequena central hidrelétrica pode ser dividido em 3 etapas principais. A primeira delas destina-se ao levantamento de informações sobre o local previsto para a instalação do empreendimento, seguida da realização de um estudo de inventário para a mensuração do potencial hidrelétrico da bacia hidrográfica. Passa-se, então, ao estudo de viabilidade, que busca a otimização técnico-econômica e ambiental do empreendimento. Após esse, é solicitado o registro ativo junto à Aneel e elaborado o projeto básico, detalhando obras civis e equipamentos hidromecânicos e eletromecânicos.

O processo de autorização para exploração de pequenos aproveitamentos hidrelétricos é formalizado por meio de outorga de autorização, após a análise do projeto básico pela Aneel. Paralelamente a todo esse processo, são tomadas as providências para a obtenção do licenciamento ambiental.

O emparelhamento de todos esses processos pode levar até 6 anos. A média considerada para esse atributo exclui, no entanto, a duração do licenciamento ambiental e da outorga do órgão regulador, analisadas na dimensão política.

\footnotetext{
${ }^{164}$ As tecnologias marcadas com "X" são aplicáveis para a faixa de potência considerada, apesar de suas vazões e quedas não serem apresentadas nesta tabela.
} 
O tempo médio de implantação é resultado da somatória dos tempos de projetos e estudos ao tempo de construção, de acordo com a equação 33 abaixo:

\section{Tempo de Implantação $=\mathrm{T}($ Projeto\&Estudos $)+\mathrm{T}$ (Construção)}

$\mathrm{T}($ Projeto\&Estudos $)=2$ anos

$\mathrm{T}$ (Construção $=\mathrm{T}$ (Desvio do Rio) $+\mathrm{T}$ (preparação do sítio $)+$ $T$ (fundação\&concretagem + T (montagem eletromecânica) + $\mathrm{T}($ comissionamento $)+\mathrm{T}$ (testes de potência $)=2$ anos

O tempo total de construção leva em média entre 18 e 24 meses. Já a etapa de estudos, antes prevista em 5 anos, reduziu-se para 2 anos em função da unificação do processo de mapeamento e monitoramento geológico e meteorológico (pluviometria, temperatura, velocidade de ventos) compartilhado entre diferentes setores, tais como agrícola, aviação ou navegação marítima.

A estimativa utilizada para o cálculo do custo de geração utiliza apenas o tempo de construção e não contabiliza o tempo médio adicional por atrasos imprevistos (cheia inesperada, por exemplo). Esse pode variar entre 6 meses e 1 ano, afetando o custo do empreendimento e a disponibilidade de mão de obra da construção.

\subsubsection{Confiabilidade}

O cálculo da confiabilidade real de um recurso energético é função de seu fator de capacidade aliado à disponibilidade da tecnologia empregada em sua conversão.

A avaliação de interrupções não previstas, como consequência de variáveis políticas e econômicas ou fenômenos naturais é estimada em $5 \%$.

No estudo de caso, considerou-se o intervalo mínimo e máximo de 53 e $67 \%$ para o fator de capacidade, ou média de 60\% dentre empreendimentos avaliados nos últimos leilões de energia (EXCELÊNCIA ENERGÉTICA, 2010).

Conforme visto no item 5.7.6, as equações utilizadas para valorar a confiabilidade de um recurso ponderam o fator de capacidade e a disponibilidade 
de uma usina, em função de uso de combustível, ou interrupções técnicas ou de outra ordem:

CVPC Conf $($ RELO) $=$ FC(RELO) $x$ FD $($ RELO) $=$ FC(RELO) $x($ FDComb) $x$ $($ FDUsina $)=0,60 \times 0,95=0,57$

Assim, considerando-se um fator de capacidade médio de 60\% multiplicado por um fator de disponibilidade de 95\%, obtém-se um fator de confiabilidade de $57 \%$.

\subsubsection{Distância de recurso energético a centro de consumo}

O atributo de distância de RELO a centro de consumo é medido pelo custo de conexão de uma usina ou sistema energético ao sistema de distribuição ou transmissão.

Agentes geradores podem optar por ambas as formas de conexão ao Sistema Interligado, conectando-se à rede de distribuição ou diretamente à de transmissão. Esta última modalidade tem sido fomentada pelo crescimento da capacidade instalada e pela consequente dificuldade de absorção no sistema de distribuidoras em até $69 \mathrm{kV}$. A conexão é feita pelo uso de Instalações de Transmissão de Interesse Exclusivo de Centrais de Geração para Conexão Compartilhada (ICGs).

Para as PCHs, o cálculo do total anual da Tarifa do Uso do Sistema considera o uso das ICGs, bem como o desconto de $50 \%$ na tarifa de uso do sistema de distribuição. Os valores da TUSDg e da ICG média consideraram a média de encargos de diferentes projetos, atualizados pelo IPCA ${ }^{165}$. A essa tarifa, acrescentam-se as alíquotas de PIS e COFINS, considerando tributação em lucro presumido.

TUSDg $=$ R $\$ 5,80 / k W$. mês

\footnotetext{
${ }^{165}$ A determinação da TUST média considerou a Resolução Homologatória n 907/2009, ANEXO II. Com base no referido anexo, foi calculada a média dos encargos de TUST dos 35 projetos listados, com os valores atualizados pelo IPCA para janeiro de 2010. A determinação do encargo da subcoletora da ICG média considerou a Resolução Homologatória nø81/2008, ANEXO II. Calculou-se, com base nos valores de encargos estabelecidos e também atualizados pelo IPCA (EXCELÉNCIA ENERGÉTICA, 2010).
} 
Encargo ICG: R\$2,59 / kW.mês

Tarifa Ajustada $=$ TUSDg $\times 50 \%+$ Encargo ICG $=R \$ 5,49 / \mathrm{kW}$. mês

Tarifa Ajustada com impostos $=\mathrm{R} \$ 5,49 /(1-9,25 \%)=\mathrm{R} \$ 6,05 / \mathrm{kW}$.mês

\subsubsection{Cômputo e Valoração de Domínio Tecnológico}

O domínio tecnológico é medido pelo cálculo do Índice de Nacionalização. Para a composição desse valor, são considerados todos os custos diretos, indiretos e juros relacionados a equipamentos e serviços de empreendimentos energéticos. De acordo com o levantamento de diferentes projetos nacionais (EXCELÊNCIA ENERGÉTICA, 2010), todos os equipamentos e serviços relacionados à construção e instalação de $\mathrm{PCHs}$ são produzidos no país, o que valida o domínio tecnológico sobre esse recurso. Dessa forma, o índice é considerado próximo ou igual a 100\%.

\subsubsection{Custo unitário de Geração de Energia}

A simulação dos custos de investimentos e de geração utilizou o método de fluxo de caixa descontado. Para tanto, considerou-se a faixa de potência média de $19,2 \mathrm{MW}$ e o custos de investimentos específico de $\mathrm{R} \$ 5.472 / \mathrm{kW}$. O fator de capacidade considerado foi de $60 \%$, valor médio entre os mínimos de $53 \%$ e $67 \%$. As taxas de juros utilizadas foram de $9 \%$ (para investimento de capital de terceiros) e 9,67\% (para investimento de capital próprio) (EXCELÊNCIA ENERGÉTICA, 2010).

Os encargos do setor elétrico considerados foram: Tarifa de Fiscalização de Serviços de Energia Elétrica (TFSEE), Contribuição Associativa CCEE (Câmara de Comercialização de Energia Elétrica), Taxa de Administração do ONS (Operador Nacional do Sistema Elétrico), Investimento em Pesquisa e Desenvolvimento (P\&D) e Tarifa de Uso dos Sistemas de Distribuição e Transmissão (TUSD e TUST).

Os custos operacionais utilizados incluem: operação e manutenção, custos administrativos e seguros. As taxas de manutenção consideradas para simulação foram de $\mathrm{R} \$ 12,95 / \mathrm{MWh}$. A tabela com os parâmetros utilizados para o cálculo do custo de geração e os resultados obtidos dessa simulação são mostrados na tabela 18 e no anexo 2. 
Tabela 18 - Parâmetros e atributos técnico-econômicos

\begin{tabular}{|c|l|}
\hline Parâmetros & \multicolumn{1}{|c|}{ Valores } \\
\hline O\&M & $\mathrm{R} \$ 12,95 / \mathrm{MWh}$ \\
\hline Administrativo & $\mathrm{R} \$ 700.000 / \mathrm{ano}$ \\
\hline TUSD & $\mathrm{R} \$ 8,39 / \mathrm{kW}$.mês \\
\hline Encargo CCEE & $\mathrm{R} \$ 250 / \mathrm{MW}$ \\
\hline Encargo ANEEL & $0,5^{\star} \mathrm{R} \$ 363^{*} \mathrm{~kW}$ \\
\hline Capital Financiado & $70,05 \%$ (BNDES - Finem) \\
\hline Custo Financeiro & $\mathrm{TJLP}+3 \%$ \\
\hline Custo de Capital Próprio & $9,67 \%$ \\
\hline Tempo de Amortização & 162 meses $(\mathrm{SAC})$ \\
\hline Período do Fluxo de Caixa & 30 anos \\
\hline Período de Construção & 22 meses \\
\hline
\end{tabular}

Tabela 19: Simulação dos Custos de Geração de PCHs

\begin{tabular}{|c|c|}
\hline Parâmetros & Valores \\
\hline Potência da Turbina (kW) & 19.200 \\
\hline Investimento Especifico (R\$/kW) & 5.472 \\
\hline Investimento Total ( em milhões de R\$) & 105,06 \\
\hline Fator de Capacidade anualizado (\%) & 60 \\
\hline Custo Unitário de Geração (R\$/MWh) & 148,22 \\
\hline
\end{tabular}

${ }^{*}$ BNDES - Finem

\subsubsection{Qualidade de Energia}

Por conta da falta de exemplos práticos de implantação de PCHs no local de estudo e da ausência de registros de comprometimento da qualidade de energia provida por PCHs a consumidores, assume-se que este atributo não tenha interferência negativa na valoração deste recurso. Os casos identificados por Galhardo e Pinho (2003) referem-se a sistemas de pequeno porte conectados a sistemas isolados, exemplo que não se aplica à situação de instalação estudada neste caso.

\subsubsection{Dimensão Política}

A valoração dos atributos da dimensão política vale-se essencialmente de análises qualitativas para mensurar $o$ potencial de implementação e aproveitamento de recursos, à luz de fatores como políticas de incentivo, ponderação de balanço e interação entre atores do setor e características de propriedade de recursos. 


\subsubsection{Instrumentos Políticos}

Em termos de incentivos políticos, as PCHs foram contempladas no Programa de Incentivo a Fontes Alternativas (Proinfa) e necessitam apenas de autorização da Aneel para implantação. Além disso, têm direito à redução das tarifas de uso dos sistemas de transmissão e distribuição e a isenção do pagamento da compensação financeira pelo uso de recursos hídricos.

Como resultado desses benefícios, em 2010 foram instalados $516 \mathrm{MW}$ distribuídos em 32 empreendimentos em construção (ANEEL, 2010).

Por outro lado, as $\mathrm{PCHs}$ têm perdido competitividade em relação às demais renováveis, por conta de mudanças no marco regulatório de registro e outorga de PCHs (Resolução 343/2008), alterações de exigências da Aneel relacionadas ao projeto básico das usinas e falta de incentivos de desoneração fiscal sobre equipamentos, como os presentes para projetos eólicos. O reflexo desse momento foi a contratação de apenas uma $\mathrm{PCH}$ nos leilões de energia renovável (em agosto de 2010) em comparação a 70 projetos eólicos e 12 de biomassa $^{166}$.

A avaliação política de geração de energia por $\mathrm{PCH}$ pode ser medida por meio de seu potencial econômico de implantação ou o potencial de mercado. Esse, por sua vez, é calculado com base na comparação entre o custo de geração de projetos de $\mathrm{PCHs}$ em condições variadas de mercado e sua comparação aos valores oferecidos nos programas e iniciativas governamentais de contratação de energias renováveis.

Assim, a metodologia considera a precificação dos leilões, o instrumento vigente de contratação de energias renováveis, considerando as condições de financiamento e de desoneração fiscal oferecidas para as PCHs. O indicador valorado é o deságio entre o preço teto e o preço médio determinados pelo último

\footnotetext{
${ }^{166}$ Atualmente, em paralelo aos leilões de energia, vem sendo proposta uma nova legislação para energias renováveis no Brasil. Esse trabalho vem acontecendo na Câmara dos Deputados, dentro da Comissão Especial de Energias Renováveis, que analisou 19 projetos de lei e produziu o texto para uma nova lei de energias renováveis em julho de 2009. Para a geração de grande porte em parques eólicos, centrais de cogeração e pequenas centrais hidrelétricas, foi prevista, no artigo 2 do substitutivo, a realização de leilões anuais, oferecendo uma quantidade mínima de 600 MW médios das fontes eólica, biomassa e pequenas centrais hidrelétricas (com $200 \mathrm{MW}$ médios para cada). Propõe-se, ainda no artigo 32 do projeto, a dedução de gastos com a aquisição de bens e prestação de serviços referentes a instalações de geração renovável do lucro operacional líquido das empresas responsáveis por eles.
} 
leilão e os patamares de custo de geração de PCHs considerando as condições de incentivo.

Utilizando os resultados obtidos para as simulações de $\mathrm{PCH}$ na dimensão econômica em comparação ao preço teto dos últimos leilões de energia renovável, obtém-se:

Tabela 20: Valoração de Instrumentos Políticos

\begin{tabular}{|c|c|}
\hline Parâmetros & Valores \\
\hline Capacidade Instalada (kW) & 19.200 \\
\hline Investimento Especifico (R\$/kW) & 5.472 \\
\hline Fator de Capacidade anualizado (\%) & 60 \\
\hline $\begin{array}{c}\text { Custo de Geração (R\$/MWh) } \\
\text { (Sem CC, Desconto 50\% TUSD) }\end{array}$ & 148,22 \\
\hline $\mathbf{\Delta R \$ \text { (PML-CUG) }}$ & $-6,28$ \\
\hline
\end{tabular}

As perspectivas de contratação e construção de novas $\mathrm{PCH}$ crescem de acordo com a estipulação de preços teto mais elevados e maiores incentivos que se reflitam em tarifas mais baixas. Preços-teto baixos, por sua vez, dificultam a competitividade de parte dos projetos, ainda que apresentem viabilidade econômica. Assim, quanto maior a margem de diferença entre o preço teto fixado por leilões e o preço de viabilização de usinas, maior seu potencial de mercado; por outro lado, uma margem é negativa indica inviabilidade do empreendimento neste tipo de competição ou instrumento político.

É importante ressaltar, que a análise desse atributo vale-se do indicador monetário (em diferença de $\mathrm{R} \$ / \mathrm{MWh}$ entre custo de viabilização e preço teto de leilões) a fim de aferir seu potencial de mercado. O uso desse indicador não se presta à seleção de um determinado recurso energético ou à análise de viabilidade desse recurso a longo prazo em conjunção com outras opções energéticas. Essa ação é realizada nas etapas de integração de recursos e elaboração de carteiras energéticas.

\subsubsection{Licenciamento Ambiental e Autorização de Construção}

O tempo total de implantação de uma usina envolve, além do período de estudos e projeto e da construção propriamente dita, processos políticos relacionados à autorização técnica e legal para a construção do empreendimento, embasada em múltiplos critérios de avaliação e aprovação. 
O processo de autorização para exploração de pequenos aproveitamentos hidrelétricos é formalizado por meio de outorga de autorização, após a análise do projeto básico pela Aneel. Havendo o aceite desse projeto, é realizada uma análise e posterior aprovação, atendendo a condições de licença prévia emitida pelo órgão ambiental, declaração de reserva de disponibilidade hídrica emitida pelo órgão gestor dos recursos hídricos e compatibilidade do projeto básico com as condições anteriores.

O licenciamento ambiental constitui uma das etapas mais críticas para a viabilização das PCHs. O processo é dividido nas etapas de licença prévia (LP), licença de instalação (LI) e licença de operação (LO). A LP é concedida na fase inicial de planejamento da central, após a apresentação do relatório de impacto ambiental simplificado. A LI é solicitada após a elaboração do projeto básico ambiental. Já a LO é solicitada após o desenvolvimento do projeto e a construção da usina.

Segue abaixo a tabela $21 \mathrm{com}$ a contabilização dos tempos médios de expedição de licenças ambientais para empreendimentos hidrelétricos, levantada em relatório do Banco Mundial (BANCO MUNDIAL, 2008).

\section{Tabela 21: Tempo médio de expedição de licenças ambientais}

\begin{tabular}{|c|c|c|c|c|c|c|c|c|}
\hline & $\begin{array}{c}\text { Dias até o envid } \\
\text { do TdR pelo } \\
\text { IBAMA ao } \\
\text { empreendedor } \\
(\mathbf{n}=\mathbf{2 0})\end{array}$ & $\begin{array}{c}\text { Dias até a entrega } \\
\text { do EIA/RIMA ao } \\
\text { Ibama } \\
(\mathbf{n}=\mathbf{1 3})\end{array}$ & $\begin{array}{c}\text { Dias até a } \\
\text { primeira } \\
\text { audiência } \\
\text { publica } \\
(\mathrm{n}=13)\end{array}$ & 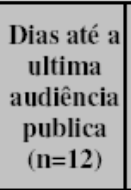 & $\begin{array}{c}\text { Dias até } \\
\text { a emissã } \\
\text { da LP } \\
(\mathrm{n}=11)\end{array}$ & $\begin{array}{c}\text { Dias até o } \\
\text { empreendedor } \\
\text { requerer a Licençą } \\
\text { de Instalação } \\
(n=13)\end{array}$ & $\begin{array}{c}\text { Dias até o } \\
\text { Ibama } \\
\text { emitir a } \\
\text { Licença de } \\
\text { Instalação } \\
(n=12)\end{array}$ & $\begin{array}{c}\text { Dias até a } \\
\text { emissão da } \\
\text { Licença de } \\
\text { Operação } \\
\text { (n=11) }\end{array}$ \\
\hline $\begin{array}{l}\text { Media } \\
14 \\
\text { total }\end{array}$ & 394 & 613 & 852 & 876 & 958 & 1103 & 1235 & 2335 \\
\hline $\begin{array}{l}\text { Media } \\
\text { etapa }\end{array}$ & 394 & 220 & 239 & 24 & 82 & 144 & 132 & 1100 \\
\hline $\begin{array}{c}\text { I.N } \\
{ }^{15} \mathrm{IBAM} \\
\mathrm{A} \\
65 / 2005\end{array}$ & 30 & $\begin{array}{c}\text { responsabilidade } \\
\text { exclusiva } \\
\text { empreendedor }\end{array}$ & & 270 & & $\begin{array}{l}\text { responsabilidade } \\
\text { exclusiva } \\
\text { empreendedor }\end{array}$ & 150 & $\begin{array}{c}\text { Depende } \\
\text { essencial- } \\
\text { mente do } \\
\text { prazo de } \\
\text { construção }\end{array}$ \\
\hline
\end{tabular}

Fonte: Banco Mundial, 2008

Ambas as etapas de autorização e licenciamento ambiental são cruciais à viabilização de empreendimentos, por serem fontes de alteração de custos e cronogramas de implantação.

No caso da outorga de autorização, o marco regulatório das $\mathrm{PCH}$ sofreu mudanças nos últimos anos. A Resolução 343/2008 da Aneel alterou as normas do processo anteriormente regido pela Resolução 395/1998. A outorga de 
autorização para o início da construção do empreendimento passou a exigir um depósito de fiel garantia do cumprimento do cronograma e a elaboração e entrega dos estudos passou a ter prazo definido. A análise dos projetos básicos dos aproveitamentos permite agora apenas um vencedor concorrendo ao projeto, através de critérios estabelecidos na resolução. O nível de exigências da Aneel referente aos estudos de inventário e projeto básico tem onerado os projetos e dificultado a viabilização dos empreendimentos.

A valoração do licenciamento ambiental e da outorga de autorização de empreendimentos é contabilizada pela duração desses processos.

$\mathrm{T}($ licenciamento $)+\mathrm{T}($ outorga $)=\mathrm{T}(\mathrm{LP})+\mathrm{T}(\mathrm{LI})+\mathrm{T}(\mathrm{LO})+\mathrm{T}(\mathrm{OA})=30+9+36+$ $14=89$ meses

O tempo máximo de expedição de licenciamento e outorga de autorização considerando-se os casos mais extremos, chega a 89 meses ou 7,4 anos. Ressalta-se que os tempos médios de licenciamento usaram como base exemplos de empreendimentos de grande porte. No entanto, a complexidade identificada para a obtenção do licenciamento de usinas de pequeno porte permite a aplicação dessas médias no presente estudo de caso.

\subsubsection{Envolvidos e Interessados}

A primeira etapa da valoração de Envolvidos e Interessados relacionados à implantação de PCHs refere-se ao mapeamento de suas funções, interesses e motivações.

Recursos energéticos, tradicionalmente considerados como alternativos, tendem a receber maiores índices de aceitação da sociedade, por um lado, por conta da redução de impactos socioambientais e maior rejeição de grandes consumidores e distribuidores, por outro, por implicarem elementos de inovação comumente relacionados a expectativas de incertezas no campo do planejamento e gerenciamento energético. Entretanto, esse não é o caso das PCHs, rechaçadas por boa parte da sociedade civil - por conta de impactos sociais e ambientais - e apoiadas por atores tradicionais do setor elétrico.

A seguir, o posicionamento dos principais atores é comentado. 
Governo Federal: A motivação do governo em utilizar o potencial hídrico para a geração de eletricidade - considerando benefícios gerenciais e de planejamento ligados à larga experiência nacional na área de hidroeletricidade, bem como a baixa emissão de gases de efeito estufa desse recurso renovável - está concentrada nos empreendimentos de grande porte. A predileção se dá em função do volume de energia gerada e da economicidade decorrente desses projetos, em oposição ao fator de capacidade reduzido e custos superiores das PCHs. Em síntese, ainda que a posição do governo não seja, de forma alguma, contrária ao desenvolvimento de PCHs, a falta de isonomia em condições de incentivo em comparação às demais fontes renováveis demonstra menos interesse do governo à exploração desse recurso, em detrimento do potencial de grandes aproveitamentos hidrelétricos.

Geradores: O domínio do gerenciamento e do planejamento do setor de PCHs não é suficiente para motivar geradores diante de incertezas relacionadas aos processos de licenciamento ambiental e a modificações regulatórias para a obtenção da outorga de funcionamento de usinas. Muitos empreendedores optaram por migrar para a área eólica, por conta de condições diferenciadas de desoneração fiscal e maiores facilidades de obtenção de licenças ambientais.

Construtores: A motivação de empresas construtoras e empreiteiras é aproveitar o grande potencial hidrelétrico nacional e construir empreendimentos de grande e pequeno porte. A localização desses projetos não representa impeditivo a essas empresas; fatores econômicos e sua relação com o risco financeiro de projetos são as principais barreiras ao posicionamento de construtores. Em alguns casos, essas empresas apresentam problemas de tratamento com as populações atingidas por barragens.

Financiadores: $O$ principal financiador de energias renováveis no Brasil é o BNDES. Na última década, o banco financiou a construção das usinas do Proinfa e de grande parte das usinas leiloadas nos leilões de biomassa e eólica. Entretanto as condições de financiamento e amortização de dívidas nem sempre resultam na viabilização de empreendimentos, seja por falta de capital próprio ou por falta de competitividade em leilões ou licitações. O BNDES apresenta uma posição teoricamente isonômica em apoio a todas as fontes de energia, mas, 
apesar de seu papel destacado no setor elétrico, não oferece as melhores condições financeiras a áreas específicas como a eólica, que se tem viabilizado majoritariamente com financiamentos do BNB (Banco do Nordeste).

Distribuidores: Apesar da ampla experiência e confiabilidade da hidroeletricidade na matriz elétrica nacional, a aceitação por parte dos distribuidores pela possibilidade de utilização dessa matriz hídrica para geração elétrica de pequeno porte tem sido dividida nos últimos tempos: os leilões de energia renovável de 2010 negociaram 70 parques eólicos e 12 centrais de cogeração a biomassa contra apenas uma $\mathrm{PCH}$, por conta da falta de competitividade tarifária. O setor vem, portanto, perdendo espaço na competição com as demais fontes renováveis e os custos mais elevados desencorajam distribuidoras a contratar esse tipo de energia, em detrimento das demais fontes.

Grandes Consumidores: $O$ posicionamento dos grandes consumidores de energia pela utilização de energia de recursos hídricos de pequeno porte é positiva, levando-se em consideração a boa confiabilidade no fornecimento de usinas hidrelétricas. Entretanto a motivação desses consumidores leva em conta, em primeiro lugar, a acessibilidade da tarifa oferecida como condição de viabilização de suas atividades e negócios.

Órgão Ambiental: As principais funções de órgãos ambientais competentes à avaliação de empreendimentos energéticos são de avaliar potenciais impactos ambientais resultantes da implantação desses projetos, autorizar sua construção - por meio da avaliação de relatórios e estudos de impacto ambiental - e acompanhar a evolução da construção e funcionamento de tais empreendimentos - por meio de monitoramento e avaliações de desempenho ambiental. O posicionamento de órgãos ambientais em âmbito federal e local, ainda que teoricamente neutro, é bastante rígido em relação ao licenciamento de empreendimentos hidrelétricos de pequeno porte. Conforme visto no item anterior, a incerteza do horizonte de expedição de licenças é fator preponderante para a implementação de empreendimentos.

Atingidos: A instalação de PCH pode incidir direta ou indiretamente sobre comunidades indígenas, quilombolas ou de outros grupos sob aspectos 
ambiental, social, político e econômico, nas diversas fases de planejamento, execução e operação do empreendimento. Dessa forma, a posição natural de grupos atingidos por esses empreendimentos, sejam eles deslocados de seus territórios ou afetados por alterações de vazão de rios e de seus múltiplos usos, tende a ser contrária à sua construção. Observam-se tentativas de agentes planejadores e construtores desses empreendimentos de reduzir a oposição dos grupos atingidos por meio de políticas de relacionamento pró-ativa e ações afirmativas de responsabilidade social com as comunidades impactadas.

Organizações Não-Governamentais: A aceitação por parte do setor das organizações não-governamentais pela possibilidade de aproveitamento de matriz hídrica para geração elétrica de pequeno porte é parcial, variando desde a oposição total em áreas ambientalmente delicadas até a aprovação de empreendimentos de pequeno impacto ambiental com a finalidade de atendimento energético a comunidades isoladas.

População: A aceitação popular de empreendimentos hidrelétricos tende a ser inversamente favorável em relação ao porte e a escala de potência adotada. No caso de PCHs, uma vez que o porte da usina não apresenta relação linear e proporcional ao seu potencial impacto socioambiental, não se pode traçar um comportamento da opinião populacional em relação a esses empreendimentos. No caso específico da Região Administrativa de Araçatuba (RAA), os estudos realizados pela equipe de pesquisadores do PIR na região indicaram, conforme relatado, favorecimento natural à exploração de recursos hídricos de médio e pequeno porte, contra-sugerindo a utilização de grande porte mediante edificação de extensas barragens, entre outros motivos, pela dificuldade de aquisição das terras necessárias por parte do governo junto aos proprietários particulares, encarecendo e impopularizando o empreendimento (USP, FAPESP, 2009c). Mesmo assim, a aceitação da população da RAA para a utilização de recursos hídricos locais para geração elétrica com potência de $1 \mathrm{MW}$ a $30 \mathrm{MW}$ é restrita.

Conjunção e Encontro de Interesses: A conjunção de interesses e o resultado do posicionamento entre os agentes descritos pode ser trabalhada por metodologias como a teoria de jogos ou mesmo dentro do processo de ranqueamento que sucede a CVPC. Uma vez que o intuito desse processo de 
valoração é de determinar os potenciais de atuação de cada agente, prévios aos resultados dessas interações, opta-se, nesse exercício, pelo mapeamento desses agentes em função de sua posição e influência no âmbito do recurso analisado (Figura 46). No caso das PCHS, por tratar-se de um recurso tradicionalmente explorado no Brasil, além de ser relativamente limpo e de boa confiabilidade energética e viabilidade técnico-econômica, o recurso tende a apresentar a aceitação de boa parte do setor elétrico e o apoio relativo de agentes governamentais. Por outro lado, a potencialidade de geração de impactos sociais e ambientais resulta na oposição, em diferentes níveis, de organizações nãogovernamentais, órgãos ambientais e sociedade como um todo.

Esta dinâmica é retratada com o mapeamento dos En-In em função de sua influência e posicionamento, na figura 45.

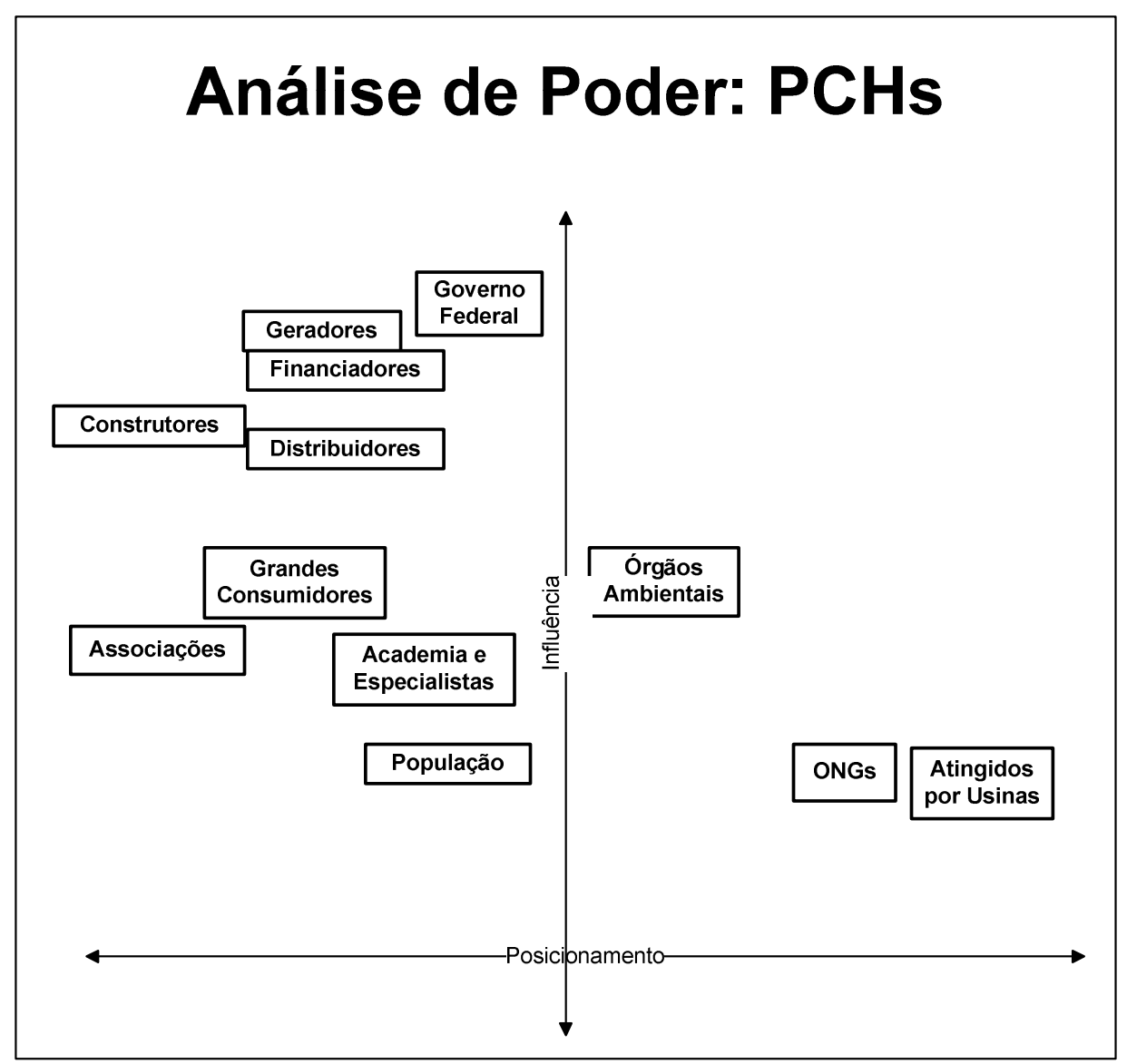

Figura 45: Análise de Poder - PCHs 


\subsubsection{Propriedade e Integração Energética}

A análise da propriedade de $\mathrm{PCHs}$ envolve a caracterização da fonte e da tecnologia utilizada em seu aproveitamento. A fonte hídrica enquadra-se como fonte regional de propriedade da União. O recurso energético envolve tecnologia totalmente nacional, de posse privada de empreendedores privados ou empresas públicas.

A avaliação do potencial de integração energética por recursos de energias renováveis aplica-se na possibilidade de compartilhamento de fontes fronteiriças - como rios - ou exportação de combustíveis ou transporte de energia por linhas de transmissão. No caso da geração por PCHs, a energia implementada na região de Araçatuba tende a contribuir ao sistema interligado nacional e ser aproveitada por consumidores dentro do submercado sul/sudeste.

\subsubsection{Dimensão Ambiental}

A valoração da dimensão ambiental para os recursos do lado da oferta divide-se em três áreas principais, abordando impactos aos meios aéreo, aquático e ao solo.

\subsubsection{Poluição do Meio Aéreo}

Uma vez que não há registro de PCHs construídas na região, trabalha-se na valoração de emissões aéreas com duas hipóteses. O cenário positivo considera que a operação de PCHs a fio d água não implica emissões de gases por não envolver a construção de reservatórios - e, consequentemente, 0 represamento de água e o alagamento de matéria orgânica, responsável pela emissão de metano. Já o cenário pessimista parte do princípio de que todo o potencial de PCHs instalado na região envolveria a construção de reservatórios de área máxima permitida por lei (ou $13 \mathrm{~km} 2$ ) e, consequentemente, na emissão de $\mathrm{CO} 2$ e $\mathrm{CH} 4{ }^{167}$.

\footnotetext{
167 Considera-se, nesse cenário, que condições para construção de $\mathrm{PCH}$ e UHEs são homogêneas e que as emissões de $\mathrm{CH} 4$ e $\mathrm{CO} 2$ dependem mais das condições de temperatura local, densidade e tipo da vegetação inundada e criticalidade de estiagens do que da própria área inundada.
} 
Nesse cenário, efetuou-se a aproximação de dados de emissão desses reservatórios para a situação média das grandes hidrelétricas construídas na região (BEARAA, 2010). A metodologia contabilizou as emissões totais de $\mathrm{CO} 2 \mathrm{e}$ $\mathrm{CH} 4$ das usinas hidrelétricas de llha Solteira, Nova Avanhandava, Jupiá e Três Irmãos, adaptando o processo de contabilização feito por Santos (2006), pelo método da câmara de difusão. A capacidade instalada total de $6.635 \mathrm{MW}$ ou a garantia física de $3.331 \mathrm{MWm}$ (ANEEL, 2010) desses empreendimentos resultam na geração de 29.182.681 MWh e na emissão de 1729 toneladas de CO2 e 25,4 toneladas de $\mathrm{CH} 4$.

O índice médio de 58,9 gCO2/ $\mathrm{kWh}$ e 0,87 gCH4/kWh aplicado ao potencial teórico de instalação de 397,73 MW de $\mathrm{PCHs}$ a um fator de capacidade médio de $60,4 \%$ produz o potencial teórico de 123,98 toneladas de CO2 e 1,83 toneladas de $\mathrm{CH} 4$.

\subsubsection{Produção de Gases de Efeito Estufa}

Com base na estimativa de gases produzidos no cenário pessimista, considerando a emissão de 123,98 toneladas de $\mathrm{CO} 2$ e 1,83 toneladas de $\mathrm{CH} 4$, aplica-se, para a determinação de gases de efeito estufa, a equação abaixo:

\section{CVPC GEE (RELO) = PEF1 xEmCH4 + PEF2xCO2 + PEF3 x N20}

Onde:

Em CH4 (PCH): Emissões totais de $\mathrm{CH} 4=1,83$;

Em CO2 (PCH): Emissões totais de $\mathrm{CO} 2=1,83$;

Em N20 (PCH): Emissões totais de N20 = 0;

PEF1 ( $\mathrm{CH} 4)$ : Potencial de Efeito Estufa de $\mathrm{CH} 4=24$;

PEF2 (CO2): Potencial de Efeito Estufa de $\mathrm{CO} 2=1$;

PEF3 (N20): Potencial de Efeito Estufa de N20=310.

GEE $(P C H)=24 \times 1,83+1 \times 123,98=167,99$ ton $\mathrm{CO} 2$ equivalente

Essa produção de gases de efeito estufa refere-se ao potencial teórico de 397,73 MW instalados na região de Araçatuba.

\subsubsection{Ocupação do Solo}

O impacto de ocupação territorial de uma hidrelétrica é, frequentemente, estimado pelo indicador Potência $(P)$ produzida por Área $(A)$ de reservatório (P/A). A tabela 22 a seguir exemplifica a relação P/A de grandes e pequenas 
hidrelétricas no Brasil, com indicadores variando de 5747,1 kW/hectare (ou 574,7 MW/km2) no caso da hidrelétrica de Ninho da Águia a 2,7 kW/hectare (ou 0,27 $\mathrm{MW} / \mathrm{km} 2)$ para a usina de Cajuru.

Tabela 22: Potência gerada por área alagada em hidrelétricas e PCHs

\begin{tabular}{|c|c|c|c|c|c|c|c|}
\hline UHE & $\begin{array}{c}\text { Potência } \\
\text { Gerada } \\
\text { (MW) }\end{array}$ & $\begin{array}{c}\text { Area } \\
\text { Alagada } \\
\text { (ha) }\end{array}$ & $\begin{array}{c}\text { MWI } \\
\text { hectare }\end{array}$ & $\begin{array}{c}\text { PCH em } \\
\text { operação/outorga }\end{array}$ & $\begin{array}{c}\text { Potência } \\
\text { Gerada } \\
\text { (KW) }\end{array}$ & $\begin{array}{c}\text { Area } \\
\text { Alagada } \\
\text { (ha) }\end{array}$ & $\begin{array}{c}\mathrm{Kw} / \\
\text { hectare }\end{array}$ \\
\hline Xingo & 5000 & 8,50 & 588.2 & Ninho da Aguia & 10000 & 1,74 & 5747,1 \\
\hline Segredo & 1260 & 8,25 & 152,7 & Marmelos & 4000 & 2,50 & 1600 \\
\hline Ita & 1820 & 15,60 & 116,7 & Pai Joaquim & 23000 & 50.00 & 460 \\
\hline Itaipu & 12600 & 134,62 & 93.6 & Martins & 7700 & 20,00 & 385 \\
\hline Belo Monte & 11000 & 122,49 & 89,8 & Paciência & 4080 & 27,40 & 148,9 \\
\hline Machadinho & 1200 & 26,20 & 45,8 & Melo & 8480 & 70.02 & 121,1 \\
\hline Garabi & 1800 & 80,00 & 22,5 & Pandeiros & 4200 & 40,00 & 105 \\
\hline Itaparica & 1500 & 83,33 & 18.0 & Dona Denise & 2880 & 34.49 & 83,5 \\
\hline Tucurui & 3900 & 280,58 & 13,9 & Dona Rita & 2408 & 35,99 & 66,9 \\
\hline Três Irmăos & 640 & 71,11 & 9,0 & Săo Bernardo & 3200 & 57,04 & 56,1 \\
\hline $\begin{array}{c}\text { Porto } \\
\text { Primavera }\end{array}$ & 1800 & 214,29 & 8,4 & Fumaça & 10080 & 341,69 & 29,5 \\
\hline Serra da Mesa & 1200 & 179,10 & 6,7 & Poço Fundo & 9160 & 320,28 & 28,6 \\
\hline Camargos & 45 & 7,38 & 6,1 & Rio das Pedras & 9280 & 400,00 & 23,2 \\
\hline Manso & 210 & 38,89 & 5,4 & Sumidouro & 2120 & 100,00 & 21,2 \\
\hline Samuel & 217 & 65,76 & 3.3 & Chicāo & 1808 & 119,74 & 15,1 \\
\hline Sobradinho & 1050 & 420,00 & 2,5 & Anil & 2080 & 149,64 & 13.9 \\
\hline Balbina & 250 & 227,27 & 1,1 & Cajuru & 7200 & 2666,67 & 2,7 \\
\hline MEDIA & & & 69,6 & & & & 523,9 \\
\hline
\end{tabular}

Fonte: CERPCH, 2004 apud BARBOSA, 2004

Considerando ambos os intervalos, tem-se que as áreas mínima e máxima ocupadas por empreendimentos de $\mathrm{PCHs}$, para o potencial teórico total são de 107,4 km2 e $228.575,4$ km2.

\subsubsection{Produção de Resíduos Sólidos}

A produção de resíduos sólidos em atividades hidrelétricas é feita pela análise de erodibilidade, que relaciona diferentes fatores como a quantidade de matéria orgânica, tipos de argilominerais, $\mathrm{pH}$, relação entre quantidade de óxidos de ferro, alumínio e sílica, e características do fluido intersticial e percolante. Ensaios de natureza física envolvem granulometria, plasticidade, massa especifica dos sólidos e umidade (PEJON, 1992, apud MIRANDA, 2005).

De acordo com a caracterização dos recursos naturais da região de Araçatuba, a unidade geológica do solo classifica-se dentro do grupo Bauru ${ }^{168}$. O volume de sedimentos é obtido por meio da relação entre a taxa local de erosão e o cálculo de perda do solo, função de fatores como a densidade

\footnotetext{
${ }^{168}$ Matriz argilosa abundante, de coloração vermelha, amiente de deposição continental, fluvial e lacustre.
} 
pluviométrica, a erosão do solo, o ângulo de inclinação do solo, os gerenciamentos dos usos dos solos existentes e os controles de erosão existentes (REIS, 2001). Utiliza-se a função abaixo, de fator de erosão, que indica o depósito anual de solo em um reservatório (se aplicável) - com a soma do solo carreado pela região a montante $(E)$, a erosão dos canais $(C)$ e a erosão da ocupação do leito (B) - pela taxa de despejo de sedimentos (R) e pela taxa de erosão local (em ton/ha).

\section{$F \mathrm{Er}=(\mathrm{E}+\mathrm{C}+\mathrm{B}) \times \mathrm{R} \times \mathrm{TE}(\mathbf{1 1})$}

A valoração de resíduos sólidos é obtida pelo Fator de erosão multiplicado pela área do corpo d’água considerado, de acordo com a equação:

\section{CVPC RS (RELO)= F Er x A (13)}

Uma vez que não há dados disponíveis sobre as variáveis consideradas, a título de demonstração de exercício do CVPC, utilizou-se a taxa de despejo de sedimentos igual a 0,20, o fator de erosão de 1,50 e taxa de erosão anual entre 40 e 80 ton/ha. Com base em dados médios de queda e vazão, obteve-se valores de formação de resíduos sólidos entre 1.630 e 2.631 m3 (vide Anexo 3).

\subsubsection{Caracterização do uso e consumo de água}

A medição do consumo de água em empreendimentos energéticos aplicase ao caso de PCHs no tocante à alteração de vazão entre montante e jusante de empreendimentos, resultando na variação de sua disponibilidade e, consequentemente, no aumento do risco de conflitos por conta do uso múltiplo desse recurso.

De acordo com PACCA (1996, apud BARBOSA, 2004), embora as PCH não utilizem volumosas acumulações de água, o impacto causado em sua disponibilidade é um dos mais significativos dentre os problemas gerados.

Nesse estudo de caso, uma vez que não se dispõe de dados reais para a medição das vazões a montante e jusante de PCHs - por não existirem usinas na região, optou-se pela iteração entre valores médios de vazões e quedas. Daí, tem-se que para usinas médias de 19,2 MW, os valores obtidos para queda e vazão, respectivamente, 78 m e 31 m3/s, de acordo com a equação abaixo: 


\section{$P=8,2 \times Q \times H(81)$}

Segundo TIAGO (et al, 2003), deve-se considerar o impacto da vazão ecológica em centrais do tipo desvio. A vazão ecológica é a redução da vazão entre a tomada d'água e o canal de fuga, a fim de manter um escoamento mínimo permanente no curso d'água. Segundo DUPAS et al. (2004, apud BARBOSA, 2004), para o cálculo de vazão, de acordo com o modelo de outorga aplicado pelo Instituto Mineiro de Gestão das Águas (IGAM), fixa-se a vazão residual mínima a jusante de cada captação como $70 \%$ da vazão Q7,10 (definida como sendo a vazão média mínima em 7 dias para um tempo de recorrência de 10 anos) para manutenção do meio biótico.

Assim, com base na vazão a montante determinada iterativamente, a vazão a jusante é recomendada em $70 \%$ de $31 \mathrm{~m} 3 / \mathrm{s}$.

Ressalta-se que a iteração realizada é hipotética, a influência da topografia pode resultar em valores diversos de vazão em decorrência das quedas consideradas. Considerando a alta variabilidade das condições topográficas em um dado curso d’água, pode-se obter variados parâmetros para secções próximas. Outro método alternativo para a determinação desses parâmetros é o emprego de gradientes de declividade. No entanto, utilizou-se o método iterativo a fim de simplificar o processo.

\subsubsection{Qualidade da água}

Considerou-se que não há emissão de poluentes nos corpos d'águas da RAA visto que não há demanda de água para a sua utilização, portanto, não acarretando na alteração dos parâmetros emissão de poluentes, DBO, DQO, alteração de temperatura ou pH.

\subsubsection{Dimensão Social}

A valoração da dimensão social trabalha parâmetros relacionados ao bem estar da sociedade e do indivíduo, ao lado de fatores socioeconômicos como geração de emprego e desenvolvimento de infraestrutura. 


\subsubsection{Geração de Empregos}

De acordo com Rutovitz (RUTOVITZ et al, 2009), a geração de empregos no setor de PCHs apresenta médias levantadas em diferentes metodologias europeias e norte-americanas. A média inferior indica 10,8 empregos/MW instalado na área de construção e instalação de usinas, 0,5 empregos/MW para a fabricação de equipamentos e 0,22 empregos/MW voltados para a operação e manutenção (PEMBINA, 2004, apud, RUTOVITZ, 2009). A média superior de empregos aponta entre 41 e 50 empregos por MW instalado, agregando todas as atividades (MITRE, 2003, apud, RUTOVITZ, 2009).

No cenário nacional, o Centro de Estudos de Referência em PCHs estima um total de 507 empregos para a construção de uma $\mathrm{PCH}$ de $20 \mathrm{MW}$, ou uma média de 25,35 empregos/MW (TIAGO et al, 2008).

Optou-se por utilizar, neste exercício, o intervalo de 11,52 a 25,35 empregos por MW para PCHs. Considerando a potência teórica de 397,73 MW, o total de empregos gerados é calculado segundo a equação:

\section{CVPC Emp (RELO) $=$ MAX $\left(\sum(\right.$ FEmp (RELO) $\times($ IN $) \times(M R) \times$ Pot(RELO) $)$}

Onde:

CVPC Emp (RELO): Cômputo e valoração de empregos para RELOs (em número de empregos); FEmp (RELO): Fator de empregos de RELOs (em empregos/MW);

IN: Índice de nacionalização de produção e/ou serviços (\%);

MR: Multiplicador regional (adimensional).

Considerando o índice de nacionalização de 100\% para o recurso energético e um fator multiplicador regional igual a 1, os fatores agregados de emprego de 11,52 e 25,35 produzem, respectivamente, o total de 4.582 e 10.082 empregos.

\subsubsection{Qualidade de Empregos}

De acordo com Tiago (et al, 2008), a geração de empregos de PCHs está concentrada nos setores de construção civil e montagem e equipamentos, absorvendo $82 \%$ de empregos do total. Assume-se que essa etapa envolva a geração máxima de $20 \%$ de empregos que exijam capacitação para 0 desempenho de cargos de engenheiro e gerente. 
$\mathrm{Na}$ etapa de operação e manutenção, em centrais médias entre 5 e 30 MW, o estudo identifica uma proporção de 5 empregos de qualificação (salários mensais iguais ou acima de $R \$ 2.800$, em valores de 2008) de um total de 32 (os outros 27 empregos remuneravam abaixo ou igual a $R \$ 1.200$ por mês, em funções de operador, técnico ou auxiliar).

A etapa que demanda maior qualificação é a fase de estudos e projetos, na qual se estima que cerca de $50 \%$ da mão de obra possua formação superior.

\subsubsection{Influência no Desenvolvimento}

Com base na metodologia desenvolvida pelo Departamento Econômico, do Banco Nacional de Desenvolvimento Econômico e Social - BNDES, que permite calcular o número de postos de trabalho criados em decorrência de um aumento de demanda no mercado, utilizou-se o número de massa salarial resultante da construção, operação e manutenção de uma $\mathrm{PCH}$ padrão de 20 MW (TIAGO et al, 2008). Essa estimativa considera a criação de empregos diretos, indiretos e de efeito renda, nos setores de mercado de equipamentos, obras civis, meio ambiente e serviços. Ressalta-se que a criação de empregos nos setores de estudos e projetos não foi contabilizada por não necessariamente ocorrer na região de implantação do projeto.

Tabela 23: Massa salarial produzida durante construção e operação de PCH

\begin{tabular}{|c|c|c|c|c|c|c|}
\hline \multicolumn{2}{|c|}{ Construção } & \multicolumn{5}{|c|}{ Operação e Manutenção } \\
\hline Ano -2 (R\$) & Ano -1 $(\mathrm{R} \$)$ & Ano 1 $(\mathrm{R} \$)$ & Ano 2 $(\mathrm{R} \$)$ & Ano 3 (R\$) & $\ldots$ & Ano 20 $(\mathrm{R} \$)$ \\
\hline $2.720 .800,00$ & $3.387 .500,00$ & $633.100,00$ & $633.100,00$ & $633.100,00$ & $\ldots$ & $633.100,00$ \\
\hline \multicolumn{7}{|c|}{$\mathbf{R} \$ \mathbf{6 3 3 . 1 0 0}$ por ano } \\
\hline
\end{tabular}

Fonte: TIAGO et al, 2008

Com base nesse montante, estima-se que a massa salarial total é a somatória dos 2 anos de construção aos 20 anos de operação, resultando em $R$ \$ 18,77 milhões no horizonte total ou $\mathrm{R} \$ 938.515$ por ano para uma $\mathrm{PCH}$ de 20 MW.

A valoração do desenvolvimento econômico considera a seguinte equação: 


\section{$\Delta$ CVPC DE $($ RELO) $=$ CVPC DE $($ RELO)/PIBlocal (21)}

Onde:

CVPC DE (RELO): Cômputo e valoração de desenvolvimento econômico de RELO (R\$); FRenda: Massa salarial anual de um determinado empreendimento ( $R / M W)$;

$\triangle$ CVPC DE (RELO): Variação de cômputo e valoração de desenvolvimento econômico de RELO (\%).

Considerando a implementação de um total de 397,73 MW de PCHs, a massa salarial produzida por ano seria equivalente a $R \$ 18,66$ milhões. Com base em um PIB regional de $R \$ 11$ bilhões no ano de 2008 , tem-se que o recurso é capaz de contribuir, potencialmente, para uma variação de $0,17 \%$ nesse valor.

A variação da valoração de desenvolvimento humano é calculado pela seguinte fórmula:

$\triangle$ CVPC DH $=\triangle$ CVPC DE $($ RELO) $/ 3$

Onde:

$\triangle$ CVPC DH (RELO): Variação de cômputo e valoração de desenvolvimento humano de RELO $(\%)$.

De acordo com a fórmula do IDH, atribuindo um peso de 1/3 para a componente de desenvolvimento econômico calculada anteriormente, obtém-se uma variação positiva de 0,054\% em desenvolvimento humano. Em termos indiretos, benefícios adicionais da construção de PCHs à infraestrutura local são materializados com base no cumprimento de condicionantes comumente contempladas e acordadas nos processos de autorização de licenças ambientais.

\subsubsection{Alteração de Conforto}

A valoração de condições de conforto para PCHs concentrou-se em fatores como poluição visual e produção de ruído. Fatores como poluição olfativa e alteração de temperatura ambiente não se aplicam a esse recurso.

A utilização de recursos hídricos sempre representa potenciais impactos nos corpos d'águas. Os impactos da geração hidrelétrica dependem da potência e das características de operação do empreendimento - relacionadas ao regime de escoamento do rio, à construção ou não de barragens e à formação de lagos. 
No caso da poluição visual, adaptou-se as seguintes funções elaboradas essencialmente para empreendimentos eólicos (HURTADO et al, 2003):

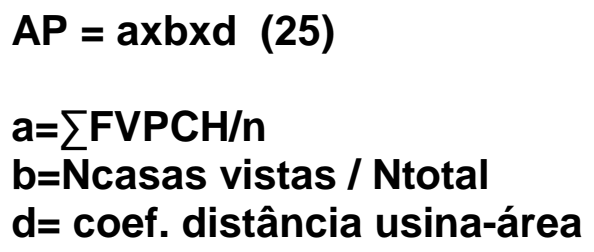

Onde:

\section{AP: Avaliação parcial;}

a: coeficiente de visibilidade da usina desde áreas afetadas (medido em diferentes pontos) ${ }^{169}$;

b: coeficiente de visibilidade da área afetada desde usina ${ }^{170}$;

$\mathrm{d}$ : coeficiente de distância entre usina e área afetada

( $d=1$ para distancia $<500 \mathrm{~m} ; \mathrm{d}=0,1$ para distância $>6000 \mathrm{~m}$ ).

O resultado da avaliação é qualitativo, variando de 0 a 1, entre impacto mínimo e impacto profundo. A valoração propriamente dita do impacto considera os coeficientes de visibilidade da usina na área afetada (a) e dessa área na usina (b), a população total da área afetada (PA) e a população total da cidade ou região $(\mathrm{PT})$, de acordo com a equação abaixo:

\section{$\mathrm{CPA}=\Sigma(\operatorname{axbxPA}) / \mathrm{PT}$}

Onde:

CPA: Coeficiente de População Afetada;

PA: População da área afetada;

PT: População total.

Uma vez que não há exemplos de $\mathrm{PCHs}$ na região e, portanto não realizamos esse tipo de pesquisa, a título de demonstração, utilizam-se coeficientes a e b iguais a 0,7 e uma população afetada de 500 pessoas sobre um total de mil pessoas de uma área hipotética considerada.

Para esses parâmetros, o coeficiente de população afetada resulta em 0,245, ou seja, $\mathbf{2 4 , 5 \%}$ da população da área afetada pela usina é visualmente impactada.

\footnotetext{
${ }^{169} \mathrm{~A}$ visibilidade da $\mathrm{PCH}$ é medida em diferentes pontos em fatores 0 ou 1 ( 0 para pontos que não a veem e 1 para pontos que a veem). A somatória é dividida pelo número de pontos medidos, produzindo resultado inferior a 1.

${ }^{170} \mathrm{O}$ coeficiente é resultado da relação entre o número de casas da área afetada vistas da usina sobre o número de casas da área afetada.
} 
Em relação ao ruído, como novamente não há registro de exemplos práticos destes empreendimentos, tomou-se como base a medição realizada por Silva (SILVA et al, 2008) na PCH Luiz Dias, na região de Itajubá. A fonte de ruído mais relevante identificada é a própria unidade hidrelétrica constituída pelo grupo gerador. A PCH a fio d'água possui uma potência instalada de 3,34 MW e compreende duas centrais.

O procedimento de medição de ruído se concentrou na casa de máquinas das duas $\mathrm{PCH}$ e no entorno delas para observação da emissão de ruído no ambiente.

Calculou-se a média dos níveis encontrados no local, bem como o erropadrão da série de medidas, com o propósito de verificar se o número de medições era suficiente para caracterizar o nível de ruído emitido, de acordo com a equação de Nível de Pressão Sonora (NPS).

Estimou-se a exposição dos operadores das $\mathrm{PCH}$, considerando tempos de exposição variados e sua conversão em Níveis de Exposição Normalizados (NEN) - correspondentes a uma jornada padrão de oito horas diárias.

O valor médio obtido para NPS foi de $86,8 \mathrm{~dB}(\mathrm{~A})$, com erro-padrão de 0,8 . O nível de ruído ambiente (Lra) foi estimado em ponto distante da central principal da PCH. Observaram-se valores entre 52 e $72 \mathrm{~dB}(\mathrm{~A}$ ) (e média de 58 $\mathrm{dB}(\mathrm{A})$ ) de níveis sonoros. Em pontos distantes da usina, o nível de ambiente observado foi de $37 \mathrm{~dB}(\mathrm{~A})$.

A valoração da poluição sonora mede a diferença percentual entre $o$ valor identificado e o valor permitido por lei. $\mathrm{Na}$ sala de controle, o nível sonoro, presente de $70 \mathrm{~dB}(\mathrm{~A})$, supera o valor máximo recomendados pela NBR-10152, de $65 \mathrm{~dB}(\mathrm{~A})$, produzindo uma diferença de $7,7 \%$. Em relação aos ruídos ambientais, o valor de $58 \mathrm{~dB}(\mathrm{~A})$ supera os $55 \mathrm{~dB}(\mathrm{~A})$ recomendados pela NBR-10151 em $5,5 \%$. Assim, a medição da poluição sonora de $\mathrm{PCH}$ varia, nesse estudo de caso, entre 5,5 e $7,7 \%$ dos valores prescritos por lei.

\subsubsection{Impacto Humano Decorrente do Espaço Ocupado}

A valoração desse atributo considera impactos como o deslocamento populacional em decorrência de projetos de $\mathrm{PCHs}$. Levando em conta que não se 
identificou a instalação de $\mathrm{PCH}$ locais, estima-se o impacto da população deslocada de acordo com a média de experiências nacionais ${ }^{171}$.

De acordo com a primeira abordagem, segundo BERMANN, existem no Brasil, aproximadamente, 2.000 barragens resultando no deslocamento de cerca de 1 milhão de pessoas. Dessas 2000 barragens, 233 apresentam potência entre 1 e $30 \mathrm{MW}$ e, portanto classificam-se como PCHs. Assim, em uma relação direta, 116,5 mil pessoas teriam sido deslocadas em decorrência da implantação de PCHs. Considerando a atual capacidade instalada de PCHs de 3.262 MW (ANEEL, 2010), a relação da população deslocada é de 35,7 pessoas por MW. Para o potencial teórico de $\mathrm{PCHs}$ na região, o número de habitantes deslocado seria de 14.199.

De acordo com Zucarelli (ASSIS, ZUCARELLI et al, 2007), um caso de deslocamento populacional considerável pela construção de uma $\mathrm{PCH}$ aconteceu na hidrelétrica de Fumaça, na qual 200 famílias foram deslocadas em consequência da construção da $\mathrm{PCH}$ de $10 \mathrm{MW}$. Nesse caso extremo, o índice de deslocamento foi de 80 pessoas/MW.

Ressalta-se que a estimativa de deslocamento por área ocupada e densidade demográfica rural da região apresenta limitações por conta da variabilidade dessa área para cada projeto de $\mathrm{PCH}$ - considerando a eliminação de reservatório em boa parte das usinas - e a relação entre o deslocamento e a área ocupada - considerando que a desapropriação não se refere apenas à área do reservatório, mas também em decorrência de múltiplos fatores, como a alteração de fluxos de rios e a perda de seus múltiplos benefícios a populações ribeirinhas $^{172}$.

\subsubsection{Influência de Impactos Ambientais à Saúde Humana}

Esse atributo avalia prejuízos à saúde e ao cultivo de alimentos de populações afetadas por PCHs. Problemas de saúde pública podem ser originados pela formação de remansos em reservatórios (se contemplados em

\footnotetext{
171 Outra possibilidade de cálculo envolveria a área total ocupada pelo potencial teórico de PCHs da região, relacionada à densidade demográfica rural e o potencial deslocamento populacional.

172 Em Rondônia, a construção de diversas PCHs resultou no desvio do Rio Branco. Catorze aldeias com população aproximada de 2 mil pessoas perderam, por consequência da alteração da vazão do rio, seu único meio de transporte e sua fonte de alimentação (BERMANN, 2007).
} 
projetos de $\mathrm{PCHs}$ ) e na decorrente proliferação de vetores transmissores de doenças endêmicas, como consequência do aumento de áreas úmidas e alagadas.

$\mathrm{Na}$ etapa de construção, a chegada de indivíduos já contaminados por doenças endêmicas transmitidas por vetores e o acúmulo de lixo podem se constituir em ambientes responsáveis à proliferação de vetores. As doenças que podem ter a incidência na população ribeirinha ampliada em função da construção de hidrelétricas são esquistossomose (caramujos), febre amarela, malária, leishmaniose, dengue, filariose, chagas e oncocerose (insetos), cólera, tifo, disenterias e parasitas (baixa higiene).

As taxas de mortalidade por caso de doenças variam entre 0,004 para a malária e 0,1264 para a febre amarela. Entretanto, em decorrência da falta de funções dose-resposta relacionando o hipotético barramento ocasionado por PCHs com a incidência de doenças de veiculação hídrica locais, optou-se por não valorar numericamente este subatributo.

Já as perdas de terras agricultáveis caracterizam-se em impactos inevitáveis e irreversíveis que ocorrem em todas as fases do empreendimento. Esses impactos, entretanto, são bem diferentes entre si, tanto no que concerne aos fatores geradores quanto às características de reversibilidade, temporalidade, localização e, principalmente, em importância e magnitude.

De forma análoga, considerando a extensão territorial da região de Araçatuba e a discrepância entre locais propícios para aproveitamento hidrelétrico e cultivo de produtos agricultáveis, não se pode estabelecer relação de conflito entre ambas as atividades. Esse exercício torna-se mais difícil considerando a falta de casos práticos de $\mathrm{PCHs}$ para a observação de possíveis impactos nessa área e da probabilidade da utilização de usinas sem reservatórios, eliminando assim impactos registrados por grandes hidrelétricas referentes às fases de implantação e enchimento de reservatórios. Vale mencionar que no caso específico de PCHs, cogita-se a possibilidade da contribuição da alteração de fluxos hídricos para o ganho de áreas agricultáveis, provocando, nesse caso, impactos positivos ao local afetado. 


\subsection{Cômputo e Valoração de Potenciais Completos de Cogeração a Bagaço de Cana-de-Açúcar}

Cogeração é um termo bastante amplo que define a produção de trabalho e calor em uma instalação termodinâmica interdependente, combinando equipamentos e processos tecnológicos, a fim de atender à demanda de eletricidade, trabalho mecânico, calor e frio da usina - além de produzir excedentes exportáveis de energia. Esse exercício de valoração considera o uso do bagaço de cana para geração adicional de eletricidade, energia adicional àquela comumente produzida com a obtenção de etanol.

A bioeletricidade conta atualmente com 7.518 MW de capacidade instalada no Brasil, dos quais 78\% são provenientes de cogeração com base em bagaço de cana-de-açúcar. Entre as fontes térmicas, é a segunda em participação na matriz elétrica, atrás apenas das UTEs a gás natural com 12.341 MW.

A escolha por cogeração a biomassa de bagaço de cana para o exercício de CVPC deve-se, a exemplo das PCHs, ao potencial energético levantado para o recurso nos estudos de PIR realizados em Araçatuba e às boas possibilidades de concretização desse potencial na região, tratadas na análise técnicoeconômica de potencial teórico de geração e custo de geração. O exercício busca quantificar, por outro lado, os impactos ambientais e sociais relacionados ao aproveitamento da cana-de-açúcar e, muitas vezes, indissociáveis de atividades de cogeração de eletricidade. A dimensão política analisa o quadro regulatório e políticas vigentes de incentivo a esse recurso energético.

\subsubsection{Dimensão Técnico-Econômica}

A valoração da dimensão técnico-econômica para recursos energéticos do lado da oferta concentra-se essencialmente em atributos voltados aos cálculos de potencial energético e custos de geração de energia, trabalhados por meio de metodologias conhecidas.

\subsubsection{Potencial Energético Teórico}

O cômputo e valoração do potencial energético teórico de bagaço de cana avaliou a disponibilidade do insumo na região de Araçatuba com base na produção de cana da região para a safra de 2008/2009. De acordo com o 
mapeamento anual do cultivo de cana-de-açúcar, realizado pelo INPE em conjunto com a Única, o CEPEA (Centro de Estudos Avançados em Economia Aplicada) e o CTC (Centro de Tecnologia Canavieira), a Região Administrativa de Araçatuba registrou uma produção de cana-de-açúcar de 471,4 mil hectares na safra 2008/2009 (AGUIAR et al, 2009). De acordo com a CONAB, a produtividade média nacional registrada pela última safra é de 79,8 toneladas por hectare. Obtém-se, portanto, um total de 37,617 milhões de toneladas de cana.

De acordo com ÚNICA et al (2009), cada tonelada de cana produz $250 \mathrm{~kg}$ de bagaço e $204 \mathrm{~kg}$ de palhas e pontas e pode gerar 199,9 kWh de eletricidade (já descontada a proporção destinada a consumo próprio). Dessa forma, a produção potencial é de 7,519 milhões de MWh ou 2.146,06 MW a um fator de capacidade médio de $40 \%$. É importante ressaltar que o uso de pontas e folhas para a cogeração considera o cenário da realização dos processos de coleta sem queimadas.

\subsubsection{Tempo de Implantação}

A instalação de um sistema de cogeração que proporcione o uso racional do recurso energético requer um estudo específico dos sistemas termodinâmicos envolvidos e dos processos operacionais a fim de determinar as condições de contorno e a combinação adequada dos recursos tecnológicos, máquinas e equipamentos disponíveis.

Uma vez conhecidas as demandas energéticas da usina, identifica-se a disponibilidade de biomassa da cana-de-açúcar - incluindo o bagaço de cana, a palha e pontas -, e a sua potencialidade energética, de forma a quantificar 0 tamanho da instalação de cogeração.

O tempo médio de implantação é resultado da somatória dos tempos de projetos e estudos ao tempo de construção, de acordo com a equação 33:

Tempo de Implantação $=\mathrm{T}($ Projeto\&Estudos $)+\mathrm{T}($ Construção $)=12+12=24$ meses

O tempo total de construção leva em média 12 meses, considerando a adaptação do sistema e a substituição de caldeiras de alta pressão. Já a etapa de estudos consome em média outros 12 meses, incluindo a monitoração da 
safra de cana e o dimensionamento do sistema necessário para converter a biomassa em eletricidade.

A estimativa utilizada para o cálculo do custo de geração contabiliza, novamente, apenas o tempo de construção e não o tempo médio adicional por atrasos imprevistos de construção do sistema ou obtenção de licenciamento.

\subsubsection{Confiabilidade}

O cálculo da confiabilidade real de um recurso energético é função de seu fator de capacidade aliado à disponibilidade da tecnologia empregada em sua conversão. A avaliação de interrupções não previstas, como consequência de variáveis políticas e econômicas ou fenômenos naturais é estimada em $5 \%$. No estudo de caso, considerou-se o intervalo mínimo e máximo de 25 a 54\% para o fator de capacidade, em média de 39,5\%, com base em levantamento de 31 usinas participantes do leilão de biomassa realizado em 2008 (EXCELÊNCIA ENERGÉTICA, 2010). Conforme visto anteriormente, as equacões utilizadas para valorar a confiabilidade de um recurso ponderam o fator de capacidade e a disponibilidade de uma usina, em função do uso de combustível ou de interrupções técnicas ou de outra ordem:

CVPC Conf $($ RELO) $=$ FC(RELO) $x$ FD $($ RELO) $=F C(R E L O) \times($ FDComb $) \times$ $($ FDUsina $)=0,395 \times 0,95=0,376$

Assim, considerando-se um fator de capacidade médio de 39,5\% multiplicado por um fator de disponibilidade de $95 \%$, obtém-se um fator de confiabilidade de $37,6 \%$.

\subsubsection{Distância de recurso energético a centro de consumo}

De forma análoga à valoração de $\mathrm{PCHs}$, o atributo de distância a centro de consumo é medido pelo custo de conexão da usina ao sistema de distribuição ou transmissão. Assim, o cálculo do total anual da Tarifa do Uso do Sistema considera o uso das ICGs e o desconto de $50 \%$ na tarifa de uso do sistema de distribuição. Os valores da TUSDg e da ICG média consideraram a média de encargos e alíquotas comentados anteriormente. 
TUSDg $=\mathrm{R} \$ 5,80 / \mathrm{kW} \cdot \mathrm{mês}$

Encargo ICG: $R \$ 2,59$ / kW.mês

Tarifa Ajustada $=$ TUSDg $\times 50 \%+$ Encargo ICG $=\mathbf{R} \$ \mathbf{5 , 4 9} / \mathbf{k W}$. mês

Tarifa Ajustada com impostos $=\mathbf{R} \$ \mathbf{5 , 4 9} /(1-9,25 \%)=\mathbf{R} \mathbf{6 , 0 5} / \mathrm{kW}$.mês

\subsubsection{Valoração de Domínio Tecnológico}

O Brasil obteve bastante êxito nos últimos anos na produção de álcool de cana, em função das condições naturais adequadas para tanto. Como consequência dessa produção, técnicas de cultivo de cana vêm, cada vez mais, sendo aperfeiçoadas e novas tecnologias foram criadas como a construção de motores a álcool e os bicombustíveis.

Dessa forma, o domínio tecnológico de sistemas de cogeração a biomassa de cana considera novamente o levantamento de diferentes projetos nacionais (EXCELÊNCIA ENERGÉTICA, 2010), que dão conta de que todos os equipamentos e serviços relacionados à construção e instalação desses sistemas são produzidos no país. A informação valida, portanto, o domínio tecnológico nacional sobre esse recurso, permitindo a utilização de valores iguais ou próximos a $100 \%$.

\subsubsection{Custo unitário de Geração de Energia}

A simulação dos custos de investimentos e de geração utilizou o método de fluxo de caixa descontado. Para tanto, considerou-se a faixa de potência média de 76,8 MW e o custo de investimento específico de $R \$ 2.330,27 / \mathrm{kW}$, de acordo com exemplos práticos (EXCELÊNCIA ENERGÉTICA, 2010). O fator de capacidade médio considerado foi de $39,5 \%$. As taxas de juros utilizadas foram $9 \%$ (para investimento de capital de terceiros) e $11,03 \%$ (para investimento de capital próprio).

Os encargos do setor elétrico considerados foram os mesmos utilizados no exercício de PCHs: TFSEE, Contribuição à CCEE, Taxa de Administração do ONS e Tarifa de Uso dos Sistemas de Distribuição e Transmissão.

Os custos operacionais utilizados incluem: operação e manutenção, custos administrativos e seguros. As taxas de manutenção consideradas para simulação foram de $R \$ 25 / M W h$ para a componente fixa e $R \$ 6 / \mathrm{kW}$.ano para a variável. $A$ tabela com os parâmetros utilizados para o cálculo do custo de geração e os 
resultados obtidos dessa simulação são mostrados nas tabelas 24 e 25 e no Anexo 2.

Tabela 24: Parâmetros e atributos técnico-econômicos

\begin{tabular}{|c|l|}
\hline Parâmetros & \multicolumn{1}{|c|}{ Valores } \\
\hline O\&M fixo & $\mathrm{R} \$ 25 / \mathrm{MWh}$ \\
\hline O\&M variável & $\mathrm{R} \$ 6 / \mathrm{kW}$. ano \\
\hline Administrativo & $\mathrm{R} \$ 700.000 /$ ano \\
\hline TUSD & $\mathrm{R} \$ 8,39 / \mathrm{kW} . \mathrm{mês}$ \\
\hline Encargo CCEE & $\mathrm{R} \$ 250 / \mathrm{MW}$ \\
\hline Encargo ANEEL & $0,5^{\star} \mathrm{R} \$ 363^{*} \mathrm{~kW}$ \\
\hline Capital Financiado & $70,05 \%$ (BNDES - Finem) \\
\hline Custo Financeiro & $\mathrm{TJLP}+3 \%$ \\
\hline Custo de Capital Próprio & $11,03 \%$ \\
\hline Tempo de Amortização & 162 meses $(\mathrm{SAC})$ \\
\hline Período do Fluxo de Caixa & 15 anos \\
\hline Período de Construção & 12 meses \\
\hline
\end{tabular}

Tabela 25: Simulação dos Custos de Geração do RELO - Biomassa

\begin{tabular}{|c|c|}
\hline Parâmetros & Valores \\
\hline Potência da Turbina (kW) & 76.800 \\
\hline Investimento Especifico (R\$/kW) & 2.330 \\
\hline Investimento Total (em milhões de R\$) & 178,96 \\
\hline Fator de Capacidade anualizado (\%) & 39,4 \\
\hline Custo Unitário de Geração (R\$/MWh) & 151,20 \\
\hline
\end{tabular}

*BNDES - Finem

\subsubsection{Qualidade de Energia}

Por conta da ausência de registros de comprometimento da qualidade de energia provida por instalações de cogeração a biomassa a consumidores de eletricidade, assume-se que este atributo não tenha interferência negativa na valoração deste recurso. Os casos identificados por Galhardo e Pinho (2003) referem-se a sistemas de pequeno porte conectados a sistemas isolados, exemplo que não se aplica à situação de instalação estudada neste caso.

\subsubsection{Dimensão Política}

A valoração dos atributos da dimensão política vale-se essencialmente de análises qualitativas para mensurar $o$ potencial de implementação e aproveitamento de recursos, à luz de fatores como políticas de incentivo, ponderação de balanço e interação entre atores do setor e características de propriedade de recursos. 


\subsubsection{Instrumentos Políticos}

Em termos de incentivos políticos, as usinas de cogeração a biomassa também foram contempladas no Programa de Incentivo a Fontes Alternativas (Proinfa) e receberam um leilão exclusivo para a fonte em 2008. Contam ainda com direito à redução das tarifas de uso dos sistemas de transmissão e distribuição. Entretanto as usinas a biomassa, a exemplo das PCHs, também têm perdido competitividade em relação à energia eólica, a mais bem sucedida em termos de contratação de energia entre 2009 e 2010. A falta de solução sobre os elevados custos de transmissão de usinas distantes das linhas, bem como a falta de isonomia de incentivos de desoneração fiscal sobre equipamentos em relação à geração eólica, resultou na contratação de apenas 12 usinas nos leilões de 2010 - ou uma capacidade instalada de apenas 190,5 MWmédios, em oposição a 70 projetos eólicos e mais de 800 MWmédios.

Um dos principais entraves à competitividade desse recurso continua sendo o custo de conexão, dependente da localização do projeto e da configuração geográfica da rede de transmissão existente, e que seria arcada pelos geradores. O preço teto do leilão, de $\mathrm{R} \$ 156 / \mathrm{MWh}$ para o leilão de energia de reserva e de $\mathrm{R} \$ 167 / \mathrm{MWh}$ para o leilão $A-3$, não foi considerado atrativo por todos os produtores. Boa parte da biomassa ainda se encontra em regiões tradicionais de cana, onde predominam usinas antigas, dependentes de grandes reformas e investimentos e maiores distâncias de conexão à rede, resultando em um maior custo para a eletricidade produzida.

A avaliação política de geração de energia por biomassa é medida por meio de seu potencial de mercado, calculado pela comparação entre o custo de geração de projetos em condições variadas de mercado e os valores oferecidos nos programas e iniciativas governamentais de contratação de energias renováveis. Considerando os leilões como instrumento vigente de contratação de energias renováveis, valora-se, nesse exercício, o deságio entre o preço teto e o preço médio determinados pelo último leilão, bem como os patamares de custo de geração de usinas a biomassa considerando as condições de incentivo.

Utilizando os resultados obtidos para as simulações de usinas de cogeração a biomassa na dimensão econômica em comparação ao preço teto 
médio dos últimos leilões de energia renovável (média de $R \$ 161,5 / \mathrm{MWh}$, entre os preços-teto de $R \$ 156 / M W h$ e $R \$ 167 / M W h$ dos últimos leilões), obtém-se:

Tabela 26: Valoração de Instrumentos Políticos

\begin{tabular}{|c|c|}
\hline Parâmetros & Valores \\
\hline Capacidade Instalada (kW) & 76.800 \\
\hline Investimento Especifico (R\$/kW) & $2.330,27$ \\
\hline Fator de Capacidade anualizado (\%) & 39,5 \\
\hline $\begin{array}{c}\text { Custo de Geração (R\$/MWh) } \\
\text { (Sem CC, Desconto 50\% TUSD) }\end{array}$ & 151,2 \\
\hline $\boldsymbol{\Delta ( P M L - C U G ) ~ ( R \$ / M W h ) ~}$ & $-10,3$ \\
\hline
\end{tabular}

\subsubsection{Licenciamento Ambiental e Autorização de Construção}

O tempo total de implantação de uma usina envolve, além do período de estudos e projeto e da construção propriamente dita, processos políticos relacionados à autorização técnica e legal para a construção do empreendimento, embasada em múltiplos critérios de avaliação e aprovação.

O atraso na obtenção de licenciamento de usinas não se resume às hidrelétricas - térmicas movidas a biomassa também aguardam o licenciamento ambiental, como é o caso das unidades Agrenco MT e Agudos.

Por conta de todo o processo de licenciamento ambiental, o planejamento para instalação e funcionamento de uma nova usina, que não passaria de um ano em condições normais, pode alcançar três anos, repercutindo em prejuízos de diferentes tipos. A demora aumenta o custo de expansão ou mesmo de instalação de novas unidades produtoras.

Atualmente a elaboração de estudos e projetos exige um custo que pode envolver a contratação de empresas especializadas. Por isso, qualquer nova solicitação acaba gerando ônus ou mesmo desestimulando a implantação de uma determinada melhoria.

Outro ponto negativo é, segundo agentes do setor, o nível de exigências para a renovação da licença de operação. No Estado de São Paulo, o decreto 47.397/2002 impõe uma série de medidas para a renovação da licença de operação, que tem validade de dois anos para destilaria e três anos para unidades de produção de açúcar. Anteriormente, não era necessária a licença de operação para manter a usina em funcionamento. Agora, a renovação - após a 
concessão da primeira licença é condicionada ao cumprimento de diferentes itens.

A valoração do licenciamento ambiental é contabilizada pela duração desses processos.

\section{$T($ licenciamento $)=T(L P)+T(L I)+T(L O)(6)$}

O tempo de expedição de licenciamento varia entre 1 e 3 anos. Esse tempo refere-se à operação de uma usina para a produção de etanol e açúcar. A atividade de cogeração, mesmo que implementada posteriormente, é indissociável desse processo de licenciamento. Ressalta-se que projetos que contemplem a cogeração de bagaço de cana desde o início do funcionamento de usinas têm potencial de reduzir esse horizonte de tempo, considerando a influência do aproveitamento do bagaço para a produção de eletricidade na redução da prática de queimadas em lavouras.

\subsubsection{Envolvidos e Interessados}

A primeira etapa da valoração de Envolvidos e Interessados relacionados à implantação de sistemas de cogeração a biomassa refere-se ao mapeamento de suas funções, interesses e motivações.

Recursos energéticos, tradicionalmente considerados como alternativos, tendem a receber maiores índices de aceitação da sociedade, por um lado, por conta da redução de impactos socioambientais e maior rejeição de grandes consumidores e distribuidores, por outro, por implicarem elementos de inovação comumente relacionados a expectativas de incertezas no campo do planejamento e gerenciamento energético.

Essa premissa se reforça no caso da cogeração a biomassa, que ainda enfrenta a resistência de usineiros tradicionais por conta de barreiras técnicas e econômicas e busca condições mais adequadas junto ao governo para viabilizar economicamente essa atividade. Em termos de impactos socioambientais, a dificuldade de dissociação desse recurso com as atividades historicamente pouco sustentáveis da cana-de-açúcar comprometem a aprovação desse recurso junto à sociedade, ainda que a utilização do bagaço para a geração de 
eletricidade se trate de uma adicionalidade energética capaz de reduzir impactos ambientais decorrentes da prática de queimadas.

A seguir, o posicionamento dos principais atores é comentado.

Governo Federal: a motivação por parte do governo em função da possibilidade de aproveitamento do bagaço da cana-de-açúcar como matéria prima para geração elétrica é positiva na medida em que favorece, assim, a cultura da cana no país, apesar de a energia resultante ser menos vantajosa economicamente se comparada à hidroeletricidade ou mesmo à energia eólica. A posição atual do governo, ainda que não possa ser considerada contrária ao desenvolvimento desse recurso, mostra-se pouco flexível em atender ao pleito de geradores por melhores condições de remuneração.

Produtores de Energia: Os produtores de energia - classificados como usineiros - apresentam posicionamento dividido em relação ao aproveitamento do bagaço de cana-de-açúcar para a produção e venda de eletricidade por questões técnicas - exemplos de dificuldade de conexão de usinas à rede de distribuição -, econômicas - lucratividade inferior às atividades essenciais da usina, de produção de açúcar e álcool - e culturais - receio de diversificação de negócios e inserção no mercado de comercialização de eletricidade. Mesmo assim, há perspectivas de que o potencial de cogeração tenda a crescer com o avanço da safra de cana-de-açúcar projetado para os próximos dez anos (ÚNICA, 2009).

Construtores: A motivação de empresas construtoras e empreiteiras é aproveitar - grande potencial nacional de cogeração a bagaço de cana e construir empreendimentos de pequeno e grande porte (em média, entre 30 e $120 \mathrm{MW}$ ). As maiores barreiras à construção desses projetos são a localização das usinas em relação a redes de distribuição, bem como sua viabilidade econômica.

Financiadores: O principal financiador de energias renováveis no Brasil é o BNDES. Na última década, o banco financiou a construção das usinas do Proinfa e de grande parte das usinas leiloadas nos certames de biomassa e energia eólica. Entretanto as condições de financiamento e amortização de dívidas nem sempre resultam na viabilização de empreendimentos, seja por falta de capital 
próprio de empreendedores ou por falta de competitividade em leilões ou licitações. A exigência de apresentação de garantias e a falta de confiança em empreendimentos caracteristicamente de administração familiar constituem barreiras à obtenção de financiamento de sistemas de cogeração em usinas.

Distribuidores: Apesar da ampla experiência da produção de cana-de-açúcar e da participação superior a 5\% de cogeração a biomassa na matriz elétrica brasileira, a aceitação dos distribuidores à possibilidade de utilização desse recurso enfrenta críticas relacionadas à sazonalidade do recurso - vinculado à safra da cana-deaçúcar. Outro argumento das concessionárias é a perda de poder econômico e político como resultado da distribuição da geração de energia em autoprodutores e um maior número de agentes. O setor de bioeletricidade vem também perdendo espaço na competição com as demais fontes renováveis nos últimos leilões e perde, por consequência, participação nas carteiras energéticas das distribuidoras.

Grandes Consumidores: O posicionamento dos grandes consumidores de energia à utilização de energia de biomassa é positivo, especialmente entre produtores de etanol que podem produzir a eletricidade localmente. Já a motivação dos demais consumidores é atrelada à acessibilidade da tarifa oferecida, como condição de viabilização de suas atividades e negócios.

Órgão Ambiental: As principais funções de órgãos ambientais competentes à avaliação de empreendimentos energéticos são de avaliar potenciais impactos ambientais resultantes da implantação desses projetos, autorizar a sua construção - por meio da avaliação de relatórios e estudos de impacto ambiental - e acompanhar a evolução da construção e funcionamento deles - por meio de monitoramento e avaliações de desempenho ambiental. Ainda que o posicionamento de órgãos ambientais em relação ao licenciamento de usinas seja rígido, a previsão da cogeração nos processos produtivos tende a aumentar as chances de obtenção dessa licença, por conta da redução de impactos ambientais de queimadas.

Atingidos: A ocupação de grandes territórios para a monocultura de cana-deaçúcar registra diferentes casos de pressão sobre pequenos agricultores para o 
arrendamento de terras e o deslocamento. Dessa forma, a posição natural de grupos atingidos por esses empreendimentos, sejam eles deslocados de seus territórios ou não, depende da natureza desse processo, em termos sociais e econômicos.

Organizações Não-Governamentais: A aceitação por parte da maioria das organizações Não-Governamentais pela possibilidade de utilização do bagaço da cana-de-açúcar para cogeração elétrica é relativamente positiva, por implicar um reaproveitamento de recursos que, de outro modo, seriam desperdiçados. Entretanto os benefícios ambientais são relativizados pela poluição advinda da queima do bagaço, bem como de todos os prejuízos ambientais e sociais da monocultura intensiva da cana. Especificamente no caso da Região Administrativa de Araçatuba, a adoção da geração por meio do aproveitamento do bagaço é relativamente consensual, considerando o potencial de geração ainda desperdiçado pelo setor sucroalcooleiro local.

Sociedade: A aceitação por parte da população em geral pela possibilidade de utilização do bagaço da cana-de-açúcar para cogeração elétrica é relativamente positiva, por implicar o reaproveitamento de recursos que de outro modo seriam desperdiçados. A redução da queima da palha de cana resultaria na minimização de impactos à saúde pública de áreas próximas aos canaviais. Em termos sociais, o setor de cogeração sucroalcooleira apresenta possibilidade de geração de empregos qualificados.

Conjunção e Encontro de Interesses: A conjunção de interesses e o resultado do posicionamento entre os agentes descritos pode ser trabalhada por metodologias como a teoria de jogos ou mesmo dentro do processo de ranqueamento que sucede a CVPC. Uma vez que o intuito desse processo de valoração é de determinar os potenciais de atuação de cada agente, prévios aos resultados dessas interações, opta-se, neste exercício, pelo mapeamento desses agentes em função de sua posição e influência no âmbito do recurso analisado (Figura 47). No caso das usinas de cogeração a biomassa, ainda que o posicionamento da maior parte dos atores analisados seja relativamente favorável à implementação do recurso, a análise apresentou uma disposição de forças diferenciada em relação à valoração de $\mathrm{PCHs}$, por conta de maiores 
obstáculos técnicos, econômicos e culturais à sua implementação, tanto por parte do setor elétrico, quanto de produtores de energia.

Esta dinâmica é retratada com o mapeamento dos En-In em função de sua influência e posicionamento, na figura 47.

\section{Análise de Poder: Cogeração a Biomassa}

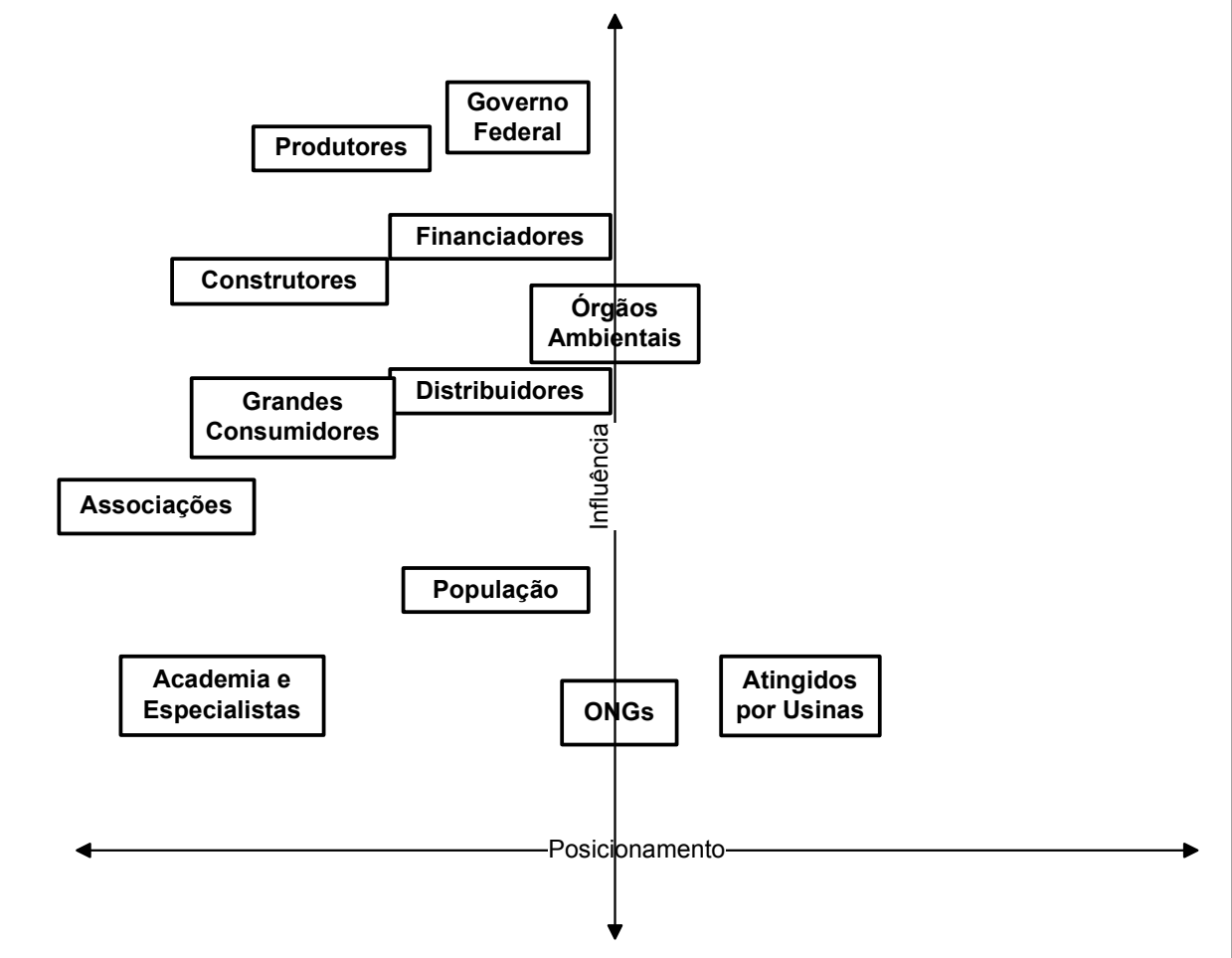

Figura 46: Análise de Poder - Cogeração a Biomassa

\subsubsection{Propriedade e Integração Energética}

A análise da propriedade de cogeração a bagaço de cana envolve a caracterização da fonte e da tecnologia utilizada em seu aproveitamento. A fonte enquadra-se como fonte regional de propriedade essencialmente particular. $O$ recurso energético envolve tecnologia totalmente nacional, de posse privada de empreendedores privados ou empresas públicas.

A avaliação do potencial de integração energética aplica-se na possibilidade de exportação de combustíveis no caso do etanol. Já no caso da cogeração de biomassa, pode-se transmitir a eletricidade; ainda que o transporte 
da cana apresente restrições de durabilidade, a biomasssa pode ser processada e transportada para a produção de eletricidade em outros locais.

\subsubsection{Dimensão Ambiental}

A valoração da dimensão ambiental para os recursos do lado da oferta divide-se em três áreas principais, abordando impactos aos meios aéreo, aquático e ao solo.

\subsubsection{Poluição do Meio Aéreo}

A poluição do meio aéreo pela emissão de diferentes tipos de gases contabiliza apenas etapas referentes ao manuseio do bagaço e da palha e sua queima em caldeira. Desta forma, estima-se que este insumo seja usado para a produção de energia e não seja, portanto, queimado nos canaviais. A queima evitada em decorrência deste processo tampouco é computada, entendendo-se que o recurso energético trata apenas da cogeração do bagaço, sem considerar o processo ou a cadeia de produção do etanol da cana.

As etapas de recuperação e transporte da palha envolvem a operação de máquinas agrícolas e o uso de caminhões. A emissão identificada deve-se, portanto, ao uso do diesel como combustível para esses equipamentos. $O$ fator de emissão calculado por Leal (2000, apud LEME, 2005) e adaptado para a recuperação total da palha é de 4,6 kgCO2eq/tc.

A queima de biomassa nas caldeiras da usina implica a emissão de $\mathrm{CH} 4$, $\mathrm{CO}, \mathrm{N} 2 \mathrm{O}, \mathrm{NOx}$ e material particulado. As emissões de $\mathrm{CO} 2$ não são contabilizadas por conta de sua reabsorção no ciclo do carbono da biomassa. De acordo com Leme (2005), os valores de emissão desses gases, obtidos junto ao IPCC e convertidos em proporção à massa de bagaço e palha utilizada e CO2 equivalente são de $6,75 \mathrm{kgCO} 2 \mathrm{eq} / \mathrm{tc}, 0,15 \mathrm{kgNOx} / \mathrm{tc}$ e 2,58kgMP/tc para o bagaço e 5,96 kgCO2 eq/tc, 0,18 kgNOx/tc e 1,80kgMP/tc para a palha.

A conversão para unidades de massa de poluente por massa de bagaço ou palha foi feita pela multiplicação do fator de emissão do IPCC pelo poder calorífico inferior $(\mathrm{PCl})$ desses combustíveis, considerando o $\mathrm{PCl}$ do bagaço igual a $7.500 \mathrm{~kJ} / \mathrm{kg}$ e da palha, $12.750 \mathrm{~kJ} / \mathrm{kg}$. A conversão em $\mathrm{kgCO} 2 e q / \mathrm{tc}$ foi feita pela multiplicação das emissões em seus potenciais de aquecimento global (PAG) e 
pela proporção de palha e bagaço por tonelada de cana (140 kg de palha e 280 kg de bagaço por tonelada de cana).

Tabela 27: Emissões aéreas de bagaço e palha de cana

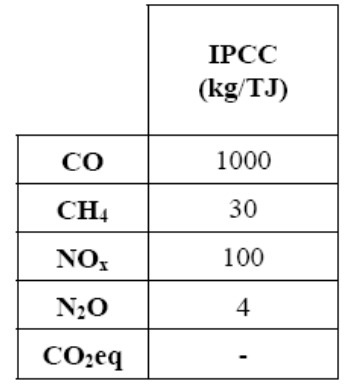

\begin{tabular}{|c|c|}
\hline \multicolumn{2}{|c|}{ Bagaço } \\
\hline $\mathbf{k g} / \mathbf{t b}$ & $\mathbf{k g C O}_{\mathbf{2}} \mathbf{e q} / \mathbf{t c}$ \\
\hline 7,50 & 2,10 \\
\hline 0,22 & 1,42 \\
\hline 0,75 & 1,05 \\
\hline 0,03 & 2,49 \\
\hline - & 7,06 \\
\hline \multicolumn{2}{|c|}{ Fonte: $\operatorname{IPCC}(1996)$} \\
\hline
\end{tabular}

\begin{tabular}{|c|c|}
\hline \multicolumn{2}{|c|}{ Palha } \\
\hline $\mathbf{k g} / \mathbf{t p}$ & $\mathbf{k g C O} \mathbf{2} \mathbf{e q} / \mathbf{t c}$ \\
\hline 12,75 & 1,78 \\
\hline 0,38 & 1,22 \\
\hline 1,27 & 0,89 \\
\hline 0,05 & 2,07 \\
\hline- & 5,96 \\
\hline
\end{tabular}

Os índices médios aplicados ao potencial teórico de 37,617 milhões de toneladas de cana produzidos na região, na safra 2008/2009, resultam em 10,533 milhões de toneladas de bagaço e 5,266 milhões de toneladas de palha.

O cômputo e valoração ds emissões aéreas de cada gás são calculados a partir dos coeficientes da tabela 27 e apresentadas na tabela 28 a seguir:

Tabela 28: CVPC Emissões aéreas de bagaço e palha de cana

\begin{tabular}{|c|c|}
\hline Gás & Mil toneladas $\mathbf{( G g )}$ \\
\hline $\mathrm{CO}$ & 146,14 \\
\hline $\mathrm{CH} 4$ & 4,32 \\
\hline $\mathrm{NOx}$ & 14,59 \\
\hline $\mathrm{N} 2 \mathrm{O}$ & 0,58 \\
\hline
\end{tabular}

\subsubsection{Produção de Gases de Efeito Estufa}

Com base na estimativa de gases produzidos, aplica-se, para a determinação de gases de efeito estufa, a equação abaixo:

CVPC GEE (RELO) = PEF1xEmCH4 + PEF2xEmCO2 + PEF3xEmN20

O resultado, somando as emissões de palha e bagaço, é de 490,53 milhões de $\mathrm{kg}$ de $\mathrm{CO} 2$ equivalente.

\subsubsection{Ocupação do Solo}

Uma vez que o recurso energético seria instalado dentro de plantas industriais, e, portanto, o uso e ocupação do solo já se dariam numa área 
industrializada, não se observa alteração do impacto já existente no local. Assim, a ocupação do solo é considerada nula para esse recurso.

\subsubsection{Produção de Resíduos Sólidos}

A produção de resíduos sólidos acontece na forma de geração de cinzas durante a queima da biomassa nas caldeiras. Depende da composição química da biomassa e da quantidade de impurezas não combustíveis introduzidas na caldeira. Neste exercício, considerou-se apenas a primeira variável para a valoração.

De acordo com Leme (2005), o conteúdo médio de cinzas presentes na matéria seca do bagaço resulta em $3,73 \%$. Considerando $280 \mathrm{~kg}$ de bagaço com $50 \%$ de umidade, por tonelada de cana, obtém-se um índice de geração de cinzas de acordo com a equação abaixo:

CVPC Res $($ RELO $)=280 \times 0,0373 \times 0,5=5 \mathrm{~kg} / \mathrm{tc}$

O valor considera a conversão de toda a cinza presente no bagaço em resíduos na caldeira. Considerando o mesmo índice de conteúdo de cinzas para a palha, obtém-se o valor total de $10 \mathrm{~kg}$ por tonelada de cana.

Tomando como base a produção de 37,617 milhões de toneladas de cana, o valor de cinzas produzidas pela queima do bagaço e da palha é de 376,17 mil toneladas.

\subsubsection{Caracterização de uso e consumo de água}

Neste exercício, considerou-se apenas o uso e consumo de água adicionais decorrentes da eventual condensação de vapor necessário à geração de excedentes de eletricidade. O restante de água usado pela usina, necessário à operação dos processos de fabricação de açúcar e álcool, não tem relação direta com a produção de excedentes de eletricidade no setor sucroalcooleiro. $\mathrm{O}$ uso e consumo adicional acontece somente nos casos em que há turbinas de condensação, no sistema de geração de energia. Nesses casos, há um circuito de água de resfriamento necessária à condensação do vapor que escapa das turbinas de condensação. 
O uso de água depende da quantidade de vapor condensado, da temperatura do vapor, das características do condensador e das torres de resfriamento e da temperatura da água de resfriamento. De acordo com Lora (et al, 2004, apud LEME, 2005), os índices de perdas totais situam-se entre $1,7 \%$ e $4,3 \%$.

De acordo com Leme (2005), considerou-se o índice de uso de água de 54 $\mathrm{m} 3 / \mathrm{tv}$ de vapor condensado (obtido junto à Usina de Itacoatiara) e índice de consumo de água de $1 \mathrm{~m} 3 / \mathrm{tv}$ de vapor condensado (Usina Barra Grande), ou $2,27 \%$ em relação à vazão de água de resfriamento. A representação desses índices na base de 1 tonelada de cana depende das características da instalação de geração de energia. A parcela do sistema que opera em condensação é de $0,171 \mathrm{tv} / \mathrm{tc}$ na safra e de $0,233 \mathrm{tv} / \mathrm{tc}$ na entressafra; logo:

- uso de água de vapor condensado na safra $=54 \times 0,171=9 \mathrm{~m} 3 / \mathrm{tc}$;

- consumo de água de vapor condensado na safra $=1 \times 0,171=0,17 \mathrm{m3} / \mathrm{tc}$;

- uso de água por condensação na entressafra $=54 \times 0,233=12 \mathrm{m3} / \mathrm{tc}$;

- consumo de água por condensação na safra $=1 \times 0,233=0,23 \mathrm{m3} / \mathrm{tc}$.

Considerando, novamente, a produção de 37,617 milhões de toneladas de cana, o valor de uso de água na safra e na entressafra é, respectivamente, 338,55 e 451,4 milhões de m3 e o consumo de água na safra e na entressafra é, respectivamente, $\mathbf{6 , 3 9}$ e 8,65 milhões de $\mathrm{m} 3$ de água.

\subsubsection{Qualidade da água}

Ainda que a produção etanol e o descarte incorreto de subprodutos como o vinhoto exerçam efeito sobre a qualidade da água em parâmetros como DBO, $\mathrm{DBQ}, \mathrm{pH}$ e temperatura, a cogeração de biomassa tem efeito reduzido sobre a qualidade da água, apresentando alteração de demanda de oxigênio dentro de padrões estabelecidos pela CETESB e emissões de efluentes em temperatura abaixo de $40^{\circ} \mathrm{C}$, também dentro de padrões da CETESB.

\subsubsection{Dimensão Social}

A valoração da dimensão social trabalha parâmetros relacionados ao bem estar da sociedade e do indivíduo, ao lado de fatores socioeconômicos como geração de emprego e desenvolvimento de infraestrutura. 


\subsubsection{Geração de Empregos}

De acordo com Rutovitz (RUTOVITZ et al, 2009), a geração de empregos no setor de cogeração a biomassa apresenta médias levantadas em diferentes metodologias europeias e norte-americanas. A média inferior indica 3,9 empregos/MW instalado na área de construção e instalação de usinas, 0,001 empregos/MW para a fabricação de equipamentos e 3,4 empregos/MW voltados para a operação e manutenção (RUTOVITZ, 2009 apud EPRI, 2001 e DTI, 2004). A média superior de empregos aponta entre 14 e 17 empregos por MW instalado, agregando todas as atividades (RUTOVITZ, 2009 apud MITRE, 2003).

Considerando a potência teórica de 2.146,06 MW, o total de empregos gerados é calculado segundo a equação:

$$
\text { CVPC Emp (RELO) }=\text { MAX }\left(\sum(\text { FEmp }(\text { RELO }) \times(\text { IN }) \times(\text { MR }) \times \text { Pot(RELO) })\right.
$$

Onde:

CVPC Emp (RELO): Cômputo e valoração de empregos para RELOs (em número de empregos); FEmp (RELO): Fator de empregos de RELOs (em empregos/MW);

IN: Índice de nacionalização de produção e/ou serviços (\%);

MR: Multiplicador regional (adimensional).

Considerando o índice de nacionalização de $100 \%$ para o recurso energético e um fator multiplicador regional igual a 1, os fatores agregados de emprego de 7,3 e 17 produzem, respectivamente, o total de 15.666 e 36.486 empregos.

\subsubsection{Qualidade de Empregos}

Ainda que a cultura de cana registre uma alta proporção de geração de empregos classificados como de baixa capacitação, salários e contratações temporárias, as atividades relacionadas à cogeração de biomassa demandam o emprego de funcionários com índices de capacitação mais elevados. Em decorrência da falta de informações discriminadas sobre os postos de trabalho criados para a cogeração, optou-se por tratar qualitativamente a avaliação deste subatributo. 


\subsubsection{Desenvolvimento Econômico e Humano}

A agroindústria canavieira altera a dinâmica urbana de pequenos e médios municípios e cria novas demandas por serviços públicos, tais como saúde, segurança, educação, abastecimento de água, tratamento de esgoto, saneamento básico, habitação, dentre outros (ASSIS et al, 2007). Por outro lado, o fluxo de trabalhadores atraídos por esses empreendimentos pressiona a infraestrutura existente, ao mesmo tempo que exige maiores investimentos por parte dos governos municipais.

A análise de desenvolvimento econômico em decorrência da venda de eletricidade em usinas de cana-de-açúcar considera a geração de empregos e a renda média anual de tais empregos para determinar a geração de receita do recurso energético.

A valoração do desenvolvimento econômico considera a seguinte equação:

CVPC DE(RELO) $=$ FRenda $\times$ Pot(RELO)

$\Delta$ CVPC DE $($ RELO) $=$ CVPC DE $($ RELO) $/$ PIBlocal (21)

Onde:

CVPC DE (RELO): Cômputo e valoração de desenvolvimento econômico de RELO (R\$); FRenda: Massa salarial anual de um determinado empreendimento ( $\mathrm{R} \$ \mathrm{MW})$.

$\triangle$ CVPC DE (RELO): Variação de cômputo e valoração de desenvolvimento econômico de RELO $(\%)$.

Em decorrência da falta de dados para essa atividade, assume-se uma renda média de $\$ 2$ mil reais mensais, que multiplicada à uma geração média de 26.076 empregos resulta na receita anual de $R \$ 625,824$ milhões de reais.

Com base em um PIB regional de $\mathrm{R} \$ 11$ bilhões no ano de 2008, tem-se que o recurso é capaz de contribuir potencialmente para uma variação de 5,69\% nesse valor.

A variação da valoração de desenvolvimento humano é calculada pela seguinte fórmula:

$\Delta$ CVPC DH $=\Delta$ CVPC DE (RELO) $/ 3$ 
Onde:

$\triangle$ CVPC DH (RELO): Variação de cômputo e valoração de desenvolvimento humano de RELO (\%).

De acordo com a fórmula do IDH, atribuindo um peso de 1/3 para a componente de desenvolvimento econômico calculada anteriormente, obtém-se uma variação positiva de 1,89\% em desenvolvimento humano.

\subsubsection{Alteração de Conforto}

A valoração de condições de conforto para a cogeração a biomassa entende como negligenciáveis impactos como poluição sonora e olfativa. A poluição visual identificada pela cultivo da cana-de-açúcar, ainda que questionável e de análise subjetiva, não pode ser valorada dentro do recurso de cogeração de bioeletricidade, uma vez que a plantação serve, primordialmente, à produção de etanol e açúcar.

\subsubsection{Impacto Humano Decorrente do Espaço Ocupado}

A expansão da cana-de-açúcar no campo e a transformação de produtores rurais em arrendatários é uma consequência clara da ocupação do espaço rural do estado de São Paulo pelo cultivo de cana.

No entanto, a cogeração é considerada apenas como adicionalidade, não exercendo, portanto, influência sobre a ocupação de espaço ou a desapropriação de populações rurais.

\subsubsection{Influência de Impactos Ambientais à Saúde Humana}

A queima dos canaviais para a colheita da cana-de-açúcar provoca notáveis efeitos à saúde de populações próximas aos canaviais - como casos de doenças crônicas do aparelho respiratório como bronquite, enfisema e asma - em decorrência do material particulado produzido e inalado por essas pessoas. Esses efeitos têm sido pesquisados e quantificados pelo Laboratório de Poluição Atmosférica Experimental (LPAE) do Departamento de Patologia da Faculdade de Medicina da Universidade de São Paulo.

A cogeração do bagaço e da palha da cana exerce, portanto, efeito positivo sobre a atenuação de impactos à saúde de populações em áreas de 
cultivo de cana-de-açúcar, uma vez que a utilização dessa biomassa em caldeiras reduz a prática de queima dos canaviais.

A redução das emissões é proporcional à quantidade de biomassa utilizada na atividade de cogeração. No entanto, a falta de indicadores doseresposta para a região impede a valoração desse atributo.

\subsection{Substituição de Chuveiros Elétricos por Sistema com Aquecimento Solar}

No Brasil, segundo dados do PROCEL, o setor residencial da região sudeste consome cerca de $26 \%$ de eletricidade em chuveiros elétricos. O índice coloca o uso final como maior consumidor de energia elétrica em residências, ao lado das geladeiras. Esta importância justifica a escolha deste recurso do lado da demanda neste estudo de caso.

O exercício analisa como recurso a substituição do chuveiro elétrico por um sistema de aquecimento solar e emprega a metodologia de CVPC discutida no item 5 deste texto.

\subsubsection{Dimensão Técnico-Econômica}

A valoração da dimensão técnico-econômica para recursos energéticos do lado da demanda concentra-se em atributos voltados aos cálculos de economia de energia e redução de demanda, trabalhados por meio de metodologias conhecidas.

\subsubsection{Redução de Demanda na Ponta}

O cálculo da Redução de Demanda na Ponta (RDP) requer algumas considerações feitas a seguir.

Segundo dados do IBGE a média de habitantes por domicílio no estado de São Paulo é igual a 3,3 (IBGE, 2006) e, de acordo com o SEADE (Fundação Sistema Estadual de Análise de Dados), a população de Araçatuba é de 727.342 habitantes (SEADE, 2010). Assim, é possível estimar que o número de domicílios na RAA é de cerca de 220.407. Segundo o Procel, o número médio de chuveiros por residência na região sudeste é de 1,1 (SOUZA, 2007). Utilizou-se uma potência máxima de $4.400 \mathrm{~W}$ para chuveiros (ABRAVA, 2007) utilizada em projetos da CDHU (Companhia de Desenvolvimento Habitacional e Urbana). 
Fixou-se um volume médio de reservatórios de 200 litros, com base em valores do programa federal "Minha casa, Minha vida"; de acordo com (ANEEL, 2008), sua Potência auxiliar (Paux) é de 750 W e o Fator de Diversidade indicado é 0,10.

\section{$R D P=N R \times N C \times\left(P C-P_{A U X}\right) \times F D \times 10^{-3}(80)$}

Onde:

RDP: redução de demanda na ponta (KW);

NR: número de residências;

NC: número médio de chuveiros por residência;

PC: potência máxima típica dos chuveiros utilizados (W);

$P_{A U X}$ : potência média do aquecimento auxiliar por residência $(W)$;

FD: fator de diversidade de demanda do chuveiro na ponta (adimensional).

A aplicação da equação com os valores mencionados resulta em $88.493,4$ kW de redução de demanda na ponta.

\subsubsection{Energia Economizada}

O cálculo da energia economizada (EE), em MWh por ano, utiliza a seguinte equação, adaptada de manual da ANEEL (2008):

\section{$E E=F S \times\left(P C-P_{A U X}\right) \times N B \times(T / 60) \times 365 \times 10^{-6} \times N R(79)$}

Onde:

NR: número de residências;

PC: potência máxima típica dos chuveiros utilizados (W);

FS: fração solar a ser definida pela concessionária/permissionária;

NB: número médio de banhos por residência;

T: tempo de duração do banho (em minutos ).

O cálculo da energia economizada partiu de um número de residências atendidas (NR) de 220.407. Considerou-se uma fração solar média (FS) de 0,6 (BALDACCI, 2009) e Potência Máxima típica do chuveiro em 4.400 W (ABRAVA, 2007); o número médio de banhos por residência (NB) foi estimado em 4 (BALDACCI, 2009) e o tempo de duração do banho (T) - análogo ao adotado pelo PROCEL - em 8 minutos.

A aplicação da fórmula resulta em 93.963,91 MWh/ano de energia economizada. 


\subsubsection{Investimento Total}

O investimento total é calculado por meio da soma do investimento no equipamento (le) e do Investimento da instalação (lins) multiplicado pelo número de residências atendidas (NR), de acordo com as seguintes equações:

\section{Unit $=I \mathrm{Eq}+\mathrm{I}$ Ins (85)}

\section{CVPC ITot (RELD) = I Unit x NR}

Onde:

I Unit: Investimento unitário $(\mathrm{R} \$)$;

I Eq: Investimento em equipamento $(\mathrm{R} \$)$;

I Ins: Investimento na instalação $(\mathrm{R} \$)$;

NR: Número de residências;

CVPC ITot (RELD): Investimento total (R\$).

De acordo com o Centro Internacional de Referência em Reuso de Água (CIRRA) (ABINEE, 2010), o investimento no equipamento individual é cerca de $R \$ 3.695,00$ enquanto o Investimento da instalação é de $R \$ 350,00$.

A instalação do equipamento em 220.407 residências totaliza $R$ \$ 891.546.315,00 de investimento total.

\subsubsection{Custo da Energia Conservada}

A receita bruta é obtida pelo cálculo do Custo da Energia Conservada (CEC) de acordo com a equação abaixo:

$\mathrm{CEC}=(\mathrm{I} \mathrm{Tot} / \Delta \mathrm{E}) \times \mathrm{FRC}(76)$

Onde:

CEC: custo da energia conservada $(\mathrm{R} \$ / \mathrm{kWh})$;

I Tot: investimento total do RELD (R\$);

$\triangle \mathrm{E}$ : energia economizada pela implementação do RELD em relação a um caso base (kWh);

FRC: Fator de Retorno de Capital (vide item 6.3.1.8).

Conforme verificado anteriormente, o Investimento total do RELD é de $\mathrm{R} \$$ 891.546.315,00 e a Energia Economizada é igual a 93.963,91 MWh/ano. Considerou-se a vida útil (n) dos coletores solares em 20 anos (DASOL, 2010) e fixou-se a taxa de desconto adotada de $8 \%$, conforme indicação do Manual para elaboração do Programa de Eficiência Energética da ANEEL. 
A aplicação dos dados na fórmula gera uma CEC de $\mathrm{R} \$$ 819,77/MWh.

\subsubsection{Custo de Operação \& Manutenção}

O custo de Operação \& Manutenção é um valor fixo igual a $2 \%$ do investimento total (DASOL, 2010), e nesse caso, é equivalente a $R \$$ $17.830 .926,30$.

\subsubsection{Tempo de Implantação}

Utilizando-se as metas de instalação de 50 mil residências para o ano de 2009 do programa federal "Minha casa, Minha vida" para compor a estimativa do tempo de implantação, produz-se o tempo total de quatro anos e meio, levando em conta o número de residências na RAA.

No entanto, uma vez que as casas utilizadas como base no recurso já estão construídas e dotadas de instalação elétrica, é possível considerar somente o tempo de implantação do aquecedor solar. A análise determinou um ponto ótimo de um ano, período que assegura que o custo de implementação do recurso não supere o valor da energia evitada, inviabilizando-o.

\subsubsection{7. Índice de Nacionalização}

Uma vez que parte dos coletores solares da Transsen é produzida em uma fábrica na cidade de Birigui, admitiu-se um Índice de nacionalização do produto em $100 \%$.

\subsubsection{Fator de Recuperação de Capital}

Considerando que RELDs contam com financiamento a juros constantes, dispensou-se o uso da metodologia de fluxo de caixa descontado neste exercício. Assim, utiliza-se o cálculo do fator de recuperação de capital, calculado pela fórmula abaixo:

$$
\begin{aligned}
& F \\
& R \\
& \text { Onde: }
\end{aligned}
$$

$\mathrm{N}=$ vida útil da ação de GLD I = taxa de rendimento anual 
No caso estudado, a vida útil do RELD é de 20 anos e a taxa de rendimento anual de $8 \%$, resultando em um FRC de 0,0864.

\subsubsection{Custo da Demanda Evitada}

O Custo da demanda evitada é dado pela fórmula abaixo:

$$
\text { CED }=\left(12 \times C_{1}\right)+\left(12 \times C_{2} \times \text { LP }\right)
$$

Onde:

CED: custo da demanda evitada (R\$/kW.ano);

$\mathrm{C}_{1}$ : custo unitário da demanda residencial no horário de ponta $(\mathrm{R} \$ / \mathrm{kW}$.mês);

$\mathrm{C}_{2}$ : custo unitário da demanda residencial no horário fora de ponta ( $\mathrm{R} \$ \mathrm{~kW}$.mês);

LP: constante de perda de demanda no posto fora de ponta, considerando $1 \mathrm{~kW}$ de perda de demanda no horário de ponta.

O setor residencial demanda algumas observações referentes à formulação utilizada. Em função da não diferenciação de tarifas de acordo com horários de ponta para o setor, seguiu-se recomendação da Aneel de utilizar valores de custo unitário de demanda do subgrupo A4, ajustados a um coeficiente igual a 1,2. Desta forma, utilizou-se valores de demanda de $R \$ 6,36 / \mathrm{kW}$ (fora da ponta) e $R \$ 27,79 / \mathrm{kW}$ (na ponta) praticados pelas distribuidoras da região, CPFL (Companhia Paulista de Energia Elétrica) e Elektro.

A constante de perda (LP) apresenta fator de carga de 0,5 para o estado de São Paulo (ANEEL, 2008), e resulta em 0,3844.

Assim, o custo de demanda evitada é calculado por:

CED $=12 \times 27,79 \times 1,2+12 \times 6,36 \times 1,2 \times 0,3844=400,18+35,21=435,39$

O CED para aquecedores solares é, portanto, $R \$ 435,39 / \mathrm{kW}$.ano.

\subsubsection{Qualidade de Energia}

O uso de sistemas de aquecimento solar tem como única função reduzir a quantidade de energia empregada durante o banho e não envolve a adição de qualquer sistema energético complementar conectado à rede. Desta forma, não se identifica qualquer tipo de comprometimento da qualidade de energia em decorrência desse recurso energético. 


\subsubsection{Dimensão Política}

A valoração dos atributos da dimensão política vale-se essencialmente de análises qualitativas para mensurar 0 potencial de implementação $e$ aproveitamento de recursos. No campo do gerenciamento do lado da demanda, os fatores preponderantes concentram-se na avaliação de políticas de incentivo e na ponderação de balanço e interação entre atores do setor. A posse e a propriedade de recursos são entendidas como questões tecnológicas e não são avaliadas para RELDs.

\subsubsection{Instrumentos Políticos}

A tecnologia de coletores solares no Brasil tem-se consolidado como uma alternativa viável ao chuveiro elétrico, após a aprovação de diferentes legislações municipais e estaduais de incentivo e/ou obrigatoriedade de instalação de coletores para edificações de tipologia caracteristicamente pública e comercial.

O desenvolvimento inicial do mercado de aquecimento solar no Brasil ocorreu entre 2001 e 2002, por conta das constrições de consumo em todos os setores e do estabelecimento de taxações sobre metas impostas de redução de consumo. Nessa época, empreendedores do setor foram incentivados a investir em pesquisa e produção de coletores, como forma de tornar a tecnologia mais acessível.

Segundo (SOARES \& RODRIGUES, 2010) até o fim de 2009 havia 28 leis aprovadas, entre municipais e estaduais, sobre sistema de aquecimento solar no Brasil. As leis em sua maioria fazem menção a obrigatoriedade do uso de coletores solares em residências com área a partir de $120 \mathrm{~m}^{2}$ ou $150 \mathrm{~m}^{2}$ e de grandes estabelecimentos comerciais que usem água quente, no entanto, é importante ressaltar que na maioria dos casos há pouca ou nenhuma fiscalização por parte do Estado que garanta o comprimento das leis, como é o caso da cidade de São Paulo.

Em adição à legislação de obrigatoriedade de instalação de coletores, citase a avaliação da eficiência desses equipamentos dentro do Programa Brasileiro de Etiquetagem - segundo o INMETRO, até 2006 mais de 160 coletores tinham sido etiquetados, sendo 62 deles com conceito A do selo PROCEL em eficiência energética. 
Mais recentemente, o governo federal tem instalado coletores solares nas unidades habitacionais do programa "Minha casa, Minha vida"; a meta para 2010 prevê a instalação de coletores em 150 mil unidades habitacionais o que promoveria uma economia de energia anual de $112.000 \mathrm{MWh}$.

Por fim, ainda não se verificou a implementação de medidas de incentivo fiscal para coletores solares, por parte dos governos federal ou estadual. A maioria dos bancos pratica juros convencionais de mercado para o financiamento de aquecedores solares, porém os bancos Santander/Real, Itaú e Bradesco possuem linhas de crédito especiais para a compra de aquecedores solares, e alguns fabricantes como a Transsen disponibilizam consórcios para seus clientes.

\subsubsection{Envolvidos e Interessados}

Com o amadurecimento dos coletores solares no Brasil nos últimos anos, essa tecnologia passou a ser uma alternativa viável à substituição dos chuveiros elétricos.

Por tratar-se de uma tecnologia que utiliza uma fonte renovável, recebe o apoio da sociedade civil e o interesse razoável do governo, em virtude do potencial de redução de investimentos para a geração de energia. Concessionárias, por outro lado, são neutras ao recurso, apesar da possibilidade de melhoria na modulação da curva de carga.

A primeira etapa da valoração de Envolvidos e Interessados refere-se ao mapeamento de suas funções, interesses e motivações.

O posicionamento dos principais atores é comentado a seguir. Ressalta-se que, para os RELDs, optou-se por dispensar o exercício da análise de poder, considerando-se o menor grau de conflito e oposição entre os En-In, em comparação ao observado em RELOs.

Governo Federal: o governo seria beneficiário da utilização em larga escala dessa tecnologia uma vez que a substituição dos chuveiros elétricos pelos coletores solares diminuiria o pico de demanda por energia elétrica entre as $17 \mathrm{e}$ 21 horas, tornando a curva de carga mais uniforme e, consequentemente, diminuindo consideravelmente a demanda de pico. Essa redução diminuiria a pressão sobre investimentos no setor elétrico e consequentes impactos socioambientais provenientes da construção de novas usinas. 
Fabricantes: $O$ Brasil possui diversos fabricantes de pequeno e médio porte. Duas empresas destacam-se por serem líderes de mercado: a Soletrol e a Transsen, que possui fábrica em Birigui. O setor teve seu crescimento retomado em 2008, em função da aprovação de legislação de instalação de coletores em alguns municípios da região, bem como da redução do custo do equipamento em virtude do aumento de sua eficiência.

Distribuidoras: A utilização de coletores solares para o aquecimento de água reduz o consumo de energia elétrica, o que deve implicar em diminuição da receita das distribuidoras. Esta, porém, posicionam-se de forma neutra em relação ao recurso, uma vez que uma posição contrária prejudicaria sua imagem frente à sociedade.

Grandes Consumidores: Segundo a ABRAVA, 14\% dos aquecedores solares são utilizados no setor terciário. A aplicação concentra-se em redes de hotelaria e hospitais para o aquecimento de água e de piscinas. Cerca de $1 \%$ dos aquecedores é aplicada na indústria para aquecimento d'água em vestiários e cozinhas industriais. Conclui-se que o posicionamento de grandes consumidores é positivo, de acordo com as atividades industriais e comerciais desenvolvidas.

Organizações Não Governamentais: De modo geral, ONGs defendem a larga aplicação do recurso na substituição dos chuveiros já que a diminuição do consumo de energia elétrica na ponta otimiza o uso do parque elétrico nacional e posterga a construção de novas usinas e consequentes impactos socioambientais. $O$ uso racional de energia contribui também à redução da emissão de gases do efeito estufa.

Sociedade: A população apoia parcialmente a aplicação do recurso em função dos seus benefícios ambientais ou mesmo sociais - considerando que 0 investimento público economizado com a eficiência energética pode, potencialmente, ser revertido para outros setores carentes como educação, saúde e infraestrutura. Por outro lado, os maiores entraves para a popularização do recurso energético são o alto investimento inicial para a aquisição do equipamento - $R \$ 4.055,00$ contra $R \$ 30,00$ de um chuveiro elétrico, de acordo 
com Hespanhol (ABINEE, 2010) - ao lado de desinteresse e falta de informação sobre a tecnologia ${ }^{173}$.

Conjunção e Encontro de Interesses: Um dos grupos conflitantes à implantação de sistemas de aquecimento solar é a indústria dos chuveiros elétricos representado pela Associação Brasileira da Indústria Elétrica e Eletrônica (ABINEE). A associação respalda-se em estudo da CIRRA (Centro Internacional de Referência em Reuso de Água) para opor-se à obrigatoriedade da instalação de coletores solares em edifícios, por motivos óbvios de mercado (ABINEE, 2010) ${ }^{174}$.

\subsubsection{Dimensão Ambiental}

A valoração da dimensão ambiental para os recursos do lado da demanda aborda essencialmente a potencial redução de impactos aos meios aéreo, aquático e ao solo em decorrência da aplicação de medidas de eficiência energética.

\subsubsection{Alteração da Vazão}

A alteração da vazão para este recurso de demanda possui um sentido diferente do aplicado à oferta. Neste caso, ela representa um parâmetro para medir a diferença de consumo de água entre o novo e o antigo equipamento, no caso entre o chuveiro elétrico e o coletor solar.

Segundo estudo do CIRRA, a vazão média de água do chuveiro é de 4,2 $\mathrm{L} / \mathrm{min}$, enquanto a vazão média do coletor solar com boiler é de $8,4 \mathrm{~L} / \mathrm{min}$. Considera-se para o cálculo da vazão, os seguintes valores:

- número de residências em que o recurso será aplicado igual a 220.407;

- número médio de chuveiros elétricos por residência igual a 1,1;

- número médio de coletores solares instalados por residência igual a 1;

\footnotetext{
173 Segundo VARELLA (2004), pesquisa realizada na cidade de Campinas apontou que 25,5\% dos entrevistados declararam desinteresse como motivo para não utilização de aquecedores solares, enquanto $28,7 \%$ alegaram falta de informação.

174 A associação argumenta que tais coletores solares são inviáveis, economicamente, se comparados ao chuveiro, e cita o aumento do consumo de água, uma vez que a água aquecida pelos coletores demora em média um minuto para atingir o ponto ideal.
} 
- tempo médio de banho de 8 minutos.

CVPC $\Delta Q=(Q m$ col. $\times$ NC $\times$ NR $\times$ t $\times$ NB $)-(Q m c h . \times N C h \times N R \times t \times N B)(87)$

Onde:

$\Delta$ Q: Alteração da Vazão (Litros.ano/residência);

Qm col.: Vazão média do coletor (Litros/minuto);

NC: número médio de coletores por residência;

NR: número de residências;

t: Tempo médio de banho;

Vm ch.: Vazão média do chuveiro (Litros/minuto);

NCh: número médio de chuveiros por residência;

NB: número de banhos por residência.

Calcula-se a diferença no consumo de água entre ambos igual a 44.150,4 litros.ano/residência.

\subsubsection{Qualidade da água}

Considerou-se que não há emissão de poluentes nos corpos d'águas da RAA visto que a função dos coletores solares é de aquecer a água.

O impacto de emissão de poluentes decorrente da fabricação destes componentes é considerado negligenciável. Desta forma, contabiliza-se como nula a emissão de poluentes, DBO, DQO, alteração de temperatura dos rios e $\mathrm{pH}$.

\subsubsection{Emissão de $\mathrm{CO}_{2}$}

Empregando-se a formulação de cálculo da linha de base abaixo, obtémse uma média de $85,33 \mathrm{~g} \cdot \mathrm{CO}_{2} / \mathrm{kWh}$ (vide Anexo 1).

$F($ base $)=\Sigma($ P\%(RELO) $\times$ F Em (RELO) $)$

Tomando como base a energia economizada de 93.963,91 MWh/ano, e considerando-se que a implementação desse recurso não gera emissões de gases de efeito estufa, utiliza-se a equação abaixo, dispensando o primeiro fator:

CVPC Em $($ RELD $)=F$ Em (RELD) $\times$ Pot $(R E L D)-F$ Em(base $) \times$ Pot $($ RELO) $=$ $-85,33 \times 93.963,91=8.017 .940,6$ 
A matriz elétrica da RAA produz, a partir de cálculo considerando a linha de base, uma média de 85,33 g. $\mathrm{CO}_{2} / \mathrm{kWh}$ (vide Anexo 1).

Considerando-se a energia economizada de 93.963,91 MWh/ano, evita-se a emissão de aproximadamente 8.017,94 toneladas de $\mathrm{CO}_{2}$ eq por ano.

\subsubsection{Ocupação de Espaço}

Ainda que a ocupação de espaço pela instalação de sistemas de aquecimento solar possa ser considerada elevada, esta apresenta a vantagem de utilizar uma área ociosa de residências, que não implica conflita com demais usos ou atividades.

Assim, o número deve ser avaliado sob a ótica de que o espaço usado para a aplicação do recurso não reduz o uso de espaço para outros fins.

O cálculo da área ocupada utiliza a fórmula a seguir:

\section{CVPC Oc (RELD) $=$ F Oc(RELD) $\times$ NR (57)}

Onde:

CVPC Oc: Área total ocupada por RELD; NR: número de residências.

O cálculo dessa área considera a área média de $2 \mathrm{~m}^{2}$ dos coletores utilizados no programa "Minha casa, Minha vida". Multiplicando-a pelo número de residências em que o recurso será aplicado, 220.407, produz-se uma área total ocupada de $440.814 \mathrm{~m}^{2}$.

\subsubsection{Dimensão Social}

A valoração da dimensão social trabalha parâmetros relacionados ao bem estar da sociedade e do indivíduo, ao lado de fatores socioeconômicos como geração de emprego e desenvolvimento de infraestrutura.

\subsubsection{Geração de Empregos}

A indústria de aquecedores solares no Brasil é formada, predominantemente, por micro e pequenas empresas. Sua estrutura é representada no fluxograma abaixo. 
O algoritmo de valoração desse atributo é determinado pela equação 58 mostrada abaixo:

\section{CVPC Emp (RELD) = F Emp (RELD) x Pot(RELD) - F Emp(base) $\times$ MR(base) x FD(base) x Pot(RELO) (66)}

A ausência da componente de redução ou deslocamento de empregos por conta da aplicação de RELD simplifica a equação para a multiplicação entre fator de emprego e potencial de economia de energia.

Segundo a DASOL-ABRAVA (2009), a tecnologia termossolar gera aproximadamente 55 empregos por MWth ${ }^{175}$. Em 2005 foram implantados 276 MWth gerando cerca de 15 mil empregos diretos.

Assim, tendo como base o índice de 55 empregos gerados por MWth e a redução de demanda na ponta, é possível estimar o número de empregos resultante da implantação do recurso em 4.867 empregos.

\subsubsection{Qualidade de empregos}

A capacitação mínima exigida para empregos da cadeia de aquecimento solar apresenta perfis diferenciados por setores e atividades.

Instalação: dos 55 empregos gerados para cada MWth da tecnologia termossolar, 20 são para a área de instalação e manutenção, para a qual não se necessita de formação em curso superior.

Comercial: para a área comercial, 15 empregos são gerados a cada MWth evitado.

Fabricação: em média, 12 empregos são gerados para fabricação de coletores solares, que exige curso técnico de eletrônica ou eletrotécnica.

Administração: dos 55 empregos por MWth, 8 são direcionados para a administração, que demanda curso técnico de administração para os cargos mais baixos na hierarquia e curso superior para o restante dos cargos.

\footnotetext{
${ }^{175} \mathrm{O}$ termo MWth indica MegaWatt térmico, medida para a produção de potência térmica dos aquecedores solares.
} 
Em síntese, dos 55 empregos gerados para cada MWth economizado, 20 demandam capacitação de curso técnico ou superior. Uma vez que não se tem registro da faixa salarial dessas funções, utiliza-se a capacitação como critério para a valoração da qualidade de empregos.

Assume-se, portanto, com base nos números anteriores, que pelo menos $36 \%$ dos empregos gerados são qualificados.

\subsubsection{Impactos à saúde}

Os chuveiros elétricos e coletores solares não possuem componentes com potencial de causar doenças nos seres humanos, porém todos os anos verificamse casos de fatalidade por eletrocução em chuveiros elétricos. Estatísticas da Associação Brasileira de Conscientização para os Perigos da Eletricidade (ABRACOPEL) indicam que, no ano passado, registrou-se 267 casos de mortalidade e 261 incêndios por curto-circuitos, dos quais 22\% dos casos ocorrem pelo uso do chuveiro elétrico.

A utilização de coletores solares apresentaria um potencial de diminuição da taxa de mortalidade calculado pela seguinte formula:

$P D A=(F A c \times T A C) \times(F C h \times N R / T C h)(88)$

Onde:

PDA: potencial de diminuição de acidentes;

FAc: porcentagem de acidentes relacionados ao chuveiro (5);

TAc: Número total de acidentes;

FCh: número médio de chuveiros por residência na região sudeste;

NR: número de residências;

TCh: número total de chuveiros no Brasil.

Considera-se a porcentagens de acidentes relacionados a chuveiros em $22 \%$, a média de chuveiros por residência no sudeste em 1,1, o número de residências igual a 220.407 e o total de chuveiros no Brasil igual 19 milhões, segundo (FAPEMIG, 2010).

Desta forma, o calculo do potencial de redução de fatalidades por acidentes relacionados ao chuveiro elétrico resulta em 0,75 mortes. 


\subsubsection{Alteração de conforto}

Os coletores solares não provocam alterações de conforto sonoro ou olfativo, somente o subatributo visual/estético sofrerá alterações em algumas situações. Caso o coletor solar seja instalado em uma casa já construída, o coletor deverá ser adaptado ao telhado de acordo com a melhor inclinação em termos de captação de luz solar e evitar destoar da arquitetura original da casa.

Para alguns casos de desempenho diferenciado de instalações, por conta da capacidade do reservatório e do sistema de apoio de aquecimento, a água do aquecedor solar pode demorar algum tempo até estar em temperatura adequada na saída da ducha, provocando incômodo térmico durante o banho.

\subsubsection{Influência no desenvolvimento}

Uma das características da implantação de uma medida de RELD é o fato de que a economia de energia implica postergação de gastos energéticos. Este efeito pode resultar na transferência de recursos economizados a outros setores econômicos ou sociais.

Para quantificar a influência no desenvolvimento foram utilizadas as equações abaixo:

CVPC DE (RELD) = Tarifa média x Pot (RELD) (68)

$\Delta$ CVPC DE $($ RELD) $=$ CVPC DE (RELD)/PIBlocal (69)

Onde:

CVPC DE (RELD): Cômputo e valoração de desenvolvimento econômico de RELD (R\$);

$\triangle$ CVPC DE (RELD): Variação de cômputo e valoração de desenvolvimento econômico de RELO (\%).

Considerando a economia de energia nos coletores solares de 93.963,91 MWh por ano e a tarifa média de energia elétrica para o setor residencial na RAA em $\mathrm{R} \$ 0,384 / \mathrm{kWh}$, obtém-se um valor total economizado de $\mathrm{R} \$ 36.082 .142$.

Tendo em vista um PIB regional de $\mathrm{R} \$ 11$ bilhões no ano de 2008 , tem-se que o recurso é capaz de contribuir potencialmente para uma variação de 0,33\% neste valor.

A variação da valoração de desenvolvimento humano é calculado pela seguinte fórmula: 
Onde:

$\triangle$ CVPC DH (RELD): Cômputo e valoração de desenvolvimento econômico de RELD (R\$);

Como a variação do PIB representa um terço no calculo de IDH, tem-se que a variação positiva do IDH seria de $0,11 \%$. O recurso também geraria renda através do salário dos trabalhadores; no entanto, esse valor não foi considerado em função do número de empregos gerados pelo recurso.

\subsection{Substituição de Lâmpada Incandescente por Lâmpadas Fluorescente Compactas}

No Brasil, segundo dados do PROCEL, o consumo de energia elétrica de lâmpadas no setor residencial para a região Sudeste é de 19\%. Essa porcentagem coloca a iluminação como terceiro uso final de maior uso de energia elétrica no setor residencial, o que justifica a escolha de tal medida para este estudo de caso.

O exercício propõe a substituição de lâmpadas incandescentes por lâmpada fluorescente compactas com reator integrado, utilizando a metodologia discutida anteriormente.

\subsubsection{Dimensão Técnico-Econômica}

A valoração da dimensão técnico-econômica para recursos energéticos do lado da demanda concentra-se em atributos voltados aos cálculos de economia de energia e redução de demanda, trabalhados por meio de metodologias conhecidas.

\subsubsection{Redução de Demanda na Ponta}

O cálculo da Redução de Demanda na Ponta (RDP), em kW, é dado pela fórmula abaixo:

$\mathrm{RDP}=\left[\left(\mathrm{NL}_{1} \times \mathrm{PL}_{1}+\mathrm{NR}_{1} \times \mathrm{PR}_{1}\right)-\left(\mathrm{NL}_{2} \times \mathrm{PL}_{2}+\mathrm{NR}_{1} \times \mathrm{PR}_{2}\right)\right] \times \mathrm{FCP} \times 10^{-3}$

Onde: 
Onde:

NL1: quantidade de lâmpadas do sistema existente;

NL2: quantidade de lâmpadas do sistema proposto;

PL1: potência da lâmpada do sistema existente (W);

PL2: potência da lâmpada do sistema proposto (W);

NR1: quantidade de reatores do sistema existente;

NR2: quantidade de reatores do sistema proposto;

PR1: potência do reator do sistema existente $(W)$;

PR2: potência do reator do sistema proposto (W);

FCP: Fator de Coincidência na Ponta a ser definido pela concessionária (adimensional).

O cálculo da Redução de Demanda na Ponta (RDP) faz algumas considerações:

- segundo dados do Sistema de Informações de Posses de Eletrodomésticos e Hábitos de Consumo (SINPHA), a média de lâmpadas por domicílio na região sudeste é igual a 8,79 (PROCEL, 2007);

- de acordo com a Fundação Sistema Estadual de Análise de Dados (SEADE), a população de Araçatuba é de 727.342 habitantes (IBGE, 2006).

Logo, estima-se o número de domicílios na RAA em cerca de 220.407 e, consequentemente, o número de lâmpadas na RAA em 1.937.377. A tabela abaixo, elaborada pelo SINPHA - Sistema de Informação de Posses e Hábitos de Uso de Aparelhos Elétricos (PROCEL, 2007), mostra a distribuição de lâmpadas por tipo e potência na região Sudeste do Brasil.

Tabela 29: Distribuição de lâmpadas por tipo na região sudeste

\begin{tabular}{|c|c|c|c|c|c|c|c|c|c|c|c|}
\hline $\begin{array}{c}25 \mathrm{~W} \\
\text { Inc. }\end{array}$ & $\begin{array}{c}40 \mathrm{~W} \\
\text { Inc. }\end{array}$ & $\begin{array}{c}60 \mathrm{~W} \\
\text { Inc. }\end{array}$ & $\begin{array}{c}100 \mathrm{~W} \\
\text { Inc. }\end{array}$ & $\begin{array}{c}150 \mathrm{~W} \\
\text { Inc. }\end{array}$ & $\begin{array}{c}200 \mathrm{~W} \\
\text { Fluor. } \\
\text { Tubular }\end{array}$ & $\begin{array}{c}40 \mathrm{~W} \\
\text { Fluor. } \\
\text { Tubular }\end{array}$ & $\begin{array}{c}\text { Fluor. } \\
\text { Comp. } \\
\text { Até15w }\end{array}$ & $\begin{array}{c}\text { Fluor. } \\
\text { Comp. } \\
>15 \mathrm{w}\end{array}$ & $\begin{array}{c}\text { Fluor. } \\
\text { Circular }\end{array}$ & Dicróica & Outro \\
\hline $0,8 \%$ & $4,13 \%$ & $46,11 \%$ & $9,53 \%$ & $0,36 \%$ & $5,48 \%$ & $6,36 \%$ & $11,45 \%$ & $12,83 \%$ & $1,87 \%$ & $0,78 \%$ & $0,28 \%$ \\
\hline
\end{tabular}

Fonte: SINPHA, 2005

Para a realização das estimativas, adotou-se como $\mathrm{PL}_{1}$ a lâmpada incandescente de $60 \mathrm{~W}$ que, como mostra a tabela acima, é a mais utilizada no setor residencial. Já a soma da $\mathrm{PL}_{2}$ com $\mathrm{PR}_{2}$ adotada é a fluorescente compacta de $15 \mathrm{~W}$, em função da sua larga representatividade. A parcela de utilização de 
lâmpadas incandescentes no setor residencial é indicada no estudo em 46,11\% do total. Portanto, o número de lâmpadas do sistema $\left(\mathrm{NL}_{1}\right)$ é igual a 893.324.

Uma vez que o objetivo do RELD é substituir lâmpadas incandescentes por fluorescentes e não diminuir o seu número, considerou-se $\mathrm{NL}_{2}$ igual a $\mathrm{NL}_{1}$. $\mathrm{PR}_{1}$ será igual a zero por não possuir reator. $\mathrm{O}$ fator de coincidência na ponta utilizado foi de 0,7 (CEB, 2006).

O valor de redução de demanda na ponta (RDP) resulta em 28.139,71 kW.

\subsubsection{Energia Economizada}

O cálculo da Energia Economizada (EE), em MWh por ano, é dado pela fórmula abaixo:

$\mathrm{EE}=\left[\left(\mathrm{NL}_{1} \times \mathrm{PL}_{1}+\mathrm{NR}_{1} \times \mathrm{PR}_{1}\right)-\left(\mathrm{NL}_{2} \times \mathrm{PL}_{2}+\mathrm{NR}_{1} \times \mathrm{PR}_{2}\right)\right] \times \mathrm{t} \times 10^{-6}(\mathrm{MWh} / \mathrm{ano})(79)$

Onde:

NL1: quantidade de lâmpadas do sistema existente;

NL2: quantidade de lâmpadas do sistema proposto;

PL1: potência da lâmpada do sistema existente (W);

PL2: potência da lâmpada do sistema proposto (W);

NR1: quantidade de reatores do sistema existente;

NR2: quantidade de reatores do sistema proposto;

PR1: potência do reator do sistema existente (W);

PR2: potência do reator do sistema proposto (W);

t: tempo de utilização das lâmpadas no ano (horas).

Para as variáveis NL1, NL2, PL1, PL2, NR1, NR2, PR1, PR2, adotou-se os mesmos critérios estabelecidos para o cálculo de RDP. O tempo de utilização de lâmpadas (t) considerado é de 5 horas diárias, o mesmo utilizado pela EPE (EPE, 2010), totalizando 1.825 horas anuais de utilização.

Assim, a Energia Economizada com a aplicação do RELD será de 73.364,23 MWh/ano.

\subsubsection{Investimento Total}

O investimento total é calculado por meio da soma do investimento no equipamento (le) e do Investimento da instalação (lins) multiplicado pelo número de residências atendidas (NR), de acordo com as seguintes equações:

I Unit =I Eq+I Ins (85) 
CVPC ITot (RELD) = I Unit x NR

Onde:

I Unit: Investimento unitário $(\mathrm{R} \$)$;

I Eq: Investimento em equipamento (R\$);

I Ins: Investimento na instalação $(\mathrm{R} \$)$;

NR: Número de residências;

CVPC ITot (RELD): Investimento total (R\$).

Considerando-se que não se identificam custos de instalação para este RELD, a partir do momento em que o próprio consumidor pode instalar as lâmpadas, o cálculo de investimento total restringe-se à quantidade de lâmpadas substituídas. Estipula-se o custo médio de uma lâmpada em $R \$ 15,00$; assim, para uma quantidade potencial de 893.324 lâmpadas substituídas, obtém-se 0 investimento total de $\mathrm{R} \$ 13.399 .860,00$.

\subsubsection{Tempo de Implantação}

O mercado brasileiro de lâmpadas fluorescentes compactas é capaz de suprir a demanda necessária para aplicação desse recurso com relativa facilidade em função da sua produção anual. Assim, ponderou-se que, caso o tempo de implantação supere um ano, o projeto seria inviabilizado economicamente, uma vez que o custo de implementação superaria o valor da energia evitada.

Assim, o ponto ótimo dessa análise de tempo de implantação do recurso foi estabelecido em 6 meses.

\subsubsection{Custo da Energia Economizada}

A receita bruta é obtida pelo cálculo do Custo da Energia Conservada (CEC) de acordo com a equação abaixo:

$\mathrm{CEC}=(\mathrm{I} \mathrm{Tot} / \Delta \mathrm{E}) \times \mathrm{FRC}(76)$

Onde:

CEC: custo da energia conservada $(\mathrm{R} \$ / \mathrm{kWh})$;

I Tot: investimento total do RELD ( $R \$)$;

$\triangle \mathrm{E}$ : energia economizada pela implementação do RELD em relação a um caso base (kWh);

$n$ : a vida útil do RELD (anos);

d: a taxa de desconto em base anual, equiparada ao INCC (IBGE, 2005) (adimensional). 
Conforme verificado anteriormente, o Investimento total do RELD é de $\mathrm{R} \$$ 13.399.860,00 e a Energia Economizada é igual a $73.364 \mathrm{MWh} /$ ano. A vida útil (n) das lâmpadas fluorescentes compactas é de 8.000 horas, ou 4 anos, para uma utilização anual, e a taxa de desconto adotada é de $8 \%$ conforme indicação do Manual para elaboração do Programa de Eficiência Energética da ANEEL.

A aplicação dos dados na fórmula produz um custo de energia economizada de $\mathrm{R} \$ 55 / \mathrm{MWh}$.

\subsubsection{Custo de Operação \& Manutenção}

O custo de Operação \& Manutenção é fixado em 2\% do investimento total, resultando no montante de $\mathrm{R} \$ 267.997,00$.

\subsubsection{7. Índice de Nacionalização}

O mercado de lâmpadas fluorescentes brasileiros conta tanto com equipamentos importados quanto nacionais. Para este recurso, optou-se por considerar a utilização de tecnologia nacional e considera-se, portanto, um índice de nacionalização de $100 \%$ dos equipamentos.

\subsubsection{Fator de Recuperação de Capital}

Considerando que RELDs contam com financiamento a juros constantes, dispensou-se o uso da metodologia de fluxo de caixa descontado neste exercício. Assim, utiliza-se o cálculo do Fator de recuperação de capital, estimado pela fórmula abaixo:

$$
\begin{aligned}
& F \\
& \text { Ende: }
\end{aligned}
$$

n: vida útil lâmpada;

i: taxa de rendimento anual.

No caso estudado, a vida útil será de 4 anos e a taxa de rendimento anual de $8 \%$, totalizando um FRC de 0,0864 ou $8,64 \%$.

\subsubsection{Custo da Demanda Evitada}


O custo da demanda evitada, em $\mathrm{R} \$$ por $\mathrm{kW}$ anuais, para lâmpadas é calculado de forma análoga ao custo do coletor solar pela fórmula de Custo da Demanda Evitada.

As variáveis do custo evitado da demanda para lâmpadas fluorescentes apresentam os mesmos valores utilizados anteriormente para coletor solar, já que o recurso em questão será aplicado na mesma região.

O CED para substituição de lâmpadas é, portanto, $R \$ 435,39 / \mathrm{kW}$.ano.

\subsubsection{Qualidade de Energia}

Conforme mencionado no item 5.7.9.2, dentre os efeitos da substituição de lâmpadas incandescentes por lâmpadas fluorescentes compactas à qualidade de energia, figuram: i) a introdução de níveis substanciais de harmônicos nos sistema de distribuição secundária e a diminuição do fator de potência e ii) a geração de harmônicos de corrente e aumento da corrente de neutro em sistemas trifásicos por conta da distorção da forma de onda de causada por reatores eletrônicos.

Em função da falta de medições de campo a fim de atestar a variação deste parâmetro, optou-se por não valorar quantitativamente este atributo.

\subsubsection{Dimensão Política}

A valoração dos atributos da dimensão política vale-se essencialmente de análises qualitativas para mensurar $o$ potencial de implementação $e$ aproveitamento de recursos. No campo do gerenciamento do lado da demanda, os fatores preponderantes concentram-se na avaliação de políticas de incentivo e na ponderação de balanço e interação entre atores do setor. A posse e a propriedade de recursos são entendidas como questões tecnológicas e não são avaliadas para RELDs.

\subsubsection{Instrumentos Políticos}

As lâmpadas fluorescentes compactas, até meados de 2000, apresentavam custo alto e baixa disponibilidade no mercado brasileiro. Porém, o período de racionamento de eletricidade, ocorrido no país entre 2001 e 2002, possibilitou a difusão dessa tecnologia como uma alternativa de economia em 
substituição às lâmpadas incandescentes. A troca voluntária desses equipamentos por consumidores dos setores residencial, comercial, industrial e público foi impulsionada devido à obrigatoriedade de redução de consumo, com sobretaxas aos que não atendessem a medida estabelecida pelo governo da época, o que contribuiu para a sua rápida popularização e consequente queda de preço.

A Lei $n^{\circ}$ 10.295, conhecida como "Lei da eficiência energética", regulamentou índices mínimos de eficiência para lâmpadas fluorescentes compactas; a elaboração desses índices considerou os valores do Programa Nacional de Etiquetagem e do Selo PROCEL (LEONELLI, 2009).

Desde o ano 2002, o governo federal editou os decretos 4544 e 4542 , isentando as lâmpadas fluorescentes da taxa de 15\% de Imposto sobre Produtos Industrializados (IPI) (BRASIL, 2006).

Propostas legislativas de banimento de lâmpadas incandescentes, adotada em diversos países do mundo e também aprovada na Argentina, foram estudadas nos últimos anos, resultando na previsão da redução progressiva da fabricação de lâmpadas incandescentes no Brasil, até o ano de 2016.

\subsubsection{Envolvidos e Interessados}

A primeira etapa da valoração de Envolvidos e Interessados refere-se ao mapeamento de suas funções, interesses e motivações. No caso deste RELD, o maior obstáculo à implementação do recurso é, antes da oposição de grupos ou atores políticos, a indiferença de parte da sociedade ou o baixo perfil de atuação de outros atores.

Como exemplo de percepção destes grupos, citam-se o apoio da população em geral e da sociedade civil. A população é favorável ao recurso uma vez que a economia de energia obtida compensa o investimento realizado. Entretanto, pesam contra a iniciativa da substituição de lâmpadas barreiras culturais e educativas. Organizações não governamentais são favoráveis ao recurso em virtude da eficiência superior da tecnologia e de seu consumo inferior em relação às lâmpadas incandescentes. Cabe ressaltar, no entanto, que esse setor defende medidas de eficiência baseadas na substituição de lâmpadas na condição de que elas sejam acompanhadas do descarte adequado dessa tecnologia após sua vida útil. 
A seguir, o posicionamento mais detalhado dos principais atores é comentado.

Governo Federal: Ainda que o governo possa beneficiar-se de resultados dessa medida, como a diminuição da demanda de energia e a consequente redução ou postergação de investimentos do setor elétrico, a falta de iniciativa em aprovar legislação favorável às lâmpadas fluorescentes denota pouco interesse deste ator em relação ao recurso.

Fabricantes: Este setor é obviamente favorável à tecnologia com a qual está vinculado. A produção de lâmpadas incandescentes ainda é defendida por seus fabricantes no Brasil, ao passo que muitas indústrias modificaram seu perfil de fabricação para atender ao crescente mercado de lâmpadas fluorescentes. Dentre esses exemplos estão a General Eletric (GE) e a Phillips, que fecharam suas fábricas de lâmpadas incandescentes em 2010, como parte do seu esforço em investir em tecnologias eficientes.

Distribuidoras: A utilização de lâmpadas fluorescentes compactas diminuirá o consumo de energia elétrica, o que acarretará a diminuição da receita das distribuidoras. Elas, porém, posicionam-se de forma neutra em relação ao recurso, uma vez que uma posição contrária prejudicaria sua imagem frente à sociedade.

ONGs: As ONGs apóiam o recurso, considerando a economia de energia que pode, potencialmente, evitar futuros impactos socioambientais da construção de novas usinas. Este apoio é condicionado à garantia de condições de descarte de equipamentos utilizados, como forma de minimizar potenciais impactos ao meioambiente.

População: A população apóia a aplicação do recurso em função de benefício econômico uma vez que a economia de energia resultará em diminuição na conta de eletricidade. Entretanto essa leitura não é feita homogeneamente por todas as classes econômicas; o custo inicial mais alto de lâmpadas fluorescentes e a grande disponibilidade de incandescentes no mercado ainda favorece o consumo dessa última tecnologia. 
Interesses Conflitantes: $O$ único interesse conflitante é o dos fabricantes de lâmpadas incandescentes. Ainda que grandes fabricantes dessas tecnologias no Brasil tenham fechado suas fábricas de lâmpadas incandescentes em 2010, como parte do seu esforço em investir em tecnologias eficientes, parte da produção nacional de lâmpadas ainda é representada pelas incandescentes.

\subsubsection{Dimensão Ambiental}

A valoração da dimensão ambiental para os recursos do lado da demanda aborda essencialmente a potencial redução de impactos aos meios aéreo, aquático e ao solo em decorrência da aplicação de medidas de eficiência energética.

\subsubsection{Emissão de G.E.E.}

O cálculo da emissão de gases de efeito estufa para RELDs segue a equação:

V Em (RELD)= F Em (RELD) x Pot(RELD) - F Em(base) $x$ Pot(RELO) (46)

Tomando como base a matriz elétrica da RAA, é possível estimar a produção média de 85,33 g. $\mathrm{CO}_{2} / \mathrm{kWh}$ em decorrência da geração de eletricidade local, utilizando-se a equação abaixo:

$F($ base $)=\sum($ P\%(RELO) $\times$ F Em (RELO) $)$

Considerando a emissão de gases de efeito estufa derivados do recurso igual a zero, a emissão de gases apresenta apenas parcela negativa, por conta de sua redução de consumo. Assim, a energia economizada de 73.364.000 kWh/ano resulta em $6.260,15$ toneladas de $\mathrm{CO}_{2}$ evitados.

\subsubsection{Qualidade da água}

O recurso não utiliza água, no entanto caso o descarte da lâmpada após sua vida útil seja feito de modo incorreto há um grande potencial de poluição da água com mercúrio. Desta forma, em função da falta de dados consistentes acerca deste atributo, optou-se por manter a avaliação qualitativa. 


\subsubsection{Produção de Resíduos Sólidos}

De acordo com a Associação Nacional de Conservação da Natureza (QUERCUS), existem, no mínimo, onze substâncias nas lâmpadas fluorescentes com potencial prejudicial à saúde humana. São eles: mercúrio, antimônio, bário, chumbo, cádmio, índio, sódio, estrôncio, vanádio, ítrio e tálio.

De acordo com o IBGE (2002), 47,1\% de todo o lixo no Brasil é destinado a aterros sanitários, $22,3 \%$ a aterros controlados e $30,5 \%$ a lixões. No que diz respeito ao lixo industrial, 70\% acaba em lugares inapropriados (FURTADO, 2006, apud POLANCO, 2007).

De posse desses dados, é possível perceber que grande parte das lâmpadas fluorescentes compactas será descartada de forma inapropriada, contribuindo para a poluição do solo e das águas ${ }^{176}$.

A equação abaixo, utilizada para o cômputo de resíduos sólidos de RELDs, quantifica o potencial de mercúrio disponível no montante total de lâmpadas fluorescentes utilizáveis na região de Araçatuba. Segundo POLANCO (2007), sua concentração por lâmpada é em média 4mg.

\section{CVPC Res $($ RELD) $=$ FR (RELD) $\times$ Pot (RELD) (100)}

Onde:

CVPC Res(RELD): cômputo e valoração de resíduos sólidos de RELD ( em kg); FR(RELD): fator de produção de resíduos sólidos de RELD ( em kg/MWh); Pot (RELD): energia economizada por RELD (em MWh).

Substitui-se o fator de resíduos pela divisão entre o Fator da Produção de Mercúrio (FPHg) e o potencial de redução de consumo do recurso, resultando na equação:

CVPC Res(RELD) $=$ FPHg $/($ Pot(RELD) $\times$ NL) $\times$ Pot(RELD) $=$ FPHg $\times$ NL (55)

\footnotetext{
176 Para reverter essa situação, é necessário criar uma política federal especifica para lâmpadas fluorescentes, regulamentada por lei, que seja devidamente fiscalizada. O Estado de São Paulo possui a Lei $\mathrm{n}^{\circ} 12.300$, de 16 de março 2006, que responsabiliza o fabricante, distribuidor e importador do produto, pelos resíduos gerados de significativo impacto ambiental incluindo o pósconsumo, eliminação, recolhimento, tratamento e disposição final de tais produtos. A Lei Estadual Paulista $n^{\circ} 10.888$, de 20 de setembro de 2001, determina a responsabilidade do fabricante pela descontaminação e destinação final das lâmpadas fluorescentes.
} 
Tendo em vista que a energia economizada na região de $73.364,23$ MWh/ano implica na substituição de 893.324 lâmpadas incandescentes por lâmpadas fluorescentes compactas, o cômputo desse atributo produz de forma cumulativa, ao longo dessa substituição, $3,57 \mathrm{Kg}$ de mercúrio.

\subsubsection{Ocupação de Espaço}

A substituição de lâmpadas incandescentes por fluorescentes compactas não produz uma diferença de ocupação de espaço relevante já que as lâmpadas serão substituídas, assim, para esse subatributo, pode-se considerar a ocupação de espaço como nula.

\subsubsection{Dimensão Social}

A valoração da dimensão social trabalha parâmetros relacionados ao bem estar da sociedade e do indivíduo, ao lado de fatores socioeconômicos como geração de emprego e desenvolvimento de infraestrutura.

\subsubsection{Geração de empregos}

Segundo (ATHERSON \& RUTOVITZ, 2009), a comparação entre fatores de geração de empregos derivados de medidas de eficiência energética para 0 setor residencial aponta resultados diversos, como 0,19 empregos/GWh na Austrália ou 0,60 empregos/GWh na Alemanha.

Uma vez que a energia economizada para esse recurso é de 73.364 MWh/ano, é possível estimar o número de empregos levando em consideração o pior caso e o caso ótimo. Para tanto, utilizou-se a equação abaixo:

\section{CVPC Emp $=$ Pot (RELD) $\times$ F Emp (RELD) (58)}

Utilizando a equação e os dados mencionados acima, produz-se o resultado de 14 empregos por ano para o pior caso e 44 empregos por ano para o caso ótimo. É importante destacar que a geração de empregos é anual, portanto mais empregos serão gerados durante a vida útil do recurso.

\subsubsection{Impactos à saúde humana}

Das onze substâncias potencialmente prejudiciais à saúde humana e ao meio ambiente presentes nas lâmpadas fluorescentes, o mercúrio é de maior 
potencial danoso em função de sua concentração. Segundo POLANCO (2007), sua concentração por lâmpada é em média $4 \mathrm{mg}$. O volume de mercúrio produzido com o descarte de lâmpadas fluorescentes foi calculado no item 6.4.3.3. No entanto, em função da falta de disponibilidade de funções doseresposta locais que associem a concentração da substância à índices de morbidade e/ou mortalidade, optou-se por não estimar diretamente o impacto do uso de lâmpadas fluorescentes à saúde humana.

\subsubsection{Alteração de conforto}

A valoração da alteração de conforto para este RELD avalia parâmetros relacionados a conforto luminoso e térmico.

A eficiência mínima para uma lâmpada de $15 \mathrm{~W}$ é de 50 lumens/watt (INMETRO, 2006), que corresponde a 750 lux. Este patamar se enquadra na classe B de iluminância por classes de tarefas visuais, recomendada para atividades com requisitos visuais normais, como trabalho médio de maquinaria ou escritórios (ABNT, 1992).

Em relação ao conforto térmico, por não serem resistivas, as lâmpadas fluorescentes compactas não emitem calor, contribuindo para a manutenção da temperatura de recintos, ao contrario de lâmpadas incandescentes que influenciam o aumento da temperatura do ambiente.

A produção de lâmpadas fluorescentes compactas concentra-se fora da RAA; assim, o desenvolvimento econômico e social oriundos da aplicação do recurso não seriam sentidos localmente. Outro ponto importante é que não é possível afirmar que essas melhorias são provenientes exclusivamente pela aplicação do recurso e não por um avanço tecnológico natural de mercado, o que dificulta a quantificação desse atributo.

\subsubsection{Influência no desenvolvimento local}

Diferentemente da valoração deste atributo para os RELOs, neste caso a economia de energia gerada pela aplicação de medidas de eficiência, ao invés de gerar capital, evita o seu gasto e possibilita que o montante seja reinvestido em outro setor.

Desta forma, presume-se, teoricamente, que a economia de energia, e consequentemente, de recursos financeiros, possa ser destinada a outro setor. 
Utilizou-se, portanto, a equação abaixo para a quantificação da influência do desenvolvimento em função do RELD:

CVPC Des(RELD)=Tarifa media x Pot (RELD) (68)

$\Delta$ CVPC DE (RELD) $=$ CVPC DE (RELD)/PIBlocal (69)

Onde:

CVPC DE (RELD): Cômputo e valoração de desenvolvimento econômico de RELDs (R\$);

$\triangle$ CVPC DE (RELD): Variação de cômputo e valoração de desenvolvimento econômico de RELD (\%).

A economia de energia de 73.364,23 MWh.ano de lâmpadas fluorescentes e a tarifa média de energia elétrica de $R \$ 0,384 / \mathrm{kWh}$ para o setor residencial, resultam em um valor economizado de $R \$ 2$ 27.925.178. Considerando o PIB regional em $R \$ 11$ bilhões no ano de 2008 , tem-se que o recurso é capaz de contribuir potencialmente para uma variação de $0,25 \%$ neste valor.

Analogamente à valoração dos demais recursos, a variação do desenvolvimento humano incorpora a variação do PIB em 1/3, resultando na variação positiva de $0,084 \%$ do IDH. 


\subsection{Resultados do Estudo de Caso}

O estudo de caso procurou validar o modelo de algoritmos para o cálculo e a valoração de potenciais completos de recursos energéticos dos lados da oferta e da demanda. A opção por experimentar a metodologia para dois recursos energéticos de cada lado (pequenas centrais hidrelétricas e sistemas de cogeração a biomassa, para a oferta de energia, e medidas de substituição de lâmpadas incandescentes por fluorescentes compactas e substituição de duchas elétricas por sistemas baseados em aquecimento solar de água, representando o lado da demanda) teve a intenção de utilizar os algoritmos de valoração em características comuns às quatro dimensões de análise e, ao mesmo tempo, inerentes a cada recurso.

Neste sentido, considera-se que o Estudo de Caso mostrou-se bem sucedido, por tratar, do lado da oferta, recursos baseados em fontes renováveis, mas de características diferentes quanto ao uso de energéticos, capacidade instalada de empreendimentos, arcabouço regulatório e impactos ambientais diversos. Do lado da demanda pode-se dizer o mesmo; avaliou-se recursos baseados em diferentes naturezas de medidas - ainda que aplicados ao mesmo setor residencial-, com rentabilidades e viabilidades econômicas distintas e amparo político e legal diferenciado.

Todos os recursos foram escolhidos por apresentarem potenciais de implantação e utilização bastante positivos na Região de Araçatuba. Dentro desse cenário, as maiores possibilidades de implantação, em termos gerais, apontam para a cogeração a bagaço de cana (do lado da oferta) e de sistemas de aquecimento solar (do lado da demanda), a despeito de seus custos econômicos mais elevados em comparação aos outros recursos estudados.

$\mathrm{Na}$ área técnico-econômica, analisando-se custo e potencial energético, aponta-se novamente a cogeração a biomassa como opção do lado da oferta e a substituição de lâmpadas como opção do lado da demanda, considerando, além de seus potenciais energéticos, a relação de custo e tempo de implantação. Segue a matriz da dimensão técnico-econômica para os recursos analisados. 
Tabela 30: Matriz da Dimensão Técnico-Econômica (DTE)

$\left[\begin{array}{c}\text { Atributo / Re curso } \\ \text { PCHs } \\ \text { Cog.Biomassa } \\ \text { Aq. Solar } \\ \text { Subst. Lâmpadas }\end{array}\right]=\left[\begin{array}{llcccc}\text { CUG } & \text { IN } & \text { Qual.En. } & \text { Conf. } & \text { Fac.Tec. } & \text { Pot.En. } \\ 148,22(\mathrm{R} \$ / M W h) & 100(\%) & 0 & 0,57(\%) & 2(\text { anos) } & 397,73(\mathrm{MW}) \\ 151,20(\mathrm{R} \$ / \mathrm{MWh}) & 100(\%) & 0 & 0,37(\%) & 1(\mathrm{ano}) & 2.146,06(\mathrm{MW}) \\ 819,77(\mathrm{R} \$ / \mathrm{MWh}) & 100(\%) & 0 & 0,10(\%) & 1(\text { ano }) & 88,49(\mathrm{MW}) \\ 55,15(\mathrm{R} \$ / \mathrm{MWh}) & 100(\%) & \Delta \text { THD } & - & 0,5(\mathrm{ano}) & 73,36(\mathrm{MW}\end{array}\right]$

A dimensão ambiental aponta novamente para vantagem de usinas de cogeração a biomassa nos atributos de impactos ao solo (ocupação), por um lado, e desvantagem em termos de emissões de gases de efeito estufa e uso de água. Em relação às emissões aéreas, cabe ressaltar que seu efeito se minimiza se computada a redução de passivos ambientais decorrentes do uso da palha e do bagaço de cana para a geração de eletricidade, bem como a reabsorção, na safra seguinte, do $\mathrm{CO} 2$ emitido. Do lado da demanda, verificam-se maiores impactos em termos de uso de água e ocupação de espaço na implantação de aquecedores solares; deve-se ressaltar, no entanto, que ambos os impactos são relativos - a ocupação espacial ocorre nos telhados de edificações, sem qualquer prejuízo sobre outras atividades sociais ou econômicas - e o aumento de vazão decorrente do uso desses sistemas pode ser contornado com projetos e equipamentos adequados.

Tabela 31: Matriz da Dimensão Ambiental (DA)

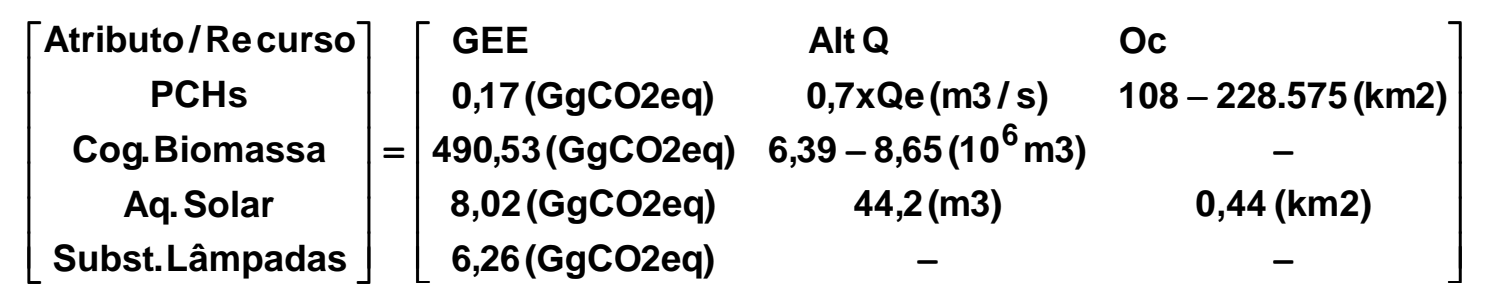

$\mathrm{Na}$ área social, a atividade de cogeração a biomassa aponta para uma maior geração de empregos e para uma maior contribuição de desenvolvimento econômico (medido pela variação do PIB) e humano (pela subsequente variação positiva do IDH). Do lado da demanda, a implantação de aquecedores solares produziu melhores resultados em termos de geração de empregos $\mathrm{e}$ desenvolvimento econômico e humano. A avaliação de impactos a saúde foi 
prejudicada pela falta de dados locais capazes de ligar fatores ambientais à índices de morbidade e/ou mortalidade.

Tabela 32: Matriz da Dimensão Social (DS)

$\left[\begin{array}{c}\text { Atributo / Re curso } \\ \text { PCHs } \\ \text { Cog. Biomassa } \\ \text { Aq. Solar } \\ \text { Subst. Lâmpadas }\end{array}\right]=\left[\begin{array}{cclcc}\text { Empregos } & \text { Desloc. Pop } & \text { Des.Econ / Hum. } & \text { Alt.Conf. } & \text { Saúde } \\ 4.582-10.082(E m p) & 14.199 \text { (pessoas) } & 0,17 \text { PIB / 0,06 IDH(\%) } & 5,5-7,7 \text { (\%dBA) } & - \\ 15.666-36.483(E m p) & - & 5,69 \mathrm{PIB} / 1,89 \text { IDH(\%) } & - & - \\ 4.867(E m p) & - & 0,39 \mathrm{PIB} / 0,13 \mathrm{IDH}(\%) & - & 0,75 \\ 14-44(E m p) & - & 0,25 \mathrm{PIB} / 0,08 \mathrm{IDH}(\%) & - & -\end{array}\right]$

Na dimensão política, verificou-se a baixa competitividade dos recursos de oferta analisados em relação aos mecanismos vigentes de contratação e comercialização de energia - ambos tiveram custos médios de geração superiores aos preços-teto oferecidos nos últimos leilões de energia. Quanto ao lado da demanda, ainda que a legislação municipal seja numericamente favorável a sistemas de aquecimento solar, a substituição de lâmpadas ganhou portaria recente do Ministério de Minas e Energia, prevendo a redução paulatina da iluminação incandescente no mercado até 2016. Em termos de posicionamento de En-In, pequenas centrais hidrelétricas e sistemas de cogeração a biomassa apresentam cenários políticos equilibrados entre agentes favoráveis e desfavoráveis aos recursos. A análise de poder não foi realizada para RELDs.

Tabela 33: Matriz da Dimensão Política (DP)

\begin{tabular}{|c|c|c|c|}
\hline Atributo/Recurso & [Instr.Políticos & Posse / Pr op. & En - In \\
\hline $\begin{array}{c}\text { PCHs } \\
\text { Cog.Biomassa }\end{array}$ & $=\begin{array}{c}-6,28(R \$ / M W h) \\
-10,30(R \$ / M W h)\end{array}$ & $\begin{array}{l}\text { Re gional / União } \\
\text { Re gional / Privado }\end{array}$ & $\begin{array}{l}\text { Qualitativo } \\
\text { Qualitativo }\end{array}$ \\
\hline Aq. Solar & 28(Leis Munic.) & - & Qualitativo \\
\hline Subst.Lâmpadas & 1(LeiFederal) & - & Qualitativo \\
\hline
\end{tabular}

Os resultados completos da valoração são mostrados nas tabelas do Anexo 1.

Como limitação do exercício, aponta-se a dificuldade de aplicação de algumas das equações propostas pelos algoritmos de CVPC, por conta da disponibilidade de dados heterogêneos, algumas vezes não compatíveis com as formulações propostas, demandando adaptações de contabilização ou resultando 
na impossibilidade de cálculo, em outros casos. No caso da valoração de potenciais energéticos da biomassa, ao contrário do que o equacionamento inicial apontava, optou-se por utilizar a massa de cana produzida localmente como base de alguns cálculos, em detrimento do potencial energético teórico desse recurso. Já no caso da avaliação de recursos do lado da demanda, o padrão de cômputo e valoração baseado em componentes positivos e negativos - representando não apenas a geração de impactos multidimensionais, mas também sua redução, decorrentes do uso eficiente de energia - não pode ser totalmente empregado, dada a ampla incerteza em relação à estimativa desses efeitos, combinada a fenômenos sociais e econômicos inexatos.

Em outras ocasiões, ainda, foi possível chegar a dados hipotéticos, a partir de iterações que permitiram a estimativa satisfatória de atributos de análise. Este foi o caso de alguns dos parâmetros da dimensão ambiental na valoração de pequenas centrais hidrelétricas, mostrado no anexo 3.

Obviamente, a utilização de mais recursos no Estudo de Caso ampliaria a utilização e a maleabilidade dos algoritmos propostos. De qualquer forma, considerou-se que os resultados alcançados por meio dos recursos energéticos escolhidos permitiu a análise de diferentes condições de valoração relacionadas aos atributos das dimensões de análise. 


\section{Considerações e Conclusões}

Nos capítulos anteriores, foram apresentadas as metodologias de cômputo e valoração completa de recursos energéticos, exemplificadas em algoritmos nas quatro dimensões de análise, aplicáveis a recursos energéticos dos lados da oferta e demanda. O processo de cômputo e valoração de recursos energéticos buscou amadurecer as pesquisas do PIR na USP no campo da quantificação de atributos multidimensionais, antes restrita em muitos casos a uma análise qualitativa, estabelecida dentro de sistemas de avaliação de custos completos.

A metodologia de CVPC processou, de forma consistente, informações prévias colhidas em campo, oferecendo potenciais e indicadores confiáveis para a avaliação dos En-In no processo de ranqueamento. Além disso, a formulação de potenciais energéticos teóricos constitui a base das etapas de integração de recursos e formação de carteiras no processo de plano preferencial, nas quais esses potenciais são refinados a valores de mercado.

A incorporação de custos de mitigação de impactos ambientais no planejamento energético seguramente favorecem a viabilização de empreendimentos energéticos de baixo grau de interferência ambiental, mesmo que sejam economicamente desfavoráveis. Na prática, ainda que esses custos não integrem a composição das tarifas energéticas, sempre serão pagos pelos envolvidos e interessados nos empreendimentos, seja pelo empreendedor considerado o poluidor em questão -, ou divididos por toda a sociedade, na forma de impactos e gastos relacionados à saúde pública.

O cômputo e a valoração dos recursos energéticos de oferta e demanda procura caracterizar esses impactos, incluindo esses parâmetros entre os demais atributos técnico-econômicos comumente presentes no planejamento energético. A etapa é essencial para a caracterização e avaliação qualitativa e quantitativa dos recursos energéticos no âmbito do Planejamento Integrado de Recursos. A avaliação das quatro dimensões de análise confere uma perspectiva completa da relação entre cada recurso energético e sua interdependência com os elementos sociais, ambientais, geográficos, políticos e culturais de uma região. As estruturas de análise das dimensões possibilitam o exercício do senso crítico na avaliação da viabilidade de um recurso energético e conferem profundidade a uma avaliação que, tradicionalmente, seria feita de forma unidimensional. 
Os exemplos de algoritmos de valoração para cada uma das dimensões tiveram por intenção mostrar o procedimento lógico da valoração de alguns parâmetros de análise, para recursos do lado da oferta e da demanda. Esses exercícios mostraram a particularidade de formulação de cada um dos algoritmos, que deve sempre ser ponderada de acordo com cada atributo e com as condições locais de limitadores e modificadores desses resultados.

O Estudo de Caso prestou-se a demonstrar, de forma prática, o cálculo dos algoritmos propostos, tomando como aplicação a Região Administrativa de Araçatuba. O exercício indicou, de forma positiva, limitações ao cálculo e valoração dos potenciais completos tanto em termos metodológicos - a delimitação das condições de contorno da CVPC - quanto em termos práticos relacionados à falta de dados locais, em decorrência da desatualização de estatísticas oficiais ou inexistência de exemplos práticos mensurados.

Quanto às condições de contorno do processo de CVPC, o desenvolvimento do trabalho em paralelo ao desenvolvimento do PIR na USP permite o exercício de moldagem de atribuições e responsabilidades de cada etapa do processo de planejamento, de forma a compor uma estrutura integrada e funcional. Assim, o tempo de pesquisa e maturação sobre o tema considerou diversos ensaios de modificações de fatores e rotinas, ora incluídos na CVPC, ora delegados a outras etapas do PIR. Nesse sentido, a metodologia concentrouse no cálculo teórico ou bruto de atributos relacionados a potenciais energéticos. O refinamento desses valores em potenciais realizáveis deve ser alocado à etapa de integração energética, com o auxílio de restrições multidimensionais impostas pelos vigilantes estabelecidos no mapeamento ambiental. Já o refinamento de potenciais específicos, como a interação entre os En-In, pode ser alocado para a etapa de ranqueamento, que apresenta, ainda que de forma indireta, possíveis resultados concretos de suas ações.

A formulação de potenciais de mercado é indicada em alguns atributos das dimensões técnico-econômica e política, mas entende-se que esse cálculo concreto e refinado cabe à etapa de formação de carteiras energéticas.

Ressalta-se novamente que a valoração tem papel fundamental no processo de planejamento integrado de recursos, uma vez que, a partir da base construída pela etapa de caracterização de recursos energéticos, organiza e formata os parâmetros de análise, construindo os limites de valoração de todos 
esses atributos. A conclusão desse processo tende a atualizar e desenvolver a estrutura do PIR na USP e fornecer parâmetros concretos e uniformes à avaliação e ao ranqueamento dos diferentes recursos energéticos do lado da oferta e da demanda, conferindo maior isonomia ao processo de implantação planejada de cada um deles. Acredita-se que esta seja, portanto, a maior contribuição deste trabalho.

Por fim, como possibilidade de próximos passos ao trabalho, sugere-se 0 aprimoramento do cômputo e valoração de recursos em alguns dos atributos das dimensões de análise, especialmente no que se refere à dimensão política, cuja leitura de Envolvidos e Interessados pode receber valorações mais concretas, com base em ferramentas como teoria de jogos ou outras.

A matriz de valoração apresentada nos resultados do estudo de caso ainda deve ser aprimorada e expandida, de modo a abranger subatributos referentes às dimensões de análise e ilustrar a interação de atributos que apresentem análises cruzadas entre as dimensões de análise - como é o caso da valoração do domínio tecnológico de recursos ou da valoração de instrumentos políticos, ambos compartilhados entre atributos das dimensões técnicoeconômica e política.

A programação da CVPC em softwares depende ainda da estruturação e do equacionamento da matriz de valoração em unidades comuns aos atributos integrantes, bem como da formatação desses atributos em valores quantitativos. 


\section{Anexo 1: Tabelas de CVPC}

\section{A.1.1. Dimensão Técnico-Econômica (PCHs)}

Dimensão Técnico-Econômica

\begin{tabular}{|c|c|c|c|}
\hline & Atributos & Resultado & Fórmula \\
\hline 1 & Potência Média por Usina (MW) & 19,2 & Valor médio de mercado \\
\hline 2 & Potencial Bruto (MW) & 397,73 & Potencial Teórico=9,81xHxQxn \\
\hline 3 & Custo de Investimento $(\mathrm{R} \$ / \mathrm{kW})$ & 5.472 & Investimento Total $(\mathrm{R} \$) /$ Potência Instalada(kW) \\
\hline 4 & Investimento Total (R\$) & 105.062 .400 & I=Potência Média x Custo de Investimento \\
\hline 5 & Confiabilidade (F. Capacidade) & 0,57 & CVPC Conf $=$ FC $\times$ FDisponibilidade \\
\hline 6 & Tarifa de Uso de T/D (ICG) (R\$/MWh) & $\mathrm{R} \$ 6,05 \times \mathrm{kW}$.mês & Tarifa Ajustada $=$ TUSDg $\times 50 \%+$ Encargo ICG \\
\hline 7 & Custo O\&M (R\$/MWh) & 12,95 & $\mathrm{CO} \& M=\mathrm{CO} \& M F+\mathrm{CO} \& M V$ \\
\hline 8 & Tempo de Construção (meses) & $18-24$ & Testudos+Tsítio+Tfundação+Tmontagem+Tcomiss.+Ttestes.op \\
\hline 9 & Índice de Nacionalização & $100 \%$ & $\ln =(z / x+z) \times 100$ \\
\hline 10 & Período do Fluxo de Caixa & 30 anos & - \\
\hline 11 & Custo Unitário de Geração ( $\mathbf{R} \mathbf{M W h}$ ) & 148,22 & Metodologia de Fluxo de Caixa Descontado \\
\hline 12 & Qualidade de Energia & - & $\Delta \mathrm{FP}, \Delta \mathrm{TDH}, \Delta \mathrm{TDHi}$ \\
\hline
\end{tabular}




\section{A.1.2. Dimensão Ambiental (PCHs)}

\begin{tabular}{|c|c|c|c|}
\hline & & $\begin{array}{l}\text { Dimensão } \\
\text { Ambiental }\end{array}$ & \\
\hline & Atributos & Resultado & Fórmula \\
\hline 1 & $\begin{array}{r}\text { Valores Base - Hidro } \\
\text { GgCO2 } \\
\text { GgCH4 } \\
\mathrm{MWm}\end{array}$ & $\begin{array}{c}\mathrm{GgCO} 2 \\
1719,14 \\
25,42519 \\
3.331\end{array}$ & Fonte: BEARAA, 2009 \\
\hline 2 & $\begin{array}{l}\text { Emissões Aéreas } \\
\text { (kgCO2) } \\
\text { (kgCH4) } \\
\text { (kgN2O) }\end{array}$ & $\begin{array}{c}1,24 \mathrm{E}+5 \\
1,83 \mathrm{E}+3 \\
0\end{array}$ & V Em $($ RELO)= F Em (RELO)*Pot(MWh) \\
\hline 3 & GEE (kgCO2eq) & $1,68 \mathrm{E}+5$ & $\mathrm{GEE}=24 \times \mathrm{EmCH} 4+\mathrm{CO} 2+310 \times \mathrm{N} 20$ \\
\hline 4 & Alteração de Vazão & $\begin{array}{l}31,26 \\
25,01\end{array}$ & $\begin{array}{l}P=8,2 \times Q \times H \\
Q e=0,7 \times Q\end{array}$ \\
\hline 5 & Qualidade da Água & - & CVPC alt rel.(RELO) $=\mathrm{V}$ alt (RELO)/Vol tot \\
\hline 6 & $\begin{array}{l}\text { Resíduos Sólidos (m3) } \\
\text { FRS }\end{array}$ & $\begin{array}{c}1.630 \\
2.631 \\
0,15\end{array}$ & $\begin{array}{l}\text { CVPC }(\text { RS RELO })=\sum(F R S(R E L O) * A(R E L O) \\
F R S=(E+C+B) \times R \times T E\end{array}$ \\
\hline 7 & $\begin{array}{l}\text { Ocupação de Espaço (km2) } \\
\text { Fator de Área Ocupada (FAO) }\end{array}$ & $\begin{array}{c}107,39 \\
228.575,43 \\
0,27 \\
574,7\end{array}$ & $\begin{array}{l}\text { CVPC Oc=FAO*Pot }(\mathrm{MW}) \\
\mathrm{FAO}=\mathrm{P} / \mathrm{A}=\text { Potência/Área Reservatório }\end{array}$ \\
\hline
\end{tabular}




\section{A.1.3. Dimensão Social (PCHs)}

Dimensão
Social

\begin{tabular}{|c|c|c|c|}
\hline & Atributos & Resultado & Fórmula \\
\hline 2 & $\begin{array}{l}\text { Empregos } \\
\text { Quantidade (emp/MW) } \\
\text { Qualidade (\%) }\end{array}$ & $\begin{array}{c}11,52-25,35 \\
4582- \\
10.082 \\
20 \text { a } 50 \%\end{array}$ & $\begin{array}{l}\text { CVPC Emp }(\text { RELO })=\operatorname{MAX}(\Sigma(\text { FEmp } \\
\left.(\text { relo })^{*}(\% I N)^{*}(\mathrm{MR})^{*} \operatorname{Pot}(\mathrm{MW})\right) \\
\text { CVPC Qual Emp (RELO) }=\mathrm{V}(\text { Emp RELO })>(\mathrm{FS}, \text { Cap, SO, CC })\end{array}$ \\
\hline 3 & $\begin{array}{l}\text { Impactos à Saúde } \\
\text { Mortalidade/Morbidade } \\
\text { FMM }\end{array}$ & $0,17-0,26$ & $\begin{array}{l}\text { CVPC }(\mathrm{MM})=\mathrm{FDR}(\text { relo })^{\star} \mathrm{FMM}^{\star}{ }^{*} \mathrm{Pot}(\mathrm{MW}) \\
\text { FDR }\end{array}$ \\
\hline & $\begin{array}{l}\text { Agricultura (kg/ha) } \\
\text { FAO }\end{array}$ & $600-2.461$ & $\begin{array}{l}\text { CVPC }(\mathrm{Ag})=\mathrm{FAO}{ }^{*} \text { Pot }(\mathrm{MW}){ }^{*} \text { Prod } . \mathrm{Ag} .+\mathrm{FAG}{ }^{*} \operatorname{Pot}(\mathrm{MW}){ }^{*} \text { Prod. } \mathrm{Ag} \\
\mathrm{FAO}=\text { área perdida agricultável }\end{array}$ \\
\hline 4 & $\begin{array}{l}\text { Deslocamento } \\
\text { Humano } \\
\text { (habitantes) } \\
\text { FAO (hab/MW) }\end{array}$ & $\begin{array}{c}14.199 \\
35,7\end{array}$ & CVPC Desl=FAOPot(MW) \\
\hline
\end{tabular}

5 Infl. Desenvolvimento (Renda/MW)

$938515 \quad$ CVPC Des(RELO)=FRenda*Pot(MW)

Econômico (\%PIB)

$18663778,5 \quad$ CVPC des/PIB=\%PIB

Humano (\%IDH)

$0,169 \quad \% \mathrm{PIB}=1 / 3 \% \mathrm{IDH}$

0,056

6 Alteração Conforto

$\begin{array}{lcc}\text { Sonoro } & \text { Medido } & \text { NPS (Nível de Pressão Sonora) } \\ \text { Médio/Limite (dBA) } & 58 / 55-70 / 65 & \\ \text { Ultrapassagem (\%) } & 5,5-7,7 & \end{array}$

Ultrapassagem (\%)

$5,5-7,7$ 


$\begin{array}{lcl}\text { Visual } & 0,49 & \mathrm{AP}=\mathrm{axbxd} \\ \mathrm{a}=0,7 & 0,245 & \mathrm{CPA}=\sum(\operatorname{axbxPA}) / \mathrm{PT} \\ \mathrm{b}=0,7 & 1 & \mathrm{a}=\sum \mathrm{PCH} / \mathrm{n}(\text { coeficiente de visibilidade desde área) } \\ \mathrm{d}=1 & 500 & \mathrm{~b} \text { (coeficiente de visibilidade desde usina) } \\ \mathrm{PA}=500 & 1000 & \\ \mathrm{PT}=1000 & \end{array}$

\section{A.1.4. Dimensão Política (PCHs)}

\section{Dimensão Política}

\section{Atributos}

Resultado

\section{Fórmula Final, [R\$/MWh]}

1 Instrumentos Políticos

$-6,28$

Leilões de Energia

141,94

$\triangle$ (PML-CUG)

PML

\section{Licenciamento (Meses)}

\section{Texp+Teia+Tlp+Tli+Tlo}

3 En-In

Governo Federal

Geradores

Grandes Consumidores

Positiva, Influente

Positiva, Influente

Análise de Poder

Atingidos

Positiva, Influente

Análise de Poder

Análise de Poder

Negativa, Pouco Infl.

Análise de Poder

\section{Posse/lntegração}

4 Energética

\section{Posse (Fonte)}

Posse (Tecnologia)

Propriedade (Fonte)

Propriedade (Tecnologia)

Int. En.

\begin{tabular}{c|c}
\hline Regional & Qualitativa \\
\hline Nacional & Qualitativa \\
União & Qualitativa \\
\hline Privado/Público & Qualitativa
\end{tabular}

Araçatuba, SIN Pot Teórico $(\mathrm{MW})+$ +- Imp.Exp.

(Submercado Sul-Sudeste) 
A.2.1. Dimensão Técnico-Econômica (Cogeração a Biomassa)

\section{Dimensão Técnico-Econômica}

\begin{tabular}{|c|c|c|c|}
\hline & Atributos & Resultado & Fórmula \\
\hline 1 & Potência Média por Usina (MW) & 76,8 & Valor médio de mercado \\
\hline 2 & Potencial Bruto (MW) & $2.146,06$ & $\begin{array}{l}\text { Potencial Teórico=Mcana } \times \text { (Fconv palha+F conv } \\
\text { bagaço)/8.760xFC }\end{array}$ \\
\hline 3 & Custo de Investimento (R\$/kW) & 2.330 & Investimento Total (R\$)/Potência Instalada(kW) \\
\hline 4 & Investimento Total (R\$) & 178.964 .736 & I=Potência Média x Custo de Investimento \\
\hline 5 & Confiabilidade (F. Capacidade) & 0,376 & CVPC Conf $=$ FC $\times$ FDisponibilidade \\
\hline 6 & Tarifa de Uso de T/D (ICG) (R\$/MWh) & $\mathrm{R} \$ 6,05 \times \mathrm{kW} . \mathrm{mês}$ & Tarifa Ajustada $=$ TUSDg $\times 50 \%+$ Encargo ICG \\
\hline 7 & $\begin{array}{c}\text { Custo O\&M (R\$/MWh) } \\
\text { Custo O\&M fixo (R\$/MWh) } \\
\text { Custo O\&M variável (R\$/kW.ano) }\end{array}$ & $\begin{array}{c}12,95 \\
25 \\
6\end{array}$ & $\mathrm{CO} \& \mathrm{M}=\mathrm{CO} \& \mathrm{MF}+\mathrm{CO} \& \mathrm{MV}$ \\
\hline 8 & Tempo de Construção (meses) & 12 & Testudos+Tsite+Tfundaçao+Tmontagem+Tcomiss.+Ttestes.op \\
\hline 9 & Índice de Nacionalização & $100 \%$ & $\ln =(z / x+z) \times 100$ \\
\hline 10 & Período do Fluxo de Caixa & 15 anos & - \\
\hline 11 & Custo Unitário de Geração (R\$/MWh) & 151,20 & Metodologia de Fluxo de Caixa Descontado \\
\hline 12 & Qualidade de Energia & - & $\Delta \mathrm{FP}, \Delta \mathrm{TDH}, \Delta \mathrm{TDHi}$ \\
\hline
\end{tabular}


A.2.2. Dimensão Ambiental (Cogeração a Biomassa)

\begin{tabular}{|c|c|c|c|}
\hline & Atributos & Resultado & Fórmula \\
\hline 1 & $\begin{array}{l}\text { Emissoes Aéreas } \\
\text { (GgCO) } \\
(\mathrm{GgNOx}) \\
(\mathrm{GgCH} 4) \\
(\mathrm{GgN} 20)\end{array}$ & $\begin{array}{c}146,14 \\
14,59 \\
4,32 \\
0,58\end{array}$ & CVPC Em (RELO)= F Em (RELO)*M(RELO) \\
\hline 2 & GEE (GgCO2eq) & $4,90 \mathrm{E}+02$ & CVPC GEE $=24 \times E m C H 4+\mathrm{CO} 2+310 \times \mathrm{N} 20$ \\
\hline 3 & $\begin{array}{l}\text { Consumo de água } \\
\text { Safra (m3) } \\
\text { Entressafra (m3) }\end{array}$ & $\begin{array}{l}6,39 E+06 \\
8,65 E+06\end{array}$ & CVPC Cons (RELO) = F Cons x M(relo) \\
\hline 4 & Qualidade da Água & - & CVPC alt rel.(RELO) $=$ CVPC alt (RELO)/Vol tot \\
\hline 5 & $\begin{array}{l}\text { Resíduos Sólidos (Gg/ano) } \\
\text { FRS (kg/ton c) }\end{array}$ & $\begin{array}{l}3,76 \\
10,00\end{array}$ & CVPC RS (RELO) $=\sum($ FRS(RELO)* M (RELO) \\
\hline 6 & $\begin{array}{l}\text { Ocupação de Espaço } \\
\text { (MW/km2) } \\
\text { Fator de Área Ocupada (FAO) }\end{array}$ & - & $\begin{array}{l}\text { CVPC Oc=FAO*Pot }(\mathrm{MW}) \\
\mathrm{FAO}=\mathrm{P} / \mathrm{A}=\text { Potência/Área }\end{array}$ \\
\hline
\end{tabular}




\section{A.2.3. Dimensão Social (Cogeração a Biomassa)}

\begin{tabular}{|c|c|c|c|}
\hline & & $\begin{array}{c}\text { Dimensão } \\
\text { Social }\end{array}$ & \\
\hline & Atributos & Resultado & Fórmula \\
\hline \multirow[t]{3}{*}{1} & $\begin{array}{l}\text { Empregos } \\
\text { Quantidade (emp/MW) }\end{array}$ & & \\
\hline & 7,3 & 15.666 & CVPC Emp $($ RELO $)=\operatorname{MAX}\left(\sum\left(\right.\right.$ FEmp $\left.(\text { RELO })^{\star}(\% \mathrm{IN})^{\star}(\mathrm{MR})^{\star} \operatorname{Pot}(\mathrm{MW})\right)$ \\
\hline & 17 & 36.483 & \\
\hline 2 & Qualidade (\%) & - & CVPC Qual Emp (RELO) $=$ V(Emp RELO) $>$ (FS, Cap, SO, CC) \\
\hline \multirow[t]{3}{*}{3} & Impactos à Saúde & & \\
\hline & Mortalidade/Morbidade & - & CVPC MM (RELO)=FDR(relo)*FMM*Pot(MW) \\
\hline & Mortes/Casos & - & FDR \\
\hline 4 & $\begin{array}{l}\text { Deslocamento } \\
\text { Humano } \\
\text { (habitantes/MW) }\end{array}$ & - & CVPC Desl=FAO*Pot(MW) \\
\hline \multirow[t]{3}{*}{5} & $\begin{array}{l}\text { Infl. Desenvolvimento } \\
\text { (Renda/emprego) }\end{array}$ & 625.824 .000 & $\begin{array}{l}\text { CVPC Des(RELO)=FRenda*Pot(MW) } \\
\text { CVPC des/PIB=\%PIB }\end{array}$ \\
\hline & Econômico (\%PIB) & 5,69 & $\% \mathrm{PIB}=1 / 3 \% \mathrm{IDH}$ \\
\hline & Humano (\%IDH) & 1,89 & \\
\hline \multirow[t]{3}{*}{6} & Alteração Conforto & & \\
\hline & Sonoro & - & NPS (Nivel de Pressao Sonora) \\
\hline & Visual & - & $\mathrm{CPA}=\Sigma(\mathrm{axbxPA}) / \mathrm{PT}$ \\
\hline
\end{tabular}




\section{A.2.4. Dimensão Política (Cogeração a Biomassa)}

Dimensão Política

\section{Atributos}

\section{Resultado}

\section{Fórmula Final, [R\$/MWh]}

1 Instrumentos Politicos

Leilões de Energia

$-10,30$

144,20

$\triangle(\mathrm{PML}-\mathrm{CUG})$

PML

2 Licenciamento (Meses)

$12-36$

Texp+Teia+Tlp+Tli+Tlo

3 En-In

Governo Federal

Geradores

Grandes Consumidores

Atingidos

Positiva, Influente

Positiva, Influente

Positiva, Influente

Negativa, Pouco Infl.

Análise de Poder

Análise de Poder

Análise de Poder

Análise de Poder

\section{Posse/Integração}

4 Energética

Posse (Fonte)

Posse (Tecnologia)

Propriedade (Fonte)

Propriedade (Tecnologia)

Int. En.

\begin{tabular}{c|c|} 
Regional & Qualitativa \\
Nacional & Qualitativa \\
Privada/Estatal & Qualitativa \\
Privado/Público & Qualitativa
\end{tabular}

Araçatuba, SIN Pot Teórico $(\mathrm{MW})+$ +- Imp.Exp.

(Submercado Sul-Sudeste) 
A.3.1. Dimensão Técnico-Econômica (Aquecedores Solares)

Dimensão Técnico-Econômica

\begin{tabular}{|c|c|c|c|}
\hline & Atributos & Resultado & Metodologia \\
\hline 1 & Potência Total (kW) & $88.493,4$ & $\mathrm{RDP}=\mathrm{NR} \times \mathrm{NC} \times(\mathrm{PC}-\mathrm{Paux}) \times \mathrm{FD} \times 10^{\wedge} 3$ \\
\hline 2 & Energia Economizada (MWh/ano) & $93.963,91$ & $\mathrm{EE}=\mathrm{FS} \times(\mathrm{PC}-\mathrm{Paux}) \times \mathrm{NB} \times(\mathrm{T} / 60) \times 365 \times 10^{-6} \times \mathrm{NR}$ \\
\hline 3 & Investimento Total (R\$) & 891.546 .315 & CVPC I Tot $($ RELD) = I Unit xNR \\
\hline 4 & $\begin{array}{c}\text { Custo da Energia Conservada } \\
\text { (R\$/MWh) }\end{array}$ & 819,77 & $\mathrm{CEC}=(\mathrm{TCC} / \triangle \mathrm{E}) \times \mathrm{FRC}$ \\
\hline 5 & Custo de O\&M (R\$) & 17.830 .926 & Inv total x 0,02 \\
\hline 6 & Tempo de Implantação & 1 ano & Análise Econômica \\
\hline 7 & Índice de Nacionalização & $100 \%$ & Análise Qualitativa \\
\hline 8 & Fator de Recuperação de Capital & 0,0864 & $F R C=i x(i+1)^{\wedge} n /\left((i+1)^{\wedge} n-1\right)$ \\
\hline 9 & $\begin{array}{l}\text { Custo Evitado de Demanda } \\
\text { (R\$/kW.ano) }\end{array}$ & 435,39 & CED $=[(12 \times C 1)+(12 \times$ C2 $\times$ LP $)] \times 1,2$ \\
\hline 10 & Qualidade de Energia & - & $\Delta \mathrm{FP}, \Delta \mathrm{TDH}, \Delta \mathrm{TDHi}$ \\
\hline
\end{tabular}


A.3.2. Dimensão Ambiental (Aquecedores Solares)

Dimensão Ambiental

\begin{tabular}{l|l} 
Atributos & Resultado Metodologia
\end{tabular}

$1 \quad$ Valores Base

CO2 85,33 g.CO2/Kwh $F($ base $)=\sum\left(P \%(R E L O){ }^{*} F\right.$ Em (RELO))

$2 \quad$ Emissões Aéreas

(GgCO2eq)

8,018 CVPC Em (RELD) $=$ F Em (RELD) $\times$ Pot(RELD) $-F$ Em(base $) \times$ Pot(RELO)

Alteração de Vazão
(litros.ano)

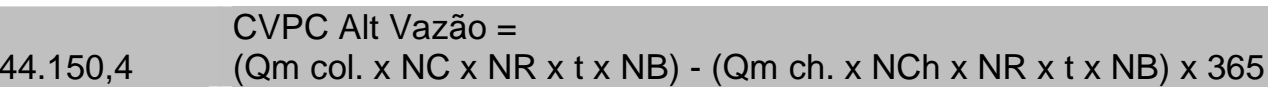

$4 \quad$ Qualidade da Água $\quad$ Neutra $\quad$ Análise Qualitativa

5 Ocupação de Espaço (m2) $440.814 \quad$ CVPC Oc=FAO*Pot (MW)

$\mathrm{CVPC} \mathrm{OC}=\mathrm{FO} \times \mathrm{NR}$ 


\section{A.3.3. Dimensão Social (Aquecedores Solares)}

\section{Dimensão Social}

\section{Atributos}

Resultado

Metodologia

\begin{tabular}{|c|c|c|c|}
\hline 1 & $\begin{array}{c}\text { Empregos } \\
\text { Quantidade (emp/MW) }\end{array}$ & $\begin{array}{c}4867 \\
55\end{array}$ & CVPC Emp = Pot Economia Energia (RELD) x F Emp (RELD) \\
\hline 2 & Qualidade (\%) & $36 \%$ & Análise Qualitativa \\
\hline 3 & Desenvolvimento & & \\
\hline & Econômico (R\$) & 36.082 .142 & CVPC Des(RELD)=Tarifa media x EE(MWh.ano) \\
\hline & Econômico (\%PIB) & 0,33 & CVPC Des/PIB=\%PIB Araçatuba \\
\hline & Humano (\%IDH) & 0,11 & $\% \mathrm{PIB}=1 / 3 \% \mathrm{IDH}$ \\
\hline
\end{tabular}

\begin{tabular}{|c|c|c|c|}
\hline 4 & Alteração Conforto & & \\
\hline & Sonoro & Neutro & Análise Qualitativa \\
\hline & Olfativo & Neutro & Análise Qualitativa \\
\hline & Térmico & Negativo & Análise Qualitativa \\
\hline & Visual & Negativo & Análise Qualitativa \\
\hline
\end{tabular}

5

Impactos a saúde

0,75

$\mathrm{PDA}=\left(\mathrm{AC}{ }^{*} \mathrm{NA}\right)^{*}\left(\mathrm{NCh}^{\star} \mathrm{NR} / \mathrm{C}\right)$ 


\section{A.3.4. Dimensão Política (Aquecedores Solares)}

\section{Dimensão Política}

\section{Atributos}

Resultado

Metodologia

$1 \quad$ Instrumentos Políticos

Leis Aprovadas (Estaduais e Municipais)

Número de Coletores Etiquetados

Programa Federal de Aplicação

Incentivos Fiscais

28

160

1

IPTU (municípios)
Análise Qualitativa

Análise Qualitativa

Análise Qualitativa

Análise Qualitativa

$\begin{array}{ccc}\text { En-In } & & \\ \text { Governo Federal } & \text { Positivo } & \text { Análise Qualitativa } \\ \text { Fabricantes } & \text { Positivo } & \text { Análise Qualitativa } \\ \text { Distribuidoras } & \text { Indiferente } & \text { Análise Qualitativa } \\ \text { Grandes Consumidores } & \text { Indiferente } & \text { Análise Qualitativa } \\ \text { ONGs } & \text { Positivo } & \text { Análise Qualitativa } \\ \text { Sociedade } & \text { Positivo } & \text { Análise Qualitativa } \\ \text { Conjunção e Encontro de Interesses } & \text { Negativo } & \text { Análise Qualitativa }\end{array}$


A.4.1. Dimensão Técnico-Econômica (Lâmpadas Fluorescentes Compactas)

Dimensão Técnico-Econômica

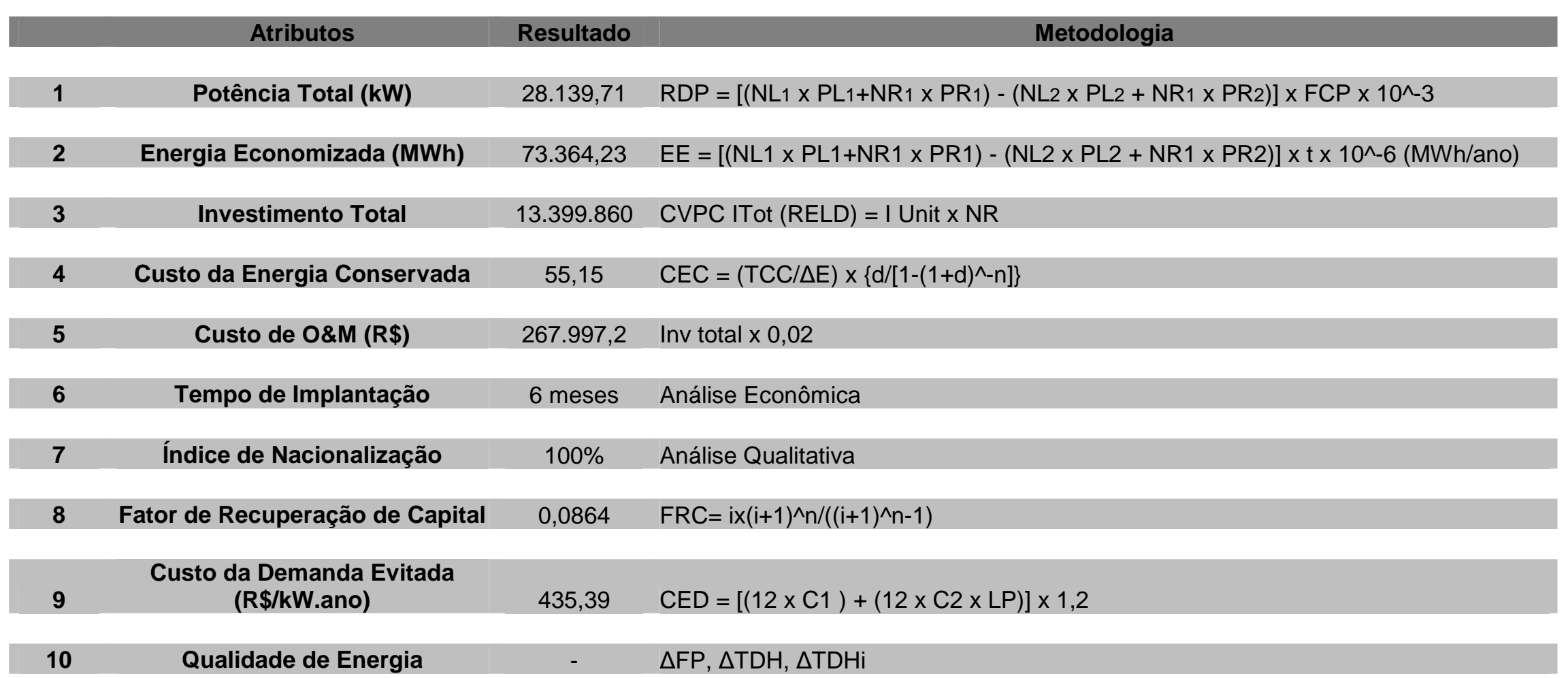


A.4.2. Dimensão Ambiental (Lâmpadas Fluorescentes Compactas)

Dimensão Ambiental

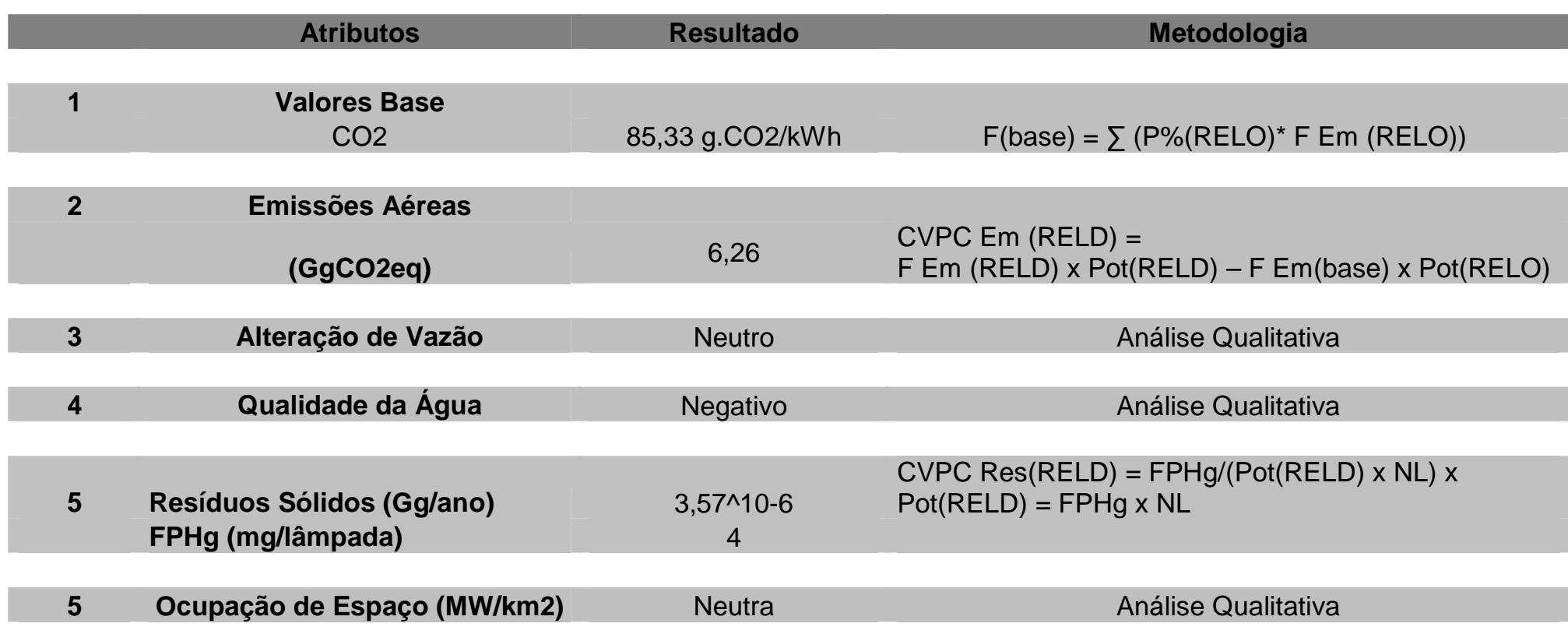


A.4.3. Dimensão Social (Lâmpadas Fluorescentes Compactas)

Dimensão Social

\begin{tabular}{|c|c|c|c|}
\hline \multicolumn{2}{|c|}{ Atributos } & Resultado & Metodologia \\
\hline 1 & $\begin{array}{c}\text { Empregos } \\
\text { Quantidade (emp/GWh) }\end{array}$ & $\begin{array}{c}14-44 \\
0,19-0,60\end{array}$ & V Emp = Pot Economia Energia (RELD) x F Emp (RELD) \\
\hline 2 & Qualidade (\%) & $36 \%$ & Análise Qualitativa \\
\hline 3 & $\begin{array}{c}\text { Desenvolvimento } \\
\text { Econômico (R\$) } \\
\text { \%PIB } \\
\text { Humano (IDH) }\end{array}$ & $\begin{array}{c}27.925 .178,43 \\
0,25 \% \\
0,08 \%\end{array}$ & $\begin{array}{l}\text { CVPC Des(RELD)=Tarifa media } \times \text { EE(MWh.ano) } \\
\text { CVPC Des/PIB=\%PIB Araçatuba }\end{array}$ \\
\hline 4 & $\begin{array}{c}\text { Alteração Conforto } \\
\text { Sonoro } \\
\text { Olfativo } \\
\text { Térmico } \\
\text { Visual }\end{array}$ & $\begin{array}{l}\text { Neutro } \\
\text { Neutro } \\
\text { Positivo } \\
\text { Positivo }\end{array}$ & $\begin{array}{l}\text { Análise Qualitativa } \\
\text { Análise Qualitativa } \\
\text { Análise Qualitativa } \\
\text { Análise Qualitativa }\end{array}$ \\
\hline 5 & $\begin{array}{c}\text { Impactos a saúde } \\
\text { FDR }\end{array}$ & $4 \mathrm{mg} / \mathrm{lamp}$ & CVPC MM (RELD)=FDR(RELD)*FMMPot(RELD) \\
\hline
\end{tabular}




\section{A.4.4. Dimensão Política (Lâmpadas Fluorescentes Compactas)}

\section{Dimensão Política}

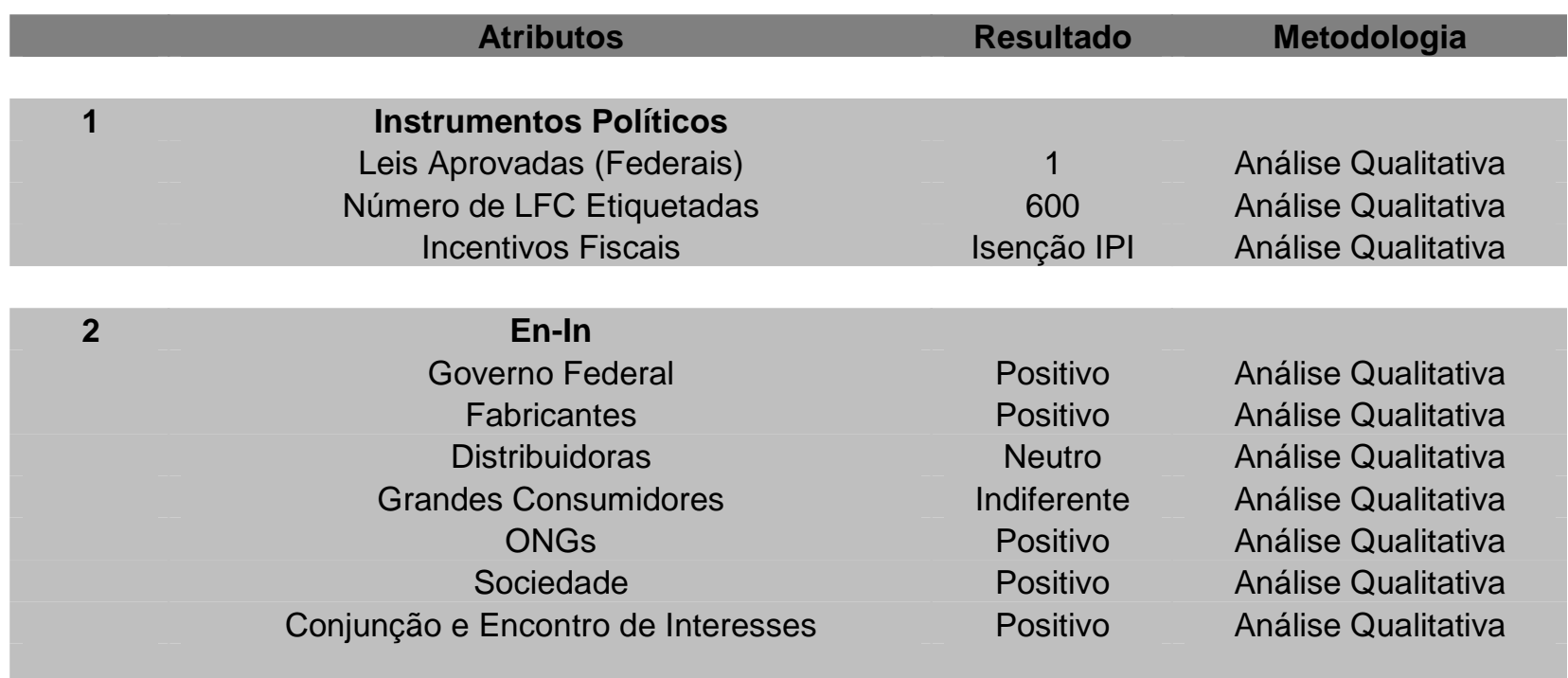




\section{Anexo 2: Resultados do Fluxo de Caixa Descontado para RELO}

\section{A.2.1. $\mathrm{PCH}$}

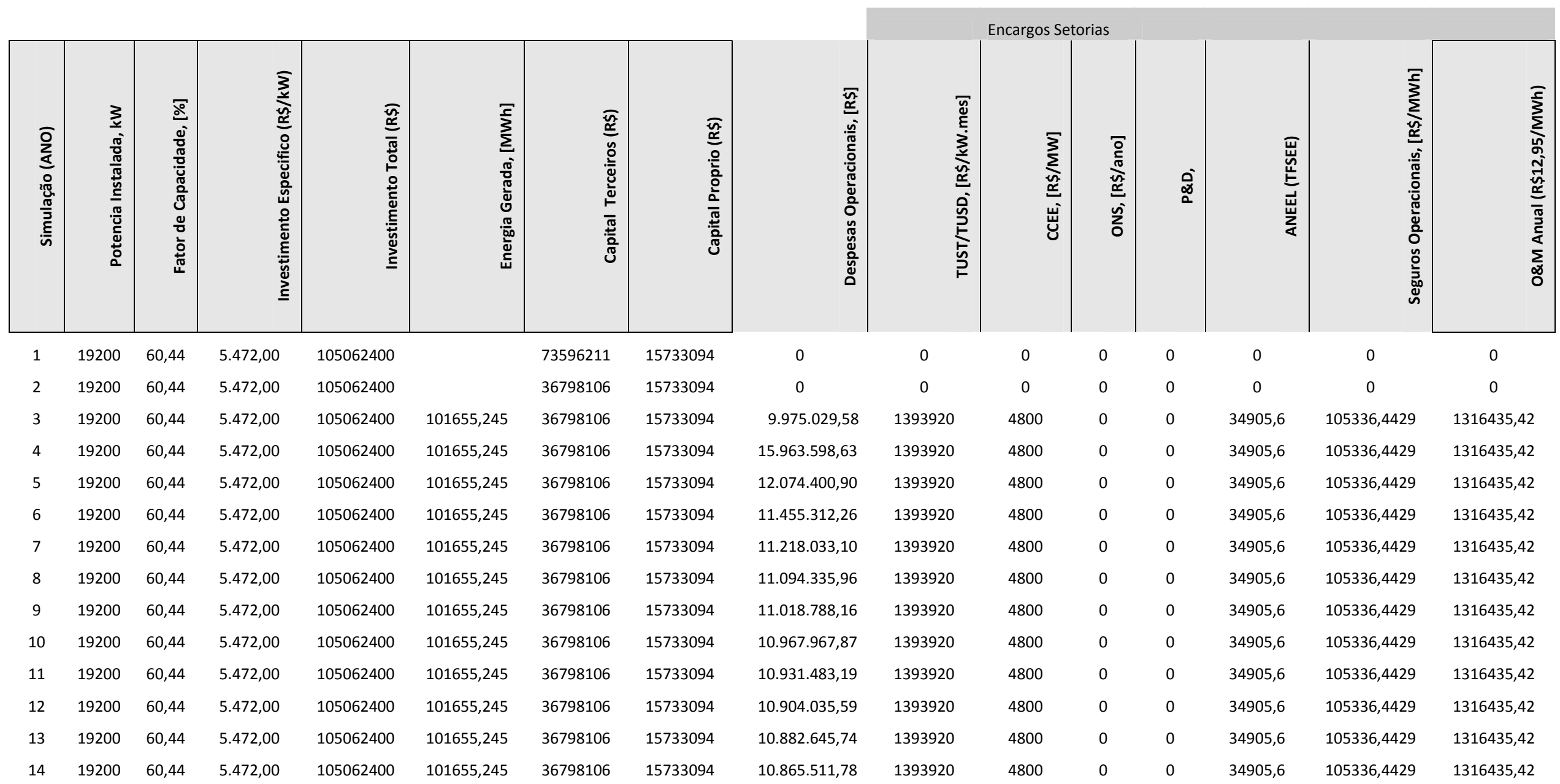




\begin{tabular}{|c|c|c|c|c|c|c|c|c|c|c|c|c|c|c|c|}
\hline \multirow[b]{2}{*}{ 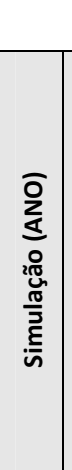 } & \multirow[b]{2}{*}{ 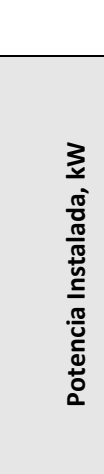 } & \multirow[b]{2}{*}{$\begin{array}{l}\bar{\delta} \\
0 \\
\frac{0}{0} \\
\frac{\pi}{0} \\
\frac{0}{0} \\
\frac{0}{0} \\
\frac{0}{0} \\
\frac{0}{0} \\
\frac{0}{0} \\
\frac{\pi}{4}\end{array}$} & \multirow[b]{2}{*}{ 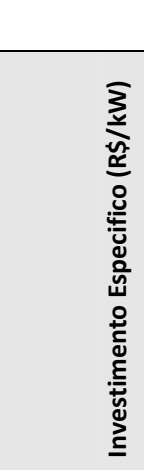 } & \multirow[b]{2}{*}{ 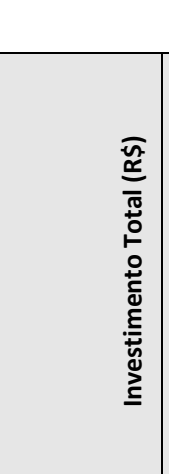 } & \multirow[b]{2}{*}{ 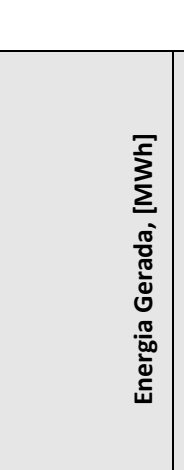 } & \multirow[b]{2}{*}{ 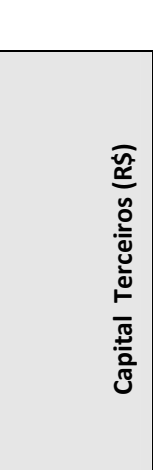 } & \multirow[b]{2}{*}{ 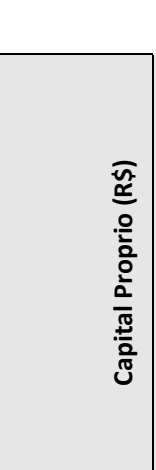 } & \multicolumn{4}{|c|}{ Encargos Setorias } & \multirow[b]{2}{*}{ ఖิ } & \multirow[b]{2}{*}{ 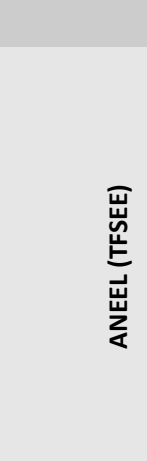 } & \multirow[b]{2}{*}{ 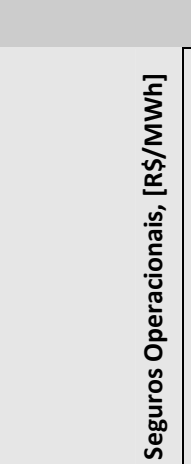 } & \multirow[b]{2}{*}{ 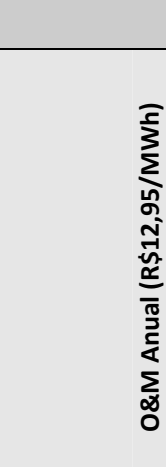 } \\
\hline & & & & & & & & \multicolumn{2}{|r|}{ 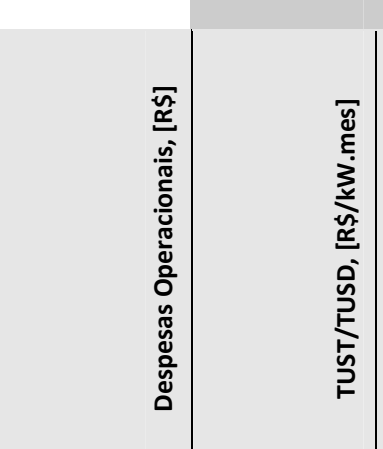 } & 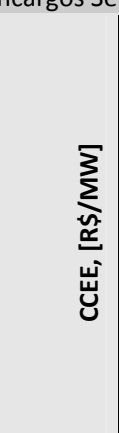 & 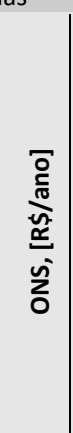 & & & & \\
\hline 15 & 19200 & 60,44 & $5.472,00$ & 105062400 & 101655,245 & 36798106 & 15733094 & $10.851 .480,82$ & 1393920 & 4800 & 0 & 0 & 34905,6 & 105336,4429 & 1316435,42 \\
\hline 16 & 19200 & 60,44 & $5.472,00$ & 105062400 & 101655,245 & 36798106 & 15733094 & $10.839 .781,29$ & 1393920 & 4800 & 0 & 0 & 34905,6 & 105336,4429 & 1316435,42 \\
\hline 17 & 19200 & 60,44 & $5.472,00$ & 105062400 & 101655,245 & 36798106 & 15733094 & $10.829 .877,50$ & 1393920 & 4800 & 0 & 0 & 34905,6 & 105336,4429 & 1316435,42 \\
\hline 18 & 19200 & 60,44 & $5.472,00$ & 105062400 & 101655,245 & 36798106 & 15733094 & $4.970 .487,24$ & 1393920 & 4800 & 0 & 0 & 34905,6 & 105336,4429 & 1316435,42 \\
\hline 19 & 19200 & 60,44 & $5.472,00$ & 105062400 & 101655,245 & 36798106 & 15733094 & $4.970 .487,24$ & 1393920 & 4800 & 0 & 0 & 34905,6 & 105336,4429 & 1316435,42 \\
\hline 20 & 19200 & 60,44 & $5.472,00$ & 105062400 & 101655,245 & 36798106 & 15733094 & $4.970 .487,24$ & 1393920 & 4800 & 0 & 0 & 34905,6 & 105336,4429 & 1316435,42 \\
\hline 21 & 19200 & 60,44 & $5.472,00$ & 105062400 & 101655,245 & 36798106 & 15733094 & $4.970 .487,24$ & 1393920 & 4800 & 0 & 0 & 34905,6 & 105336,4429 & 1316435,42 \\
\hline 22 & 19200 & 60,44 & $5.472,00$ & 105062400 & 101655,245 & 36798106 & 15733094 & $4.970 .487,24$ & 1393920 & 4800 & 0 & 0 & 34905,6 & 105336,4429 & 1316435,42 \\
\hline 23 & 19200 & 60,44 & $5.472,00$ & 105062400 & 101655,245 & 36798106 & 15733094 & $4.970 .487,24$ & 1393920 & 4800 & 0 & 0 & 34905,6 & 105336,4429 & 1316435,42 \\
\hline 24 & 19200 & 60,44 & $5.472,00$ & 105062400 & 101655,245 & 36798106 & 15733094 & $4.970 .487,24$ & 1393920 & 4800 & 0 & 0 & 34905,6 & 105336,4429 & 1316435,42 \\
\hline 25 & 19200 & 60,44 & $5.472,00$ & 105062400 & 101655,245 & 36798106 & 15733094 & $4.970 .487,24$ & 1393920 & 4800 & 0 & 0 & 34905,6 & 105336,4429 & 1316435,42 \\
\hline 26 & 19200 & 60,44 & $5.472,00$ & 105062400 & 101655,245 & 36798106 & 15733094 & $4.970 .487,24$ & 1393920 & 4800 & 0 & 0 & 34905,6 & 105336,4429 & 1316435,42 \\
\hline 27 & 19200 & 60,44 & $5.472,00$ & 105062400 & 101655,245 & 36798106 & 15733094 & $4.970 .487,24$ & 1393920 & 4800 & 0 & 0 & 34905,6 & 105336,4429 & 1316435,42 \\
\hline 28 & 19200 & 60,44 & $5.472,00$ & 105062400 & 101655,245 & 36798106 & 15733094 & $4.970 .487,24$ & 1393920 & 4800 & 0 & 0 & 34905,6 & 105336,4429 & 1316435,42 \\
\hline 29 & 19200 & 60,44 & $5.472,00$ & 105062400 & 101655,245 & 36798106 & 15733094 & $4.970 .487,24$ & 1393920 & 4800 & 0 & 0 & 34905,6 & 105336,4429 & 1316435,42 \\
\hline 30 & 19200 & 60,44 & $5.472,00$ & 105062400 & 101655,245 & 36798106 & 15733094 & $4.970 .487,24$ & 1393920 & 4800 & 0 & 0 & 34905,6 & 105336,4429 & 1316435,42 \\
\hline 31 & 19200 & 60,44 & $5.472,00$ & 105062400 & 101655,245 & 36798106 & 15733094 & $4.970 .487,24$ & 1393920 & 4800 & & & 34905,6 & 105336,4429 & 1316435,42 \\
\hline 32 & 19200 & 60,44 & $5.472,00$ & 105062400 & 101655,245 & 36798106 & 15733094 & $4.970 .487,24$ & 1393920 & 4800 & & & 34905,6 & 105336,4429 & 1316435,42 \\
\hline
\end{tabular}




\section{Continuação}

\begin{tabular}{|c|c|c|c|c|c|c|c|c|c|c|c|c|c|}
\hline 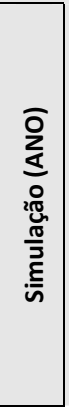 & 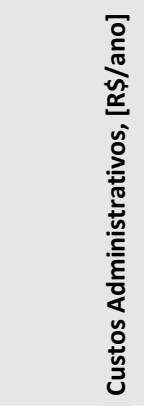 & 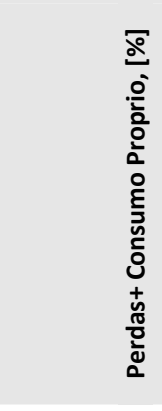 & 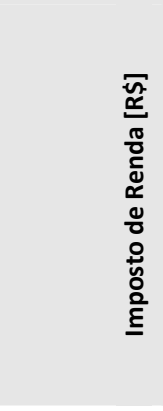 & 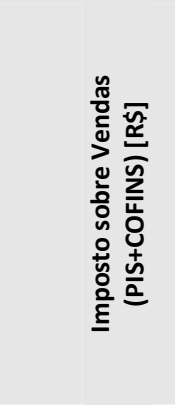 & & 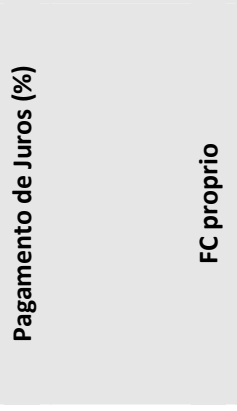 & 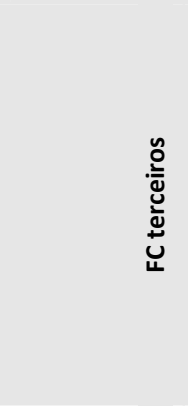 & 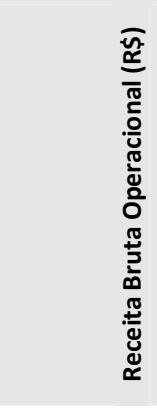 & 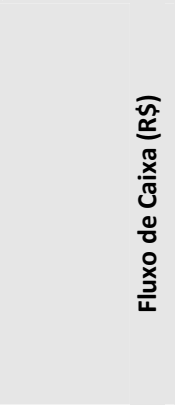 & 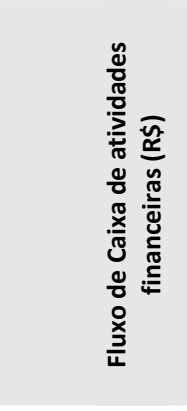 & 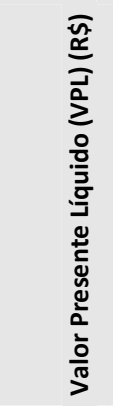 & 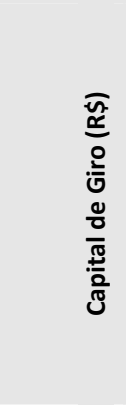 & 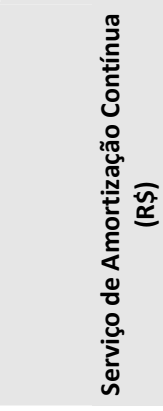 \\
\hline 1 & 0 & 0 & 0 & 0 & & & & & & & $9,67 \%$ & & \\
\hline 2 & 0 & 0 & 0 & 0 & & $-90716549,36$ & $-37542940,18$ & & -105062400 & & & & \\
\hline 3 & 700000 & 606737,91 & 646133,74 & 768956,03 & 6,8 & $-91981474,82$ & $-74090170,73$ & 21067289 & 11092258,99 & $5.004 .542,35$ & $R \$ 0,00$ & 6000000 & 5004542,348 \\
\hline 4 & 700000 & 606737,91 & 646133,74 & 768956,03 & 15,12 & $-93134867,24$ & $-76647510,76$ & 21067289 & 5103689,947 & $5.988 .569,05$ & & 6000000 & 10993111,39 \\
\hline 5 & 700000 & 606737,91 & 646133,74 & 768956,03 & 13,85 & $-94186560,88$ & $-78993694,27$ & 21067289 & 8992887,68 & $2.099 .371,31$ & & 6000000 & 7103913,661 \\
\hline 6 & 700000 & 606737,91 & 646133,74 & 768956,03 & 12,65 & $-95145522,9$ & $-81146156,21$ & 21067289 & 9611976,313 & $1.480 .282,68$ & & 6000000 & 6484825,028 \\
\hline 7 & 700000 & 606737,91 & 646133,74 & 768956,03 & 11,55 & $-96019929,77$ & $-83120891,94$ & 21067289 & 9849255,477 & $1.243 .003,52$ & & 6000000 & 6247545,864 \\
\hline 8 & 700000 & 606737,91 & 646133,74 & 768956,03 & 10,49 & $-96817237,03$ & $-84932576,09$ & 21067289 & 9972952,619 & $1.119 .306,37$ & & 6000000 & 6123848,722 \\
\hline 9 & 700000 & 606737,91 & 646133,74 & 768956,03 & 9,52 & $-97544242,83$ & $-86594671,64$ & 21067289 & 10048500,42 & $1.043 .758,58$ & & 6000000 & 6048300,924 \\
\hline 10 & 700000 & 606737,91 & 646133,74 & 768956,03 & 8,62 & $-98207145,9$ & $-88119529,95$ & 21067289 & 10099320,71 & $992.938,29$ & & 6000000 & 5997480,634 \\
\hline 11 & 700000 & 606737,91 & 646133,74 & 768956,03 & 7,78 & $-98811598,41$ & $-89518482,52$ & 21067289 & 10135805,39 & $956.453,60$ & & 6000000 & 5960995,949 \\
\hline 12 & 700000 & 606737,91 & 646133,74 & 768956,03 & 6,99 & $-99362754,16$ & $-90801925,25$ & 21067289 & 10163252,98 & $929.006,01$ & & 6000000 & 5933548,357 \\
\hline 13 & 700000 & 606737,91 & 646133,74 & 768956,03 & 6,26 & $-99865312,52$ & $-91979395,64$ & 21067289 & 10184642,84 & $907.616,15$ & & 6000000 & 5912158,501 \\
\hline 14 & 700000 & 606737,91 & 646133,74 & 768956,03 & 5,58 & $-100323558,5$ & $-93059643,71$ & 21067289 & 10201776,8 & $890.482,19$ & & 6000000 & 5895024,539 \\
\hline
\end{tabular}




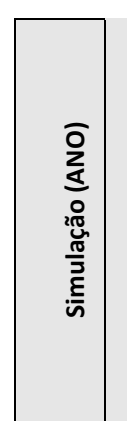

15

$16 \quad 70000$

$17 \quad 700000$

$18 \quad 700000$

$19 \quad 700000$

$20 \quad 700000$

$21 \quad 700000$

$22 \quad 700000$

$23 \quad 700000$

24700000

$25 \quad 700000$

$26 \quad 700000$

$27 \quad 700000$

$28 \quad 700000$

$29 \quad 700000$

$30 \quad 700000$

$31 \quad 700000$

$32 \quad 700000$

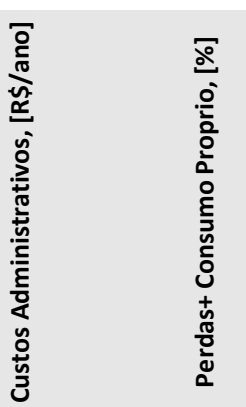

606737,91

606737,91

606737,91

606737,91

606737,91

606737,91

606737,91

606737,91

606737,91

606737,91

606737,91

606737,91

606737,91

606737,91

606737,91

606737,91

606737,91

606737,91

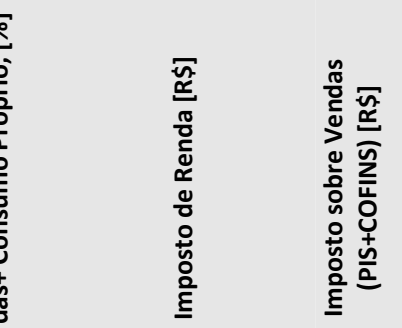

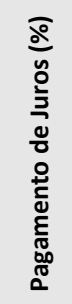

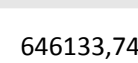

646133,74

768956,03

646133,74

768956,03

768956,03

646133,74

646133,74

68956,03

646133,74

646133,74

646133,74

646133,74

646133,74

646133,74

646133,74

646133,74

646133,74

646133,74

646133,74

646133,74
768956,03

768956,03

768956,03

768956,03

768956,03

768956,03

768956,03

768956,03

768956,03

768956,03

768956,03

768956,03

768956,03

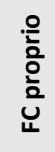

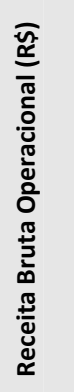

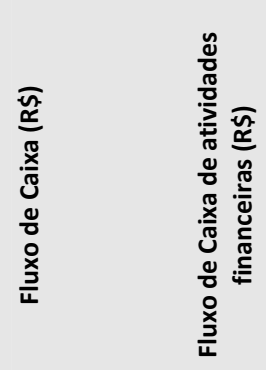

$876.451,23$

$864.751,70$

$854.847,91$

-94959920,16 21067289

$-101786574,1-96559344,84 \quad 21067289$

$-102075415,5 \quad-97261431,96 \quad 21067289$

$\begin{array}{lll}-102338788,7 & -97905548,59 & 21067289\end{array}$

$-102578939,4 \quad-98496481,28 \quad 21067289$

$\begin{array}{lll}-102797915,1 & -99038621,35 & 21067289\end{array}$

$\begin{array}{lll}-102997582,9 & -99535997,57 & 21067289\end{array}$

$\begin{array}{lll}-103179645,3 & -99992306,03 & 21067289\end{array}$

$-103345654,5-100410937,6 \quad 21067289$

$-103497026,2-100795003,3 \quad 21067289$

$-103635050,9-101147357,2 \quad 21067289$

$\begin{array}{lll}-103760905,4 & -101470617,6 & 21067289\end{array}$

$\begin{array}{lll}-103875662,9 & -101767186,8 & 21067289\end{array}$

$\begin{array}{lll}-103980301,8 & -102039268,6 & 21067289\end{array}$

$\begin{array}{lll}-104075714,3 & -102288885 & 21067289\end{array}$

$-104162713,9-102517890,8 \quad 21067289$

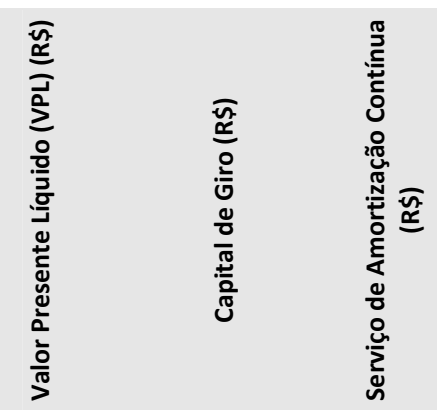

$6000000 \quad 5880993,581$

$6000000 \quad 5869294,05$

$6000000 \quad 5859390,262$

6000000

6000000

6000000

6000000

6000000

6000000

6000000

6000000

6000000

6000000

6000000

6000000

6000000

6000000

6000000 


\section{A. 2. 2. Cogeração a Biomassa}

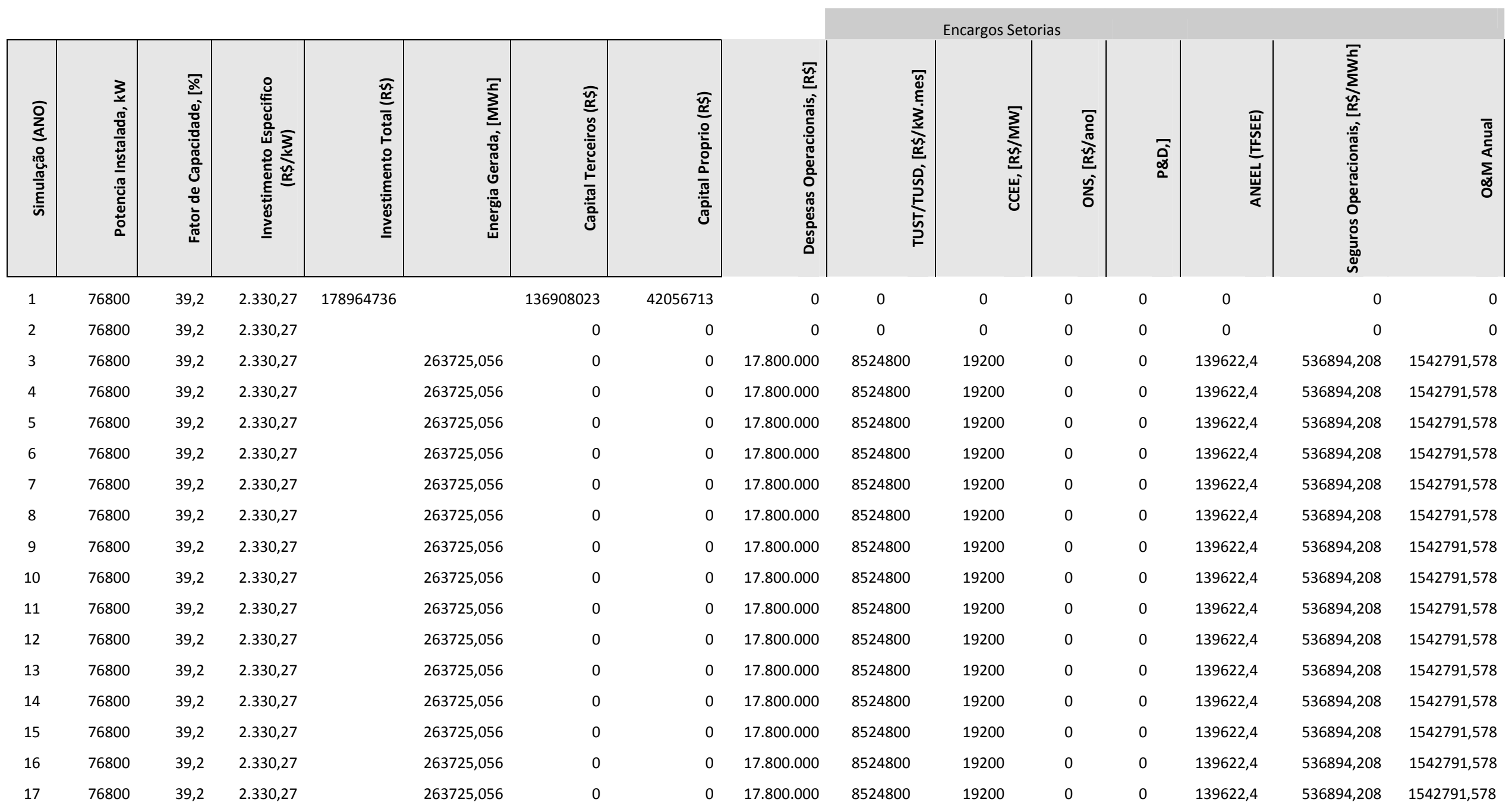




\begin{tabular}{|c|c|c|c|c|c|c|c|c|c|c|c|c|c|c|c|}
\hline & Encargos & Setorias & & & & & & & & & & & & & \\
\hline 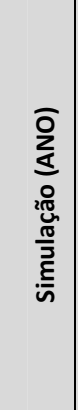 & 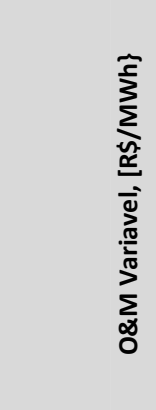 & 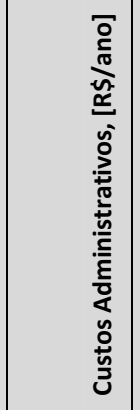 & 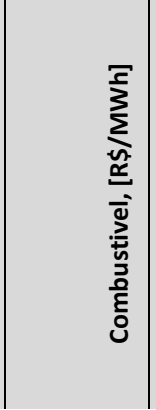 & 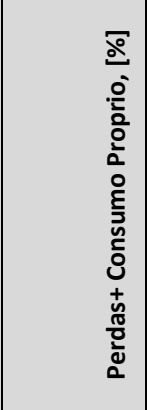 & 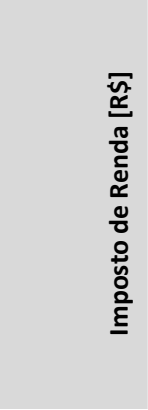 & 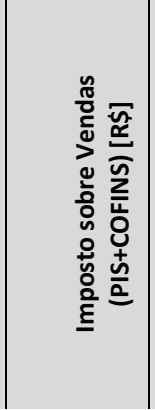 & 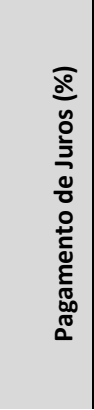 & 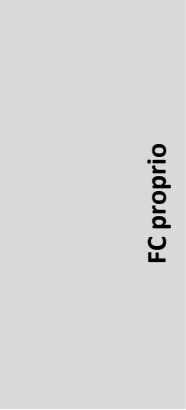 & 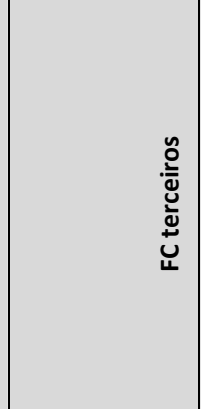 & 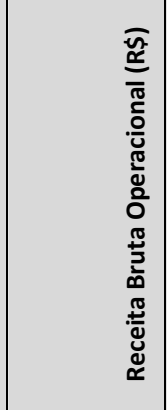 & 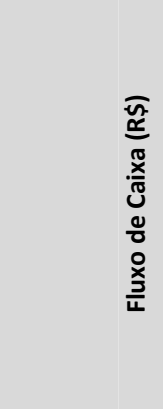 & 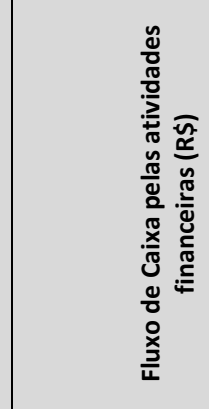 & 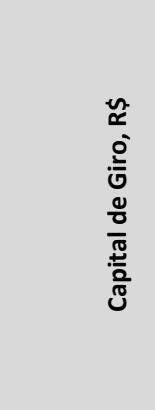 & 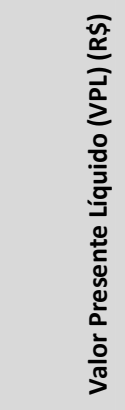 & 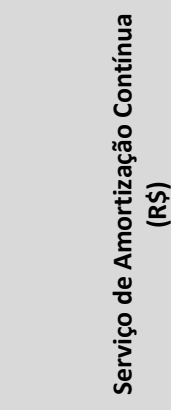 \\
\hline 1 & 0 & 0 & & 0 & 0 & 0 & & & & & & & & $11,03 \%$ & \\
\hline 2 & & 0 & & 0 & 0 & 0 & & $-140616315,3$ & $-53361045,14$ & & -178964736 & & & & \\
\hline 3 & 1920000 & 0 & 5124177,8 & 1148400,6 & 1196250,6 & 1455438,2 & 6,8 & 0 & & 39875019,2 & 25.115 .019 & $(5.013 .004,76)$ & 0 & $R \$ 0,00$ & 5.448 .939 \\
\hline 4 & 1920000 & 0 & 5124177,8 & 1148400,6 & 1196250,6 & 1455438,2 & 15,12 & 0 & & 39875019,2 & 25.115.019 & $(11.131 .185,59)$ & 0 & & 20182246,79 \\
\hline 5 & 1920000 & 0 & 5124177,8 & 1148400,6 & 1196250,6 & 1455438,2 & 13,85 & 0 & & 39875019,2 & 25.115 .019 & $(10.193 .389,63)$ & 3040000 & & 18459573,65 \\
\hline 6 & 1920000 & 0 & 5124177,8 & 1148400,6 & 1196250,6 & 1455438,2 & 12,65 & 0 & & 39875019,2 & 25.115 .019 & $(9.312 .991,44)$ & 3040000 & & 16881731,18 \\
\hline 7 & 1920000 & 0 & 5124177,8 & 1148400,6 & 1196250,6 & 1455438,2 & 11,55 & 0 & & 39875019,2 & 25.115.019 & $(8.502 .193,88)$ & 3040000 & & 15398201,1 \\
\hline 8 & 1920000 & 0 & 5124177,8 & 1148400,6 & 1196250,6 & 1455438,2 & 10,49 & 0 & & 39875019,2 & 25.115 .019 & $(7.724 .221,27)$ & 3040000 & & 14035978,77 \\
\hline 9 & 1920000 & 0 & 5124177,8 & 1148400,6 & 1196250,6 & 1455438,2 & 9,52 & 0 & & 39875019,2 & 25.115 .019 & $(7.009 .087,35)$ & 3040000 & & 12721168,84 \\
\hline 10 & 1920000 & 0 & 5124177,8 & 1148400,6 & 1196250,6 & 1455438,2 & 8,62 & 0 & & 39875019,2 & 25.115 .019 & $(6.342 .592,21)$ & 3040000 & & 11519684,18 \\
\hline 11 & 1920000 & 0 & 5124177,8 & 1148400,6 & 1196250,6 & 1455438,2 & 7,78 & 0 & & 39875019,2 & 25.115.019 & $(5.727 .353,78)$ & 3040000 & & 10416489,6 \\
\hline 12 & 1920000 & 0 & 5124177,8 & 1148400,6 & 1196250,6 & 1455438,2 & 6,99 & 0 & & 39875019,2 & 25.115 .019 & $(5.143 .984,36)$ & 3040000 & & 9369735,23 \\
\hline 13 & 1920000 & 0 & 5124177,8 & 1148400,6 & 1196250,6 & 1455438,2 & 6,26 & 0 & & 39875019,2 & 25.115.019 & $(4.606 .504,17)$ & 3040000 & & 8378940,373 \\
\hline 14 & 1920000 & 0 & 5124177,8 & 1148400,6 & 1196250,6 & 1455438,2 & 5,58 & 0 & & 39875019,2 & 25.115.019 & $(4.106 .913,35)$ & 3040000 & & 7471173,531 \\
\hline 15 & 1920000 & 0 & 5124177,8 & 1148400,6 & 1196250,6 & 1455438,2 & 4,95 & 0 & & 39875019,2 & 25.115 .019 & $(3.644 .430,52)$ & 3040000 & & 6640745,718 \\
\hline 16 & 1920000 & 0 & 5124177,8 & 1148400,6 & 1196250,6 & 1455438,2 & 4,36 & 0 & & 39875019,2 & 22.075 .019 & $(3.212 .257,10)$ & 3040000 & & 5862863,999 \\
\hline 17 & 1920000 & 0 & 5124177,8 & 1148400,6 & 1196250,6 & 1455438,2 & 0,33 & 0 & & 39875019,2 & 22.075.019 & $(244.236,25)$ & 3040000 & & 1330008,106 \\
\hline
\end{tabular}




\section{Anexo 3: Simulações de Erosão e Vazão de PCHs}

\section{A.3.1. Estudo de Erosão de PCHs}

Cálculo da Queda Media bruta da Região de Araçatuba

(m)

$\begin{array}{rrrrr}80 & 9 & 60 & 25 & 3 \\ 8 & 40 & 71 & 38 & 30 \\ 53 & 31 & 63 & 21 & 14 \\ 42 & 47 & 16 & 24 & 17 \\ 5 & 48 & 43 & 45 & 11 \\ 10 & 95 & 143 & 68 & 2 \\ 51 & 55 & 28 & 39 & 7 \\ 81 & 41 & 43 & 43 & 25 \\ 76 & 14 & 15 & 9 & 16 \\ 88 & 40 & 37 & 25 & 6 \\ 90 & 95 & 63 & 94 & 53 \\ 14 & 35 & 5 & 56 & 59 \\ 114 & 71 & 25 & 7 & 26 \\ 138 & 36 & 45 & 17 & 75 \\ 50 & 70 & 52 & 40 & 66 \\ 47 & 30 & 35 & 42 & 42 \\ 30 & 17 & 21 & 87 & 28 \\ 37 & 30 & 66 & 39 & 54 \\ 21 & 21 & 87 & 62 & 2 \\ 4 & 36 & 17 & 101 & 32 \\ 59 & 50 & 58 & 79 & 57 \\ 97 & 9 & 66 & 161 & 39 \\ 142 & 63 & 48 & 96 & 91 \\ 99 & 92 & 91 & 53 & 40 \\ 18 & 46 & 68 & 21 & 97 \\ 42 & 23 & 65 & 98 & 129 \\ 46 & 66 & 42 & 84 & 2 \\ 42 & 43 & 31 & 102 & 18 \\ 46 & 78 & 51 & 161 & 31 \\ 88 & 72 & 15 & 67 & 28 \\ 20 & 8 & 36 & 60 & 59 \\ 108 & 3 & 27 & 47 & 36\end{array}$

47,5039
Cálculo da Vazão Média da R.A.A. ～(m3/s)

$\begin{array}{rrrrrrrr}1,53 & 3,78 & 1,49 & 3,42 & 5,56 & 3,04 & 9,54 & 6,47 \\ 1,53 & 3,78 & 4,23 & 3,42 & 5,56 & 3,04 & 9,54 & 6,47 \\ 1,53 & 3,78 & 4,23 & 3,42 & 1,05 & 3,04 & 9,54 & 6,47 \\ 5,35 & 3,78 & 4,23 & 3,00 & 1,05 & 3,04 & 9,54 & 6,47 \\ 5,35 & 3,78 & 4,23 & 3,00 & 1,05 & 0,803 & 9,54 & 6,47 \\ 5,35 & 3,78 & 4,23 & 3,00 & 1,05 & 5,67 & 9,54 & 6,47 \\ 5,35 & 2,91 & 4,23 & 2,25 & 4,07 & 5,67 & 9,54 & 6,47 \\ 5,35 & 2,91 & 4,23 & 2,25 & 4,07 & 5,67 & 9,54 & 6,47 \\ 5,35 & 2,91 & 4,18 & 2,25 & 4,07 & 5,67 & 9,54 & 6,47 \\ 5,35 & 2,91 & 4,18 & 2,25 & 4,07 & 5,67 & 9,54 & 4,66 \\ 5,35 & 2,31 & 4,18 & 2,25 & 4,07 & 5,67 & 9,54 & 4,66 \\ 5,35 & 2,31 & 4,18 & 6,61 & 4,07 & 5,67 & 9,54 & 4,66 \\ 2,79 & 2,31 & 4,18 & 6,61 & 4,18 & 5,67 & 9,54 & 4,66 \\ 1,54 & 2,31 & 4,18 & 6,61 & 4,18 & 5,67 & 2,26 & 4,66 \\ 1,54 & 2,31 & 4,18 & 6,61 & 4,18 & 5,67 & 2,26 & 4,66 \\ 1,54 & 2,31 & 2,34 & 6,61 & 4,18 & 5,67 & 2,26 & 4,66 \\ 1,54 & 2,31 & 2,34 & 6,61 & 4,18 & 5,67 & 2,26 & 4,66 \\ 2,70 & 2,31 & 2,34 & 6,61 & 4,18 & 5,67 & 4,4 & 4,66 \\ 2,70 & 2,31 & 2,34 & 6,61 & 4,18 & 5,57 & 4,4 & 4,66 \\ 2,70 & 2,31 & 3,92 & 6,61 & 4,18 & 0,947 & 4,4 & 0 \\ 2,70 & 2,66 & 3,92 & 6,61 & 4,18 & 0,947 & 4,4 & 0 \\ 2,70 & 2,66 & 3,92 & 1,00 & 4,18 & 9,54 & 4,4 & 0 \\ 2,70 & 2,66 & 3,92 & 1,00 & 4,18 & 9,54 & 4,4 & 0 \\ 2,70 & 2,66 & 3,92 & 5,56 & 4,18 & 9,54 & 4,4 & 0 \\ 2,70 & 2,66 & 3,92 & 5,56 & 2,59 & 9,54 & 4,4 & 0 \\ 3,78 & 2,66 & 3,92 & 5,56 & 2,59 & 9,54 & 4,4 & 0 \\ 3,78 & 2,66 & 3,92 & 5,56 & 2,59 & 9,54 & 4,4 & 0 \\ 3,78 & 2,66 & 3,92 & 5,56 & 2,59 & 9,54 & 6,47 & 0 \\ 3,78 & 2,66 & 3,42 & 5,56 & 2,59 & 9,54 & 6,47 & 0 \\ 3,78 & 2,66 & 3,42 & 5,56 & 2,59 & 9,54 & 6,47 & 0 \\ 3,78 & 1,49 & 3,42 & 5,56 & 2,59 & 9,54 & 6,47 & 0 \\ 3,78 & 1,49 & 3,42 & 5,56 & 3,04 & 9,54 & 6,47 & 0 \\ & \text { Vazão } & & & & & & \\ & \text { Media } & 4,2518 & & & & & \end{array}$




\section{A.3.2. Iterações de Volume Médio, Área Inundada, Vazão}

Volume Médio R.A.A.

\begin{tabular}{|c|c|c|c|}
\hline & $\begin{array}{c}\text { Prof. } \\
\text { Reserv. }\end{array}$ & $\begin{array}{c}\text { Área } \\
\text { Reserv. }\end{array}$ & $\begin{array}{c}\text { Vol. } \\
\text { Res. m3 }\end{array}$ \\
\hline \multirow[t]{13}{*}{10000} & 0 & 1 & 0 \\
\hline & 2,5 & 2 & 5 \\
\hline & 5 & 3 & 15 \\
\hline & 7,5 & 4 & 30 \\
\hline & 10 & 5 & 50 \\
\hline & 12,5 & 6 & 75 \\
\hline & 15 & 7 & 105 \\
\hline & 17,5 & 8 & 140 \\
\hline & 20 & 9 & 180 \\
\hline & 22,5 & 10 & 225 \\
\hline & 25 & 11 & 275 \\
\hline & 27,5 & 12 & 330 \\
\hline & 30 & 13 & 390 \\
\hline
\end{tabular}

Volume Médio na Região
Área Inundada R.A.A.

Densidade $\left(1 \mathrm{t}=0,67 \mathrm{~m}^{\wedge} 3 /\right.$ ton $)$

0,67

\section{Fator de Erosão}

1,56

Faror de Despejo

0,2

140
Vazão PCH

$\begin{array}{ccc}\mathbf{Q}(\mathbf{m} \mathbf{3} / \mathbf{s}) & \mathbf{H}(\mathbf{m}) & \mathbf{P}(\mathbf{M W}) \\ 0 & 0 & 0 \\ 5 & 2 & 82 \\ 10 & 4 & 328 \\ 15 & 6 & 738 \\ 20 & 8 & 1312 \\ 25 & 10 & 2050 \\ 30 & 12 & 2952 \\ 35 & 14 & 4018 \\ 40 & 16 & 5248 \\ 45 & 18 & 6642 \\ 50 & 20 & 8200 \\ 55 & 22 & 9922 \\ 60 & 24 & 11808 \\ 65 & 26 & 13858 \\ 70 & 28 & 16072 \\ \mathbf{7 5} & \mathbf{3 0} & \mathbf{1 8 4 5 0} \\ 80 & 32 & 20992 \\ 85 & 34 & 23698 \\ 90 & 36 & 26568 \\ 95 & 38 & 29602 \\ 100 & 40 & 32800 \\ 78 & 31 & 19827,6\end{array}$




\section{A.3.3.Variação Anual Capacidade Média de Reservatórios em Função de Erosão}

\begin{tabular}{|c|c|c|c|c|}
\hline Ano & Taxa de Erosão Anual (ton/ano) & V Reserv / Erodido (adim) & V Sedimentado (adim) & Redução Anual Cap ( \\
\hline 0 & 40 & 135,876 & 0,3 & 1630,512 \\
\hline 1 & 44 & 135,876 & 0,3 & 1793,5632 \\
\hline 2 & 47 & 135,876 & 0,3 & 1915,8516 \\
\hline 3 & 50 & 135,876 & 0,3 & 2038,14 \\
\hline 4 & 53 & 135,876 & 0,3 & 2160,4284 \\
\hline 5 & 56 & 135,876 & 0,3 & 2282,7168 \\
\hline 6 & 59 & 135,876 & 0,3 & 2405,0052 \\
\hline 7 & 61 & 135,876 & 0,3 & 2486,5308 \\
\hline 8 & 63 & 135,876 & 0,3 & 2568,0564 \\
\hline 9 & 65 & 135,876 & 0,3 & 2649,582 \\
\hline 10 & 67 & 135,876 & 0,3 & 2731,1076 \\
\hline 11 & 69 & 135,876 & 0,3 & 2812,6332 \\
\hline 12 & 71 & 135,876 & 0,3 & 2894,1588 \\
\hline 13 & 73 & 135,876 & 0,3 & 2975,6844 \\
\hline 14 & 74 & 135,876 & 0,3 & 3016,4472 \\
\hline 15 & 75 & 135,876 & 0,3 & 3057,21 \\
\hline 16 & 76 & 135,876 & 0,3 & 3097,9728 \\
\hline 17 & 77 & 135,876 & 0,3 & 3138,7356 \\
\hline 18 & 78 & 135,876 & 0,3 & 3179,4984 \\
\hline 19 & 79 & 135,876 & 0,3 & 3220,2612 \\
\hline 20 & 80 & 135,876 & 0,3 & 3261,024 \\
\hline 21 & 80 & 135,876 & 0,3 & 3261,024 \\
\hline 22 & 80 & 135,876 & 0,3 & 3261,024 \\
\hline 23 & 80 & 135,876 & 0,3 & 3261,024 \\
\hline 24 & 80 & 135,876 & 0,3 & 3261,024 \\
\hline 25 & 80 & 135,876 & 0,3 & 3261,024 \\
\hline 26 & 80 & 135,876 & 0,3 & 3261,024 \\
\hline 27 & 80 & 135,876 & 0,3 & 3261,024 \\
\hline 28 & 80 & 135,876 & 0,3 & 3261,024 \\
\hline 29 & 80 & 135,876 & 0,3 & 3261,024 \\
\hline 30 & 80 & 135,876 & 0,3 & 3261,024 \\
\hline
\end{tabular}




\section{Bibliografia}

ABEEÓLICA - Associação Brasileira de Energia Eólica, "Renovento - Regime Especial de Tributação para Incentivo ao Desenvolvimento da Indústria Eólica Nacional", Brasília, 2009.

ALMEIDA PRADO, F. A., HEIDEIER, R. B. "O crescimento da intensidade de emissões de gases de efeito estufa na matriz elétrica brasileira - uma visão crítica." Não publicado. São Paulo, 2008.

ÁLVARES, G.C., JARA, R.M., JULIÁN, J.R.R., BIELSA, J.I.G. "Study of the Effects on Employment of Public Aid to Renewable Energy Sources". Universidad Rey Juán Carlos. Madrid, 2009.

AMARANTE, O.A.C., BROWER, M., ZACK, J. "Atlas do Potencial Eólico Brasileiro". Ministério de Minas e Energia e Eletrobrás. Brasília, 2001.

ABILUX - Associação Brasileira da Indústria de lluminação. "Levantamento do Estágio Tecnológico do Setor Iluminação". 2005. Disponível Online:

http://www.abilux.com.br/pdf/diagnostico.pdf

ABNT - Associação Brasileira de Normas Técnicas. "Iluminância de Interiores". 1991. Disponível Online:

http://www.labcon.ufsc.br/anexos/13.pdf

ABRAVA - Associação Brasileira de Refrigeração, Ar Condicionado, Ventilação e Aquecimento "Workshop de Aquecimento Solar em Habitação de Interesse Social". 2010. Disponível Online:

http://www.cidadessolares.org.br/downloads/CDHU.ppt.pdf

AGÊNCIA NACIONAL DE ENERGIA ELÉTRICA (ANEEL), "Resolução 267 de 2007". Brasília, 2007a.

AGÊNCIA NACIONAL DE ENERGIA ELÉTRICA (ANEEL), "Nota Técnica no 053/2007-SRT/ANEEL". Brasília, 2007b.

Agência Nacional de Energia Elétrica (ANEEL), "Manual para Elaboração do Programa de Eficiência Energética". 2008a. Disponível Online:

http://www.aneel.gov.br/arquivos/PDF/aren2008300 2.pdf

AGÊNCIA NACIONAL DE ENERGIA ELÉTRICA (ANEEL), "Resolução Normativa №320, de 10 de Junho de 2008". Brasília, 2008b.

AGÊNCIA NACIONAL DE ENERGIA ELÉTRICA (ANEEL) - Superintendência de Pesquisa e Desenvolvimento e Eficiência Energética (SPE), "Manual para Elaboração do Programa de Eficiência Energética". Brasília, 2008b.

AGÊNCIA NACIONAL DE ENERGIA ELÉTRICA (ANEEL), "Atlas de Energia Elétrica do Brasil”. Terceira Edição. Brasília, 2009. 
ALVES, S.S. "Tipificação dos Instrumentos de políticas de apoio à eficiência energética: a experiência mundial e o cenário nacional". Dissertação de Mestrado. Departamento de Energia e Automação da Escola Politécnica da Universidade de São Paulo. São Paulo, 2007.

ARAÚJO, N.M.C. "Avaliação de Atenuadores de Ruído Passivos Resistivos para Grupos Geradores de Energia". Dissertação de Mestrado. Faculdade de Engenharia Civil, Arquitetura e Urbanismo, Unicamp, Campinas, 2004

ASSIS, W.F.T.A., ZUCARELLI, M.C., ORTIZ, L. "Despoluindo Incertezas Impactos Territoriais da Expansão das Monoculturas Energéticas no Brasil e Replicabilidade de Modelos Sustentáveis de Produção e Uso de Biocombustíveis", Núcleo Amigos da Terra / Brasil, Instituto Vitae Cívilis e ECOA - Ecologia e Ação, 2007. Disponível online:

http://www.natbrasil.org.br/Docs/biocombustiveis/expansao biocombustiveis brasil.pdf

ASTORGA, O. A. M. et alli, "Um estudo da substituição das lâmpadas incandescentes por lâmpadas fluorescentes compactas em instalações elétricas residenciais e o compromisso entre conservação e qualidade de energia". XVI SNPTEE - Seminário Nacional de Produção e Transmissão de Energia Elétrica, 2001.

AVELINO, A.F.T., GORDON, A.M.P.L. "Comparative Analysis of Energy Resources: The Sustainable Chalenge for the XXI Century", 22nd International Conference on Efficiency, Cost, Optimization Simulation and Environmental Impact of Energy Systems. Paraná, 2009.

BAITELO, R.L. "Modelagem Completa e Análise dos Recursos Energéticos do Lado da Demanda para o PIR". Dissertação de Mestrado. Departamento de Energia e Automação da Escola Politécnica da Universidade de São Paulo. São Paulo, 2006.

BAITELO, R. L. "Cortina de Fumaça - As Emissões de gases estufa e outros impactos da energia nuclear" -. Published by Greenpeace Brazil. 26p. São Paulo, November, 2007. Disponível online:

http://www.greenpeace.org/raw/content/brasil/documentos/nuclear/cortina-de-fuma-a.pdf

BAITELO, R.L., PIVA, L.H. , FURTADO, M. "Mudanças Climáticas e Medidas Nacionais de Mitigação". InterfacEHS - Revista de Gestão Integrada em Saúde do Trabalho e Meio Ambiente. 10 p. 2007. Disponível online:

http://interfacehs.sp.senac.br/br/artigos.asp?ed=5\&cod artigo $=89$

BAITELO, R.L. "A Caminho da Sustentabilidade Energética - Como desenvolver um mercado de energias renováveis no Brasil".Greenpeace Brazil. São Paulo, 2008. Disponível online:

http://www.greenpeace.org/brasil/documentos/energia/a-caminho-da-sustentabilidade

BAITELO, R.L., FURTADO, M.C., SOLIANO; O.L, "Propostas De Um Marco Regulatório Para Políticas Públicas De Incentivo a Energias Renováveis No Brasil" Publicado no XII CBE - Congresso Brasileiro de Energia. Rio de Janeiro, 2008. 
BAITELO, R.L., M.E.M. UDAETA, GALVÃO, L.C.R., "Metodologia de Valoração de Recursos Energéticos do Lado da Oferta: Exemplo para Fontes Energéticas Fósseis" Publicado no VI CLAGTEE - Congresso Latino Americano de Geração e Transmissão de Energia Elétrica. Ubatuba, 2009.

BAITELO, R.L., FURTADO, M.C., SOLIANO; O.L, "Perspectivas de Políticas Públicas para Energias Renováveis no Brasil" Publicado no VI CLAGTEE Congresso Latino Americano de Geração e Transmissão de Energia Elétrica. Ubatuba, 2009.

BAITELO, R.L., FURTADO, M.C., GALVÃO, L.C.R., UDAETA, M.E.M., FADIGAS, E.A.F.A. "Analysis of Policies for the Development of New Renewable Energy Sources in Brazil" Publicado no 29th IAEE/USAEE North American Conference. Calgary, 2010.

BALDACCI, EDUARDO. "Eficiência Energética em Programas da CDHU". CBCS, CDHU. 2009. Disponível Online:

http://www.cbcs.org.br/userfiles/comitestematicos/energia/Eduardo\%20Baldacci\%20Sem\%5B1\%5 D.\%20CBCS-CDHU\%2005-11-09.pdf

BANCO MUNDIAL, "Licenciamento Ambiental de Empreendimentos Hidrelétricos no Brasil - Uma contribuição para o debate". Relatório № 40995-BR. 2008.

BARBA-GUTIERREZ, Y, ADENSO-DIAZ, B., HOPPA, M. "An Analysis of Some Environmental Consequences of European Electrical and Electronic Waste Regulation". Resources, Conservation and Recycling, 52, páginas 481-495. 2008.

BARNES, E.A., "Valores de Mercado da Pesca Comercial" in "Águas Turvas -. Alertas sobre as consequências de barrar o maior afluente do Amazonas." International Rivers Network. São Paulo, 2008.

BERMANN, C. "A Repotenciação de Usinas Hidrelétricas como Alternativa para o Aumento da Oferta de Energia no Brasil com Proteção Ambiental". Grupo de Estudos de Política Energética WWF. Brasília, 2004.

BERMANN, C. "Impasses e Controvérsias da Hidreletricidade". Publicado em Estudos Avançados 21, n. 59, p. 139 a 153. Jan/Abr 2007. Disponível online: http://www.iee.usp.br/biblioteca/producao/2007/Artigos\%20de\%20Periodicos/Bermannimpasses.pdf

BERNSTEIN, M; LEMBERT, R.; LOUGHRAN, D; ORTIZ, D.; "The Public Benefit of California`s Investments in Energy Efficiency". RAND. California, 2000.

BERNAL, J.L.O.; "Modelagem para o Aproveitamento Sustentável dos Biocombustíveis, Energia Eólica e Solar dentro do PIR Local: Estudo de Caso do PIR da Região de Araçatuba". Dissertação de Mestrado. Programa Interunidades de Pós-graduação em Energia da Universidade de São Paulo. São Paulo, 2009. 
BLANCO, M.A. "O Conforto Luminoso como Fator de Inclusão Escolar do Portador de Baixa Visão nas Escolas Públicas Regulares do Distrito Federal" Dissertação de Mestrado. Faculdade de Arquitetura e Urbanismo. Universidade Federal de Brasília. Brasília, 2007

BLUMSTEIN, C. "Program evaluation and incentives for administrators of energyefficiency programs: Can evaluation solve the principal/agent problem?" Energy Policy. Publicado em 11 de junho de 2010. Disponível online: http://dx.doi.org/10.1016/i.enpol.2010.06.011

BOLLEN, M. H. J., What is power quality?", Eletric Power Systems Reasearch, 66, pags. 5-14. 2003.

BORBA, R.F.; "Carvão Mineral". In Balanço Mineral Brasileiro. Departamento Nacional de Produção Mineral, Ministério de Minas e Energia. Brasília, 2001.

BRADFORD, P.; JOHANSSON, T. "Integrated Resource Planning in the Context of China's Electricity Situation" Preparado pelo Regulatory Assistance Project - RAP para o Programa de Energia Sustentável da China. Apresentado no Fórum de Desenvolvimento da China. Junho, 2005. Disponível online: http://www.raponline.org/docs/IRPinChina.pdf

BRASIL. "Decreto n. ${ }^{\circ} 5.163$, de 30 de julho de 2004, Regulamenta a comercialização de energia elétrica, o processo de outorga de concessões e de autorizações de geração de energia elétrica, e dá outras providências". Diário Oficial da Republica Federativa do Brasil, seção 1 p.1. Brasília, DF, 2004.

BRASIL. "Decreto n. ${ }^{\circ} 7.154$, de 9 de abril de 2010, Sistematiza e regulamenta a atuação de órgãos públicos federais, estabelecendo procedimentos a serem observados para autorizar e realizar estudos de aproveitamentos de potenciais de energia hidráulica e sistemas de transmissão e distribuição de energia elétrica no interior de unidades de conservação bem como para autorizar a instalação de sistemas de transmissão e distribuição de energia elétrica em unidades de conservação de uso sustentável". Diário Oficial da Republica Federativa do Brasil, seção 1 p.1. Brasília, DF, 12 de abril de 2010.

BRASIL. Ministério do Desenvolvimento, "Estabelece os Índices Mínimos de Eficiência Energética para Lâmpadas Fluorescentes Compactas - LFC, com Reator Integrado, de Fabricação Nacional". Portaria n. 289, de 16 de Novembro de 2006. Disponível Online:

http://www.inmetro.gov.br/legislacao/rtac/pdf/RTAC001074.pdf

BRASIL. "Projeto de Lei Complementar 315/2009 (PL 54/2003 do deputado Chico da Princesa), que "Altera 0 art. $1^{\circ}$ da Lei oㅡ 8.001, de 13 de março de 1990, regulamentado pelo Decreto Federal $\mathrm{n}^{\circ}$ 1, de 11 de janeiro de 1991, que trata da parcela pertencente aos estados e municípios do produto da Compensação Financeira dos Recursos Hídricos - CFRH". Disponível online: http://www.senado.gov.br/atividade/materia/detalhes.asp?p cod mate $=94536$ 
BREDARIOL, C.S.; "Conflito Ambiental e Negociação Para uma Política Local de Meio Ambiente". Tese de Doutorado. Programa de Planejamento Energético. Universidade Federal do Rio de Janeiro. Rio de Janeiro, 2001.

BRITISH PETROLEUM; "Update on Gulf of México Oil Spill". Website da BP. Acessado em 3 de setembro. Disponível online:

http://www.bp.com/genericarticle.do?categoryld=2012968\&contentld=7064849

BOYLE, G., "Renewable Energy". Second edition. Oxford University Press, Oxford, 2004.

BMU - BUNDESMINISTERIUM FÜR UMWELTSCHUTZ (Ministério Federal para o Meio Ambiente, Conservação Natural e Segurança Nuclear da Alemanha) "Renewable Energies - Innovation for a Sustainable Energy Future". Alemanha, 2009. Disponível online:

http://www.bmu.de/files/pdfs/allgemein/application/pdf/ee innovationen energiezukunft en bf.pdf

CASADESUS-MASANELL, R.; MITCHELL, J. "Greenpeace". Estudo de Caso 708-418 da Harvard Business School, 2007.

CASADESUS-MASANELL, R.; MITCHELL, J. " World Wildlife Fund for Nature (WWF)". Estudo de Caso 708-417, Harvard Business School, 2007.

CEB - Companhia Energética de Brasília. "Programa de Eficiência Energética". 2006. Disponível Online:

http://www.ceb.com.br/CebNovo/Ceb/arquivos/Pdf/minuta.pdf

Central Pollution Control Board "Draft Report of the Expert Committee on Odour Pollution and its Control". Ministry of Environment and Forests, Government of India, 2007. Disponível online:

http://www.cpcb.nic.in/latest/draft-odour-report.pdf

CONAMA - Conselho Nacional de Meio Ambiente, "Resolução CONAMA № 001, de 23 de janeiro de 1986". Ministério do Meio Ambiente. Brasília, 1986.

CONFEDERAÇÃO NACIONAL DOS MUNICÍPIOS. Relatório Técnico. 2008

COSTA, H.C.M.; NETO, F.A. "A Integração Energética na América Latina sob a Otica da Economia Institucional". Artigo publicado no 4o PDPETRO Congresso Brasileiro de Pesquisa e Desenvolvimento em Petróleo e Gás. Campinas, 2007.

COSTA, L.; "Vencedor de Belo Monte elimina construção de canal e reduz custo da obra". Publicado no Jornal da Energia em 24 de maio de 2010. Disponível online:

http://www.jornaldaenergia.com.br/ler noticia.php?id noticia=3514

COUTURE, T., CORY, K. "State Clean Energy Policies Analysis (SCEPA) Project: An Analysis of Renewable Energy Feed-in Tariffs in the United States", 2009.

CRUZ, S. L. M., MELO, G.S.V.M., SOEIRO, N.S., SILVA, P.T.A., CARDOSO,H.F.S. SETÚBAL, F.A.N. "Medição da potência sonora de um 
grupo moto-gerador e simulação do campo acústico em uma usina termelétrica" 8 Congresso iberoamericano de Engenharia Mecânica. Cuzco, 2007.

DAMATO, J.C., BUENO, J.E., RICCIULLI, D.L.S.; ASTORGA, O.A.M.; Análise Comparativa das Lâmpadas de Vapor de Sódio a Alta Pressão e de Vapor de Mercúrio com a Lâmpada a Estado Sólido (LED) em Sistemas de lluminação Pública". Publicado no VI CLAGTEE - Congresso Latino Americano de Geração e Transmissão de Energia Elétrica. Ubatuba, 2009.

DASOL - Departamento Nacional de Aquecimento Solar. "Noções Iniciais sobre o Aquecimento Solar". Disponível Online:

http://mesasolar.org/tecnica/Nocoes.pdf

DATTA, S., Power Pollution Caused By Lighting Control Systems, IEEE Industry Applications Society Annual Meeting, 1991.

DELOITTE, "Macroeconomic Study on the impact of the Wind Energy sector in Spain". Comissionado pela Asociación Empresarial Eólica. Madrid, 2008.

DIAMOND, J. "Colapso".Tradução de Alexandre Raposo. 6a Edição. Editora Record. Rio de Janeiro, 2009.

DUGAN, R.C. et alli, Electrical Power Systems Quality, second edition, McGrawHill. 2002.

D'SA, A. "Integrated resource planning (IRP) and power sector reform in developing countries". Energy Policy Vol. 33, Vol. 33, págs.271-1285. 2005.

ELETROBRÁS, MINISTÉRIO DE MINAS E ENERGIA, "RIMA - Relatório de Impacto Ambiental. Aproveitamento Hidrelétrico de Belo Monte". Brasília, 2009.

ELETRONUCLEAR, "Perguntas e Respostas Angra 2 ; Desempenho/Operação". Acessado em junho de 2009. Disponível online:

http://www.eletronuclear.gov.br/perguntas respostas/perguntas respostas.php?id categoria=2\&id subcategoria $=5$

EMPRESA DE PESQUISAS ENERGÉTICAS - EPE, "Plano Nacional de Energia 2030. Rio de Janeiro, 2007. Disponível online:

http://www.epe.gov.br/PNE/Forms/Empreendimento.aspx

EMPRESA DE PESQUISAS ENERGÉTICAS - EPE - e Ministério de Minas e Energia - MME "Nota Técnica 1ํㅡㄹ Leilão de Energia de reserva - 2008". Rio de Janeiro, 2008.

EMPRESA DE PESQUISAS ENERGÉTICAS - EPE. "Eficiência Energética na Indústria e nas Residências". 2010. Disponível Online:

http://www.epe.gov.br/mercado/Documents/S\%C3\%A9rie\%20Estudos\%20de\%20 Energia/20100809 4.pdf 
EMPRESA DE PESQUISAS ENERGÉTICAS - EPE - e Ministério de Minas e Energia - MME. "Plano Decenal de Expansão de Energia 2010-2019. Rio de Janeiro, 2010.

EMPRESA DE PESQUISAS ENERGÉTICAS - EPE - e Ministério de Minas e Energia - MME. "Balanço Energético Nacional BEN 2010". Rio de Janeiro, 2010. Disponível online:

http://www.energiabrasil.gov.br/BEN/DadosEstaduais.asp.

ENERGY INNOVATIONS. "Energy Innovations: A Prosperous Path to a Clean Environment. Alliance to Save Energy, American Council for na Energy Efficiency Economy, Natural Resources Defense Council, Tellus Institute and Union of Concerned Scientists. EUA, 1997.

EXCELÊNCIA ENERGÉTICA, "Estudo analítico comparativo dos custos finais de geração de energia elétrica a partir de fonte nuclear com os de fontes renováveis e óleo combustível no Brasil". Comissionado por Greenpeace Brasil. São Paulo, 2010.

EUROPEAN WIND ENERGY ASSOCIATION - EWEA, "Wind at Work - Wind Energy and Job Creation in the EU”. 2009.

FAIRLIE, I., SUMNER, D. "The other report on Chernobyl”. Relatório comissionado pelo Partido Verde do Parlamento Europeu. Berlin, Brussels, Kiev, Abril de 2006.

FAIRLIE, I. "Comentary: Childhood Cancer near Nuclear Power Stations". Publicado em Environmental Health, BioMed Central. Setembro, 2009. Disponível online:

http://www.ehjournal.net/content/pdf/1476-069X-8-43.pdf

FAPEMIG - Fundação de Amparo a Pesquisa do Estado de Minas Gerais.

"Chuveiro Econômico de Câmara Dupla". 2010. Disponível Online:

http://www.institutoinovacao.com.br/downloads/Chuveiro\%20economico.pdf

FERREIRA, M.E.T. "A Queimadas da Cana e seu Impacto”. Publicado em Açúcar Ético. Junho de 2006. Disponível online:

http://www.sucre-ethique.org/A-queimada-da-cana-e-seu-impacto.html

FERRO, F.; "Substitutivo ao Projeto de Lei N. 630 de 2003", Relatório apresentado à Comissão Especial de Energias Renováveis, Câmara dos Deputados. Brasília, setembro de 2009.

FISK, W.J. "Health And Productivity Gains From Better Indoor Environments And Their Relationship With Building Energy Efficiency". Annu. Rev. Energy Environ. 25:537-66. 2000.

FISHER, R.; URY, W.; PATTON, B. "Getting to Yes - Negotiating Agreement without giving in". Universidade de Direito de Harvard. Estados Unidos, 1983.

FOOD STANDARD AGENCY, "Post-Chernobyl Monitoring and Controls - 
Report of Cumbrian Summer Survey". Food Protection Division. 2008. Agosto, 2009. Disponível online:

http://www.food.gov.uk/multimedia/pdfs/chernobyleng08.pdf

FONSECA, F.R. "Uso De Algoritmos Auxiliares de Tomadas de Decisão Baseados Na Teoria dos Jogos - Cômputo e Valoração do Potencial Completo da Dimensão Política do Planejamento Integrado de Recursos Energéticos Hídricos". Trabalho final da disciplina PEA 5730 - Planejamento Integrado de Recursos. São Paulo, 2010.

FUJII, R.J., UDAETA, M.E.M. "Modelagem Completa e Análise dos Recursos Energéticos do Lado da Demanda para o PIR". Dissertação de Mestrado. Departamento de Energia e Automação da Escola Politécnica da Universidade de São Paulo. São Paulo, 2006.

FURTADO, M.C., FADIGAS, E.A.F.A., BAITELO, R.L., "Análise de Políticas Públicas para Novas Energias Renováveis no Brasil" Publicado no VII Congresso Brasileiro de Planejamento Energético. São Paulo, 2010.

GAMA, S.Z. "Integração Energética na América Latina". III Seminário Mercados Eletricidade e Gás Natural "Investimento, Risco e Regulação". Faculdade de Economia da Universidade do Porto. Portugal, 2010. Disponível online:

http://www.fep.up.pt/conferencias/energia2010/Apresentacoes/ApresentacaoSinval\%20Gama\%20 \%5BCompatibility\%20Mode\%5D.pdf

GAMA, P. H. R. P. e OLIVEIRA, A., "Conservação de Energia e sua relação com a qualidade de Energia Elétrica". XV SNPTEE - Seminário Nacional de Produção e Transmissão de Energia Elétrica, 1999.

GELLER, R.; ATTALI, S., "The Experience With Energy Efficiency Policies And Programmes In IEA Countries - Learning from the Critics". IEA Information Paper. França, 2005.

GEPEA - Departamento de Engenharia de Energia e Automação Elétricas da

Escola Politécnica da Universidade de São Paulo. "Estudo para Identificação e Sugestão de incentivos Fiscais para a Implementação de projetos de Tecnologia de Eficiência Energética". 2009. Disponível Online:

http://www.pea.usp.br/images/stories/beta/consultapublica.pdf

GOLDEMBERG,J. "The Case for Renewable Energies" Thematic Background Paper - International Conference for Renewable Energies. Bonn, 2004.

GRAÇA, V.A.C.; KOWALTOWSKI, D. C. C. K. "Metodologia De Avaliação De Conforto Ambiental Com O Conceito De Otimização Multicritério Para Projetos Escolares". ENCAC, CUTEDI. Curitiba, 2003

GRACE, R.C.; RICKERSON, W.; Porter, K.; DeCesaro, J.; Corfee, K.; Wingate, M.; Lesser, J. "California Feed-in Tariff Design and Policy Options, Second Draft". California Energy Commission, 2008. 
GREENPEACE, "Descentralizing Thai Power towards a sustainable energy system". Publicado pelo Greenpeace Sudeste Asiático. Tailândia, 2006. Disponível online:

http://www.palangthai.org/docs/DecentralizingThaiPower.pdf

GREENPEACE, "HFCs: A Growing Threat to the Climate". Estados Unidos, 2008.

Disponível online:

http://www.greenpeace.org/usa/press-center/reports4/hfcs-a-growing-threat

GUYOT, J.L.; CONCEIÇÃO, S., GUIMARÃES, V., SANTOS, J.B.; LONGUINHOS, R. "Medição de vazão com ADCP - Primeiros resultados na bacia Amazônica". A Água em Revista, 3(4) : 26-30. CPRM, Rio de Janeiro, 1995.

GWEC - GLOBAL WIND ENERGY COUNCIL "Global Wind Energy Outlook 2010". Fevereiro, 2010. Disponível online:

http://www.gwec.net/index.php?id=92

HANLEYA, N., MCGREGORB, P.G., SWALESB, J.K., TURNERB, K. "Do increases in energy efficiency improve environmental quality and sustainability?". Ecological Economics 6 8, páginas 692 a 709. 2009.

HITT, N.P., HENDRYX, M. "Ecological Integrity of Streams Related to Human Cancer Mortality Rates". Publicado em Ecohealth, Abril de 2010. Disponível online:

http://lib.bioinfo.pl/pmid:20361230

HERNANDEZ, M.C.M. "Revolución Energética en Cuba: Sus Impactos". Monografia publicada no site http:www.monografias.com. 2007. Disponível online:

http://www.monografias.com/trabajos45/revolucion-energetica/revolucion-energetica.shtml

HU, Z.: WEN, Q.; Wang, J.; TA, X.; NEZHAD, H., SHAN, B., HAN, X.; "Integrated resource strategic planning in China". Energy Policy 38 pags. 4635-4642. 2010.

HUNT, T.M. "Five Lectures on Environmental Effects of Geothermal Utilization" Lectures on environmental studies. United Nations University, Geothermal Training Programme. Islândia, 2001.

HURTADO, J.P., Fernandez J., Parrondo J.L., Blanco E. "Spanish method of visual impact evaluation in wind farms". Renewable and Sustainable Energy Reviews. Edição 8, páginas 483 a 491. 2004.

IAEA - International Atomic Energy Agency, "Operating Experience with Nuclear Power Stations in Member States in 2009". Power Reactor Information System, 2009. Disponível online:

http://www.iaea.org/programmes/a2/

IBAMA - Instituto Brasileiro do Meio Ambiente e dos Recursos Naturais. Instrução Normativa n.7 de 9 de abril de 2009. Brasília, 2009. Disponível online:

http://www.abdir.com.br/legislacao/legislacao abdir 15409 2.pdf 
IBGE - Instituto Brasileiro de Geografia e Estatística. "Número médio de moradores em domicílios particulares, por recebimento de dinheiro de programa social do governo, no mês de referência, Segundo as Unidades da Federação". 2006. Disponível Online:

http://www.ibge.gov.br/home/estatistica/populacao/trabalhoerendimento/pnad2006/suplementos/re nda/tabelas/tab4014.pdfhttp://www.ibge.gov.br/home/estatistica/populacao/trabalhoerendimento/p nad2006/suplementos/renda/tabelas/tab4014.pdf

IBGE - instituto Brasileiro de Geografia e Estatística. "Pesquisa Nacional de

Saneamento Básico 2000". 2000. Disponível online:

http://www.ibge.gov.br/home/presidencia/noticias/27032002pnsb.shtm

IEA - Internacional Energy Agency, "World Energy Outlook 2009”.

Disponível online:

http://www.worldenergyoutlook.org/

IEA - Internacional Energy Agency, "World Energy Outlook 2010”.

Disponível online:

http://www.worldenergyoutlook.org/

IEA - Internacional Energy Agency, "Global Renewable Energy - Policies and Measures". Acessado em 4 de dezembro de 2009. Disponível Online:

http://www.iea.org/textbase/pm/?mode=re

INSTITUTO ACENDE BRASIL E PSR "Programa Energia Transparente - Sétima

Edição" Julho de 2009. Disponível online:

http://www.acendebrasil.com.br/site/materias/Apresentacoes.asp?id=229

INSTITUTO ACENDE BRASIL, "VI Fórum Instituto Acende Brasil: O Homem, a Usina e o Poder Público". Brasília, 2010. Disponível online:

http://www.acendebrasil.com.br/archives/files/20100427 VI Forum AcendeBrasil Rev 0 Net.pdf

INSTITUTO ACENDE BRASIL, "Energia e Geopolítica: Compromisso e Oportunismo". White Paper - Edição n.1. Agosto de 2010.

IPCC - International Panel on Climate Change, "Fourth Assessment Report", 2007. Disponível online:

http://www.ipcc.ch/

JACOBSON, M.Z. "Review of Solutions to Global Warming, Air Polution, and Energy Security". Energy and Environmental Science, 2008.

Institute for Agriculture and Trade Policy (IATP) apud JACOBSON, M.Z., "Water use by ethanol plants: Potential challenges". Summary Data Sheet. 2006.

MINISTÉRIO DAS RELAÇOES EXTERIORES. Website consultado em setembro de 2010. Online:

http://www.itamaraty.gov.br

JANK, M.S., NEVES, E. "Cana-de-açucar - Entre o velho e o novo", O Estado de

São Paulo", Publicado em 27 de agosto de 2008. Disponível online:

http://www.estadao.com.br/estadaodehoje/20080827/not imp231379,0.php 
JANNUZZI, G.M. "Avaliação do Programa de Incentivos à Substituição de Lâmpadas incandescentes por Fluorescentes Compactas ou Circulares em Fortaleza (DEREO)". 1998. Disponível Online:

http://www.fem.unicamp.br/ iannuzzi/documents/RelatorioFinal-Procel-Coelce.pdf

JANNUZZI, G.M. e MELO, C.A. "Padrões de Eficiência Energética para Equipamentos Elétricos de Uso Residencial no Brasil”. 2009. Disponível Online:

http://www.sbpe.org.br/socios/download.php?id=233

JANNUZZI, G.M. "Planejamento Integrado de Recursos: Uso Eficiente de Energia e Desenvolvimento Regional". Relatório Final de Projeto UNICAMP/PNUD/PROCEL 1995. Disponível online: http://www.fem.unicamp.br/ jannuzzi/documents/PIR-regional.pdf

JANUZZI, G. M. E SWISHER, J. N. P.; "Planejamento Integrado de Recursos Energéticos - Meio Ambiente, Conservação de Energia e Fontes Renováveis", Editora Autores Associados. Campinas, 1997.

KAYGUSUZ, K. "Environmental Impacts of the Solar Energy Systems". Energy Sources, Part A: Recovery, Utilization, and Environmental Effects, Volume 31, Issue 15, páginas 1376-1386. 2009.

KELMAN, J. "Desafios do Regulador”. Editora Synergia, 2009.

KLEIN, A. et al "Evaluation of different feed-in tariff design options - Best practice paper for the International Feed-in Cooperation". Fraunhofer Institut Systems and Innovation Research, 2006.

LANGEWIESCHE, W. "O Bazar Atômico: A Escalada do Pobrerio Nuclear". Tradução José Viegas. Companhia das Letras. São Paulo, 2007.

LOVINS, A.B. "Four Nuclear Myths - A commentary on Stewart Brand's Whole Earth Discipline and on similar writings". Rocky Mountain Institute. 2009.

LEITE, A.D. "A Energia do Brasil”. Elsevier Editora. Segunda Edição, 2007.

LU, W. "Potential energy savings and environmental impacts of energy efficiency standards for vapor compression central air conditioning units in China". Energy Policy 35, páginas 1709 a 1717. 2007.

LUZ, J. M. e FELBERBAUM, M. I. , "Ensaios em reatores eletrônicos e o impacto na conservação de energia elétrica", III SBQEE - Seminário Brasileiro de Qualidade de Energia Elétrica. Brasília, 1999.

MALLON, K. "Renewable Energy Policy and Politics" Editora Earthscan. Londres, 2006.

MARIANO, J.B. "Impactos Ambientais do Refino do Petróleo". Dissertação de Mestrado, Coordenação dos Programas de Pós-Graduação de Engenharia da Universidade Federal do Rio de Janeiro, 2001. 
MARIANO, J.B. "Proposta de Metodologia de Avaliação Integrada de Riscos e Impactos Ambientais para Estudos de Avaliação Ambiental Estratégica do Setor de Petróleo e Gás Natural em Áreas Offshore". Tese de Doutorado, Coordenação dos Programas de Pós-Graduação de Engenharia da Universidade Federal do Rio de Janeiro, 2007.

MARTINS, M.A.C. "O Mito do Índice de Nacionalização e a Administração dos Incentivos Fiscais de Importação" IPEA, SEPLAN. Brasília, 1976. Disponível online:

http://www.aeconomiadobrasil.com.br/pdf/197603.ipea.ind.nac.inc.fisc.imp.pdf

McCOLL, S.L.; VEITCH, J.A. "Full-Spectrum Fluorescent Lighting Effects on People: A Critical Review". IRC Internal Report No. 659. Página 53. 2001.

MEDEIROS, J.P.P.G. "Proposta de Metodologia para O Cálculo das Tarifas de Uso dos Sistemas de Distribuição Aplicáveis a Unidades Geradoras". Dissertação de Mestrado, Coordenação dos Programas de Pós-Graduação de Engenharia da Universidade Federal do Rio de Janeiro, 2001.

MEINSHAUSEN, M., MEINSHAUSEN, N., Hare, W., Raper, S.C.B., Frieler, K., Knutti, R., Frame, D.J., Allen, M.R. " Greenhouse-gas emission targets for limiting global warming to $2^{\circ} \mathrm{C}$ ". Publicado em Natur e - International Weekly Journal of Science. Março de 2009. Disponível online:

http://www.nature.com/nature/journal/v458/n7242/full/nature08017.html

MESQUITA, E.N., MILAZZO, M. L. "Emissão de gases de efeito estufa de reservatórios de usinas hidrelétricas". III Congreso CIER de la Energía Comision de Integracion Energética Regional, Comitê Nacional Brasil. Medelin, 2007.

MINISTÉRIO DE CIÊNCIA E TECNOLOGIA, "Inventário Brasileiro das Emissões e Remoções Antrópicas de Gases de Efeito Estufa - Informações Gerais e Resultados Preliminares". Brasília, 2009.

MINISTÉRIO DE MINAS E ENERGIA, "Belo Monte é licitada com deságio de 6\%". Disponível online:

http://www.mme.gov.br/mme/noticias/destaque foto/destaque 0082.html

NEJDAWI, I. M. et alli, Harmonics Trend in NE USA: A Preliminary Survey, IEEE Transactions on Power Delivery, vol. 14, no. 4, 1999.

NORTH AMERICAN ELECTRIC RELIABILITY COUNCIL (NERC), "2000-2004 Generating Availability Report". 2005.

NEUMAYER, E. "The human development index and sustainability - a constructive proposal”. Analysis. Ecological Economics 39. Págs. 101-114. 2001.

NIJKAMP, P.; "A qualitative evaluation model for environmental management with conflict priorities"; in Environmental Policy Analysis, Nijkamp J. ed.; John Wiley \& Sons. Estados Unidos, 1980. 
NOORBAKHSK, F. "The Human Development Index: Some Technical Issues And Alternative Indices" Journal of International Development J. Int. Dev. 10. Págs. 589 a 605.1998.

ODONGO, F., "Valoração Socioambiental do PIR na RAA Araçatuba". Novos Instrumentos de Planejamento Energético Regional visando o Desenvolvimento Sustentável - Relatório Técnico Científico da Fase 2, São Paulo, 2008.

OPERADOR NACIONAL DO SISTEMA, ONS "Plano Anual da Operação Energética - PEN 2009". Rio de Janeiro, 2009. Disponível online: http://www.abrace.org.br/download/PEN\%202009 VOL1 SUMEX 29-06.09.pdf

PAULA, M.A.R.; ALENCAR, H.S.; MOURA, E.D.A. "Desenvolvimento de uma metodologia para a adequação ambiental de Centrais Hidrelétricas quanto ao nível de ruído sonoro". 4o. Encontro de Energia no Meio Rural. Campinas, 2002.

PARSONS, D. "The Environmental Impacto of Compact Fluorescent Lamps and Incandescent Lamps for Australian Conditions". The Environmental Engineer Journal of the Society for Sustainability and Environmental Engineering. Páginas 8-14. Australia, 2006.

PIAZZA, F.C. "Elaboração de Plano de Emergência para Impactos Ambientais de Extração de Carvão a Subsolo" Trabalho de Conclusão de Curso de Engenharia Ambiental, Universidade do Extremo Sul Catarinense. Criciúma, 2006.

http://www.comiteitajai.org.br/dspace/bitstream/123456789/581/1/TCC\%20Fabiana\%20Piazza.pdf

PIMENTA, F., KEMPTON, W., GARVINE, R. "Combining meteorological stations and satellite data to evaluate the offshore wind power resource of Southeastern Brazil". Renewable Energy, 33(11), págs. 2375-2387. 2008.

PNUMA - Programa das Nações Unidas para o Meio Ambiente - e World Watch Institute "Green Jobs: Towards Decent Work in a Sustainable, Low-Carbon World", 2008.

PNUMA - Programa das Nações Unidas para o Meio Ambiente, "Tendências Globais de Investimentos em Energias Renováveis", 2010.

POLANCO, SARA. "A situação da destinação pós-consumo de lâmpadas de mercúrio no Brasil". Dissertação de Mestrado, Instituto Mauá de Tecnologia. São Caetano, 2007.

PRADO, G.R. "Estudo de contaminação ambiental por urânio no município de Caetité-BA, utilizando dentes de humanos como bioindicadores", Dissertação de Mestrado, Instituto de Física da Universidade de São Paulo, 2008. 
PROCEL "Conservação de Energia - Eficiência Energética de Instalações e Equipamentos", 2" edição, Eletrobrás/Procel, Editora da EFEI, 2001.

PREFEITURA MUNICIPAL DE CAMAÇARI "Camaçari ganha duas usinas termoelétricas". Diário Oficial de Camaçari, Ano V - № 249 - de 05 a 11 de abril de 2008.

QUERCUS - Associação Nacional de Conservação da Natureza. "Caracterização da produção de resíduos em Portuga". 2001. Disponível Online:

http://residuos.quercus.pt/xFiles/scContentDeployer pt/docs/DocSite1837.pdf

REIS, M. M. "Custos Ambientais associados à Geração Elétrica: Hidrelétricas x Térmicas a Gás Natural". Dissertação de Mestrado, Coordenação dos Programas de Pós-Graduação de Engenharia da Universidade Federal do Rio de Janeiro, 2001.

RICKERSON, W.; GRACE, R.C. "The Debate over Fixed Price Incentives for Renewable Electricity in Europe and the United States: Fallout and Future Directions", 2007.

RODRIGUES, I.C., GONÇALVES, D. B., ALVES, F.J.C. "Água: captação, uso, destinação e a cobrança pelo uso no setor sucroalcooleiro da Bacia Hidrográfica do rio Mogi-Guaçu". III Seminário Economia do Meio Ambiente: Regulação Estatal e Auto-Regulação Empresarial para o Desenvolvimento Sustentável. Campinas, 2003.

RUTOVITZ, J., ATHERTON, A. "Energy Sector Jobs to 2030: a Global Analysis". Institute for Sustainable Futures, University of Technology, Sidney, 2009.

SACHS, I.; VIEIRA, P.F.(organizador) "Rumo à Ecossocioeconomia - Teoria e Prática do Desenvolvimento". Cortez Editora. São Paulo, 2007

SALOMON, K.R. "Avaliação Quantitativa do Impacto Ambiental das Emissões Gasosas e do Uso da Água de Resfriamento em Instalações de Geração Termelétrica". Dissertação de Mestrado, Programa de Pós-Graduação em Engenharia da Energia da Universidade Federal de Itajubá, 2003.

SANTOS, S.M.S.B.M e HERNANDEZ, F.M. "Painel de Especialistas - Análise Crítica do Estudo de Impacto Ambiental do Aproveitamento Hidrelétrico de Belo Monte". Belém, 2009. Disponível online:

http://www.socioambiental.org/banco imagens/pdfs/Belo Monte Painel especialistas ElA.pdf

SAUER, I.L., CARVALHO, J.F. "Does Brazil Need New Nuclear Power Plants", Publicado no periódico Energy Policy Edição 37, Janeiro de 2009.

SCHIERMEIER, Q.; TOLLEFSON, J.; SCULLY, T.; WITZE, A.; MORTON, O.; "Electricity without Carbon". Publicado na Revista Nature, Agosto de 2008.

SEADE - Fundação Sistema Estadual de Análise de Dados. "Região Administrativa de Araçatuba". 2010. Disponível Online: 
http://www.ibge.gov.br/home/estatistica/populacao/trabalhoerendimento/pnad2006/suplementos/re nda/tabelas/tab4014.pdf

SECOM/Prefeitura de São Luís apud ABCM - Associação Brasileira do Carvão Mineral "Projeto da Termelétrica é apresentado a Secretários municipais em São Luís". São Luís, 2009.

SERRA. R.V., MOTHÉ, N., MORETT, D. "Mazelas Da Distribuição Espacial Das Rendas Petrolíferas No Brasil e Ensinamentos a Partir das Experiências Sulamericanas". XII Encontro Da Associação Nacional De Pós-Graduação e Pesquisa em Planejamento Urbano e Regional. Belém, 2007.

SILVA, L.F.; RICARDO, M.; BERNARDES, M.E.C. "Análise dos Níveis Sonoros gerados na Operação de PCH: Aspectos Ambientais e Ocupacionais". Publicado no VI Simpósio Brasileiro sobre Pequenas e Médias Centrais Hidrelétricas. Belo Horizonte, 2008.

SILVEIRA, P.M., ABREU, J.P.G., Almeida, J.E.L., PRINA, R., CARVALHO, S.G. "Avaliação dos Efeitos das Cargas Não Lineares Residenciais na Qualidade da Energia Elétrica de um Sistema de Distribuição". Congresso Brasileiro de Automática. Gramado, 2004.

SINPHA - Sistema de Informações de Posse de Eletrodomésticos e Hábitos de Consumo. "Bens de Consumo - Chuveiro". 2005a. Disponível Online:

http://www.eletrobras.com/pci/Sinpha/Relatorios.asp\#menu36

SINPHA - Sistema de Informação de Posse de Eletrodomésticos e Hábitos de Consumo. "GLD - Distribuição por Tipos de Lâmpadas". 2005b. Disponível Online:

http://www.eletrobras.com/pci/Sinpha/gldTipo.asp

SINPHA - Sistema de Informação de Posse de Eletrodomésticos e Hábitos de Consumo. "Iluminação - Iluminação Domiciliar". 2005c. Disponível Online: http://www.eletrobras.com/pci/Sinpha/RelLampDom.asp\#tbGrafAbsoluto

SOARES, F.H.N., RAMOS, D.S. "Impactos da Operação de Usinas Termelétricas contratadas por disponibilidade no custo da energia adquirida em leilões de energia". XIII ERIAC - Encontro Regional Iberoamericano de Cigré. Peru, 2009a.

SOARES, F.H.N., RAMOS, D.S. "Tarifas De Uso Dos Sistemas De Distribuição Para Geradores: Uma Proposta De Modelagem Para Obtenção De Eficiência Econômica Via Sinal Locacional.”. Xiii ERIAC - Encontro Regional Iberoamericano de Cigré. Peru, 2009b.

SOVACOOL, B.K., "The costs of failure: A preliminary assessment of major energy accidents, 1907-2007”. Energy Policy 36, pág. 1806. 2008a.

SOVACOOL, B.K., "The intermittency of wind, solar, and renewable electricity generators: Technical barrier or rhetorical excuse?". Utilities Policy 17. 2008b. 
SOVACOOL, B.K., "Valuing the greenhouse gas emissions from nuclear power: A critical survey”. Energy Policy 36, págs. 2940-2953. 2008c.

STERLICHE, S.P.W.; SOUZA, E.B.C.; "Apontamentos sobre a aplicação dos royalties da Itaipu Binacional e o processo de desenvolvimento". Publicado na Revista Brasileira de Gestão e Desenvolvimento Regional em 14 de maio de 2008.

STORM LEUWEEN, J.W., SMITH, P. "Nuclear Power - The Energy Balance".

Fevereiro de 2008. Disponível online:

http://www.stormsmith.nl/

SULLIVAN, M.P. "Venezuela: Political Conditions and U.S. Policy". Relatório do Serviço de Pesquisa Congressional Norte-Americano (CRS). Divisão de Relações Internacionais, Defesa e Comércio. Disponível online:

http://fpc.state.gov/documents/organization/109526.pdf

SWISHER, J.N.; JANNUZZI, G.M., REDLINGER, R.Y. "Tools and Methods for Integrated Resources Planning : Improving Energy Efficiency and Protecting the Environment" UNEP Collaborating Centre on Energy and Environment. 1997.

SWITKES, G., "Águas Turvas -. Alertas sobre as consequências de barrar o maior afluente do Amazonas." International Rivers Network. São Paulo, 2008.

TEIXEIRA, D.R. "Termelétrica a Gás Natural: Análise jurídica do uso dos recursos naturais água e ar no entorno de ambiente urbano. Estudo de Casos". Dissertação de Mestrado, Programa de Pós-Graduação em Engenharia da Energia da Universidade Federal de Itajubá, 2003.

TIBA, C., FRAIDENRAICH, N., LYRA, F. J. M., GROSSI, H. G., MOSZKOWICZ, M. "CD ROM Atlas Solarimétrico do Brasil". 2003.

TVA - Tenessee Valley Authority. "Energy Vision 2020" Capítulo 2 - Integrated Resources Planning. Disponível online:

http://www.tva.gov/environment/reports/energyvision2020/

TESKE, "Target for Clean Energy- The Greenpeace Position for a New Renewable Energy Electricity Directive", 2005.

TIAGO Fo., G.L, GALHARDO, C.R., DUARTE, E.R.B.C., ANTILOGA, J.G.A. "Impactos Sócio-Econômicos das Pequenas Centrais Hidrelétricas inseridas no Programa de Incentivo as Fontes Alternativas de Energia (Proinfa)" Revista Brasileira de Energia, Vol. 14, No. 1, págs. 145-166. 2008.

TIAGO Fo., G.L, GALHARDO, C.R., ANTILOGA, J.G.A.; FERRARI, J.T. "Um Panorama das Pequenas Centrais no Brasil". PCH Notícias. v. 33, p. 19-23, 2007.

TOLMASQUIM, M. T. "Fontes Renováveis de Energia no Brasil". Editora Interciência. Rio de Janeiro, 2003. 
UDAETA, M.E.M . "Planejamento Integrado de Recursos Energéticos - PIR - para - Setor Elétrico (pensando o Desenvolvimento Sustentável)". Tese de Doutorado. Departamento de Energia e Automação da Escola Politécnica da Universidade de São Paulo, 1997.

UDAETA, M.E.M., GALVÃO, L.C.R., BAITELO, R. L. , BIAGUE, M.F. "Caracterização Completa de Análise Energética dentro do PIR para os Usos Finais no Estado de São Paulo" Pesquisa para SESP e CTEEP. São Paulo, 2006.

UDAETA, M. E .M.; GIMENES, A. L. V.; GALVÃO, L.C.R; BAITELO, R.L."Estado de Arte e Síntese dos Trabalhos realizados no GEPEA acerca do PIR na Fase II". Relatório Técnico-Científico. Universidade de São Paulo, 2003.

UDAETA, M.E.M., GRIMONI, J.A.B. "Modelo Institucional do Setor Elétrico" Relatório Técnico. Departamento de Energia e Automação da Escola Politécnica da Universidade de São Paulo. São Paulo, 2004.

UDAETA, M.E.M., GALVÃO, L.C.R., GRIMONI, J.A.B. "Iniciação a Conceitos de Sistemas Energéticos para o Desenvolvimento Limpo", Edusp. São Paulo, 2004.

UNECE - UNITED NATIONS ECONOMIC COMISSION FOR EUROPE; Cooperative Programme for Monitoring and Evaluation of the Long-range Transmission of Air pollutants in Europe - EMEP. Emep/Corinair Emission inventory guidebook 2007. Copenhagen: EEA, 2007. Disponível online:

http://reports.eea.europa.eu/EMEPCORINAIR5/en/page002.html

UNICA - União da Indústria de Cana-de-Açúcar. "Etanol e Bioeletricidade - A cana-de-açúcar no futuro da matriz energética". 2009.

UNICA - União da Indústria de Cana-de-Açúcar. "Programa Renovação". 2010. Disponível online:

http://www.unica.com.br/Renovacao/default.asp

U.S. DEPARTMENT OF ENERGY "Concentrating Solar Power Commercial Application Study: Reducing Water Consumption of Concentrating Solar Power Electricity Generation". Report to Congress. Washington D.C., 2007.

USP, FAPESP, "Relatório Técnico Científico Final da Fase 1". Incluído no Projeto de Políticas Públicas "Novos Instrumentos de Planejamento Energético Regional visando o Desenvolvimento Sustentável - Fase 1". São Paulo, 2004.

USP, FAPESP, "Relatório Técnico Científico Final da Fase 2 - ano 1". Incluído no Projeto de Políticas Públicas "Novos Instrumentos de Planejamento Energético Regional visando o Desenvolvimento Sustentável - Fase 2". São Paulo, 2006.

USP, FAPESP, "Relatório Técnico Científico de Inventário Ambiental". Incluído no Projeto de Políticas Públicas "Novos Instrumentos de Planejamento 
Energético Regional visando o Desenvolvimento Sustentável - Fase 2". São Paulo, 2008a.

USP, FAPESP. "Relatório Técnico Científico Final da Fase 2 - ano 2". Incluído no Projeto de Políticas Públicas "Novos Instrumentos de Planejamento Energético Regional visando o Desenvolvimento Sustentável - Fase 2". São Paulo, 2008b.

USP, FAPESP, "Relatório Técnico Científico da Fase 2 - Valoração de Recursos Energéticos de Oferta". Incluído no Projeto de Políticas Públicas "Novos Instrumentos de Planejamento Energético Regional visando 0 Desenvolvimento Sustentável - Fase 2". FAPESP e USP. São Paulo, 2008c.

USP, FAPESP "Relatório Técnico Científico de Elaboração da Mina de Dados". Incluído no Projeto de Políticas Públicas "Novos Instrumentos de Planejamento Energético Regional visando o Desenvolvimento Sustentável Fase 2". São Paulo, 2008d.

USP, FAPESP, "Relatório Técnico Científico Final da Fase 2 - ano 3". Incluído no Projeto de Políticas Públicas "Novos Instrumentos de Planejamento Energético Regional visando o Desenvolvimento Sustentável - Fase 2". FAPESP e USP. São Paulo, 2009a.

USP, FAPESP, "Relatório Técnico Científico - Modelamento Energo-Ambiental do PIR para a RAA Araçatuba". Incluído no Projeto de Políticas Públicas "Novos Instrumentos de Planejamento Energético Regional visando o Desenvolvimento Sustentável - Fase 2". São Paulo, 2009b.

USP, FAPESP, "Relatório Técnico Científico de Valoração Política". Incluído no Projeto de Políticas Públicas "Novos Instrumentos de Planejamento Energético Regional visando o Desenvolvimento Sustentável - Fase 2". São Paulo, 2009c.

USP, FAPESP "Relatório Técnico Científico de Valoração Técnico-Econômica". Incluído no Projeto de Políticas Públicas "Novos Instrumentos de Planejamento Energético Regional visando o Desenvolvimento Sustentável Fase 2". São Paulo, 2009d.

USP, FAPESP, "Relatório Técnico Científico de Valoração Ambiental". Incluído no Projeto de Políticas Públicas "Novos Instrumentos de Planejamento Energético Regional visando o Desenvolvimento Sustentável - Fase 2". FAPESP e USP. São Paulo, 2009e.

USP, FAPESP, "Relatório Técnico Científico de Valoração Social". Incluído no Projeto de Políticas Públicas "Novos Instrumentos de Planejamento Energético Regional visando o Desenvolvimento Sustentável - Fase 2". FAPESP e USP. São Paulo, 2009 .

USP, FAPESP, "Relatório Técnico Científico da Fase 2 - Plano Preferencial". Incluído no Projeto de Políticas Públicas "Novos Instrumentos de Planejamento Energético Regional visando o Desenvolvimento Sustentável Fase 2". São Paulo, 2009g. 
VARELLA, F.K.O.M. "Tecnologia Solar Residencial: Inserção de Aquecedores de Água no Distrito de Barão Geraldo - Campinas". Dissertação de Mestrado, Departamento de Energia da Universidade Estadual de Campinas. Campinas, 2004.

VINE, E; SATHAYE, J.; "Guidelines for the Monitoring, Evaluation, Reporting, Verification, and Certification of Energy-Efficiency Projects for Climate Change Mitigation" Lawrence Berkeley National Laboratory, 1999.

VINE, E.; HAMRIN J.; EYRE N.; CROSSLEY D.; MALONEY, M.; WATT, G.; "Public policy analysis of energy efficiency and load management in changing electricity businesses" Energy Policy 31. Paginas 405-430. 2003.

WILKINS, A.J., WILKINSON, P. "A tint to reduce eye-straint from fluorescent lighting: Preliminary observations". Ophtalmic and Physiological Optics. Volume 11, Issue 2, pags. 172-175. 1991.

WISER, R., BOLINGER, M.. BARBOSE, G. "Using the Federal Production Tax Credit to Build a Durable Market for Wind Power in the United States" Publicado em The Electricity Journal, Elsevier, 2007.

WITTMANN, D., BONILLA, S.H. "Determination of Relevant Environmental Impacts and Benefits Caused by Balbina Hydropower at Amazon" Second International Workshop - Advances in Cleaner Production. São Paulo, 2009.

OECD International Atomic Energy Agency (IAEA) apud WORLD NUCLEAR ASSOCIATION (WNA), "Uranium 2009: Resources, Production and Demand". Publicado pela OECD Publishing. 2009.

YOUNOS, T., HILL, R., POOLE, H. "Water Dependency of Energy Production and Power Generation Systems". VWRRC Special Report No. SR46-2009. Virginia Water Resources Research Center. Virginia Polytechnic Institute And State University. Blacksburg, 2009.

YUSHI, M. HONG, S. FUQIANG, Y. "The True Cost of Coal". Greenpeace, Energy Foundation, WWF. China, 2008. Disponível online:

http://www.greenpeace.org/raw/content/china/en/press/reports/the-true-cost-of-coal.pdf

ZAMBUJO, M.J; CHURRO, D.; RODRIGUES, C.C.; COELHO, J.L.B., "Parques Eólicos - Estudo dos Impactos no Ambiente Sonoro II - Configuração Optimizada de Potências Sonoras" Congresso Internacional Acústica 2004, Guimarães, Portugal, 2004

ZINDLER, E. "The American Recovery and Reinvestment Act: A User's Guide", New Energy Finance. Londres, 2009. 